Stions

1. A Edited by Susanna Burghartz, Lucas Burkart,

1. Christine Göttler and Ulinka Rublack

\title{
Materialized Identities in Early Modern Culture,
}

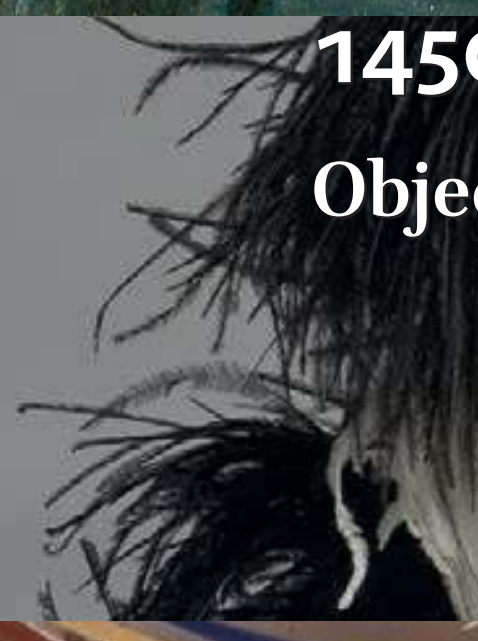

$0-1750$ 
Materialized Identities in Early Modern Culture, 1450-1750 


\title{
Visual and Material Culture, 1300-170o
}

\begin{abstract}
A forum for innovative research on the role of images and objects in the late medieval and early modern periods, Visual and Material Culture, 1300-1700 publishes monographs and essay collections that combine rigorous investigation with critical inquiry to present new narratives on a wide range of topics, from traditional arts to seemingly ordinary things. Recognizing the fluidity of images, objects, and ideas, this series fosters cross-cultural as well as multi-disciplinary exploration. We consider proposals from across the spectrum of analytic approaches and methodologies.
\end{abstract}

\section{Series Editor}

Dr. Allison Levy, an art historian, has written and/or edited three scholarly books, and she has been the recipient of numerous grants and awards, from the National Endowment for the Humanities, the American Association of University Women, the Getty Research Institute, the Dumbarton Oaks Research Library of Harvard University, the Whiting Foundation and the Bogliasco Foundation, among others. www.allisonlevy.com. 


\title{
Materialized Identities in Early Modern Culture, 1450-1750
}

\author{
Objects, Affects, Effects
}

\author{
Edited by \\ Susanna Burghartz, Lucas Burkart, \\ Christine Göttler, and Ulinka Rublack
}


The publication of this book is made possible by a grant from the Swiss National Science Foundation

Cover illustration: Details from Karel van Mander, Before the Flood, 1600 . Oil on copper, $31.1 \times 15.6 \mathrm{~cm}$. Frankfurt am Main, Städel Museum, inv. no. 2088. Image (C Städel Museum, photo: U. Edelmann / Artothek; High felt hat with silk pile and ostrich feathers, of the kind sourced by Hans Fugger during the second half of the sixteenth century. H: $22.5 \mathrm{~cm}$. Nuremberg, German National Museum. Image (C) Germanisches Nationalmuseum, Nürnberg. Photo: M. Runge; Glass bowl, Murano, around 1500. D: $25.50 \mathrm{~cm}, \mathrm{H}: 7.0 \mathrm{~cm}$. London, British Museum, museum number: S.375. Image (C) The Trustees of the British Museum; Jean Jacques Boissard, Gentil' donne venetiane/ Quando portano bruno et Vedoé, costume book [Trachtenbuch] for Johann Jakob Fugger, 1559, fol. 63. Pen and ink drawing. Herzogin Anna Amalia Library, Cod. Oct. 193. Image (c) Klassik Stiftung Weimar, HAAB, Signatur: Oct 193. OpenAccess: "All rights reserved."

Cover design: Coördesign, Leiden Lay-out: Crius Group, Hulshout
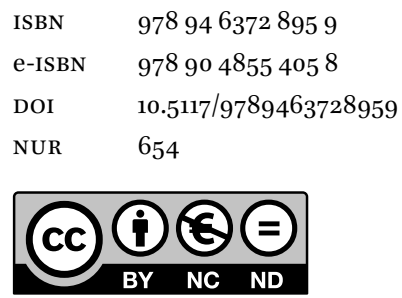

Creative Commons License CC BY NC ND

(http://creativecommons.org/licenses/by-nc/3.o)

@ The authors / Amsterdam University Press B.V., Amsterdam 2021

All rights reserved. Without limiting the rights under copyright reserved above, no part of this book may be reproduced, stored in or introduced into a retrieval system, or transmitted, in any form or by any means (electronic, mechanical, photocopying, recording or otherwise) without the written permission of both the copyright owner and the authors of the book.

Every effort has been made to obtain permission to use all copyrighted illustrations reproduced in this book. Nonetheless, whosoever believes to have rights to this material is advised to contact the publisher. 


\section{Table of Contents}

$\begin{array}{ll}\text { List of Illustrations } & 7\end{array}$

$\begin{array}{ll}\text { Acknowledgements } & 21\end{array}$

Introduction: Materializing Identities: The Affective Values of Matter in

Early Modern Europe

Susanna Burghartz, Lucas Burkart, Christine Göttler, and Ulinka Rublack

\section{Part 1 Glass}

1. Negotiating the Pleasure of Glass: Production, Consumption, and Affective Regimes in Renaissance Venice

Lucas Burkart

2. Shaping Identity through Glass in Renaissance Venice

Rachele Scuro

\section{Part 2 Feathers}

3. Making Featherwork in Early Modern Europe

Stefan Han $\beta$

4. Performing America: Featherwork and Affective Politics Ulinka Rublack

\section{Part 3 Gold Paint}

5. Yellow, Vermilion, and Gold: Colour in Karel van Mander's

Schilder-Boeck

Christine Göttler 
6. Shimmering Virtue: Joris Hoefnagel and the Uses of Shell Gold in the Early Modern Period

Michèle Seehafer

\section{Part 4 Veils}

7. "Fashioned with Marvellous Skill": Veils and the Costume Books of Sixteenth-Century Europe

Katherine Bond

8. Moral Materials: Veiling in Early Modern Protestant Cities. The Cases of Basel and Zurich

Susanna Burghartz

Index 


\section{List of Illustrations}

Figure 0.1 Hieronymus Francken II and Jan Brueghel the Elder (attributed to), Archduke Albert and Archduchess Isabella visiting the Collection of Pierre Roose, ca. 1621-1623. Oil on panel, $94.0 \times 123.3 \mathrm{~cm}$, detail. Baltimore, Walters Art Gallery, inv. no. 37.2010. Image (C) The Walters Art Museum, Baltimore. $\quad 25$

Figure 0.2 Glass bowl, Murano, around 1500. D: $25.50 \mathrm{~cm}, \mathrm{H}: 7.0 \mathrm{~cm}$. London, British Museum, museum number: S.375. Image (C) The Trustees of the British Museum.

Figure $0.3 \quad J$ Jean Jacques Boissard, Gentil' donne venetiane/ Quando portano bruno et Vedoé, costume book [Trachtenbuch] for Johann Jakob Fugger, 1559, fol. 63. Pen and ink drawing. Herzogin Anna Amalia Library, Cod. Oct. 193. Image (c) Klassik Stiftung Weimar.

Figure $0.4 \quad$ High felt hat with silk pile and ostrich feathers, of the kind sourced by Hans Fugger during the second half of the sixteenth century. $\mathrm{H}: \mathbf{2 2 . 5} \mathrm{cm}$. Nuremberg, German National Museum. Image (c) Germanisches Nationalmuseum, Nürnberg. Photo: M. Runge.

Figure 0.5 Karel van Mander, Before the Flood, 16oo. Oil on copper, $31.1 \times 15.6 \mathrm{~cm}$. Frankfurt am Main, Städel Museum, inv. no. 2088. Image (C) Städel Museum. Photo: U. Edelmann / Artothek.

Figure 1.1 Trading route through Eastern Mediterranean Sea taken by Santa Maria delle Grazie in 1590. Image (C) Nicolai Kölmel. 60

Figure 1.2 Cargo list of Santa Maria delle Grazie. Fol. 3v. Venice, Archivio di Stato di Venezia, Miscellanea Gregolin, shelf no. b. 14, reg. D. Image (c) Archivio di Stato di Venezia.

Figure 1.3 Bunch of red enamelled seed beads, around 1800. D: 0.5 $\mathrm{mm}$, Venice or Murano, Private Collection. Image (C) Julia Burkart.

Figure 1.4 Map of the Dalmatian Coast with locations of Gnalič and Koločep shipwrecks. Image (C) Nicolai Kölmel.

Figure 1.5 Window panes from the Gnalič shipwreck with straw, which served as protection against breaking during transport, end of the sixteenth century. Murano, D: $21 \mathrm{~cm}$. Biograd na Moru, Zavičajni Muzej Biograd na Moru, inv. no. G42. Image (C) Ivana Asić. 
Figure 1.6 Glass beads from the Gnalič shipwreck, end of the sixteenth century. Murano, L: 0.4-0.9 cm. Biograd na Moru, Zavičajni Muzej Biograd na Moru, inv. no. G250. Image $\odot$ Ivana Asić.

Figure 1.7 Ewer of chalcedony glass, ca. 1500-1525. Blown, with added spout, handle and foot from Murano, $30.5 \mathrm{~cm} \times 19.5$ $\mathrm{cm}$ max. London, Victoria and Albert Museum, inv. no. 1828-18255. Image (c) Victoria and Albert Museum, London.

Figure 1.8 The Rothschild Bowl, 1500-1510. Lattimo with colour enamelling. Murano, H: $5.9 \mathrm{~cm}$, Rim D: $14.1 \mathrm{~cm}$, Foot D: $6.3 \mathrm{~cm}$. Corning, NY, The Corning Museum of Glass, inv. no. 76.3.17. Image $\odot$ The Corning Museum of Glass.

Figure 1.9 Three steps of replicating/blowing a goblet and the corresponding original three-bubble goblet, ca. 1550. Murano, H: $16.6 \mathrm{~cm}$, Rim D: $10.3 \mathrm{~cm}$, Foot D: $8.5 \mathrm{~cm}$. Corning, NY, The Corning Museum of Glass, inv. no. 68.3.64. Images (c) Courtesy of The Corning Museum of Glass.

Paolo Veronese, The Wedding Feast at Cana, 1563. Oil on canvas, $677 \times 994 \mathrm{~cm}$. Image @ RMN-Grand Palais (musée du Louvre) / Michel Urtado.

Figure 1.10

Figure 1.11 Venetian crystal goblet, end of sixteenth century. H: 14.6 $\mathrm{cm}$. Murano, Museo del vetro, inv. no. Cl. VI n. 01092. Image (C) Photo Archive - Fondazione Musei Civici di Venezia.

Figure 1.12 Paolo Veronese, The Wedding Feast at Cana, detail of Fig. 1.10: A young man contemplating the transparency of an elevated crystal goblet filled with water transformed into wine.

Figure 1.13 Titian, Pietro Aretino, ca. 1537. Oil on canvas, 102.0 × 85.7 $\mathrm{cm}$. New York, Frick Collection, Henry Clay Frick Bequest, inv. no. 1905.1.115. Image ( ) The Frick Collection.

Figure 1.14 Glass dildo found in Trier, first half of the sixteenth century. L: $17.5 \mathrm{~cm}$, Shaft D: ca. $4 \mathrm{~cm}$. Trier, Rheinisches Landesmuseum Trier, inv. no. GG 735; 1910,645. Image (c) GDKE/Rheinisches Landesmuseum Trier / Thomas Zühmer.

Figure 1.15 Glass dildo from Flanders or Italy, first half of the seventeenth century. L: $26.5 \mathrm{~cm}$. Paris, Musée de Cluny, Musée national du Moyen Âge, inv. no. NNI619. Image (C) RMN-Grand Palais (musée de Cluny - musée national du Moyen Âge) / Franck Raux. 
Figure 1.16 Marcantonio Raimondi, Woman with a Dildo, ca. 1525.

Engraving $14.1 \times 7.0 \mathrm{~cm}$. Stockholm, Nationalmuseum, inv. no. NMG B 1169/199o. Image (C) Cecilia Heisser / Nationalmuseum.

Figure 1.17 Plate with a Woman and a Basket of 'Fruits', ca. 1530. Tinglazed earthenware (maiolica), D: $34.5 \mathrm{~cm}$. Paris, Musée du Louvre, inv. no. O.A. 1256. Image (C) RMN-Grand Palais (musée du Louvre) / Stéphane Maréchalle.

Figure 2.1 Jacopo de Barbari, View of Venice, 1500. Woodcut, detail: The island of Murano. In the lower part, crossed by three bridges, is the canal called the "rio dei verieri" with its workshops overlooking the two quays. Venice, Museo Correr, inv. Cl. XLIV n. 0057. Image 2020 (C) Photo Archive - Fondazione Musei Civici di Venezia.

Figure 2.2 Giuseppe Maria Mitelli, Fornace da vetri, 1698. Etching, $211 \times 311 \mathrm{~cm}$. Milan, Castello Sforzesco, inv. no. RM m. 2-1. Image (C) Civica Raccolta delle Stampe Achille Bertarelli Castello Sforzesco - Milano.

Figure 2.3 Blown colourless glass beaker, seventeenth century. H: 8.6 $\mathrm{cm}$, Rim D: $7.2 \mathrm{~cm}$. Corning, NY, The Corning Museum of Glass, inv. no. 2009.3.89. Image (c) The Corning Museum of Glass.

Figure 2.4 Albrecht Dürer, Saint Jerome in His Study, 1514. Engraving, $25 \times 20 \mathrm{~cm}$. Karlsruhe, Staatliche Kunsthalle, inv. no. I 834. Image (C) Staatliche Kunsthalle Karlsruhe.

Figure 2.5 Diamond-engraved glass dish, with opaque white threads, cold-painted and gilded, ca. $1560 \mathrm{~s}$. W: $27.0 \mathrm{~cm}$ max.

London, Victoria and Albert Museum, inv. no. C.178-1936. Image (C) Victoria and Albert Museum, London.

Figure 2.6 Ewer of filigree glass ("a retortoli" and "a fili"), ca. 1575-1600. H: $11.5 \mathrm{~cm}, \mathrm{~W}: 9.0 \mathrm{~cm}$ max. London, Victoria and Albert Museum, inv. no. 1914A-1855. Image (C) Victoria and Albert Museum, London.

Figure 2.7 Reticello goblet, ca. 1575-1600. H: $30.5 \mathrm{~cm}, \mathrm{~W}: 15.3 \mathrm{~cm}$. London, Victoria and Albert Museum, inv. no. 1816-1855. Image (C) Victoria and Albert Museum, London.

Figure 2.8 Ice glass aspersorium, seventeenth century. $\mathrm{H}: 11.4 \mathrm{~cm}, \mathrm{~W}$ : $16.8 \mathrm{~cm}$, D: $13.9 \mathrm{~cm}$. Corning, NY, The Corning Museum of Glass, inv. no. 2000.3.5. Image (C) The Corning Museum of Glass. 
Figure 2.9 Scheme of the relations existing among the members of the Bortolussi family (in grey) and their relatives. The model depicts only the individuals mentioned in the chapter, and not the full family tree. Image (C) Rachele Scuro. 123

Figure 3.1 Unknown artist, Nuremberg feather-worker Johann Wurmbein. Water colours and tempera on paper, $226 \times 166$ mm. In Hausbuch der Mendelschen Zwölfbrüderstiftung, 1667 , fol. 151v. Nuremberg, Stadtbibliothek im Bildungscampus Nürnberg, Amb.317b.2 $2^{\circ}$ f.151v. Image (C) Stadtbibliothek im Bildungscampus Nürnberg.

Figure 3.2 Unknown artist (Nicolas de Larmessin II?), French feather-worker advertising his products, after 1695. Print, $277 \times 185 \mathrm{~mm}$. France, Musée Carnavalet Paris, shelf no. G.5067. Image (c) Musée Carnavalet / Roger-Viollet.

Figure $3 \cdot 3$ Unknown artist, "Plumassier panachier." Engraving, $418 \times 267 \mathrm{~mm}$. In Denis Diderot and Jean-Baptiste le Rond d'Alembert, Encyclopédie, vol. 8, Paris: Briasson etc., 1771, plate II. Cambridge, Library of St John's College, Kk.7.59. Image (C) By permission of the Master and Fellows of St John's College, Cambridge.

Figure 3.4 German hat with partially destroyed ostrich feathers, late sixteenth century. Felt, woven silk satin, and ostrich feathers, c. $170 \times 290 \times 280 \mathrm{~mm}$. Hannover, Historisches Museum Hannover, inv. no. L 1436. Image (C) Historisches Museum Hannover. Photo: Reinhard Gottschalk.

Figure 3.5 Cartouche used to attach panaches onto a leather hat, ca. 16oo. Leather, starched parchment, animal hair, and threads, $268 \mathrm{~mm}$ diameter and $190 \mathrm{~mm}$ height of the entire hat. Nuremberg, Germanisches Nationalmuseum, inv. no. T1593. Image (C) Germanisches Nationalmuseum, Nürnberg. Photo: Petra Kreß.

Figure 3.6 Lucas Cranach the Elder, Portrait ofJohn Frederick I, Elector of Saxony, unknown date. Oil on panel, $628 \times 397 \mathrm{~mm}$. Private collection. Image (C) Christie's Images/Bridgeman Images.

Figure 3.7 The feather-beret of Christoph Kress zu Kressenstein, 1530. Silk satin, ostrich feathers, wires and spangles, $55^{\circ}$ mm diameter. Nuremberg, Germanisches Nationalmuseum, inv. no. T3784. Image (c) Germanisches Nationalmuseum, Nürnberg. Photo: Monika Runge. 
Figure 3.8 Niklaus Manuel, Back View of a Confederate, 1514-1515. Ink drawing, $272 \times 191 \mathrm{~mm}$. Bern, Graphische Sammlung, Kunstmuseum Bern, inv. no. A1979.100. Image @ KMBern. $\quad{ }_{158}^{8}$

Figure 3.9 Urs Graf, Mercenary's Feather Costume, 1523. Ink drawing, $215 \times 153$ mm. Basel, Kunstmuseum Basel, U.X.95. Image (C) Bilddaten gemeinfrei Kunstmuseum Basel.

Figure 3.10 Unknown artist, "Plumassier panachier": A Parisian feather-workshop and some of its instruments. Engraving, $418 \times 267 \mathrm{~mm}$. In Denis Diderot and Jean-Baptiste le Rond d'Alembert, Encyclopédie, vol. 8, Paris: Briasson etc., 1771, plate 1. Cambridge, Library of St John's College, Kk.7.59. Image (C) By permission of the Master and Fellows of St John's College, Cambridge.

Figure 3.11 Carving ostrich feathers while remaking feather-work at The School of Historical Dress in London. Image (C) Stefan Hanß.

Figure 3.12 Dyed blue and yellow ostrich feathers sewn together at The School of Historical Dress London. Image @ Stefan Hanß.

Figure 3.13 George Gower, Queen Elizabeth I, ca. 1588. Oil on canvas, $1010 \times 978 \mathrm{~mm}$. The Leicester Galleries, no signature. Image $($ ) The Leicester Galleries.

Figure 3.14 The Messel feather fan. South American and Dutch origin, ca. 1665 . Feathers on woven panels, $340 \times 230 \mathrm{~mm}$. Cambridge, Fitzwilliam Museum, inv. no. M.358-1985. Image (c) The Fitzwilliam Museum, Cambridge.

Figures 3.15a-b The Messel feather fan. South American and Dutch origin, ca. 1665, detail of Fig. 3.14. Detail: Showing vibrantly coloured feather mosaics of flowers. Dino-Lite USB microscope AM7013MZT. Image @ Stefan Hanß.

Figure 4.1 Procession at the Württemberg Court in Stuttgart, 1599: The sixth scene with Duke Frederick as Lady America. Watercolour, pigment, and gold on paper, $29.9 \times 53.3$ $\mathrm{cm}$. Weimar, Graphische Sammlungen, Klassik Stiftung Weimar, inv. no. KK 207. Image @ Stiftung Weimarer Klassik und Kunstsammlungen/Museen. Photo: Roland Dreßler.

Figure 4.2 Theodor de Bry after Jacques le Moyne de Morgues, The queen-elect is brought to the king. Engraving. In Theodor de Bry, Der ander Theyl, der newlich erfundenen 
Landtschafft Americce, Frankfurt am Main: Johann Feyerabendt, 1591, Plate XXXVII. Universitäts-Bibliothek Heidelberg. Image (c) Universitäts-Bibliothek Heidelberg.

Figure 4.3 Red and Yellow Feather Aztec / Mexica Warrior Shield. Stuttgart, Landesmuseum. Image (c) Landesmuseum Württemberg, Hendrik Zwietasch. 195

Figure 4.4 Procession at the Württemberg Court in Stuttgart, 1599: The second scene. Watercolour, pigment, and gold on paper, $30.5 \times 49.8 \mathrm{~cm}$. Weimar, Graphische Sammlungen, Klassik Stiftung Weimar, inv. no. KK 203. Image (C) Stiftung Weimarer Klassik und Kunstsammlungen/Museen. Photo: Roland Dreßler.

Figure 4.5 Procession at the Württemberg Court in Stuttgart, 1599: The third scene. Watercolour, pigment, and gold on paper, $29.9 \times 45.5 \mathrm{~cm}$. Weimar, Graphische Sammlungen, Klassik Stiftung Weimar, inv. no. KK 204. Image (C) Stiftung Weimarer Klassik und Kunstsammlungen/Museen. Photo: Roland Dreßler.

Figure 4.6 Procession at the Württemberg Court in Stuttgart, 1599: The fourth scene. Watercolour, pigment, and gold on paper, $29.8 \times 41.0 \mathrm{~cm}$. Weimar, Graphische Sammlungen, Klassik Stiftung Weimar, inv. no. KK 205. Image (C) Stiftung Weimarer Klassik und Kunstsammlungen/Museen. Photo: Roland Dreßler.

Figure 4.7 Procession at the Württemberg Court in Stuttgart, 1599: The seventh scene. Watercolour, pigment, and gold on paper, $29.8 \times 42.0 \mathrm{~cm}$. Weimar, Graphische Sammlungen, Klassik Stiftung Weimar, inv. no. KK 208. Image (C) Stiftung Weimarer Klassik und Kunstsammlungen/Museen. Photo: Roland Dreßler.

Figure 4.8 Costume image of an Ottoman soldier with a striking feather-headdress. Gouache and brown ink on paper, $15.5 \times 11.5 \mathrm{~cm}$. In album amicorum of Bernardus Paludanus, 1575-1630, fol. 294r. The Hague, Koninklijke Bibliotheek, shelf no. 133 M 63. Image (c) KB | National library.

Figure 4.9 Procession at the Württemberg Court in Stuttgart, 1599: The final scene. Watercolour, pigment, and gold on paper, $29.6 \times 38.6 \mathrm{~cm}$. Weimar, Graphische Sammlungen, Klassik Stiftung Weimar, inv. no. KK 209. Image (C) Stiftung 
Weimarer Klassik und Kunstsammlungen/Museen.

Photo: Roland Dreßler.

Figure 4.10 Procession at the Württemberg Court in Stuttgart, 1599:

The fifth scene. Watercolour, pigment, and gold on paper, $30.0 \times 50.9 \mathrm{~cm}$. Weimar, Graphische Sammlungen, Klassik Stiftung Weimar, inv. no. KK 206. Image (c) Stiftung Weimarer Klassik und Kunstsammlungen/Museen. Photo: Roland Dreßler.

Figure 5.1 Karel van Mander, Emblematic Depiction, 1600 (reverse of Fig. 0.5 - see the "Introduction" to this volume). Oil on copper, $31.1 \times 15.6 \mathrm{~cm}$. Frankfurt am Main, Städel Museum, inv. no. 2088. Image $@$ Städel Museum. Photo: U. Edelmann / Artothek.

Figure 5.2 Karel van Mander, The Continence of Scipio, 1600. Oil on copper, $44 \times 79 \mathrm{~cm}$. Amsterdam, Rijksmuseum, inv. no. SK-A-469o. Image (c) Rijksmuseum.

Figure 5.3 Karel van Mander, Allegory of Nature, 1600 (reverse of Fig. 5.2). Oil on copper, $44 \times 79 \mathrm{~cm}$. Amsterdam, Rijksmuseum, inv. no. SK-A-469o. Image $\odot$ Rijksmuseum.

Figures 5.4a-c Karel van Mander, Allegory of Nature, details of Fig. 5.3: Painted imitation of red-veined stone to the left (Fig. 5.4a) and the right (Figs. 5.4b and c) of the central scene with traces of fingerprints. Photo: Private archive.

Figure 5.5 Rembrandt, Belshazzar's Feast, about 1636-38. Canvas, $167.6 \times 209.2 \mathrm{~cm}$. London, The National Gallery, NG 6350 . Image (c) The National Gallery, London.

Figure 5.6 Rembrandt, Belshazzar's Feast, detail of Fig. 5.5: Both the gold lettering and the light yellow accents on the embroidery were made with lead-tin yellow.

Figure 5.7 Hendrick Goltzius, Without Ceres and Bacchus, Venus Would Freeze (Sine Cerere et Libero friget Venus), 1599-1602. Pen and brown ink, brush and oil, on bluegrey prepared canvas, $105.1 \times 80.0 \mathrm{~cm}$. Philadelphia, Philadelphia Museum of Art, inv. no. 1990-100-1. Image (c) Philadelphia Museum of Art. Purchased: The Mr. and Mrs. Walter H. Annenberg Fund for Major Acquisitions, the Henry P. Mcllhenny Fund in memory of Frances P. McIlhenny, and other Museum funds.

Figure 5.8 Hendrick Goltzius, "Eer boven Gold" (Honour above gold), 1600 . Pen in brown ink, $18.4 \times 12.4 \mathrm{~cm}$. Vienna, The 
Albertina Museum, inv. no. 8076. Image (c) The Albertina Museum. 265

Figure 5.9 The emblems of the painterly arts, painted or carved by Peter Paul Rubens on a spandrel of his garden loggia. Detail from: Jacobus Harrewijn after Jacques van Croes, View of the Garden of the Rubenshuis, 1692. Engraving. Antwerp, Museum Plantin-Moretus, inv. no. PK.OP.17875. Image (c) Collectie Stad Antwerpen, Museum Plantin-Moretus. 266

Figure 5.10 Mercury with maulstick on top of the garden screen. Detail from Jacobus Harrewijn after Jacques van Croes, View of the Courtyard of the Rubenshuis. Engraving. Antwerp, Museum Plantin-Moretus, inv. no. PK.OP.17876. Image (C) Collectie Stad Antwerpen, Museum Plantin-Moretus. 266

Figure 5.11 Hendrick Goltzius, Mercury, 1611. Oil on canvas, $214 \times 120$ $\mathrm{cm}$. Haarlem, Frans Hals Museum, on long-term loan from the Royal Cabinet of Paintings, Mauritshuis, The Hague, inv. no. 44. Image ( $)$ Frans Hals Museum, photo: René Gerritsen.

Figure 5.12 Hendrick Goltzius, Mercury, detail of Fig. 5.11: Full of wit and sexual innuendo, the detail playfully alludes to the potency of Goltzius's brushwork.

Figure 5.13 Hendrick Goltzius, Allegory of the Arts, 1611. Oil on canvas, $181.0 \times 256.8 \mathrm{~cm}$. Basel, Kunstmuseum Basel, BirmannSammlung 1859, inv. no. 252. Image (C) Kunstmuseum Basel. 269

Figure 5.14 Hendrick Goltzius, Allegory of the Arts, detail of Fig. 5.13: Golden caduceus escaping from the furnace held by the Venus-like figure.

Figure 5.15 Hendrick Goltzius, Allegory of the Arts, detail of Fig. 5.13: An alchemist's alembic and the painter's palette. 270

Figure 6.1 Joris Hoefnagel, Allegory of the Rule of Duke Albert Vof Bavaria, 1579. Gouache on parchment, $23.5 \times 18.0 \mathrm{~cm}$. Berlin, Kupferstichkabinett der Staatlichen Museen Berlin, inv. no. KdZ 4804. Image @ Kupferstichkabinett, Staatliche Museen Berlin.

Figure 6.2 Joris Hoefnagel, Allegory of the Rule of Duke Albert V, detail of Fig. 6.1: Panoramic view of Landshut and inscription.

Figure 6.3 Joris Hoefnagel, Allegory of the Rule of Duke Albert V, detail of Fig. 6.1: Central part of the composition with two nymphs. 
Figure 6.4 Joris Hoefnagel, Allegory of the Rule of Duke Albert $V$, detail of Fig. 6.1: Golden initial of Albert V, the ducal hat, and the two double-headed eagles.

292

Figure 6.5 Joris Hoefnagel, Allegory of the Rule of Duke Albert $V$, detail of Fig. 6.1: Signum showing a lion protecting a lamb. 294

Figure 6.6 Joris Hoefnagel, Allegory of the Rule of Duke Albert $V$, detail of Fig. 6.1: Shield showing Hercules fighting the Nemean lion.

Figure 6.7 Joris Hoefnagel, Allegory of the Rule of Duke Albert $V$, detail of Fig. 6.1: The honouring of the musical arts.

Figure 6.8 Joris Hoefnagel, Allegory of the Rule of Duke Albert $V$, detail of Fig. 6.1: The honouring of the visual arts. 296

Figure 6.9 Joris Hoefnagel, Allegory for Abraham Ortelius, 1593. Pen and black ink and gouache, heightened with gold on parchment, $11.8 \times 16.5 \mathrm{~cm}$. Antwerp, Museum PlantinMoretus, Prentenkabinet, inv. no. PK.OT.00535. Image (c) Collectie Stad Antwerpen, Museum Plantin-Moretus.

Figure 6.10 Joris Hoefnagel, Allegory for Abraham Ortelius, detail of Fig. 6.9: Sea shells serving as containers for various pigments.

Figure 6.11 Joris Hoefnagel, Allegory for Abraham Ortelius, detail of Fig. 6.9: The owl holding a caduceus with a brush as its central staff.

Figure 6.12 Photograph from the reconstruction of the recipe of the Liber illuministarum, showing the grey granular mass after grinding. Image (c) Michèle Seehafer.

Figure 6.13 Photograph from the reconstruction of the recipe of the Liber illuministarum, showing the pouring off of the water from the mussel shell. Image (c) Franca Mader.

Figure 6.14 Photograph from the reconstruction of the recipe of the Kunstbüchlin, showing the mixture of gold leaf, sea salt, honey, and "ayr weyß." Image @ Michèle Seehafer.

Figure 6.15 Photograph of reconstructed shell-gold paint (nos. 1-3 from the reconstruction of the recipe of the Liber illuministarum and $5^{-6}$ from the reconstruction of the recipe of the Kunstbüchlin) and modern pearlescent pigments (no. 4). Image (c) Michèle Seehafer.

Figure 6.16 Joris Hoefnagel, Guide for Constructing the Ligature ffi, 1591-1596. Watercolours, gold and silver paint, and ink on parchment, $16.6 \times 12.4 \mathrm{~cm}$ (sheet). In Joris Hoefnagel and 
Georg Bocskay, Mira calligraphiae monumenta, 1561-1562 and 1591-1596, fol. 151v, detail: Painting tools. Los Angeles, J. Paul Getty Museum, shelf. no. Ms. 20 (86.MV.527). Image (C) Digital image courtesy of the Getty's Open Content Program / J. Paul Getty Museum, Los Angeles.

Figure 7.1 Cesare Vecellio, Gentildonne ne' Regimenti. Woodcut, $16.7 \times 12.5 \mathrm{~cm}$. In Cesare Vecellio, Degli habiti antichi, et moderni di diverse parti del mondo, Venice: Damian Zenaro, 1590, plate 135. Gentlewomen in Venetian Outposts and Territories. Düsseldorf, Universitäts- und Landesbibliothek Düsseldorf, inv. no. $\mathrm{H}_{32}$. Image (C) Universitäts- und Landesbibliothek Düsseldorf.

Figure 7.2 Jean Jacques Boissard, Women of Padua. Engraving on paper, $27.9 \times 76.5 \mathrm{~cm}$. In Habitus variarum orbis gentium. Habitz de nations estranges. Trachten mancherley Völcker des Erdskreytz, Mechelen: Caspar Rutz, 1581, fol. 15. Paris, Bibliothèque nationale de France, inv. no. 4-OB-25. Image (C) Bibliothèque nationale de France.

Figure 7.3 Cesare Vecellio, Citelle Nobili. Woodcut, $16.7 \times 12.5 \mathrm{~cm}$. In Cesare Vecellio, Degli habiti antichi, et moderni di diverse parti del mondo, Venice: Damian Zenaro, 1590, plate 199. Noble Girls of Bologna Going from Home to Church. Düsseldorf, Universitäts- und Landesbibliothek Düsseldorf, inv. no. $\mathrm{H}_{32}$. Image (C) Universitäts- und Landesbibliothek Düsseldorf.

Figure 7.4 (After Jean Jacques Boissard), Venetian Gentlewomen. Gouache on paper. In Trachtenbuch. Darinen viller Volckher unnd Nationen Klaidung [...], 1580, ill. 55. Berlin, Lipperheidesche Kostümbibliothek, inv. no. Lipp Aa 20. Image (C) Lipperheidesche Kostümbibliothek.

Figure 7.5 Cesare Vecellio, Donzelle. Woodcut, $16.7 \times 12.5 \mathrm{~cm}$. In Cesare Vecellio, Degli habiti antichi, et moderni di diverse parti del mondo, Venice: Damian Zenaro, 1590, plate 125. Maidens and Girls of Venice. Düsseldorf, Universitätsund Landesbibliothek Düsseldorf, inv. no. $\mathrm{H}_{32}$. Image (C) Universitäts- und Landesbibliothek Düsseldorf. Cesare Vecellio, Donzelle Contadine. Woodcut, $16.7 \times 12.5$ cm. In Cesare Vecellio, Degli habiti antichi, et moderni di diverse parti del mondo, Venice: Damian Zenaro, 1590, plate 192. Girls of the Peasantry and Artisan Class in Parma. Düsseldorf, Universitäts- und Landesbibliothek

Figure 7.6 
Düsseldorf, inv. no. $\mathrm{H}_{32}$. Image (C) Universitäts- und Landesbibliothek Düsseldorf.

Figure 7.7 Cesare Vecellio, Matrone Vedove Moderne. Woodcut, $16.7 \times 12.5 \mathrm{~cm}$. In Cesare Vecellio, Degli habiti antichi, et moderni di diverse parti del mondo, Venice: Damian Zenaro, 1590, plate 29. Noble Widows of Modern Rome. Düsseldorf, Universitäts- und Landesbibliothek Düsseldorf, inv. no. $\mathrm{H}_{32}$. Image (C) Universitäts- und Landesbibliothek Düsseldorf.

Figure 7.8 Jean Jacques Boissard, Women of Verdun. Engraving on paper, $27.9 \times 76.5 \mathrm{~cm}$. In Habitus variarum orbis gentium. Habitz de nations estranges. Trachten mancherley Völcker des Erdskreytz, 1581, fol. 31. Paris, Bibliothèque nationale de France, inv. no. 4-OB-25. Image (C) Bibliothèque nationale de France.

Figure 7.9 Woman of San Sebastián. Pen and ink, gouache, watercolour, and gold on paper. In Costumes de femmes de diverses contrées, sixteenth century, ill. 24. Paris, Bibliothèque nationale de France, inv. no. RESERVE 4-OB-23. Image (C) Bibliothèque nationale de France.

Figure 7.10 Women from Astorga, Spain. Pen, ink, and gouache on paper, $20 \times 20 \mathrm{~cm}$. In Códice de Trajes, ca. 1550, ill. 19 . Madrid, Biblioteca Nacional de España, inv. no. Res/285. Image (C) Biblioteca Nacional de España.

Figure 7.11 Woman from Saint-Jean-Pied-de-Port. Pen, ink, and gouache on paper. In Recueil. Costumes de Femmes de diverses contrées, late fifteenth century, ill. 19. Paris, Bibliothèque nationale de France, inv. no. RESERVE OB-55-4. Image (C) Bibliothèque nationale de France.

Figure 7.12 Christoph Weiditz, Wealthy Women in Biscay. Pen and gouache, gold and silver, $15 \times 20 \mathrm{~cm}$. In Christoph Weiditz, Trachtenbuch, Augsburg, 1530-1540, ill. 121. Nuremberg, Germanisches Nationalmuseum, inv. no. Hs 22474. Image (C) Germanisches Nationalmuseum.

Figure 8.1 Albrecht Dürer, A Woman of Nuremberg Dressed for Church, 1500. Pen in black-grey ink and watercolour, $32.0 \times 20.4 \mathrm{~cm}$. Vienna, The Albertina Museum, inv. no. 3069. Image (C) The Albertina Museum, Vienna.

Figure 8.2 Albrecht Dürer, Women of Nuremberg and Venice, ca. 1495. Pen in dark-grey brown ink on paper, $24.5 \times 15.9 \mathrm{~cm}$. 
Frankfurt am Main, Graphische Sammlung Städelsches Kunstinstitut, inv. no. 696. Image (C) bpk / Städel Museum / Ursula Edelmann.

Figure 8.3 Hans Holbein the Younger, $A$ Woman of Basel Turned to the Right, ca. 1523. Pen and brush in black ink, grey wash, $29.0 \times 19.7 \mathrm{~cm}$. Basel, Kupferstichkabinett, AmerbachKabinett 1662, Kunstmuseum Basel, inv. no. 1662.142. Image (C) Kunstmuseum Basel.

Figure 8.4 Hans Holbein the Younger. Madonna des Bürgermeisters Jakob Meyer zum Hasen ('Schutzmantelmadonna'), $1525 / 26$ and 1528 . Oil on limewood, $146.5 \times 102.0 \mathrm{~cm}$, detail: At left Magdalena Bär, late wife of Jakob Meyer zum Hasen, at right Dorothea Kannengiesser, second wife of Jakob Meyer zum Hasen and daughter Anna. Sammlung Würth, inv. no. 14910. Image (C) Sammlung Würth. Photo: Philipp Schönborn, München.

Figure 8.5 Falkner Stammbücher I-IV (details). Image (C) Falkner

Stammbuch I: Basel, Historisches Museum Basel, inv. no. 1887.159; Falkner Stammbuch II: Basel, Historisches Museum Basel, inv. no. 1984.279; Falkner Stammbuch III: Basel, Staatsarchiv Basel, PA 445a 2; Falkner Stammbuch IV: Basel, Historisches Museum Basel, inv. no. 1916.94.

Figure 8.6 Noble and burgher women wearing veils and chin-cloths, in Johan Carolus, Evidens Designatio, Strasbourg 16o6, from left: plate 49: Nobilis Foemina vestitu in Luctu; plate 53: Foemina Argentinensis pulla veste induta; plate 42: Foemina mediocris conditionis ad sacra se conferens. Image (C) Universitäts- und Landesbibliothek SachsenAnhalt, Halle, Saale, urn:nbn:de:gbv:3:3-7713.

Figure 8.7a Hans Heinrich Glaser, A Woman Wearing Mourning Dress for her Husband. Etching. In Hans Heinrich Glaser, 'Habitus solennes hodie Basiliensibus ...', $10.4 \times 6.1 \mathrm{~cm}, \mathrm{Ba}-$ sel, 1624. Historisches Museum Basel, inv. no. 1983.641.31. Image (C) Historisches Museum Basel; 8.7b: Hans Heinrich Glaser, Honourable Women Going Home Together. Etching. In Hans Heinrich Glaser, Basler Kleidung aller hoh- und nidriger Standts-Personen, Basel: Hans Heinrich Glaser, 1634, plate 40. Basel, Universitätsbibliothek Basel, Falk 1464. Image (C) Universitätsbibliothek Basel. 
Figure 8.8a Johann Rudolf Huber, Basler Trachten von Anno 1700, Nr. 13: Woman Wearing the Sturz, ca. 1700. Pencil and crayon on paper, $31.9 \times 21.2 \mathrm{~cm}$. Kunst Museum Winterthur, Graphische Sammlung, Geschenk von Johann Rudolf Schellenberg d.J., 1849; Photo: Susanna Burghartz; 8.8b: Anna Magdalena de Beyer after Barbara WentzMeyer, Woman Dressed for Church Wearing Sturz and Tüchli. Etching, $19.2 \times 14.9 \mathrm{~cm}$. In Eigentliche Vorstellung Der Kleider Tracht Lob, Basel: Anna Magdalena de Beyer, ca. 1700. Basel, Historisches Museum Basel, inv. no. 1987.701. Image (C) Historisches Museum Basel.

Figure 8.9a Anna Waser, Portrait of Regula Escher-Werdmüller, Wife of Mayor Heinrich Escher, 1690 . Oil on canvas, $25.7 \times 22.0$ $\mathrm{cm}$. Zurich, Zentralbibliothek Zurich, inv. no. 378. Image

(C) Zentralbibliothek Zürich, Graphische Sammlung und Fotoarchiv; 8.9b: Anonymous, Portrait of Catharina Hirzel-Orelli, about 166o-1670. Oil on canvas, 91.5 × 75.5 $\mathrm{cm}$. Schweizerisches Nationalmuseum, IN-7170. Image (C) Schweizerisches Nationalmuseum.

Figure 8.10 David Herrliberger, Communion in the Zurich Fraumünster. Engraving. In David Herrliberger, Kurze Beschreibung der Gottesdienstlichen Gebräuche, Wie solche in der Reformirten Kirchen der Stadt und Landschaft Zürich begangen werden, Zurich: Daniel Eckenstein, 1751, plate VII/2. Zurich, Zentralbibliothek Zurich, shelf no. Res 11, 10.3931/e-rara-18198. Image (C) Zentralbibliothek Zurich.

Figure 8.11 Veil and bodice from the Gottenkleid of the Edlibach Family, 1600-170o. Zurich, Schweizerisches Nationalmuseum, inv. no. DEP-1008.7 + DEP-1008.1. Image (C) Schweizerisches Nationalmuseum.

Figure 8.12a-b Johann Andreas Pfeffel, Noblewoman in her church-wear, and Burgher woman in her church-wear. Engraving. In Johann Andreas Pfeffel, Schweizerisches Trachten-Cabinet, Augsburg, ca. 1750, plates 8 and 10. Schweizerische Nationalbibliothek Bern. Image (C) https://www.e-helvetica. nb.admin.ch/search?urn=nbdig-26228. 



\section{Acknowledgements}

This book results from crossovers, transgressions, and an unusually intensive research collaboration. We have deliberately positioned our project between two disciplines - history and art history - two countries - Switzerland and the United Kingdom - and two research cultures - universities and museums. It is only thanks to the Swiss National Science Foundation's special funding scheme "Money Follows Cooperation" that this collaboration and the whole project could take place so successfully. For this, we would like to express our sincere gratitude to the anonymous evaluators of our application who encouraged our research project with their comments.

Over a four-year period, we were able to come together as a research group in London, Cambridge, Bern, and Basel to discuss with colleagues and meet with curators.

Our site visits to the Fitzwilliam Museum and the Hamilton Kerr Institute in Cambridge, the Historical Museums in Bern and Basel, the Kunstmuseum Basel, the Museum der Kulturen Basel, the Swiss National Museum's Collections Centre in Affoltern, and the Abegg-Stiftung in Riggisberg allowed us the opportunity to discuss materials and techniques in relation to concrete objects in these collections, try out hands-on techniques, and explore new possibilities of digital microscopy.

Our special thanks go to the curators, conservators, and practitioners Vicky Avery, Bodo Brinkmann, Alexander Brust, Spike Bucklow, Hilary Davidson, Andrea Franzen, Anna Jolly, Susan Marti, Elke Mürau, Michael Peter, Margret Ribbert, Sabine Söll, Dora Thornton, and Evelin Wetter. They generously shared their time and knowledge, thus making possible a project that could not have happened without this communication across fields and disciplines.

As historians and art historians, we can mostly only grasp the materiality of things through written words or visual representations. Thanks to our site visits and collaborative practices, we were able to find new ways to integrate aspects of material culture as well as questions of materialized identity.

Finally, for publishing a book centring on the agency and allure of tangible material objects Amsterdam University Press provides a unique venue. We offer our very special thanks to Erika Gaffney, Senior Commissioning Editor, Early Modern History and Art History, for her enthusiastic support of our project from its very beginnings, and to Allison Levy, for accepting our book for publication in the series "Visual and Material Culture, 1300-1700," edited by her. We would also like to extend our thanks to the two anonymous reviewers for their encouragement and helpful advice. It is a pleasure to acknowledge the superb work of Jonathan Hoare who copy edited, proofread, and indexed our volume with commitment and 
professional expertise. At Amsterdam University Press, we express our gratitude to Chantal Nicolaes, Head of Desk Editing and Production, for her considerable efforts to publish this book in its best possible shape.

Last but not least, for their exceptional support and intellectual collegiality, we owe very special thanks to three pioneering women in the field of material culture studies: Marta Ajmar, Evelyn Welch, and Pamela H. Smith. 


\title{
Introduction: Materializing Identities: The Affective Values of Matter in Early Modern Europe
}

\author{
Susanna Burghartz, Lucas Burkart, Christine Göttler, and Ulinka \\ Rublack
}

In November 1575, the Augsburg merchant Hans Fugger was busy. He excitedly received two hundred loose, black ostrich feathers alongside two bound feather panaches in the "current Saxon manner" from Nuremberg and returned feathers to Munich as they were not up to date in style. Three months later, Fugger wrote to his Nuremberg agent about further fashionable new Saxon hats for his servants. He continued to inspect deliveries from Nuremberg to control their quality and sent patterns for hats he wanted to have made and accessorized. Each time he noted how much the feathers which adorned them pleased him. His esteem of feathers was no passing passion. In January 1578, Fugger noted the "incredibly beautiful and delicate" material of the new hats from Nuremberg. By 1585 , he went to even greater efforts to source eighty to one hundred "really long, delicate and beautiful" heron feathers from either Venice or Vienna, where they were traded via Constantinople and Hungary. ${ }^{1}$ Hans Fugger was one of many contemporaries deeply fascinated by the sensual qualities of materials. Fifty years later, Lewes Roberts told readers of his merchant's handbook that "All commodities are known by the senses." He added: "experience tells us that all commodities are not learned by one sense alone, though otherwise never so perfect; not yet by two, but sometimes by three, sometimes by foure, and sometimes by all.". During the same period, artists all over Europe strove

1 Die Korrespondenz Hans Fuggers von 1566 bis 1594. Regesten der Kopierbücher aus dem Fuggerarchiv, ed. Christl Karnehm, 3 vols. (Munich: Kommission für Bayerische Landesgeschichte, 2003), vol. 1, 589, 618, 702, 704, 708-709, 728, 781, 784, 1277, 179o; vol. 2, Part II, nos. 2694-2695, 2720, 2731.

2 Lewes Roberts, The Merchants Mappe of Commerce: Wherein, The Vniversall Manner and Matter of Trade, is compendiously handled (London: Ralph Mabb, 1638), 41. On Roberts see Thomas Leng, "Epistemology:

Burghartz, S., L. Burkart, C. Göttler, U. Rublack, Materialized Identities in Early Modern Culture, 1450-1750: Objects, Affects, Effects. Amsterdam: Amsterdam University Press, 2021 DOI 10.5117/9789463728959_INTRO 
to represent newly achieved qualities of transparency in glass, the translucency of veil fabrics, the vibrancy and shimmer of feathers, or the mystery of imitating and mimicking the lustre of gold and silver in painting. ${ }^{3}$ Artisans learned about innovative techniques, perfected their practical skills, and multiplied their offerings when dealing with materials from the New and Old Worlds to an unprecedented extent. Pursuing ingenious materials and fashions, consumers likewise cultivated new sensibilities for material qualities, which in turn stimulated their buying behaviour. Political and cultural elites engaged in practices of distinctive representation as well as competitive collecting. They furthermore involved themselves in intense debates on luxury and conspicuous consumption, worked out in an ever-growing discourse on materiality and its everyday use in a whole cluster of specific genres such as memoirs, mandates, drawings, paintings, and plays.

This book addresses the interest in the material world of the Renaissance and early modern period that fascinated contemporaries and has been richly explored in recent years. Our volume aims to be distinctive in three regards: it engages with the agentive qualities of matter and aims to show how affective dimensions in history connect with material history. Most importantly, it explores how the use of materials and artefacts interrelated with social, cultural, and religious identifications, which have so far been underexplored in regard to their affective valences and qualities. The book thus aims to refocus our understanding of the meaning of the material world in this period. Rather than reducing the importance of the material world solely to patterns of consumption through the social life of finished goods, we argue that it is important to address the vibrancy of matter itself, that is to say the ability of things to exceed their status as mute objects through their material properties, such as softness or translucency. ${ }^{4}$ Matter and materials interrelated

Expertise and Knowledge in the World of Commerce," in Mercantilism Reimagined: Political Economy in Early Modern Britain and Its Empire, ed. Philip J. Stern and Carl Wennerlind (New York: Oxford University Press, 2014), 97-113, here 101-102. For the intersection of commerce, knowledge and the senses see esp. Susanne Friedrich, "Unter Einsatz aller Sinne. Zum ökonomischen Blick und dem Sammeln von Wissen in der Frühphase der niederländischen Ostindienkompanie (1602-ca. 1650)," Historische Anthropologie 28, no. 3 (2020): 379-398.

3 Recent literature on the allure of shiny and translucent surfaces: Marta Ajmar, "The Renaissance in Material Culture: Material Mimesis as Force and Evidence of Globalization," in The Routledge Handbook of Archaeology and Globalization, ed. Tamar Hodos (London and New York: Routledge, 2017), 669-686; Sven Dupré, "The Art of Glassmaking and the Nature of Stones: The Role of Imitation in Anselm De Boodt's Classification of Stones," in Steinformen: Materialität, Qualität, Imitation, ed. Isabella Augart, Maurice Saß, and Iris Wenderholm, Naturbilder 8 (Berlin and Boston, MA: De Gruyter, 2019), 207-220.

4 See for example Ulinka Rublack, "Matter in the Material Renaissance," Past and Present 219, no. 1 (2013): 41-85 and Rublack, "Befeathering the European: The Matter of Feathers in the Material Renaissance," The American Historical Review 126, no. 1 (March 2021): 19-53, https://doi.org/10.1093/ahr/rhaboo6; Thomas Raff, Die Sprache der Materialien. Anleitung zu einer Ikonologie der Werkstoffe (Munich: Deutscher Kunstverlag, 1994); Jane Bennett, Vibrant Matter: A Political Ecology of Things (Durham, NC: Duke University Press, 


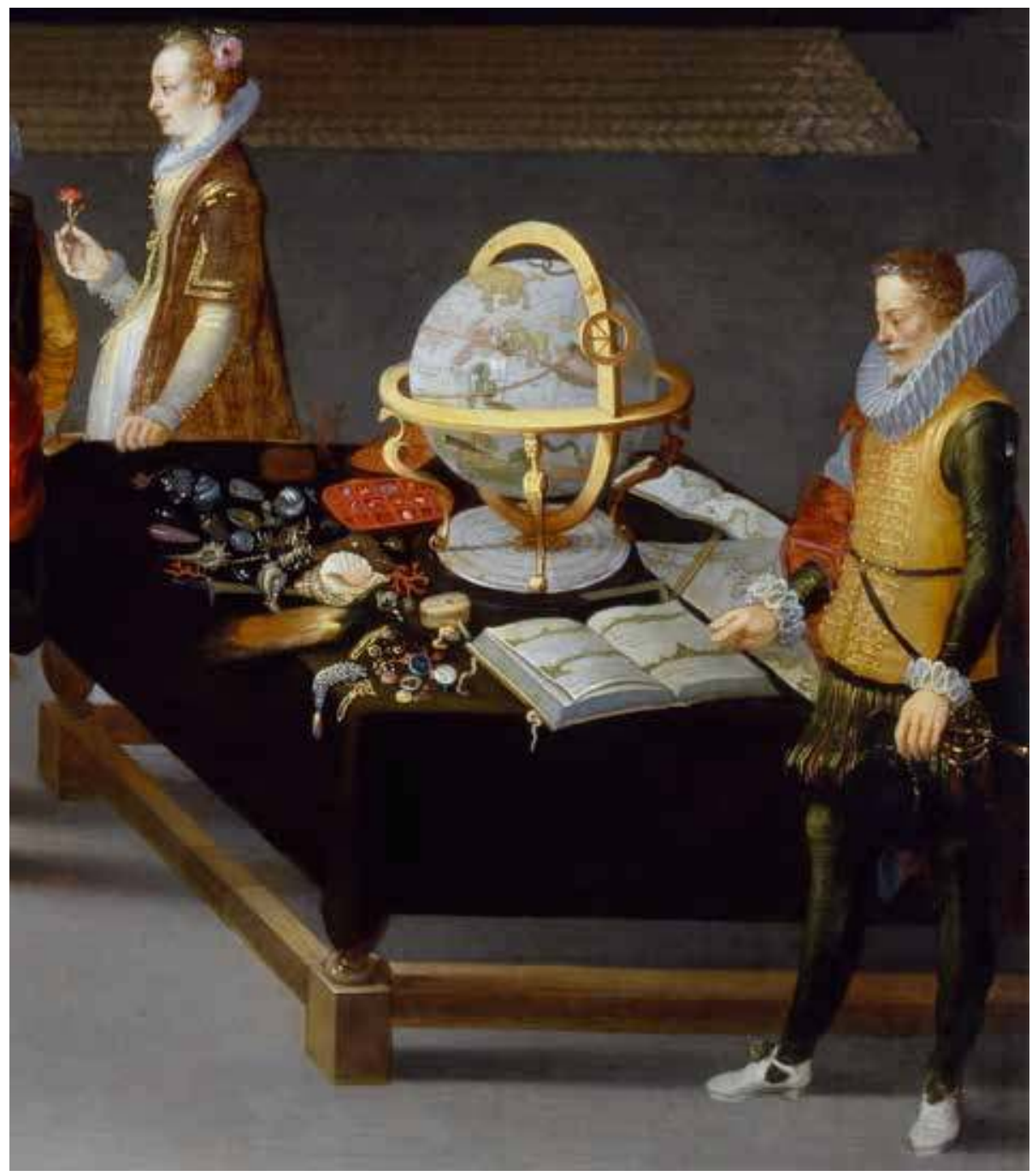

Figure 0.1: Hieronymus Francken II and Jan Brueghel the Elder (attributed to), Archduke Albert and Archduchess Isabella visiting the Collection of Pierre Roose, ca. 1621-1623. Oil on panel, $94.0 \times 123.3 \mathrm{~cm}$, detail. Baltimore, Walters Art Gallery, inv. no. 37.2010. Image $\odot$ The Walters Art Museum, Baltimore.

First produced in Antwerp in the early seventeenth century, paintings of constcamers featuring liefhebbers (lovers, enthusiasts) of art promoted an affective culture of collecting and display centring on rare and novel things. The detail shows a table laid with objects of knowledge and desire, both natural and man-made, including a celestial globe, a book with coastal profiles, several pieces of jewellery, shells and precious stones, a bird of paradise, and what seems to be a Javanese kris. Engaging all the senses, the tangible microcosm of the Spanish empire stimulated new ways of knowing and approaching the material world. 
with the meanings humans ascribed to things and these interactions explain how they could affect the senses and emotions. This raises several important questions. How were interactions with particular materials valorized and which emotions did they elicit in specific knowledge and emotional communities? Can we identify how material qualities and meaning were influenced and changed by the affects of viewers, producers, and users? How were such affective material properties and powers described, interpreted, and performed? Just how did the interplay of matter and emotion shape individual and group identities?

To explore these questions, we examine the period from the fifteenth to the eighteenth centuries in Europe, which produced that increasingly diverse and rich world of goods. We focus on materials that have received less attention from researchers, such as veil fabrics, shell gold, and the whole range of pigments, and look at regions and places that have been less frequently addressed in research on material culture, such as the Württemberg court in Germany, Swiss cities, or the Spanish Basque country. We try to ask specifically about production cultures and their effects on the affective worlds of consumption, display, and the formation of identities. And we show how the encounter with new materials and ways of making and consuming affected the vocabularies of visual and sensuous perception and taste. Finally we wish to contribute to widening scholarly perspectives by including the material worlds of the late sixteenth and seventeenth centuries beyond the two main areas of research on early modern consumption culture to date - the Renaissance and the Enlightenment. ${ }^{5}$

Historians of emotions have firmly established that each period is distinguished by different emotional styles, communities, mandatory regimes, and responses to them. However, the role of objects as constitutive of identities, subjectivities, and emotions has only recently begun to attract historians' attention. ${ }^{6}$ Material culture studies and the history of emotions need to be brought into a fruitful dialogue, and this implies that we need to be sensitive to contemporary understandings of the emotions and their effects. The assumption that the meanings of matter are fixed and "authentic" has been likewise criticized as problematic, and there has been vigorous debate about the notion that things or materials might "speak" their own language.7 By taking these current debates into new directions by historizing

2010), xvi; Pamela H. Smith and Tonny Beentjes, "Nature and Art, Making and Knowing: Reconstructing Sixteenth-Century Life-Casting Techniques," Renaissance Quarterly 63, no. 1 (2010): 128-179.

5 For a pioneering exhibition that looked at the entire early modern period see Melissa Calaresu, Mary Laven, and Vicky Avery, eds., Treasured Possessions from the Renaissance to the Enlightenment (London: Philip Wilson Publishers, 2015).

6 For a pioneering collection see Stephanie Downes, Sally Holloway, and Sarah Randles, eds., Feeling Things: Objects and Emotions through History (Oxford: Oxford University Press, 2018).

7 Michael Stolberg, "Emotions and the Body in Early Modern Medicine," Emotion Review 11, no. 2 (April 2019):113-122; Bennett, Vibrant Matter; Tim Ingold, “The Textility of Making," Cambridge Journal of 


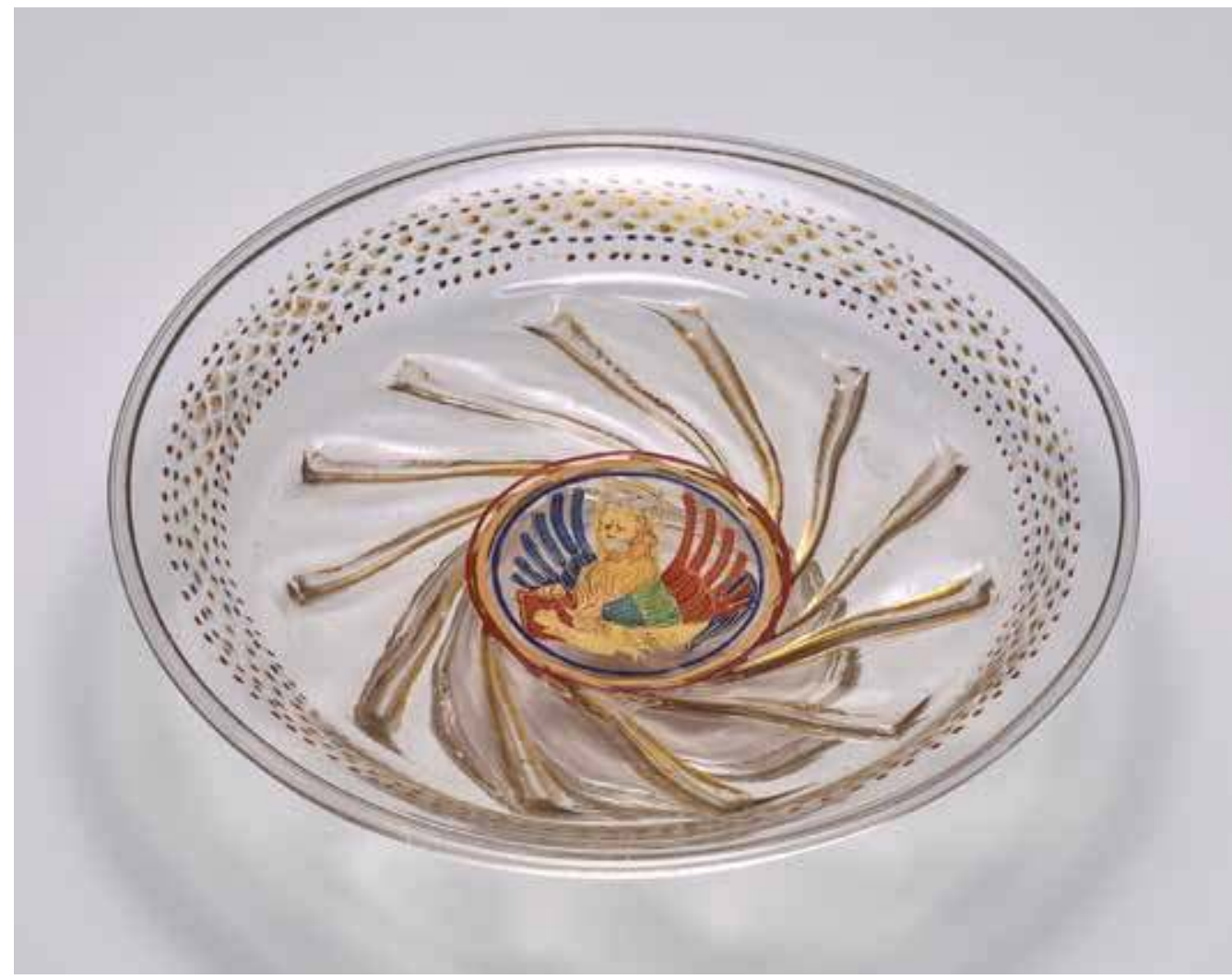

Figure 0.2: Glass bowl, Murano, around 1500. D: $25.50 \mathrm{~cm}, \mathrm{H}: 7.0 \mathrm{~cm}$. London, British Museum, museum number: S.375. Image @ The Trustees of the British Museum.

Renaissance societies developed innovative artistry and ingenious inventions when dealing with materialities. This glass bowl from a Murano workshop almost transcends its own materiality by creating effects of translucency and spotless transparency. Additionally, the representation of the Republic's patron saint in the centre of the bowl underlines the artefact's close connection with Venice. Produced in the Lagoon for both the domestic market and for export, however, its distinct malleability and manifest quality to imitate other materials made glass a common Renaissance materiality that was particularly apt to respond to formal and stylistic desires of the time. 
early modern affects associated with objects, this project responds to a need to formulate nuanced accounts of agentive materialities in relation to early modern social life, religion, politics, and cultures. Materialized identities often emerged and crystallized through the use of novel materials or new material processes.

While the materials, materialities, and objects explored in this book are different, they all share the alluring qualities of shine, glow, and translucency that particularly attracted contemporaries. The project approaches these qualities through four themes: glass, feathers, painted gold, and veils, which will be discussed in relation to specific individuals, material milieus, as well as interpretative communities. These four types of materialities and object groups were each attached to different sensory regimes and valorizations, which underwent significant changes during this period. Intricate work with new technologies and frequently inexpensive mineral, vegetable, or animal materials such as glass, fibres, pigments, and feathers could rise tremendously in esteem. Specific sites of production, consumption, and practice created specific affective regimes throughout time, inducing fundamental changes in the relationship of materials, bodies, and people, resulting in corresponding re-evaluations of these relationships.

\section{Relating to Things}

The wider approach underpinning this project builds on recent sociological studies that have re-evaluated the relationship between people and things. Recent studies have advocated overcoming any dualism between a socio-cultural and a material sphere. "Interobjectivity" expands the concept of intersubjectivity as founding the social. Seizing on parts of Latour's actor-network theory, Andreas Reckwitz hence posits the idea of artefacts as "hybrid objects" that are material and cultural at the same time. "The social," he argues, "is both evolving and reproducing within networks between humans and objects." 8

In Reckwitz's understanding, the material sphere is anything but limited to a common notion of objects and things. His framework of practice theory explicitly describes two categories that are also at the core of this volume: Affects/emotions and space both help to shape individual and collective identities, strengthen communities, and in turn are moulded by them. This approach is inspiring because it allows us to connect the material world with the social, encompassing human actions and artefacts' agency in one dynamic scheme. By consequence, it can serve as a hermeneutic

Economics 34, no. 1 (2010): 91-102; Ludmilla Jordanova, "Review of Lorraine Daston ed., Things that Talk," The British Journal for the History of Science 39, no. 3 (2006): 436.

8 Andreas Reckwitz, "Affective Spaces: A Praxeological Outlook," Rethinking History 16, no. 2 (2012): 241-258, here 251 . 
framework for both specific historical constellations and historical change itself. These methodological reflections contribute to our understanding of social and cultural identities in the making by highlighting the connections between the material and the social, space and practices, and production and consumption as mutually effective.

The contributors work from the premise that subjectivities in this period emerged in relation to an ever-increasing object world. Artefacts embodied and produced values, and they reflected and shaped emotional desires as well as bodily sensations. Such a "material Renaissance" has been brought into focus in various interdisciplinary studies that initially highlighted the importance of architecture and exquisite artefacts. These opened a window onto the experience of consumers while principally focusing on secular objects as tools to claim status distinction and hence on status satisfaction as the key emotion involved. ${ }^{9}$ More recent research has broadened the spectrum of how the "world of things" can affect humans in all realms of their existence, including their spiritual lives. Studies increasingly focus on material aspects of production processes and their effects on makers, traders, and consumers. ${ }^{10}$

Objects shaped identities beyond the specific milieus of their production, not only by means of social mobility but also by the materials themselves and their processing. Different markets formed the social and economic platform where producers, traders, and consumers of matter converged. Evelyn Welch has convincingly shown that the prerequisite for a functioning market is a shared sensitivity for the material on both sides, suppliers as well as demanders, first and foremost where price formation is concerned. ${ }^{11}$ Building on such research, historians have since followed the engagement with crafted, commodified things into the sixteenth and seventeenth centuries by exploring which groups of society involved themselves with a wide

9 Richard Goldthwaite, Wealth and the Demand for Art, 1300-16oo (Baltimore, MD: Johns Hopkins University Press, 1993); Lisa Jardine, Worldly Goods: A New History of the Renaissance (New York: Nan A. Talese/Doubleday, 1996); Evelyn Welch, Shopping in the Renaissance: Consumer Cultures in Italy, 1400-16oo (New Haven, CT and London: Yale University Press, 2005); Evelyn Welch and Michelle O'Malley, eds., The Material Renaissance (Manchester: Manchester University Press, 2007).

10 Adrian W. B. Randolph, Touching Objects: Intimate Experiences of Italian Fifteenth-Century Art (New Haven, CT: Yale University Press, 2014). The Challenge of the Object: Proceedings of the 33rd Congress of the International Committee of the History of Art = Die Herausforderung des Objekts. Akten des 33. Internationalen Kunsthistorikerkongresses, 4 vols., ed. G. Ulrich Großmann and Petra Krutisch (Nürnberg: Verlag des Germanischen Nationalmuseums, 2013); Catherine Richardson, Tara Hamling, and David Gaimster, eds., The Routledge Handbook of Material Culture in Early Modern Europe (London and New York: Routledge, 2017); Maya Corry, Marco Faini, and Alessia Meneghin, eds., Domestic Devotions in Early Modern Italy, Intersections 59/1 (Leiden and Boston, MA: Brill, 2019); Marco Faini and Alessia Meneghin, eds., Domestic Devotions in the Early Modern World, Intersections 59/2 (Leiden and Boston, MA: Brill, 2019); Wietse de Boer and Christine Göttler, eds., Religion and the Senses in Early Modern Europe, Intersections 26 (Leiden and Boston, MA: Brill, 2013). 11 Welch and O'Malley, The Material Renaissance; Evelyn Welch, “The Senses in the Marketplace: Sensory Knowledge in a Material World," in A Cultural History of the Senses in the Renaissance, ed. Herman Roodenburg (London: Bloomsbury, 2016), 61-86. 
range of vegetable, mineral, animal, and even human matter, in what way, and for what purposes. Recent research has drawn particular attention to the importance of overseas expansion in facilitating the intensified trade of slaves, precious stones, coral, birds, plants, medicines, artists' materials, fabrics, and food stuffs. In addition, there has also been research into how engagement with matter and materials relates to the formation of various types of knowledge and the ascription of virtue. ${ }^{12}$

Such research draws attention to the fact that the use of material goods was at individuals' disposal but nonetheless followed shared values. The freedom to purchase as many luxury goods as one wished was hampered by socially negotiated norms such as sumptuary legislation, which meticulously prescribed how such goods could be displayed in public. The supposed contradiction between these two habits of consumption strongly suggests that vivid cultural discourses about the appropriateness of the material in the social realm fundamentally contributed to identity formation across Europe. Consumption habits and cultural discourses about matter moreover constantly reacted to spheres of production and the availability of material resources - "material milieus" connected social communities and contributed to their coherence.

\section{Thinking Materiality}

A consideration of such material milieus implies a methodological focus on the crucial phase of their material emergence, making, and "becoming." ${ }^{3}$ This can be made relevant in several respects: first, the materials from which artefacts were generated had unique properties. Second, we need to understand how these properties shaped meanings, forms, and ideas in dialogue with makers or cultivators

12 Pamela H. Smith, The Body of the Artisan: Art and Experience in the Scientific Revolution (Chicago, IL: University of Chicago Press, 2004); Ursula Klein and Emma C. Spary, eds., Materials and Expertise in Early Modern Europe: Between Market and Laboratory (Chicago, IL: University of Chicago Press, 2010); Sven Dupré, ed., Laboratories of Art: Alchemy and Art Technology from Antiquity to the 18th Century (Cham: Springer, 2014); Ann-Sophie Lehmann, Frits Scholten, and H. Perry Chapman, eds., Meaning in Materials, 140o-180o, Netherlands Yearbook for History of Art 62 (Leiden: Brill, 2013); Corinne Maitte, "The Cities of Glass: Privileges and Innovations in Early Modern Europe," in Innovation and Creativity in Late Medieval and Early Modern European Cities, ed. Karel Davids and Bert de Munck (Farnham, Surrey: Ashgate, 2014), 35-54. The drawing of two Venetian noblewomen, Gentil' donne venetiane (Fig. o.3), recently attributed to Jean Jacques Boissard and dated 1559 by Michael Thimann ("Erinnerung an das Fremde: Jean Jacques Boissards Trachtenbuch für Johann Jakob Fugger: Zu Provenienz und Zuschreibung der Bildhandschrift Cod. Oct. 193 in der Herzogin Anna Amalia Bibliothek Weimar," MarburgerJahrbuch für Kunstwissenschaft 31 (2005): 117-148) shows in a particular way how delicate materials addressed the senses, even including smell. See also Evelyn Welch, "Scented Buttons and Perfumed Gloves: Smelling Things in Renaissance Italy," in Ornamentalism: The Art of Renaissance Accessories, ed. Bella Mirabella (Ann Arbor, MI: University of Michigan Press, 2011), 13-39. 13 Most vocally Elizabeth Hallam and Tim Ingold, eds., Making and Growing: Anthropological Studies of Organisms and Artefacts (Farnham, Surrey: Ashgate, 2014). 


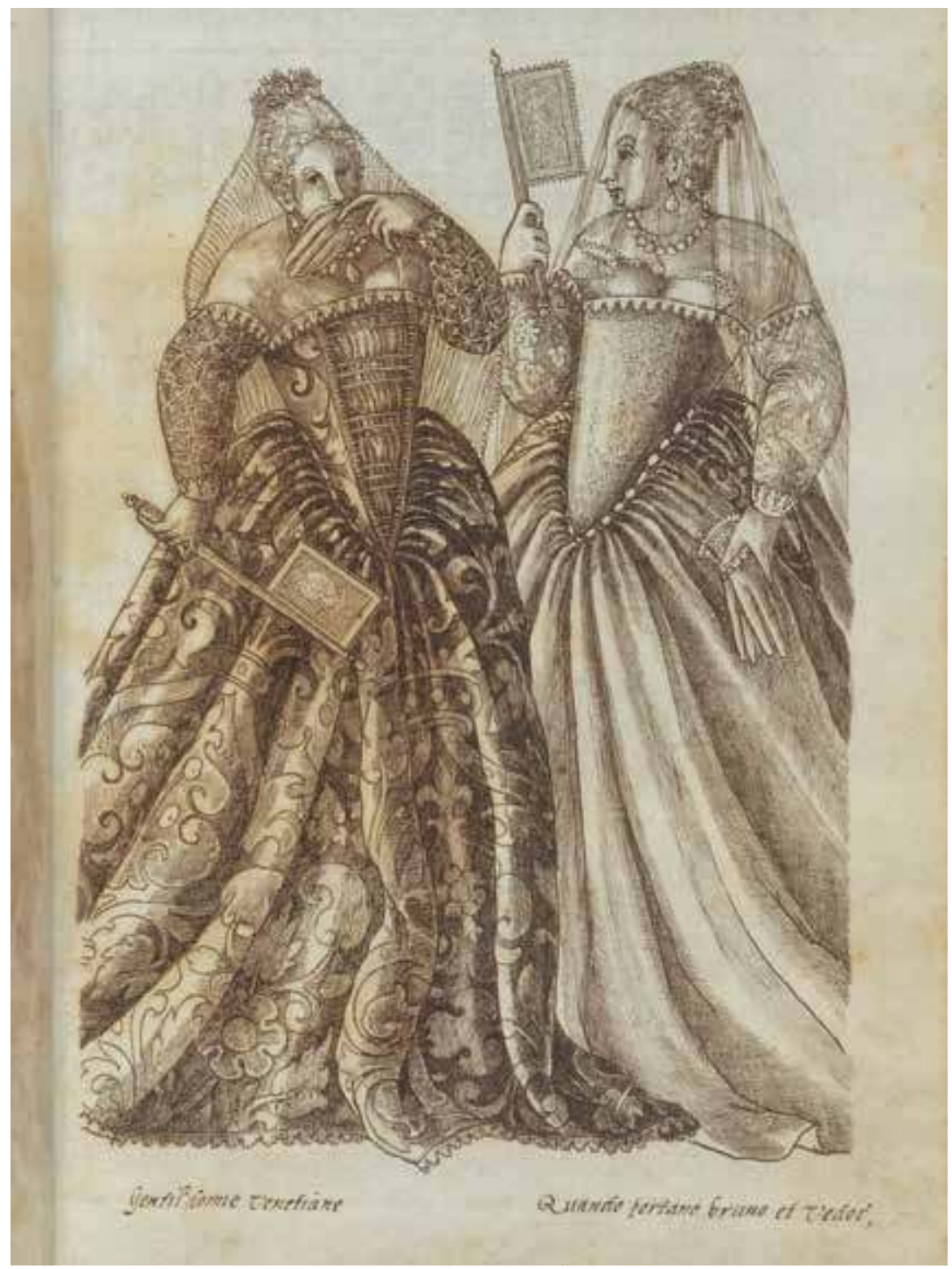

Figure 0.3: Jean Jacques Boissard, Gentil' donne venetiane/ Quando portano bruno et Vedoé, costume book [Trachtenbuch] for Johann Jakob Fugger, 1559, fol. 63. Pen and ink drawing. Herzogin Anna Amalia Library, Cod. Oct. 193. Image ๑ Klassik Stiftung Weimar. OpenAccess: "All rights reserved."

The two Venetian noblewomen, "when dressed in dark colours and widowed," model precious, gossamer mourning veils. Made from striped or crimped, translucent textiles, they represent the highest artisanal standard that was produced at the time in centres like Bologna. Alongside the veils' visually stimulating, delicate materiality, the women's fashionable, perfumed gloves address the sense of smell. The scents they carried offered protection to the highly permeable and vulnerable early modern body. As well as mental, moral, and physical dangers, they also indicated the luxury afforded by the wealthy. 
during this process of becoming, as much as in the further course of an object's life or unbecoming. In the case of viticulture or pottery, of course, the properties of specific soils have always been recognized as shaping their end product and commanding a grower's or maker's sustained attention to specific geologies and ecologies in active processes of "environing." But in the case of other objects, the role of materials has often been obscured. Michael Baxandall's by now classical exploration of the chemical structure of limewood, its properties, and supply, remained unusual among art historians for a very long time even though he showed how it shaped German Renaissance sculpture. ${ }^{14}$ For the early modern period, Michael Cole, Rebecca Zorach, Christine Göttler, Ann-Sophie Lehmann, and others have more recently spearheaded a "re-materialization" of the discipline. Such research includes consideration of what it meant to paint with different media, such as oils, to understand how techniques evolved in a dialogue with materials, and also the experience and cultural evaluation of their effects, such as surface sheen and lustre..$^{15}$

This third dimension is crucial. It questions how particular types of matter and their effects were loaded with cultural significance, which tends to be historically contingent, but also interrelated with their material base. Sheen, for example, interlinks with surfaces it bonds on to. A linen canvas, panel, or copper plate hence required elaborate types of preparation to optimize the effects of sheen. An archaeology of how such materials and technologies were used thus provides important clues into how important such effects were held to be and what they were associated with. Efforts to enhance lustre, shine, and brilliance (or, conversely, the matte, faded, and roughly textured) consequently elicit questions about the ways in which these qualities were intrinsic to how an object

\footnotetext{
14 Michael Baxandall, The Limewood Sculptors of Renaissance Germany (New Haven, CT: Yale University Press, 1980).

15 Since the mid-1990s, there has been an ever-increasing number of art historical studies on materiality and materials; far from being exhaustive, the following list is meant to be suggestive of the variety of possible topics. For a discussion of recent research with a focus on sculptural materials: Michael Wayne Cole, "The Cult of Materials," in Sculpture through Its Material Histories, ed. Sébastien Clerbois and Martina Droth (Oxford: Lang, 2011), 1-15. See further Suzanne B. Butters, The Triumph of Vulcan: Sculptors' Tools, Porphyry, and the Prince in Ducal Florence, 2 vols. (Florence: Olschki, 1996); Michael Wayne Cole, "Cellini's Blood," The Art Bulletin 81 (1999): 215-235; Rebecca Zorach, Blood, Milk, Ink, Gold: Abundance and Excess in the French Renaissance (Chicago, IL: University of Chicago Press, 2005); Lehmann, Scholten, and Chapman, Meaning in Materials; Christy Anderson, Anne Dunlop, and Pamela H. Smith, eds., The Matter of Art: Materials, Practices, Cultural Logics, c. 1250-1750 (Manchester: Manchester University Press, 2015). For the role of painting media and techniques and their effects on viewers' perceptions: Ann-Sophie Lehmann, "Das Medium als Mediator: Eine Materialtheorie für (Öl-) Bilder," Zeitschrift für Ästhetik und allgemeine Kunstwissenschaft 57 (2002): 69-88. Recent contributions on affective responses stimulated by objects and materials within the context of early modern globalization include: Alessandro Russo, Gerhard Wolf, Diana Fane, and Luisa Elena Alcalá, eds., Images Take Flight: Feather Art in Mexico and Europe, 1400-170o (Munich: Hirmer, 2015); Christine Göttler and Mia M. Mochizuki, eds., The Nomadic Object: The Challenge of World for Early Modern Religious Art, Intersections 53 (Leiden and Boston, MA: Brill, 2018).
} 
might turn into an agent in particular social networks that were likely to value splendour and sheen. Such qualities connected to an object's power and presence.

The upshot of such perspectives is easy to follow but profound in implications for new research methods and areas. History was not made by disembodied minds generating abstract ideas, but in dialogue with materials that shaped cultures. Enquiry into where materials came from and how they were used and acquired cultural association typically reveals a surprising amount of material experimentation and nuanced material perception in the global Renaissance and thereafter. The well-known rise of oil painting is only one case in point, and in itself reveals what other case studies further elaborate. The closer one looks, the more evident it becomes that general material descriptors, such as "oil on canvas," in oil painting, or "silk" in textiles, are misleading abstractions. Different species of silkworms could be handled in different ways to keep temperatures steady, for example, while the silk thread could be extracted and turned into a fibre in a variety of ways, all of which shaped the texture, tension, and strength of the end product.

This underlines the sheer intelligence and effort required to work with materials as well as the great ecological variety so characteristic of this period. Walnut or linseed oils, which were often used for painting, could thus be applied in different parts of a painting, themselves differing in their properties depending on where they came from, how they had been transported, how old they were, or even how they were stored. Makers could experience this endless variety of material properties as obstacles, take advantage of them, or seek to manage them by standardizing known supplies. ${ }^{16}$

Michelangelo acutely struggled with these problems during the winter of 1508 . In Rome, this famous artist stared in disbelief at the ceiling of the Sistine chapel. His image of the Flood began to grow mould and obscured the figures. By January, the thirty-two-year-old turned to the pope in despair about the state of his work and did not dare to ask the pope for pay. Michelangelo knew how Tuscan materials behaved in particular temperatures, but not those in Roman surroundings in the freezing cold. An important part of how he matured and succeeded as a painter was to develop his material knowledge in relation to different environments and material properties of matter, or, as contemporaries put it, his "mindful hand."17

16 These issues are explored in Pamela H. Smith, Amy R.W. Meyers, and Harold J. Cook, eds., Ways of Knowing: The Material Culture of Empirical Knowledge (Ann Arbor, MI: Bard Graduate Centre; University of Michigan Press, 2014).

17 Giorgio Vasari, Lives of the Painters, Sculptors and Architects, trans. Gaston du C. de Vere, vol. 2 (New York: Knopf, 1996), 667. Cf. Fabrizio Mancinelli, "Michelangelo's Working Technique and Methods on the Ceiling of the Sistine Chapel," in Michelangelo, the Sistine Chapel: The Restoration of the Ceiling Frescoes, vol. 1, ed. Fabrizio Mancinelli (Treviso: Canova, 2001), 15-28, especially 24-26. For the notion of the "mindful hand," see Lissa Roberts, Simon Schaffer, and Peter Dear, eds., The Mindful Hand:Inquiry and Invention from the Late Renaissance to Early Industrialisation (Amsterdam: Nederlandse Akademie van Wetenschappen, 2007). 
Material experimentation and innovation in this way typically thrived from failure in the first instance. Material achievement is hence revealed in the persistence and problem-solving abilities of makers. An enquiry into such processes has two main implications. It first tends to draw attention to a much larger number of collaborators and makers than a traditional focus on the sole master-genius like Michelangelo would lead us to believe. Around and alongside such a man would have been those who knew, for instance, about the best animal parts collected at particular times of the year from which to make the most suitable glue. Many material achievements were reached cumulatively and in milieus which fostered experimentation by translating skill sets from one area to another. This means, secondly, that such complex material knowledge could interlink with wider understandings about the body and the universe. The early modern period, on which this volume focuses, was a time in which the macrocosm in many contexts was thought to interrelate with the microcosm. The strength and nature of biochemical substances, for instance, was held to vary in relation to the cycle of the moon and seasons. In addition, a maker's diet might interrelate with her or his breath and the outcome of working with metals, for example. Body, mind, and the cosmos were not necessarily conceived as distinct or irrelevant forces. Such investments increased through surging vitalism and Paracelsianism in natural philosophy, the extraordinary interest in astrology and alchemy, as well as the greater emphasis upon the way in which religious belief and matter flowed into each other during an age of the Counter-Reformation. ${ }^{18}$

Historians of science, art historians, conservators, archaeologists, and anthropologists as well as historians of the environment have all helped to introduce such perspectives in discussions of the material turn. This profoundly re-shapes the nature of historical research through new research questions as well as new research tools and interdisciplinary methods. These include historical reconstruction, digital microscopy, 3-D modelling, chemical analysis, and object handling. The Materialized Identities project hence drew on the knowledge of conservators, curators, and makers to understand the vibrancy of matter and agency of objects. Analysis resulting from the experience of object handling and historical reconstruction underlie all chapters and are embedded as case studies in three of our four sections. Digital microscopy contributes to Stefan Hanß's study into the allure of exotic feathers and their skilled assemblages in early modern headwear. As Hanß argues, microscopy helps us to trace artisanal ingenuity through making craftsmanship visible, for instance by drawing attention to the careful layering of colours to achieve particular effects. ${ }^{19}$ Michèle Seehafer collaborated with a gilder

18 Smith, Meyers, and Cook, Ways of Knowing.

19 Stefan Hanß, "Digital Microscopy and Early Modern Embroidery," in Writing Material Culture History, 2nd ed., ed. Anne Gerritsen and Giorgio Riello (London: Bloomsbury, 2021), 214-221; Stefan Hanß, "New 


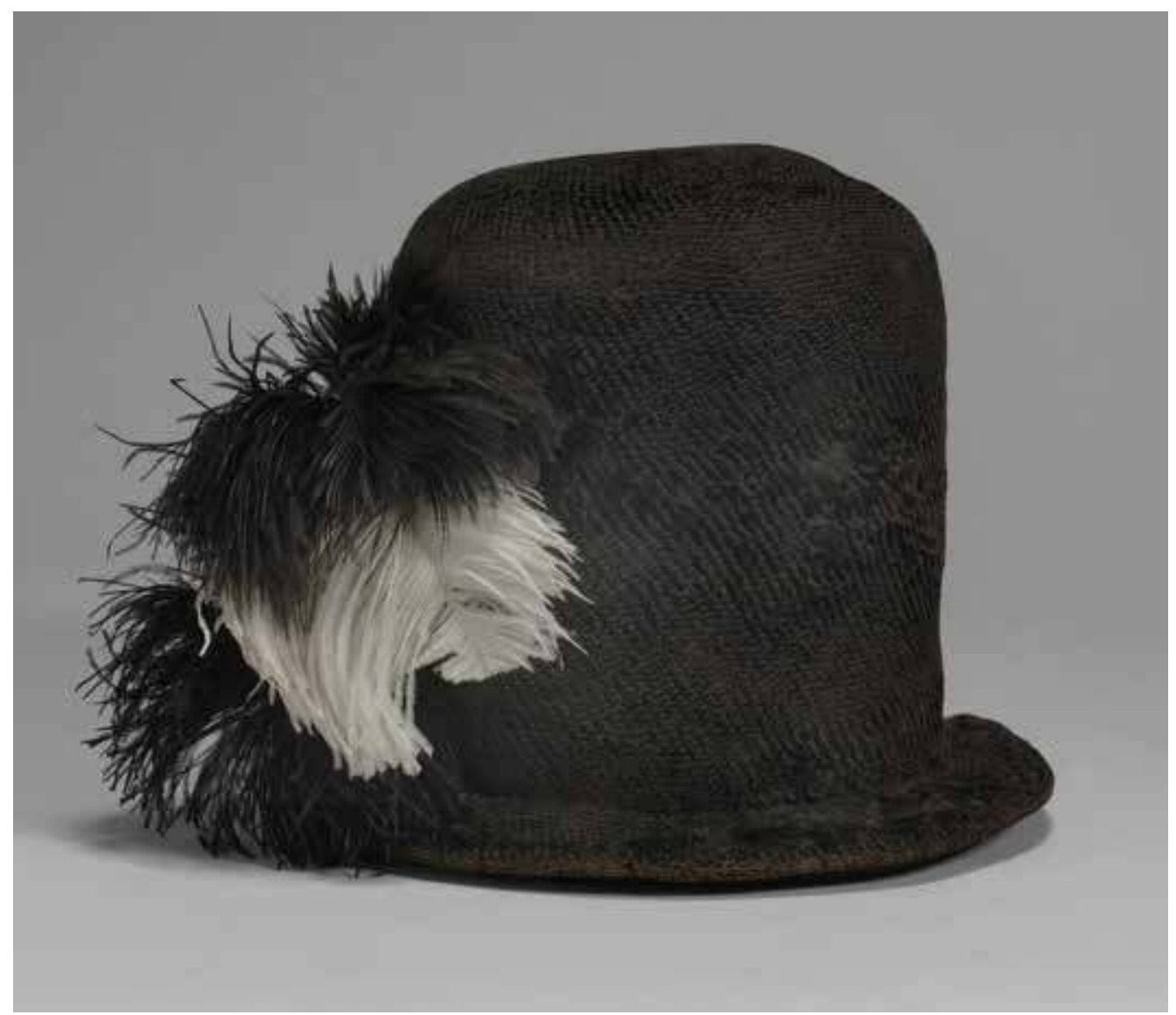

Figure 0.4: High felt hat with silk pile and ostrich feathers, of the kind sourced by Hans Fugger during the second half of the sixteenth century. $\mathrm{H}: 22.5 \mathrm{~cm}$. Nuremberg, German National Museum. Image @ Germanisches Nationalmuseum, Nürnberg. Photo: M. Runge.

These hats were relatively cheaply produced through new techniques that imitated velvet and were similarly soft. The ostrich feathers on this hat were added later but cohere with images from the period. They would have contributed to the new haptic and affective experience of a supremely soft piece of headwear for men. 
and conservator to reconstruct two sixteenth-century recipes for shell gold. The intellectual, sensory, and physical engagement with these recipes led her to redefine the concept of virtuosity that encompasses preparatory and performative work. Working together with dress historian Hilary Davidson, Katy Bond and Susanna Burghartz explored her concept of the "embodied turn" to understand translucency and malleability as key characteristics of veil fabrics. ${ }^{20}$

Yet a crucial question less frequently addressed by recent research remains just how affects and ideas arose from embodied experiences of matter and material worlds, such as feathers, fabrics, paints and glass, and how specific social milieus influenced the ways in which human subjectivity and cultural understanding during this period might be said to have emerged from this engagement with materials and their properties. ${ }^{21}$ Just how does materiality evoke affects and facilitate thought, sensuousness, the imagination, and emotions? ${ }^{22}$ This interest in affective responses follows from a focus on "agentive materials" - that is, specific material qualities, material perceptions, and cultures of material experimentation, as well as collecting and media and performance strategies in specific social networks.

\section{Evoking Affects}

Gazing upon Aztec treasures at the Brussels court in 1520, Albrecht Dürer found himself overcome by the artefacts, textiles, and weapons "from the new land of gold." Recording the encounter in his diary, the Nuremberg artist admitted he did "not know how to express" his thoughts. Trying nonetheless to articulate his feelings, he famously proclaimed: "All the days of my life I have seen nothing that rejoiced my heart so much as these things [...] and I marvelled at the subtle ingenia of people in foreign lands." 23 The artisans' ingenium - that artistic invention and "innate

\footnotetext{
World Feathers and the Matter of Early Modern Ingenuity: Digital Microscopes, Period Hands, and Period Eyes," in Ingenuity in the Making: Materials and Technique in Early Modern Europe, ed. Alexander Marr, Richard Oosterhoff, and José Ramón Marcaida (Pittsburgh, PA: Pittsburgh University Press, 2021, in press). 20 Hilary Davidson, "The Embodied Turn: Making and Remaking Dress as an Academic Practice," Fashion Theory 23, no. 3 (2019): 329-362, DOI: 10.1080/1362704X.2019.1603859.

21 Rublack, "Matter in the Material Renaissance."

22 Anthropologists and archaeologists have been at the forefront of posing these questions, see Nicole Boivin, Material Culture, Material Minds: The Role of Things in Human Thought, Society and Evolution (Cambridge: Cambridge University Press, 2008). For a recent summary and discussion see Timothy J. LeCain, The Matter of History: How Things Create the Past (Cambridge: Cambridge University Press, 2017). 23 Translation as quoted in Hugh Honour, The New Golden Land: European Images of America from the Discoveries to the Present Time (New York: Pantheon Books, 1975), 28. Original passage may be consulted in Albrecht Dürer, Schriftlicher Nachlass, ed. Hans Rupprich, vol. 1 (Berlin: Deutscher Verein für Kunstwissenschaft, 1956), 155 .
} 
talent" to transform matter and activate its wondrous qualities - produced such an affective response in Dürer that it physically manifested itself as a quickening of the heart and a blossoming in the chest. ${ }^{24}$ Dürer's familiarity with Nuremberg's "culture of ingenuity," ${ }^{25}$ his expert knowledge of the goldsmith craft, and his experience of worldly goods circulating around Venice and Antwerp guided his reaction and its focus on ingenium, a concept that existed in intimate relationship with vibrant matter. ${ }^{26}$ While the novelty of objects and materials from the New Worlds provoked particularly explicit outbursts of wonder and admiration in Renaissance Europe, Dürer's well-known exclamation underscores the physical sensations that engaged people from all walks of life as they fashioned, handled, used, and observed material goods.

This applies to the physical sensation of wearing textiles like veils on the body, as well as to noticing the slightest of scents during the preparation of shell gold, sensing delicacy when handling fragile glass objects, and experiencing joy when observing shimmering, fluttering feathers and feather panaches. These experiences could enable joyful emotions or relate to constraints. In early eighteenth-century Protestant Basel, for example, the wife of town citizen Walter Merian declared that she could no longer bear the excessively stiff veil she had to wear in church because of her bad constitution. Others reported even more drastically on the negative health effects of church veils and their rupture of the church community. A notary testified that his wife was very narrow-chested and bothered her neighbours in church with her coughing when she wore the veil. ${ }^{27}$ Colours were believed to have transformative powers over the bodies and minds of animals and humans, as Karel van Mander and other writers on art have documented with many examples. These examples illustrate just how closely material properties and effects interlinked with bodily affects. Moreover, they clearly show that embodied experiences played a central role in the evaluation of things, as they shaped people's emotions and feelings towards different materials and objects and vice versa.

As set out above, cultural theories inspired by Bruno Latour have increasingly addressed human-object relationships in recent years. With the affective turn,

24 This interpretation of ingenium in the Renaissance mindset is described by Michael Baxandall in Giotto and the Orators: Humanist Observers of Painting in Italy and the Discovery of Pictorial Composition, 1350-1450 (Oxford: Clarendon Press, 1971).

25 For the broad semantic field of ingenium in early modern Europe: Alexander Marr, Raphaële Garrod, José Ramón Marcaida, and Richard J. Oosterhoff, eds., logodaedalus: Word Histories of Ingenuity in Early Modern Europe (Pittsburgh, PA: University of Pittsburgh Press, 2018), 19.

26 Alexander Marr, "Ingenuity in Nuremberg: Dürer and Stabius's Instrument Prints," The Art Bulletin 10o, no. 3 (2018): $48-79$.

27 StaBS, Protokolle E 13,1, on 27 November 1709. 
"doing things" ${ }^{\text {"8 }}$ and "feeling things"29 have entered into the vocabulary of cultural historians. As precognitive and prelinguistic physical reactions, affects are phenomena that simultaneously affect and are affected, prompt and discern embodied sensations. They have a relational function, connecting bodies and things as well as bodies or people to one another. Because affects are preconscious, they cannot be suppressed: "affect is, in a way, 'matter in motion' since it 'moves' the body."30 As Kathleen Stewart puts it, matter and materials have "a heartbeat. ${ }^{31}$ Like things, matter and materiality do not remain static, but receive a specific relational agency as they effect affects. This makes affects paramount for dealing with materiality and renders the senses, sensory perception, and material qualities a meaningful question for historical analysis. ${ }^{32}$

When dealing with affects, processes, relationships, energies, rhythms, flows, and forces come to the fore, rather than fixed structures. With this perspective, things begin to move, just as bodies or people do. A world in which things happen and act (in relation to one another) becomes tangible. Things touch and affect people and bodies emotionally and viscerally. They evoke affects through senses, perceptions, and mental reactions. The new theories of the cultural therefore reach the conclusion that the interactions and interrelations of people and things are necessarily connected to emotions and affects, and must become part of corresponding analyses of the social. They also agree to not strictly separate affects and emotions, but rather address both as part of a continuum between body and mind, which can no longer be thought of as independent of each other. By paying attention to materials affecting bodies and arousing emotions, it is easier to understand feelings as no longer primarily inner states, but as practices based on dynamic relationships between things, bodies, and minds.

From a praxeological point of view, space therefore comes into play. It is only through the interrelation of affects and spaces that affect-cultures are formatted. As Reckwitz argues, they exceed the registers of classical social analysis - the normative, the rational, and the semiotic. Instead, his praxeological perspective on the social provides "a conceptualization of emotions and affects and simultaneously of artefacts and space, which integrates them as basic components of sociality."33

28 Jo Labanyi, “Doing Things: Emotion, Affect, and Materiality," Journal of Spanish Cultural Studies 11, nos. 3-4 (2010): 223-233.

29 Downes, Holloway, and Randles, Feeling Things.

30 Labanyi, "Doing Things," 225.

31 Kathleen Stewart, "In the World that Affect Proposed," Cultural Anthropology 32, no. 2 (2017): 192-198, here 196.

32 Stewart notes the same for anthropology: "Affects helped return anthropology to sense and sensation, materialities, and viscera." Stewart, "In the World that Affect Proposed," 194.

33 Reckwitz, "Affective Spaces," 242. 
Such a concept assumes that bodies and material objects form networks in which "social practices" develop. With their relational powers, affects play an essential role. Bodies and things react physically and mentally to materials that cause reactions via the senses, material properties, and the mind. This is where artisans and their "mindful hands" require consideration..$^{34}$

At this point we develop Reckwitz's framework further by thinking about how materials and artisans were attuned to and moulded things to create particular sensations, desires, and emotional reactions. We look at the world of makers, with their agency to prepare materials for affective reactions, and consider the abilities and sensitivities of users and consumers to react to specific material features and to appropriate them.

In order to explain the cultural change of affective structures through history, it is furthermore crucial to analyse the emergence of new affective sites and constellations; this brings to life new artefact-space complexes as well as new cultures and regimes of affects. Rublack's contribution, for instance, shows how exotic feathers and their replicas could inform specific emotional styles and embodied practices in a leading Protestant court advocating commerce, industry, and delight in commodities as a means to reach social harmony. Here, feathers became agents that "enmeshed" an audience to endorse social, economic, and political norms, forming part of an affective culture and habitus reproduced in similar spaces and environments..$^{35}$ The same is true for specific groups of women, such as Zurich's patrician wives. Going to church was a ritual in which the sensory experience of translucent, fine veils and their paradoxically stiff composition made them a unified body within the Sunday congregation. Scuro's example of Murano, on the other hand, shows how on the island of glass a specific atmosphere could be created by the proximity of workshops and their shared experience of intense physical exertion and heat, accompanied by the acute mutual observation of secret recipes. Seehafer, moreover, observes that the shimmering surface of a shell-gold-illuminated page could enact a site for both contemplating the bonds of patronage and exploring the reciprocities of friendship. Focusing on Haarlem at the turn of the seventeenth century, Göttler traces the emergence of a new culture of connoisseurship and expertise revolving around singular artworks, objects, and technologies. As in the case of Antwerp these shared interests in the tangible world of things were fostered by engaged rather than traditional or authoritative knowledge and guided by friendship and social interactions. Thus courts, cities, workshops, sites of production, books, images, or church rooms could create specific conditions and constellations for

34 Roberts, Schaffer, and Dear, The Mindful Hand.

35 Petra Lange-Berndt, "Introduction: How to Be Complicit with Materials," in Materiality, ed. Petra Lange-Berndt (London: Whitechapel Gallery and MIT Press, 2015), 18. 
affective relationships between materials, things, bodies, and people. Throughout history, then, specific materials and specific sites of production, consumption, and knowledge could create particular affective regimes.

\section{Touching on Values}

Among the sites that impressed themselves most deeply on the mind of the Saxon nobleman Johann Wilhelm Neumair during his travels through Antwerp in February 1614, were Plantin's publishing firm, the "Tapissierspand" with its display of tapestries woven with silver and gold, the "House of Glass," where "Venetian style glass was produced in Antwerp in beauty almost equal to that of Murano and Venice," and the houses of the city's most renowned painters, Jan Brueghel the Elder and Peter Paul Rubens. While Rubens's large paintings brought very high prices, ranging between one to five hundred guldens, Brueghel's subtly and skilfully painted small panels with landscapes excited the wonder and amazement of those who looked at them. ${ }^{6}$ Neumair's account is relevant because it documents the multiple functions of these places as sites of production, display, valuation, and wonder as well as the emotions stirred up by luxury materials, virtuoso technologies, and glittering things. Judgements about the value, worth, and qualities of material objects were thus also shaped by affective components. Inventories, auction catalogues, and the letters exchanged between art collectors, agents, and artists open up a window into the complexities of judgement about the value of artworks and objects. Establishing the value of a material object was an unstable process. It emerged within a dynamic interplay between various considerations including the labour and skill invested in its making, its material, style, and aesthetic allure, as well as the ways in which it was described and displayed. ${ }^{37}$

Feathers, veils, paints, and glass - the object groups investigated by the authors of this volume in their various interpretative contexts - were each subject to different kinds of valorizations, which underwent significant changes during this period.

36 Neumair undertook these travels in the entourage of Duke Johann Ernst the Younger of Saxe-Weimar: Johann Wilhelm Neumair von Ramsla, Des durchlauchtigen hochgebornen Fürsten und Herrn, Herrn Johann Ernsten des Jüngern, Hertzogen zu Sachsen, Gülich, Cleve und Berg [...] Reise in Franckreich, Engelland und Niederland (Leipzig: Henning Große der Jüngere, 1620), 261.

37 Bert De Munck and Lyna Dries "Locating and Dislocating Value: A Pragmatic Approach to Early Modern and Nineteenth-Century Economic Practices," in Concepts of Value in European Material Culture, 1500-1900, ed. Bert De Munck and Lyna Dries (Burlington, VT: Ashgate, 2015), 1-29; Christine Göttler, Bart Ramakers, and Joanna Woodall, “Trading Values in Early Modern Antwerp: An Introduction," in Trading Values in Early Modern Antwerp, ed. Christine Göttler, Bart Ramakers, and Joanna Woodall, Netherlands Yearbook for History of Art 64 (Leiden: Brill, 2014), 8-37; Evelyn Welch, "Making Money: Pricing and Payments in Renaissance Europe," in Welch and O'Malley, The Material Renaissance, 71-84. 


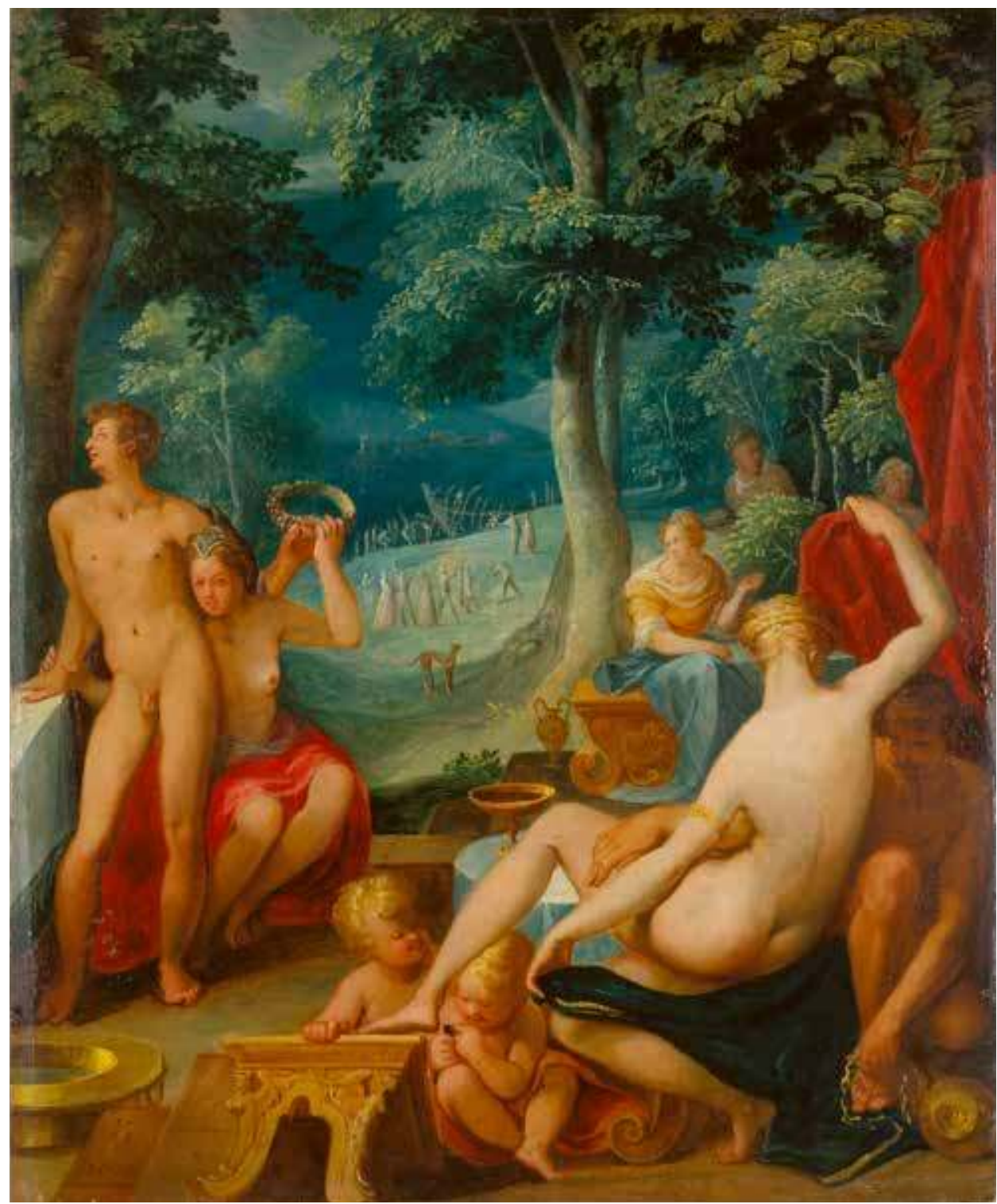

Figure 0.5: Karel van Mander, Before the Flood, 1600. Oil on copper, $31.1 \times 15.6 \mathrm{~cm}$. Frankfurt am Main, Städel Museum, inv. no. 2088. Image @ Städel Museum. Photo: U. Edelmann / Artothek.

Created in the auspicious year of 1600, Van Mander's depiction of nude figures in a landscape setting is a self-assertive statement about his role as a painter-poet and a promoter of Netherlandish art. The reflecting surfaces of the golden vessels and the golden hues on the foliage display his mastery in "reflexy const," considered as the greatest achievement of Netherlandish art. The metallic support enhances the jewel-like appearance of this small painting in oil that catered to a growing taste among art collectors for effects of light and shade. 
Skill and ingenuity - considered by Baxandall back in 1972 to be defining features of fifteenth-century Italian painting ${ }^{38}$ - have since been researched with regard to a broad variety of media and techniques, from arts involving costly metals to those based on almost "worthless" materials such as glass and paint. ${ }^{39}$ Intricate work using new, foreign, or not readily available (secret) technologies and frequently inexpensive materials rose tremendously in esteem. Early modern courts and cities competed against each other for both access to raw materials and the knowledge about how to process them into valuable products.

In early modern usage, Latin valor and its vernacular equivalents were linked to vis, virtus, and potentia, notions used to designate material or immaterial entities or things imbued with power, strength, and animating force. ${ }^{40}$ In a world of expanding markets and trades, the value of objects was increasingly tied to their power to seize the eye and stimulate desires, elicit affects, and act as a binding force. Over the time period considered in this book, different repertoires and hierarchies of values were competing against each other, and the multiple relationships between monetary, moral, spiritual, aesthetic, and affective values became increasingly complex and unstable. Early modern men and women were well aware of the fluidity and volatility of material values. Elaborating on values and the market, the Flemish Jesuit Leonardus Lessius, in his 1605 De iustitia e iure (OfJustice and Law) states that such things as "gems, special dogs or falcons, exotic birds, and ancient paintings" that do not have a "legal or common price," could nonetheless not be sold for whatever the owner wants, but "should be priced according to the common estimation of knowledgeable men or through the estimation of the seller himself." Lessius also allows the seller, who "feels very strongly about the good [...] to estimate his personal affections, provided this estimation comes about in good faith. ${ }^{141}$ But how were the values of the luxury items on Lessius's list determined? Was it according to their

38 Michael Baxandall, Painting and Experience in Fifteenth Century Italy: A Primer in the Social History of Pictorial Style (Oxford: Oxford University Press, 1988), 14-16.

39 For glass (in addition to the contributions in this volume): Sven Dupré, "The Value of Glass and the Translation of Artisanal Knowledge," in Göttler, Ramakers, and Woodall, Trading Values, 138-161; Corine Maitte, "Façon de Venise: Determining the Value of Glass in Early Modern Europe," in De Munck and Lyna, Concepts of Value in Early Modern Material Culture, 209-237; Pamela O. Long, Artisan/Practitioners and the Rise of the New Sciences, 1400-16oo (Corvallis, OR: Oregon State University Press, 2011), 1-9.

40 Olga Weijers and Marijke Gumbert-Hepp, eds., Lexicon latinitatis nederlandicae medii aevi, vol. 8 (Leiden and Boston, MA: Brill, 2005), 5247: waarde, vis, virtus, dignitas; achting; bonum iudicium; kracht; vigor.

41 Cited from: Leonardus Lessius, S.J., On Buying and Selling (1605), translation by Wim Decock, introduction by Wim Decock, Journal of Markets \& Morality 10, no. 2 (Fall 2007): 433-516, at 470-471 (liber II, cap. 21, 15-17); Leonardus Lessius, De iustitia et iure caeterisque virtutibus cardinalibus libri IV (Leuven: Jan Maes, 1605), 253: "[...] ut sunt quaedam gemmae, insignes canes, falcones, aves indicae, picturae veteres, \& similia $[\ldots]$ nempe res tales no[n] posse vendi pro arbitrio venditoris, sed iuxta aestimationem intelligentiu[m], vel certe iuxta aestimationem ipsius venditoris [...]." 
singularity, rarity, or beauty, their novelty or age, or the time, skill, and knowledge invested in their making, breeding, or growing? Debates on wealth and luxury within and across confessions complicated definitions of value. The global movement of materials, objects, and techniques, as well as the emergence of new luxury items, broadened the range of values and interests. The secrecy surrounding the manufacture of exotic luxuries such as porcelain and lacquer added to their value and prestige, and initiated numerous attempts to imitate the translucent quality of their glazes that were so pleasing to European eyes. ${ }^{42}$ But the sheer quantities of Chinese export porcelain that entered the European market in the seventeenth century also transformed the desired tableware into everyday household items. ${ }^{43} \mathrm{In}$ sixteenth-century Venice, Venetian glass had acquired equally mundane qualities, as amply documented in the contributions by Lucas Burkart and Rachele Scuro.

Of particular interest in the context of this book is the emergence of loosely connected groups of experts who shared interests in rare objects, elaborate instruments, exceptionally beautiful artworks, material practices (such as drawing), and craft skills. Artisans' workshops, artists' studios, printing shops, meeting places of guilds, and rhetorician chambers, as well as private households with their libraries and collections, could all serve as sites of judgement, assessment, and valuation. In the preface to the widely read Schilder-Boeck of 1604, the painter and poet Karel van Mander recommended Prague with its many constcamers as a site ideally suited to "estimate and calculate [the] values and prices" of precious works, including paintings. ${ }^{44}$ Inventories drawn up by practitioners and traders engaged in certain crafts (i.e. silversmiths and book sellers) provide additional insight into local practices of assessment. Such material-based sensuous knowledge was often described as "judgement," or a kind of knowing that could not be learned from books alone but which also required skilled and sensitive hands as well as practised eyes. Likewise, individuals combining virtue, expert material knowledge, and observational skills were called either virtuosi or liefhebbers. ${ }^{45}$ Coined in Antwerp, the Dutch word liefhebber, in particular, underscores the affective and emotional

42 Craig Clunas, "Luxury Knowledge: The Xiushilu ('Records of Lacquering') of 1625," Techniques et cultures 29 (1997): 27-40.

43 Claudia Swan, "Lost in Translation: Exoticism in Early Modern Holland," in Art in Iran and Europe in the 17th Century: Exchange and Reception, ed. Axel Langer (Zurich: Museum Rietberg, 2013), 100-116.

44 Karel van Mander, Het Schilder-Boeck (Haarlem: Paschier van Wesbusch, 1604), fol. *iiiiv.

45 Harold J. Cook, Matters of Exchange: Commerce, Medicine, and Science in the Dutch Golden Age (New Haven, CT: Yale University Press, 2007); Elizabeth Honig, "The Beholder as a Work of Art: A Study in the Location of Value in Seventeenth-Century Flemish Painting," in Image and Self-Image in Netherlandish Art, 1550-1750, ed. Reindert Falkenburg, Jan de Jong, Herman Roodenburg, and Frits Scholten, Netherlands Yearbook for History of Art 46 (Leiden: Brill, 1995), 252-297; Vera Keller, “The 'Lover' and Early Modern Fandom," Transformative Works and Cultures 7 (2011), https://doi.org/10.3983/twc.2011.0351. 
dimensions of these shared activities. ${ }^{6}$ The emphasis on the sensuous experience of objects of knowledge and art was also a response to the massive destruction targeting the "sensual materiality" of images that occurred during the waves of iconoclasm. ${ }^{47}$ The focus on bodily and affective practices, has increased scholars' awareness of the levels of attentiveness and discernment expected from skilled craftsmen and artists. A heightened sense for colours and shades, for example, distinguished a whole range of early modern professionals including physicians, metallurgists, glassmakers, featherworkers, and, of course, painters. But, as is also shown by several contributions in this book, forms of material and sensuous discernment extended beyond the visual to include tactile values and qualities such as temperature, texture, and weight.

Finally, as Pamela H. Smith and others have shown, there was an almost explosive increase in written records left by practitioners and makers involved in a wide range of specializations from the 1400 s onwards. These writings express authors' self-assertion about their own creative acts in engaging with the material world, which was viewed as closely related to the cosmic and divine orders. ${ }^{48}$ Written in the vernacular, they were directed at both fellow artisans and a steadily growing group of "lovers" who shared their affective interests in material objects and the ways in which they were made. Such writings were in themselves innovative acts of verbal dexterity, in that they created a language to converse about matter, materiality, and objects in a range of social contexts, as Christine Göttler's contribution argues. They also helped develop repertoires of aesthetic and moral values associated with material appearances and sensations, such as transparency and glow, but also durability and longevity, the very qualities that drew early modern eyes to the objects and materials that are at the centre of this book.

\section{Four Fields of Enquiry}

This volume's distinctive perspective lies in its commitment to place the entanglement of humans, materials, and environments at the heart of our analyses, emphasizing that the subjectivities of matter are fundamentally social, awakened by the interrelation between space, bodies, and things. It focuses on glass, gold paints, feathers, and veils in order to examine artefacts and objects that have very different textures and

46 Cornelius Kiliaan, Etymologicum teutonicae linguae (Antwerp: Jan Moretus, 1599): amator, amans, fautor, studiosus, lief-hebber der konsten.

47 Koenraad Jonckheere, "Images of Stone: The Physicality of Art and the Image Debates in the Sixteenth Century," in Lehmann, Scholten, and Chapman, Meaning in Materials, 116-147.

48 Pamela H. Smith, "Why Write a Book? From Lived Experience to the Written Word in Early Modern Europe," Bulletin of the German Historical Institute 47 (2010): 25-50. 
span the whole spectrum of animal, vegetable, as well as mineral matter. Investigating these four different types of materials, we will address their wide range of medial qualities, such as transparency and opacity, stability and transmutability as well as softness and solidity, qualities that were by no means constant and could shift within historical parameters. They were manipulated by craft skills and chemical processes, provoked by site-specific, environmental conditions, and enhanced by bodies-in-motion. Across the contributions, the impact of light and colour is profound. Early modern Europeans enthused over the qualities of luminosity and lustre, delighting in glistening veils, shimmering shell gold, dazzling crystal glass, and iridescent feathers. Knowledge of the techniques and skills that enhanced properties of light went hand-in-hand with the exploitation of elemental forces to activate these materials' radiance. Through analyses like these, the following contributions tease out the complex ways matter, elemental conditions, and embodied sensory experiences intertwined in Renaissance and early modern Europe.

The first section focuses on glass, an antique technology and a pervasive art form. From the Renaissance down to the present day, however, glass has been closely associated with Venice and the nearby island of Murano. This section analyses how glass contributed to the shaping of social and cultural identities in Renaissance Venice. Lucas Burkart's contribution examines the economic importance of glass for the Republic. Its ubiquity as a consumer and export good is considered by Burkart to be the basis of a highly developed sense for the material's features and qualities, which reveals itself in contemporary literature and visual culture. Glass was so embedded into the popular interpretative framework of contemporaries that it fed into discussions about the nature of the sacred and the profane and formulated a lexicon for affective and bodily regimes. Rachele Scuro's essay studies the organizational, institutional, and social sites the glass industry cultivated in the Venetian Lagoon. Focusing on glass-making families and their workshops, Scuro explores the collective dynamics between production sites, artistic ingenuity, the circulation of knowledge, and the social mobility of the people involved in the Murano glass industry. Burkart and Scuro jointly show that material qualities including transparency, surface texture, and colour occupied the experimental chemical practices of glassmakers as much if not more than form. Inexpensive, malleable, and highly imitative, glass enriched its societal position not by the intrinsic rarity of its minerals so much as by the allure of its unique characteristics and the skilled hands that worked it. The mutual affinities between matter, the social body, and artistry fostered the industry's ingenuity and innovation, making glass an integral part of the community's identity.

The next section focuses on a fragile animal material - feathers - and their application in dress. In 1480 few Europeans were depicted wearing feathers, yet within decades, as feathers and featherwork from the Americas began to be eagerly received 
in Europe, feathers became prestigious objects indispensable to achieve a military as well as a "gallant" look. Feathers could be part of specific emotional styles and embodied practices. They indexed courage and masculine daring, but also subtlety, amorousness, and artistry. They frequently characterized lovers or musicians. The dyeing of feathers in multiple colours and its crafting into intricate shapes turned into a major sixteenth-century European fashion trend. To understand this uncharted and surprising history this section focuses first on the feather-makers positioned in different European cities, who together advanced a new and buoyant craft. Stefan Hanß shows that the application of complex techniques helped to perform feathers' material properties - their lightness, translucency, motility, and colourfulness - in culturally appreciated forms. Hanß's contribution highlights the intricate processing skills and knowledge about raw materials which made featherworking a subtle and valued craft. Ulinka Rublack turns to the Lutheran court of Württemberg, where elaborate feather displays formed part of an endorsement of trade and pleasure in artefacts designed to accomplish societal concord and civilization. Feathers not only fostered emotional communication but aimed at affective transformation in performances which sought, above all, to stabilize optimism about future discoveries, territorial development, and the strength of the Protestant Union on the eve of the Thirty Years' War. Materials could thus be deployed in the re-coding of emotional values and political ideas. Feathers, Hanß and Rublack demonstrate, were sensorially rich. Registering environmental conditions and bodily motions, they generated embodied sensations and embedded themselves into early modern affective regimes.

Gold, as a material used by artists and as a metal whose vibrant visual appearances can be imitated and emulated through paints, forms the central reference point of the next section. Whereas the wide range of yellow pigments used by early modern painters displays their skills in recreating the appearance of other materials and techniques, in its liquid form, gold brought its connotations of preciousness to the artist's page, where it enriched discourses about honour, craft skill, and mastery over matter. Moreover, the properties of gold and gold-imitating pigments - their brightness and their capacity to shimmer and glow - augmented their emotional resonances. Focusing on the four chapters on colour in Karel van Mander's SchilderBoeck (Haarlem, 1604), the most important treatise on Netherlandish painting of its time, Christine Göttler's contribution examines the dynamic relationship between yellow, vermilion, and gold, including their material and sensory affinities and their life-like and lively appearances. Van Mander's practical and theoretical explorations into painting - as an art requiring both ingenuity and experience - form part of a much larger project to establish a new vocabulary for writing and talking about the values and virtues of Netherlandish paintings, including their visual and tactile allure. Both a painter and a writer van Mander developed what can be understood as contemporaneous theory about the allure of glowing and sparkling surfaces, made 
possible by the Netherlandish "invention" of painting in oil. With the example of the celebrated Antwerp illuminator Joris Hoefnagel, Michèle Seehafer explores how shell gold, a well-known but exclusive painter's material in the early modern period, was used to reference artistic virtuosity and mediate friendship and patronage in different social environments and milieus. Aspirations and social relationships were negotiated through Hoefnagel's gifting of lavishly gilded illuminations, upon which gold flourishes served as a site to materialize professional identities. As a whole, the section engages with the growing interest in a "connected" history of art that takes into account shared forms of knowledge and sensitivities about material properties, their affective values, and interpretative potentials.

Lastly the volume turns to veils, a universal garment in the wardrobes of early modern European women. Made of linen, silk, and cotton fibres, their drape, shape, weight, and light-density varied considerably, particularly as new fashions and changing desires brought diverse veil-cloths to the market, the trade of professional veil-makers situated across European centres. In this abundant marketplace, veils' material characteristics incorporated the delicate and diaphanous, the heavy and densely woven, and the stiffly starched and flowing. In this section, the question of their materiality proves to be the key to deciphering veils' affective dynamics and symbolic meanings. Katherine Bond attends to the vibrant visual culture that sprung up to document the transformative powers of these malleable veils, emphasizing the veil's capability to materialize social and cultural identities. Sixteenth-century costume books paid close attention to the sensory affects of diverse forms of veils, where they contributed to discourses about youth, beauty, and widowhood. Following the enchanting powers of Italian sheer silk veils to the artful compositions of linen veils in the north of Spain, Bond demonstrates that veils and their idiosyncratic forms invigorated women's position within their communities. The early modern Protestant cities that Susanna Burghartz deals with in her contribution reveal the veil as a site of negotiation and agency; a battleground that highlights the degree of attentiveness certain Protestant cultures paid to material issues. Women's veils caused consternation and debate among civic and ecclesiastical authorities, weavers and entrepreneurs, and church-going women, as the fashioning of veils clashed with growing rivalries over economic resources, labour, and morality. Concentrating on the tension between tradition and fashion in the cities of Basel and Zurich from the fifteenth through to the eighteenth centuries, the historically changing relationship between veils' materiality, form, and the embodied sensations and emotions they enacted is shown to be contingent upon shifting societal pressures, legislative mandates, and identity politics. Both case studies sharpen our attention for embodied experiences and the emotional effects of dress codes and their regulation. This section thus engages with the intense interactions of materiality and identity, its bodily sensations, and cultural meanings. 
The objects encountered in our studies take on meaning in different confessional as well as social settings, often eliciting considerable emotional excitement and an absorbing sense that the world could be renewed through making. Each case study shows how makers, urban consumers, communities of like-minded individuals, and courts mutually spurred on innovation, rooted in their sensuous and emotional responses to matter and its value regimes.

Our methodology combines an in-depth qualitative analysis of serial records and ego-documents with object-led approaches. Items of visual, print, and manuscript culture, as well as social spaces like courts, workshops, streets, and churches are highlighted as important sites in which the affective resonances of materials were teased out, and as such were indispensable for charging materiality with cultural meaning. Qualities such as the transparency of cristallo glass, the gracility of feathers, the gleam of shell gold, the allure of yellows and reds, or the pliability of veil-cloths began to be linked to emotions and desires, shaping a widely approved, but nonetheless debated "period sense" that bound societies into communities of shared arguments about values and vocabularies. Researching, handling, or remaking such materials or artefacts enables scholars to engage with them as sensory objects, as potentially novel and striking visual acts in their time. This provides us with a better sense of how they might have incorporated or superseded elements of tradition. Putting featherwork under the microscope, reconstructing Zurich church veils, or recreating shell gold used in miniatures, illuminates contemporaries' sensitivity for matter and its manifold possibilities. By uniting object- and material-centred approaches with the history of affects in these ways, our book reveals how the interplay between vibrant matter and sensorially attuned contemporaries re-shaped early modern Europe.

\section{Bibliography}

\section{Unpublished Primary Sources}

Staatsarchiv Basel-Stadt (StaBS)

StaBS, Protokolle E 13,1 (27.11.1709)

\section{Primary Published Sources}

Die Korrespondenz Hans Fuggers von 1566 bis 1594. Regesten der Kopierbücher aus dem Fuggerarchiv, edited by Christl Karnehm, 3 vols. Munich: Kommission für Bayerische Landesgeschichte, 2003 .

Honour, Hugh. The New Golden Land: European Images of America from the Discoveries to the Present Time. New York: Pantheon Books, 1975. 
Kiliaan, Cornelis. Etymologicum teutonicae linguae. Antwerp: Jan Moretus, 1599.

Lessius, Leonardus. De iustitia et iure caeterisque virtutibus cardinalibus libri IV. Leuven: Jan Maes, 1605 .

Lessius, Leonardus, S.J. On Buying and Selling (1605), translation by Wim Decock, introduction by Wim Decock. Journal of Markets \& Morality 10, no. 2 (Fall 2007): 433-516.

Neumair von Ramsla, Johann Wilhelm. Des durchlauchtigen hochgebornen Fürsten und Herrn, Herrn Johann Ernsten des Jüngern, Hertzogen zu Sachsen, Gülich, Cleve und Berg [...] Reise in Franckreich, Engelland und Niederland. Leipzig: Henning Große der Jüngere, 1620.

Roberts, Lewes. The Merchants Mappe of Commerce: Wherein, The Vniversall Manner and Matter of Trade, is compendiously handled. London: Ralph Mabb, 1638.

van Mander, Karel. Het Schilder-Boeck. Haarlem: Paschier van Wesbusch, 1604.

Vasari, Giorgio. Lives of the Painters, Sculptors and Architects, translated by Gaston du C. de Vere, vol. 2. New York: Knopf, 1996.

\section{Secondary Literature}

Ajmar, Marta. "The Renaissance in Material Culture: Material Mimesis as Force and Evidence of Globalization." In The Routledge Handbook of Archaeology and Globalization, edited by Tamar Hodos, 669-686. London and New York: Routledge, 2017.

Anderson, Christy, Anne Dunlop, and Pamela H. Smith, eds. The Matter of Art: Materials, Practices, Cultural Logics, c. 1250-1750. Manchester: Manchester University Press, 2015.

Baxandall, Michael. Giotto and the Orators: Humanist Observers of Painting in Italy and the Discovery of Pictorial Composition, 1350-1450. Oxford: Clarendon Press, 1971.

Baxandall, Michael. The Limewood Sculptors of Renaissance Germany. New Haven, CT: Yale University Press, 1980.

Baxandall, Michael. Painting and Experience in Fifteenth Century Italy: A Primer in the Social History of Pictorial Style. Oxford: Oxford University Press, 1988.

Bennett, Jane. Vibrant Matter: A Political Ecology of Things. Durham, NC: Duke University Press, 2010.

Boivin, Nicole. Material Culture, Material Minds: The Role of Things in Human Thought, Society and Evolution. Cambridge: Cambridge University Press, 2008.

Butters, Suzanne B. The Triumph of Vulcan: Sculptors' Tools, Porphyry, and the Prince in Ducal Florence, 2 vols. Florence: Olschki, 1996.

Calaresu, Melissa, Mary Laven, and Vicky Avery, eds. Treasured Possessions from the Renaissance to the Enlightenment. London: Philip Wilson Publishers, 2015.

Clunas, Craig. "Luxury Knowledge: The Xiushilu ('Records of Lacquering') of 1625." Techniques et cultures 29 (1997): 27-40.

Cole, Michael Wayne. “Cellini's Blood." The Art Bulletin 81 (1999): 215-235.

Cole, Michael Wayne. "The Cult of Materials.” In Sculpture through Its Material Histories, edited by Sébastien Clerbois and Martina Droth, 1-15. Oxford: Lang, 2011. 
Cook, Harold J. Matters of Exchange: Commerce, Medicine, and Science in the Dutch Golden Age. New Haven, CT: Yale University Press, 2007.

Corry, Maya, Marco Faini, and Alessia Meneghin, eds. Domestic Devotions in Early Modern Italy. Intersections 59/1. Leiden and Boston, MA: Brill, 2019.

Davidson, Hilary. "The Embodied Turn: Making and Remaking Dress as an Academic Practice." Fashion Theory 23, no. 3 (2019): 329-362. DOI: 10.1080/1362704X.2019.1603859. de Boer, Wietse, and Christine Göttler, eds. Religion and the Senses in Early Modern Europe. Intersections 26. Leiden and Boston, MA: Brill, 2013.

De Munck, Bert, and Lyna Dries. "Locating and Dislocating Value: A Pragmatic Approach to Early Modern and Nineteenth-Century Economic Practices." In Concepts of Value in European Material Culture, 1500-1900, edited by Bert De Munck and Lyna Dries, 1-29. Burlington, VT: Ashgate, 2015.

Downes, Stephanie, Sally Holloway, and Sarah Randles, eds. Feeling Things: Objects and Emotions through History. Oxford: Oxford University Press, 2018.

Dupré, Sven, ed. Laboratories of Art: Alchemy and Art Technology from Antiquity to the 18th Century. Cham: Springer, 2014.

Dupré, Sven. "The Value of Glass and the Translation of Artisanal Knowledge." In Trading Values in Early Modern Antwerp, edited by Christine Göttler, Bart Ramakers, and Joanna Woodall, 138-161. Netherlands Yearbook for History of Art 64. Leiden: Brill, 2014.

Dupré, Sven. "The Art of Glassmaking and the Nature of Stones: The Role of Imitation in Anselm De Boodt's Classification of Stones." In Steinformen: Materialität, Qualität, Imitation, edited by Isabella Augart, Maurice Saß, and Iris Wenderholm, 207-220. Naturbilder 8. Berlin and Boston, MA: De Gruyter, 2019.

Faini, Marco, and Alessia Meneghin, eds. Domestic Devotions in the Early Modern World. Intersections 59/2. Leiden and Boston, MA: Brill, 2019.

Friedrich, Susanne. "Unter Einsatz aller Sinne. Zum ökonomischen Blick und dem Sammeln von Wissen in der Frühphase der niederländischen Ostindienkompanie (1602-ca. 1650).” Historische Anthropologie 28, no. 3 (2020): 379-398.

Goldthwaite, Richard. Wealth and the Demand for Art, 1300-1600. Baltimore, MD: Johns Hopkins University Press, 1993.

Göttler, Christine, and Mia M. Mochizuki, eds. The Nomadic Object: The Challenge of World for Early Modern Religious Art. Intersections 53. Leiden and Boston, MA: Brill, 2018.

Göttler, Christine, Bart Ramakers, and Joanna Woodall. "Trading Values in Early Modern Antwerp: An Introduction." In Trading Values in Early Modern Antwerp, edited by Christine Göttler, Bart Ramakers, and Joanna Woodall, 8-37. Netherlands Yearbook for History of Art 64. Leiden: Brill, 2014.

Großmann, Ulrich, and Petra Krutisch, eds. The Challenge of the Object:Proceedings of the 33 rd Congress of the International Committee of the History of Art = Die Herausforderung des Objekts. Akten des 33. Internationalen Kunsthistorikerkongresses, 4 vols. Nürnberg: Verlag des Germanischen Nationalmuseums, 2013. 
Hallam, Elizabeth, and Tim Ingold, eds. Making and Growing: Anthropological Studies of Organisms and Artefacts. Farnham, Surrey: Ashgate, 2014.

Hanß, Stefan. "Digital Microscopy and Early Modern Embroidery." In Writing Material Culture History, 2nd ed., edited by Anne Gerritsen and Giorgio Riello, 214-221. London: Bloomsbury, 2021.

Hanß, Stefan. "New World Feathers and the Matter of Early Modern Ingenuity: Digital Microscopes, Period Hands, and Period Eyes." In Ingenuity in the Making: Materials and Technique in Early Modern Europe, edited by Alexander Marr, Richard Oosterhoff, and José Ramón Marcaida. Pittsburgh, PA: Pittsburgh University Press, 2021, in press.

Honig, Elizabeth. "The Beholder as a Work of Art: A Study in the Location of Value in Seventeenth-Century Flemish Painting." In Image and Self-Image in Netherlandish Art, 1550-1750, edited by Reindert Falkenburg, Jan de Jong, Herman Roodenburg, and Frits Scholten, 252-297. Netherlands Yearbook for History of Art 46. Leiden: Brill, 1995. Ingold, Tim. "The Textility of Making." Cambridge Journal of Economics 34, no. 1 (2010): 91-102.

Jardine, Lisa. Worldly Goods: A New History of the Renaissance. New York: Nan A. Talese/ Doubleday, 1996.

Jonckheere, Koenraad. "Images of Stone: The Physicality of Art and the Image Debates in the Sixteenth Century." In Meaning in Materials, 1400-180o, edited by Ann-Sophie Lehmann, Frits Scholten, and H. Perry Chapman, 116-147. Netherlands Yearbook for History of Art 62. Leiden: Brill, 2013.

Jordanova, Ludmilla. "Review of Lorraine Daston ed., Things that Talk." The British Journal for the History of Science 39, no. 3 (2006): 436-437.

Keller, Vera. "The 'Lover' and Early Modern Fandom." Transformative Works and Cultures 7 (2011). https://doi.org/10.3983/twc.2011.0351.

Klein, Ursula, and Emma C. Spary, eds. Materials and Expertise in Early Modern Europe: Between Market and Laboratory. Chicago, IL: University of Chicago Press, 2010.

Labanyi, Jo. "Doing Things: Emotion, Affect, and Materiality." Journal of Spanish Cultural Studies 11, nos. 3-4 (2010): 223-233.

Lange-Berndt, Petra. “Introduction: How to Be Complicit with Materials." In Materiality, edited by Petra Lange-Berndt, 12-23. London: Whitechapel Gallery and MIT Press, 2015.

LeCain, Timothy J. The Matter of History: How Things Create the Past. Cambridge: Cambridge University Press, 2017.

Lehmann, Ann-Sophie. "Das Medium als Mediator: Eine Materialtheorie für (Öl-) Bilder.” Zeitschrift für Ästhetik und allgemeine Kunstwissenschaft 57 (2002): 69-88.

Lehmann, Ann-Sophie, Frits Scholten, and H. Perry Chapman, eds. Meaning in Materials, 1400-180o. Netherlands Yearbook for History of Art 62. Leiden: Brill, 2013.

Leng, Thomas. "Epistemology: Expertise and Knowledge in the World of Commerce." In Mercantilism Reimagined:Political Economy in Early Modern Britain and Its Empire, edited by Philip J. Stern and Carl Wennerlind, 97-113. New York: Oxford University Press, 2014. 
Long, Pamela O. Artisan/Practitioners and the Rise of the New Sciences, 1400-16oo. Corvallis, OR: Oregon State University Press, 2011.

Maitte, Corinne. "The Cities of Glass: Privileges and Innovations in Early Modern Europe." In Innovation and Creativity in Late Medieval and Early Modern European Cities, edited by Karel Davids and Bert de Munck, 35-54. Farnham, Surrey: Ashgate, 2014.

Maitte, Corine. "Façon de Venise: Determining the Value of Glass in Early Modern Europe." In Concepts of Value in European Material Culture, 1500-19oo, edited by Bert De Munck and Lyna Dries, 209-237. Burlington, VT: Ashgate, 2015.

Mancinelli, Fabrizio. "Michelangelo's Working Technique and Methods on the Ceiling of the Sistine Chapel." In Michelangelo, the Sistine Chapel: The Restoration of the Ceiling Frescoes, vol. 1, edited by Fabrizio Mancinelli, 15-28. Treviso: Canova, 2001.

Marr, Alexander. "Ingenuity in Nuremberg: Dürer and Stabius's Instrument Prints." The Art Bulletin 100, no. 3 (2018): 48-79.

Marr, Alexander, Raphaële Garrod, José Ramón Marcaida, and Richard J. Oosterhoff, eds. logodaedalus: Word Histories of Ingenuity in Early Modern Europe. Pittsburgh, PA: University of Pittsburgh Press, 2018.

Raff, Thomas. Die Sprache der Materialien. Anleitung zu einer Ikonologie der Werkstoffe. Munich: Deutscher Kunstverlag, 1994.

Randolph, Adrian W. B. Touching Objects: Intimate Experiences of Italian Fifteenth-Century Art. New Haven, CT: Yale University Press, 2014.

Reckwitz, Andreas. "Affective Spaces: A Praxeological Outlook." Rethinking History 16, no. 2 (2012): 241-258.

Richardson, Catherine, Tara Hamling, and David Gaimster, eds. The Routledge Handbook of Material Culture in Early Modern Europe. London and New York: Routledge, 2017.

Roberts, Lissa, Simon Schaffer, and Peter Dear, eds. The Mindful Hand: Inquiry and Invention from the Late Renaissance to Early Industrialisation. Amsterdam: Nederlandse Akademie van Wetenschappen, 2007.

Rublack, Ulinka. “Matter in the Material Renaissance." Past and Present 219, no. 1 (2013): $41-85$.

Rublack, Ulinka. "Befeathering the European: The Matter of Feathers in the Material Renaissance." The American Historical Review 126, no. 1 (March 2021): 19-53, http://doi. org/10.1093/ahr/rhaboo6.

Russo, Alessandro, Gerhard Wolf, Diana Fane, and Luisa Elena Alcalá, eds. Images Take Flight: Feather Art in Mexico and Europe, 1400-1700. Munich: Hirmer, 2015.

Smith, Pamela H. The Body of the Artisan: Art and Experience in the Scientific Revolution. Chicago, IL: University of Chicago Press, 2004.

Smith, Pamela H. "Why Write a Book? From Lived Experience to the Written Word in Early Modern Europe." Bulletin of the German Historical Institute 47 (2010): 25-50.

Smith, Pamela H., and Tonny Beentjes. "Nature and Art, Making and Knowing: Reconstructing Sixteenth-Century Life-Casting Techniques." Renaissance Quarterly 63, no. 1(2010):128-179. 
Smith, Pamela H., Amy R. W. Meyers, and Harold J. Cook, eds. Ways of Knowing: The Material Culture of Empirical Knowledge. Ann Arbor, MI: Bard Graduate Centre; University of Michigan Press, 2014.

Stewart, Kathleen. "In the World that Affect Proposed." Cultural Anthropology 32, no. 2 (2017): 192-198.

Stolberg, Michael. "Emotions and the Body in Early Modern Medicine." Emotion Review 11, no. 2 (April 2019): 113-122.

Swan, Claudia. "Lost in Translation: Exoticism in Early Modern Holland." In Art in Iran and Europe in the 17th Century: Exchange and Reception, edited by Axel Langer, 100-116. Zurich: Museum Rietberg, 2013.

Thimann, Michael. "Erinnerung an das Fremde: Jean Jacques Boissards Trachtenbuch für Johann Jakob Fugger: Zu Provenienz und Zuschreibung der Bildhandschrift Cod. Oct. 193 in der Herzogin Anna Amalia Bibliothek Weimar." Marburger Jahrbuch für Kunstwissenschaft 31 (2005): 117-148.

Weijers, Olga, and Marijke Gumbert-Hepp, eds. Lexicon latinitatis nederlandicae medii aevi, vol. 8. Leiden and Boston, MA: Brill, 2005.

Welch, Evelyn. Shopping in the Renaissance: Consumer Cultures in Italy, 1400-1600. New Haven, CT and London: Yale University Press, 2005.

Welch, Evelyn. "Scented Buttons and Perfumed Gloves: Smelling Things in Renaissance Italy." In Ornamentalism: The Art of Renaissance Accessories, edited by Bella Mirabella, 13-39. Ann Arbor, MI: University of Michigan Press, 2011.

Welch, Evelyn. "The Senses in the Marketplace: Sensory Knowledge in a Material World." In A Cultural History of the Senses in the Renaissance, edited by Herman Roodenburg, 61-86. London: Bloomsbury, 2016.

Welch, Evelyn, and Michelle O'Malley, eds. The Material Renaissance. Manchester: Manchester University Press, 2007.

Zorach, Rebecca. Blood, Milk, Ink, Gold:Abundance and Excess in the French Renaissance. Chicago, IL: University of Chicago Press, 2005. 


\section{About the Editors}

Susanna Burghartz is professor of Renaissance and Early Modern History at the University of Basel. She has published on Reformation, confessionalization and gender history, as well as early European globalization and material culture. Her current research investigates advertising journals as the new marketplaces for the emerging consumer society of the eighteenth century, and includes a micro-global history of the Leisler family and Basel's silk ribbon industry.

Lucas Burkart has been Professor of History at the University of Basel since 2012. His research interests encompass the cultural history of the Middle Ages and the Renaissance, the history of material culture, and the history of historiography. Currently, he is also overseeing the completion of the critical edition of the works by Jacob Burckhardt.

Christine Göttler, Professor emerita of Art History at the University of Bern, specializes in the art of early modern Europe, with a focus on the Netherlands. She has published widely on collecting practices, historical aspects of artists' materials, and the imagery of solitude. Her current projects explore Peter Paul Rubens's engagement with Antwerp's global world and the relationship between landscape and nature.

Ulinka Rublack is Professor of Early Modern History at Cambridge University and Fellow of St John's College. In addition to research on Reformation and on gender history, Rublack specializes in the history of dress. Her books on this subject include Dressing Up: Cultural Identity in Renaissance Europe, Oxford University Press: 2010. 


\section{Part 1}

Glass 



\title{
1. Negotiating the Pleasure of Glass: Production, Consumption, and Affective Regimes in Renaissance Venice
}

\author{
Lucas Burkart
}

\begin{abstract}
Since the Renaissance, glass has been associated with Venice like no other material. It represents a local industry and its international prestige. While research has mostly focused on high-end products, this chapter takes a broader approach. It illuminates the entire spectrum of glass production and its significance for the economy and trade of Renaissance Venice. It investigates how glass as a material affected the society of Renaissance Venice. In general, the low price of glass made it in general affordable to growing social groups and its distinct malleability allowed them to participate in the formal and aesthetic ideals of the Renaissance. Given the industry's economic and trading importance, glass was ubiquitous in Venice; diverse professional and social groups were engaged in it, generated a shared sense for the material and developed a nuanced lexicon that was used in social, cultural, and religious debates. In material, pictorial as well as literary form glass and its material features served to establish affective regimes that served to navigate through an increasing material world and contemporarily shape a community's identity.
\end{abstract}

Keywords: Venetian glass industry; high and low glass; trading glass; Renaissance taste for glass; sacred matter and erotic material

Between $145^{0}$ and 1650, glass objects produced in Venice and on the nearby island of Murano enjoyed the highest reputation in Europe and beyond. Contemporary travellers to the Lagoon witnessed the art when visiting the local glass workshops

Burghartz, S., L. Burkart, C. Göttler, U. Rublack, Materialized Identities in Early Modern Culture, 1450-1750: Objects, Affects, Effects. Amsterdam: Amsterdam University Press, 2021

DOI 10.5117/9789463728959_CHO1 
and their accounts spread the fame of Venetian glass. On his return from the Holy Land, the Dominican friar Felix Fabri recorded such a visit in his Evagatorium, "there is no other place on earth you can find such precious glass as is produced there every day." Fabri's admiration arose from the masters' industriousness (industriosi artifices), but he was even more excited about the material properties of glass. These masters "out of the fragile material, formed vases so elegant that they almost exceeded those adorned with gold, silver, and precious stones." More than a hundred years later, the English travel writer Thomas Coryat took the same line by highlighting the material characteristics of glass production, "I passed in a Gondola to pleasant Murano, distant about a little mile from the citie, where they make their delicate glasses, so famous over al Christendome for the incomparable finenes thereof, and in one of their working houses I made a glass my selfe." ${ }^{2}$ Despite having different reasons for visiting the Lagoon, Fabri and Coryat shared the same view of the Venetian glass industry. Both accounts are typical for the period. Murano was considered the most important production site, while glass was seen as a specifically Venetian material.

In the long historiographical tradition on Venetian glass, these views were more or less conserved and replicated. Most studies, both local and international, directed attention to the unique form and style in the high-end production of Venetian glass, and its artistic ingenuity and development after the invention of cristallo around 1450. This focus has been supported by the representation of precious glass objects in paintings by renowned artists of Renaissance Venice such as Bellini, Carpaccio, Titian, Tintoretto, Veronese, and others.

This chapter proposes a shift in perspective, to view Venetian glass as a material in the making and to analyse the impact it had on shaping Venetian social identities and affective regimes. It will thus explore the economic, societal, and cultural framework in which glass developed in Renaissance Venice. This broad focus is in contrast to conventional research that has usually been devoted to the relatively narrow segment of high-end glass production. It has been deliberately chosen because it brings the material as such to the forefront and allows it to appropriately include the ubiquity of glass in the variety of its products in the interpretation of its material properties and impact on Venetian Renaissance society. Focusing on the analysis of the material characteristics of glass also means enriching the

1 "non enim reperiuntur hodie in mundo tam pretiosa vitra, sicut ibi sunt cottidie, [...] industriosi artifices, qui ex fragili materia formant vasa tam elegantia, ut paene superent aurea, argentea, pretiosis lapidibus ornata vasa [...]." Fratris Felicis Fabri Evagatorium in Terrae Sanctae, Arabie et Aegyptiae Peregrinationem, ed. Konrad D. Hassler, vol. 3, Bibliothek des Literarischen Vereins in Stuttgart 18 (Stuttgart: Stuttgardiæ, 1849), 395 .

2 Thomas Coryate, Coryat's crudities: hastily gobled up in five moneths travells in France, Savoy, Italy, Rhetia commonly called the Grisons country, Helvetia alias Switzerland, some parts of high Germany and the Netherlands (Glasgow: James MacLehose and Sons, 1905), 387. 
investigation with a sensorially oriented idea of social identity. Such an approach seizes upon the visual appeal of crystal glass that scholarship has long stressed. Highly transparent and virtually spotless, cristallo became synonymous with Venetian glass, and was known as vetro alla Vinitiana or venedisches glas and famous for its ingenuity and artistic innovation in general. As façon de Venise, a term first documented in 1549, these very ideas were spread in Europe and beyond. ${ }^{3}$ Despite the close association with light and, therefore, the symbolic, in both Christianity and Islam, the aesthetic appeal of glass was not only visual but sensual. Material properties of glass, such as its smooth surface, ornamental value, and malleable form, provoked sensual pleasure and added to the affective value of Venetian glass.

Inspired by recent studies on the history of Renaissance material culture, this chapter argues that glass had an agentive and affective impact as both a commodity and as a material. It will, therefore, adopt a material perspective and investigate the effects of glass in Renaissance Venice. An analysis of glass as a material involves an examination of how it was produced, consumed, and utilized. It will be argued that the materiality of glass played a crucial role in Venetian economy, society, and culture.

Such an approach has to contend with a wide range of sources, both textual and visual, along with surviving artefacts. While this body of sources is well known to researchers in the field, they provide new insights when analysed from the perspective of agentive matter. Ubiquitous in the urban space and more closely associated with Venice than any other material, glass enriched the material world of the time, fostered a trade in consumer products and luxury goods, and inspired contemporary imagination. Glass became desirable and in high demand. The appeal of Venetian glass, however, arose not only from its availability as a commodity and the associated consumer demand, but was also due to its unique material features and the knowledge and expertise of Venetian professional glassmakers. As a consequence, the material affected not only producers but wider social strata. The material features of glass were negotiated and exploited beyond furnaces and workshops. In social action and communication, Venetian glass generated a material lexicon that was widely used, secured material value, and shaped social identities.

Yet before turning to the emotive effects and affective impact of glass as a material, this chapter investigates more closely the material relations of glass in Renaissance Venice. What types and forms of glass were crafted in the city? Who was involved

3 For façon de Venise, its semantics, and historiographical challenges see Erwin Baumgartner, Reflets de Venise: Gläser des 16. und 17. Jahrhunderts in Schweizer Sammlungen:verres des XVIe et XVIIe siècles de collections suisses, Publications du Vitrocentre Romont (Bern: Lang, 2015), 13. For its first use as a label-term see Alexandre Pinchart, "Les fabriques de verres de Venise d'Anvers et de Bruxelles au XVIième et au XVIIième siècle," Bulletin des Commissions Royales d'Art et d'Archéologie 21 (1882): 343-394, in particular 371f.; Florent Pholien, La verrerie et ses artistes au pays de Liège (Liège: Bénard, 1899), 50. 
in its production, commerce, and consumption and, finally, what networks enabled both the circulation of glass objects and exchange about its cultural meaning?

\section{Mapping an Industry - Venetian Trading Networks and Glass Product Lines}

In the summer of 1590, the vessel Santa Maria delle Grazie left the Lagoon, with stopovers in Zakynthos, Kythira, Crete, and Cyprus, before finally reaching its destination in Tripoli, where some of the freight was carried on land to Aleppo in Syria (Fig. 1.1). In a document, probably drawn up by the owner Stefano Patti, the entire cargo of the vessel was registered. ${ }^{4}$ More than 190 affiliates contributed to the shipment with loads of different sizes (Fig. 1.2). Every entry is identified in the margin with the owner's trademark, marking where the respective goods needed to be unloaded and delivered. Additionally, the source records the type of commodity and its packaging, its destination, the recipient, and finally the corresponding tax

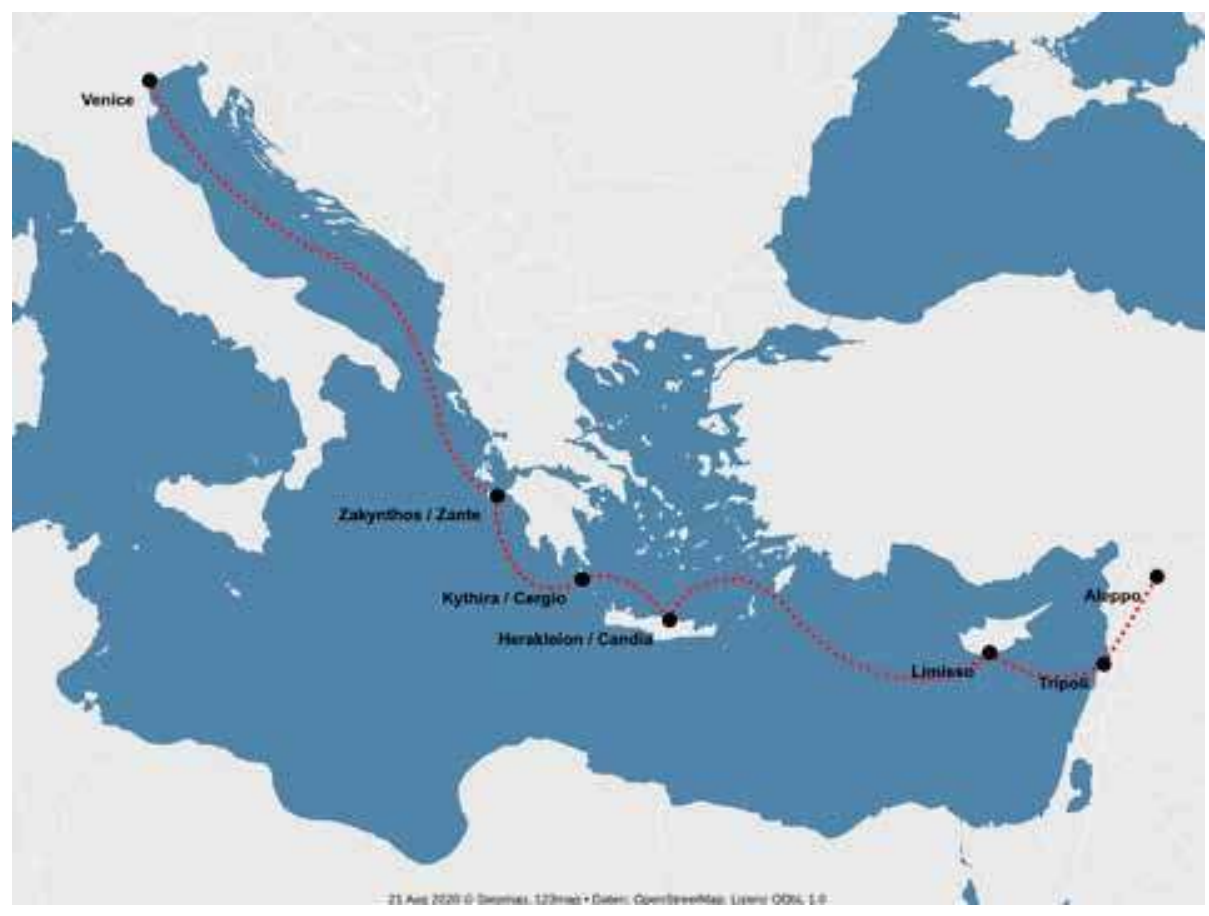

Figure 1.1: Trading route through Eastern Mediterranean Sea taken by Santa Maria delle Grazie in 1590. Image ๔ Nicolai Kölmel. 


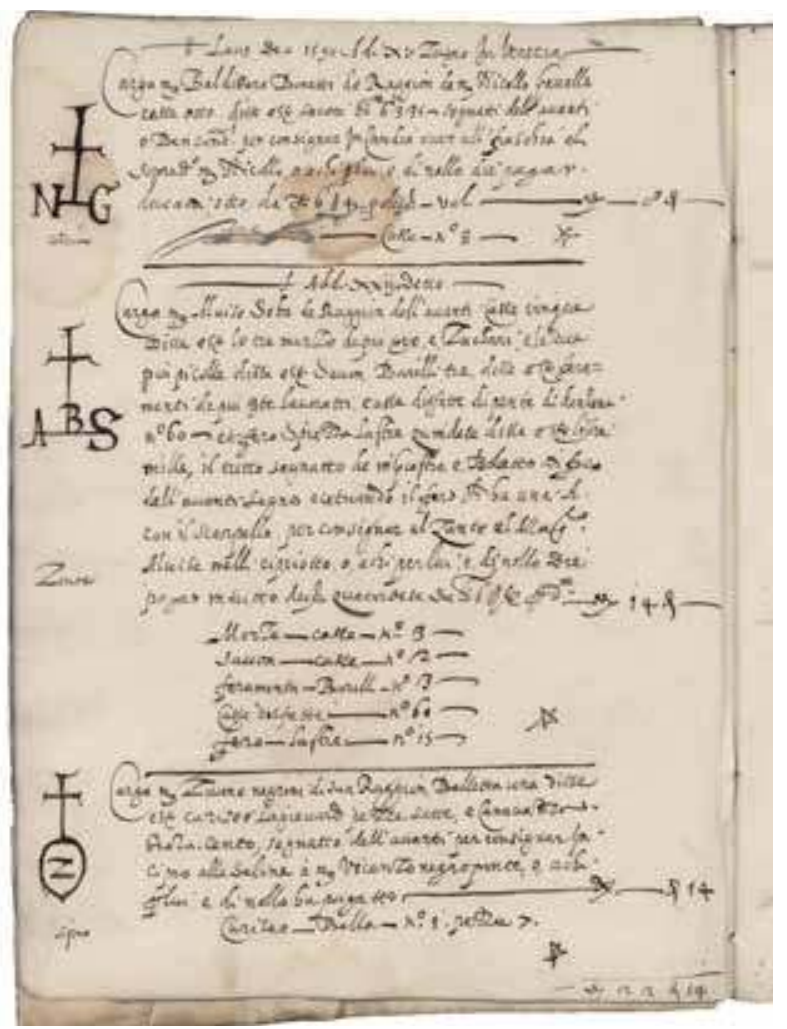

Figure 1.2: Cargo list of Santa Maria delle Grazie. Fol. 3v. Venice, Archivio di Stato di Venezia, Miscellanea Gregolin, shelf no. b. 14, reg. D. Image $\odot$ Archivio di Stato di Venezia.

for transport and insurance. The shipment included all sorts of goods including textiles, money, ironwork, paper, soap, barrels, weapons, braids, ropes, rabbit furs, a horse, and a number of glass objects too, particularly mirrors, beads, and unspecified glass (vero/i, vedro/i), probably drinking glasses and/or window panes. All the glass was packed in casse and cassette. While unspecified glass objects were unloaded at all stopovers, the mirrors and beads were all delivered to the final two destinations of Tripoli and Aleppo.

The composition of such cargoes can be deduced from the study of late sixteenthcentury Venetian maritime insurance policies conducted by Alberto Tenenti. ${ }^{5}$ As far as the written evidence specifies, most exported glass was mass-produced, namely beads, jewellery made of glass (conterie), mirrors, window panes, and beakers. Although the documents here do indicate exact quantities, the measuring unit of casse or cassetoni occasionally amounted to the impressive number of more than 1,700 pieces, containing beakers (gotti), bottles (ingistere), bells (chanpanele), and reeds (pivette)

5 Alberto Tenenti, Naufrages, corsaires et assurances maritimes à Venise: 1592-1609 (Paris: S.E.V.P.E.N., 1959). 


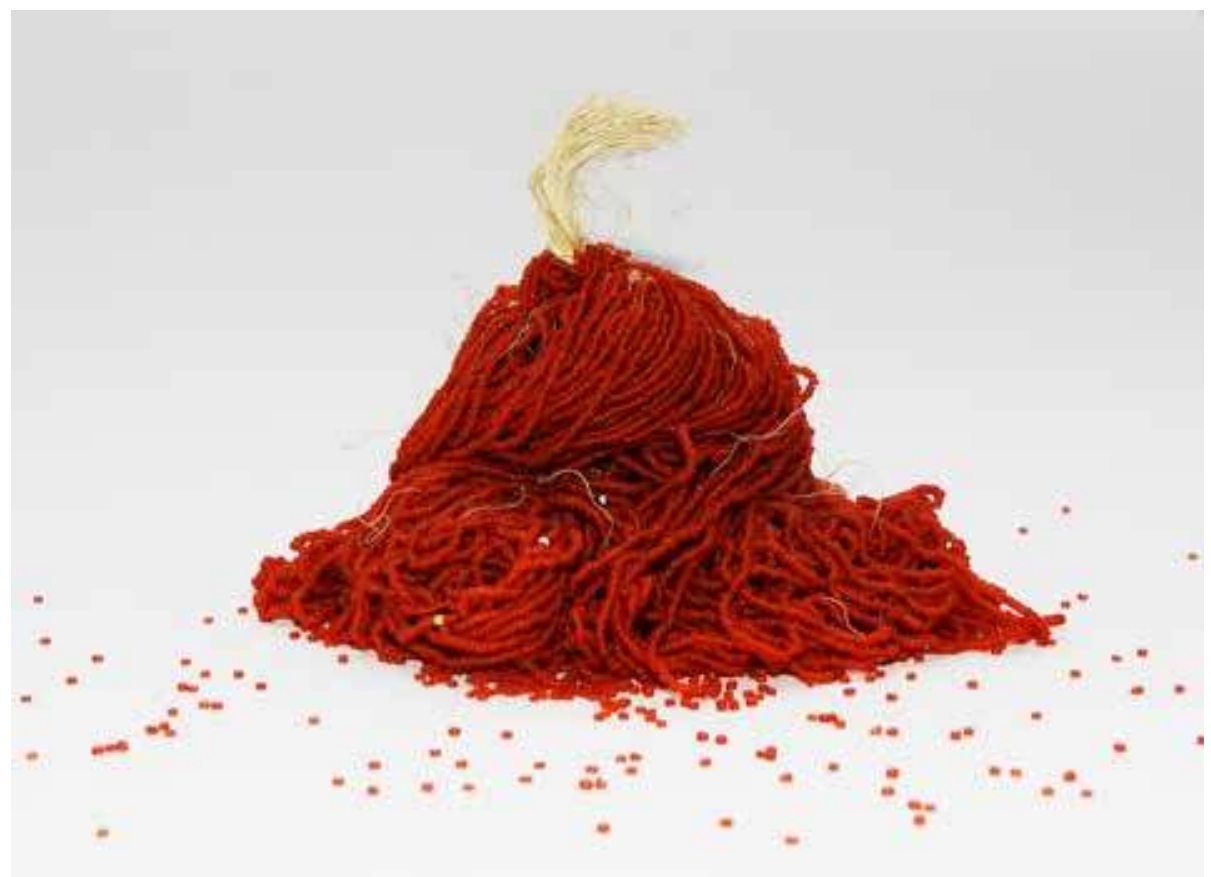

Figure 1.3: Bunch of red enamelled seed beads, around 1800. D: $0.5 \mathrm{~mm}$, Venice or Murano, Private Collection. Image ๑ Julia Burkart.

to make pearls (margarite). ${ }^{6}$ The quantity of exported glass beads can be ascertained more precisely. They were measured in quantities of miera or migliara, literally meaning 1,00o pieces. Beads, however, were not counted but weighed. Onboard the Sant'Andrea, which left Venice in September 1601 for Cadiz, there was a cargo of 3,646 migliara glass beads, approximately 3,646,00o pieces. Another shipment on the same vessel contained 2,646 migliara of aggierini and latimi, approximately 2,646,000 beads of blue and milk white. Yet another shipment comprised 361 mazzi of smaltiti assortiti, bunches of enamelled seed beads of different colours destined for further processing (Fig. 1.3). Finally, glass jewellery worth 2,400 ducats was also on board.

The sheer quantity of objects aboard Venetian vessels is stunning and their economic value considerable. These insurance papers, however, normally only register the cargoes of vessels that were shipwrecked or looted by corsairs and pirates. It is thus impossible to extrapolate from these sources any total number of beads exported from Venice. Nevertheless, it is appreciable that despite the low value of both glass sheets and objects, the amount of exported glass must have

6 See Luigi Zecchin, "Il quaderno dei Bortolussi," in Vetro e vetrai di Murano, ed. Luigi Zecchin, vol. 2 (Venice: Arsenale Editrice, 1989), 186-189. 


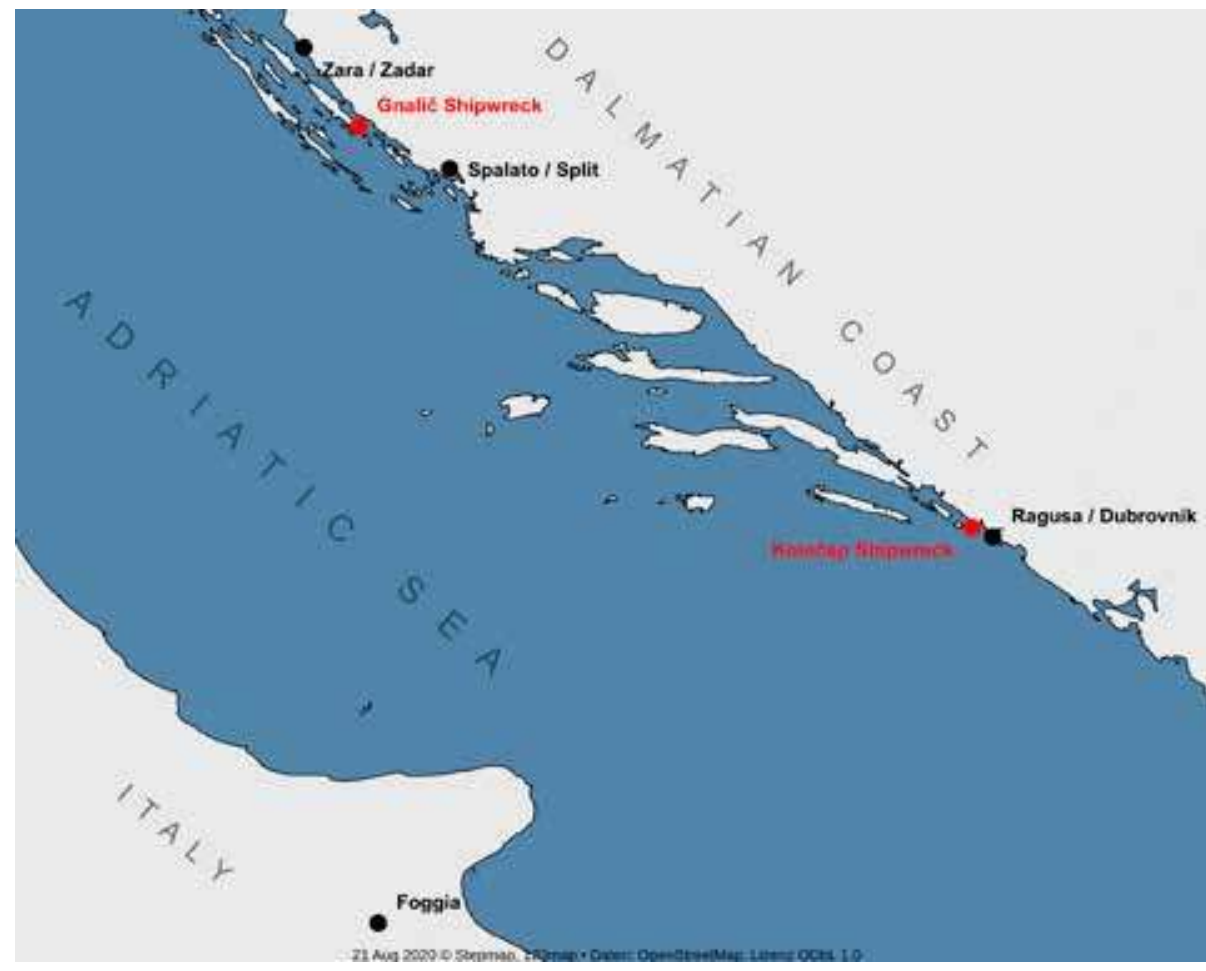

Figure 1.4: Map of the Dalmatian Coast with locations of Gnalič and Koločep shipwrecks. Image $\odot$ Nicolai Kölmel.

comprised a substantial economic and trading share. Although hardly ever studied systematically, it seems obvious that mass production was the economic backbone of the Venetian glass industry.

These observations are confirmed by archaeological finds. In the Adriatic Sea, off the Croatian coast, two shipwrecks from around 1600 have been found and partially recovered. One of these, the Gnalič wreck identified as the Gagiana or Gagliana, sailed from Venice probably to Constantinople and was shipwrecked at the beginning of 1583 off the coast of Biograd na Moru. ${ }^{7}$ Corroborating the evidence in surviving textual sources, archaeological evidence indicates that most of the cargo on board the Gnalič wreck consisted of glass artefacts of two different categories: flat glass, namely mirrors and window panes $(25 \%)$, and tableware and vessels (75\%). More than 700 window panes were recovered (Fig. 1.5). Most of them were

7 Astone Gasparetto, “The Gnalić Wreck: Identification of the Ship,” Journal of Glass Studies 15 (1973): 79-84; Mitja Guštin, Sauro Gelichi, and Konrad Spindler, eds., The Heritage of the Serenissima: The Presentation of the Architectural and Archaeological Remains of the Venetian Republic (Koper: Založba Annales, 2006), 99-104; Irena Lazar, "I vetri del relitto di Gnalić," in L'avventura del vetro dal Rinascimento al Novecento tra Venezia e mondi lontani, ed. Aldo Bova (Milan: Skira, 2010), 103-109. 


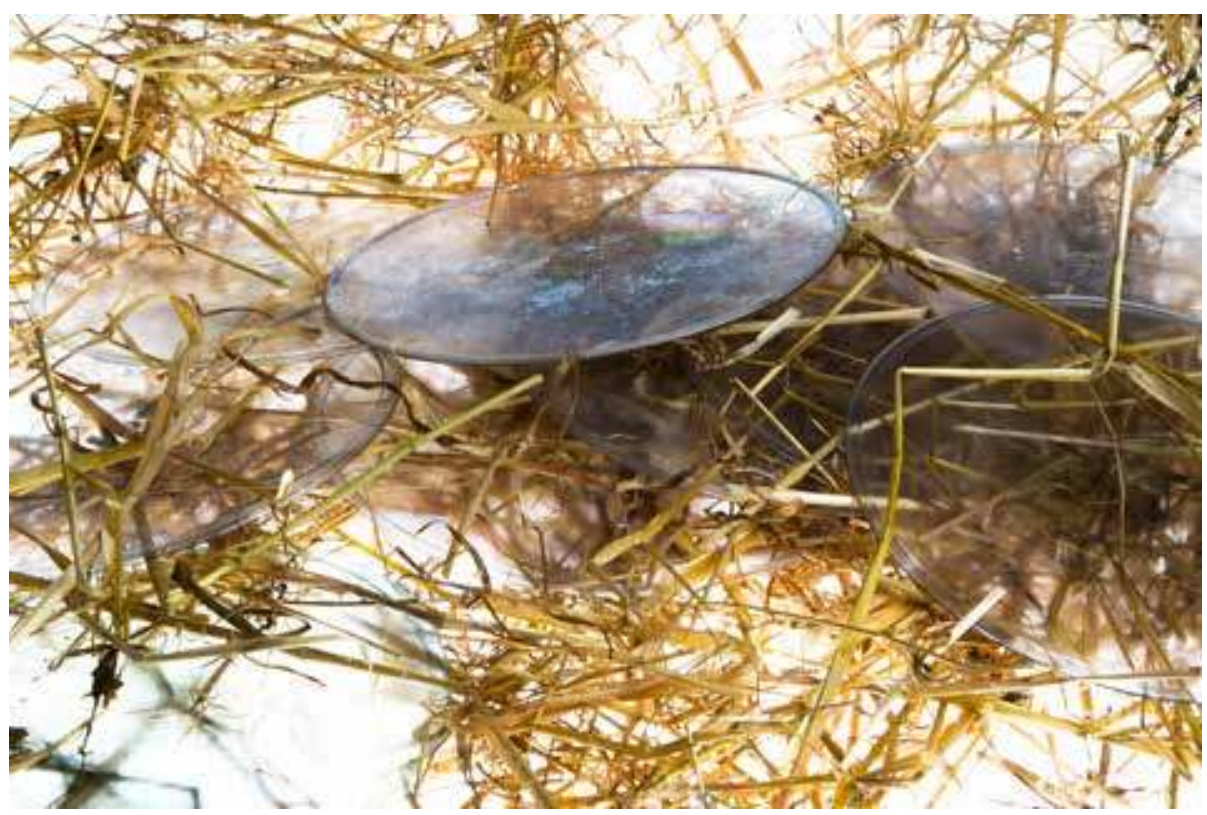

Figure 1.5: Window panes from the Gnalič shipwreck with straw, which served as protection against breaking during transport, end of the sixteenth century. Murano, D: $21 \mathrm{~cm}$. Biograd na Moru, Zavičajni Muzej Biograd na Moru, inv. no. G42. Image @ Ivana Asić.

made through standard production methods, intended to meet the demands of a general market. ${ }^{8}$ Glass beads were found in the wreck as well. Despite the large quantities of exported glass beads recorded in written sources, the Gnalič shipwreck presents only a small number of beads totalling around 2.5 kilograms (Fig. 1.6). ${ }^{9}$

The ship's original departure from Venice is confirmed, yet the study of the cargo challenges the idea of Venice as an unrivalled site of glass production. About 250 pairs of spectacles, probably from Germany, were not produced in but only shipped from Venice. Stylistic analysis of other artefacts reinforces this hypothesis. Around sixty-five objects found in the wreck were discernibly of Islamic origin. Spots of coloured glass were applied to the surfaces of glass bodies in a way not practised in European workshops. A type of flask found at the site with a narrow neck and a pronounced rim cannot be attested to Western production manuals

8 The finds of the Koločep wreck confirm this. Here the rectangular window panes have been detected still in their wooden boxes lined up one next to the other with a layer of straw or seaweed in between to avoid breaking during transportation. Irena Radić Rossi, "Il relitto di Koločep, Croazia," in Bova, L'avventura del vetro, $111-115$, in particular figs. $3-5$.

9 Irena Lazar and Hugh Willmott, "The Late 16th Century Glass from the Gnalić Wreck: An Overview of Forms," in Guštin et al., Heritage of the Serenissima, 99-104. Lazar, "I vetri," 108. 


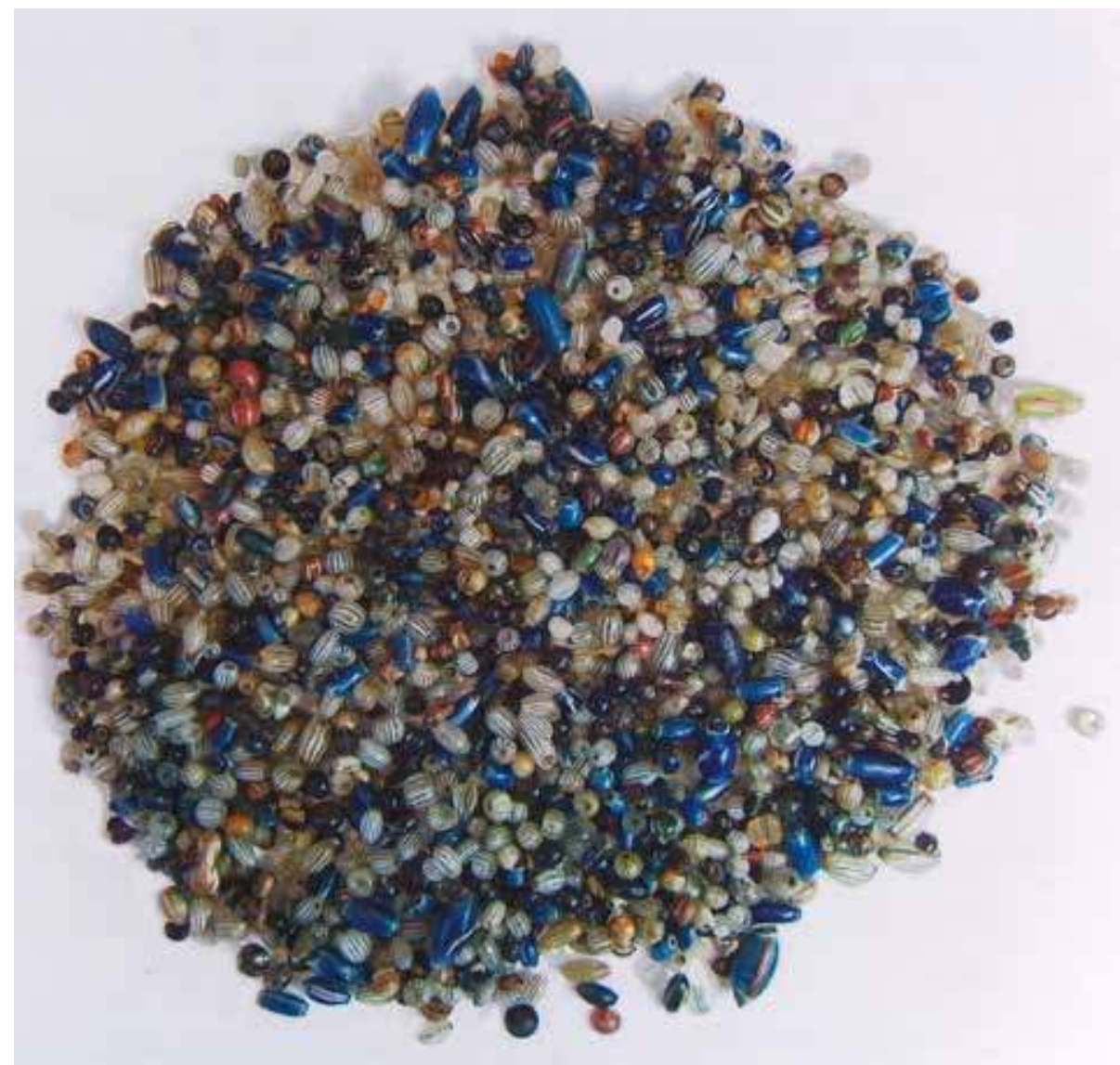

Figure 1.6: Glass beads from the Gnalič shipwreck, end of the sixteenth century. Murano, L: $0.4-0.9 \mathrm{~cm}$. Biograd na Moru, Zavičajni Muzej Biograd na Moru, inv. no. G250. Image @ Ivana Asić.

either. ${ }^{10}$ The glass carried in the Gagliana's hold came from varying places of origin and, therefore, emphasizes Venice's role as a major hub for glass trade in the Mediterranean.

Mass-produced items made from glass, however, were not only essential to Venetian trade but cultivated a significant presence in the city's private households as well as in urban craft industries. Despite moving furnaces from Venice to Murano in 1291, due to the risk of fire, glass production never entirely disappeared from the city. Various guilds continued to craft glass, specializing in processing either semi-finished glass or manufactured glass objects. Whereas the glass industry in Murano was organized in the dominating arte dei verieri, the city of Venice was home to at least six guilds that processed glass in one way or another: the arti dei 
perleri, margariteri, cristaleri e paternostreri, specchieri, finestrieri, and gioiellieri manufactured glass while the arti dei venditori divetro, dei marzeri, dei muschieri, and the arte dei strazaroli regularly sold glass on a retail scale and complemented the considerable number of people dealing and handling the material. Recent scholarship has convincingly argued that material mattered considerably more in the pre-industrial world than in modern times. ${ }^{11}$ The pre-modern material world was characterized by a close engagement between individual actors and materials, which produced embodied knowledge. Moreover, this engagement spawned a highly developed sensitivity for processed materials and their agentive power.

Post-mortem inventories of artisans and shopkeepers document the impressive degree to which glass was present in people's lives. Domenego Bortolussi, the head of the shop la nave in Murano, kept accounts of his trade with Milan in the years 1540 and 1541 . He recorded more than 10,00o blown glass objects that were packed and shipped from his shop to the Lombardic capital. ${ }^{12}$ Master Jacob, the owner of a shop (marzer) in the parish of San Zulian, collected not only glass lamps, but traded beads, rosaries, and pearls of different size, shape, and colour in remarkable quantities. He also kept 1,420 pairs of glasses. ${ }^{13}$ Master Jacob's holdings seem modest if compared to Francesco's shop "the Angel" where among many other kinds of glass artefacts, almost 700 mirrors were stored. ${ }^{14}$

Evelyn Welch has argued that visual and tactile knowledge were important acquired skills for any profitable market behaviour in the Renaissance. ${ }^{15}$ It was essential that both buyers and sellers could distinguish high- and low-quality materials and artisanal production. Venetian shopkeepers clearly needed this knowledge to establish prices. Although it is not known how prices were set, the sources offer some illustrative evidence.${ }^{16}$ In the case of mirrors, size, lucidity, and the reflexivity of the glass were significant factors, as was the material and artistic execution of the frame. In the inventory of the bottega dell'Angelo, six mirrors with ebony frames made by a certain master Zuan Maria Marangon were listed. ${ }^{17}$ Material qualities were decisive

11 Ulinka Rublack, "Matter in the Material Renaissance," Past \& Present 219, no. 1 (2013): 41-85.

12 See Zecchin, "Il quaderno," 186-189. For the Bortolussi, see Rachele Scuro's chapter in this volume.

13 ASVe, CI, Misc., b. 35, fasc. 23 (18 September 1531).

14 ASVe, CI, Misc., b. 38, fasc. 29 (2 April 1547).

15 Evelyn Welch, "The Senses in the Marketplace: Sensory Knowledge in a Material World," in A Cultural History of the Senses in the Renaissance, ed. Herman Roodenburg (London: Bloomsbury, 2016), 61-86. This perspective was introduced by Michael Baxandall and has been widely adopted from both his Painting and Experience (1972) and The Limewood Sculptors of Renaissance Germany (1980).

16 The inventory of Jacob of Milan, who owned the shop "the lily," is one of the rare cases where most of the entries include prices. ASVe, CI, Misc., b. 40, fasc. 70 (15 May 1564). For the question of pricing see Evelyn Welch, "Making Money: Pricing and Payments in Renaissance Italy," in The Material Renaissance, ed. Michelle O'Malley and Evelyn Welch (Manchester: Manchester University Press, 2007), 71-84.

17 ASVe, CI, Misc., b. 38, fasc. 29 (2 April 1547), fol. 15v. 
not only for mirrors but for virtually all glass artefacts, for which contemporaries possessed a distinct sense. The colours of beads for rosaries, for instance, are described in the inventories as: de calcedonia, bianchi, negri, mori, zali, limonzini; false pearls were described as negre, dorade, inarzentade, or de garavana, probably meaning from the caravans, i.e. coming from the East or with "orientalizing" patterns.

Welch's argument is confirmed by the Venetian evidence. Moreover, this material sensitivity applies not only to the prestigious high-end production of glass art but in similar ways to mass-produced items. ${ }^{18}$ Finally, the inventories show that a refined vocabulary was not only required from the retailers but from consumers too. Inventories, usually put together by notaries, describe the material world surrounding them in rich detail. This material lexicon served the purpose of identifying the described object's value in socio-economic and legal processes such as inheritance, marriage, sales, and pawnbroking. Used for these crucial social actions, this rich material vocabulary confirms that a sense for the material was equally shared among producers, wholesalers, retailers, and clients.

In Murano and Venice, mass-produced items made from glass were fabricated, manufactured, exported, locally retailed, and consumed. Material culture, therefore, involved wide social strata, reached deep into the urban crafts and the body politic, and affected everyone engaging with it. Thanks to its low material value, glass was ubiquitous in Renaissance Venice and, at the same time, flourished in a richness of styles, shapes, colours, and qualities that not only exist in surviving artefacts but also in textual sources from the time. Finally, these sources show that the variety of production and material quality that existed required a corresponding vocabulary that disseminated a sense for glass's material features across a wide social spectrum in Renaissance Venice and beyond.

\section{The Power of Simulation and Adaption - Consuming Glass in the Renaissance}

The physical and terminological ubiquity of glass in the Lagoon made Venice not only the first marketplace for glass commodities but a centre of especial sensitivity

18 Luca Molà has argued that matter and identity are not only linked through the consumption of commodities, thus visible for historical research into consumer habits. His analysis of diplomatic relations between Venice and the Ottoman Empire, which includes a systematic review of Venetian glassware ordered by the Senate as gifts to Members of the High Porte (pp. 67-68), suggests convincingly that producers were well aware of both the political implications of these artefacts and the social prestige of producing them. Luca Molà, "Material Diplomacy: Venetian Gifts for the Ottoman Empire in the Late Renaissance," in Global Gifts: The Material Culture of Diplomacy in Early Modern Eurasia, ed. Zoltán Biedermann, Giorgio Riello, and Anne Gerritsen (Cambridge: Cambridge University Press, 2018), 56-87. 
for the material itself. Yet, according to Welch, in the Renaissance this sensitivity was neither restricted nor exclusively nourished by producers. It was shared by consumers and their cultural expectations. For glass, this shared sensitivity is particularly convincing because the most important material feature of glass, its vast capacity to simulate, gets to the core of a more general discussion about Renaissance art and culture. Simulation was key to the very idea of the Renaissance. Renaissance art and material culture strongly aimed to imitate and improve upon specific historical and aesthetic models. In scholarship focused mostly on form and style, the case of glass indicates the importance of materiality in such debates. Glass could not only assume virtually any form but could additionally simulate precious materials such as gemstones. Whereas gemstones were still appreciated as mirabilia, glass objects became increasingly artificia, man-made elements that emulated and improved upon nature itself.

When Isabella d'Este, one of the finest collectors in Renaissance Italy, corresponded with her agent in Venice, Lorenzo da Pavia, her expectations as a consumer clearly emerged. In letters between the two, both the colour and form of glass objects were negotiated at length. In 1503 , Lorenzo was instructed to purchase two drinking vases in Murano that Isabella wanted to be of fanciful and beautiful form (de qualche foza fantasticha e bela). In order to satisfy her demand, Lorenzo asked her for a draft version of the commissioned objects. ${ }^{19}$ Four years later, Lorenzo sent two green enamelled cups and one of cristallo to Mantua, with a note that the cups were not currently available in other colours because the required pigments were not available in the workshops. ${ }^{20}$ The request for a physical model of the cups, however, was not only expressed by Lorenzo in order to please the marchioness. Isabelle d'Este herself drew from existing artefacts in her collection to aid in her purchasing. In 1507 , she wrote to Venice, "I'm sending a silver plate to give an example of how in Murano five similar ones made from enamelled glass of different colours shall be manufactured; I expect those promptly together with the silver template." ${ }^{21}$ In 1512, Isabella reacted to the delivery of several glass beakers she did not like with a sketch that should be followed to produce a new set of at least a dozen beakers with lids. ${ }^{22}$

19 ASMn, AG, b. 1440, Carteggio di Inviati e Diversi, c. 296, cart. 1f. (28 September 1503).

20 ASMn, AG, b. 1891, Corrispondenza con Isabella d'Este, provenienze diverse, c. 359, cart., if. (13 April 1507).

21 ASMn, AG, b. 2994, Copialettere particolari d'Isabella d'Este, lib. 20, cc. 29v-3or (9 April 1507). "Mandiamovi etiam una piadenetta de argento per monstra acioché a Murano ne facciati fare cinque simile de vetro de smalto de diversi colori et mandarneli subito, insieme cum quella de argento [...].” 22 ASMn, AG, b. 2996, Copialettere particolari d'Isabella d'Este, lib. 30, c. 3v (29 February 1512). "Diceti vero che li bichieri che ne haveti mandati non sono belli. Ve mandiamo un dessigno: faretine far al meglior m.ro che sij a Murano una donzena a quella foggia col suo coperto [...]." 
Isabella d'Este's status as a renowned collector is exceptional; her approach towards Venetian glass, however, was not. By the end of the sixteenth century, Isabella's grandson, Guglielmo Gonzaga, had developed a similar relationship with agents based in Venice. The duke sent detailed instructions to his agents to negotiate with master craftsmen in Murano. In January 1572, for instance, the duke's agent, Bartolomeo del Calice, promised to send someone to Murano with a beaker brought from Mantua. The agent was to ask the Muranese masters to reproduce it, but to apply a smaller pattern of decorative forms (lacrime), and to use thinner and more beautiful cristallo. He then promised to keep the wooden model of the beaker in order to create a sample set of six beakers with other, probably more qualified, masters. ${ }^{23}$

Customers of the stature of Isabella d'Este and Guglielmo Gonzaga did not leave the production of glass artefacts to the ingenuity of workshops alone. The correspondence rather highlights the decisive role commissioners and agents played in the production process. All parties involved shared a sense for the processed material and contributed to define the style, shape, and colour of the objects produced. The sense for a material such as glass, its specific qualities, and its production was negotiated and shared proportionally by producers, retailers, and consumers in the material world of the Renaissance. ${ }^{24}$ In the view of Lorenzo da Pavia, this was absolutely necessary; he harshly reprimanded local glassmasters, calling them mastri poveri de invencione. ${ }^{25}$

The importance of mutual interaction between producers, intermediaries such as agents or dealers, and consumers is also confirmed by recent scholarship on branding strategies. The way specific goods could be distinguished from other rival products must take into consideration that early modern commodity markets were less transparent than today. ${ }^{26}$ The branding of Venetian glass production follows

23 ASMn, AG, b. 1505, Carteggio di Inviati e Diversi, f. III, cc. 564-565 (31 January 1572). “[...] che subito si mandò a Murano con la mostra del gotto che mi ha mandato vostra signoria illustrissima per vedere se 'I maestro che fece li altro potteva farli con le lachrime più menude et de cristallo più sottile et più bello [...] Nondimeno ho tenuto la forma di legno appresso di me per pottere provare qualche altro maestro et cusì ne faro fare ancora meza dozena et li manderò."

24 This is, for instance, confirmed by the commissions of Sokollu Mehmet Pasha, grand vizier of Murad III, who in 1578 ordered 2,00o round window panes (rui) from Venice. The glass, however, was only one "currency of artefacts" the vizier requested; moreover, he expressed very clearly his views on these artefacts' material quality, artistry, and value. In the correspondence of the Venetian bailo, who acted as an intermediary, these artefacts figured as gifts but were in fact tribute payments to secure good relations with the High Porte, critical for Venetian trade to the Levant. See Julian Raby, "The Serenissima and the Sublime Porte: Art in the Art of Diplomacy, 1453-1600," in Venice and the Islamic World, 828-1797, ed. Stefano Carboni (New Haven, CT and London: The Metropolitan Museum of Art, 2007), 90-119, here 97. 25 ASMn, AG, b. 1440, Carteggio di Inviati e Diversi, c. 296, cart. 1f. (28 September 1503).

26 Richardson, Gary, "Brand Names before the Industrial Revolution," in NBER Working Papers No. 13930 (April 2008): 1-55. 
slightly different patterns than other goods do. If branding can be considered as an attempt to guarantee the quality of a product and its raw materials and to tie them closely to an origin, then glass à la façon de Venise is actually more likely to skim the added value of this quality assurance. By connecting Venice inseparably with the highest standards of formal innovation, artistic ingenuity, and material perfection - namely complete transparency - the brand automatically measures all glass production against it and at the same time declares it an imitation. The material properties of glass itself thus formed the ground on which the branding for Venetian glass production was based, while for other goods markings, declarations, and stamps were common on either the products themselves or their packaging. ${ }^{27} \mathrm{~A}$ prerequisite for this was in any case a sensitivity for these very material characteristics, which was jointly developed and shared by producers, traders, and consumers.

The approach taken in this paper was inspired by the work of Michael Baxandall, who argued that Renaissance art was created, consumed, and understood under specific cultural conditions. Individual and collective experiences contributed to a "visual culture" that shaped Renaissance art. Moreover, around 1500, he observed a shift from the estimation of the cost of raw materials and ingredients of painting, towards the artist's craftsmanship. ${ }^{28}$ For the context studied here, one could expand Baxandall's "period eye" to "period senses." Such an approach not only insists on the importance of material sensitivity, craftmanship, and the organization of production processes but defines material conditions, artistic creation, and cultural consumption as mutually intertwined. The correspondence between patron and agent shows how active consumers shaped the glass artefacts they purchased. Moreover, it is obvious from these letters that the specific material qualities of glass were particularly suited for such a cultural negotiation process.

In this light, it is worthwhile to turn our attention to Venetian glass production and its transformation between $145^{\circ}$ and $155^{\circ}$. In contrast to traditional historiography that attached much weight to the Venetian legislation that supposedly fostered the industry's heyday, it will be argued that the rise and reputation of Venetian glass started from the specific material features of glass that perfectly met the consumerist desires of Renaissance societies.

27 Ilja Van Damme, “From a 'Knowledgable' Salesman towards a 'Recognizable' Product? Questioning Branding Strategies before Industrialization (Antwerp, Seventeenth to Nineteenth Centuries)," in Concepts of Value in European Material Culture, 1500-1900, ed. Bert De Munck and Lyna Dries, 75-101 (Farnham, Surrey: Ashgate, 2015).

28 Michael Baxandall, Painting and Experience in Fifteenth-Century Italy: A Primer in the Social History of Pictorial Style (Oxford: Clarendon Press, 1972). Michael Baxandall, The Limewood Sculptors of Renaissance Germany, rev. ed. (New Haven, CT: Yale University Press, 1982). For a discussion of this approach see: Adrian Rifkin, About Michael Baxandall (Oxford: Blackwell, 1999). 
In her chapter, Rachele Scuro demonstrates that the glass industry was not only characterized by high social mobility, but also that this social structure promoted an atmosphere in which innovation and experimentation with the material flourished. Additionally, recent scholarship has abandoned the idea that guild regulations were essentially hostile to innovation and modernization in general and rather emphasize their essential role to this end. ${ }^{29}$ In fact, a sixteenth-century manuscript assembling different regulations from the arte deiverieri di Murano confirms this observation. The introductory formula of the document (arenga) reads as follows: "Et chel mestier nostro di verieri da Murano fano ogni zorno cose nuove per inzegno et subtilita di maistri per le experientie che se vedano per zornata et azo che si nobil mestier remagni qui in Muran a laude et gloria de la Serenissima Sig.a nostra et del mestier nostro di verieri di Murano $[. ..] .^{n 0}$ In short, everyday innovation was claimed to be resident with the masters, central to the guild's self-image, and, finally, something that contributed to the praise and glory of the Republic. The idea of the inherent innovation of the art of glass making is telling and refers to an industry ready to push artisanal boundaries and to experiment with a material's features.

According to a well-established but yet legendary account, the invention of cristallo was made by Angelo Barovier in his Murano workshop around 1450. Cristallo undeniably raised Venetian glass production to new heights by capturing perfect transparency in a material object. This artificial innovation was enthusiastically received because it combined precious rock crystal with the lightness of blown glass. As a dissimulation, the material utopia cristallo presented itself as an artificium created from the material components used in the art.

Other innovations in the Venetian glass industry proceeded to imitate existing materials. Calcedonio, for instance, resembled a mineral and was achieved by adding to a melting of cristallo copper oxyd, minium, and metallic powder, best obtained from blacksmiths, as an early seventeenth-century recipe book reports..$^{31}$ The result was marvellous since it materialized a contradiction between the associated and the processed material: visually solid, opaque, and stony, the artefact's lightweight,

29 See Stephen R. Epstein and Maarten Prak, eds., Guilds, Innovation and the European Economy, 1400-180o (Cambridge: Cambridge University Press, 2008). For glass see Francesca Trivellato, "Guilds, Technology and Economic Change in Early Modern Venice," in Epstein and Prak, Guilds, Innovation and the European Economy, 199-231. Corinne Maite, Les chemins de verre: les migrations des verriers d'Altare et de Venise, XVIe-XIXe siècles (Rennes: Presses universitaires de Rennes, 2009). Karel Davids and Bert De Munck, eds., Innovation and Creativity in Late Medieval and Early Modern European Cities (Farnham, Surrey: Ashgate, 2014).

30 ASVe, Arti, b. 726, 10, Die XVII februarij MDX.mo (after fol. 91v). For a short overview on the reorganization of guild regulations in the fifteenth century see Attilia Dorigato, L'arte del vetro a Murano (Venice: Arsenale, 2002), 34 .

31 Luigi Zecchin, Il ricettario Darduin: un codice vetrario del Seicento trascritto e commentato (Venice: Arsenale, 1986), 171. 


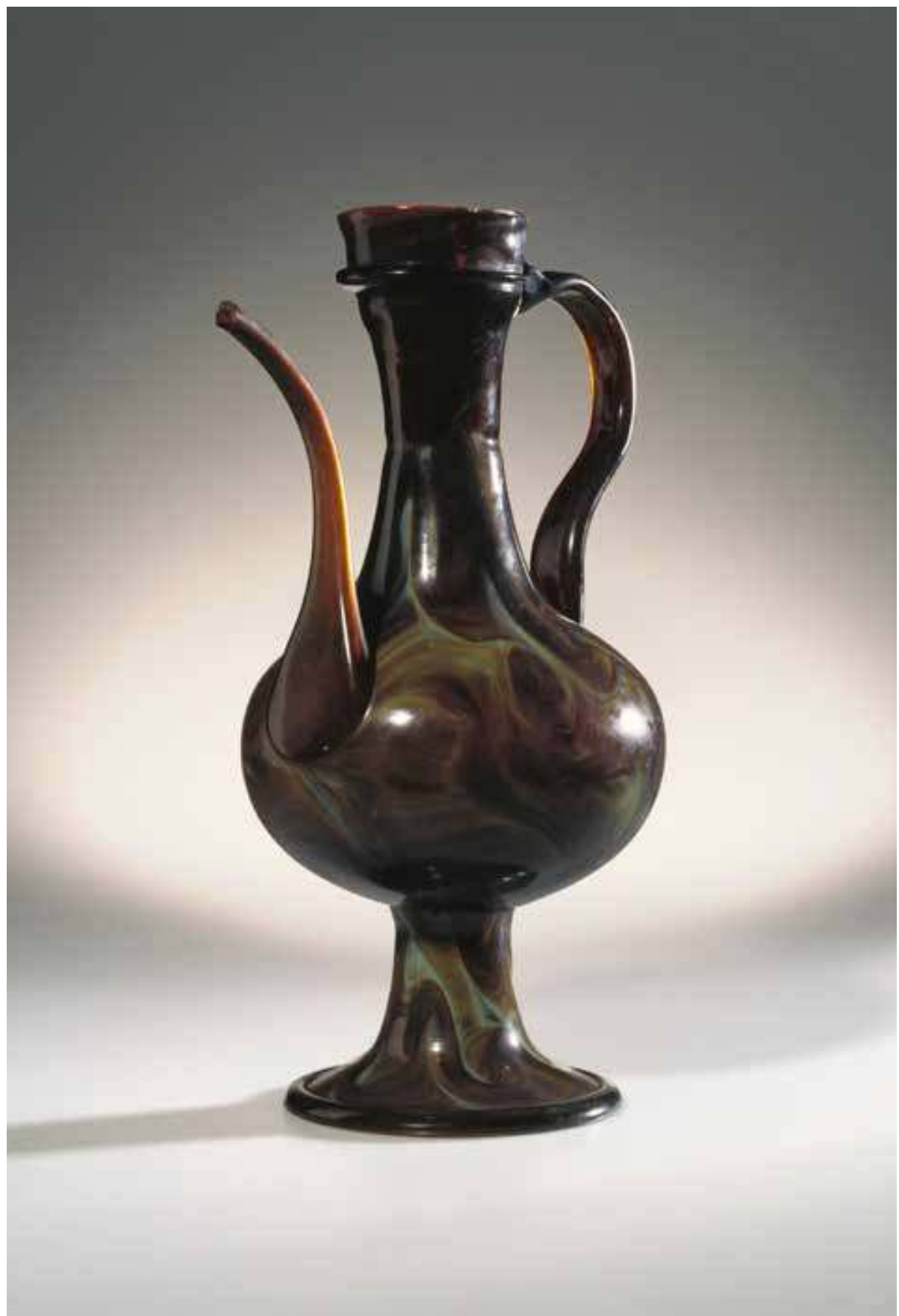

Figure 1.7: Ewer of chalcedony glass, ca. 1500-1525. Blown, with added spout, handle and foot from Murano, $30.5 \mathrm{~cm} \times 19.5 \mathrm{~cm}$ max. London, Victoria and Albert Museum, inv. no. 1828-18255. Image $\odot$ Victoria and Albert Museum, London. 


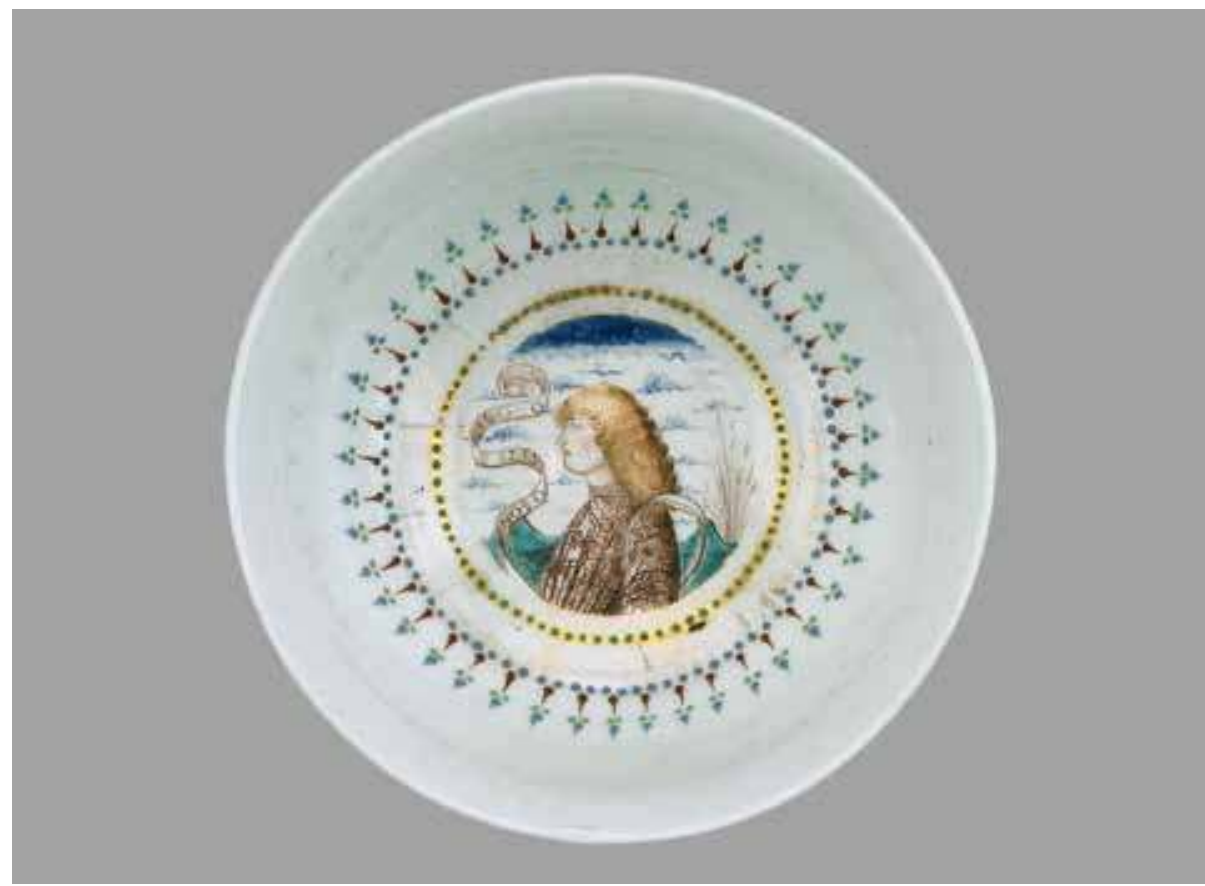

Figure 1.8: The Rothschild Bowl, 1500-1510. Lattimo with colour enamelling. Murano, H: $5.9 \mathrm{~cm}, \operatorname{Rim} \mathrm{D}$ : $14.1 \mathrm{~cm}$, Foot D: $6.3 \mathrm{~cm}$. Corning, NY, The Corning Museum of Glass, inv. no. 76.3.17. Image ๑ The Corning Museum of Glass.

wispy nature would only be discovered when lifted or dropped (Fig. 1.7). Another example further illustrates Venetian glassmakers' finesse for simulating material, form, and colour. Around the middle of the fifteenth century, porcelain from China appeared in Europe and became immediately extremely popular. In spite of the increasing demand for porcelain, Europeans until the eighteenth century were only able to produce a porcelain substitute, often referred to as "soft paste porcelain" or "fritware." Venetian glassmakers, however, promptly responded with the invention of lattimo, a milky glass displaying the desired fineness and whitish colour of porcelain, as the Rothschild bowl conserved by the Corning glass museum shows (Fig. 1.8). This dissimulation encompassed the evolvement of artisanal knowledge and techniques as well as the swift orientation towards an increasing trans-local market for luxury goods. No other place was potentially better prepared to respond to these challenges than Venice; here, an advanced glass industry met one of the most important trading hubs for Renaissance commodities and consumer culture.

Recalling Isabella d'Este's expectations for her commission - vasi de qualche foza fantasticha e bela - malleability seems to have been another material feature admired in glass. In his treatise Pirotechnia, the Art of Fire, Vanuccio Biringuccio stressed malleability as a key feature of glassmaking, "I cannot understand 
how the artificer made it so beautifully and marvellously." Biringuccio calls glass manufacture an "almost impossible art" that, recalling the topos, not only simulates nature but surpasses it. ${ }^{2}$ For Biringuccio "it seems that all the metals must give way to glass in beauty." In the characteristic style of a paragone, he proclaims glass art superior to the other arts and contemporary glass masters more inventive than their antique predecessors. However, this appraisal was explained mostly by the material's features. "It is a material," he continues, "whose body, as we see, is transparent and lustrous, and it is coloured with substances or traces of metal to any kind of desired colour, in such a way that with the beauty of gems it deceives the judgement of the eyes of very experienced men." 33 Moreover, despite the capacity to deceive, Biringuccio assesses glass as ethically above any suspicion since "considering its brief and short life, owing to its brittleness, it cannot and must not be given too much love, and it must be used and kept in mind as an example of the life of man and of the things of this world which, though beautiful, are transitory and frail." According to Biringuccio, glass art was not only the most prized of all arts but ideal in a Christian sense too; "all the effects of glass are marvellous."34

Glass, however, was not only appreciated in contemporary art theory and ethics, but also in Renaissance social life. Patrick McCray has pointed out that the relatively sudden expansion of Venetian luxury glass manufacturing in the mid-fifteenth century was initiated from within Italian Renaissance culture, as the aforementioned examples from Mantua confirm. ${ }^{35}$ Yet the developing consumer desires of new social classes in the Renaissance world increased the demand for luxury goods. Glass artefacts became extremely popular for their cost-effectiveness, although most consumers would still consider them luxury goods. Biringuccio's preference for glass over gold and silver was, therefore, not only morally motivated but anchored in the social realities of the time. Glass allowed wider social strata to increasingly participate in the cultural life of the Renaissance and to follow, imitate, and possibly surpass idealized moral and aesthetic models both ancient and contemporary. Luxury glass artefacts were the most affordable way to display one's own taste and education rather than sheer wealth.

Still, this new orientation did not develop suddenly. In all crafts, tradition was an important source of innovation. The three trendsetting innovations of cristallo, calcedonio, and lattimo did not at first transform the industry at large, although the importance of cristallo was immediately acknowledged. Until around 1500 , the

32 The Pirotechnia of Vannoccio Biringuccio, ed. and trans. Harvey S. Mudd, Cyril Stanley Smith, and Martha Teach Gnudi (New York: The American Institute of Mining and Metallurgical Engineers, 1942), 126-133.

33 Ibid., 127.

34 Ibid., 132.

35 Patrick McCray, Glassmaking in Renaissance Venice: The Fragile Craft (Aldershot: Ashgate, 1999), 65. 

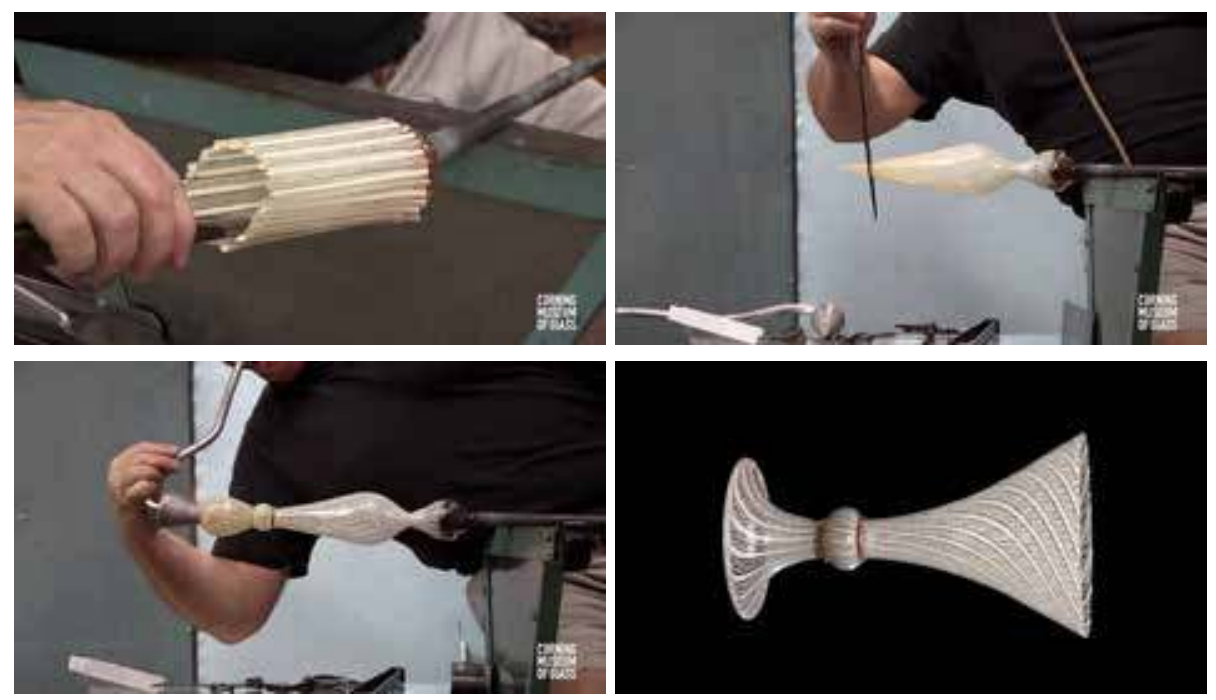

Figure 1.9: Three steps of replicating/blowing a goblet and the corresponding original three-bubble goblet, ca. 1550. Murano, H: $16.6 \mathrm{~cm}$, Rim D: $10.3 \mathrm{~cm}$, Foot D: $8.5 \mathrm{~cm}$. Corning, NY, The Corning Museum of Glass, inv. no. 68.3.64. Images $\odot$ Courtesy of The Corning Museum of Glass.

art of glass making was quite traditional. In terms of decorative techniques, the influence of high-quality, enamelled glass from Syria or Egypt was still perceptible, if not dominant. Carrying on this technique, Venetian glassmakers continued to decorate transparent and coloured glass with polychrome enamelling, adapting it to more Western tastes and standards. This trend was particularly inspired by Renaissance painting and was increasingly applied to glass art. Style, iconography, and visual repertoires met the tastes of a Christian audience familiar with the revival of antiquity. The Rothschild bowl mentioned above is a fine example of how material innovation and decorative tradition coexisted in one artefact (see Fig. 1.8). The lattimo bowl simulates Chinese porcelain but is decorated with the portrait of a long-haired blond youth in Renaissance style.

From the beginning of the sixteenth century, however, the more traditional decoration techniques and patterns began to lose importance. Instead, expertise in handling the material and techniques of making and fabricating glass became central to the art's evolvement. Only at this point in time was glassmaking fully emancipated as an art, emerging comprehensively from within and exploiting the material's qualities to fully promote artistic innovations. The change was paradigmatic and its effects can be observed in the arenga from 1510 quoted above, which foregrounds the ingenuity and innovative ability of the guild's members.

Early sixteenth-century innovations confirm this shift. Filigrana, retortoli, and reticello shared a common purpose: to create decorative filigree patterns with simple or twisted lattimo strings applied to the cristallo. Once attached, the milky 
strings fused with the cristallo in a second stage of heating. Blowing the molten glass, a pattern of symmetrical strings (simple [filigrana] or twisted [retortoli, reticello]) materialized that perfectly outlined the object's shape. The technique's distinctiveness comes from the contradictory combination of the object's curved body and the regularity of its straight, decorative pattern (Fig. 1.9). Such innovations significantly reduced the importance of painted glass, highlighting the increasing number of ways glassmakers could exploit its malleability instead.

Further innovations confirm glassmaking's increasing inspiration from experimentation with materiality. Although a well-known technique in both antique and medieval glass art, diamond point engraving, resurrected in Venice by the middle of the sixteenth century, was applied equally to transparent and coloured glass and became very popular across Europe. The technique exploits the discrepancy between a glossy surface and a more muted subsurface, exhibiting the fact that the two layers of the material refracted light differently. Another technique exploited the materiality of glass rather differently. Vetro ghiaccio converted a physical reaction of the making process into a decorative pattern. The decoration, resembling ice, was translucent but not transparent and was obtained by immersing the half-worked, molten glass in cold water thus creating a fractured ice effect within the material. Vetro ghiaccio exemplifies the argument foregrounded here since it underlines how the Venetian glass industry developed by increasingly paying attention to the object's making.

The invention of new types of glass was accompanied by a developing colour palette. Red, green, yellow, purple, and blue glass were commonly produced. The significance of colour is best expressed in the written sources. The recipe book of the Darduin family, dating from the early seventeenth century and containing a collection of recipes spanning three generations of masters, reveals an overwhelmingly variegated colour vocabulary. Blue occurs in at least three tonalities (acqua marina, azuro, turchino), while red, green, and yellow appear in at least four different tones each. ${ }^{36}$ Moreover, one colour term could denote many hues. The ricettario, for instance, files at least sixteen different recipes for producing roseate glass (rosechier); most probably, the various instructions led to different shades of colour. Altogether, the vocabulary of the recipe book shows that early modern craftsmanship had a much more cultivated sense for colour differences than we commonly do in the present day.

The focus on colour in the ricettario Darduin is not exceptional. Recipe books for Renaissance glassmaking are almost exclusively concerned with colours; apparently, the chemical composition of the molten glass ( fritta) was the stage in the production process that could be best transferred in writing and passed from one master to 
another. By contrast, the written sources fail to mention handling or blowing glass and do not acknowledge the artful creativity of the bizzarerie at all. Either these aspects of artisanal knowledge were hard to record or it was unnecessary to do so. ${ }^{37}$ In other words, both the innovative techniques of the Venetian glass industry and new typologies of written sources focused on the material and much less on form and style.

The shift of perspective from form to material offers the opportunity to tell a different story about the development of glass art in Renaissance Venice. It highlights the increasing expertise in handling and making, stresses the participation of wider social groups in the process of shaping the Renaissance material world, and, finally, unveils the existence of a period sense affording a cultural framework for the art's development, the understanding of the material in the making, and its socio-cultural effects. ${ }^{3}$

\section{Transparent or Invisible - “Cristallo" and the Body of Christ}

Associations between Venetian glass studies and the masterpieces of Renaissance painting are often made. Traditional historiography mostly exploited this link to confirm the evolution of form and style in artistic glassmaking. Shifting attention to a material perspective does not contradict this link. Examining glass through a material lens rather offers a new perspective on the social and cultural importance of the visual arts.

In 1562 Paolo Veronese (1528-1588) was commissioned to decorate the refectory of the Dominican island monastery of San Giorgio Maggiore. The monastery had recently undergone a series of renovations mainly executed by Andrea Palladio..$^{39}$ The contract gave clear guidance, "[Veronese] is to represent the story of the Supper of the Miracle worked by Christ at Cana in Galilee [...] and the said Master Paulo will be obliged to use the highest quality pigments in the work, of the kind that are approved by all experts."40 The painting depicts the biblical narrative for both an ecclesiastical and lay audience of the monastery and displays the wealth of Renaissance Venice in the vivid setting of a festive banquet (Fig. 1.10). It has been

37 Lambros Malafouris, “At the Potter's Wheel: An Argument for Material Agency," in Material Agency Towards a Non-Anthropocentric Approach, ed. Carl Knappet and Lambros Malafouris (New York: Springer, 2008), 19-36.

38 McCray, Glassmaking, 68.

39 Tracy E. Cooper, Palladio's Venice: Architecture and Society in a Renaissance Republic (New Haven,

CT: Yale University Press, 2005).

40 David Chambers and Brian Pullan, with Jennifer Fletcher, eds., Venice: A Documentary History, 1450-1630, repr. (Oxford and Cambridge, MA: Blackwell, 1992), 414. 


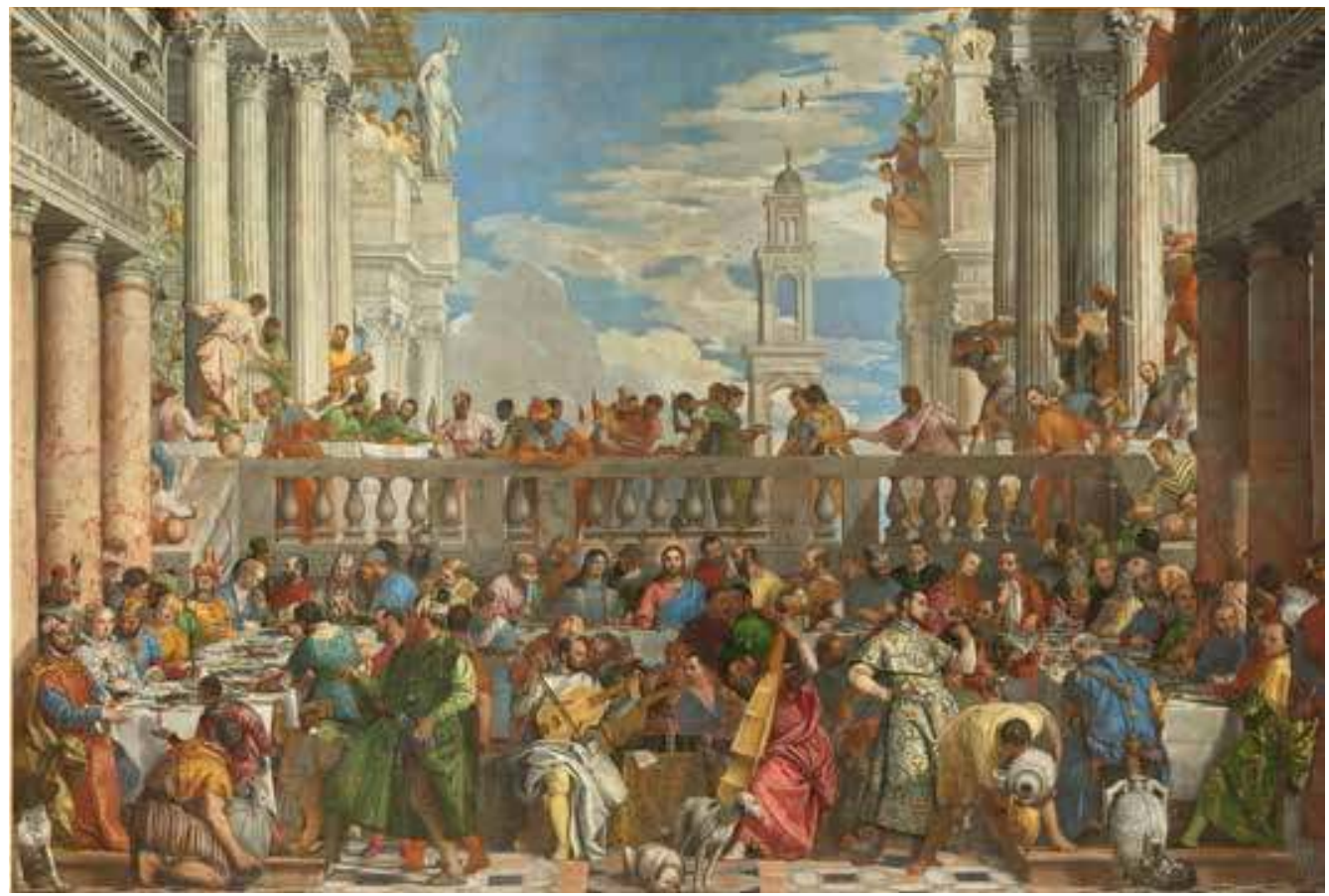

Figure 1.10: Paolo Veronese, The Wedding Feast at Cana, 1563. Oil on canvas, $677 \times 994 \mathrm{~cm}$. Image $\odot \mathrm{RMN}-$ Grand Palais (musée du Louvre) / Michel Urtado.

convincingly argued that neither the choice of the subject nor the sumptuous execution by Veronese contravene the site and the function of a Dominican refectory. The study of Italian refectories from the fourteenth to the sixteenth century has shown that their iconographies habitually referred to the Eucharist, often depicting the Last Supper and the Crucifixion. According to Creighton Gilbert, Veronese's Wedding of Cana transferred the mystery of transubstantiation from sacramental terms to a more mundane setting. ${ }^{41}$ Veronese lavishly painted the biblical narrative in a scene evoking both Renaissance Venice and its pictorial traditions: the architecture, the perspectives, the depicted characters, and the richness of the material world represented the culture of solemn feasting in Renaissance Venice. However, Veronese conserved the holiness of the scene by placing the figures of Christ and the Virgin Mary in the very centre of the painting, distinguishing them from the other characters with haloes and antiquated clothing. Navigating between the sacred and profane, the painting portrays the representation of the miracle first performed by Christ as a typological preannouncement of the Eucharist and locates it in the Venetian Lagoon.

41 Creighton Gilbert, "Last Suppers and Their Refectories," in The Pursuit of Holiness in Late Medieval and Renaissance Religion, ed. Charles Trinkhaus and Heiko A. Obermann (Leiden: Brill, 1974), 371-402. 
Although both aspects have been acknowledged in historiography, the sacred has mostly been considered the core message and the profane merely its exterior setting. Following a study by Kate Hanson, this chapter argues for a more intertwined importance of the "language of the banquet" by which Veronese "constructed a highly artificial scene that conveyed religious meaning through the specific deployment of markers of realism related to banqueting and eating."42 Following Hanson's argument, particular attention will be paid to the role of glass in Veronese's monumental painting.

The elegantly shaped crystal goblets depicted in the painting correspond to a type produced in local industry (Fig. 1.11). Together with precious plates, bowls, and jugs made from silver and gold, glass tableware used for contemporary banquets formed a primary opportunity to display both political and social power. ${ }^{43}$ Veronese follows the biblical narrative closely and depicts the moment when, near the end of the wedding banquet, the wine supply fell short. Numerous courses of fish and meat would already have been served before the diners' last course of fruits and nuts. In the painting, excess is less directed at the food and more to the tableware and precious textiles worn by the guests. To perform social and political power by conspicuous consumption, however, was not only a concern of artistic representation. In fact, the introduction of sumptuary legislation in Venice started with the attempt to regulate private spending, particularly during wedding banquets. ${ }^{44}$ Although glass is, except for its widespread use for false pearls, never mentioned in Venetian sumptuary norms, the ubiquity of glass in everyday life as well as in Veronese's painting emphasizes its constituent role in a performative culture of conspicuous consumption and sociability.

42 Kate H. Hanson, "The Language of the Banquet: Reconsidering Paolo Veronese's Wedding at Cana," Invisible Culture: An Electronic Journal for Visual Culture 14 (Winter 2010). Accessed on 9 July 2018. http:// www.rochester.edu/in_visible_culture/Issue_14/hanson/.

43 Patricia Fortini Brown, "Behind the Walls: The Material Culture of Venetian Elites," in Venice Reconsidered: The History of Civilization of an Italian City-State, 1297-1797, ed. John Martin and Dennis Romano (Baltimore, MD: Johns Hopkins University Press, 2000), 295-338.

44 For a general overview of Italian sumptuary legislation see Maria Giuseppina Muzzarelli, ed., $L a$ legislazione suntuaria, secoli XIII-XVI:Emilia-Romagna, Pubblicazioni degli Archivi di Stato Fonti (Rome: Ministero per i beni e le attività culturali, 2002). For Venice see Pompeo Molmenti, La storia di Venezia nella vita privata dalle origini alla caduta della Repubblica, vol. 6 (Bergamo: Istituto italiano d'arti grafiche, 1922). For a social historical reading see Diane Owen Hughes, "Sumptuary Law and Social Relations in Renaissance Italy," in Disputes and Settlements: Law and Human Relations in the West, ed. John Bossy (Cambridge: Cambridge University Press, 1983), 69-99. For the fruitless attempts to implement sumptuary legislation see Jane Bridgeman, "Pagare le pompe: Why Quattrocento Sumptuary Laws Did Not Work," in Women in Italian Renaissance Culture and Society, ed. Letizia Panizza (Oxford: Legenda, 200o), 209-226. Finally, for the risk that private profusion could pose to the state see Matteo Casini, "Banquets, Food and Dance: Youth Companies at the Table in Renaissance Venice," Ludica. Annali di storia e civiltà del gioco 19-20 (2013-2014): 182-192. 


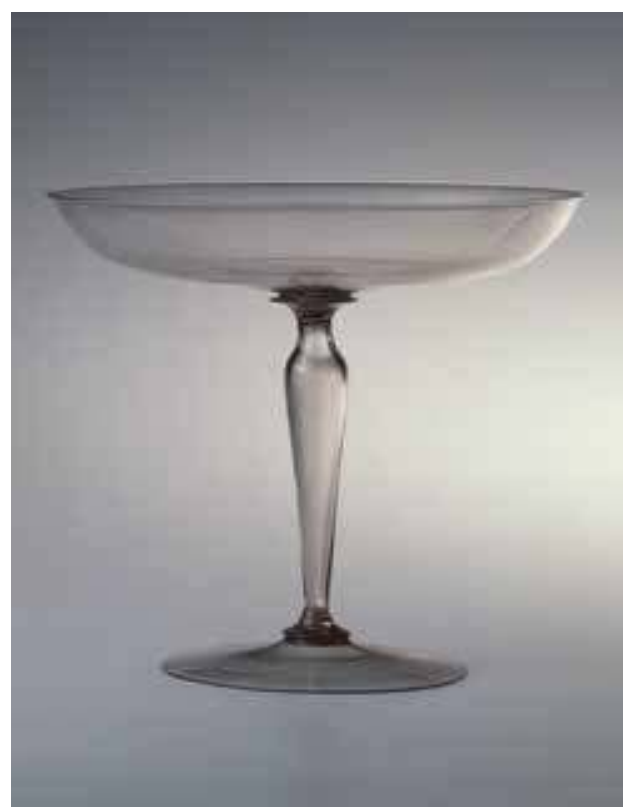

Figure 1.11: Venetian crystal goblet, end of sixteenth century. $\mathrm{H}: 14.6 \mathrm{~cm}$. Murano, Museo del vetro, inv. no. Cl. VI n. 01092. Image @ Photo Archive - Fondazione Musei Civici di Venezia.

It has been conclusively shown that the source for Veronese's composition was not the text of the Gospel according to John (2: 1-12) but an adaption by Pietro Aretino $\left(1492-155^{6}\right)$ that proved extremely popular in the sixteenth century. ${ }^{45}$ First published in 1535 by Francesco Marcolini in Venice, the Humanità di Christo was reprinted ten times in Italy before Veronese started work in San Giorgio. Aretino adds significant details to the Gospel's narrative. "The most solemn, the most noble and the most comely people of the city gathered" and "the tables were set up and decorated vases of gold and pure silver were placed on them [...] while the bride was resplendent in nuptial ornaments. ${ }^{46}$ None of these details are present in the Gospel but arose from Aretino's cultural imagination. His text and Veronese's painting are inspired by a contemporary material world and its social framework, harnessed to convey the mystery of the Christian faith to contemporary readers and spectators. The focus on glass in Veronese's painting draws attention to materiality as an agentic power in the mutual interaction between the material and symbolic worlds. In this sense, setting the biblical narrative against the backdrop of Venetian sumptuous banqueting culture did not secularize the miracle but performed it in a language both familiar and precious to the audience.

45 Philipp P. Fehl, "Veronese's Decorum: Notes on the Marriage at Cana," in Art, the Ape of Nature: Studies in Honor of H.W. Janson, ed. Moshe Barash and Lucy Freeman Sandler (New York and Englewood Cliffs, NJ: H.N. Abrams, Prentice Hall, 1981), 341-365.

46 Pietro Aretino, I tre libri della humanità di Christo (Venice: Nicolini da Sabio, 1535), libro secondo, no page numbers. For the English translation of the paragraph see Giuseppe Pavanello, "Più vino per la festa," in The Miracle of Cana: The Originality of the Re-production (Venice: Cierre Edizioni, 2011), 24. 
Accordingly, Aretino and Veronese assigned a prominent role to glass artefacts. "The servants drew the liquid and took it to the master of ceremonies, who, on smelling the wine that had been harvested from celestial vineyards, cheered up, like a man whose senses had come back to him thanks to the power of vinegar with which he had bathed his wrists. And on tasting, he felt its mordent sweetness distil right down to his toes. And filling a crystal cup [coppa di Christallo] with it, he would have sworn that the cup was full of distilled rubies." ${ }^{37}$ To witness the miracle, three bodily senses were involved in Aretino's account: smell, taste, and sight. Their impact on the observer is described in a vocabulary that evokes on its part the resurrection, the glory of Christ, and eternal life. To smell the wine reawakens all bodily senses, to taste it means to relish in its heavenly sweetness, and to examine it evokes images of precious rubies that were both a symbol of Christ's glory and of the walls of heavenly Jerusalem. In fact, Aretino concludes the paragraph by saying, "since it was the first miracle that Jesus had made in that region to show all his glory, its marvel amazed everyone. Whence the disciples believed in him. ${ }^{m 8}$ To witness the glory of Christianity involved both the body and the senses. A sensory experience strengthened faith in return. Sacred and profane thus met in bodily experiences shaped by the material world.

As part of the contemporary consumerist culture in Venice, precious glass cups form an almost natural element of a banquet's adornment. The poet from Arezzo, however, assigned a crucial role to these artefacts by exploiting the rhetorical device of paronomasia (Christo and Christallo). The poet thus suggested a direct link between transparency as the distinctive material feature of Venetian glass and the Saviour. In Veronese's painting, this idea is both displayed and expanded upon. In the left foreground, a richly dressed, black African servant offers wine in a crystal goblet to the bridegroom. The presentation of the miraculous wine appears to be overseen by the master of ceremony. Dressed in a dark green outer garment and an "orientalizing" headdress, the master of ceremony explains the miracle to the bridal couple. In the foreground, on the right, another figure attracts the observer with his elegant and dynamic bodily posture (Fig. 1.12). In contrapposto, his right arm propped up at his hip, he lifts a crystal cup filled with wine to examine the sacred liquid up close. He stands out due to the brilliance of his lavish white garment and its decorative pattern.

In the painting it is through sight that the miracle is examined and the glory of Christ is witnessed. In fact, Veronese's tableau not only represents the biblical narrative, set within the scenery of a contemporary banquet, but simultaneously engages with the power of visuality. The act of looking is addressed in different ways that evoke various affective regimes. Whereas the gaze of the bearded man sitting to the left of 


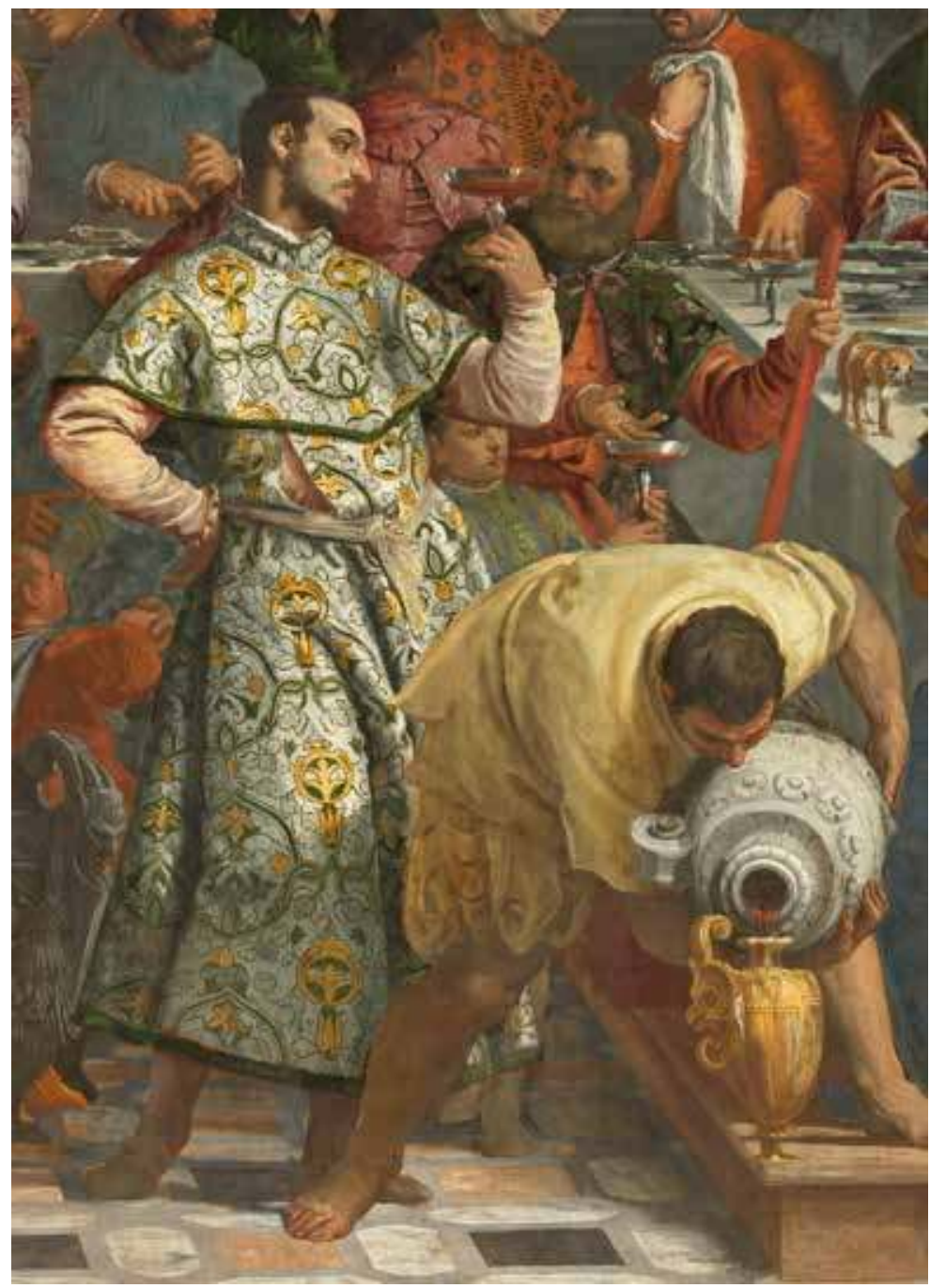

Figure 1.12: Paolo Veronese, The Wedding Feast at Cana, detail of Fig. 1.10: A young man contemplating the transparency of an elevated crystal goblet filled with water transformed into wine.

the bride is seemingly inappropriately directed to the newlywed hostess's décolleté, two figures sitting at the opposite table look up to the sky. The visual interaction between the profane and sacred, however, centres upon the figure dressed in white.

In accordance with anti-reformationist beliefs, the visual sense epitomizes contemplation and transcendency. In this figure, the hints for such a reading are manifold. First, in lifting the crystal goblet, the young man evokes the imagery of the chalice of the Eucharist. Second, he witnesses Christ's passion in the transformed wine he examines through the crystal goblet. Finally, his contemplation brings him 
closer to Christ in a bodily sense too, at least in the eyes of the attentive observer. The desired imitatio Christi shows a fold or a slash on the side of the figure's white garment alluding to the wound on Christ's side. Both the position and the form are unequivocal; they cannot be confused with luxuriously slashed precious textiles and other contemporary fashions displayed elsewhere in the painting.

In regard to religious contemplation, the transparency of the crystal goblet proves crucial. In fact, it is the nine goblets depicted in the painting that reveal the presence of the miraculous wine at the banquet. Besides the servant shown in the right foreground, who pours the transfigured wine in a smaller pitcher made from gold, the wine is visible only in the spotless transparency of the crystal goblets.

The figure of the young man becomes the painting's central negotiating site. Witnessing the miracle within the depicted biblical narrative, he gives an example to be followed by the audience of the painting in San Giorgio. Through the gesture of lifting the goblet, he closely relates the Christological mystery to an artefact that evokes both the reputation of the local glass industry and the banqueting culture of Renaissance Venice. Finally, he transmits a comforting message to the audience by resolving the moral contradiction between modesty as a Christian value and the richness of the contemporary material world. The wound on the side of Christ appears with him on the white silk garment, as if the latter were part of his body. The painting thus unites sumptuous banqueting culture and religious contemplation, for which glass contributes substantially to the affective and bodily regimes at stake.

However, the figure essentially in command of determining these regimes is not the young, glorified goblet-holder but the authoritative bearded man next to him. He directs his young companion to another goblet filled with wine and guides him through his contemplative and bodily experience of the material world. Research has recognized this figure to be none other than Pietro Aretino whose famous portrait by his friend Titian supports such an identification (Fig. 1.13).49

When Veronese was working for San Giorgio, Aretino had been dead for several years. Nevertheless, to integrate his portrait into a religious painting was clearly a political statement. In 1559, shortly before dying, Pope Paul IV published the first Index librorum prohibitorum, which listed Aretino's complete works. $5^{\circ}$ Yet Veronese and

49 A tradition going back to the end of the seventeenth century endeavoured to identify various characters in the painting, from the bridal couple to the remarkable musicians and the bearded man. Aretino's identification, however, seems rather convincing since it is not only based on comparative analysis with Titian's portrait but also on the painting's compositional allusions to the narrative of the Wedding at Cana in the Humanità di Christo. See Fehl, "Veronese's Decorum," 344. Moreover, this identification alludes to the circle of learned men who had formed around Aretino since Titian executed his portrait for the editor Francesco Marcolini, who published the Humanità di Christo in 1535.

50 Veronese was not the only artist who commemorated the poet's notable influence in Venetian art and politics. See Fehl, "Veronese's Decorum," 347. 


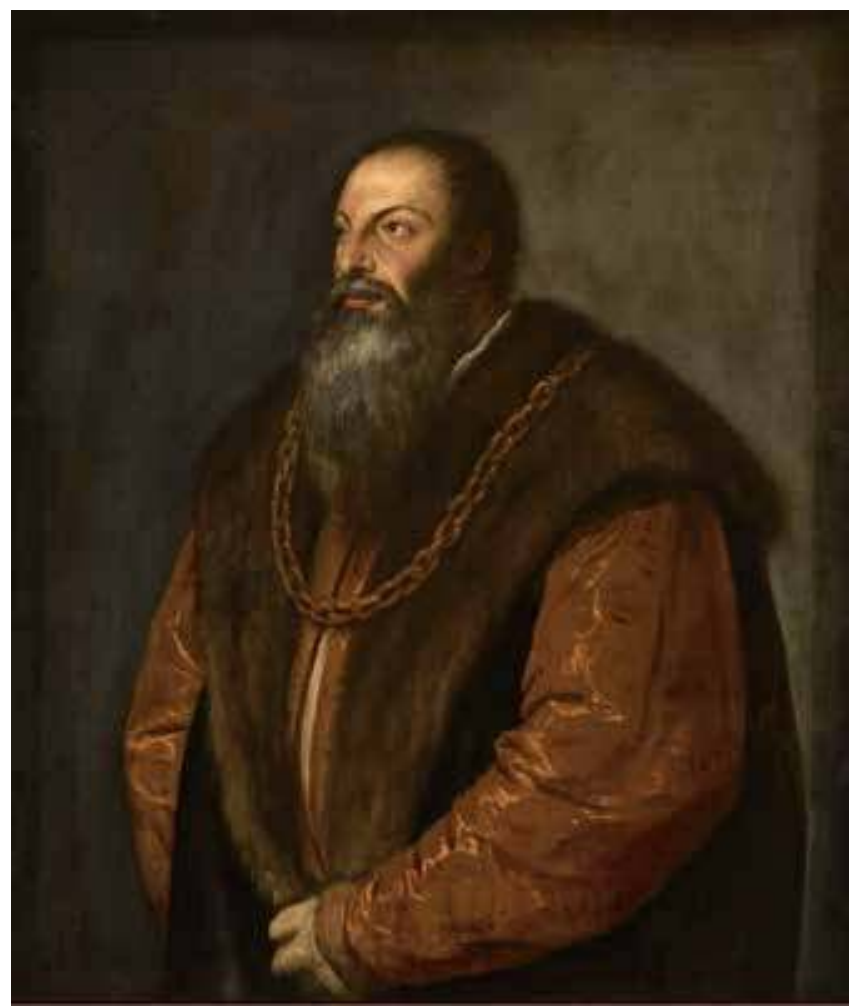

Figure 1.13: Titian, Pietro Aretino, ca. 1537. Oil on canvas, $102.0 \times 85.7 \mathrm{~cm}$. New York, Frick Collection, Henry Clay Frick Bequest, inv. no. 1905.1.115. Image @ The Frick Collection.

Aretino shared a vision of and a sense for the material world representing religious belief. The material richness in both Veronese's painting and the lives of Venetian elites did not necessarily contradict Christian religion but rather offered a way to combine the sacred and profane. The increasingly material world of Renaissance Venice could inspire contemplative imagination and support spiritual reflection. Transparency as the main material feature of crystal glass was particularly apt for such a purpose.

Aretino's religious beliefs set forth in his opere sacre such as the Humanità di Christo have long been overshadowed by his frivolous satirical prose. His acquaintance with discussions on Catholic reform have equally been underestimated. ${ }^{51}$ In

51 It has been detailed how Aretino was part of these debates in the 1530s, how his notions are taken up in his sacred works, and, finally, how the aggressive wing of the Catholic reform condemned these positions in the 1540 s and during the Council of Trent. See Christopher Cairns, Pietro Aretino and the Republic of Venice: Researches on Aretino and His Circle in Venice, 1527-1556, Biblioteca dell'“Archivum Romanicum" Serie 1, Storia, letteratura, paleografia (Florence: Leo S. Olschki, 1985), in particular 69-124. Raymond B. Waddington, "Pietro Aretino, Religious Writer," Renaissance Studies: Journal of the Society for Renaissance Studies 20 (2006): 277-292. 
Venice he belonged to a circle of intellectuals that discussed the reform of the Church in more liberal terms than the Roman faction..$^{2}$ After the Diet of Regensburg in 1541 , the Roman views on reform eventually became dominant. The deaths of two leading reformers and supporters of the Venetian party, Gasparo Contarini (1542) and Gian Matteo Giberti (1543), additionally confirmed the shift in power that was clearly felt in Venice. In a letter sent to Paolo Giovio in February 1546, Aretino expressed fears of censorship and even the burning of his own sacred works. 53

Aretino's interest in the material world of his times in general, and in Venetian glass in particular, was not confined to the representation of religious attitudes or the language of his sacred works. In his correspondence, wine and precious glass adopted a much more profane meaning, indicative of their importance for a performative social culture endorsed through consumption habits and material values. In a letter from 1529, Aretino expressed his thanks for a gift of wine, "And the little tear it brings to the eyes of those who drink it brings tears to mine as I write about it now; so you can imagine its effect upon me when I see it bubble and sparkle in a fine crystal cup. In short, all the other wines you have sent me have in comparison lost all credit when I try to recall them. And I am indeed sorry that Messer Benedetto sent me those two caps of gold and turquoise silk, for I would prefer to have had wine such as this instead." ${ }^{54}$ The value of a fine wine surpassed silk as the most important commodity of the Venetian economy. The link between excellent wine and sumptuous clothes, however, made both commodities markers of social status. Moreover, drinking such fine wine brought tears of joy to his eyes, and did so again when remembering it. Wine's emotive effects were experienced when beheld through a crystal cup (vetro puro); thus transparency, the celebrated material quality of Venetian glass, is once again evoked when describing feelings. Consuming wine, fine silk, and crystal glass in Renaissance Venice were not only matters of economic wealth and cultural taste; when performed and shared in correspondence, they contributed to the shaping of social and emotional communities. ${ }^{55}$ In Aretino's work we find a material lexicon that was widely disseminated among humanists in Venice and beyond. Aretino's published letters, ranging from religious, satiric, and pornographic writings, established a linguistic repertoire for material goods and bodily senses that connected religious

52 Raymond B. Waddington, “Aretino, Titian, and 'La Humanità di Christo'," in Forms of Faith in Sixteenth Century Italy, ed. Abigail Brundin and Matthew Treherne (Aldershot: Ashgate, 2009), 171-198, in particular 194.

53 Cairns, Pietro Aretino, in particular 112-116.

54 Pietro Aretino, Selected Letters, trans. George Bull (Harmondsworth: Penguin Books, 1976), 63-64.

55 Douglas Biow has argued that the individual and his bodily experiences and desires, his affects and emotions formed the linguistic repertoire used by Aretino to articulate social critique and religious reform. Douglas Biow, In Your Face: Professional Improprieties and the Art of Being Conspicuous in Sixteenth-Century Italy (Stanford, CA: Stanford University Press, 2010), esp. 63-91. 
beliefs, ideas of reform, artistic production, and social communities. At the same time, the collected letters shaped a prototype of individuality: the humanist that made his "living out of ink" aspired for social ascension.

\section{Material as Reform - Glass and Bodily Regimes in Renaissance Venice}

Just one year before Aretino published the Humanità di Christo he had another text printed, probably with Francesco Marcolini. In the Ragionamento della Nanna e della Antonia fatto a Roma sotto una ficaia (1534), two women discuss the possible life avenues for Nanna's daughter, Pippa.$^{5}$ In the course of a conversation, the advantages and drawbacks of becoming a nun, a wife, or a prostitute are debated. A dialogue between courtesans acts as a parody of contemporary treatises of virtue; indeed, Aretino transgresses most of the social and ethical conventions he outlined in his sacred writings.

Douglas Biow has suggested reading the Raggionamenti as a draft for Renaissance individualism directed against Castiglione's Il libro del Cortegiano. Castiglione positioned professional self-development within the affective and bodily regimes of court culture, for which he invented the term sprezzatura. Aretino, in contrast, set the stage for shaping individual identities in a more open framework that included both wider social sites and players. Here, Aretino pursues a discourse of social reform that goes beyond the inversion of courtly behaviour. Conspicuous consumption, in the manifold facets of the term, was not primarily directed at self-control and the taste for objects of distinction, but was represented in the bodily demands for food and sex. ${ }^{57}$ As in his sacred works, Aretino exploits the contemporary material world to articulate his ideas of social reform and views about individual self-development.

Describing the most pious condition of womanhood - entering a convent - Nanna reports how her expectations proved wrong. Exuberance, frivolity, and lasciviousness characterized her experience, and excessive feasting instead of pious fasting was common. The richness and variety of food available in the convent seem to infringe on the sumptuary legislation of the Venetian authorities. In other words, Aretino's parody targets not only the inappropriate behaviour of the clergy but employs the vocabulary of Venetian banqueting familiar to his audience from both pictorial and textual sources. As in the Humanità di Christo, Aretino exploits the material world of Renaissance Venice to challenge the line between the sacred and profane.

56 Pietro Aretino, Seigiornate: ragionamento della Nanna e della Antonia (1534), ed. Giovanni Aquilecchia (Bari: Laterza, 1969).

57 Biow, In Your Face, 69, 82. Biow convincingly shows how Aretino exploited the semantic field of consumption to closely tie food and sex in his linguistic repertoire and how bodily desires and their satisfaction bridged the two. 
Both the consumption of materials and commodities as well as their integration in Renaissance imagery led to emotive and bodily regimes. Nanna recounts how gastronomic excess gave way to the pleasures of the flesh in the nunnery. After dinner one night,

NANNA: $\quad[\ldots]$ a fine lad [came in] with a basket in his hand [...].

ANTONIA: What did he do with the basket, and what was in it?

NANNA: $\quad$ Wait a while. The lad [...] said: "Greetings to your ladyships;" and then, he added: "A servant of this fine brigade brings you the fruits of the earthly paradise." And uncovering his gift, he placed it on the table, and at once, there was a clap like thunder, as the whole company burst into laughter [...].

$[\ldots]$

ANTONIA: What were the fruits, tell me.

NANNA: They were those glass fruits which are made by Murano of Venice, in the likeness of a K[azzo, i.e. penis], except that they have two little bells which would be an honor to any big cymbal.

ANTONIA: Ah, ha, now [...] I've got you.

NANNA: And she was not merely fortunate, but blessed, who came by the thickest and broadest one; and none could keep from kissing her own, as she remarked: "These overcome the temptations of the flesh." 5

In this passage, Murano, the most famous production site of the time, and the glass artefacts produced there, are inextricably linked with sexual desire. ${ }^{59}$

From the meal Nanna proceeded to a richly decorated room. On the first wall, the life of Saint Nafissa, patron of prostitutes and bawds, was depicted. On the second was an image of Masetto, the gardener from Boccaccio's Decameron who satisfied nuns' sexual desires. A portrait gallery of nuns with their lovers and offspring was displayed on the next wall, and on the fourth was a representation of tutti i modi e tutte le vie che si può chiavare e farsi chiavare. ${ }^{60}$

Although Aretino does not describe this last painting in detail, in the 1530s, Duke Francesco II Gonzaga commissioned Giulio Romano to execute a similar fresco-cycle for the Palazzo del Té in Mantua. The frescoes do not remain, but a partly fragmentary series of copies by Marcantonio Raimondi survived and circulated. These frescoes

58 Aretino, Ragionamento, 13 .

59 Aretino used various terms to denote glass dildoes, which is an English (not an Italian) term, that only appeared for the first time in 1593; all are associated with glass (frutti christallini, carota di vetro, cotale divetro) and some with Murano (pastinaca Muranese). See Patricia Simons, "The Cultural History of 'Seigneur Dildoe'," in Sex Acts in Early Modern Italy: Practice, Performance, Perversion, Punishment, ed. Allison Levy (Farnham, Surrey: Ashgate, 2010), 77-91.

60 Aretino, Ragionamento, 16. 
were identified as imodi, corresponding with the term Aretino used to describe the pictorial decoration in his account. ${ }^{61}$ As Linda Wolk-Simon has noticed, $i$ modi were not merely frivolous representations, but were new pictorial renderings that aimed to show the bodily parts of lovers and to reflect artistic ideals such as foreshortening and liveliness of composition. Thus the two lovers in most cases do "not lie face to face but in a sinuous interlocking position that juxtaposes the man's face and the woman's breasts and buttocks. ${ }^{n 2}$ Interestingly enough, the only sexual position from the entire pictorial cycle that Aretino describes fulfils these exact requirements: giving herself to a desperate man out of piety, Aretino writes, Saint Nafissa turns her back on him. In other words, the account can also be read as an ekphrasis and, therefore, as a humanistic engagement with classical and contemporary sources and models. ${ }^{63}$ Nevertheless, to mock the power of painting by depicting an unfettered orgy remained a scandal, regardless of its classical models and humanist foundations. For the Church, a pictorial programme such as i modi was a major offence because it swapped vices for virtues and carnal excess for spiritual awareness. ${ }^{64}$

In the further course of the conversation, Nanna reports not only how she used one of these glass fruits on herself but describes the emotive effects it provoked. The combination of pain and sweet delight at the beginning is soon replaced by pure joy and ecstasy. "When completely inserted as described, I thought to be put to death but this death was sweeter than eternal life." Again, Aretino exploits the vocabulary of religious imagination to parodistically stage carnal lust as virtue. He showed in literary form a vision of female sexuality that, once published, was shared by his mostly male readership. Aretino's language is, as always, hallmarked by a great sensitivity for the material features of the world described. While contemplating the glass dildo she selected from the basket, Nanna divulges its secrets.

NANNA: Unfortunately, I had no warm water close at hand as the nun did who taught me the accurate use of crystal fruits; but necessity is the mother of invention: I simply peed into the thing.

ANTONIA: How did you do that?

61 On the complex relationship between Romano's painting and Raimondi's engravings see Bette Talvacchia, Taking Positions: On the Erotic in Renaissance Culture (Princeton, NJ: Princeton University Press, 1999), 3-19.

62 Linda Wolk-Simon, "Rapture to the Greedy Eyes': Profane Love in the Renaissance," in Art and Love in Renaissance Italy, ed. Andrea Bayer (New York: Metropolitan Museum of Art, 2009), 45-58 and 200-202 (cat. Nr. 99).

63 This engagement took place in a general framework about legitimacy and illegitimacy that applied to all sorts of texts, images, and objects in Italian Renaissance culture. See for instance Talvacchia, Taking Positions, 101-124.

64 The gravity of the offence was proven for Marcantonio Raimondi who, in 1524, was briefly incarcerated by Pope Clement VII for his $i$ modi engravings. 
NANNA: There was a little hole through which warm water could be poured in. ${ }^{6}$

The passage underlines Aretino's firm acquaintance with the objects, the material properties of glass, and its emotive effects, in particular its distinct malleability and high conductivity of temperature that elevated Nanna's bodily pleasure.

Besides the obvious gender issues that deserve a study of their own, Aretino's description does not only stem from male literary imagination, but is itself indicative of a material Renaissance. Indeed, a few examples of glass dildoes have survived in European collections where they are labelled as hoax drinking glasses (Figs. 1.14 and 1.15), an attribution that seems unlikely. ${ }^{66}$ In the light of erotic love and sex in Renaissance art and culture, there is no reason to marginalize them. Instead, they must be considered part of a Renaissance culture that drew on classical heritage and documented period senses and artistic taste. ${ }^{67}$ An engraving by Marcantonio Raimondi links the material objects not only to Aretino's Ragionamenti but also to pictorial representation of erotic culture. The artist shows a classical nymph standing in a generic landscape using a dildo (Fig. 1.16). ${ }^{68}$ It seems that both Raimondi and Aretino were artists that adjusted their artistic production based on consumer demand. By printing their works, they were no longer constrained to the desires of the upper ranks of Renaissance society. Their works thus became accessible to an increasing number of consumers who were unrestrained by wealth, humanistic erudition, and classical taste. ${ }^{69}$

65 Aretino, Ragionamento, 22.

66 Robert Schmidt, Das Glas (Berlin: Vereinigung Wissenschaftlicher Verleger, 1922), 156. Erwin Baumgartner and Ingeborg Krueger, Phönix aus Sand und Asche: Glas des Mittelalters (Munich: Klinkhardt und Biermann, 1988), 421-422. A. M. Koldeweij and A. Willemsen, eds., Heilig en Profaan. Laatmiddeleeuwse insignes in culturhistorisch perspectief(Amsterdam: Van Soeren, 1995), 18. Sabine Faust, Peter Seewaldt, and Monika Weidner, "Erotische Kunstwerke im Rheinischen Landesmuseum Trier," Funde und Ausgrabungen im Bezirk Trier 39 (2007): 39-59, in particular 57. More examples are conserved in Herne (Westfalen) and Rennes. Determining their age is complex. Whereas these studies support origins in the sixteenth century, or even earlier, Wolk-Simon argues for a later dating. See Wolk-Simon, "Profane Love," note 88. 67 The small number of surviving glass dildoes is not surprising. The fragility of the material on the one hand and the taboo of (female) masturbation in Christian societies on the other constituted a poor framework for their conservation over the centuries.

68 David Landau and Peter W. Parshall, The Renaissance Print: 1470-1550 (New Haven, CT and London: Yale University Press, 1994), 298. It has been suggested that the existence of only one single copy of this engraving is due to effective censorship efforts by the Catholic Church. See Wolk-Simon, "Profane Love," note 88 . The engraving has been considered a fragment. See Simons, "Seigneur Dildoe," 8o.

69 For the dynamics between the printing market and erotic imagery/literature see Sara F. MatthewsGrieco, "Satyrs and Sausages: Erotic Strategies and the Print Market in Cinquecento Italy," in Erotic Cultures of Renaissance Italy: Visual Culture in Early Modernity, ed. Sara F. Matthews-Grieco (Farnham, Surrey: Ashgate, 2010), 19-6o. 


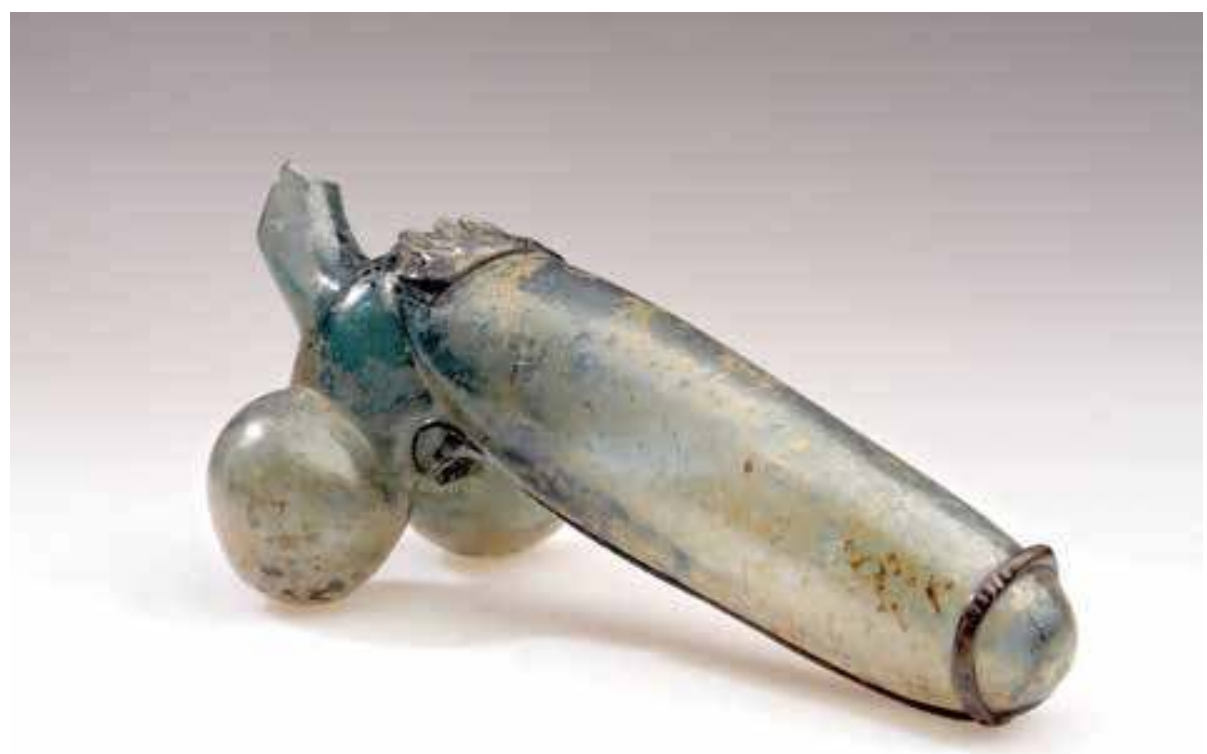

Figure 1.14: Glass dildo found in Trier, first half of the sixteenth century. L: $17.5 \mathrm{~cm}$, Shaft D: ca. $4 \mathrm{~cm}$. Trier, Rheinisches Landesmuseum Trier, inv. no. GG 735; 1910,645. Image @ GDKE/Rheinisches Landesmuseum Trier / Thomas Zühmer.

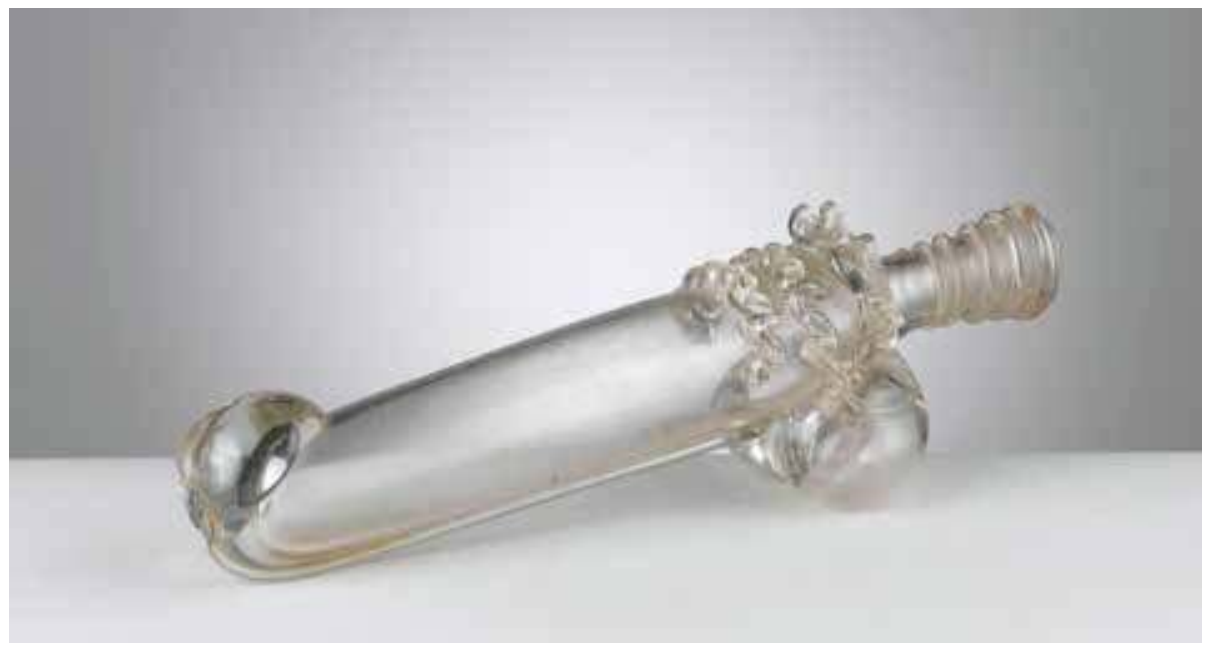

Figure 1.15: Glass dildo from Flanders or Italy, first half of the seventeenth century. L: $26.5 \mathrm{~cm}$. Paris, Musée de Cluny, Musée national du Moyen Âge, inv. no. NNI619. Image @ RMN-Grand Palais (musée de Cluny - musée national du Moyen Âge) / Franck Raux. 


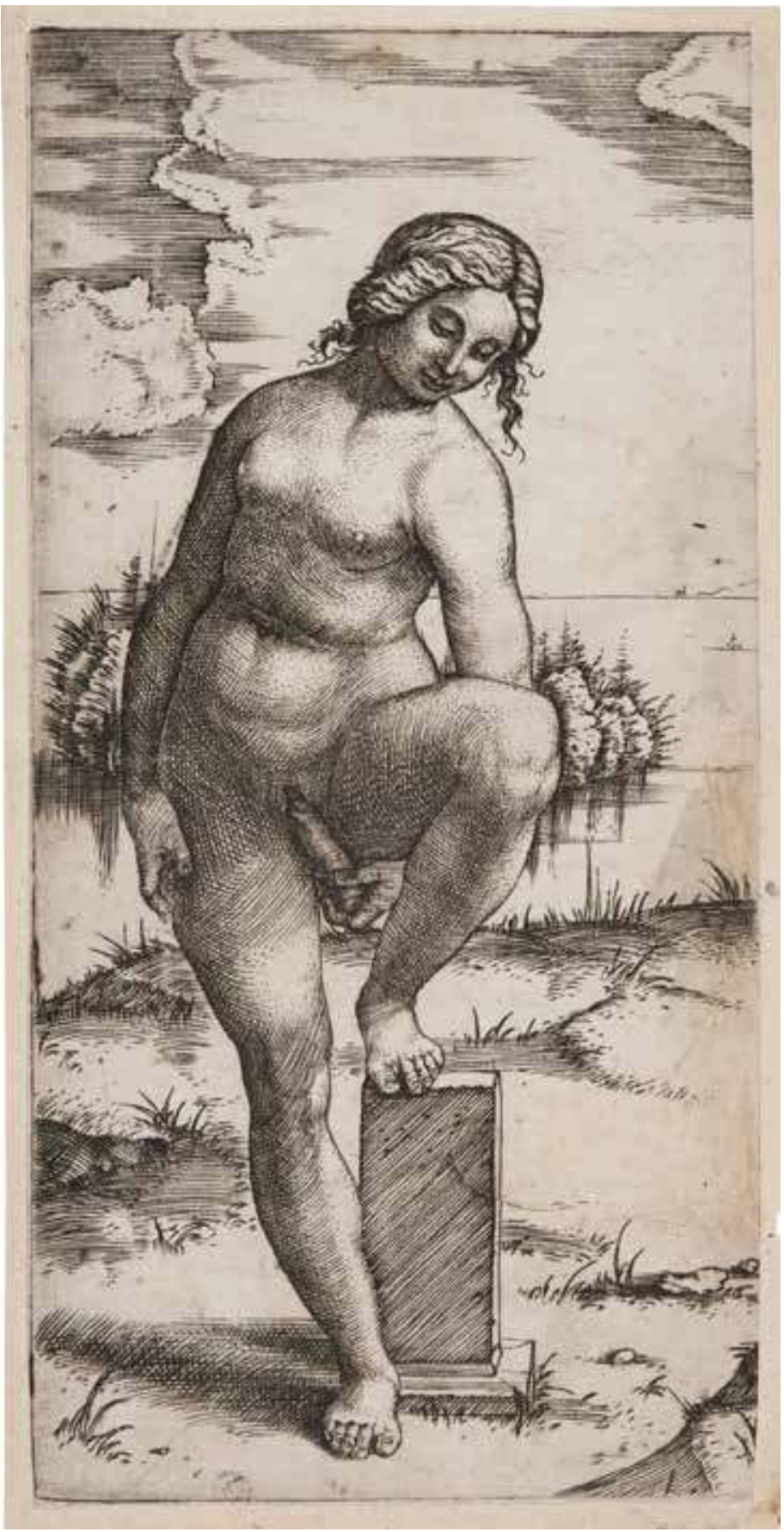

Figure 1.16: Marcantonio Raimondi, Woman with a Dildo, ca. 1525. Engraving $14.1 \times 7.0 \mathrm{~cm}$. Stockholm, Nationalmuseum, inv. no. NMG B 1169/1990. Image @ Cecilia Heisser / Nationalmuseum. 


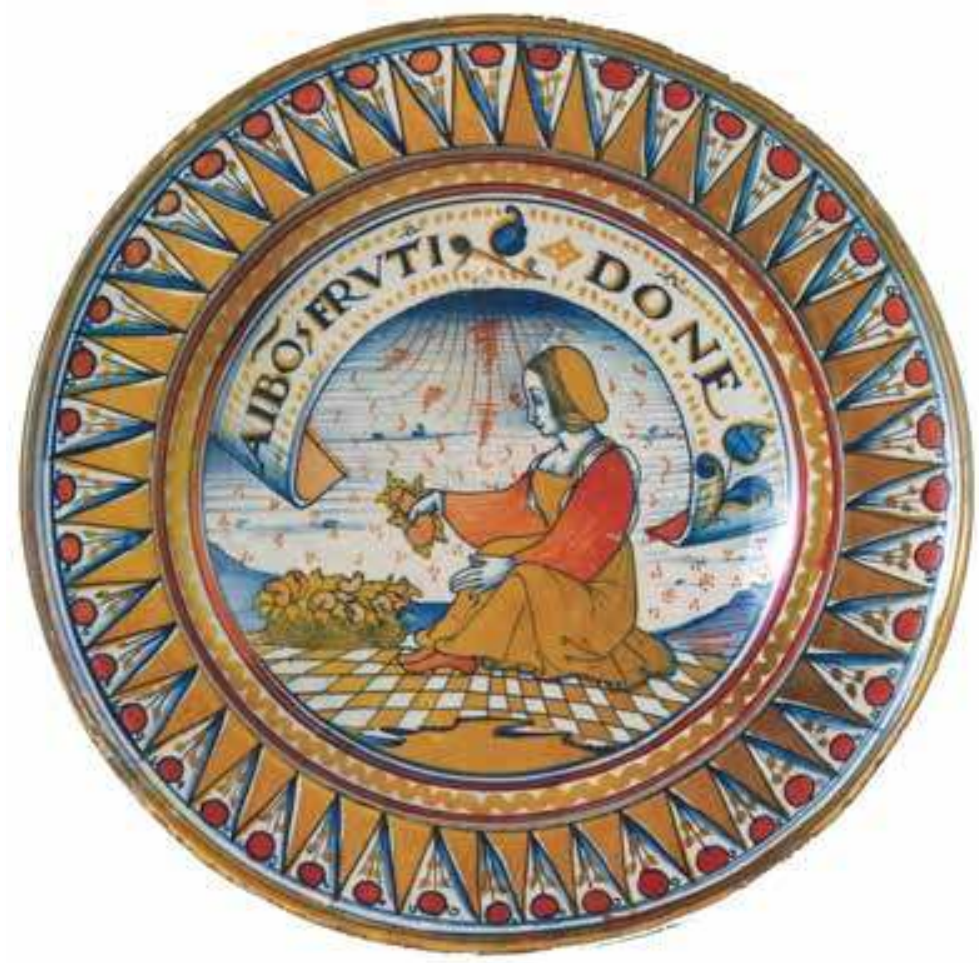

Figure 1.17: Plate with a Woman and a Basket of 'Fruits', ca. 1530. Tin-glazed earthenware (maiolica), D: $34.5 \mathrm{~cm}$. Paris, Musée du Louvre, inv. no. O.A. 1256. Image @ RMN-Grand Palais (musée du Louvre) / Stéphane Maréchalle.

The surviving dildoes underline the importance of materiality and material sensitivity in Renaissance culture. They show how craftsmanship engaged with the materiality of objects and how a material sense contributed to develop and establish commodities for Renaissance societies. The link between female masturbation, its affects, and the prominent role of glass and its material qualities are deeply embedded in Renaissance culture and reflected in an increasing world of goods and consumption. As Linda Wolk-Simon has argued, in this world, images, texts, and objects mutually alluded to each other, their meanings transgressing artistic genres. A majolica plate from the early sixteenth century brings these threads together (Fig. 1.17). A seated woman picks up a phallic shaped object from a basket filled with fruits. The inscription reads AI BO[NI] FRUTI DONE (to the good/pleasant fruits, women) and confirms Aretino's use of the term "fruit" in an erotic sense. At the same time, the artistically designed majolica plate attests to the prevalence of erotic culture in the material world of the Renaissance. Marta Aijmar has pointed out that such an object "certainly resonated with a contemporary audience accustomed 
to such licentious anecdotes and salacious literature. Visually, however, it seems to speak a language of sexual exuberance and fertility more than obscenity."70

The idea of a period sense and the material lexicon of glass offer a framework in which source material that may seem heterogeneous and distinct can be interpreted from a common viewpoint. Such a view not only broadens our understanding of the material world in the Renaissance but analyses the mutual interaction between individuals, artefacts, and texts.

\section{Conclusion}

An approach that focuses on glass as a material propels a well-established field of research in various new directions. It moves perspectives of production and consumption closer together. At the same time, it presents the heterogeneity of Venetian glass production and reveals the industry's economic and trading impact on Venice as a major trading hub in the Mediterranean. Furthermore, it shows that a sense for the material was equally shared by producers and consumers and that both contributed to the development of the art and the marvellous world of goods. Yet the intense engagement people had with glass as a material in Venice generated a nuanced lexicon that was used in social, cultural, and religious debates. In the case of Aretino, it even served to promote ideas of religious, ecclesiastic, and social reform, exploiting different literary genres. Aretino established a linguistic repertoire that connected a highly developed sense for the material world of his time, its impact on the individual's body and soul, and, finally, the affective regimes of religious, social, and cultural life in Renaissance Italy. Just as glass offered a scheme to link sacred and profane in Aretino's writings, it could also be visually exploited, as in the paintings of Paolo Veronese. Finally, the interaction between individuals and glass artefacts in Renaissance Venice shaped the material's features. Transparency and translucency marked visual delight. Ideal for religious symbolic interpretation, glass's capacity to simulate precious materials fostered aemulatio of models both classical and contemporary. The material characteristics of glass, however, aroused not only visual delight in educated beholders and renowned collectors. The malleability of glass was crucial to both imitating classical and inventing new forms that could provoke sensual and carnal pleasure. In Renaissance Venice, the encounter between glass and pleasure occurred in the realm of conspicuous consumption as well as in the literary imagination of learned humanists. The material world manifested not only wealth but also acted as a tool for their own self-development.

70 See Marta Ajmar-Wollheim, "The Spirit Is Ready, but the Flesh Is Tired': Erotic Objects and Marriage in Early Modern Italy," in Matthews-Grieco, Erotic Cultures, 148. 
For both consumption and culture, the material features of glass were crucial, and materiality served as an interface between them.

\section{Bibliography}

\section{Unpublished Primary Sources}

Archivio di Stato di Venezia, Venice (ASVe)

Arti, b. 726,10

CI, Misc., b. 35 , fasc. 23 ; b. 38 , fasc. 29 ; b. 40 , fasc. 70

Miscellanea Gregolin, b. 14, reg. D

Archivio di Stato di Mantua (ASMn)

AG, b. 1440, Carteggio di Inviati e Diversi

AG, b. 1505, Carteggio di Inviati e Diversi, f. III

AG, b. 1891, Corrispondenza con Isabella d'Este, provenienze diverse

AG, b. 2994, Copialettere particolari d'Isabella d'Este, lib. 20

AG, b. 2996, Copialettere particolari d'Isabella d'Este, lib. 30

\section{Primary Published Sources}

Aretino, Pietro. I tre libri della humanità di Christo. Venice: Nicolini da Sabio, 1535.

Aretino, Pietro. Sei giornate: ragionamento della Nanna e della Antonia (1534), edited by Giovanni Aquilecchia. Bari: Laterza, 1969.

Aretino, Pietro. Selected Letters, translated by George Bull. Harmondsworth: Penguin Books, 1976.

Coryate, Thomas. Coryat's crudities: hastily gobled up in five moneths travells in France, Savoy, Italy, Rhetia commonly called the Grisons country, Helvetia alias Switzerland, some parts of high Germany and the Netherlands. Glasgow: James Maclehose and Sons, 1905.

Fratris Felicis Fabri Evagatorium in Terrae Sanctae, Arabie et Aegyptiae Peregrinationem, edited by Konrad D. Hassler, 3 vols. Bibliothek des Literarischen Vereins in Stuttgart 18. Stuttgart: Stuttgardiæ, 1843-1849.

The Pirotechnia of Vannoccio Biringuccio, edited and translated by Harvey S. Mudd, Cyril Stanley Smith, and Martha Teach Gnudi. New York: The American Institute of Mining and Metallurgical Engineers, 1942.

\section{Secondary Literature}

Ajmar-Wollheim, Marta. “The Spirit Is Ready, but the Flesh Is Tired': Erotic Objects and Marriage in Early Modern Italy." In Erotic Cultures of Renaissance Italy: Visual Culture 
in Early Modernity, edited by Sarah F. Matthews-Grieco, 141-169. Farnham, Surrey: Ashgate, 2010.

Baumgartner, Erwin. Reflets de Venise: Gläser des 16. und 17. Jahrhunderts in Schweizer Sammlungen - Verres des XVIe et XVIIe siècles de collections suisses. Publications du Vitrocentre Romont. Bern: Lang, 2015.

Baumgartner, Erwin, and Ingeborg Krueger. Phönix aus Sand und Asche: Glas des Mittelalters. Munich: Klinkhardt und Biermann, 1988.

Baxandall, Michael. Painting and Experience in Fifteenth-Century Italy: A Primer in the Social History of Pictorial Style. Oxford: Clarendon Press, 1972.

Baxandall, Michael. The Limewood Sculptors of Renaissance Germany, rev. ed. New Haven, CT: Yale University Press, 1982.

Biow, Douglas. In Your Face: Professional Improprieties and the Art of Being Conspicuous in Sixteenth-Century Italy. Stanford, CA: Stanford University Press, 2010.

Bova, Aldo, ed. L'avventura del vetro dal Rinascimento al Novecento tra Venezia e mondi lontani. Milan: Skira, 2010.

Bridgeman, Jane. "Pagare le pompe: Why Quattrocento Sumptuary Laws Did Not Work." In Women in Italian Renaissance Culture and Society, edited by Letizia Panizza, 209-226. Oxford: Legenda, 2000.

Cairns, Christopher. Pietro Aretino and the Republic of Venice: Researches on Aretino and His Circle in Venice, 1527-1556. Biblioteca dell'“Archivum Romanicum" Serie 1, Storia, letteratura, paleografia. Florence: Leo S. Olschki, 1985.

Casini, Matteo. "Banquets, Food and Dance: Youth Companies at the Table in Renaissance Venice." Ludica. Annali di storia e civiltà del gioco 19-20 (2013-2014): 182-192.

Chambers, David, and Brian Pullan, with Jennifer Fletcher, eds. Venice: A Documentary History, 1450-1630, repr. Oxford and Cambridge, MA: Blackwell, 1992.

Cooper, Tracy E. Palladio's Venice: Architecture and Society in a Renaissance Republic. New Haven, CT: Yale University Press, 2005.

Davids, Karel, and Bert De Munck, eds. Innovation and Creativity in Late Medieval and Early Modern European Cities. Farnham, Surrey: Ashgate, 2014.

Dorigato, Attilia. L'arte del vetro a Murano. Venice: Arsenale, 2002.

Epstein, Stephen R., and Maarten Prak, eds. Guilds, Innovation and the European Economy, 1400-180o. Cambridge: Cambridge University Press, 2008.

Faust, Sabine, Peter Seewaldt, and Monika Weidner. "Erotische Kunstwerke im Rheinischen Landesmuseum Trier." Funde und Ausgrabungen im Bezirk Trier 39 (2007): 39-59.

Fehl, Philipp P. “Veronese's Decorum: Notes on the Marriage at Cana." In Art, the Ape of Nature: Studies in Honor of H.W. Janson, edited by Moshe Barash and Lucy Freeman Sandler, 341-365. New York and Englewood Cliffs, NJ: H.N. Abrams, Prentice Hall, 1981. Fortini Brown, Patricia. "Behind the Walls: The Material Culture of Venetian Elites." In Venice Reconsidered: The History of Civilization of an Italian City-State, 1297-1797, edited by John Martin and Dennis Romano, 295-338. Baltimore, MD: Johns Hopkins University Press, 2000. 
Gasparetto, Astone. “The Gnalić Wreck: Identification of the Ship.” Journal of Glass Studies 15 (1973): 79-84.

Gilbert, Creighton. "Last Suppers and Their Refectories." In The Pursuit of Holiness in Late Medieval and Renaissance Religion, edited by Charles Trinkhaus and Heiko A. Obermann, 371-402. Leiden: Brill, 1974.

Guštin, Mitja, Sauro Gelichi, and Konrad Spindler, eds. The Heritage of the Serenissima: The Presentation of the Architectural and Archaeological Remains of the Venetian Republic. Koper: Založba Annales, 2006.

Hanson, Kate H. “The Language of the Banquet: Reconsidering Paolo Veronese's Wedding at Cana." Invisible Culture: An Electronic Journal for Visual Culture 14 (Winter 2010). Accessed on 22 April 2021. http://www.rochester.edu/in_visible_culture/Issue_14/hanson/.

Koldeweij, A. M., and A. Willemsen, eds. Heilig en Profaan. Laatmiddeleeuwse insignes in culturhistorisch perspectief. Amsterdam: Van Soeren, 1995.

Landau, David, and Peter W. Parshall. The Renaissance Print: 1470-1550. New Haven, CT and London: Yale University Press, 1994.

Lazar, Irena. "I vetri del relitto di Gnalić." In L'avventura del vetro dal Rinascimento al Novecento tra Venezia e mondi lontani, edited by Aldo Bova, 103-109. Milan: Skira, 2010.

Lazar, Irena, and Hugh Willmott. "The Late 16th Century Glass from the Gnalić Wreck: An Overview of Forms." In The Heritage of the Serenissima: The Presentation of the Architectural and Archaeological Remains of the Venetian Republic, edited by Mitja Guštin, Sauro Gelichi, and Konrad Spindler, 99-104. Koper: Založba Annales, 2006.

Maite, Corinne. Les chemins de verre: les migrations des verriers d'Altare et de Venise, XVIe-XIXe siècles. Rennes: Presses universitaires de Rennes, 2009.

Malafouris, Lambros. "At the Potter's Wheel: An Argument for Material Agency." In Material Agency towards a Non-Anthropocentric Approach, edited by Carl Knappet and Lambros Malafouris, 19-36. New York: Springer, 2008.

Matthews-Grieco, Sara F., ed. Erotic Cultures of Renaissance Italy: Visual Culture in Early Modernity. Farnham, Surrey: Ashgate, 2010.

Matthews-Grieco, Sara F. "Satyrs and Sausages: Erotic Strategies and the Print Market in Cinquecento Italy." In Erotic Cultures of Renaissance Italy: Visual Culture in Early Modernity, edited by Sarah F. Matthews-Grieco, 19-6o. Farnham, Surrey: Ashgate, 2010.

McCray, Patrick. Glassmaking in Renaissance Venice: The Fragile Craft. Aldershot: Ashgate, 1999.

Molà, Luca. "Material Diplomacy: Venetian Gifts for the Ottoman Empire in the Late Renaissance." In Global Gifts: The Material Culture of Diplomacy in Early Modern Eurasia, edited by Zoltán Biedermann, Giorgio Riello, and Anne Gerritsen, 56-87. Cambridge: Cambridge University Press, 2018.

Molmenti, Pompeo. La storia di Venezia nella vita privata dalle origini alla caduta della Repubblica, vol. 6. Bergamo: Istitutione Italiana d'arti grafiche, 1922. 
Muzzarelli, Maria Giuseppina, ed. La legislazione suntuaria, secoliXIII-XVI:Emilia-Romagna. Pubblicazioni degli Archivi di Stato Fonti. Rome: Ministero per i beni e le attività culturali, 2002.

Owen Hughes, Diane. "Sumptuary Law and Social Relations in Renaissance Italy." In Disputes and Settlements: Law and Human Relations in the West, edited by John Bossy, 69-99. Cambridge: Cambridge University Press, 1983.

Pavanello, Giuseppe. "Più vino per la festa." In The Miracle of Cana: The Originality of the Re-production, 15-28. Venice: Cierre Edizioni, 2011.

Pholien, Florent. La verrerie et ses artistes au pays de Liège. Liège: Bénard, 1899.

Pinchart, Alexandre. "Les fabriques de verres de Venise d'Anvers et de Bruxelles au XVIième et au XVIIième siècle." Bulletin des Commissions Royales d'Art et d'Archéologie 21 (1882):343-394.

Raby, Julian. "The Serenissima and the Sublime Porte: Art in the Art of Diplomacy, 1453-160o." In Venice and the Islamic World, 828-1797, edited by Stefano Carboni, 90-119. New Haven, CT and London: The Metropolitan Museum of Art, 2007.

Radić Rossi, Irena. "Il relitto di Koločep, Croazia." In L'avventura del vetro dal Rinascimento al Novecento tra Venezia e mondi lontani, edited by Aldo Bova, 111-115. Milan: Skira, 2010.

Richardson, Gary. "Brand Names before the Industrial Revolution." In NBER Working Papers No. 13930 (April 2008): 1-55.

Rifkin, Adrian. About Michael Baxandall. Oxford: Blackwell, 1999.

Rublack, Ulinka. "Matter in the Material Renaissance." Past \& Present 219, no. 1 (2013): 41-85.

Schmidt, Robert. Das Glas. Berlin: Vereinigung Wissenschaftlicher Verleger, 1922.

Simons, Patricia. “The Cultural History of 'Seigneur Dildoe'.” In Sex Acts in Early Modern Italy: Practice, Performance, Perversion, Punishment, edited by Allison Levy, 77-91. Farnham, Surrey: Ashgate, 2010.

Talvacchia, Bette. Taking Positions: On the Erotic in Renaissance Culture. Princeton, NJ: Princeton University Press, 1999.

Tenenti, Alberto. Naufrages, corsaires et assurances maritimes à Venise: 1592-16og. Paris: S.E.V.P.E.N., 1959 .

Trivellato, Francesca. "Guilds, Technology and Economic Change in Early Modern Venice." In Guilds, Innovation and the European Economy, 1400-180o, edited by Stephen R. Epstein and Maarten Prak, 199-231. Cambridge: Cambridge University Press, 2008.

Van Damme, Ilja. “From a 'Knowledgable' Salesman towards a 'Recognizable' Product? Questioning Branding Strategies before Industrialization (Antwerp, Seventeenth to Nineteenth Centuries)." In Concepts of Value in European Material Culture, 1500-19oo, edited by Bert De Munck and Lyna Dries, 75-101. Farnham, Surrey: Ashgate, 2015.

Waddington, Raymond B. "Pietro Aretino, Religious Writer." Renaissance Studies:Journal of the Society for Renaissance Studies 20 (2006): 277-292.

Waddington, Raymond B. “Aretino, Titian, and 'La Humanità di Christo'." In Forms of Faith in Sixteenth Century Italy, edited by Abigail Brundin and Matthew Treherne, 171-198. Aldershot: Ashgate, 2009. 
Welch, Evelyn. "Making Money: Pricing and Payments in Renaissance Italy." In The Material Renaissance, edited by Michelle O'Malley and Evelyn Welch, 71-84. Manchester: Manchester University Press, 2007.

Welch, Evelyn. "The Senses in the Marketplace: Sensory Knowledge in a Material World." In A Cultural History of the Senses in the Renaissance, edited by Herman Roodenburg, 61-86. London: Bloomsbury, 2016.

Wolk-Simon, Linda. "Rapture to the Greedy Eyes': Profane Love in the Renaissance." In Art and Love in Renaissance Italy, edited by Andrea Bayer, 45-58. New York: Metropolitan Museum of Art, 2009.

Zecchin, Luigi. Il ricettario Darduin: un codice vetrario del Seicento trascritto e commentato. Venice: Arsenale, 1986.

Zecchin, Luigi. "Il quaderno dei Bortolussi." In Vetro e vetrai di Murano, edited by Luigi Zecchin, vol. 2. Venice: Arsenale Editrice, 1989.

\section{About the Author}

Lucas Burkart has been Professor of History at the University of Basel since 2012. His research interests encompass the cultural history of the Middle Ages and the Renaissance, the history of material culture, and the history of historiography. Currently, he is also overseeing the completion of the critical edition of the works by Jacob Burckhardt. 


\title{
2. Shaping Identity through Glass in Renaissance Venice
}

\author{
Rachele Scuro
}

\begin{abstract}
:
This essay investigates the role of the glass business in shaping the identity of glassmakers in Renaissance Venice. First, it re-examines the debated issue of secretiveness, highlighting the role played by immigration and emigration, and stressing how mobility affected the intersection between secrets and the creation of a distinctive identity. It then focuses on trade, examining the role played by the Venetian high political bodies in protecting a manufacturing that became a matter of state. It argues that thanks to government protection the participation of glass entrepreneurs in commerce did not need any formal branding, yet only to be recognized as "Venetian." Lastly, the case study of the Bortolussi family shows the strategies of those glassmakers who tried to ascend to a superior social status, that of Venetian "cittadini originari."
\end{abstract}

Keywords: Renaissance Venetian glass; early modern Venetian economy; Venetian citizenship; Venetian glass entrepreneurship; early modern Venetian glass; early modern Venetian society

A long-established tradition associates Venetian glass with the idea of secretive-
ness, a self-constructed myth that was later bequeathed from the Serenissima to
modern historiography. In fact, during the medieval and early modern period,
the aim to prevent the spread of the secreti found concrete basis in legislation
that prohibited glassmakers to emigrate. Scholars have consequently read this
recurring series of orders and reprimands as proof of the active role played by
Venice in protecting an expertise that should have remained unshared and
guarded as "property" that was not only typical of a master or a professional

Burghartz, S., L. Burkart, C. Göttler, U. Rublack, Materialized Identities in Early Modern Culture, 1450-1750: Objects, Affects, Effects. Amsterdam: Amsterdam University Press, 2021

DOI 10.5117/9789463728959_CHO2 
group, but of the city itself. ${ }^{1}$ This set of protectionist strategies was shared among the republic, the glassmakers' guild, and its entrepreneurs. ${ }^{2}$ Secrets became an instrument to mark a distinctive knowledge that had to be protected from anyone outside the city and its workers, who were seen as their sole, rightful owners. ${ }^{3}$

Yet, following Koen Vermeir's analysis, the concepts of secrecy and openness should no longer be read as mere opposites. ${ }^{4}$ Furthermore, the very notions of secrets and secrecy have to be distinguished, as there can be secrets without secrecy (e.g. simple recipes, skills, or techniques), as well as secrecy without actual secrets. Secrecy and openness are thus norms or values that regulate behaviours, and characteristics of practices that can be modulated by a rhetorical play decided by the actors involved. It follows that in order to differentiate between types of secrecy based on the actors, the discussion needs to be historicized. Moreover, regarding the ideas of both "open" and "secret," it is important to specify the "by whom" and "for whom." For instance, can a secret kept by a group of hundreds of people still be considered as such?5 This is also the case for the community of glass workers in Murano and Venice, for whom an interpretation of openness and secrecy as gradational categories can be applied. The two are thus seen as positive categories about which the central question remains, who actually had access to that knowledge? ${ }^{6}$ Is it possible to rethink secrecy in the Muranese environment as an "open secret"? ${ }^{7}$ And if so, what were its effects on the creation of a group identity? ${ }^{8}$

1 Paolo Preto, I segreti di Venezia. Spionaggio e controspionaggio ai tempi della Serenissima (Milan: il Saggiatore, 2010), 403-422.

2 For an excursus on the history of Venetian glass, see Rosa Barovier Mentasti, "La vetraria veneziana," in Storia di Venezia. Temi. L'Arte, ed. Rodolfo Pallucchini, vol. 2 (Rome: Treccani, 1995), 845-905. The most famous scholar on Murano glass was Luigi Zecchin, whose works are now collected into three volumes, see Luigi Zecchin, Vetro e vetrai. Studi sulla storia del vetro, 3 vols. (Venice: Arsenale Editrice, 1987-1990). They followed the study of Astone Gasparetto, Il vetro di Murano dalle origini ad oggi (Vicenza: Neri Pozza, 1958). More recently the technological and labour market aspects of early modern Venetian glass have been analysed by Patrick McCray, Glassmaking in Renaissance Venice: The Fragile Craft (Aldershot: Ashgate, 1999) and Francesca Trivellato, Fondamenta dei vetrai. Lavoro, tecnologia e mercato a Venezia tra Sei e Settecento (Rome: Donzelli, 200o).

3 On the topic of secretiveness in early modern arts and crafts, see Sven Dupré and Christine Göttler, eds., Knowledge and Discernment in the Early Modern Arts (London: Routledge, 2017) and Timothy McCall, Sean Roberts, and Giancarlo Fiorenza, eds., Visual Cultures of Secrecy in Early Modern Europe (Kirksville, MO: Truman State University Press, 2013).

4 Koen Vermeir, "Openness versus Secrecy? Historical and Historiographical Remarks," The British Journal for the History of Science 45, no. 2 (2012): 166-167.

5 Ibid., 169 .

6 Ibid., 171-172.

7 An "open secret" can be open and secret concurrently, for instance, it can be intentionally concealed or denied to a larger audience, while actively discussed within a select group; Vermeir, "Openness," $175^{-176 . ~}$

8 On the effects of secrecy in the development of identitarian categories, see Georg Simmel, "The Sociology of Secrecy and of Secret Societies," American Journal of Sociology 11, no. 4 (1906): 441-498. 
Starting from these questions, this analysis aims at investigating the role played by Muranese glass industry members in shaping the inner identity of the group, as well as their identitarian relationship with Venice. I will open my analysis by re-examining the debated issue of secretiveness and openness with regard to the group's internal practices, to highlight the effects played by both immigration and emigration, and the transfer of knowledge resulting from the labour organization and geographic peculiarities of the island. I will also stress how the mobility of craftspeople, who moved between the furnaces of the island, of Italy, and then of Europe, affected the intersection between secrets and the creation of a shared identity that was professional, cultural, and social.

I will then transfer the connection existing between the material and its crafters to a larger perspective to include the institutional aspects along with other socio-economic factors that linked this bond to Venice as a city and a state. I will analyse the synergy existing between glassmakers and the Venetian high political bodies to protect an industry which, due to the international success it had reached through its luxury output, had become a matter of state. I will argue that, as a result of governmental shielding, glass entrepreneurs did not need any formal brand or label other than being recognized as Venetian. Thus, the identitarian sense maintained by the oligopolistic families leading the branches merged with the name of Venice itself, as had happened to the commodities produced in their furnaces. At the same time, the state was actively promoting a policy aimed at benefiting from international recognition and the positive effects on the local economy deriving from the high-end production of glass, as well as, if not mainly, from its mass production.

In the final section I will use the case study of the Bortolussi family to examine the strategies of social ascent designed by those glassmakers who, from the second half of the sixteenth century, aspired to transcend their original status and reach the highest rank for non-nobles within Venetian society, that of the cittadini originari of Venice. Literature has usually argued that glassmakers only resorted to this when familial strategies pointed to alternative careers for some individuals in the kinsgroup. On the contrary, I will consider how the process intertwined with the evolution of a self-identitarian definition of the leading glass families, which in turn progressed thanks to their economic success and exogamic marriage strategies. I will also analyse how this aspiration to receive official recognition as belonging to the higher social ranks of the capital was helped by the monopolistic position they held in an industry that, since the last part of the previous century, had become economically strategic as well as linked to both a material and a mastery essential to the representation of Venice in the world. 


\section{Secretiveness and Identity: The Circulation of People and Knowledge}

The idea of strict secretiveness around the matter of glass expertise and workmanship, as traditionally presented in literature, is largely contradicted by Venetian archival sources. In fact, between the fifteenth and sixteenth centuries, the composition of the population of the Muranese glassmakers showed a strong rate of mobility, as proved by sources like notarial contracts and inventories, or the jurisdictional documentation in the registers of the Podestà di Murano, the Venetian officer in charge of the island as the local representative of the central power. Moreover, the trend applies to both workers coming to the island and to local glassmakers who decided to leave the Lagoon to move abroad or to the newly acquired subject cities of the mainland state.

During the first half of the fifteenth century, a robust immigration rate can be observed from the sources. This was a consequence of the policies adopted by Venice to encourage artisan immigration after the Black Death and the War of Chioggia (1378-1381). The trend continued up to the beginning of the sixteenth century, thanks to the integration of the mainland state into the capital's economy during the Quattrocento. ${ }^{9}$ Notably, these latecomers constituted some of the most important glassmaker families of the early modern period, such as the Bortolussis, who will be analysed later in this chapter. These initial observations encourage widening the traditional perspective on the Venetian glass industry, including recognition of its place within the circulation of material skills and knowledge in Renaissance Italy and Europe. ${ }^{10}$

The flow of manpower and knowledge is significantly proved by the provenance of those immigrants, which can be pinpointed to three main areas. Firstly, the towns of the Po valley, in particular those of the newly conquered Veneto; secondly, the Dalmatian area, the traditional birthplace of many workers in the Venetian manufacturing industry; ${ }^{11}$ and thirdly, Tuscany, a region in which the glass industry had already developed high degrees of specialization and diffusion of its products. ${ }^{12}$ The stability of the new arrivals was also remarkable: they were usually able to settle down in Murano and find a prominent place within the glass industry in a short period of time, thus becoming fully integrated within the local community by the first or second generation.

Furthermore, despite the first half of the fifteenth century having usually been considered a moment of crisis for the Muranese glass industry, a certain level of

9 On trends and examples in the case of glassmakers, refer to Zecchin, Vetro, 3:191-198.

10 Corinne Maitte, "Larte del vetro; innovazione e trasmissione delle tecniche," in Il rinascimento italiano e l'Europa, vol. 3: Produzione e tecniche, ed. Philippe Braunstein and Luca Molà (Vicenza: Angelo Colla, 2007), 236.

11 From that region came, for instance, the families Caner and Ballarin; see Zecchin, Vetro, 1:202-206.

12 Guido Taddei, L'arte del vetro in Firenze e nel suo dominio (Florence: Le Monnier, 1954). 
vitality is instead proved by the contrary emigration rate. This trend involved not only the foreign segment of the manpower, but also local families of established tradition. In most cases, the latter chose nearby destinations, and decided to move to cities of the mainland state, counting on a set of fiscal and trade privileges accorded by the capital to the new subject districts. As a consequence, in contrast to the traditional idea of Murano being the only place where glass could be manufactured within the Venetian state, in a brief span of time Padua, Vicenza, and above all Treviso, ${ }^{13}$ saw the opening of new furnaces owned and managed by Muranese glassmakers. ${ }^{14}$

Although the prohibition to export manpower outside of Murano had been a cornerstone in the regulation of the guild since its first statutes, ${ }^{15}$ it had also been traditionally accepted, de facto if not by law, that workers would resort to seasonal expatriations. To justify their temporary transfer, glassmakers had for centuries claimed that emigration was forced on them due to the constraints created by Venetian laws, in particular the imposition of an excessively long period of vacanza for the furnaces in Murano (i.e. the period when fires had to stay out, which initially was for five months). In these circumstances, emigration was claimed to be the only viable solution to extend the glassmakers' working season, in order to sustain their families and business. ${ }^{16}$ However, this reason does not sufficiently explain their emigration trends by the end of the Middle Ages. Firstly, because during the fifteenth century the state actively tried to overcome the previous medieval directive by extending the annual working period. ${ }^{17}$ Secondly, because for many, the months spent working outside Murano were not at all coincidental with the shutdown required by the regulation.

Thus, although legislation had on the one hand been insistently condemning expatriation since the Middle Ages, on the other hand Renaissance glassmakers as a community did not usually see a temporary transfer as a deplorable choice, and the official protectionist intents found less support once faced with personal, familial, and group issues. In general, a certain degree of mobility was never seen

13 Zecchin, Vetro, 2:318-326. On the individualistic attitude of Muranese migrants: Corinne Maitte, "Les migrations de travail comme ressources: verriers altarais et vénitiens, XVIe-XVIIIe siècle," Mélanges de l'École française de Rome 123, no. 1 (2011): 3-9.

14 Bergamo, at the western corner of the Terraferma, was initially the single authorized exception. However, by the middle of the fifteenth century, furnaces were permitted in the subject cities, but were only allowed to produce low-quality glass. Trivellato, Fondamenta, 223.

15 Giovanni Monticolo, ed., I capitolari delle arti veneziane sottoposte alla Giustizia e poi alla Giustizia Vecchia. Dalle origini al MCCCXXX, vol. 2 (Rome: Istituto Storico per le Fonti della Storia d'Italia, 1905), 66.

16 Once on trial, these were the typical justifications glassmakers gave.

17 At the beginning of the sixteenth century, the vacanza was finally fixed between the end of July and the beginning of October. On the regulation of the annual putting out of the furnaces through the fifteenth and sixteenth centuries, see Paolo Zecchin, "La cavata dei vetrai muranesi," Rivista della Stazione Sperimentale del Vetro 5 (1995): 207-218. 
as reprehensible until a later period, ${ }^{18}$ and never implied difficulties for reinsertion into the social life and job market of the island. Therefore, the relocation of some Muranese glassmakers to cities of the Terraferma at the beginning of the Quattrocento anticipated what was going to develop further over the following centuries: that the chance to move to other Italian and European areas, for short or long periods, was perceived as a natural one if it could sufficiently justify the losses in Venice by providing more significant earnings. ${ }^{19}$

From this perspective, the concepts of "secret" and "secretiveness" in the Venetian glass industry need to be considered through the interrelation between familial and professional bonds, especially because Muranese society was still quite homogeneous up to and during the fifteenth century. ${ }^{20}$ Additionally, the positioning of all the furnaces in a limited space, in the form of one parish and the two banks along the canal rio deiverieri, reinforced the exchange of people and knowledge (Fig. 2.1). In this context, technological and stylistic innovations could not remain secret; on the contrary, they were to be shared and become a "collective identifier."

This hypothesis is sustained by the manufacturing organization of the furnaces: different to today, the creation of a single object was divided into many phases, each one entrusted to a different master or worker with different specializations and skills. ${ }^{21}$ Workers were also accustomed to working side by side, thus becoming familiar with all the stages of production as viewers if not as makers, regardless of their age, level of experience, or status within the workshop. Knowledge was, therefore, seamlessly passed down from one person to the next through physical presence in the workshop and observation.

Moreover, within the local industry the staff - both masters and unspecialized labourers - were usually characterized by a high rate of mobility, as work contracts

18 The offender was often reported by close relatives, likely due to previous arrangements within the family to reduce the de facto outlay of the fixed pecuniary fine, which was to be partially given to the denouncer. Examples in ASVe, PodMur, b. 19, fasc. 1, c. 115v (17.01.1446) and b. 116-117, c. 240r (25.05.1598). 19 By the middle of the sixteenth century, this tendency had become a chronic problem that the state tried in vain to resolve; see BMC, IV L 13, ch. 131, cc. 49r-52r (28.02.1543mv); ch. 135, c. 53r-v (27.10.1547); ch. 137, cc. 55r-56r (18.09.1549); ch. 147, c. $63 \mathrm{v}$ (18.11.1597). For instance, in 1569, Battista Guado and Gianandrea Barovier were denounced for having moved to Antwerp (ASVe, PodMur, b. 71, c. 1123r [14.02.1569]).

20 The masters who owned the workshops had far more resources than most of their employees, yet still in the Quattrocento it was common for them to work at their furnace in person, thus developing a sense of strong familiarity with their personnel. Furthermore, in a small island like Murano, closeness helped to create a sense of group identity: the place of work and residence were merged in a sense of community. This explains why professional endogamy was quite common there, in contrast to other Venetian guilds (see Dennis Romano, Patricians and Popolani: The Social Foundations of the Venetia Renaissance State [Baltimore, MD and London: Johns Hopkins University Press, 1987], 77-79).

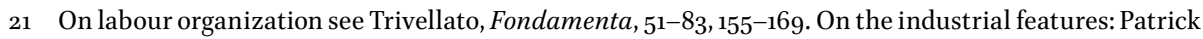
McCray, "Creating Networks of Skill: Technology Transfer and the Glass Industry of Venice," Journal of European Economic History 28, no. 2 (1999): 301-303. 


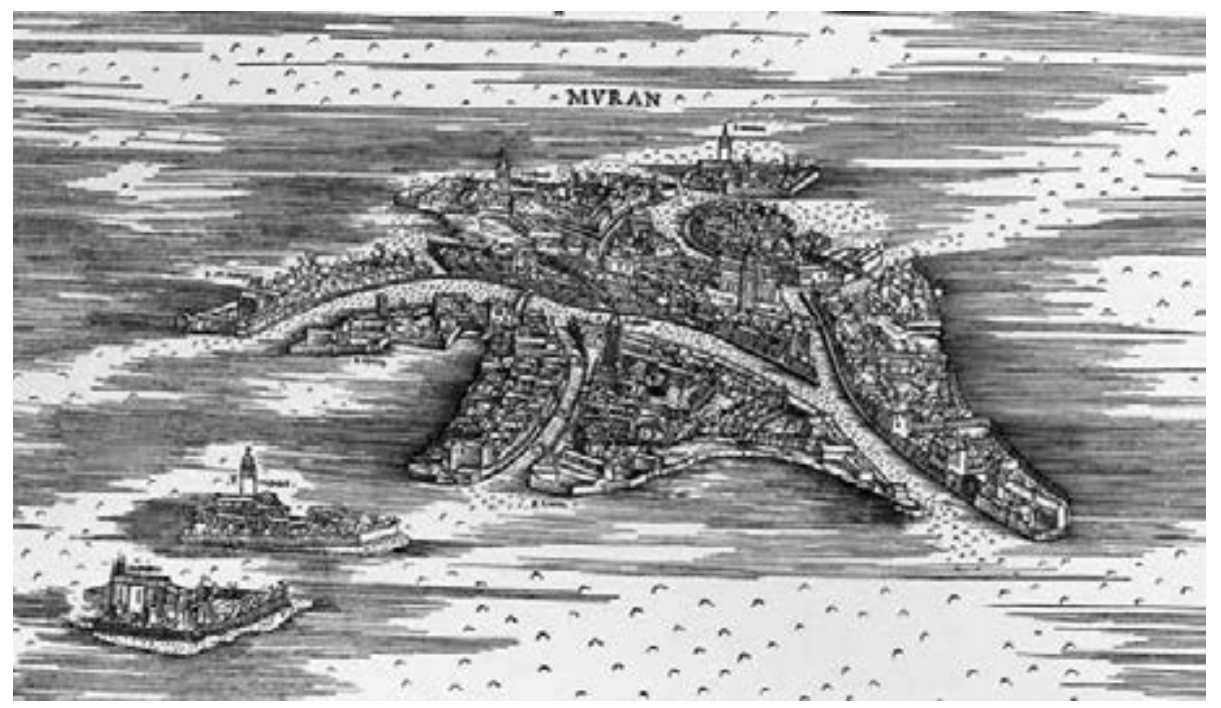

Figure 2.1: Jacopo de Barbari, View of Venice, 1500. Woodcut, detail: The island of Murano. In the lower part, crossed by three bridges, is the canal called the "rio dei verieri" with its workshops overlooking the two quays. Venice, Museo Correr, inv. Cl. XLIV n. 0057. Image 2020 @ Photo Archive - Fondazione Musei Civici di Venezia.

were normally agreed for one year only, corresponding to the working year fixed by the Venetian regulation. Both masters and workers usually changed their place of work annually, to pursue better working and salary conditions. This resulted in a steady flow of skills and craftsmanship, in addition to other parallel ways of sharing knowledge, such as family and neighbourhood relationships. Within one or two years, a large part of the manpower would have changed their workplace and thus would have transferred from one furnace to another any sort of innovation or "secret" previously acquired.

From a fashion point of view, not even that short span of time was necessary to disseminate new trends, as the proximity of shops and furnaces would have spread any novelty within days or months once objects had been put on display and seen by other experienced masters. Therefore, if the annual rotation of employees could perhaps have avoided, for example, the diffusion of the secret for a specific shade of enamel - at least for some years - it was nonetheless unlikely that the manual process to obtain rosette beads, filigree glass, or any other new method or trend could remain concealed within a single furnace for very long, after being crafted in front of other colleagues. ${ }^{22}$ It was that embodied craftsmanship that created, on the one

22 Practice would have done the rest, possibly bringing about even more ingenious innovations. Recipe books (focused on chemical aspects) could not protect more than a share of the "secret," while the industry's success largely remained in artisans' embodied knowledge. Additionally, "making" expertise 
hand, a common, shared knowledge and a set of valuable skills transferable only by practice with masters, ${ }^{23}$ and on the other, a sense of community and identity based on sharing a mastery unknown to other glass centres, with secrecy as a dynamic process creating special bonds and a sense of community. ${ }^{24}$

The rapid spread of knowledge within the boundaries of Murano is shown even in the paradigmatic case of the process of refinement that led to the creation of crystal glass and ushered in Venetian glassware's season of undisputed fame. Around the 145 os a new type of vetro cristallino made its appearance, tied to the business of the Barovier family. The Baroviers themselves, however, were the first to share their expertise and to work in partnership with other glassmakers. Apparently, not even this "invention" was perceived as a long-lasting, distinctive secret for a single family or workshop, regardless of the fact that they had sensed its potential on the market.

In 1460 a contract stipulated between Taddeo Barovier, head of the fraterna, ${ }^{25}$ and master Bartolomeo Visentin is one such example: the two joined their business for ten years with the aim of opening a new furnace to produce crystalware. ${ }^{26}$ Two elements are particularly relevant. First, Visentin was a first-generation newcomer to Murano, ${ }^{27}$ but had nevertheless already learnt the techniques to produce cristallo and was so well instructed as to be put at the head of the workshop as the working

could not be transferred through text without the imitation process possible only in the workshop. Glassmakers had to design processes to gain the expected result, but these were largely tacit skills that require training and time, and a stimulating co-working workspace. On reconstructing craftsmanship and technical knowledge from written texts in the case of Renaissance recipe books, see Pamela $\mathrm{H}$. Smith, "Historians in the Laboratory: Reconstruction of Renaissance Art and Technology in the Making and Knowing Project," Art History 39, no. 2 (2016): 210-233. On embodied knowledge, see the interesting considerations in the video by the glassmaker Ian Hankey: Hankey, video contribution to Ways of Making and Knowing: The Material Culture of Empirical Knowledge, ed. P. H. Smith, A. R. W. Meyers, and H. J. Cook (Chicago, IL: University of Chicago Press, 2014), accessed on 19 August 2019, https://www.youtube.com/ watch?v=sSBY6Lc2-hU.

23 This was clear to the Tuscan priest Antonio Neri, the first divulgator on Venetian glass, who in 1612 published his glassmaking manual L'Arte vetraria. At the end of the recipe for flux to make crystal glass, he ruminated that experience makes a person discover and learn more than any long study, aware of the impossibility to transfer in a sentence that tacit expertise; Antonio Neri, L'Arte vetraria. 1612, ed. Rosa Barovier Mentasti (Milan: Il Polifilo, 1980), ch. 6, 8. See also McCray, "Creating," 316-323.

24 Koen Vermeir and Dániel Margócsy, "States of Secrecy: An Introduction," The British Journal for the History of Sciences 45, no. 2 (2012): 161, 164.

25 On the typical fraterna system: Frederic C. Lane, "Family Partnership and Joint Venture in the Venetian Republic," The Journal of Economic History 4, no. 2 (1944): 178-196.

26 ASVe, PodMur, b. 26, fasc. 2, sd (01.10.1460). Taddeo probably intended to add crystal glass to the products he already traded overseas.

27 He must have been very young on his arrival, as in 1420, he was denounced for having worked outside Murano. At that time, he was still called "from Vicenza," the provenance from which originated the family surname; see Zecchin, Vetro, 3:39. 
partner and supervisor to the manufacturing process. Probably one of the Baroviers had taught him the "secret" technology. Nonetheless, it is remarkable that Taddeo chose him among the others without fear of sharing the innovation with someone whose kin had not been living in Murano for generations. Moreover, the basis of the method was probably already diffused among the majority of workers on the island, while only the subtlest phases of the refinement process were yet to be widespread. ${ }^{28}$

Secondly, in case of a premature break of the agreement, the Visentins swore to conceal the expertise acquired if they were to find a new employer, although that would not have applied were the break due to the decision to open their own furnace. After all, ten years was generally considered the customary time frame to protect the outcome of an innovation, a period of time long enough to guarantee a patent and to compensate future losses coming from the diffusion of the new methods. ${ }^{29}$ In sum, not even crystal glass, the material that granted Venetian glassware permanent success within the world's imagery of luxury and elegance, was preserved as a secret according to our modern understanding, but as a community "open secret."

The aim then was not to prevent the sharing of secrets in the Lagoon but their leakage outside its borders. In fact, once makers acquired the technical skills and the manual dexterity, Venice provided an easy supply of the necessary raw materials, often imported from abroad; namely, ashes from Syria or pebbles from the Ticino river. ${ }^{30}$ These (or similar) materials could, however, have been shipped to many other parts of the peninsula or the continent, where a well-equipped master would have been able to produce the same items if possessing the right craftsmanship.

As a consequence, the Serenissima's attention towards the glass industry and its "secrets" strengthened when the fame of crystal glass started to be highly valued in an international context. The capacity to maintain a monopoly on the production of this innovation went from being a family and community affair to a state concern, pursued by the highest bodies of the republic. This also enhanced the perception of these secrets as typically Venetian. With the recent involvement of the government,

28 A $145^{8}$ ducal letter shows that the Mozetos and Angelis were producing crystal glass too; ASVe, PodMur, b. 23, $s d\left(21.02 .145^{8}\right)$.

29 The republic usually granted patent privileges for the same length of time; see Carlo Poni and Roberto Breveglieri, "Three Centuries of Venetian Patents 1474-1796," Acta historiae rerum naturalium nec non technicarum 17 (1982): 381-393 and Luca Molà, "Inventors, Patents and the Market for Innovations in Renaissance Italy," in Italian Technology from the Renaissance to the Twentieth Century, ed. Anna Guagnini and Luca Molà, 7-34, History of Technology 32 (London: Bloomsbury, 2014) and Luca Molà, "Stato e impresa privilegi per l'introduzione di nuove arti e brevetti," in Braunstein and Molà, Il rinascimento, 3:533-572. 30 Eliyahu Ashtor and Guidobaldo Cevidalli, "Levantine Alkali Ashes and European Industries," Journal of European Economic History 12, no. 3 (1983): 475-522; David Jacoby, "Raw Materials for the Glass Industries of Venice and the Terraferma, about 1370 - about 1470," Journal of Glass Studies 35 (1995): 65-90. 
once the material became strategically associated with other luxury crafts of the city (including silk), ${ }^{31}$ secretiveness surrounding crystal and glass became not only a concern for the glassmakers as a collective body, but for the republic as a whole, protecting not only an industry but the state's reputation and its public representation. This is because Venice was employing the fascination of secrecy to strengthen its trading position, based on the notion that those aware of the secret, but who did not have access to it, would desire crystal glass more fervently. ${ }^{2}$

Thus, in contrast to earlier times, ${ }^{33}$ the migration of masters was no longer condoned because the professional, internal "secrets" they took with them had in the meantime become secrets of state, or a state "brand." Besides, the migration of skills was worsening a situation in which even non-Venetian glassmakers abroad were developing and producing items by imitation, the so-called façon de Venise glassware. ${ }^{34}$ This included, for instance, the glassmakers of Altare, who had shared knowledge of the Muranese technology since the later Middle Ages. ${ }^{35}$

As a result, the government took the role of guarantor for the Muranese branch to protect its fragile internal and external equilibrium.$^{36}$ From the second half of the sixteenth century it strengthened its opposition to any form of migration and proliferation of technical knowledge outside the Lagoon, with the aim of preserving the iconic image of its glass industry, dynamized too by a foreign narrative of distinction. The state therefore recognized the distinction of the industry from the perspective of a common identification. This process was not dissimilar to the myth of Venice itself and the self-construction of an ideal to be displayed in front of both foreigners and Venetians alike. ${ }^{37}$ In this sense, the idea of secrets per se was not oriented to a single individual or group but to Muranese-Venetian glassmaking

\footnotetext{
31 See Luca Molà, The Silk Industry of Renaissance Venice (Baltimore, MD and London: Johns Hopkins University Press, 200o).

32 Vermeir and Margócsy, "Introduction," 161.

33 This share of knowledge during the Middle Ages is indirectly proved by linguistic analysis of recipe books, which owed much to the Muranese vernacular; Cesare Moretti, Carlo Stefano Salerno, and Sabina Tommasi Ferroni, eds., Ricette vetrarie muranesi. Gaspare Brunoro e il manoscritto di Danzica (Florence: Nardini Editore, 2001), 23-27.

34 The rise of furnaces working products in the Venetian style in various European regions will not be touched on in this chapter. For a general overview, see the following volumes: Johan Veeckman, Sarah Jennings, et al., eds., Majolica and Glass: From Italy to Antwerp and Beyond. The Transfer of Technology in the 16th-17th Century (Antwerp: Stad Antwerpen, 2002) and Jutta-Annette Page, ed., Beyond Venice: Glass in Venetian Style, 1500-1750 (Manchester, VT: The Corning Museum of Glass, 2004).

35 On the relationship between the Altarese glass masters and Europe, especially in the French context, see Corinne Maitte, Les Chemins de verre. Les migrations des verriers d'Altare et de Venise (XVIe-XIXe siècle) (Rennes: Presses Universitaires de Rennes, 2009).

36 Trivellato, Fondamenta, 51-84.

37 On the myth of Venice and its self-representation as a state, a civitas, and a communitas, see Robert Finlay, “The Immortal Republic: The Myth of Venice during the Italian Wars (1494-1530)," The
} 
as an emanation of the republic. Only at a second stage would it imply the modern concept of competition among single entrepreneurs.

\section{Branding without a Brand: Trading Strategies in Venetian Glassmaking}

As highlighted by Corinne Maitte, the international success of Murano glassware in the Renaissance had a strong impact on the identification of the material with Venice and Murano in following centuries, distorting the fact that the island was not the only place where it was worked. ${ }^{38}$ Furthermore, the position given to luxury crystalware in the majority of studies has skewed analysis on the nature of the Venetian industry, as research has generally focused solely on its high-end output, neglecting the fact that glass was mainly a mass-produced artefact.

This situation is only apparently contradicted by the fact that Venetian glass was never branded until recent times and that even individual labels were not used, with the exception of shop signs that in many cases became the surname of the families who owned them. ${ }^{39}$ While a buyer entering a shop in Murano might have recognized that name (and possibly its reputation), a foreign customer would not have had the same awareness. Nevertheless, no different to today, it is undeniable that the association of Venice with glass was almost unanimously perceived as a sort of brand and a promise of quality.

The innovations created in Renaissance Venice projected that reputation further, stressing the material's pliability and shininess that allowed objects of increased artistic value to be produced. These innovations were also the result of shifting early modern attitudes towards material culture that merged an interest in materials' alchemical aspects with new concepts of value: ${ }^{40}$ the latter not residing in intrinsic corporeal attributes so much as in the mastery of artifices..$^{41}$ In other words, virtuoso

Sixteenth-Century Journal 30, no. 4 (1999): 931-944 and James S. Grubb, "When Myths Lose Power: Four Decades of Venetian Historiography," The Journal of Modern History 58, no. 1 (1986): 43-94.

38 Corinne Maitte, “Façon de Venise: Determining the Value of Glass in Early Modern Europe," in Concepts of Value in European Material Culture, 1500-19oo, ed. Bert de Munck and Dries Lyna (Farnham, Surrey: Ashgate, 2015), 213.

39 For instance, the mermaid of the Serena (Sirena) family, or the moon of the Lunas. Zecchin, Vetro, 2:182 and 3:72-77.

40 McCray, "Creating," 312-313, 316-323 and Sven Dupré, "The Value of Glass and the Translation of Artisanal Knowledge in Early Modern Antwerp," in Trading Values in Early Modern Antwerp, ed. Christine Göttler, Bart Ramakers, and Joanna Woodall (Leiden: Brill, 2014), 147-151.

41 See the case studies in Concepts of Value and the overarching view in De Munck's and Lyna's introduction: "Locating and Dislocating Value: A Pragmatic Approach to Early Modern and Nineteenth-Century Economic Patterns," in De Munck and Lyna, Concepts of Value, 1-29. 
craftsmanship became a distinctive feature, hence the need to secure distinctive knowledge under a monopolistic control over the industry, as was accorded by political authority. This association could thus be used as a substitute for a brand name on the international market.

On this matter, the attitude of the Venetian government played a central role. Among the city guilds, the glassmakers had benefited from a privileged position since the Middle Ages, but their definitive success followed the international recognition accorded to crystal glass, mirroring the city's status as a major centre of luxury manufacture. It was, then, the instant fascination cristallo held over the elites of the time, and the desire this exclusive material evoked among those at the head of the political, social, and cultural spheres, that turned it into a state affair. The workshops in Murano started to be included in the customary tour of the city's marvels organized for notables visiting Venice. The Serenissima was more than willing to exploit foreigners' fascination for the glass making process and the uniqueness of the site where it happened (Fig. 2.2). Besides, as a cross-cultural material, glass made for the perfect diplomatic gift, which the republic could subtly use to gain foreign benevolence, especially in the case of its high-end products. ${ }^{42}$

In this context, the highest bodies of the state conveniently supported an already existing oligarchy within the guild which ultimately left one of the most recognizable crafts produced in the Lagoon under the control of a small group of families. In a sector in which expertise was primary, and the provision of raw materials was completely under the supervision of the guild, limiting access to its highest ranks reinforced among its members the identification between the guild and its products, the guild and the city, and finally the city as a protector of an identifiable business.

This perception was strengthened by the direct relationship between the guild and the city's highest governing bodies. Two moments marked this bond. In 1469 the basis for the success of the oligarchic aspirations of the major families (and the most ambitious newcomers) who worked on the island was founded with a ducal letter. It did not simply reaffirm the general monopoly of Muranese manufacturing, but also established a clear hierarchy among the islands' workers, based on their

\footnotetext{
42 Marta Ajmar-Wollheim and Luca Molà, "Cross-Cultural Objects in the Early Modern Period," in Global Design History, ed. Glenn Adamson, Giorgio Riello, and Sarah Teasley (London: Routledge, 2011), 12-13. In Venetian diplomacy, the fame of glass was especially exploited for relations with the Ottoman court and the recurring exchange of gifts "requested" by the Islamic side. It united the political role of "giving" as an act of honour with the use of gifts to ease contention. Glass goods constituted market transactions that could be counter-gifted. On the role of gifts in pre-capitalistic markets, Martha C. Howell, Commerce before Capitalism in Europe, 1300-160o (Cambridge: Cambridge University Press, 2010), 145-159, $171-207$. See also Deborah Howard, "Diplomacy and Culture," in Islamic Artefacts in the Mediterranean World: Trade, Gift Exchange and Artistic Transfer, ed. Catarina Schmidt Arcangeli and Gerhard Wolf(Venice: Marsilio, 2011), 161-172.
} 


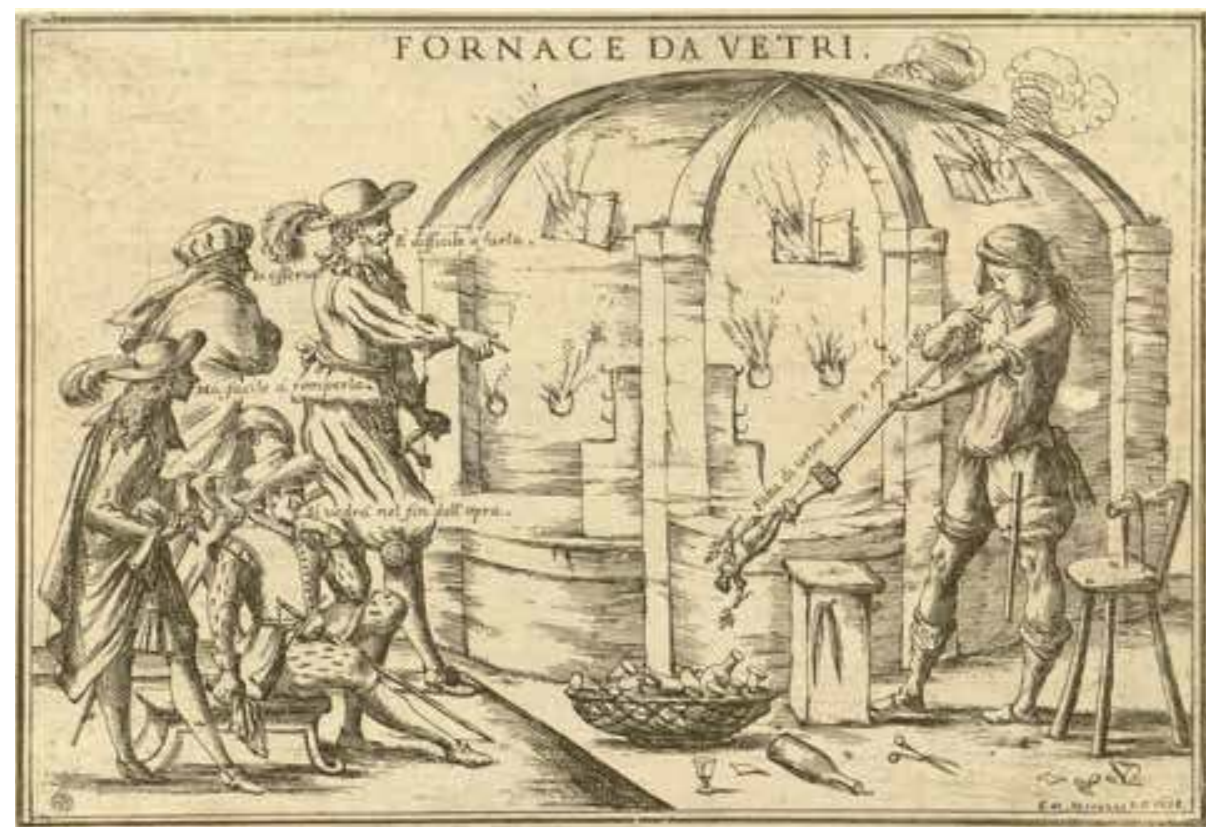

Figure 2.2: Giuseppe Maria Mitelli, Fornace da vetri, 1698. Etching, $211 \times 311 \mathrm{~cm}$. Milan, Castello Sforzesco, inv. no. RM m. 2-1. Image $\odot$ Civica Raccolta delle Stampe Achille Bertarelli - Castello Sforzesco - Milano.

origin..$^{43}$ The state embraced the requests of leading families to protect their status and businesses, so from that year on, only people born in Murano were allowed to learn how to craft crystal or to own a furnace. Even business partners were permitted to come from only Murano or Venice.

The second turning point happened in 1482, when the Council of Ten decided to take the guild's regulations under its authority, which it would keep until the mideighteenth century. ${ }^{44}$ This direct relationship with the state's highest political body increased the power of the guild (especially over the other artifiglie), ${ }^{45}$ and marked their clear social distinction. ${ }^{46}$ This position was further reinforced by prohibiting the trade of crystalware in Venice, the only exception being the glassmakers' own stalls during the fair of the Sensa. Whoever wanted to buy crystal had to go to Murano to purchase it exclusively at the local shops. ${ }^{47}$

43 BMC, IV L 13, ch. 73, cc. 19r-21v (16.01.1468mv).

44 Trivellato, Fondamenta, 19.

45 Until that moment the guild had been subject to the customary magistrates: the Old Justice and the Provveditori di Comun, which remained in charge of the other guilds' glass-working procedures.

46 McCray, "Creating," 310.

47 BMC, IV L 13, ch. 74-76, cc. 22r-23r (18.01.1481mv). See also the conflicts with glass sellers (ASVe, Arti, $725, \mathrm{ch} .36\left[31.03 .15^{22}\right]$ and $\left.44\left[28.04 \cdot 15^{23}\right]\right)$. 
The reason was simple: glass was beneficial to the city's economy and image, thus the demands of its prominent families had to be supported, as long as they continued to be profitable for the state. In cases of internal conflict, the authorities would have used their power to correct excesses or impose their will. It was a sentiment shared among the governmental authorities, expressed for instance a few years later in the Senate's deliberation to reiterate the aforementioned prohibitions. The Pregadi explained these actions were taken to preserve and encourage the Muranese glass industry, which was of great benefit to Venice. ${ }^{4}$

Thanks to favourable state policy, the glass trade largely stayed in the hands of its Muranese leaders during the early modern period. In fact, the patriciate usually did not take part in glass trading at all, limiting their interest to their political prerogatives. Venetian patricians were arguably more interested in the way they could use the fame of glass as a political tool rather than for personal profit. ${ }^{49}$ Glass entrepreneurs reciprocated, offering certain (not codified) product standards around luxury items to appeal to elites..$^{50} \mathrm{In}$ its most common form glass provided a mass consumption commodity that sustained the Venetian hub, as was the case with plain tableware (Fig. 2.3).

In contrast to the textile industry, glass manufacture was left to the will of its producers, as neither the state nor the guild ever imposed pre-fixed standard levels around production. Moreover, during the Renaissance, general technological prescriptions became even less strict, compared to the Middle Ages. ${ }^{11}$ These freedoms sustained a certain level of competition among the guild's glassmakers, a condition which for a century promoted a positive attitude towards experimentation and resulted in the products that sealed the fortune of both Venetian glassware and the oligopolistic group controlling it. $5^{2}$ It encouraged innovation and the competitive circulation of those collective, yet subtle, secrets that made Muranese glass identifiable and highly valued, while creating the conditions for the birth of an unofficial brand that was based on the city of Venice itself, rather than on the names of single workshops.

An impression of the wide range of innovative items that resulted from these favourable conditions can be found in the inventories of the period's Muranese

48 Ibid., ch. 102, cc. 29v-30v (31.10.1489).

49 On the cultural role of glass within Venetian society see the first and second paragraphs of Lucas Burkart's chapter in this book.

$5^{0}$ These were largely based on the monopolistic use of the highest quality raw materials, see Monticolo, I capitolari, 2:89, and the scarce market participation of lower quality Spanish ashes, see Rafael María Girón-Pascual, "Cenizas, cristal y jabón. El comercio de la barrilla y sus derivados entre España e Italia a finales del siglo XVI," eHumanista 38 (2018): 221-225.

51 Corinne Maitte, "Labels, Brands, and Market Integration in the Modern Era," Business and Economic History 7 (2009): 13-16.

52 On this trend in European proto-industry see Stephan R. Epstein, "Craft Guilds, Apprenticeship, and Technological Change in Preindustrial Europe,” The Journal of Economic History 58, no. 3 (1998): 693-705. 


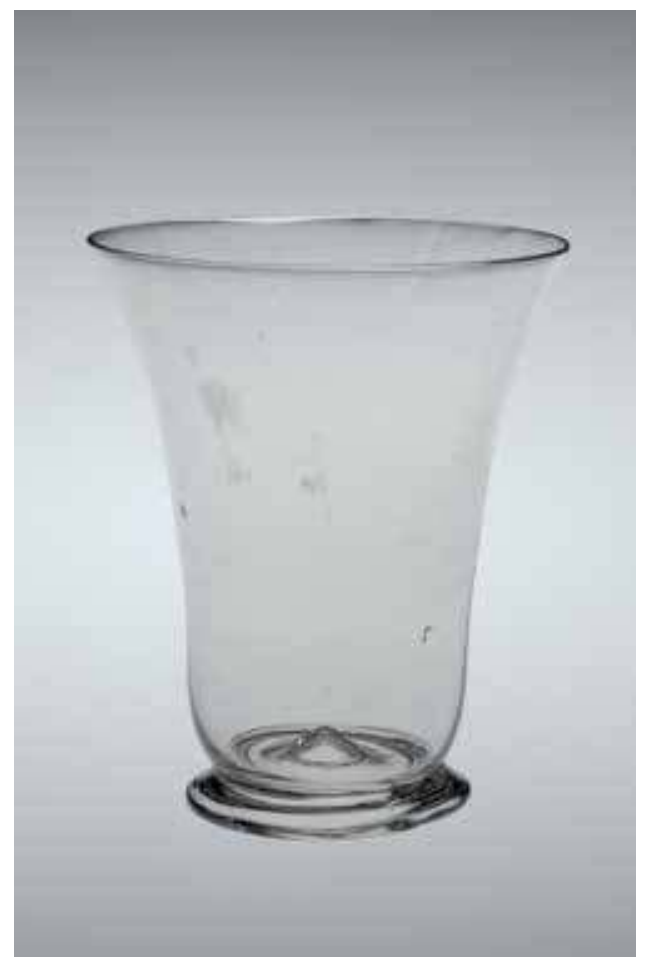

Figure 2.3: Blown colourless glass beaker, seventeenth century. $\mathrm{H}: 8.6 \mathrm{~cm}$, Rim D: $7.2 \mathrm{~cm}$. Corning, NY, The Corning Museum of Glass, inv. no. 2009.3.89. Image $\odot$ The Corning Museum of Glass.

glass shops. ${ }^{53}$ At the beginning of the seventeenth century, Marco Barovier was selling different types of crystalware (chrestali di diverse sorti), such as jugs, vases, ewers, tazze, and all kinds of drinking vessels in hundreds of pieces, together with little statues in the shape of animals. Precious crystal and filigree items were also available in abundance at his shop, as well as common objects like tavern ewers (grosse da hostaria) and chamber pots. He even traded lamps and windowpanes. ${ }^{54}$ Some years later, the Dall'Aquilas were also selling crystalware and chalcedony glass in Padua in the range of hundreds of pieces, ${ }^{55}$ while Cristina Brunoro had items totalling 1,484 ducats in her Milanese shop (850 of which were crystalware, equivalent to approximately 17,000 pieces). She also traded common glassware and frit..$^{6}$

53 Rosa Barovier Mentasti and Cristina Tonini, "Tools to Study Glass: Inventories, Paintings and Graphic Works of the 16th Century," in Study Days on Venetian Glass: Approximately 1600 , ed. Rosa Barovier Mentasti and Cristina Tonini, Atti, vol. 172, fasc. 1 (Venice: Istituto Veneto di Scienze, Lettere ed Arti, 2013-2014), 23-31.

54 ASVe, PodMur, b. 205, sd (04.09.1636).

55 Ibid., $s d(21.05 \cdot 1647)$.

56 Ibid., sd(o9.12.1672). 
Arguably, the situation had been similar during the previous century, when the quantitative and qualitative range of items displayed on shelves or stored in closets would have surely surprised any visitor. In 1578 the house of Gian Antonio Zanchi was full of all sorts of objects made in the local furnaces, waiting to be resold: gilded and filigree glass was available in dozens of shapes, together with enamelled glassware, figurines and reliefs, ice glass, and strings of beads (paternostri). ${ }^{57}$ The inventory of the house and shops of the glassmaker Antonio of Alvise, under the sign of the Three Moors (Ai Tre Mori), is equally rich, attesting to the ingenuity of the glass masters. ${ }^{5}$ Among the strangest and most expensive pieces, some of which must have been peculiar even for the period, included, for instance, thirty enamelled glasses in the French style decorated with coats of arms and a parrot cage (una cheba da papagà). By contrast, a completely different clientele would have bought what was in the shop of Leonardo Caner: that is, house lamps and glassware for daily use. 59

In other cases, the inventories' results are less rich at first glance, for instance that composed for Giovanni Bortolussi's house in 1589. Regarding glass, the notary registered 700 mirror sheets, but no other product. ${ }^{60}$ More indicative of the dominance the Bortolussi family enjoyed over the century is another source, an earlier notebook kept by one of Giovanni's cousins while managing the family shop in Milan. ${ }^{61}$ It states, for instance, that several crates full of glassware had been sold between February and May 1540, comprehensive of some of the most recent and trendy innovations in glassmaking, fashioned into vessels of various shapes. In another record of eleven boxes, a remarkable number of items totalling more than 10,700 pieces were listed to be sent from Murano to Lombardy in the same year. Half of them were plain drinking glasses, footed vessels, or jugs aimed at everyday use, but less conventional products were present too. Some were gilded, and a few were decorated using new methods and included diamond-point engraved pieces and elegant, high-footed tazze enhanced by fine filigree. ${ }^{62}$

As shown by the above-mentioned examples, luxury artefacts were a significant part of Venetian glass production. Since they appealed to the richest representatives

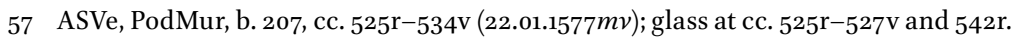

$5^{8}$ Ibid., cc. 114r-121r (9-10 and 17.11.1569), and cc. 118r-120r, 134r-136v (03 and 09.09.1570).

59 Ibid., cc. 311r-312v (24.06.1574). Among them: common glasses, cesendelli-lamps, lamps, ewers, chamber pots, and vessels for hair-dyeing (zucche da bionda).

6 o ASVe, GP, b. 339 (n. 4), inv. 82 (27.06.1589).

61 Zecchin, Vetro, 2:182.

62 Zecchin, Vetro, 2:187-188. Interestingly the notes hint at the prices of some objects: meze nose (receptacles shaped as walnut shells) of filigree glass were sold for between 4 and 9 soldi each, while the same items in plain glass cost 10 lire to the hundred (i.e. 2 soldi each). Overall, they were quite cheap. By contrast, vases worked with the more difficult to craft reticello technique could reach 2.5 lire apiece. 
of European and international families and courts, ${ }^{63}$ they could enhance the name of some masters while spreading the primacy of Venetian glass among refined social circles. ${ }^{64}$ But to continue to focus exclusively on them would have been a mistake. Even while high-end sales surely contributed to the profits of the branch, they could not sustain the industry alone. Yet, the reputation of such products was essential for the trade of glassware as a mass commodity, which was based mainly on glass beads, windowpanes, and mirrors, as well as plain glass. It can thus be argued that high- and low-end production went hand in hand, working in synergy.

For example, in 1461, a trial which positioned Marco and Giovanni Barovier against the merchant Marco Rosso was not about crystal but concerned a shipment of enamels to Syria, probably to supply artisans who specialized in metalwork. ${ }^{65}$ Moreover, the very existence of a glass-resellers' guild points to the solid market for common glass. ${ }^{66}$ As a series of chapters from 1482 in the glassmakers' guild's book show, even commerce with Germany was largely made up of windowpanes - called rui after their rounded shape - and common drinking vessels. ${ }^{6}{ }^{6}$ In the case of the windowpanes, the statutes prescribed that all orders from the German merchants of the Fondaco had to be spread among the members of the guild, while no workshop was allowed to sell more than 10,000 rui per single sale. ${ }^{68}$ Through rotation, the guild prevented conflicts among its associates in a trade that was inexpensive per item, but profitable in big numbers (Fig. 2.4)..$^{69}$

63 For example, in Florence, inventories prove that at the end of the fifteenth century Muranese novelties were already appreciated and displayed by major local families; see James R. Lindow, "For Use and Display: Selected Furnishing and Domestic Goods in Fifteenth-Century Florentine Interiors," Renaissance Studies 19, no. 5 (2005): 643-644.

64 In the 1570s members of the Tre Mori family moved to Florence to work for duke Cosimo I; later the Venetian Republic granted Cosimo II permission to call to his court the masters Luna. Cosimo I had had a personal interest in glassmaking, but arguably both Cosimos were well aware that the arrival of Venetian masters would have indirectly helped the technological upgrade of the local industry. See Zecchin, Vetro, 1:145-147 and 2:171-176; and Anna Laghi, "Migrazioni venete: influenza e originalità nella produzione vetraria toscana fra '50o e '6oo," Antichità Viva 26, no. 4 (1987): 43-51.

65 ASVe, GP, Sentenze a Giustizia, reg. 130, cc. $45 \mathrm{v}-46 \mathrm{v}$ (16.01.146omv).

66 Unfortunately, with the exception of crystal mirrors, the lack of information on glass stands out in Venetian sources, in which it is usually mentioned only as containers of unspecified items. A large survey on fifteenth/sixteenth-century inventories (e.g. the hundreds in ASVe, Cancelleria Inferiore, Miscellanea, Inventari, bb. 34-38), has proved that in Venice the interest for high-range glass artefacts was below the bar until the middle of the seventeenth century. Instead, it can be argued that common glass must have been quite easy to find. Its absence in the sources could be due to its very cheap price and rapid turnover.

67 Zecchin, Vetro, 2:37-38.

68 Respectively BMC, IV L 13, ch. 91, c. 27r and ch. 98 , c. 28r-v.

69 Contemporary quantitative sources (e.g. fiscal ones) on export and internal consumption are not available for the period, but a rough idea can be grasped when compared against the data available for 


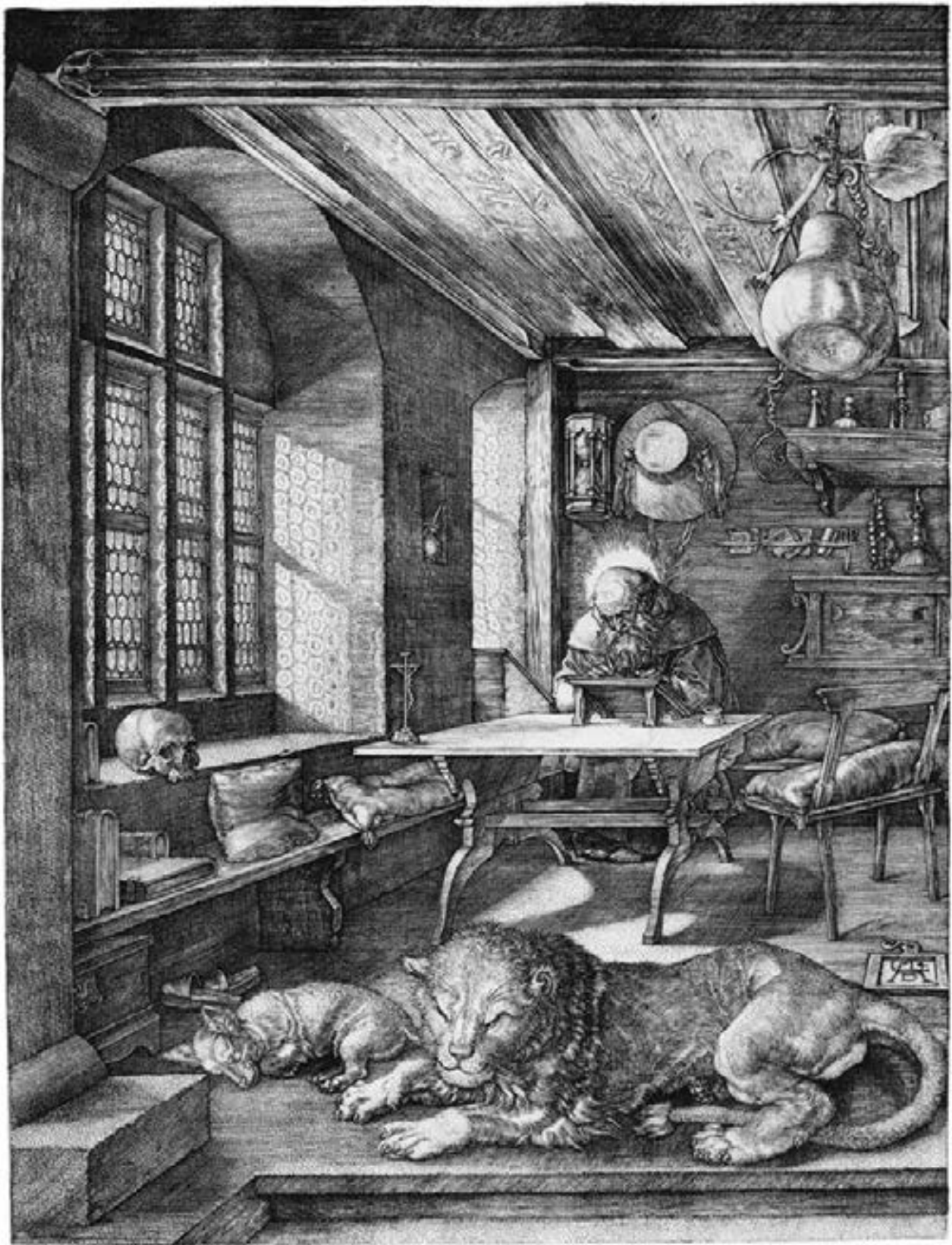

Figure 2.4: Albrecht Dürer, Saint Jerome in His Study, 1514. Engraving, $25 \times 20 \mathrm{~cm}$. Karlsruhe, Staatliche Kunsthalle, inv. no. I 834. Image ๑ Staatliche Kunsthalle Karlsruhe. 
Lastly, this context favoured the emergence of a sense of Venetian innovation amongst its clientele. In fact, the years roughly between $145^{\circ}$ and $155^{\circ}$ marked a unique phase in the history of glass innovation and restyling: first cristallo, promptly followed by lattimo, then new shapes in glass beading and the rediscovery of chalcedony glass. ${ }^{70}$ The following decades saw even stronger modernization. In 1527 the Serena brothers patented filigree glass, ${ }^{71}$ and in 1549 Angelo dal Gallo claimed the technique used to engrave a glass surface with a diamond (Fig. 2.5). $7^{2}$ In the meantime, unknown masters discovered how to produce the geometrical net ornamentation typical of reticello, while in 1507 Angelo's relatives had already obtained a twenty-year patent for the discovery of a method to produce mirrors from crystal glass, ${ }^{73}$ which by the end of the century became Venice's major glass production. ${ }^{74}$

The ability to master new solutions and ideas, and to share them in a competitive but collective atmosphere, remained a compelling force behind Muranese production until the end of the sixteenth century, despite a slowdown after the 1560 s and a shift towards micro-improvements rather than macro innovations. During these decades glassmakers collectively responded to the new populuxe demand, ${ }^{75}$ sharing their expertise..$^{6}$ The results actively looked to find improved solutions to satisfy the desires coming from customers, especially the urban middle classes. After glass had been used to imitate other more expensive luxury materials, Muranese entrepreneurs precociously sensed the emergence of new stylistic values and the resulting market. They succeeded because they moulded the material to meet new tastes. They abandoned copying and responded with originality and uniqueness to contemporary sensitivities. In doing so, they set a new distinctive fashion for glass based on shape, transparency, brilliance, and new chromatic tastes. Shape, especially in the case of blown objects, overtook material preciousness, while

the last decades of the eighteenth century, summarized in Trivellato, Fondamenta, 230-232.

70 Gianni Moretti, "La Rosetta. Storia e tecnologia della perla di vetro veneziana più conosciuta al mondo," Rivista della Stazione Sperimentale del Vetro 1 (2005): 27-39; and on the history of glass jewels Barbara Bettoni, Perle divetro e gioie false. Produzioni e cultura del gioiello non prezioso nell'Italia moderna (Venice: Marsilio, 2017).

71 ASVe, CX, Deliberazioni, Comuni, reg. 3, cc. 111v-112r (19.10.1527) and ASVe, NotT, b. 203, c. 174r-v (o8-09.08.1538). By that time the style was already widespread in Murano.

72 ASVe, Senato, Terra, filze, f. 9, fasc. "Vincenzo de Anzolo dal Gallo" (28.01-03.08.1549).

73 ASVe, CX, Misti, reg. 31, c. 125r (19.05.1507) and fil. 20, n. 103 (19.05.1507).

74 Paolo Zecchin, "Gli specchi veneziani," Rivista della Stazione Sperimentale del Vetro 6 (1993): $299-307$.

75 The term refers to the lower-end luxury goods that became popular among large segments of the population during the Renaissance; Francesca Trivellato, "Guilds, Technology, and Economic Change in Early Modern Venice," in Guilds, Innovation, and the European Economy, 140o-180o, ed. Stephan R. Epstein and Maarten Prak (Cambridge: Cambridge University Press, 2008), 204.

76 McCray, The Fragile Craft. 


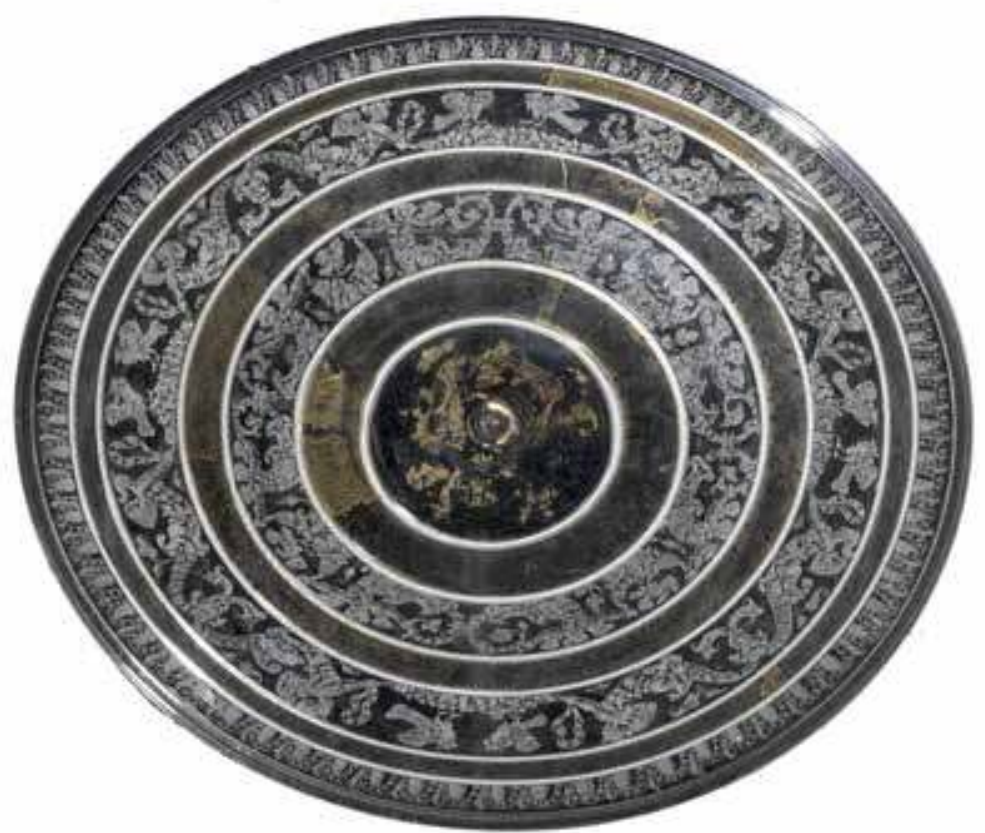

Figure 2.5: Diamond-engraved glass dish, with opaque white threads, cold-painted and gilded, ca. 1560s. W: $27.0 \mathrm{~cm}$ max. London, Victoria and Albert Museum, inv. no. C.178-1936. Image ๑ Victoria and Albert Museum, London.

material effects came to surpass decoration. In particular, painted decoration was replaced by the subtle combination of transparency with simple but appealing touches of colour, or by the sophisticated play between crystal glimmer and the translucency that came from the white, thin lattimo strings of filigree (Figs. 2.6 and 2.7).

This new Venetian style was not simply the expression of a new concept of beauty. Seen from a managerial point of view, it was also functional. Its methods generally excluded other guilds like painters and put all the production stages in the hands of the furnace staff. It made it possible to work the objects entirely in the same space, increasing control over the whole production process as well as easing the planning of future trends. Moreover, these new techniques usually resorted to far less costly raw materials, above all by limiting the recourse to gold, as gilded surfaces progressively diminished in appeal. The case of ice glass is emblematic: a surprising and beautiful effect resembling cracked ice was gained just from using cold water, dexterity, and a strong familiarity with the reaction of the material to the thermal shock (Fig. 2.8). In sum, the birth of fresher stylistic values in Venetian glass manufacture was not just a de facto way of branding without a brand by 


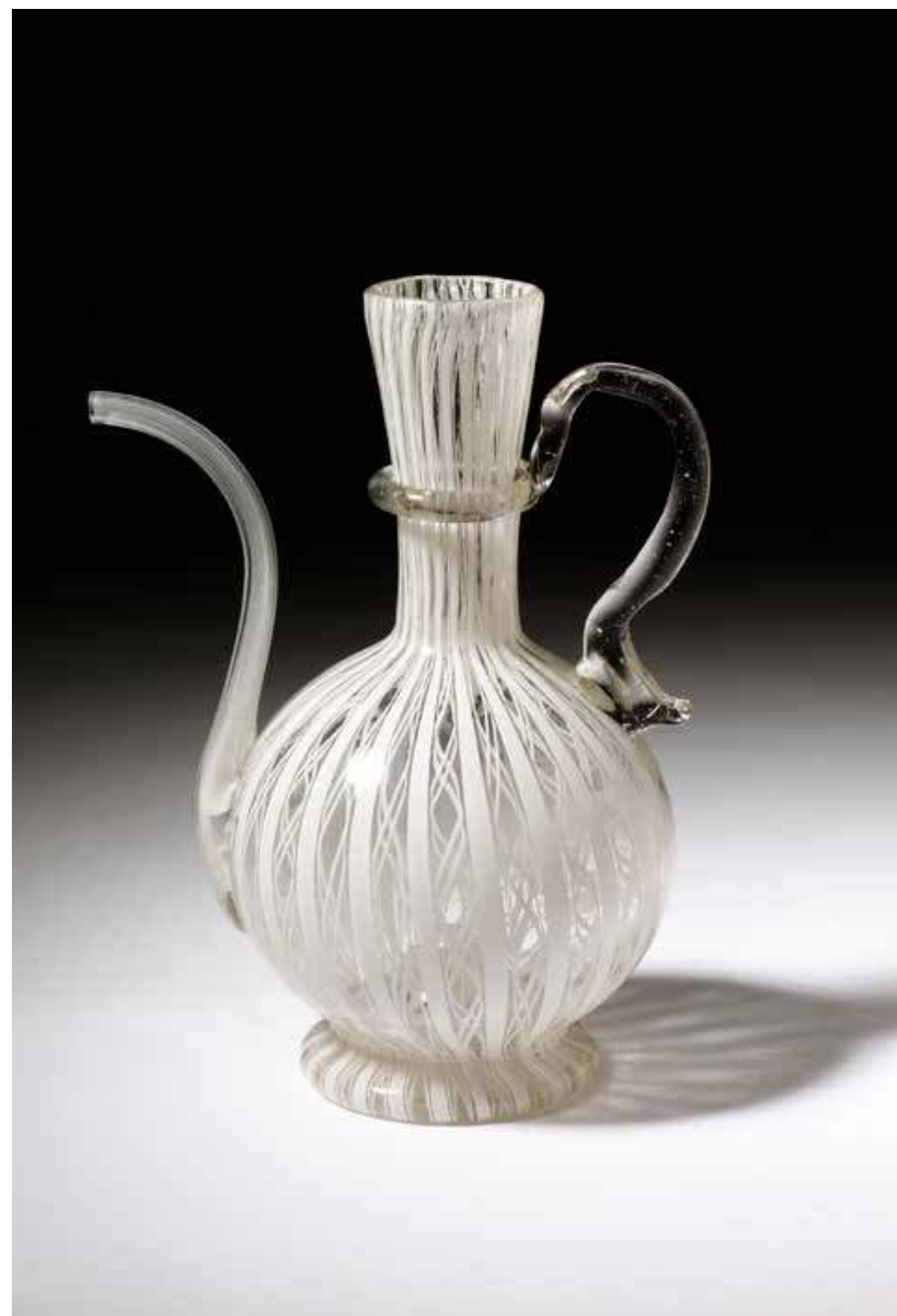

Figure 2.6: Ewer of filigree glass ("a retortoli" and "a fili"), ca. 1575-1600. H: $11.5 \mathrm{~cm}, \mathrm{~W}: 9.0 \mathrm{~cm}$ max. London, Victoria and Albert Museum, inv. no. 1914A-1855. Image ๑ Victoria and Albert Museum, London. 


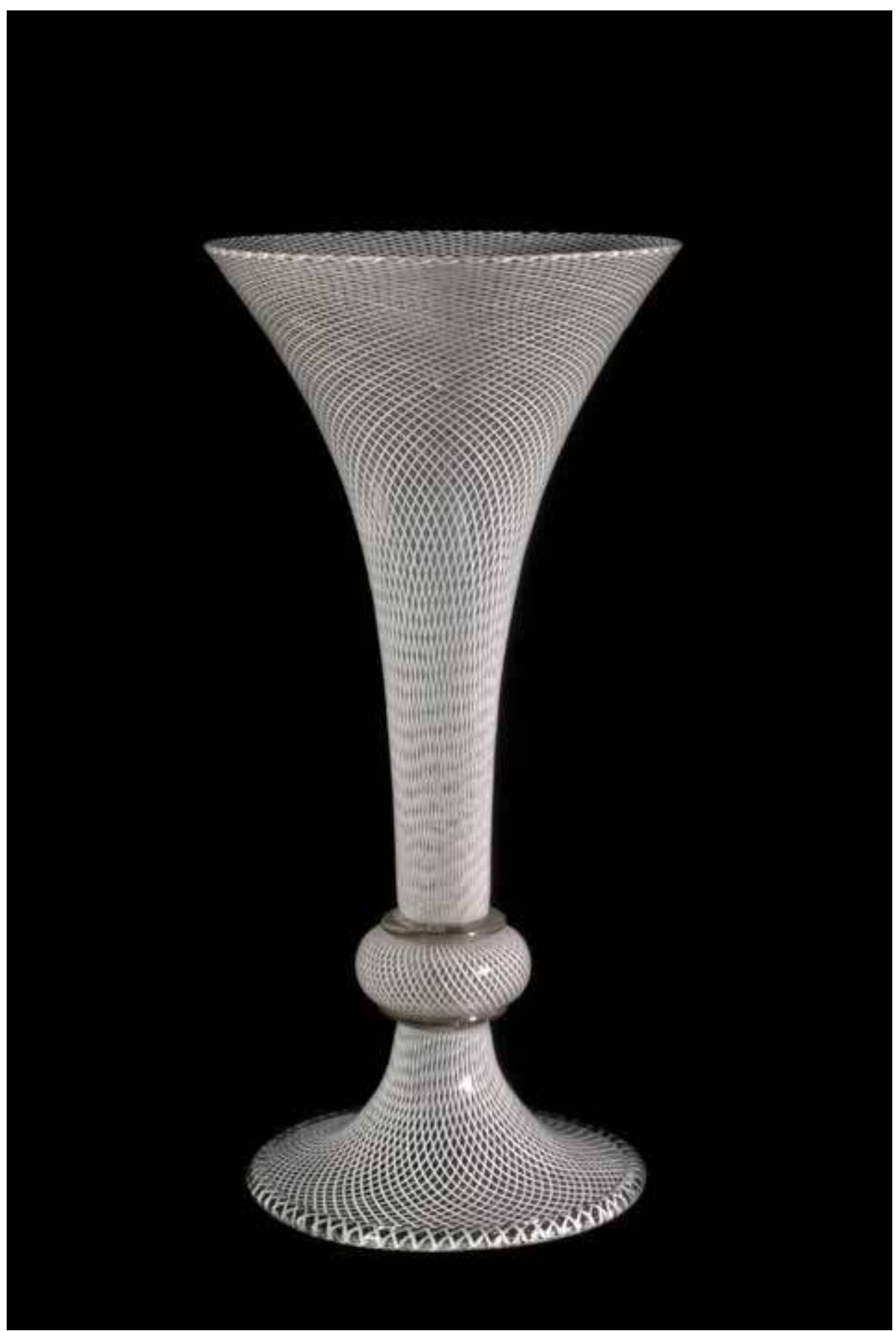

Figure 2.7: Reticello goblet, ca. 1575-1600. H: $30.5 \mathrm{~cm}, \mathrm{~W}: 15.3 \mathrm{~cm}$. London, Victoria and Albert Museum, inv. no. 1816-1855. Image $\odot$ Victoria and Albert Museum, London. 


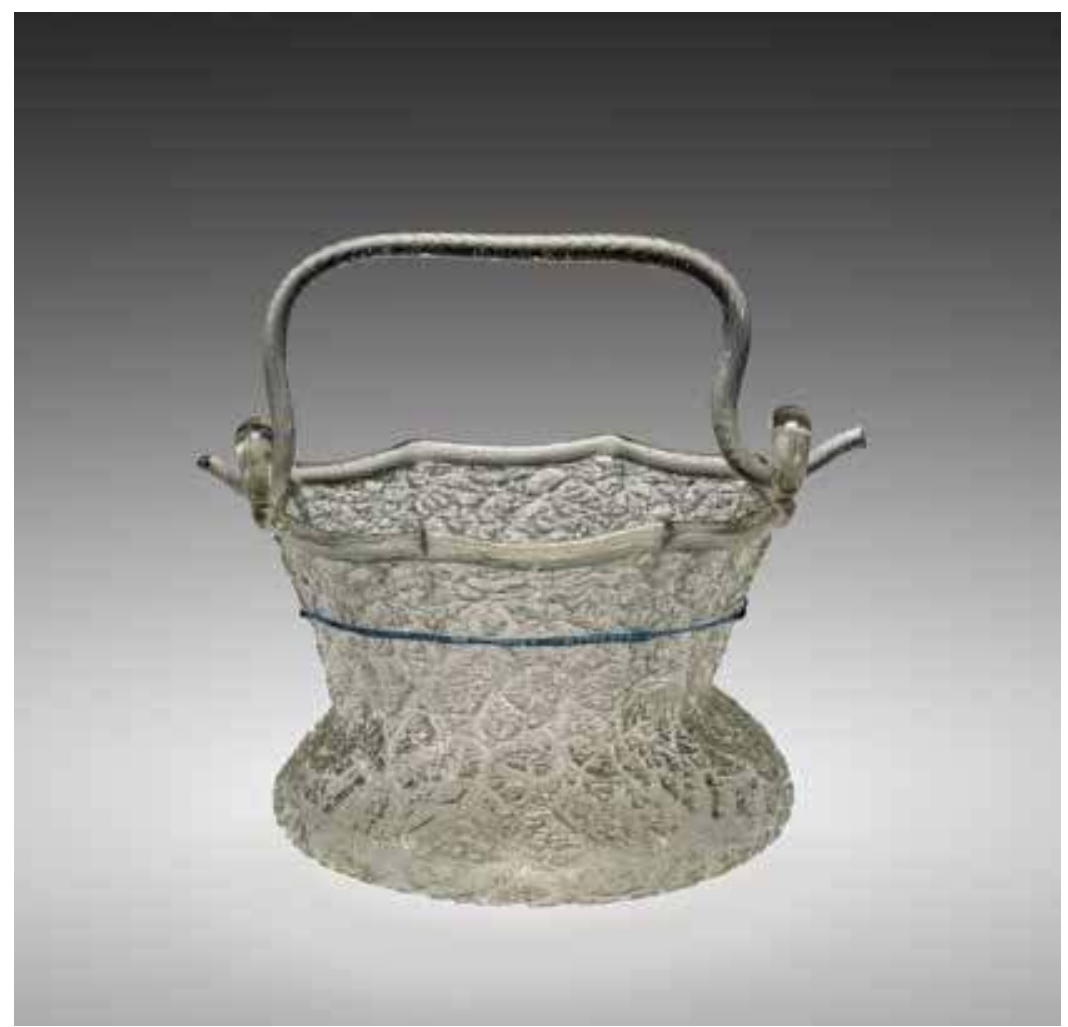

Figure 2.8: Ice glass aspersorium, seventeenth century. $\mathrm{H}: 11.4 \mathrm{~cm}, \mathrm{~W}: 16.8 \mathrm{~cm}, \mathrm{D}: 13.9 \mathrm{~cm}$. Corning, NY, The Corning Museum of Glass, inv. no. 2000.3.5. Image @ The Corning Museum of Glass.

means of stylistic techniques; it also stimulated experimentation to create items which could be put totally under the productive and commercial control of glass entrepreneurs, while reducing costs. In this, the state eased the process, protecting the guild and its leaders since their entrepreneurial success had beneficial results for both Venice's economy and its international prestige.

\section{Professional Identity and Social Ascent: The Case of the Bortolussi Family}

The case of the Bortolussis offers a vivid example of the strategies adopted by those families that used the success of the glass sector to improve their social and economic position as merchant-entrepreneurs and aspiring cives. The family most likely originated in Rimini and moved to the Venetian dominion before the end of the fourteenth century, when, in 1381, they gained privileges for helping defend the city port during 
the War of Chioggia.77 They did not become involved in glassmaking, however, for at least a century. Domenico Bortolussi, the forefather of the Muranese glassmakers, spent his life as a water carrier and participated in the glass sector only as a trader of wood to supply the furnaces. Yet, in doing so, he had become recognized as a Muranese civis and had held public offices, a condition that allowed his two sons to engage in the glass industry despite the lack of an earlier familial tradition. Regardless of being a first-generation glassmaker, Bortolo became the owner of a furnace under the sign of the "Ship" and even managed to reach the head of the guild by 1528 , while his brother Iacopo was among the Muranese glass traders at the Lanciano fairs in $1531 .^{78}$

Bortolo and Iacopo initially operated as a fraterna, and by the 1540 s were already managing a business generating several thousand pieces a year. Thus, thanks to their entrepreneurial approach, by the middle of the century they were able to gain a solid position among the most powerful dealers in the sector. It is important to note that they benefited from the protectionist stance of the republic to strengthen their business and status; yet, to secure their social ascent, they needed to combine patrimonial growth with a wise matrimonial strategy. Their dual aim was to maintain a prominent position within the guild and the Muranese community, while also forging bonds of affinity with prominent families from the capital.

Bortolo's branch of the family, comprising eight sons and three daughters, exemplifies this tendency (Fig. 2.9). ${ }^{79}$ In fact, the paths of Bortolo and Iacopo eventually diverged so much that, at a later stage, the names of the former and his heirs are the only ones to appear in relation to glass. Hence, it was Bortolo who sealed the connection between his family and the glass business. To do so, among other things, he arranged the marriage of his daughter Cecilia into another emerging family, the Darduins. ${ }^{80}$ The girl wed Vincenzo, who was then building his firm, despite

77 ASVe, Miscellanea Codici, Storia Veneta (Cittadinanze Tassini), vol. VII (B-C), b. 10, pp. 398-400 and ibid., Storia Veneta (Cittadinanze Toderini), vol. I (A-B), b. 4, c. 381r. See also the chapter in Anna Bellavitis, Identité, mariage, mobilité sociale. Citoyennes et citoyens à Venise au XVIe siècle (Rome: École Française de Rome, 2001), 269-273. In 1389, to reward foreigners who stayed in the city during the war, Venice eased the acquisition of citizenship for those who had asked for it within one year, see Reinhold C. Mueller, Immigrazione e cittadinanza nella Venezia medieval (Rome: Viella, 2010), 28. Still, there is no evidence that any Bortolussis took this opportunity.

78 On the first documented appearances of the Bortolussis in Murano: Zecchin, Vetro, 2:186-189; in Lanciano: Corrado Marciani, "Il commercio dei cristalli alle fiere di Lanciano nel secolo XVI," Archivio Storico per le Province Napoletane 39 (1959): 315, 320.

79 ASVe, NotT, b. 209, c. 82r (10.02.1556). See also Bellavitis, Identité, 269.

80 See Bellavitis, Identité, 269-270. On the Darduin family: Zecchin, Vetro, 2:167-170. The family descended from a German glass packer working at the Fondaco dei tedeschi who married a Muranese woman. In the late sixteenth century, it was within their circle that the most famous recipe book of Venetian glassmaking was written; see Luigi Zecchin, Il ricettario Darduin. Un codice vetraio del Seicento trascritto e commentato (Venice: Arsenale Editrice, 1986). 


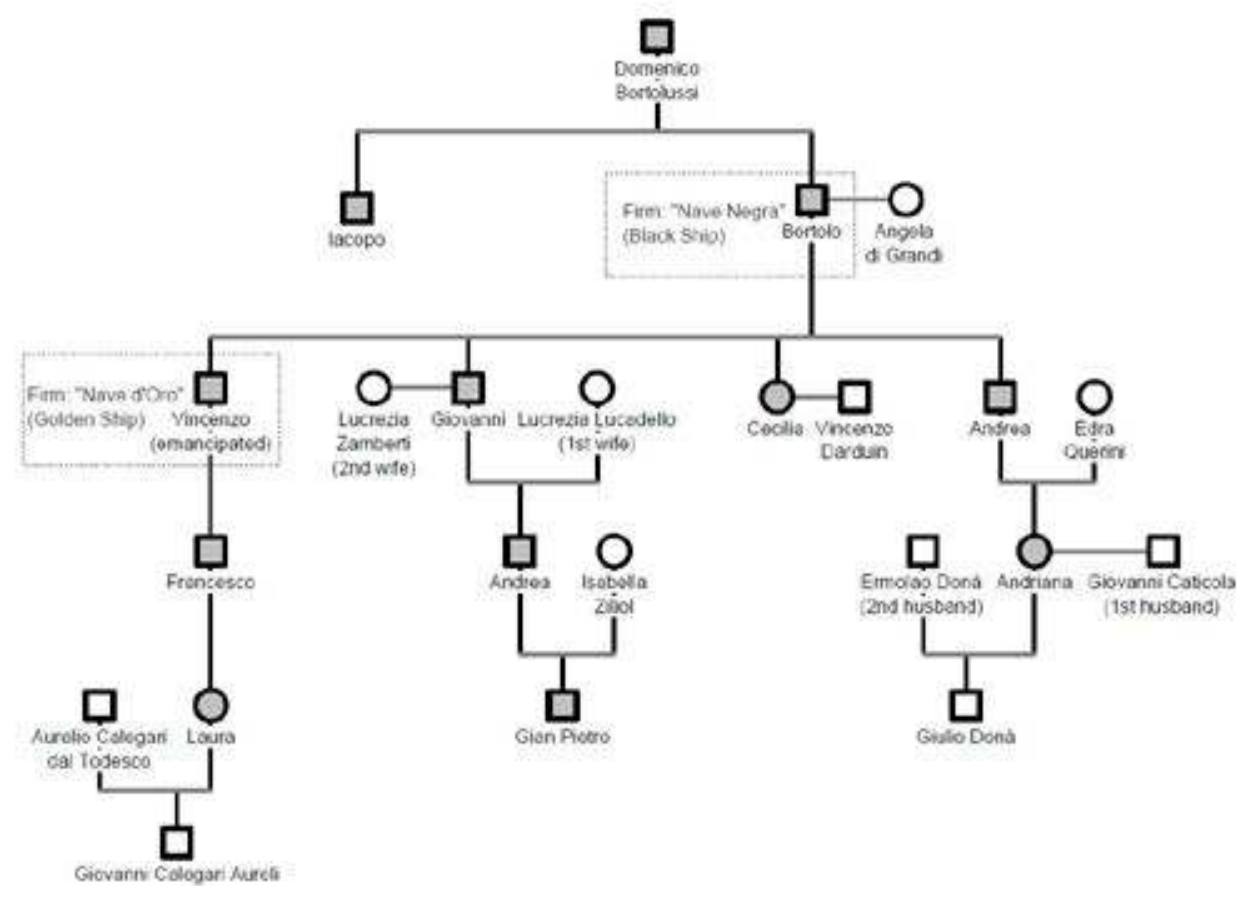

Figure 2.9: Scheme of the relations existing among the members of the Bortolussi family (in grey) and their relatives. The model depicts only the individuals mentioned in the chapter, and not the full family tree. Image ๑ Rachele Scuro.

the fact that in 1566 his sons had been accused of illegally opening their furnace, ${ }^{81}$ lacking the mandatory Muranese citizenship. ${ }^{82}$ It took decades for the Darduins to be officially recognized as rightful guild members and owners of a furnace..$^{83}$ However, in the uncertain moment of consolidation, the relationship between the two families helped them both to reinforce their place in the industry.

With regard to the male line, Bortolo's son Vincenzo emancipated quite early in order to open his own furnace. The decision launched another branch of the family, which distinguished itself from the paternal line by its sign. Bortolo and his lineage kept the original black ship (Nave Negra), while Vincenzo's vessel became golden-coloured (Nave Aurea or Nave d'Oro). ${ }^{84}$ His choice was not followed by his

81 ASVe, PodMur, b. 213, $s d(13.05 \cdot 1560)$.

82 Ibid., $s d(26.11 .1560)$.

83 BMC, IV L 13 , ch. 140, c. 59 r (21.06.1581).

84 In 156o Vincenzo's daughter Giulia married Piero, son of Domenico Ballarin (ASVe, NotA, reg. 3265, c. 101r-v [21.02.156o] and cc. 291r-292r [25.02.156o]). This union with one of the most important families of the island allowed Vincenzo to solidify his position in the industry, as Giulia's father-in-law was not only a master but also an influential entrepreneur. Arguably Vincenzo used an earlier family alliance 
brothers, however, who continued to manage the family business together, later joined by their male children. In the following years, between the 1550 and the 1570 s, a series of deaths left Giovanni at the head of the family for more than twenty years. This partnership was, however, broken when the cousins entered adulthood.

Up to that moment, Giovanni had followed the path traced by his father before him, both in networking and in his trading strategies. Three of his brothers had married into the Venetian patriciate (namely the Querini family), ${ }^{85}$ and the same plan was followed once he and his surviving brothers faced the task of finding suitable spouses for their offspring. For example, when Piero made his will in 1568, he asked his brothers to find proper husbands for his daughters. ${ }^{86}$ Once again, the uncles favoured partners from honourable Venetian families rather than from the island's elite.

The family's marriage strategy had obviously progressed. First, it had secured their professional relationship within the Muranese milieu and the guild by means of Cecilia's marriage to a Darduin, while choosing wives from the patriciate or the cittadini originari families for the majority of Bortolo's sons. In the next generation, women also took part in this process of social promotion by means of their marriage. This peaked in 1596, when Andriana (daughter of the late Andrea) married the nobleman Ermolao Donà for her second marriage. The significant amount of 6,000 ducats required for her dowry could not have been gathered without the effective management of the family patrimony during the previous decades. ${ }^{87}$

When the fraterna was split in 1588, a detailed list of all the goods was drawn up, to be divided into the individual family branches. The assets were apportioned into four parts: one share passed to Giovanni's line while the others went to the male heirs of his deceased brothers. ${ }^{88}$ The list covered fourteen folios and included hundreds of movable goods, as well as real estate in Murano, Venice, and in the district of Treviso, ${ }^{89}$ making up a combined value of several thousand ducats. Interestingly, credits and debts were also counted, thus providing important information about their trade. Their furnace (inclusive of glassware) was valued to 4,062 ducats - plus 523 ducats in mirrors - and comprised credits obtained in Lisbon for more than 7,200 ducats, in Sicily for 5,000 , in Seville for 1,288, and in Constantinople for over

to secure the wedding agreement, as before the Bortolussis entered glassmaking, one of their daughters married a natural son of the late Giorgio Ballarin, see Cesare Moretti and Tullio Toninato, eds., Ricettario vetrario del Rinascimento. Trascrizione da un manoscritto anonimo veneziano (Venice: Marsilio, 2001 ), 15. 85 Their wives were three sisters, too, as stated in Edra and Elisabetta's testaments; ASVe, NotT, b. 209, n. $191(11.02 .1556)$ and n. $84(25.11 .1562)$.

86 Bellavitis, Identité, 271 and ASVe, AvC, b. 373/13, fasc. 23 (11.08.1568).

87 ASVe, AvC, b. 114, n. 774 (o2.08.1596) and AvC, b. 9o, cc. 109v-110r (26.11.1596 and 16.04.1597). See also Bellavitis, Identité, 272.

88 ASVe, NotA, b. 3311, sd (01.07.1588).

89 As reported of 1582 in ASVe, Dieci Savi sopra le Decime di Rialto, b. 167, n. 340; also in Bellavitis, Identité, 270. 
1,500 ducats. Their debts totalled 6,287 ducats and were mainly the result of the purchase of the raw materials needed for glass production.

The dissolution of the prosperous Bortolussis' business might have seemed an irrational decision, but it was motivated by the aspirations of the younger generations, to whom the status of mere glass entrepreneurs was no longer enough. Only Giovanni and his heirs were still interested in the furnaces as their main line of business, while the other family branches were already moving into other professional affairs and were more focused on the capital rather than on the island. ${ }^{\circ}$ This was a trend that several of Giovanni's descendants would also pursue during the following century. Consequently, their ties with glassmaking were to remain mostly indirect: as investors or as owners of buildings rented to professional glassmakers. Hence, by the third generation, the family did not strongly pursue social distinction within the boundaries of Murano as they had done earlier..$^{11}$ They instead aimed at the opportunities offered by the Venetian bureaucratic apparatus and the liberal professions, probably also influenced by the familial imprinting coming from their mothers, wives, and relatives who were part of the Venetian group of the cittadini originari.

After the closing of Venice's Major Council at the beginning of the fourteenth century, and the concentrating of political power solely in the hands of the patriciate, citizenship had become a distinctive social status, more so than in other cities, where the prospect of entering the elite group was still possible, at least theoretically. For those excluded from political power, being a citizen became essential in order to fully participate in both local and overseas trading opportunities, as different privileges were subject to the type of citizenship a person owned. ${ }^{2}$ Furthermore, citizenship was crucial to differentiate oneself from the mass of the popolani and to start a career in public office. The latter, in particular, became more appealing after the decision of the Council of Ten to take under its control the Venetian chancery in 1462. As in the case of the glassmakers' guild, an unmediated relationship with the highest political body of the state was a sign of social distinction in itself.

Therefore, if after the crisis of Agnadello (1509), positions as state officials became more desirable, seen as a guarantee against economic difficulties, ${ }^{93}$ their appeal

90 In 1589 Giovanni created a new partnership with two of his nephews to trade various commodities (mercancie diverse); ASVe, PodMur, b. 234, c. 328r-v (13.05.1589).

91 This process found its conclusion between 1602 and 1605 with the creation of a Golden Book that listed the families of Muranese citizenship, modelled after the books of Venetian patricians and cives. See Vincenzo Zanetti, ed., Il Libro d'Oro di Murano (Venice, 1883).

92 During the last decades, historians have analysed in depth the condition of the Venetian citizen class, especially the immigrants who acquired this status. See: Brian Pullan, “'Three Orders of Inhabitants': Social Hierarchies in the Republic of Venice," in Orders and Hierarchies in Late Medieval and Renaissance Europe, ed. Jeffrey Denton (London: Macmillan, 1999), 147-168; and Mueller, Immigrazione.

93 Matteo Casini, "La cittadinanza originaria di Venezia tra i secoli XV e XVI. Una linea interpretativa," in Studiveneti offerti a Gaetano Cozzi, ed. Gino Benzoni (Padua: Il Cardo, 1992), 142-143, 145-148. 
increased further when in 1569 new laws rigorously defined the mandatory characteristics needed to enter the limited group of families that had meanwhile gained a monopolistic role in the Venetian administration. Firstly, one had to prove having been born in Venice, like his father and grandfather before him; and secondly, it was necessary to hold the more impalpable social and economic trait of being an "honourable" and "civil" man, in other words rich and not practising manual labour. From that moment on, being a cittadino originario was at once defined by binding requisites while also becoming a mandatory title to work as a state bureaucrat. More generally, they became the highest social rank among the non-noble people of Venice. ${ }^{94}$

It is compelling that, as anticipated, this path was chosen by Giovanni's descendants - his son Andrea and grandson Gian Pietro - in a matter of decades. The turning point occurred when, in 1624, Andrea asked for the recognition of this title for his son, producing a rich dossier to demonstrate the merits of his request. ${ }^{95}$ First, he proved the three required grades of ascendance. Gian Pietro's condition was reinforced by the family's marriage strategy to unite their children with members of the Venetian patriciate. Accordingly, the dossier highlights Gian Pietro's maternal line and the fact that his grandfather, Giulio Ziliol had held the high office of cancellier inferior. ${ }^{96}$ This kinship established the basis for a further ascension, as the young man married a girl from a noble family of Treviso, the Avogadros. ${ }^{97}$ This was a second foreseeable choice for the Bortolussis, who during the previous century had accumulated real estate in that part of the Terraferma.

Nonetheless, beyond matters of lineage, the core of the request resided in the way Gian Pietro and his father were living, and how the late Giovanni had lived before them. What Andrea emphasized was that none of them had ever practised manual work. On the contrary, they had all lived honourably in the civil way: in Venetian terminology, none of the three maifece arte mecanica, et visse sempre civilmente et honoratamente. ${ }^{8}$ Francesca Trivellato has highlighted the apparent contradiction in the double condition of being a citizen originario and a glassmaker,

94 On the evolution of Venetian citizenship: Andrea Zannini, Burocrazia e burocrati a Venezia in età moderna: i cittadini originari (sec. XVI-XVIII) (Venice: IVSLA, 1993); James S. Grubb, "Elite Citizens," in Venice Reconsidered: The History and Civilization of an Italian City-State: 1297-1797, ed. John Martin and Dennis Romano (Baltimore, MD and London: Johns Hopkins University Press, 200o), 339-364; and Bellavitis, Identité.

95 ASVe, AvC, b. 373/13, fasc. 23 (1624).

96 The two families shared not only a distant Ferrarese origin, but also their use of mercantile success to ascend Venetian society before turning to offices and liberal professions thanks to their cittadinanza originaria. On the Ziliols see Anna Bellavitis, "Quando la Seconda Corona della Veneta Repubblica si racconta': la Cronichetta de ca' Ziliol,” in Family Memoirs from Venice (15th-17th Centuries), ed. James S. Grubb (Rome: Viella, 200o), XXXIII-XXXIX.

97 ASVe, AvC, b. 373/12, fasc. 23 (26.06.1624).

98 Ibid., in the application (17.06.1624). 
because if the first implied a complete detachment from manual labour, the latter rather presumed a distinct practical knowledge, as the guild prescribed that only those who had passed the examination to become masters could own a furnace (in addition to possessing Muranese citizenship). ${ }^{99}$ Andrea and Gian Pietro might have only owned shares in the business and have never worked with glass (after all, Andrea had also moved to his father-in-law's house in Venice), but that was surely not Giovanni's case. Supposing it was unlikely that Giovanni actively worked at the furnace during his adult years heading the family business, he nonetheless must have practised during his youth.

In Venice the condition of rich merchants (especially of mercante grosso, who could trade overseas) had always been as civil, if not more so, than property owners. This was not a problem, though, as the Bortolussis were both. Yet, the separation from manual labour was an unavoidable trait too, and the condition of artifex mechanicus remained an insurmountable obstacle to gain the title. ${ }^{100}$ The ambiguity was there and proved difficult to solve, however, all seven testifiers confirmed Andrea's statements.

In addition, the applicant and his supporters highlighted a third mandatory attribute: being cultivated. This was also part of the prerequisites, along with possessing a set of distinctive habits in living and dressing that were socially recognized as privileged. Hence, to cover Giovanni's weaker traits, attention was shifted to the characteristics typical of a "civil man" - first of all, the people he had practised with, and those exterior trappings that in the Renaissance played a fundamental role in social distinction. Some testifiers emphasized that he had had servants and owned a gondola, ${ }^{101}$ yet what everyone remarked upon was the way he dressed: that visible, material code that would have made his social status immediately discernible. Giovanni and all his male children wore the typical clothing of Venetian men belonging to higher social ranks: the distinctive a comeo sleeves. ${ }^{102} \mathrm{He}$ was perceived as a merchant rather than a glassmaker, and a relative described him as the manager of a glass business, who had commercial employees and a shop at the sign of the Ship. ${ }^{103}$

99 Trivellato, Fondamenta, 94-97 and ch. 171 in the Mariegola dei Fioleri (1544).

100 Andrea Zannini, "Il 'pregiudizio meccanico' a Venezia in età moderna. Significato e trasformazioni di una frontiera sociale," in Le regole dei mestieri e delle professioni, secoli XV-XIX, ed. Marco Meriggi and Alessandro Pastore (Milan: Franco Angeli, 2000), 36-51.

101 ASVe, AvC, b. 373/13, fasc. 23 (19.06.1624) and (18.06.1624).

102 These are full sleeves closed at the wrist, a universally recognized exterior sign. They appear, for example, in Baldassare Castiglione, Libro del cortegiano (Venice, 1546), 63, and are also described as typically Venetian in Cesare Vecellio, De gli habiti antichi, et moderni di diverse parti del mondo libri due (Venice: Damian Zenaro, 1590), plate $5^{2}$. 103 ASVe, AvC, b. 373/13, fasc. 23 (24.06.1624). 
As a last confirmation of Giovanni's status, Marcantonio Barovier pointed out that the Bortolussi family had married some of its daughters into the Venetian patriciate and the cittadini originari families. ${ }^{104}$ On the matter of exogamic marriages between the nobility and non-nobles, Venice was more liberal than other cities and the Bortolussis had not shied away from establishing blood ties with patricians. Their family's origin and its connection to glass remained embedded in a sort of "mythological" tradition that attributed special privilege to glassmakers. In contrast to other popolane, their daughters would produce patrician heirs, if married to patricians. ${ }^{105}$ Beyond the myth, in those few instances when a girl whose ancestors were glassmakers married into nobility, this would usually have happened only after her family had completely abandoned the industry. At least in one significant case, however, it occurred while the bride's relatives were still glass entrepreneurs: the above-mentioned Andriana Bortolussi wed Ermolao Donà while her uncle (and father figure) was still in the glass business and her brothers held shares in the branch. Thus, it was Giulio, born to the couple in $1599,{ }^{106}$ who was probably the person Marcantonio Barovier referred to when reporting on nobles descending from Giovanni's nieces serving in the Major Council.

In the end, the successful outcome of the application marked the departure of that branch of the Bortolussi family from the business in Murano, as well as its final social ascent. It was an honourable way to enter the distinguished small circle of state bureaucrats or to diversify the social and professional role of some individuals through kinship. It was an honourable way to switch one profitable profession for another. ${ }^{107}$

The final question remains how this process was affected by the privileged status glassmaking held in comparison to other manual work. In other words, how did associations with glass affect the Bortolussis' initial condition and identity, contrasting with their claim of being "civil men" who were not to be considered artifices mechanici, even in the case of their grandfathers and ancestors. In this conflict between two identitarian backgrounds, glassmaking's position within Venetian society overcame obstacles of status and is indicative of their self-perception. It was a duality perfectly embraced by those who vouched for Giovanni Calegari Aureli's appointment of cittadinanza originaria in $1628 .{ }^{108}$

A kinsman of the Bortolussis, ${ }^{109}$ Giovanni was the owner of a furnace in Murano like his father and grandfather before him. Being a middle-aged man, he was not seeking this title in order to start a career in public office like his cousins, rather to

104 Ibid., (19.06.1624) and (26.06.1624).

105 Trivellato, Fondamenta, 97.

106 ASVe, AvC, reg. 57, c. 107 r.

107 Trivellato, Fondamenta, 101.

108 ASVe, AvC, b. 370/10, fasc. 70 (1628).

109 His mother was the granddaughter of Vincenzo from the family branch that established the shop Nave d'Oro. 
gain further social prestige. The fact that at the moment of his application he still operated in the glass industry created some initial problems, ${ }^{110}$ although it relays important clues about the opinions of the testifiers. The testifiers publicly explained why, due to the very nature of glassworking, those who held the highest positions within the glass profession were not to be considered mere manual workers. To them, glassmaking was not an ars mechanica, but an industria in the Latin sense of the word: like alchemy, it was based on distinctive expertise and ingenuity. It was not a matter of simple execution, but conceptual design and research. The Venetian tradition had already put some guilds in a privileged position, conferring to them a certain grade of "nobility" due to the symbolic value attributed to the materials they worked, ${ }^{111}$ yet glassworkers took this further, using it to sustain their right to benefit from a higher reputation among Venice's subjects.

The glassmaker Piero Carati states it plainly: "glassmaking is not a manual work, but an industria,"112 thus it would not have diminished one's respectability, even in the case of those masters and entrepreneurs who, every now and then, happened to work with their hands and not only run the business. Furthermore, two other testifiers affirmed that glassmakers were not to be considered akin to simple salaried craftsmen in any case, while a third stressed that Giovanni and his ancestors had never actually practised a mechanical art, and that if they had occasionally worked glass, it was only at their own furnace. ${ }^{113}$ Finally, to strengthen the superior position of glassworking over other industries, a last testimony stated that glassmaking was not humble artisanal work, rather an "honourable profession." The proof lay in the fact that it was the only guild to be put under the authority of the most important political body (i.e. the Council of Ten), while the others were subject to the common magistrates of the Old Justice. ${ }^{114}$

To conclude, after one and a half centuries the symbolic and political position of glass as a state affair had become part of the self-depiction of the industry and its men, together with its close relationship to the highest ranks of Venetian society: a commonly shared value among Venetians. Thus, for many (and first and foremost the glassmakers), it followed that the status of glassmaking was to be placed on top of the other arti with their weaker group identities. Since the mid-fifteenth century, the combined power of artistic innovation, trading success, political connections, and symbolic meaning had thus developed new social recognition for glassmaking, giving its richest entrepreneurial families the opportunity to be accepted as equals

110 ASVe, AvC, b. 370/10, fasc. 70 (o1 and 28.08.1628). The concession was first rejected. Once discussed again, it passed, although not unanimously.

111 Trivellato, Fondamenta, 91-94.

112 ASVe, AvC, b. 370/10, fasc. 70 (29.07.1628).

113 Ibid., (24 and 27.07.1628).

114 Ibid., (21.07.1628). 
by many of the Venetian elite, despite their artisanal origin. Some of those successful men, such as the Bortolussis, chose to use the new identity they had shaped through the glass industry to later pursue ambitions within the city and ultimately reach the highest positions commoners could aspire to in the republic. It was thanks to the development of this identitarian process that, when the incipient signs of a crisis within the glass industry came into focus by the end of the sixteenth century, they could use the connection and non-formal identification between Venice and the material of glass to secure something grounded in their cultural and sentimental sphere: their unique role within the society of the Serenissima.

\section{Bibliography}

\section{Unpublished Primary Sources}

Archivio di Stato di Venezia, Venice (ASVe)

Arti, 725 , ch. 36, 44, 102

AvC (Avogaria di Comun), b. 9o; b. 114, n. 774; b. 370/10, fasc. 7o; b. 373/12, fasc. 23; b.

373/13, fasc. 23; reg. 57

Cancelleria Inferiore, Miscellanea, Inventari, bb. 34-38

CX (Consiglio dei Dieci), Deliberazioni, Comuni, reg. 3

CX (Consiglio dei Dieci), Misti, reg. 31; fil. 20, n. 103

Dieci Savi sopra le Decime di Rialto, b. 167, n. 340

GP (Giudici di Petizion), b. 339 (n. 4), inv. 82

GP (Giudici di Petizion), Sentenze a Giustizia, reg. 130

Miscellanea Codici, Storia Veneta (Cittadinanze Tassini), vol. VII (B-C), b. 10; Storia Veneta (Cittadinanze Toderini), vol. I (A-B), b. 4

NotA (Notarile, Atti), b. 3311; reg. 3265

NotT (Notarile, Testamenti), b. 203; 209, n. 84, 191

PodMur (Podestà di Murano), b. 19, 23, 26, 71, 116-117, 205, 207, 213, 234

Senato, Terra, filze, f. 9, fasc. "Vincenzo de Anzolo dal Gallo"

Biblioteca del Museo Correr, Venice (BMC)

IV L 13 (Mariegola dei fioleri, 1539-1544 ), ch. 73-76, 91, 98, 131, 135, 137, 140, 147

\section{Published Primary Sources}

Castiglione, Baldassare. Libro del cortegiano. Venice, 1546.

Vecellio, Cesare. De gli habiti antichi, et moderni di diverse parti del mondo libri due. Venice:

Damian Zenaro, 1590. 


\section{Secondary Literature}

Ajmar-Wollheim, Marta, and Luca Molà. "Cross-Cultural Objects in the Early Modern Period." In Global Design History, edited by Glenn Adamson, Giorgio Riello, and Sarah Teasley, 11-20. London: Routledge, 2011.

Ashtor, Eliyahu, and Guidobaldo Cevidalli. "Levantine Alkali Ashes and European Industries." Journal of European Economic History 12, no. 3 (1983): 475-522.

Barovier Mentasti, Rosa. “La vetraria veneziana.” In Storia di Venezia. Temi. L’Arte, edited by Rodolfo Pallucchini, vol. 2, 845-905. Rome: Treccani, 1995.

Barovier Mentasti, Rosa, and Cristina Tonini. "Tools to Study Glass: Inventories, Paintings and Graphic Works of the 16th Century." In Study Days on Venetian Glass: Approximately 16oos, edited by Rosa Barovier Mentasti and Cristina Tonini, Atti, vol. 172, fasc. 1, 2-34. Venice: Istituto Veneto di Scienze, Lettere ed Arti, 2013-2014.

Bellavitis, Anna. “Quando la Seconda Corona della Veneta Repubblica si racconta': la Cronichetta de ca' Ziliol." In Family Memoirs from Venice (15th-17th Centuries), edited by James S. Grubb, XXXI-LI. Rome: Viella, 2000.

Bellavitis, Anna. Identité, mariage, mobilité sociale. Citoyennes et citoyens à Venise au XVIe siècle. Rome: École Française de Rome, 2001.

Bettoni, Barbara. Perle di vetro e gioie false. Produzioni e cultura del gioiello non prezioso nell'Italia moderna. Venice: Marsilio, 2017.

Braunstein, Philippe, and Luca Molà, eds. Il rinascimento italiano e l'Europa, vol. 3: Produzione e tecniche. Vicenza: Angelo Colla, 2007.

Casini, Matteo. "La cittadinanza originaria di Venezia tra i secoli XV e XVI. Una linea interpretativa." In Studiveneti offerti a Gaetano Cozzi, edited by Gino Benzoni, 133-150. Padua: Il Cardo, 1992.

De Munck, Bert, and Dries Lyna, eds. Concepts of Value in European Material Culture, 1500-190o. Farnham, Surrey: Ashgate, 2015.

De Munck, Bert, and Dries Lyna. "Locating and Dislocating Value: A Pragmatic Approach to Early Modern and Nineteenth-Century Economic Patterns." In Concepts of Value in European Material Culture, 1500-1900, edited by Bert De Munck and Dries Lyna, 1-29. Farnham, Surrey: Ashgate, 2015.

Dupré, Sven. "The Value of Glass and the Translation of Artisanal Knowledge in Early Modern Antwerp." In Trading Values in Early Modern Antwerp, edited by Christine Göttler, Bart Ramakers, and Joanna Woodall, 139-161. Leiden: Brill, 2014.

Dupré, Sven, and Christine Göttler, eds. Knowledge and Discernment in the Early Modern Arts. London: Routledge, 2017.

Epstein, Stephan R. "Craft Guilds, Apprenticeship, and Technological Change in Preindustrial Europe." The Journal of Economic History 58, no. 3 (1998): 684-713.

Finlay, Robert. "The Immortal Republic: The Myth of Venice during the Italian Wars (1494-1530)." The Sixteenth-Century Journal 30, no. 4 (1999): 931-944. 
Gasparetto, Astone. Il vetro di Murano dalle origini ad oggi. Vicenza: Neri Pozza, 1958.

Girón-Pascual, Rafael María. “Cenizas, cristal y jabón. El comercio de la barrilla y sus derivados entre España e Italia a finales del siglo XVI." eHumanista 38 (2018): 215-232.

Grubb, James S. "When Myths Lose Power: Four Decades of Venetian Historiography." The Journal of Modern History 58, no. 1 (1986): 43-94.

Grubb, James S. “Elite Citizens.” In Venice Reconsidered: The History and Civilization of an Italian City-State: 1297-1797, edited by John Martin and Dennis Romano, 339-364. Baltimore, MD and London: Johns Hopkins University Press, 2000.

Hankey, Ian. Video contribution to Ways of Making and Knowing: The Material Culture of Empirical Knowledge, edited by P. H. Smith, A. R. W. Meyers, and H. J. Cook. Chicago, IL: University of Chicago Press, 2014. Accessed on 19 August 2019. https://www.youtube. com/watch?v=sSBY6Lc2-hU.

Howard, Deborah. "Diplomacy and Culture." In Islamic Artefacts in the Mediterranean World: Trade, Gift Exchange and Artistic Transfer, edited by Catarina Schmidt Arcangeli and Gerhard Wolf, 161-172. Venice: Marsilio, 2011.

Howell, Martha C. Commerce before Capitalism in Europe, 1300-1600. Cambridge: Cambridge University Press, 2010.

Jacoby, David. "Raw Materials for the Glass Industries of Venice and the Terraferma, about 1370 - about 1470." Journal of Glass Studies 35 (1995): 65-9o.

Laghi, Anna. "Migrazioni venete: influenza e originalità nella produzione vetraria toscana fra '50o e '6oo.” Antichità Viva 26, no. 4 (1987): 43-51.

Lane, Frederic C. "Family Partnership and Joint Venture in the Venetian Republic." The Journal of Economic History 4, no. 2 (1944): 178-196.

Lindow, James R. "For Use and Display: Selected Furnishing and Domestic Goods in Fifteenth-Century Florentine Interiors." Renaissance Studies 19, no. 5 (2005): 634-646.

Maitte, Corinne. "Larte del vetro; innovazione e trasmissione delle tecniche." In Il rinascimento italiano e l'Europa, vol. 3: Produzione e tecniche, edited by Philippe Braunstein and Luca Molà, 235-259. Vicenza: Angelo Colla, 2007.

Maitte, Corinne. "Labels, Brands, and Market Integration in the Modern Era." Business and Economic History 7 (2009): 1-17. On-line open access http://www.thebhc.org/sites/ default/files/maitte.pdf [checked 25.03.2019].

Maitte, Corinne. Les Chemins de verre. Les migrations des verriers d'Altare et de Venise (XVIe-XIXe siècle). Rennes: Presses Universitaires de Rennes, 2009.

Maitte, Corinne. "Les migrations de travail comme ressources: verriers altarais et vénitiens, XVIe-XVIIIe siècle." Mélanges de l'École française de Rome 123, no. 1 (2011): 33-47.

Maitte, Corinne. "Façon de Venise: Determining the Value of Glass in Early Modern Europe." In Concepts of Value in European Material Culture, 1500-1900, edited by Bert De Munck and Dries Lyna, 209-237. Farnham, Surrey: Ashgate, 2015.

Marciani, Corrado. "Il commercio dei cristalli alle fiere di Lanciano nel secolo XVI." Archivio Storico per le Province Napoletane 39 (1959): 315-324. 
McCall, Timothy, Sean Roberts, and Giancarlo Fiorenza, eds. Visual Cultures of Secrecy in Early Modern Europe. Kirksville, MO: Truman State University Press, 2013.

McCray, Patrick. "Creating Networks of Skill: Technology Transfer and the Glass Industry of Venice." Journal of European Economic History 28, no. 2 (1999): 301-333.

McCray, Patrick. Glassmaking in Renaissance Venice: The Fragile Craft. Aldershot: Ashgate, 1999.

Molà, Luca. The Silk Industry of Renaissance Venice. Baltimore, MD and London: Johns Hopkins University Press, 2000.

Molà, Luca. "Stato e impresa privilegi per l'introduzione di nuove arti e brevetti." In Il rinascimento italiano e l'Europa, vol. 3: Produzione e tecniche, edited by Philippe Braunstein and Luca Molà, 533-572. Vicenza: Angelo Colla, 2007.

Molà, Luca. "Inventors, Patents and the Market for Innovations in Renaissance Italy." In Italian Technology from the Renaissance to the Twentieth Century, edited by Anna Guagnini and Luca Molà, 7-34. History of Technology 32. London: Bloomsbury, 2014.

Monticolo, Giovanni, ed. I capitolari delle arti veneziane sottoposte alla Giustizia e poi alla Giustizia Vecchia. Dalle origini al MCCCXXX, vol. 2. Rome: Istituto Storico per le Fonti della Storia d'Italia, 1905 .

Moretti, Cesare, Carlo Stefano Salerno, and Sabina Tommasi Ferroni, eds. Ricette vetrarie muranesi. Gaspare Brunoro e il manoscritto di Danzica. Florence: Nardini Editore, 2001.

Moretti, Cesare, and Tullio Toninato, eds. Ricettario vetrario del Rinascimento. Trascrizione da un manoscritto anonimo veneziano. Venice: Marsilio, 2001.

Moretti, Gianni. "La Rosetta. Storia e tecnologia della perla di vetro veneziana più conosciuta al mondo." Rivista della Stazione Sperimentale del Vetro 1 (2005): 27-39.

Mueller, Reinhold C. Immigrazione e cittadinanza nella Venezia medieval. Rome: Viella, 2010.

Neri, Antonio. L'arte vetraria. 1612, edited by Rosa Barovier Mentasti. Milan: Il Polifilo, 1980.

Page, Jutta-Annette, ed. Beyond Venice: Glass in Venetian Style, 1500-1750. Manchester, VT: The Corning Museum of Glass, 2004.

Poni, Carlo, and Roberto Breveglieri. “Three Centuries of Venetian Patents 1474-1796." Acta historiae rerum naturalium nec non technicarum 17 (1982): 381-393.

Preto, Paolo. I segreti di Venezia. Spionaggio e controspionaggio ai tempi della Serenissima. Milan: il Saggiatore, 2010.

Pullan, Brian. “Three Orders of Inhabitants': Social Hierarchies in the Republic of Venice." In Orders and Hierarchies in Late Medieval and Renaissance Europe, edited by Jeffrey Denton, 147-168. London: Macmillan, 1999.

Romano, Dennis. Patricians and Popolani: The Social Foundations of the Venetia Renaissance State. Baltimore, MD and London: Johns Hopkins University Press, 1987.

Simmel, Georg. "The Sociology of Secrecy and of Secret Societies." American Journal of Sociology 11, no. 4 (1906): 441-498.

Smith, Pamela H. "Historians in the Laboratory: Reconstruction of Renaissance Art and Technology in the Making and Knowing Project." Art History 39, no. 2 (2016): 210-233. 
Taddei, Guido. L'arte del vetro in Firenze e nel suo dominio. Florence: Le Monnier, 1954.

Trivellato, Francesca. Fondamenta dei vetrai. Lavoro, tecnologia e mercato a Venezia tra Sei e Settecento. Rome: Donzelli, 2000.

Trivellato, Francesca. "Guilds, Technology, and Economic Change in Early Modern Venice." In Guilds, Innovation, and the European Economy, 1400-1800, edited by Stephan R. Epstein and Maarten Prak, 199-231. Cambridge: Cambridge University Press, 2008.

Veeckman, Johan, Sarah Jennings, et al., eds. Majolica and Glass: From Italy to Antwerp and Beyond. The Transfer of Technology in the 16th-17th Century. Antwerp: Stad Antwerpen, 2002.

Vermeir, Koen. "Openness versus Secrecy? Historical and Historiographical Remarks.” The British Journal for the History of Science 45, no. 2 (2012): 165-188.

Vermeir, Koen, and Dániel Margócsy. "States of Secrecy: An Introduction.” The British Journal for the History of Sciences 45, no. 2 (2012): 153-164.

Zanetti, Vincenzo, ed. Il Libro d'Oro di Murano. Venice, 1883.

Zannini, Andrea. Burocrazia e burocrati a Venezia in età moderna: i cittadini originari (sec. XVI-XVIII). Venice: IVSLA, 1993.

Zannini, Andrea. "Il 'pregiudizio meccanico' a Venezia in età moderna. Significato e trasformazioni di una frontiera sociale." In Le regole dei mestieri e delle professioni, secoli $X V-X I X$, edited by Marco Meriggi and Alessandro Pastore, $36-51$. Milan: Franco Angeli, 2000.

Zecchin, Luigi. Il ricettario Darduin. Un codice vetraio del Seicento trascritto e commentato. Venice: Arsenale Editrice, 1986.

Zecchin, Luigi. Vetro e vetrai. Studi sulla storia del vetro, 3 vols. Venice: Arsenale Editrice, 1987-1990.

Zecchin, Paolo. “Gli specchi veneziani." Rivista della Stazione Sperimentale del Vetro 6 (1993): 299-307.

Zecchin, Paolo. "La cavata dei vetrai muranesi." Rivista della Stazione Sperimentale del Vetro 5 (1995): 207-218.

\section{About the Author}

Rachele Scuro gained her PhD in Medieval History at the University of Siena. She has worked at the Universities of Basel, Verona and Venice and has collaborated with the University of Cambridge, and is now a research fellow at the University of Milan-Bicocca. Her main research topics are the history of the Jews, and the economic history of the Venetian state. 


\title{
Part 2
}

\author{
Feathers
}





\title{
3. Making Featherwork in Early Modern Europe
}

\author{
Stefan Han $\beta$
}

\begin{abstract}
This chapter charts the unknown history of early modern European featherworking and its relationship with the world of matter and making. Focusing on featherworkers' activities in Antwerp, Brussels, Dresden, Leipzig, London, Madrid, Milan, Nuremberg, Paris, Prague, Stuttgart, Turin, and Venice between 1500 and 1800, I study the people, production, networks, materials, techniques, and products of this largely forgotten craft. Over the course of these centuries, artisans developed their initial engagements with feathers from a culture of making to an entrepreneurial culture of decorum. These European artisans' forms of material engagement, I argue, engendered feathers' affective atmospheres. The craft of featherworking affected the material translation of aesthetics since the application of complex techniques helped to perform the material properties of feathers.
\end{abstract}

Keywords: feathers; featherwork; feather-workers; making; material engagement and assemblages; affective artefacts

\section{Craft Expertise and Aesthetics}

Featherwork is widely associated with indigenous cultures. The arrival of New World feathers in late fifteenth-century Europe, however, caused pure excitement across the entire continent. ${ }^{1}$ These feathers' strikingly novel properties - the iridescence,

1 Stefan Hanß, "New World Feathers and the Matter of Early Modern Ingenuity: Digital Microscopes, Period Hands, and Period Eyes," in Ingenuity in the Making: Materials and Technique in Early Modern Europe, ed. Alexander Marr, Richard Oosterhoff, and José Ramón Marcaida (Pittsburgh, PA: Pittsburgh

Burghartz, S., L. Burkart, C. Göttler, U. Rublack, Materialized Identities in Early Modern Culture, 1450-1750: Objects, Affects, Effects. Amsterdam: Amsterdam University Press, 2021 DOI 10.5117/9789463728959_CHO3 
lightness, colour intensity, motility, and gracility of feathers of American species like Amazonian parrots, Mesoamerican resplendent quetzals, and South American hummingbirds - defined their "affective capacities" to stimulate "emotional response(s)."2 In the "material Renaissance," feathers became highly sought-after products, traded over far-reaching distances and sold in hubs like Seville, Paris, Amsterdam, Venice, or London for the display of refined taste. ${ }^{3}$ During the sixteenth and seventeenth centuries, Europeans were eager to purchase, collect, and store feathers and they invested plenty of energy, money, and time in their transformation. Consequently, European artisans increasingly specialized in featherworking throughout the sixteenth and seventeenth centuries.

This chapter charts the hitherto unknown history of early modern European featherworking and its relationship with the world of matter and making. ${ }^{4}$ Focusing on feather-workers' activities in Antwerp, Brussels, Dresden, Leipzig, London, Madrid, Milan, Nuremberg, Paris, Prague, Stuttgart, Turin, and Venice between 1500 and 180o, I study the people, production, networks, materials, techniques, and products of this largely forgotten craft. Over the course of these centuries, different products became fashionable. Artisans developed their initial engagements with feathers from a culture of making to an entrepreneurial culture of decorum. Besides hats and panaches, feathers were increasingly attached to all different kinds of things and an astonishing variety of materials became significant for such manufacturing processes. Over the entire early modern period, however, these European artisans' forms of material engagement engendered feathers' affective atmospheres. ${ }^{5}$ I argue that the craft of featherworking affected the material translation of aesthetics since the application of complex techniques helped to perform the material properties of feathers - such as their lightness, translucency, motility, and colourfulness - in culturally appreciated forms. This is what made featherwork matter for early modern materialized identities.

University Press, 2021, in press); Stefan Hanß, “Material Encounters: Knotting Cultures in Early Modern Peru and Spain," The Historical Journal 62, no. 3 (2019): 583-615.

2 Oliver J. T. Harris and Tim F. Sørensen, "Rethinking Emotion and Material Culture," Archaeological Dialogues 17, no. 2 (2010): 146, 150.

3 Ulinka Rublack, "Befeathering the European: The Matter of Feathers in the Material Renaissance," The American Historical Review 126, no. 1 (March 2021): 19-53, https://doi.org/10.1093/ahr/rhaboo6; Stefan Hanß, "The Material Creativity of Affective Artefacts in the Dutch Colonial World: Imaging and Imagining Early Modern Feather Fans," Current Anthropology (in press); Stefan Hanß and Ulinka Rublack, "Knowledge Production, Image Networks, and the Material Significance of Feathers in Late Humanist Heidelberg," Renaissance Quarterly 74, no. 2 (2021): 1-39.

4 Michelle O'Malley and Evelyn S. Welch, eds., The Material Renaissance (Manchester: Manchester University Press, 2007); Pamela H. Smith and Tonny Beentjes, "Nature and Art, Making and Knowing: Reconstructing Sixteenth-Century Life-Casting Techniques," Renaissance Quarterly 63 (Fall 2010): 128-179; Ulinka Rublack, "Matter in the Material Renaissance," Past and Present 219 (2013): 41-85.

5 Andreas Reckwitz, "Affective Spaces: A Praxeological Outlook," Rethinking History 16, no. 2 (2012): $241-258$. 
This chapter reconsiders our understanding of the transformation and challenges of early modern material worlds. Featherworking artisans faced considerable challenges. The special characteristics of feathers caused the high cultural esteem in which sixteenth-century Europeans held this material. These properties, however, also opened a wide range of affordances for the processing of feathers. ${ }^{6}$ At first glance, feathers appear to be easily processable. A closer examination, however, reveals that their material properties gave rise to formidable obstacles. Handling such particularly soft objects was often described in comparison to graceful Renaissance textiles like "deep-napped velvet(s)." ${ }^{7}$ However, precisely this tactile experience relied upon feathers' finely developed barbs, barbules, and hooklets, which were easily damaged by handling and treatments. The iridescence that ensured the vibrancy of the material to Renaissance observers faded when featherwork was exposed to intense light and water. Low room humidity, for example, embrittled feathers. ${ }^{8}$ Their very composition made feathers extremely susceptible to damage. Feathers contain more than 90 percent proteins. This chemical cocktail makes feathers predisposed to damage caused by insects, as the tailor of the southern German court of Württemberg came to realize in 1596. Overseeing the duke's inventory, the tailor came across the miserable appearance of a grey, feather hat. He crossed out the entry and added that "the cockroaches have eaten this." According to an inventory from 1621, the Prague imperial collections' aigrettes were similarly "quite consumed by worms."

For handling the difficulties and properties of such delicate materials, featherworkers had to master a set of complex skills that aimed to respond to the new "sensory education" caused by, and further promoting, a changing material

6 James J. Gibson, "The Theory of Affordances," in Perceiving, Acting, and Knowing: Toward an Ecological Psychology, ed. Robert E. Shaw (Hillsdale, NJ: Erlbaum, 1977), 127-137; Ann-Sophie Lehmann, "The Matter of the Medium: Some Tools for an Art Theoretical Interpretation of Materials," in The Matter of Art: Materials, Technologies, Meanings, 1200-170o, ed. Christy Anderson, Anne Dunlop, and Pamela H. Smith (Manchester: Manchester University Press, 2014), 21-41.

7 Jean de Léry, History of a Voyage to the Land of Brazil, otherwise called America, trans. Janet Whatley (Berkeley and Los Angeles, CA and Oxford: University of California Press, 1990), 6o. For a broader discussion, see Hanß, "Material Encounters."

8 Chad M. Eliason and Matthew D. Shawkey, "Decreased Hydrophobicity of Iridescent Feathers: A Potential Cost of Shiny Plumage," Journal of Experimental Biology 214 (2011): 2157-2163; C. V. Horie, "Fading of Feathers by Light," in gth Triennial Meeting, Dresden, German Democratic Republic, 26-31 August 199o, ed. International Council of Museums Conservation Committee (Los Angeles, CA: International Council of Museums Conservation Committee, 1990), 431-436.

9 HStAS, A 202, vol. 2394, Nr. 4, 5r; B. S. Harrap and E. F. Woods. "Species Differences in the Proteins of Feathers," Comparative Biochemistry and Physiology 20 (1967): 449-46o.

10 Heinrich Zimmermann, "Das Inventar der Prager Schatz- und Kunstkammer vom 6. Dezember 1621: nach Akten des K. und K. Reichsfinanzarchives in Wien," Kunsthistorische Sammlungen des Allerhöchsten Kaiserhauses 25 (1905): LX. 
environment. ${ }^{11}$ In this chapter, I not only chart the history of early modern European featherworking, I also discuss artisans' proficiency in material transformation and enaction. By studying the feather-workers' dexterity and creativity, I conceptualize early modern featherworking as material engagement embedded in the featherworkshops' material assemblages. Various protagonists engaged with the materiality of feathers to ensure their availability, to craft their shape, and to shape their aesthetics. These artisans' material worlds - their labour organization, manual skills, and artisanal techniques - reveal how knowledge of matter and its transformation lent early modern featherwork cultural significance. On a methodological level, I combine in-depth archival research with an object-centred approach. I relate documents and artefacts with more recent debates on affordances, engagement, assemblage, and affects and thus connect history with archaeology. ${ }^{12}$ By examining the making of affective artefacts, this chapter studies the crafting of early modern materialized identities.

\section{Crafting the Feather Craze}

Johann Wurmbein is one of at least eighteen Nuremberg artisans who manufactured feathers into panaches, crowns, and collars during the sixteenth and seventeenth centuries. The portrait shows his pride to be among craftsmen who mastered materials that had become indispensable items of gallantry (Fig. 3.1). In Paris between around 1500 and 1800 , at least 247 feather-workers sold and advertised a wide range of products including headwear, collars, shoulder and elbow adornments, necklaces, panaches, fans, and shin guards (Fig. 3.2). ${ }^{13}$ Such images reveal the self-understanding of the artisans and similarly "demonstrate the adornment potential" of feathers to clients, pointing to the imagined needs and desired wants that novel commodities like feathers evoked. ${ }^{14}$ "Artifacts act en masse to effect people," and so too did feathers in regard to early modern craftsmen and clients: "groups of related objects [...] create stylistic universes which affect producers and users of new objects, bound by the canons of style." ${ }^{\prime 5}$ Featherwork

\footnotetext{
11 Beverly Lemire, Global Trade and the Transformation of Consumer Cultures: The Material World Remade, c. 1500-1820 (Cambridge: Cambridge University Press, 2018), 82.

12 Gibson, "Affordances"; Lambros Malafouris, How Things Shape the Mind: A Theory of Material Engagement (Cambridge, MA and London: MIT Press, 2013); Yannis Hamilakis and Andrew M. Jones, "Archaeology and Assemblage," Cambridge Archaeological Journal 27, no. 1 (2017): 77-84.

13 Resulting from my in-depth study of 166 finding aids in the Archives Nationales Paris.

14 Lemire, Global Trade, 79 f.

15 Chris Gosden, "What Do Objects Want?," Journal of Archaeological Method and Theory 12, no. 3 (2005): $193 \mathrm{f}$.
} 


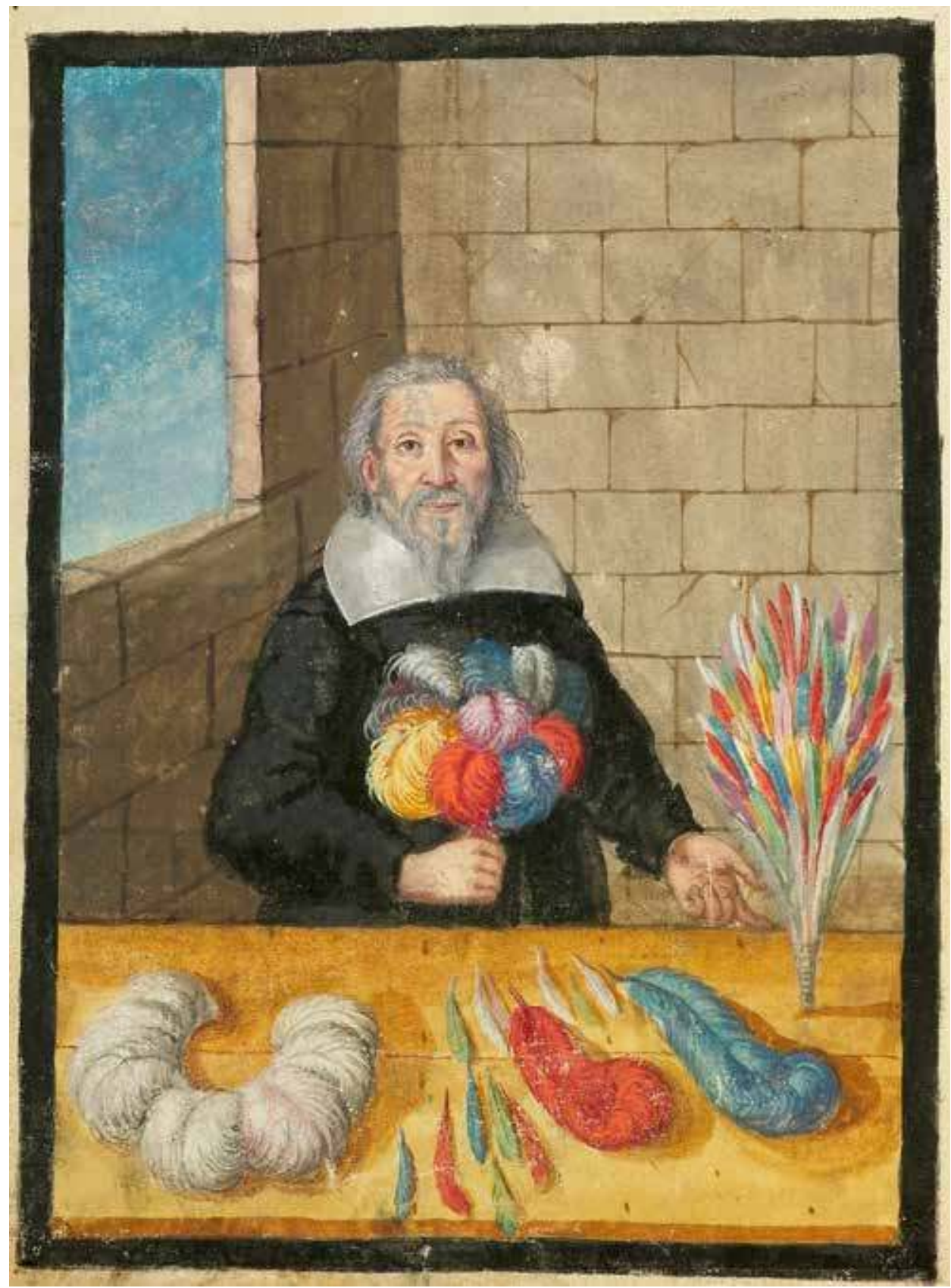

Figure 3.1: Unknown artist, Nuremberg feather-worker Johann Wurmbein. Water colours and tempera on paper, $226 \times 166 \mathrm{~mm}$. In Hausbuch der Mendelschen Zwölfbrüderstiftung, 1667, fol. 151v. Nuremberg, Stadtbibliothek im Bildungscampus Nürnberg, Amb.317b. $2^{\circ}$, f.151v. Image ๑ Stadtbibliothek im Bildungscampus Nürnberg. 


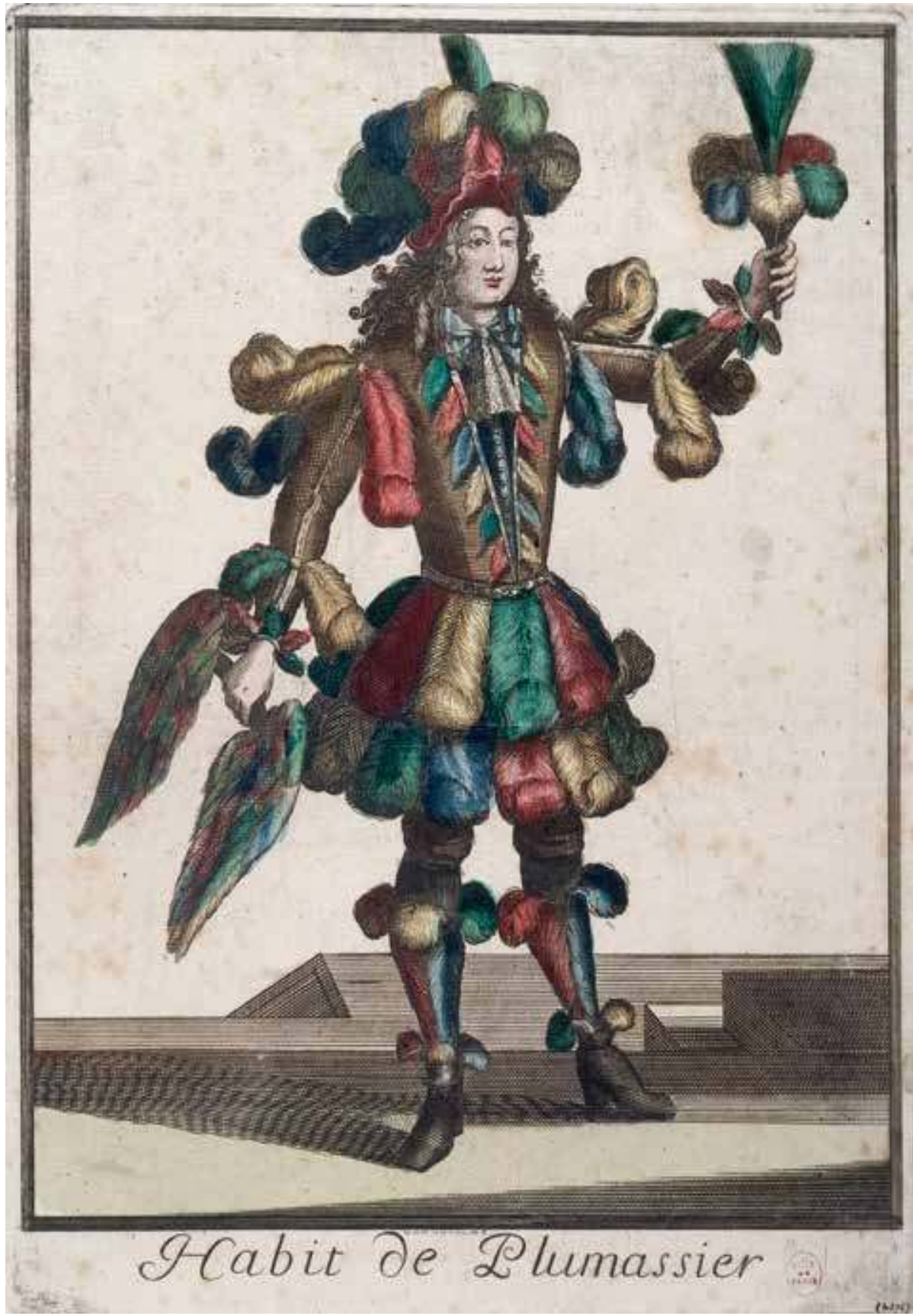

Figure 3.2: Unknown artist (Nicolas de Larmessin II?), French feather-worker advertising his products, after 1695. Print, $277 \times 185$ mm. France, Musée Carnavalet Paris, shelf no. G.5067. Image ๔ Musée Carnavalet / Roger-Viollet. 
also became a catalyst for economic entrepreneurship and engendered cultures of taste. The recent routines of global commerce provided Europeans with access to new materials. Just as Beverly Lemire argued for early modern ribbons, feathers too, belonged among novel "goods essential to this consumerist change providing new sorts of employment and new systems of delight. ${ }^{m 6}$ Feathers inspired the entrepreneurial industriousness that responded to and further generated the demand for desired commodities. An increasing number of protagonists - makers, mercers, and clients - engaged in producing and purchasing the featherwork that transformed material lives in early modern Europe.

Feathers engendered craft professionalization and specialization. Starting at the beginning of the sixteenth century, artisans across Europe began to organize themselves into feather-worker guilds, whose statutes manifested featherworking as a craft bound by rules and a code of honour. In 1530, Brussels feather-workers commissioned their statutes. A "privileged guild" of plumassiers was founded in Antwerp in 1579. Twenty years later, Henry IV issued the statutes of Parisian feather-workers. Elector John George I proclaimed the regulations of Saxonian feather-workers in 1615 . Those regulations of the Nuremberg artisans who specialized in processing feathers were announced nine years later. ${ }^{17}$ Guild statutes shaped the craft's principles, defining its ritual bonds. Leipzig and Dresden feather-workers, for instance, needed to pay regular fees that helped to balance periods of low income. Representatives were elected and met twice a year. Those who wished to become a master feather-worker needed to provide proof of being born in wedlock, having finished one's apprenticeship and afterward travelled in good behaviour, having worked another year with a master after their return, being a local citizen, and having successfully passed the guild's examination, a milestone which was followed by banquets. ${ }^{18}$ Both producing and trading featherwork was restricted to guild members. The rise of Parisian plumassiers, therefore, coincided with the distinction between craftsmen (maittres) and salespersons (marchands). As a widely circulating commodity, feathers and featherwork shaped consumerist desires and caused the fashionability of panaches - a tuft of a varying number of differently manufactured feathers, whose production and trade became the subject of specialized panachemakers (panachers). Those contravening the guild's statutes were severely punished. Parisian plumassiers who employed non-French apprentices had to pay 500 livres to the guild's elders. In 1630, they took proceedings against Pierre Huon, who had

16 Lemire, Global Trade, 79.

17 AVB/ASB, registre n ${ }^{\circ} 3426$; SA, GA\#4254, 7\#1150; Denis Diderot and Jean B. d'Alembert, eds., Encyclopédie ou Dictionnaire raisonné des sciences, des arts et des métiers, vol. 12 (Paris: Samuel Fauche, 1765), 798; August Jegel, ed., Alt-Nürnberger Handwerksrecht und seine Beziehungen zu anderen (Nürnberg-Reichelsdorf: Schmidt, 1965), 511.

18 StadtAL, LXIV Nr. 46, 11r-24v. Special thanks to Bridget Heal. 
sold his featherwork via a marchand bonnetier. ${ }^{19}$ Leipzig feather-workers proceeded against Hans Kolbe, a fellow artisan from Weida, who had asked for citizenship in order to run his own feather-workshop in 1607. Leipzig artisans emphasized that Kolbe was a "blood-foreign" who had engaged in extramarital intercourse "with a foreign and alien maid," his later wife from Glaucha. For the same reason, a similar enquiry in Magdeburg had already failed. Neither becoming a citizen nor having married an honourable burgess excluded young artisans from profits in times of increasing industriousness and competition. ${ }^{20}$

Guild restrictions responded to both the material demands of feathers, which required substantial training, and the high mobility of feather-workers, who needed to have access to the global trade of feathers. Important economic hubs, courts, as well as port and trade fair cities like Antwerp, Brussels, Leipzig, London, Madrid, Nuremberg, Paris, Prague, Seville, and Venice became important sites for feather-workers' activities. The Antwerp feather-merchant Antoine Verra, for instance, regularly travelled to Paris - most likely to buy and sell feathers - and even owned estates en route. ${ }^{21}$ Parisian featherwork-merchant Nicolas Le Trotteur settled in Vienna. ${ }^{22}$ Other Parisian feather-workers formed associations and signed contracts with traders that sold feathers and panaches in Lyon, Reims, and Spain. ${ }^{23}$ Such profit-securing strategies responded to the flows of goods ensuring access to materials, resources, and markets. Turin piumassari had specialized in sending bunches of capon feathers first to Paris and then to Spain and the New World for their suitability as feather dusters. ${ }^{24}$ In 1567 René Guynault, who ran his featherworkshop on the Pont Notre-Dame in Paris, set up a joint venture with the London feather-worker Sébastien Bonnefoy comprising an annual exchange worth 25 écus d'or soleil. ${ }^{25}$ Further names of feather-workers active in early modern England clearly point to their continental background. Henry VIII's feather-worker was called Gerard van Hartell. The name of Edward VI's feather-worker of Saint Peter by Tower, Middlesex, was Paul Vrelande (d. 1551). John Gascarde manufactured feathers in Blackfriars, London, until $1604 \cdot{ }^{26}$ Moreover, Nuremberg's first documented feather-

AST, commercio, mazzo 20 da ordin. cat. 4. Warm thanks to Alessandro Malusa.

AN, MC/ET/VIII/316 (1567/06/o1).

26 Maria Hayward, Dress at the Court of King Henry VIII: The Wardrobe Book of the Wardrobe of the Robes prepared by James Worsley in December 1516, edited from Harley MS 2284, and his Inventory prepared on 17 January 1521, edited from Harley MS 4217, both in the British Library (Leeds: Maney, 2007), 334; TNA, PROB 11/34/234; PROB 11/104/348. 
worker Johann Rat, alias Jan de Rat, was presumably from the Low Countries. ${ }^{27}$ Migrating artisans established elaborate networks that connected featherworking hubs, promoting a sense of professional community and advancing the mobility of artisanal knowledge.

The mobility of early modern feather-workers was a vital element of their entrepreneurship. These European artisans' profits relied on their ability to partake in the global trade of feathers - access to such markets and networks defined the success or failure of a person's featherworking business. Nuremberg feather-worker Hans Wollandt, for example, regularly visited Venice to have access to a Mediterranean hub of, and trendsetter in, featherworking. Here, Wollandt also convinced a Venetian shopkeeper to allow him to take care of the latter's adolescent son, Bartholomäus Viatis, who was sent to Nuremberg. In his later autobiographical records, Bartholomäus describes the Nuremberg feather-worker Wollandt as one of the "false hearts" that he had met throughout his life. Despite Wollandt's promise to offer Bartholomäus shelter, clothing, and provisions while training him as an apprentice, Viatis lamented "how hard I was reared in particular by his wife." For three years in a row, the feather-worker apprentice did not drink any beverage other than water. Not even shoes were given to him and frost stigmata covered his thighs still years later. At the end of his apprenticeship, Viatis agreed to serve Wollandt as a business partner in Lyon for another four years, yet Wollandt plunged into debt, ruining the business and the reputation of Viatis. Only in 1565 was Viatis able to break with Wollandt and his co-partners. Four years later, he was granted citizenship in Nuremberg. In his journal, Viatis recorded these biographical hardships for his children's guidance, narrating his story as a feather-worker apprentice who had become a well-to-do merchant and respectable businessman. ${ }^{28}$

This biographical transformation, once again, relied on Viatis's participation in broader commercial networks recorded in his "secret journal." Viatis regularly visited the Frankfurt fair, yet he also maintained close ties with creditors in Bolzano, Venice, and Milan. He joined Daniel Igler's feather-trading business in Milan, until he left for a journey to Wrocław and finally settled in Nuremberg again. Here, Viatis continued to store the financial records that document his commercial ties with merchants, dressmakers, cloth-makers, dyers, and feather-workers in Erfurt, Leipzig, Antwerp, and Italy. Feather-workers Conrath Grisser and Bernhardt Helm,

27 StAN, B14/II Nr. 31, 64r. Rat's support for a brewer from Bruges, who had settled in Nuremberg, further corroborates this observation.

28 StAN, E1/1905, Nr. 1, Jornal vnd Schuldtbu[o]ch of Bartholomäus Viatis (1579), 1r-3v, 6r. Cf. Gerhard Seibold, Die Viatis und Peller: Beiträge zur Geschichte ihrer Handelsgesellschaft (Cologne: Böhlau, 1977). Archival records prove these personal notes' correctness: StadtAN, B14/I, Nr. 90, 35V-38r (1574/o3/og) with reference to the missing folio 220 of StadtAN, B14/III, Nr. 35 . 
for instance, owed Viatis 224 gulden of which to receive he had only "little hope."29 Feather-workers' supra-regional mobility and their far-reaching networks were a vital part of the entrepreneurial strategies that made considerable economic success possible.

The impressive demand for feathers, in fact, allowed highly specialized artisans to make a profitable living. Women, besides men, became successful entrepreneurs. Nuremberg feather-worker Johann Rat's wife, Felicitas, sold a feather beret for 5 gulden 3 pfund and 29 pfennig in $15333^{30}$ Two years later, Claude Jablier sold a total of 995 feathers in Paris. Twenty years on, she was still a well-known featherwork trader. ${ }^{31}$ Madames plumassières Denise Feucher and Marie Dangicourt welcomed customers in their early seventeenth-century shops, and Marie Joseph Toutain ran a successful featherwork and fashion shop in the rue Saint-Denis in the 1780 s. $^{32}$ Featherworking, in fact, made entire families prosper. When the Nuremberg house was sold to Rat's five children in 1547, the dwelling had tripled its value to 1,000 gulden. ${ }^{3}$ Thomas, a son of Rat's first marriage, established his own feather-workshop in $155^{2 .}{ }^{34}$ His brother Anthonius, moreover, maintained business relations with the Negelein, one of the major featherworking families in seventeenth-century Nuremberg: Hans (1572-1641), Adrian (d. 1686), and Johann Stephan (d. 1725/9) were all well-known feather-workers. ${ }^{35}$ In seventeenth-century Paris, the Poirier cousins Jean and Barthélemy as well as André, Claude, Hierosme, Jacques (I and II), Jean, Jérôme, and Pierre Pancatelin dominated the featherworking trade. ${ }^{36}$ Strategic marriages consolidated such well-to-do featherworking dynasties, who established ties with other feather-workers or artisans active in different crafts that were often related to feather-workers' activities. When Hans Negelein died in 1641, his wife Ursula married the "honourable and ingenious feather-decorator Georg Paul Jung." Hanns Maller's widow likewise married another Nuremberg feather-worker, Georg Kramer. ${ }^{37}$ Their workshops, instruments, goods, equipment, and clients made widows, themselves active artisans, a good catch for men aspiring

29 StAN, E1/1905, Nr. 1, 1r-4r, 8v, 41r, 44v, $111 \mathrm{v}$.

30 StadtAN, B14/II, Nr. 34, 146v (1533/08/28).

31 AN, MC/ET/III/12 (1535/05/28); Châtelet de Paris, Y//10o, 56v.

32 AN, MC/ET/VIII/564, 6or; MC/ET/VIII/593, 364r; Châtelet de Paris, Y//196, 269r; MC/ET/XXII/52 (1787/07/o9).

33 StadtAN, B14/I, Nr. 194, 56r; B14/I, Nr. 62, 1 r.

34 StadtAN, B14/I, Nr. 68, 38 r.

35 StadtAN, B14/II, Nr. 36, 147r; B14/I, Nr. 162, 152r-154r; E8, Nr. 2333/17; E1/1158, Nr. 1, 5rf., 13r; B14/I, Nr. 181, 102v-104r; D1, Nr. 776, Nr. 18; E8, Nr. 2333/14; E8, Nr. 2333/38.

$36 \mathrm{AN}, \mathrm{MC} / \mathrm{ET} / \mathrm{VIII} / 589,234 \mathrm{r} ; \mathrm{MC} / \mathrm{ET} / \mathrm{XI} / 109$, fol. VII/XX/XI; MC/ET/XXIV/342, fol. IIII/C/XXVII; MC/ ET/XXXIV/33 (1624/11/24); MC/ET/XXIV/338, fol. IIII/C/VIII; MC/ET/II/166 (1641/o6/23); MC/ET/CV/587 (1634/02/02).

37 StadtAN, F5, Nr. 3/V, 1592; A1, Schwabach (1598/05/31). 
to commercial and social success. Their privileged positions often resulted in wealth and power. Nuremberg feather-workers Hans Negelein, Mathes Mair, and Georg Paul Jung, for example, served the city's Great Council for five, nine, and seventeen years respectively. ${ }^{3}$

The desire for feather products led to the foundation of numerous shops. In Paris, the Pont Notre-Dame had become the main featherworking address from at least 1540, when Michel David was processing North African ostrich feathers there. ${ }^{39}$ Only forty years later, Hory, Maloiseau, and Noël ran three feather-workshops on that bridge. ${ }^{40}$ Feather-workers like Claude Pancatelin invested highly - 1,0oo livres in 1635 - to install workshops in such vibrant commercial zones, as to do so facilitated access to an ever-increasing number of customers. ${ }^{41}$ In Nuremberg, the Plattenmarkt became a central featherworking venue after Rat established his workshop there in 1508. In 1524, Rat moved into a larger building nearby. Lienhard Moler transferred his workshop from the central market square to the Plattenmarkt in 1548. Hans Wollandt followed in 1555 . Nuremberg feather-workshops prospered either in hubs or in short walking distances to areas of public significance like markets or the guildhall..$^{22}$ Municipal and guild regulations tried to manage the urban flows of feathers. Parisian plumassiers ran only one store. ${ }^{43}$ Nuremberg feather-workers were allowed to run either one shop or one market stall; door-to-door selling was explicitly forbidden. ${ }^{44}$ Notwithstanding such regulations, grocers offered feathers of poultry - used to pad blankets - as well as ostrich feathers in local markets, causing "considerable damage" to feather-workers. 45

Topographies of featherworking were characterized by the remarkable dynamism resulting from the mutual exchanges between urban and courtly milieus. ${ }^{46}$ When

38 StadtAN, GSI152, Obj.Nr. 58.725, 58.870, 59.30o.

39 AN, MC/ET/XXXIII/24, 266v.

40 AN, MC/ET/XXIX/73 (1581/o1/19); MC/ET/LXXXIV/27 (1586/11/14); Châtelet de Paris, Y//127, 370v (1586/02/01).

41 AN, MC/ET/XXIV/342, 427 r.

42 Johann Rat(z) (StadtAN, F5, Nr. 3/I, 2, 1508/og/14; B14/I, Nr. 194, 56r, 1524-1547); Lienhard Moler (B14/I, Nr. 57, 170v, 1544-1548; B14/I, Nr. 62, 108r; E29/I, Nr. 397; F5, Nr. 3/III, 11r-14r, 18r, 1548-1557); Jacob Wasser (B14/I, Nr. 57, 45r, 1545); Hans Wollandt/Bartholomäus Viatis (B14/I, Nr. 71, 11rf.; B14/I, Nr. 90, 35v-38r, 1555-1574); Thomas Ratz (B14/I, Nr. 68, 38r, GNM, Perg.-Urk. 1587/05/05, 1552-1587); Elias Fuchs (StadtAN, E18, U56; U58; U61; U64af., 1568-1573); Hanns Maller (F5, Nr. 3/V, 1592); Georg Kramer (B14/I, Nr. 116, 222v, 1601); Hans Negelein (B14/I, Nr. 133, 246vff., 1621-1548); Georg Paul Jung (B14/I, Nr. 133, 246vff., 1648-1568); Johann Stephan Negelein (B14/I, Nr. 181, 102v-104r, 1684-1686). I could not locate the workshops of Joachim Fehlhorn (StadtAN, E17/II, Nr. 677), Hans Lauff, Mathes Mair, Adrian Negelein, Jacob Stoy, and Johann Wurmbein.

$43 \mathrm{BnF}$, ms. fr. $21798,236 \mathrm{v}$.

44 Jegel, Handwerksrecht, 511.

45 StadtAL, LXIV Nr. 46, 22v; StadtAN, A6, Nr. 691 (1625/06/18).

46 Evelyn Welch, "Art on the Edge: Hair and Hands in Renaissance Italy," Renaissance Studies 23, no. 3 (2009): $260-268$. 
the French royal feather-worker Barthélemy Poirier sold items worth 1,612 livres to François de la Rochefoucauld in 1620, it was the merchant Antoine de Vauconsains who traded the commodities. ${ }^{47}$ By running their own stores in Paris, many of Poirier's colleagues and fellow royal panache-makers, in fact, were in constant touch with urban feather-workers. ${ }^{48}$ The imperial feather-worker Jan Fuchs likewise owned a shop in late-sixteenth-century Prague; he advertised his products by painting the words Perzyssmukyrz and Federschmücker on the wall. ${ }^{49}$ Purchase orders and quittances point to the significance of urban, military, and courtly elites as the driving forces behind the manufacturing of feathers.

Court society, with its demands for splendidly symbolic display, contributed to making featherworking a burgeoning field. ${ }^{\circ}$ On the occasion of the entry of Catherine de' Medici into Paris in 1549, the Duke of Enghien had commissioned his private tailor to buy feathers from Thomas Flache. Building on this reputation, the Parisian artisan worked as the Duke of Nevers's private feather-worker a few years later..$^{1}$ The wedding of Louis XIII and Anne of Austria caused François de Bourbon, cousin of the French king's father, to commission a number of products from two feather-workers at the Pont Notre-Dame, Pierre Clauseau and Germain Hersent: these included twenty-seven large panaches for horses, each of them containing aigrettes and thirty doubled ostrich feathers of red, blue, and white colours decorated with gold wires; another twenty panaches made of nine doubled ostrich feathers; six panaches of four ostrich feathers composed in two layers; and one hundred further aigrettes..$^{2}$ For tournaments held at the Buen Retiro Palace in Madrid in 1633 , Felipe Arroyo earned altogether 7,800 reales for manufacturing 1,800 pearl-white and black feathers into twenty-four panaches of different sizes. ${ }^{33}$ Knowing the significance of court festivities for the entire craft, French and German guilds ensured that featherwork would be produced on such occasions and prohibited apprentices to ask for higher salaries. ${ }^{54}$ These examples illustrate how courts stimulated the demand for featherwork, yet they also demonstrate that featherwork became a significant portion of court economies. The southern German court of Württemberg spent 921 florins on the Stuttgart feather-worker

47 AN, MC/ET/VIII/603 (1620/03/o9).

48 AN, MC/ET/II/179 (1646/o3/20); MC/ET/II/183 (1647/04/11); MC/ET/VIII/666 (1649/o8/o8).

49 Pavel Vlček et al., eds., Umělecké památky Prahy, vol. 3 (Prague: Academia, 1999), 207. Warm thanks to Suzanna Ivanič.

$5^{0}$ For a detailed discussion of this in regard to the Spanish court, see Stefan Hanß, "Material CrossReferencing in the Age of Courtly Consumption: Feathers and the Making of Luxury Experiences at the Early Modern Spanish Court" (forthcoming).

51 AN, MC/ET/C/31 (1549/02/13); MC/ET/III/240/A-B (1557/10/10).

$5^{2}$ AN, MC/ET/LXXIII/279, 23 r (1612/03/15).

53 AGP, sección de expedientes personales, caja 151, expediente 7.

54 BnF, ms. fr. 21798, 233v; StadtAL, LXIV Nr. 46, 17 rf. 
Hans Dannenritter on the occasion of the Regensburg Imperial Diet in 1594; a sum that made up almost two-thirds of the court's entire annual expenses spent on textiles. ${ }^{55}$

Manufactured feathers - their colour, quantity, fluffiness, and decoration materialized emotional atmospheres and courtly hierarchies as a court's symbolic language was based on a material vocabulary. To gain proficiency in such a vocabulary, European monarchs employed their own feather-workers, who mastered the material demands and possibilities of feathers. Henry VIII of England commissioned featherwork by his personal plumier. At the Spanish court, royal plumajeros are documented since at least 1564 . French plumassiers $d u$ Roi produced featherwork from as early as $1541 .{ }^{6}$ Rulers thereby ensured the availability and adequacy of featherwork. In 1564, for instance, Philip II commissioned the royal feather-worker Miguel de Torres to prepare six white and yellow feathers to be given to a recently converted "moor." Three years later, when six indigenous visitors from Florida arrived in Madrid together with a returning Basque man, the plumajero had to manufacture twenty-eight coloured feathers for the decoration of hats. ${ }^{57}$ In France, Louis XIV's ballet performances required feather headwear of outstanding artisanship that aimed both to resonate with the king's movements and to capture the emotional resonances of luminosity and motility. ${ }^{8}$ Appointed as valets de chambre, royal feather-workers' embeddedness within court society enabled them to study the king's body and motions in order to develop appropriate material responses and corresponding artistic techniques. ${ }^{59}$ Such examples vividly illustrate how feathers stimulated systems of labour and styles of fashion as well as how artisans crafted the early modern feather craze.

\section{Material Engagement: Skills and Creativity}

For featherwork to be able to enact affectual spheres to such an astonishing extent, artisans were required to manufacture products that matched potential buyers'

55 HStAS, A 256, vol. 81, 332v-333v. Receipts related to the activities of artisans in Stuttgart will be edited in Stefan Hanß, ed., Court and Material Culture in Early Modern Germany: A Sourcebook on the Duke of Württemberg's Payments to Artisans, Stuttgart, 1592-1628 (Amsterdam: Amsterdam University Press, forthcoming).

56 Hayward, Dress, 334; AGP, Administración General, leg.5.26o, exp.1; AN, MC/ET/XIX/158 (1541/05/18); Hanß, "Material Cross-Referencing."

57 AGP, Administración General, leg.5.26o, exp.1, 1r, 2r.

$5^{8}$ Henri Gissey, Louis XIV in the Guise of Apollo, no date (seventeenth century). Graphite, watercolour, bodycolour, and gold paint on vellum, $304 \times 225 \mathrm{~mm}, \mathrm{RC}, \mathrm{RCIN} 913071$.

59 AN, MC/ET/VIII/104 (1574/06/05); MC/ET/XXIX/152 (1600/02/21). 
desires. Their capability relied on feather-workers' expertise in acts of material transformation. By engaging with feathers' affordances on a very sensory level, artisans developed crucial cognitive skills in transforming this material. In the words of the French king, the esteem of feather-workers resulted from their manual dexterity, which was capable "to repair the defects of nature" and "to capture the benevolence of the hearts of the most serene highnesses on earth by the work of their [the feather-workers'] hands." ${ }^{60}$ Manufacturing feathers with intricate techniques in order to improve and foreground their material properties, such as the variety and vibrancy of colours or the fluffiness of their appearance, made feather-workers virtuosos in material transformation and presentation. When confronted with what Hernán Cortés described as the natural perfection of New World feathers, the splendour of which had been nowhere-else-seen, ${ }^{61}$ European artisans started to dye feathers of domestic and foreign birds, such as ostrich feathers, by applying intricate techniques. Accepting "the sensorial impact and role of these material things, ${ }^{12}$ means to conceptualize featherworking as acts of material engagement through the study of feather-workers' skills, creativity, and knowledge as a result of extended human-things relationships. ${ }^{63}$

Responding to the intricacy of virtuoso skills for material transformation, guild regulations predominantly addressed questions of apprenticeship. After six years of learning, Parisian apprentices had to craft featherwork in the presence of the guild's most honourable members, who examined the quality of the piece before granting the apprentice the title of a maitre. ${ }^{64}$ In Leipzig, apprentices had to manufacture two different panaches within six weeks - a time span that highlights how time consuming it was to prepare and dry every plume and to sew them together into a panache. The first task was a large panache of twenty feathers dyed in at least three colours with an aigrette at its upper end and three feathers of more than 1 metre in length each tied to the panache's lower end in what was called the "Roman manner." The second panache had to comprise thirty feathers on each side; positioned on its upper end, the panache's three white aigrettes had to be framed by twelve small feathers. In an interim audit, the guild's elders examined the quality of all dyed and processed feathers before allowing the apprentice to

60 BnF, ms. fr. 21798, 238rf.: "reparé les defauts de la nature, captiuer la bienueillance des cœurs des plus grands de la terre, par le trauail de leurs mains."

61 Pascual de Gayangos, ed., Cartas y relaciones de Hernan Cortés al Emperador Carlos V (Paris: Imprenta Central de los Ferro-Carriles, 1866), 101, 109; Alessandra Russo, The Untranslatable Image: A Mestizo History of the Arts in New Spain, 1500-160o (Austin, TX: University of Texas Press, 2014), 20-28.

62 Yannis Hamilakis, Archaeology of the Senses: Human Experience, Memory, and Affect (Cambridge: Cambridge University Press, 2013), 181f.

63 Cf. Hanß, "Material Creativity of Affective Artefacts in the Dutch Colonial World."

64 BnF, ms. fr. 21798, 231r-232v. 
continue manufacturing them into panaches. At least five years of training were needed to master that exam. ${ }^{65}$ In Nuremberg, feather-workers were prohibited to train maidservants and only one apprentice was allowed to be employed for a maximum of five years. Afterwards, artisans had to wait at least one year before hiring a new trainee. ${ }^{66}$

Such regulations framed labour markets by limiting access to profitable businesses, ensuring high prices, and forming artisanal communities. Furthermore, guilds regulated the period an apprentice might spend learning complex techniques. Around 1550, Bartholomäus Viatis still served his master as an apprentice of seven years. His autobiography foregrounds not only his time of hardship, but also his self-awareness of having turned from an apprentice into a virtuous artisan. The feather-worker proudly stated that his apprenticeship served him "to learn to work, ${ }^{n 67}$ thus, to become proficient in skilled featherworking through repetitive and innovative exercises in material engagement. In the end, Viatis's hands knew what to do: ${ }^{68}$ his featherwork featured the same quality as the products of artisans with an income of 80 gulden. "Without aspiring to fame," Viatis states, "nobody else in this city was able to sew feathers in the same manner except fully [trained] feather-workers." ${ }^{\prime 69}$ In response to the increase of feather-workers, guilds' restrictions also ensured the quality of the crafts as well as its focus on intricate, hands-on knowledge, further promoting a climate of competition and innovation. ${ }^{70}$

Acquiring material proficiencies through sensorial experience and prolonged engagement was crucial for the transformation of feathers into cherished featherwork. Featherworking artisans had to develop skills that relied on tacit knowledge and their amenability towards sensory feedback.${ }^{71}$ Different affordances characterized the various types of feathers of different species, which shaped the possibilities of their manufacture and required different treatments..$^{72}$ Feather-workers, therefore, differentiated between "primary" and "secondary" ostrich feathers according to their age when being plucked. ${ }^{73}$ This coincides with a more general trend of the time: the early modern period experienced an increasing interest in the world's material

65 StadtAL, LXIV Nr. 46, 15rf., 18r-19r.

66 Jegel, Handwerksrecht, 511.

67 StAN, E1/1905, Nr. 1, 1 (1579).

68 David A. Rosenbaum, Knowing Hands: The Cognitive Psychology of Manual Control (Cambridge: Cambridge University Press, 2017).

69 StAN, E1/1905, Nr. 1, 1v.

70 Stephan R. Epstein and Maarten Prak, eds., Guilds, Innovation and the European Economy, 1400-180o (Cambridge: Cambridge University Press, 2009).

71 Malafouris, Things, 79-82, 207-226.

72 Gibson, "Affordances."

Diderot and d'Alembert, Encyclopédie, 12:80o. 
details. Feathers rated among the first objects examined under microscopes. Published in treatises and encyclopaedias, the results of such investigations created further knowledge about the physical composition of feathers and the extent to which details like barbules mattered for the colour, form, and shape of feathers. ${ }^{74}$ For feather-workers, such knowledge manifested in hands-on experience and expertise that, consequently, started to matter to enlightened encyclopaedic enterprises. In order to curl feathers, for instance, artisans had to fix feathers with the left hand while using a special knife (couteau à friser) with the right. The ways in which feather-workers' right thumbs applied fine doses of pressure on the barbs, as we read in encyclopaedias and manuals, defined the feather's shape and quality: only those pieces which required corrections had to be treated, as the entire object's beauty could be easily damaged if too much pressure was applied (Fig. $3 \cdot 3)^{75}$ The intricacy of this and similar techniques, which required dexterity and malleability of the grip of the hand, often made feather-workers start their six-year-long training in childhood..$^{6}$

Feather-workers' cognitive world of embodied skills, tacit knowledge, and material proficiency manifests in surviving objects and resonates with sixteenth-century artisanal epistemology's new focus on bodily engagement with nature and matter. ${ }^{77}$ It took years to gain perfection in turning observation into action when processing plumage, since apprentices needed to train their hands and eyes by experimenting with materials and acquiring routines in performing techniques. Artisans had to learn how to sew feathers onto a bonnet with the help of a ribbon and how to fold the starched brim, or to attach a loop, in order to hide the stitches from view (Fig. 3.4..$^{7}$ Around 160o, a leather cap was decorated with cords, metal threads, and two cartouches that fixed in place the heraldic emblem and the panache. Starched parchment filled with animal hair and threads built the skeleton of the cartouche, into which feather quills were positioned. Artisans then fixed the panache with three stitches above the cartouche (Fig. 3.5). ${ }^{79}$

Manufacturing feathers of domestic and foreign species meant applying highly intricate and experimental techniques, as Lucas Cranach the Elder's portraits of the

74 Richard Hooke, Micrographia: or some Physiological Descriptions of Minute Bodies made by Magnifying Glasses with Observations and Inquiries thereupon (London: John Martyn, 1665), 167-169, scheme XXII; Diderot and d'Alembert, Encyclopédie, 12:799.

75 Élisabeth-Félice Bayle-Mouillard, Manuel du fleuriste artificiel [...] (Paris: Roret, 1829), $220 f$.

76 AN, MC/ET/III/489 (1610/11/11).

77 Pamela H. Smith, The Body of the Artisan: Art and Experience in the Scientific Revolution (Chicago, IL: University of Chicago Press, 2004).

78 HM, L1435f.; Alheidis von Rohr, “Kleidung eines Patriziers aus Einbeck vom Ende des 16. Jahrhunderts," Waffen- und Kostümkunde 18 (1976): 69-75.

79 GNM, T1593; Jutta Zander-Seidel, ed., In Mode: Kleider und Bilder aus Renaissance und Frühbarock (Nuremberg: Germanisches Nationalmuseum, 2015), 13of. 


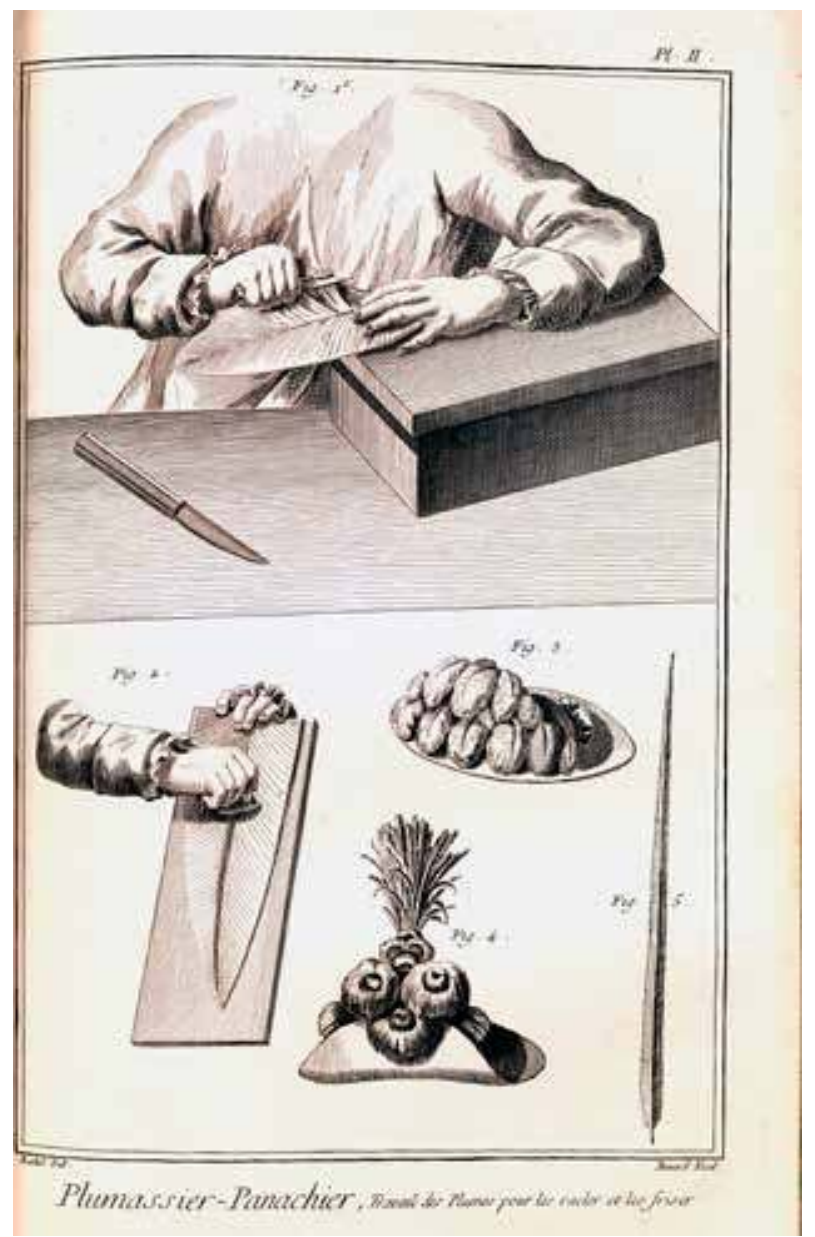

Figure 3.3: Unknown artist, "Plumassier panachier." Engraving, $418 \times 267 \mathrm{~mm}$. In Denis Diderot and Jean-Baptiste le Rond d'Alembert, Encyclopédie, vol. 8, Paris: Briasson etc., 1771, plate II. Cambridge, Library of St John's College, Kk.7.59. Image @ By permission of the Master and Fellows of St John's College, Cambridge.

Elector of Saxony, painted in the 1520s, further demonstrate (Fig. 3.6). To match the entire apparel, feathers could be dyed either in red-gold and dark-silver, or bleached, and each group of barbs were curled. Being decorated with pearls and gold spangles that weighed down their shape granted feathers a dignified resonance when being moved. Such featherworking crafted a material presence that made feathers instantiate splendour. Another telling example is the beret given by Emperor Charles V to Christoph Kress zu Kressenstein, the Nuremberg envoy at the Imperial Diet in Augsburg in 1530 (Fig. 3.7). Artisans stitched the feathers with wires and threads onto the beret. Craftsmen diligently attached twisted metal threads and spangles, 


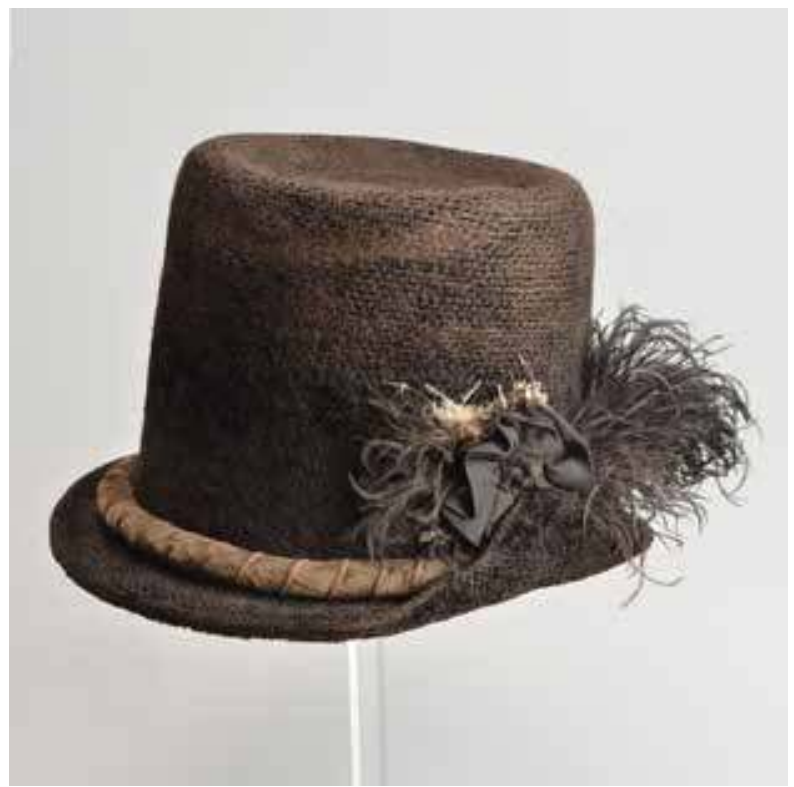

Figure 3.4: German hat with partially destroyed ostrich feathers, late sixteenth century. Felt, woven silk satin, and ostrich feathers, c. $170 \times 290 \times 280$ mm. Hannover, Historisches Museum Hannover, inv. no. L 1436 . Image $\odot$ Historisches Museum Hannover. Photo: Reinhard Gottschalk.

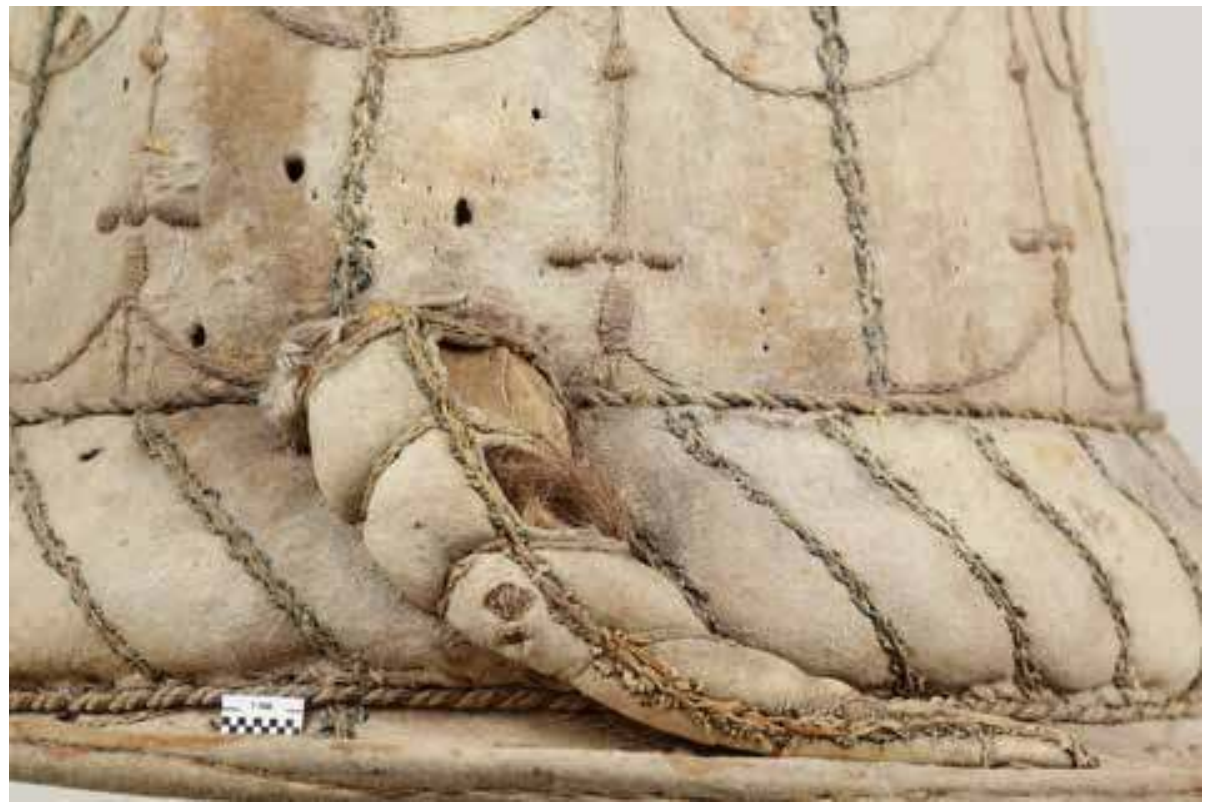

Figure 3.5: Cartouche used to attach panaches onto a leather hat, ca. 1600. Leather, starched parchment, animal hair, and threads, $268 \mathrm{~mm}$ diameter and $190 \mathrm{~mm}$ height of the entire hat. Nuremberg, Germanisches Nationalmuseum, inv. no. T1593. Image @ Germanisches Nationalmuseum, Nürnberg. Photo: Petra Kreß. 


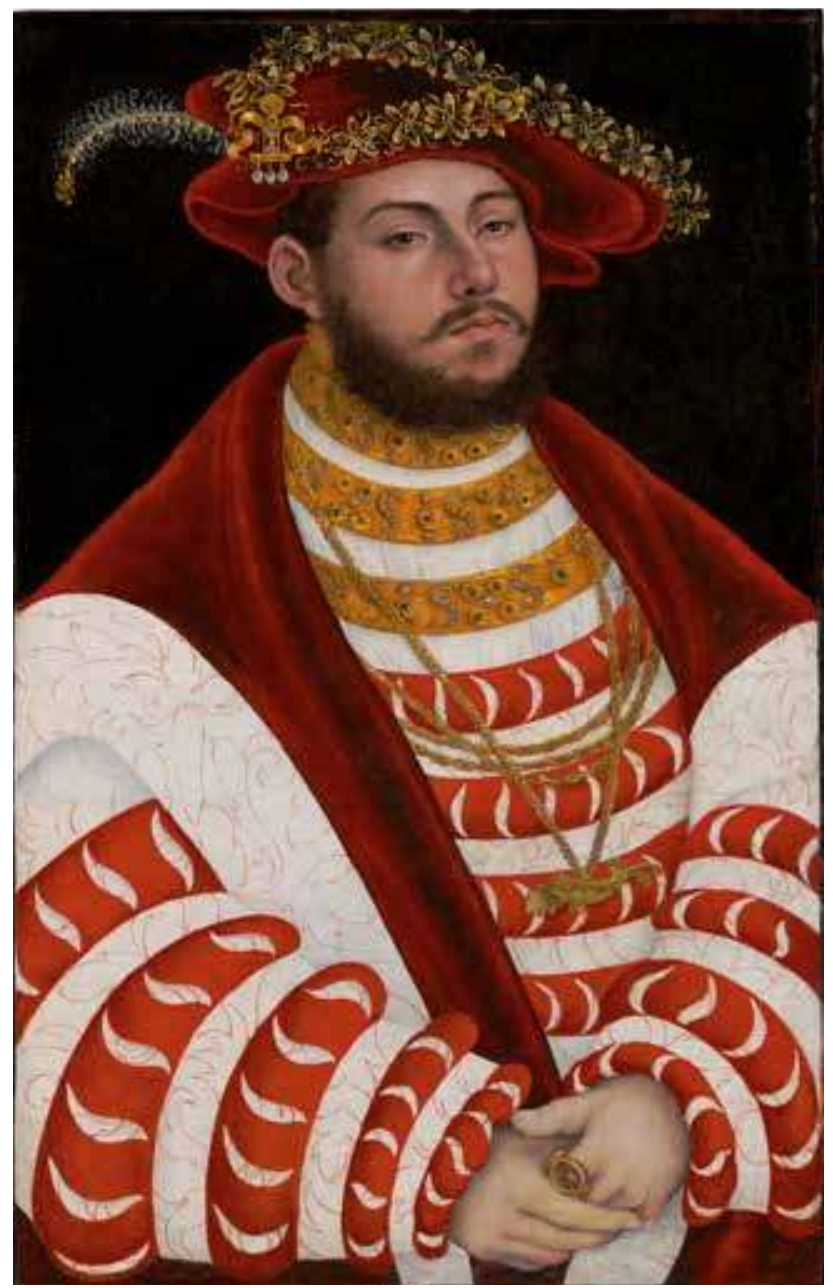

Figure 3.6: Lucas Cranach the Elder, Portrait of John Frederick I, Elector of Saxony, unknown date. Oil on panel, $628 \times 397 \mathrm{~mm}$. Private collection. Image $\odot$ Christie's Images/Bridgeman Images.

punched out of silver gilt, into the feathers to create colour contrasts. ${ }^{80}$ Such objects, as southern German and English documents reveal, often adorned feathers. ${ }^{8}$ After the death of the Württemberg court feather-worker Hans Dannenritter, his widow continued to sell feathers, gold, and silver threads. ${ }^{82}$ Sixteenth-century Augsburg inventories even contain references to Spanish spangles, which were themselves

80 GNM, T3784; Zander-Seidel, Mode, 4off., 272.

81 Janet Arnold, Queen Elizabeth's Wardrobe Unlock'd: The Inventories of the Wardrobe of Robes prepared in July 1600 [...] (Leeds: British Library, 1988), 201.

82 HStAS, A256 vol. 91, 339r. 


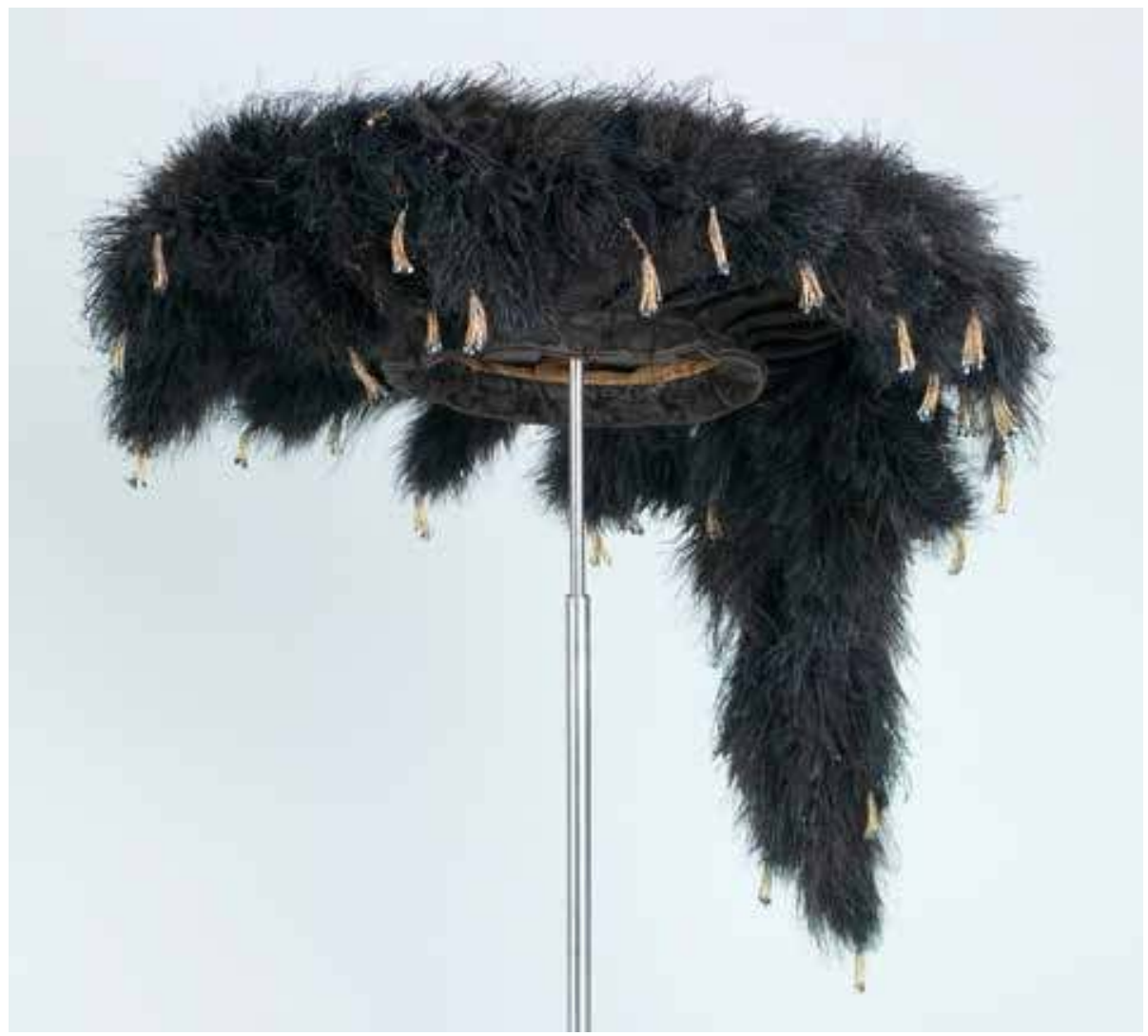

Figure 3.7: The feather-beret of Christoph Kress zu Kressenstein, 1530. Silk satin, ostrich feathers, wires and spangles, $550 \mathrm{~mm}$ diameter. Nuremberg, Germanisches Nationalmuseum, inv. no. T3784. Image $\odot$ Germanisches Nationalmuseum, Nürnberg. Photo: Monika Runge.

"melted like feathers." 83 Two panaches with thirty-six golden spangles cost the substantial amount of 66 gulden in Stuttgart in $1602 .^{84}$

Such innovative acts of creativity, resulting from the artisans' experimental engagement with feathers, served to foreground exactly those properties of featherwork that were held in high esteem. For this reason, feather-workers (Federmacher) became more and more feather-decorators (Federschmücker), whose work was praised for its delicatesse. ${ }^{85}$ Hans Dannenritter, Adam Eßlinger, Wolfgang Wolf, and Jacob Unangst, all courtly feather-workers in Stuttgart, were compensated

83 Norbert Lieb, Octavian Secundus Fugger (1549-160o) und die Kunst (Tübingen: Mohr, 1980), NI209, 325 .

84 HStAS, A256 vol. 89, $382 \mathrm{v}$.

85 BnF, ms. fr. 21798, $229 v$. 
for dyeing feathers and turning them into panaches of either fluffy or pointed appearance. Yet these artisans also manufactured hats; they produced metal threads, sewed garters, and engaged in silk embroidery. ${ }^{86}$ Similarly, Nuremberg feather-workers sold feathers alongside borders and trims. ${ }^{87}$ In the vibrant craft atmosphere of early modern European cities, feather-workers maintained close contacts with jewellers, goldsmiths, wiredrawers, tailors, and clock-makers. ${ }^{88}$ Especially in Paris, feather-workers' experimenting hands established a craft of highly refined and widely purchased luxury products: maitres manufactured feathers into civil and military panaches, headdresses, headwear composed out of several levels, head adornments, hairbows, woven and stitched feather textiles, necklaces, muffs, masks, and garlands, and bouquets of feathers and flowers for men, women, children, horses, and mules alike or as banqueting, altarpiece, funeral, carriage, and street decorations. Peacock feathers were sewn onto garlands. Black fleurs-aigrettes - composed out of cock, raven, and turkey feathers - as well as feathered baldachin decorations staged feelings of sorrow and loss during funerals, while white feathered wings were widely used for performances of angels during processions. ${ }^{89}$ In her shop in the rue Dauphine, Marie Thérese Guerrier sold five muffs made out of black cock feathers for 12 livres and 10 sols; four arrangements of cock feathers to be attached to textiles, meanwhile, cost 48 livres. Besides this, she also owned "three indigenous capes of different colours" as well as chinoiserie vestments. ${ }^{90}$ French artisans produced feather tapestries and decorated entire furniture with feathers. A bed adorned with more than 50,00o feathers of hens, ducks, jays, peacocks, and pheasants, produced by a French feather-worker active in London, was purchased by August II of Saxony in 1723. He then commissioned the bed curtains to be further processed into wall decorations that then decorated the Dresden "feather chamber."91

Being artists in their own right, feather-workers' subtle creativity also attracted the interest of painters. Niklaus Manuel shows how various layers of fluffy ostrich feathers, oversized yet elegantly curled, are fixed to a man's cap (Fig. 3.8). A bell

\footnotetext{
86 Hanß, Court and Material Culture.

87 StadtAN, GSI152, Obj.Nr. 58.725 .

88 StadtAN, E1/1158, Nr. 1, 4rf., 7r, 12r; B14/I, Nr. 181, 102v; B14/I, Nr. 133, 246vff.; B14/II, Nr. 13, 8v; AN, MC/ $\mathrm{ET} / \mathrm{XXIII} / 123$ (1611/og/08); MC/ET/XXX/475 (1782/04/06).

89 BnF, ms. fr. 21798, 23ov; Denis Diderot and Jean B. d'Alembert, eds., Encyclopédie ou Dictionnaire raisonné des sciences, des arts et des métiers, vol. 2 (Paris: Briasson et al., 1751), 366, 626; "Plumassier panachier," Denis Diderot and Jean B. d'Alembert, eds., Encyclopédie ou Dictionnaire raisonné des sciences, des arts et des métiers, vol. 8 (plates) (Paris: Briasson, 1771), pl. IV; AN, MC/ET/XXXIII/24, 266v; Bayle-Mouillard, Manuel, 225.

90 AN, MC/ET/XXVII/457 (1784/03/29), 5r, 6v, $9 \mathrm{v}$.

91 Bayle-Mouillard, Manuel, 228-230; Cornelia Hofmann, Das Federzimmer Augusts des Starken (Dresden: Verlag der Kunst, 2003).
} 


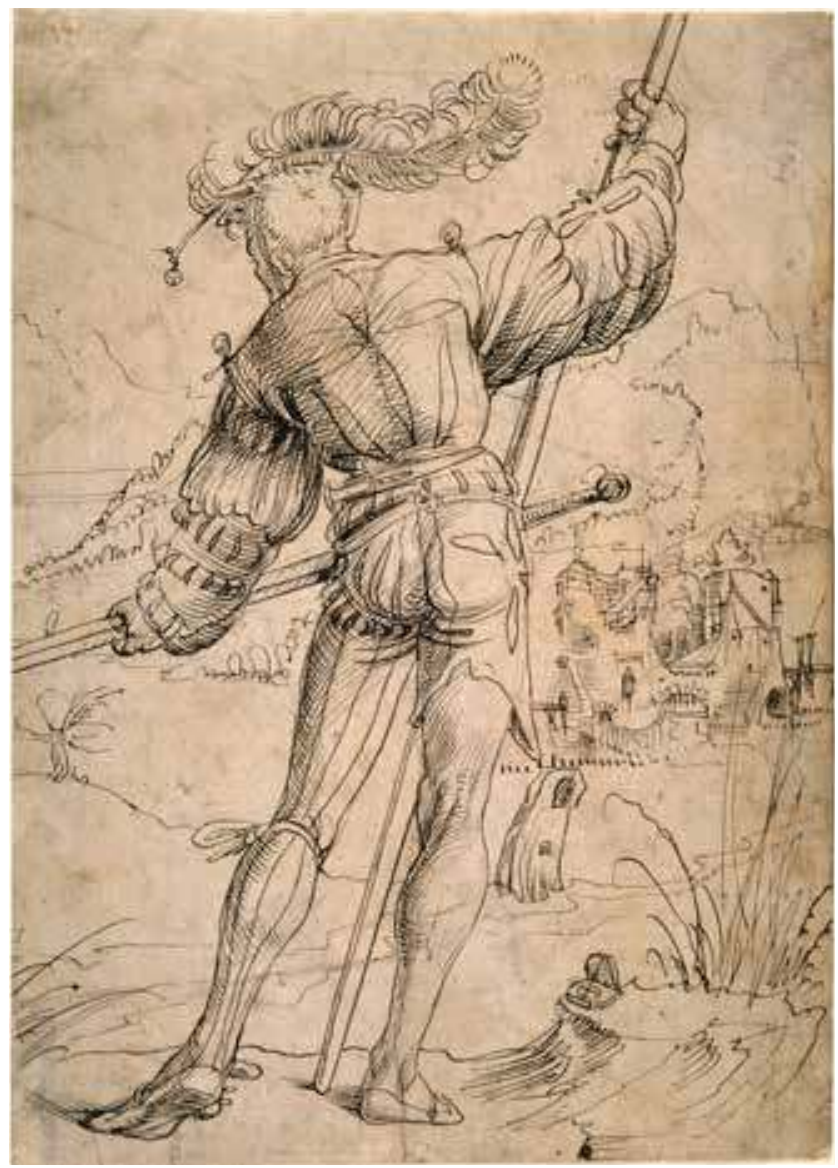

Figure 3.8: Niklaus Manuel, Back View of a Confederate, 1514-1515. Ink drawing, $272 \times 191 \mathrm{~mm}$. Bern, Graphische Sammlung, Kunstmuseum Bern, inv. no. A1979.100. Image @ KMBern.

is tied to the quill as it adorns and balances the construction. Alluding to a fool's jingles, the bell also makes satirical associations. The artisans' skills emphasized the fluffy appearance and elegantly curved motility of feathers, a characteristic that the artist uses to capture the aesthetics of chivalry, gracility, and ease. Given the significance of fashion for the shaping of Renaissance bodies, feathers featured prominently in early modern "polychrome sculpting." ${ }^{\text {"2 }}$ Exuberantly long feathers, for example, heavily affected the performance of postures and gestures. Feathers' delicate appearance not only multiplied gracile movements and the bodily poise, but also demanded a set of certain postures that relied on the body's upright positioning,

92 Ulinka Rublack, "Renaissance Dress, Cultures of Making, and the Period Eye," West 86th: A Journal of Decorative Arts, Design History, and Material Culture 23 (2016): 6-34. 


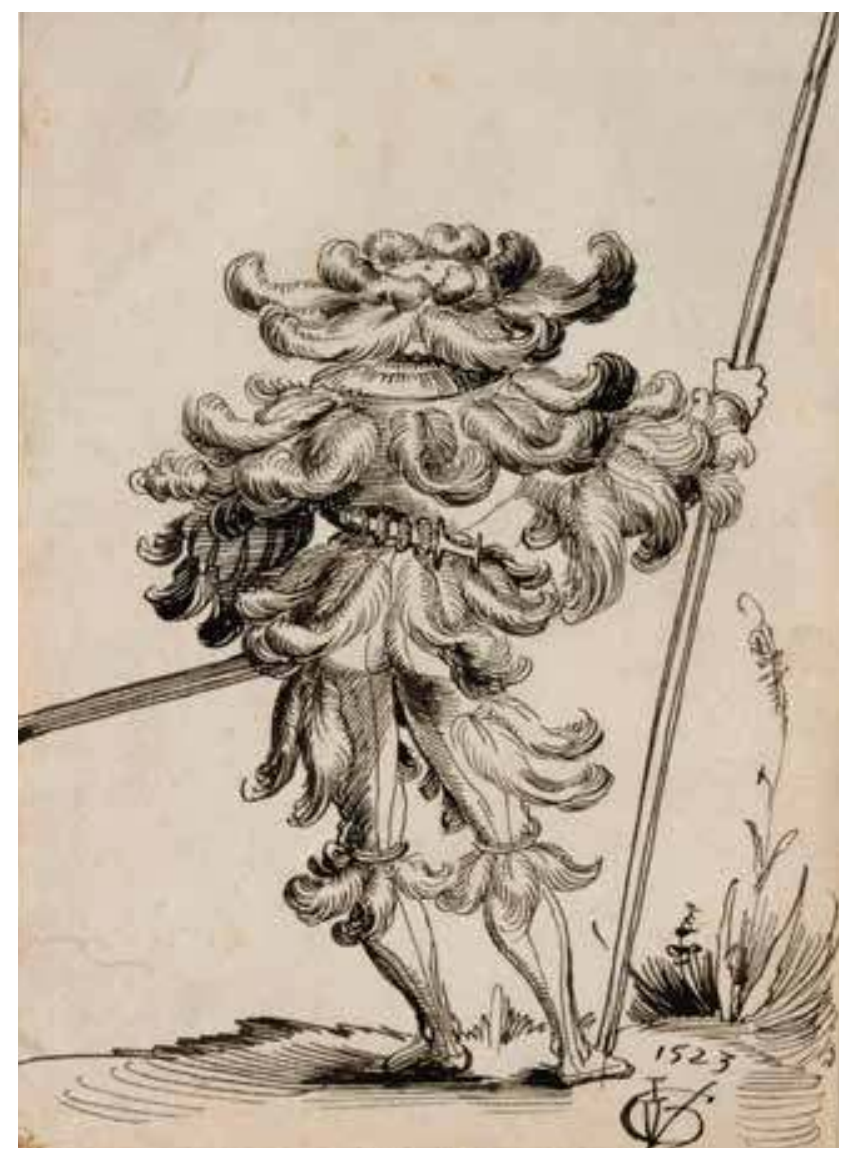

Figure 3.9: Urs Graf, Mercenary's Feather Costume, 1523. Ink drawing, $215 \times 153 \mathrm{~mm}$. Basel, Kunstmuseum Basel, U.X.95. Image @ Bilddaten gemeinfrei Kunstmuseum Basel.

tension, and balance. An awareness for how feathers "would come alive on the body of a wearer through their properties [...] and through movement"93 reveals how materials laboured on and with the body, thereby shaping bodily appearances and aesthetics such as chivalrous or flirtatious registers. ${ }^{94}$ Feather-workers' proficiency in the aesthetic transformation of materials made feathers stage bodily and emotional aesthetics. Artisans and artists were amazed by such transformative acts also visible in mercenary costumes, to whose fabrics, caps, belts, and garters a plethora of feathers could be sewn (Fig. 3.9). Staging luxury as well as haughtiness, pride,

93 Ibid., 7; Denis Bruna, ed., Fashioning the Body: An Intimate History of the Silhouette (New Haven, CT: Yale University Press, 2015).

94 Hans Schäufelein, The Wedding Dancers, ca. 1530 s. Print, $263 \times 214 \mathrm{~mm}$, The British Museum, London (BM), Print \& Drawings, E, 8.114. 
and satire, such virtuoso material and visual performances made featherwork a galanterie, which Augsburg art dealer Philipp Hainhofer, when being placed under house arrest by Swedish troops, was even able to use as a bribe to buy his freedom. ${ }^{95}$

\section{Material Assemblages: (Re)Making Feather-Workshops}

Artisans' workshops (Fig. 3.10) comprised several storerooms with deliberate spatial arrangements. In studios (ateliers) with wooden furniture, tables, candlesticks, sinks, vases, chests, hearths, caldrons, tubs, instruments, and a variety of natural materials, feather-workers manufactured and dyed feathers or worked with flowers. Feathers were stored in caskets, boxes, bunches, and bags in separate rooms (magasins). While a small bunch could contain, as in a couple of cases, 136 or 248 heron feathers, another recorded bunch only stored four male egret feathers; surely this was because of these feathers' particular delicacy, which was the yardstick for their quality and price. If this material characteristic had already been damaged, such garzotti were additionally stored in bunches of hundreds, which facilitated counting. ${ }^{6}$ Account books and manuscripts were kept separately. In the store (boutique), display drawers (étalages) presented the feather pieces and mirrors helped to convince customers to purchase the goods. ${ }^{97}$

Hitherto unknown inventories of feather-workshops in early modern Venice, Paris, and Madrid highlight their character as complex aggregations of materials and things: assemblages that, due "to the vitality of the materialities that constitute it," shaped one's "understandings of life and matter" as much as they engendered craft production. ${ }^{8}$ In such workshops, the artisan's embodied skills met with an assemblage of materials with their own distinct affordances; a productive convergence that shaped both the routines and innovations of feather-workers' material engagement. ${ }^{99}$ The sheer quantity and diversity of feathered products resulting from such acts of material engagement are striking. In 1592 and 1634, the Venetian stores of

95 SUSBA, $2^{\circ} \operatorname{Cod}$ S68, 6v (1632/o4/14); Christoph Emmendörffer, "Wunde Welt: Hainhofers Diarium der schwedischen Besatzung Augsburgs," in Wunderwelt: Der Pommersche Kunstschrank, ed. Christoph Emmendörffer and Christof Trepesch (Berlin and Munich: Deutscher Kunstverlag, 2014), 471.

96 ASVe, Giudici di petizion, inventari di eredità, tutele, curatele, oppure richiesti in causa, b. 36o/25, n. 79 (1647/10/12), 6r; b. 340/5, n. 55 (1591/01/12 m.v.), 1vf.

97 AN, MC/ET/XCVIII/716; MC/ET/LXXXIV/27 (1585/o2/21); MC/ET/XXVII/457 (1784/o3/2), 3r; MC/ET/ XXIII/477 (1731/06/o9).

98 Hamilakis and Jones, "Archaeology and Assemblage," 81; Jane Bennett, Vibrant Matter: A Political Ecology of Things (Durham, NC and London: Duke University Press, 2010), 34; Beatriz Marín-Aguilera, "Inhabiting Domestic Space: Becoming Different in the Early Iron Age Western Mediterranean," Journal of Mediterranean Archaeology 31, no. 1 (2018): 77-100.

99 Gibson, "Affordances"; Malafouris, Things. 


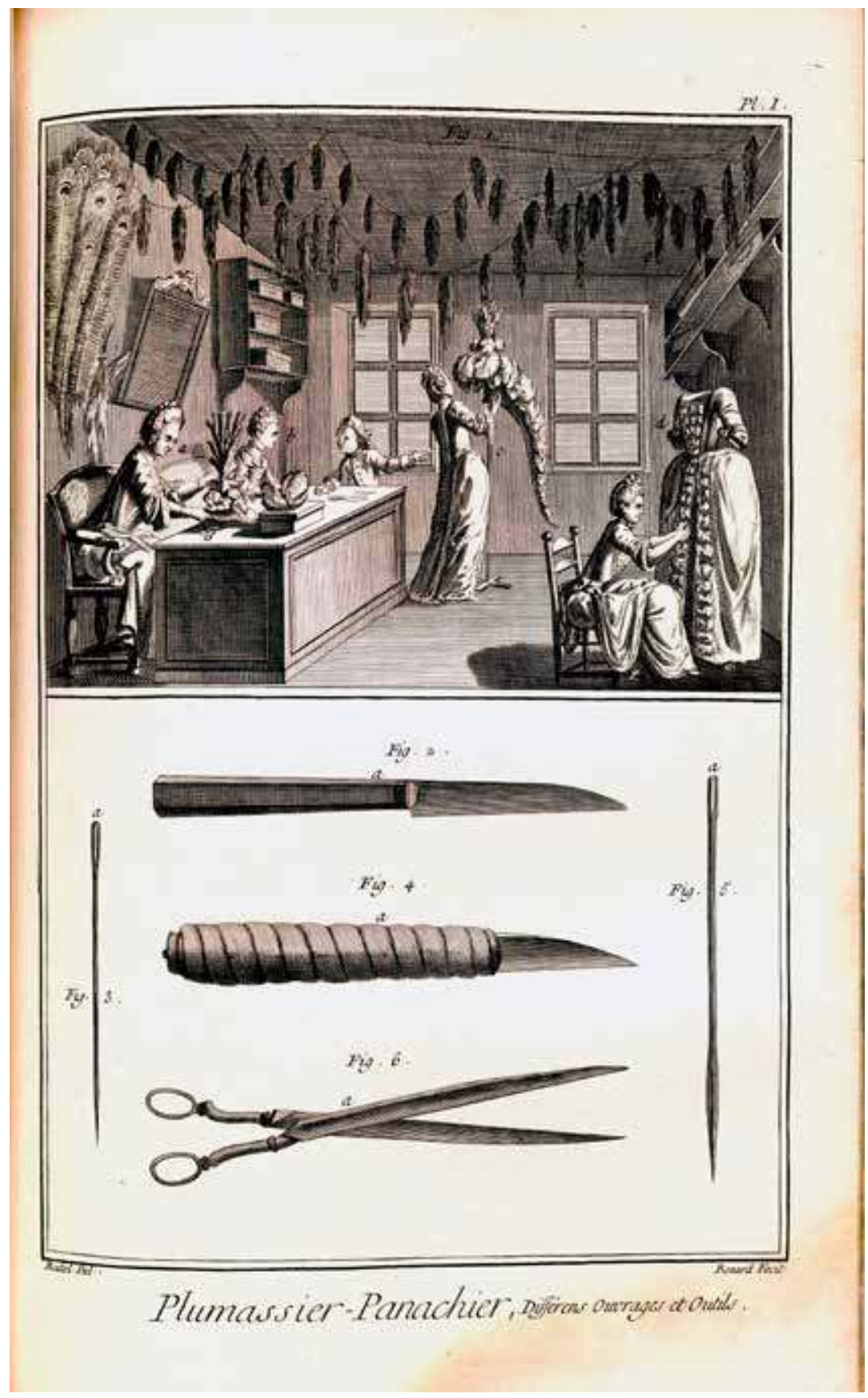

Figure 3.10: Unknown artist, "Plumassier panachier": A Parisian feather-workshop and some of its instruments. Engraving, $418 \times 267$ mm. In Denis Diderot and Jean-Baptiste le Rond d'Alembert, Encyclopédie, vol. 8, Paris: Briasson etc., 1771, plate 1. Cambridge, Library of St John's College, Kk.7.59. Image ® By permission of the Master and Fellows of St John's College, Cambridge. 


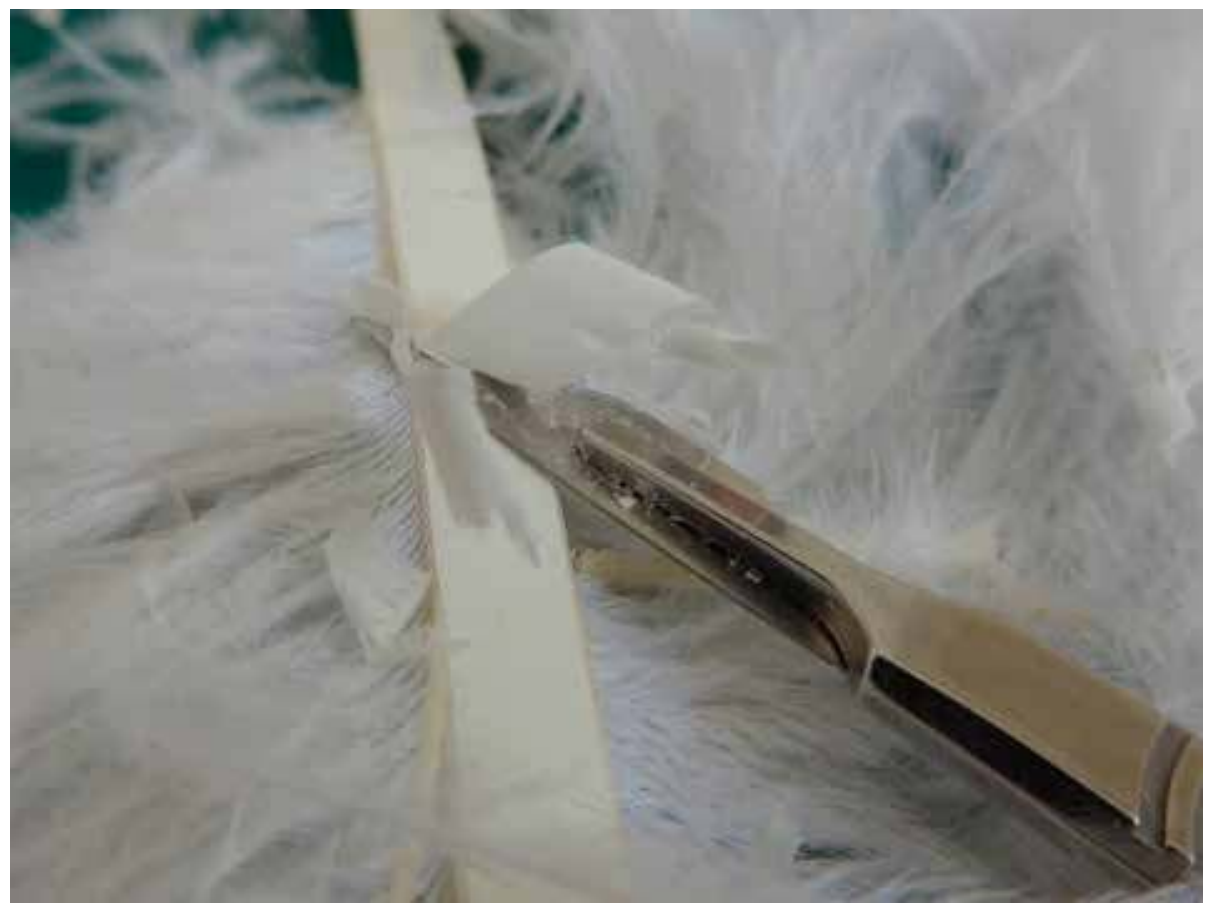

Figure 3.11: Carving ostrich feathers while remaking feather-work at The School of Historical Dress in London. Image ๑ Stefan Hanß.

the pennachieri Giacomo Savioni and Girolamo Zoni held 30,431 and 4,293 feathered items respectively. Near San Salvador, marzer Battista Duceardi offered more than 128,955 feathers and feather products in 1587 . Five minutes away, on the Rialto Bridge, feather-worker Francesco Maselli held 12,375 feather products in $1647{ }^{100}$ Conceptualizing such feather-workshops as assemblages means to examine the actual making of featherwork as an example of processual human-things relationships. The integration of remaking experiments conducted with Jenny Tiramani and Ulinka Rublack at The School of Historical Dress in London on 27 April 2017 helps reconsidering the challenges, demands, constraints, and possibilities of such human-things relationships. Remaking, in this sense, helps unfolding the artisans' sensory engagement with their material surroundings (Figs. 3.11 and 3.12).

Inventories reveal the vibrancy of the trade in domestic and foreign bird feathers, all of them maintaining striking properties: feathers of herons (soft), egrets (delicate, spiky), ostriches (fluffy), swans (white), parrots (colourful), and birds of paradise 


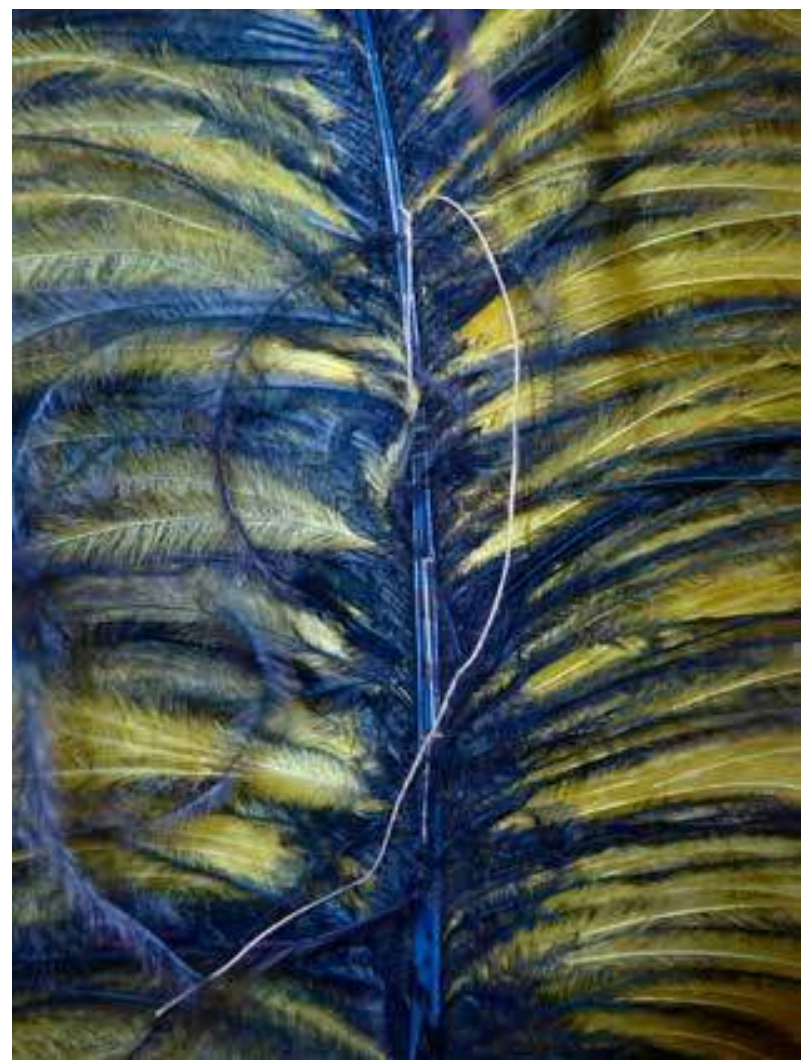

Figure 3.12: Dyed blue and yellow ostrich feathers sewn together at The School of Historical Dress London. Image $\odot$ Stefan Hanß.

(iridescent). Such qualities defined the aesthetic, visual, tactile, and emotional resonances of featherwork and made artisans invest in mercantile networks. Parisian artisans manufactured feathers from the Netherlands and England. ${ }^{101}$ Egyptian herons and North African ostrich feathers had been traded in early modern Venice since at least the late Middle Ages, in fact..$^{102}$ The night heron's white feathers arrived in Madrid from the Spanish Duchy of Milan. ${ }^{103}$ Taxidermy was particularly suitable as this bird's feathers were already cleansed from preen oils. Strikingly colourful American feathers arrived in Seville and were further traded. In Prague, Rudolf II collected not only the feathers of parrots, but also the feathers of swallows and

$101 \mathrm{AN}, \mathrm{MC} / \mathrm{ET} / \mathrm{VIII} / 530$ (1561/11/21); MC/ET/XXVII/457 (1784/03/29), 8v-10r.

102 Nile Green, "Ostrich Eggs and Peacock Feathers: Sacred Objects as Cultural Exchange between Christianity and Islam," Al-Masāq 18 (2006): 27-66; Abraham David, "Jewish Involvement in Ostrich Feathers Trade between Egypt and Venice in the 16th Century as Reflected in Documents from the Cairo Genizah," Judaica: Beiträge zum Verstehen des Judentums 74/1-2 (2018): 82-95. 103 AGP, Administración General, leg.5.260, exp.1 (1584). 
egrets as well as "indigenous red feathers to tie"; that is, Amazonian feathers to be attached to textile pieces like "indigenous caps" and a "feather cape" that were likewise collected. ${ }^{104}$ For purchasing such rarities, the Stuttgart court bought indigenous feather-costumes, parrots, and parrot feathers from the Nuremberg stores of Levin Hulsius and Zacharias Ringsgewanden in 1597/98. ${ }^{105}$ This Württemberg court regularly purchased feathers and featherwork from Nuremberg, but also from Augsburg and Amsterdam. ${ }^{106}$ The grandchild of Nuremberg feather-worker and later successful merchant Bartholomäus Viatis, Johann Andreas (1625-1698), owned "an indigenous dress, studded with rare feathers, and similar caps and shoes" as well as "one still quite well preserved bird-of-paradise."107 Birds of paradise, rare species from the Maluku Islands and the Indonesian archipelago that were also traded by the Venetian feather-worker Maselli in 1647, were imported to the Mediterranean via either the Asian route along the Mughal, Safavid, and Ottoman courts or from the Spanish Philippines via colonial Mexico. ${ }^{108}$ The Leipzig and Frankfurt fairs as well as the activities of journeying peddlers further vitalized the supra-regional flow of feathers, tying dense and vibrant material webs across Europe and the globe. ${ }^{109}$

Plumage of birds of paradise, cranes, and parrots were extremely rare and globally traded commodities, yet the feather craze went along with the rediscovery of domestic aviculture that resulted in a whole specialized branch of the business of fowling that developed dextrous strategies for capturing birds without harming their plumage. ${ }^{110}$ Some Venetian artisans used feathers of the corn bunting and calandra lark as the plumage was characterized by a shiny brown hue, a quality that contemporaries appreciated when studying New World birds. ${ }^{111}$ When estimating the possessions of Savioni in the early 1590s, two fellow feather-workers stated that

104 AGI, Indiferente General, 420, L.8, 6or; Audiencia de Santa Fe, 987, L.2, 14v; Paula Findlen, "Afterword: How (Early Modern) Things Travel," in The Global Lives of Things: The Material Culture of Connections in the Early Modern World, ed. Anne Gerritsen and Giorgio Riello (London: Routledge, 2016), 241-246; Zimmermann, "Inventar," XX, XXXIII, LXf. On taxidermy, cf. Hanß and Rublack, "Knowledge Production." 105 HStAS, A256 vol. 85, 372r, 376vf.

106 HStAS, A256 vol. 85 (1597/98), 378r; A256 vol. 86, 371v; A256 vol. 87, 362r; A256 vol. 93, 364r; A256 vol. 95, 365br; A256 vol. 96, 333v, 337rf.; A256 vol. 97, 338ar.

107 StAN, E1/1905, Nr. 18, 4v.

108 José Ramón Marcaida López, “El ave del paraíso: historia natural y alegoría," in Alegorías: imagen y discurso en la España Moderna, ed. María Tausiet (Madrid: Consejo Superior de Investigaciones Científicas, 2014), 93-108; Claudia Swan, "Exotica on the Move: Birds of Paradise in Early Modern Holland," Art History 38 , no. 4 (2015): 621-635.

109 StadtAL, LXIV Nr. 46, 23r; HStAS, A256 vol. 89, 382v.

110 Giovanni P. Olina, Vccelliera overo discorso della natvra, e proprieta di diversi vccelli [...] (Rome: Andrea Fei, 1622); Hanß and Rublack, "Knowledge Production."

111 Peter Martyr (Pietro Martire d'Anghiera), De Orbe Novo Decades I-VIII, ed. Rosanna Mazzacane and Elisa Magoncalda, 2 vols. (Genoa: Dipartimento di archeologia, filologia classica e loro tradizioni, 2005), IV $9,12-17$. 
Table 3.1: Taxidermies, feathers, and featherwork in the Venetian shops of Battista Duceardi (1587), Giacomo Savioni (1592), Girolamo Zoni (1634), and Francesco Maselli (1647)

\begin{tabular}{lcccc}
\hline feather-related items & Duceardi & Savioni & Zoni & Maselli \\
& $(1587)$ & $(1592)$ & $(1634)$ & $(1647)$ \\
\hline
\end{tabular}

\section{feathers and taxidermy}

heron feathers

black heron feathers

480

heron feathers to be bunched together

heads and necks of herons

2,400

heads of white herons

necks of white herons

300

necks of black herons

black herons, presumably in their entire stature

Egyptian herons

700

5,895

3,200

particularly small feathers of the corn bunting

feathers of the calandra lark

300

2,500

3,800

male egret feathers

dyed male egret feathers

white and dyed male egret feathers

18,600

70,000

200

200

125

crane feathers

170

parrot feathers

feathers of the bird of paradise

processed ostrich feathers

raw, untreated ostrich feathers (pene greze)

black, second-hand

405

in a single layer

1,200

ostrich feathers (pene)

black and white ostrich feathers of small and large

size

black ostrich feathers

black ostrich feathers, to be washed starched black ostrich feathers of small size 


\begin{tabular}{lcr}
\hline feather-related items & $\begin{array}{c}\text { Duceardi } \\
(\mathbf{1 5 8 7})\end{array}$ & $\begin{array}{r}\text { Savioni } \\
\text { (1592) }\end{array}$ \\
\hline $\begin{array}{l}\text { starched black and white ostrich feathers of medium } \\
\text { and large size } \\
\text { black ostrich feathers put aside for a fan }\end{array}$ & 175 & 750 \\
\hline
\end{tabular}

halved ostrich feathers (mezze penne), white or dyed

single ostrich feathers (ugnole/ugniole)

white

white, to be further processed

1,000

black

black, to be washed

2,700

dyed

dyed in superior quality

50

dyed in inferior quality

dyed and starched

dyed with spotted surface (so-called pene alla madre, pene machiade, or simply machiadille)

two layers of ostrich feathers sewn together (penne doppie)

single ostrich feathers put aside for sewing

starched and doubled ostrich feathers

dyed and doubled ostrich feathers

dyed and doubled ostrich feathers, to be starched

dyed, starched, and doubled ostrich feathers

dyed, starched, and doubled ostrich feathers in

medium and large sizes

doubled ostrich feathers in small size

doubled ostrich feathers in small size, dyed in various colours

starched and doubled ostrich feathers, black and black

starched and doubled ostrich feathers, black and black, medium-sized and in large size

doubled ostrich feathers, white and black

doubled ostrich feathers, white and white, to be

further processed

doubled ostrich feathers, white and dyed

doubled ostrich feathers, white and red

three layers of ostrich feathers sewn together (penne duppie tre pen[n]e I[']una)

tripled ostrich feathers, dyed in excellent quality tripled ostrich feathers, dyed in inferior quality 


\begin{tabular}{|c|c|c|c|c|}
\hline feather-related items & $\begin{array}{c}\text { Duceardi } \\
\text { (1587) }\end{array}$ & $\begin{array}{c}\text { Savioni } \\
\text { (1592) }\end{array}$ & $\begin{array}{c}\text { Zoni } \\
\text { (1634) }\end{array}$ & $\begin{array}{c}\text { Maselli } \\
\text { (1647) }\end{array}$ \\
\hline \multicolumn{5}{|l|}{ manufactured feathers } \\
\hline \multicolumn{5}{|l|}{ ostrich feathers for women } \\
\hline single layers, dyed & 430 & & & \\
\hline grey & 187 & & & \\
\hline ostrich feathers for esquire & 43 & & & \\
\hline \multicolumn{5}{|l|}{ leaf-like shaped feathers (folle) } \\
\hline in a single layer (folle ugnolle) & 800 & & 500 & \\
\hline in a single layer, black & & 400 & & \\
\hline in a single layer, dyed & & & & 1,800 \\
\hline in a single layer, dyed, to be further processed & 651 & & & \\
\hline doubled (folle doppie), white and dyed & $2,225(+x)$ & & 200 & 700 \\
\hline doubled, black, and dyed & & 2,765 & & \\
\hline spear-like shaped feathers (lanzette), smaller/larger size & 1,350 & & 2,000 & \\
\hline white and silver & 76 & & & \\
\hline white and dyed & & & & 28 \\
\hline starched & 225 & & & \\
\hline with a thimble-like top? (Ianzette dazerali) & & & & 335 \\
\hline \multicolumn{5}{|l|}{ panaches } \\
\hline black panaches & & 125 & & \\
\hline panaches, to be washed & 800 & & & \\
\hline starched panaches & & & 400 & \\
\hline small panaches for peasants & & & 30 & \\
\hline panaches for women, to be washed & 16 & & & \\
\hline panaches of a single layer & & 46 & 200 & 110 \\
\hline panaches of a single layer, white and dyed & 372 & & & \\
\hline panaches of a single layer, dyed and starched & 100 & & & \\
\hline panaches of two layers & 525 & & & \\
\hline panaches of two layers, to be further processed & ca. 300 & & & \\
\hline panaches of two layers, starched, large size & 100 & & & \\
\hline panaches composed out of hundred feathers & & & & 1,400 \\
\hline \multicolumn{5}{|l|}{ top part of feathers (cime) } \\
\hline white and dyed & & & & 1,099 \\
\hline out of a single layer of dyed feathers & & 72 & & \\
\hline doubled & & 675 & & \\
\hline doubled, black & 35 & & & \\
\hline doubled, black, starched & 575 & & & \\
\hline small, white & 236 & & & \\
\hline small, dyed & 300 & & & \\
\hline small, dyed, doubled & 57 & & & \\
\hline not clarified group of objects & 250 & & & \\
\hline
\end{tabular}




\begin{tabular}{|c|c|c|c|c|}
\hline feather-related items & $\begin{array}{l}\text { Duceardi } \\
(1587)\end{array}$ & $\begin{array}{l}\text { Savioni } \\
\text { (1592) }\end{array}$ & $\begin{array}{c}\text { Zoni } \\
(1634)\end{array}$ & $\begin{array}{c}\text { Maselli } \\
(1647)\end{array}$ \\
\hline \multicolumn{5}{|l|}{ mattresses (stramazzi) } \\
\hline white & & & & 17 \\
\hline dyed & & & & 16 \\
\hline dyed and small & & & & 15 \\
\hline dyed, medium size & & & & 36 \\
\hline small, dyed in various colours & & & & 56 \\
\hline small, dyed & & & & 30 \\
\hline \multicolumn{5}{|l|}{ caskets with feathers glued onto it } \\
\hline black and white & & & 27 & \\
\hline dyed & & & 50 & 20 \\
\hline separately stored handles & & & & 143 \\
\hline \multicolumn{5}{|l|}{ feather fans (ventagli/ventaggi) } \\
\hline black & 5 & & & \\
\hline white and black & & 1 & & \\
\hline handles for black father fans & 90 & & & \\
\hline old and new white handles made from bone & 23 & & & \\
\hline old and new ivory handles & 12 & & & \\
\hline \multicolumn{5}{|l|}{ small feather fans (ventolline) } \\
\hline produced from dyed male egret feathers & & & & 2 \\
\hline $\begin{array}{l}\text { small feather fans produced from particularly small } \\
\text { feathers }\end{array}$ & & & & 48 \\
\hline dyed/painted (colloratte) & & & 23 & \\
\hline handles for feather fans & & & 24 & 2 \\
\hline \multicolumn{5}{|l|}{ different kinds of feathers stored together } \\
\hline doubled ostrich feathers and panaches, to be starched & & 45 & & \\
\hline feathers from the heron's head and female egret feathers & 150 & & & \\
\hline $\begin{array}{l}\text { doubled ostrich feathers in black and of large size } \\
\text { together with the starched top part of feathers }\end{array}$ & & 200 & & \\
\hline
\end{tabular}

Sources: ASVe, Giudici di petizion, inventari di eredità, tutele, curatele, oppure richiesti in causa, b. 339/4, n. 53; b. 340/5, n. 55; b. 354/19, n. 39; b. 360/25, n. 79.

thirty-six calandra lark feathers corresponded to one ducat and 14 grossi. Seven hundred heron feathers, by comparison, cost 142 ducats. ${ }^{112}$ However, artisans still valued the latter because of their "distinctive structure," which depended on the bird's different types of feathers. Herons' "lanceolate plumes [...] have edges with

112 ASVe, Giudici di petizion, inventari di eredità, tutele, curatele, oppure richiesti in causa, b. 340/5, n. 55, Giacomo Savioni (1591/01/12, m.v.). 
few barbs, giving them a frayed appearance. Aigrettes have long shanks with long elements and minimal barbs, such that they are loose and flexible. Filoplumes are long and hairy."13 Such ornithological peculiarities defined the huge price range of heron feathers and provided artisans with an astonishing material variety to work with; a variety that feather-workers deliberately increased by purchasing an impressive range of flowers. ${ }^{114}$

Feather-workers first washed feathers in hot water with soap. The feathers had to be moved constantly for around five minutes. ${ }^{115}$ For degreasing the feathers of preen oil, they were washed in ash that had been boiled in water and mixed with soap. Again, the feathers had to be constantly stirred. ${ }^{116}$ In a next step, feathers such as ostrich were dyed. Recipes, of course, varied between regions, period, and workshop, and individual expertise affected artisans' choices. According to sixteenth-century Venetian recipes, feather-workers used ash, metal salts, and dyestuffs to achieve specific colours. ${ }^{117}$ Eighteenth-century Parisian recipes document correspondingly sophisticated knowledge. For whitening, feathers were washed in chalk. Indigo and azure pigments served as blue dyestuffs that were mixed in large quantities with cold water. Wood and ferrous sulphate helped feathers to take on a deep black, while acid and ammonium salt or indigo turned feathers green. For purple dyeing, feathers were prepared with alum before being dyed in a very hot water and brazilwood mix for several hours. The very same ingredients mixed together made feathers appear red after half a day of treatment. Pale pink was achieved with saffron and cold lemon squash; yellow with saffron and alum. To dye feathers orange, the seeds of the American achiote flower were boiled in the water into which the feathers were soaked as soon as the liquid had cooled off. ${ }^{118}$ French inventories of the same decades contain references to copper green, yellow, alum, and blue vitriol dyestuff. Above all, their descriptions illustrate the material surrounding of such complex procedures: in her Parisian feather-workshop in 1784, Marie Thérese Guerrier used, for the dyeing and washing of feathers, "a large copper tub in red [...], another large copper tub in yellow [...], two small copper tubs in red, two kettles with copper handles in red, a big copper kettle in yellow, a medium copper kettle in yellow, two small copper caldrons in yellow, [and] a copper pot for red-washing" worth 140 livres. ${ }^{119}$ The availability of such objects and obstinacy of the materials they

113 James A. Kushlan and James A. Hancock, The Herons (Oxford: Oxford University Press, 2005), 8.

114 In late eighteenth-century Paris, aigrettes cost between 1, 2 and 80 livres. AN, MC/ET/XXVII/457 (1784/o3/29), 9v; MC/ET/XCVIII/716 (1797), 18v-25r (here 20v); MC/ET/LXXXIV/27 (1586/11/14).

115 Bayle-Mouillard, Manuel, 213 f.

116 Ibid., 216.

117 Rublack, "Befeathering the European."

118 Bayle-Mouillard, Manuel, 214-218.

119 AN, MC/ET/XCVIII/716 (1797), 25rf.; MC/ET/XXVII/457 (1784/o3/29), 1or. 
processed challenged and defined artisanal work. It needed financial investment in materials as well as considerable training to know the correct temperatures for boiling water and the right moment to stop treatments. In order to match buyers' different aesthetic interests and financial circumstances, feather-workers dyed feathers in superior and inferior qualities. Even spotted surfaces were sometimes achieved.

To accomplish the softness and fluffy volume of feathers after such intense treatment, it was crucial to reshape the structure of the barbs and barbules. The often axial arrangement of windows in Nuremberg feather-workshops ensured the constant air flow that was required to dry the washed feathers when put on the line. French feather-workers also dried feathers under the sun or under low temperature in a drying closet (étuve). Artisans then beat them upon a table and rearranged the barbs by hand. A female feather-worker in eighteenth-century France applied yet another time-consuming drying technique. She impaled feathers on toothpicks and arranged them on a green in such a manner that they were exposed to a constant circulation of air. After a period of fifteen days, air and condensation restored the feathers to their full beauty. ${ }^{120}$ Such intricate techniques made feathers precious commodities. In Madrid, even a "simple" black or white ostrich feather cost $3^{1 / 2}$ reales in 1564 . A single heron feather in white, yellow, or purple cost 2 reales twenty years later. ${ }^{121}$ Such prices - found all over Europe - rendered it worthy to re-engage with already used feathers. In French workshops, for instance, used feathers were boiled in bunches, sulphurized, dyed anew, and treated with heat, hands, and scissors before being sold again. ${ }^{122}$

Artisans further processed feathers by cutting them in the form of leaves and small spears. Venetian inventories labelled these products folle and lanzette; in Stuttgart, the latter were called Spitzfedern. ${ }^{123}$ Both types of processed feathers were either sold or used for further manufacturing. Sometimes, the full and fluffy top parts of ostrich feathers were cut off and sold as cime or cimette, which could easily be attached to caps. Ostrich feathers were starched, sliced into two halves along the shaft, and sewn together according to different sizes, shapes, and colours. For such manufacturing, feather-workers needed to be skilled and patient in needlework and in the use of sharp knives (cf. Fig. 3.11). In Stuttgart in 1621, a Federmeßerlin - maybe used for cutting quills for writing - cost the considerable sum of 4 gulden. A Prague inventory of the same year mentions that Rudolf II had collected "Ottoman feather knives." ${ }^{\prime 24}$ Handling the knives used to manufacture feathers was definitely not easy, although we have to bear in mind that feather-workers lived in a milieu in which the careful cutting

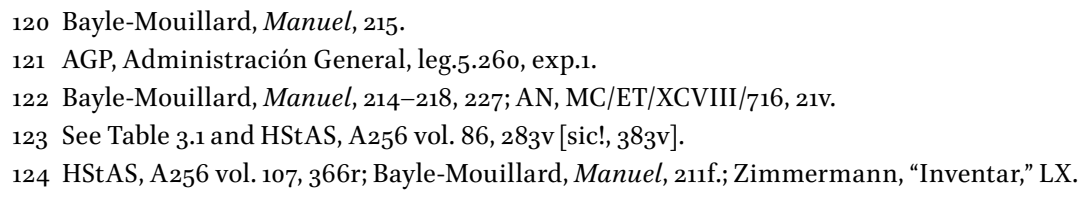


of quills was an indispensable skill for scribes and artists. ${ }^{125}$ Sewing the feathers together in two, three, or even more layers was similarly demanding due to the shaft's hard composition (cf. Fig. 3.12). Such doubled feathers (plumes doubles) seem to have been particularly popular. ${ }^{126}$ Feather-workers then bent and curled feathers using irons and also applied gold leaf and jewellery. ${ }^{127}$ In 1577 , the Nuremberger Wolfgang Münzer owned black, white, yellow, and red ostrich feathers, all "looped with gold (wire)" along their spines. Furthermore, he possessed three "adorned" parrot feathers and another three crane feathers "decorated with gold" - here, the metal threads interacted with the metallic iridescence of the feathers of certain parrots. ${ }^{128}$ According to their characteristics and treatment, feathers were then processed into a large variety of products such as (starched) panaches or spear-like lanzette, which were themselves often doubled and starched in order to achieve a particular material stiffness. Inventories also mention caskets with feathers glued onto them. Similar leather caskets with decorative motifs, often showing New World birds stitched onto them, are also preserved from the colonial Americas. ${ }^{129}$ Hence, it seems reasonable to assume that Venetian feather-workers' caskets could have been adorned with precious feathers of rare avian species that themselves evoked associations of the wider world. All these different kinds of treatments defined how feathers might have been used, to which purpose, and whether by men or women. Feather-workers' material knowledge, creativity, and dexterity, above all, helped feathers to stage their properties in ways that clients appreciated so much.

\section{Affective Fields: Panaches and Fans}

The inventories also point to the significance of panaches and feather fans - telling examples for the discussion of how makers' skills in material transformation attended to objects' sensorial properties. Discussing the relationship between things and emotions, archaeologists have developed the concept of "affective fields": humanthings relationships that stimulate emotional responses; emotions being defined "as the act of being moved [...] tied to [...] the perception of particular bodily states." ${ }^{\prime 130}$

125 Cennino d'Andrea Cennini, "Il Libro dell'Arte": The Craftman's Handbook, trans. Daniel V. Thompson Jr. (New York: Dover, 2016), 8; Wolfgang Fugger, Ein nutzlich vnd wolgegrundt Formular, Manncherleÿ scho[e]ner schriefften [...] (Nuremberg: Valentin Geißler, 1553), bijr.

126 AN, MC/ET/III/308 (1558/01/28).

127 Ibid.

128 Jutta Zander-Seidel, Textiler Hausrat: Kleidung und Haustextilien in Nürnberg von 1500-1650 (Munich: Deutscher Kunstverlag, 1990), 226.

129 Museu de l'Art de la Pell, Vic (MAP), no shelfmark, cistella (seventeenth-century Mexico).

130 Harris and Sørensen, "Rethinking," 149-153. 
Following this line of enquiry, it is important to examine how artisans' handgrips affected the sensory experience of handling objects. In the case of panaches - a very specific and extremely popular product of European featherworking - the hands of the makers met those of the users. While artisans' hands shaped the motility of feathers, the hands of clients arranged the artefact for the movements of bodies and their capacity to move other people. Feather-workers' abilities in making crafted the conditions for sensorial engagements with materials: artisans helped featherwork to attract the senses and to establish affective resonances.

Early modern featherworking is characterized by an increasingly intricate tradition of panache-making. Consequently, panaches became associated with local fashion styles and featured prominently in sixteenth-century costume books' representations of the sartorial appearances of women from different regions. ${ }^{131}$ Such prints helped to make panaches fashionable, identificatory items whose styles began to travel. Spanish-style panaches became en vogue in sixteenth-century Paris. In his shop on the Pont Notre-Dame, Jehan Maloiseau sold "a large Spanish-style panache" for 48 sols in 1586 . By comparison, customers had to pay 20 sols for four black panaches and only 15 sols for a bundle of "nine small panaches."132 Even in seventeenth-century Peru, Castilian feather panaches were precious luxury items used by mestizos. ${ }^{133}$ The appreciation of Spanish-style panaches resulted from their decorativeness. In 1584, a Madrid feather-worker manufactured a total of forty-eight feathers into panaches that cost 6 reales. Panaches composed out of altogether twelve violet, yellow, and white feathers cost 8 reales. Similarly costly was a panache made out of fourteen feathers dyed in white, yellowish-green, brown, and intense red. ${ }^{134}$ Fashion trends, of course, changed and are hard to specify - in eighteenth-century Paris, Russian panaches had become fashionable ${ }^{135}$ - yet a rich and diverse engagement with panache-making was a general trend in early modern featherworking. Jean-Marie Aubertin even offered panaches de fantaisie for sale in late eighteenth-century Paris. ${ }^{136}$

Evolving from this intricate tradition of panache-making, fans engendered people's fantasies. Queen Elizabeth I consciously staged feather fans as artefacts of royal splendour. Portraits show the monarch handling a panache composed out of dozens of intensely dyed, small ostrich feathers. A few years later, Elizabeth

131 Hans Weigel, Habitus prcecipvorvm popvlorum [...] (Nuremberg: Hans Weigel, 1577), CXXIIIIf., CXXXIIII, CXLVf., CXLVIII; Jost Amman, Gynceceum, siue theatrvm mvliervm [...] (Frankfurt: Sigmund Feyerabend, 1586).

132 AN, MC/ET/LXXXIV/27 (1586/11/14), 5r-6r.

133 Hanß, "Material Encounters," 601.

134 AGP, Administración General, leg.5.260, exp.1 (1584).

135 Bayle-Mouillard, Manuel, 226.

$136 \mathrm{AN}, \mathrm{MC} / \mathrm{ET} / \mathrm{XCVIII} / 716,20 \mathrm{v}$. 


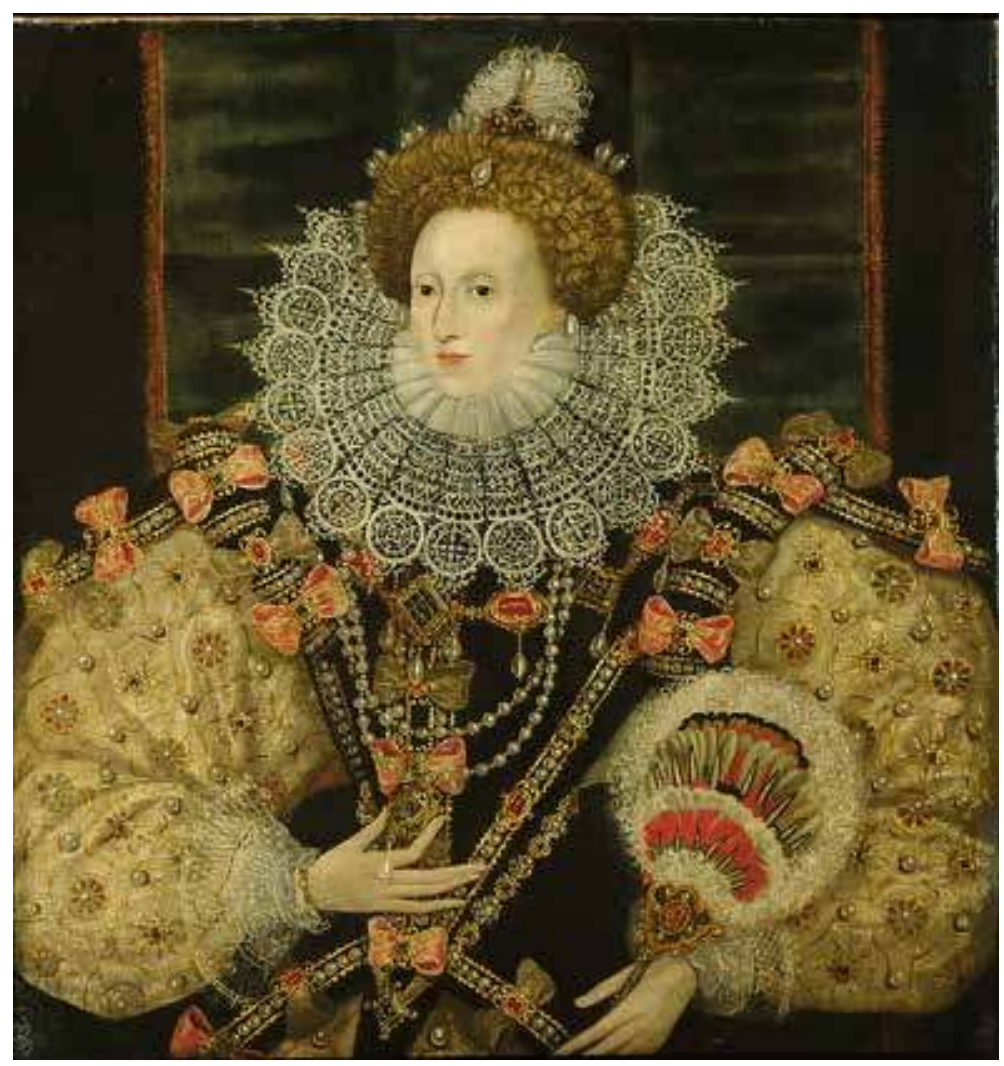

Figure 3.13: George Gower, Queen Elizabeth I, ca. 1588. Oil on canvas, $1010 \times 978 \mathrm{~mm}$. The Leicester Galleries, no signature. Image $\odot$ The Leicester Galleries.

used fans manufactured from astonishingly large, bowed ostrich feathers. ${ }^{137}$ According to inventories, the monarch owned fans composed out of tawny, straw-colour, carnation, white, and ashen feathers. The handles were made from bone, ivory, silver, and gold and were set with pearls and jewels. For preserving the integrity of such precious items, feather fans were stored in separate boxes wrapped in leather, taffeta, and paper. ${ }^{138}$ Both feather-workers and painters clearly tried to capture these material interplays, establishing affective atmospheres. Jewellery applications and colour arrangements made feather fans crucial elements of splendid apparels, a visual tradition that culminates in a slightly later portrait showing Elizabeth handling a fan composed with colourful Amazonian feathers framed by curled ostrich feathers traded via North Africa (Fig. 3.13). As

137 Anonymous, Queen Elizabeth I, ca. 1575, National Portrait Gallery, London (NPG), NPG 2082; Anonymous, Queen Elizabeth I, ca. 1585-1590, NPG 2471.

138 Arnold, Wardrobe, 230, 349f. 


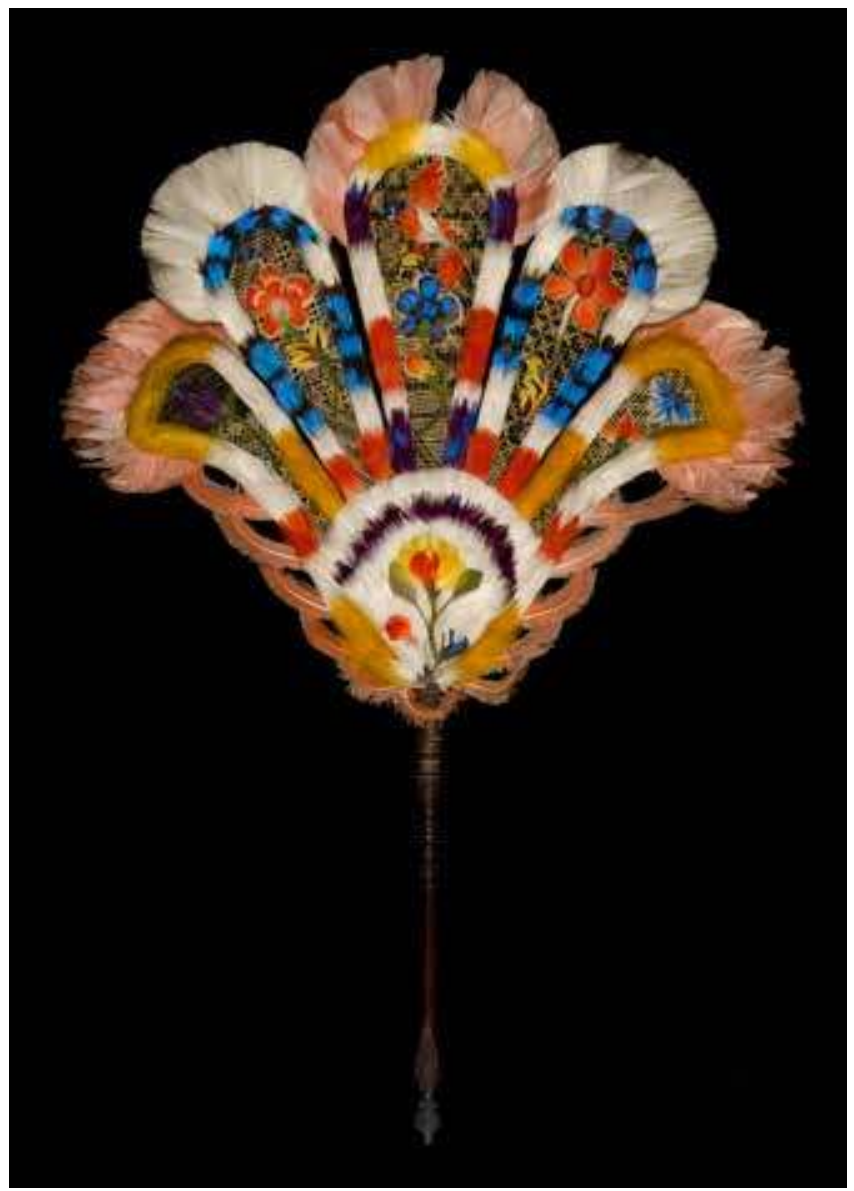

Figure 3.14: The Messel feather fan. South American and Dutch origin, ca. 1665. Feathers on woven panels, $340 \times 230$ mm. Cambridge, Fitzwilliam Museum, inv. no. M.358-1985. Image $\odot$ The Fitzwilliam Museum, Cambridge.

global artefacts, feather fans evoked associations of imperial treasures. It is no surprise that Francis Drake presented Elizabeth a fan comprising red and white feathers in 1587; she also holds a feather fan in the armada portrait, celebrating the Spanish defeat a year later. ${ }^{139}$ Similarly, the so-called Messel fan points to the global material trajectories of the Dutch Empire (Fig. 3.14). Produced in the late seventeenth century, the fan's mosaics are composed out of feathers that belonged to American species like the purple-breasted cotinga amabilis, found in the Dutch colonies of Brazil, the Guyanas, and Suriname. Finely cut feathers stitched onto woven panels, sometimes with a second layer of glued feathers, show scenes of 
exotic flowers, birds, butterflies, and insects. ${ }^{140}$ Such intricate techniques of feather fan-making are dazzling, especially as they are proof of acts of material creativity in response to the first arrival of feather fans in Northern Europe from Italy in the

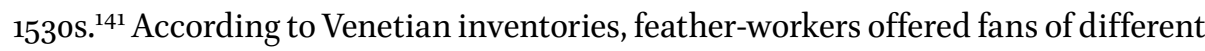
sizes, colours, and handles. In mid-sixteenth-century Milan, it was even "possible to buy paper templates for fans that could be cut out, coloured, used to hold feathers and then thrown away once they had disintegrated." ${ }^{142}$ Responding to the spread of techniques and tastes, Venetian feather-workers started to manufacture particularly small feathers into fans; a miniaturizing trend that also affected sixteenth-century Parisian featherworking. ${ }^{143}$

Both luxury and mass-produced feather fans captivated the senses - their visual effects can hardly be overestimated (Fig. 3.15a-b) - and it is this condition that relates the matter of feathers with bodies. Fast handling might have animated impressions of exotic fauna. The observation of a Württemberg visitor to the English court in 1595 is particularly important to bear in mind when discussing the relationship between feather fans, the body, and the senses: people used feather fans "to cool themselves." ${ }^{144}$ In a period that considered circulating air a crucial element of health regimes, French kings even awarded "new invention(s)" in fan-making with special privileges. ${ }^{145}$ In the visual culture of this period, precious cords or chains are seen to have tied fans to belts. Upon being detached, fans were elegantly held between the thumb and forefinger. When handled, feather fans partially un/covered the sleeves' lacework and distributed the scent of perfumed gloves, bracelets, and jewellery. ${ }^{146}$ Compared to panaches, the arrangement and handling of fans granted them a greater capacity to redistribute air and its sensory impressions. For providing feathers with scents and mastering this material's ability to extend pleasant olfactory experiences, French royal panache-makers and feather-workers maintained close contacts with glove-perfumers. ${ }^{147}$ Feathers' tantalizing scents complimented the seductive softness they maintained that generated erotic atmospheres; accordingly,

140 For a detailed discussion of the Messel Standing Feather Fan and the results from its analysis with imaging technology, see Hanß, "Material Creativity of Affective Artefacts in the Dutch Colonial World." 141 Hayward, Dress, $188 \mathrm{f}$.

142 Welch, "Art," 264f.; Agostino Carracci's sheet for fan-making, Milan, ca. 158o, etching, $369 \times 251$ mm, The British Museum, London (BM), Print \& Drawings, 1891,0713.652.

143 AN, MC/ET/III/308 (1558/01/28).

144 Arnold, Wardrobe, 132.

145 Sandra Cavallo and Tessa Storey, Healthy Living in Late Renaissance Italy (Oxford: Oxford University Press, 2013); AN, O/1/34, 350v.

146 Arnold, Wardrobe, 28-43; Evelyn Welch, "Scented Buttons and Perfumed Gloves: Smelling Things in Renaissance Italy," in Ornamentalism: The Art of Renaissance Accessories, ed. Bella Mirabella (Ann Arbor, MI: University of Michigan Press, 2011), 13-39.

147 AN, MC/ET/II/176 (1645/03/13-1645/04/05); Welch, "Buttons." 

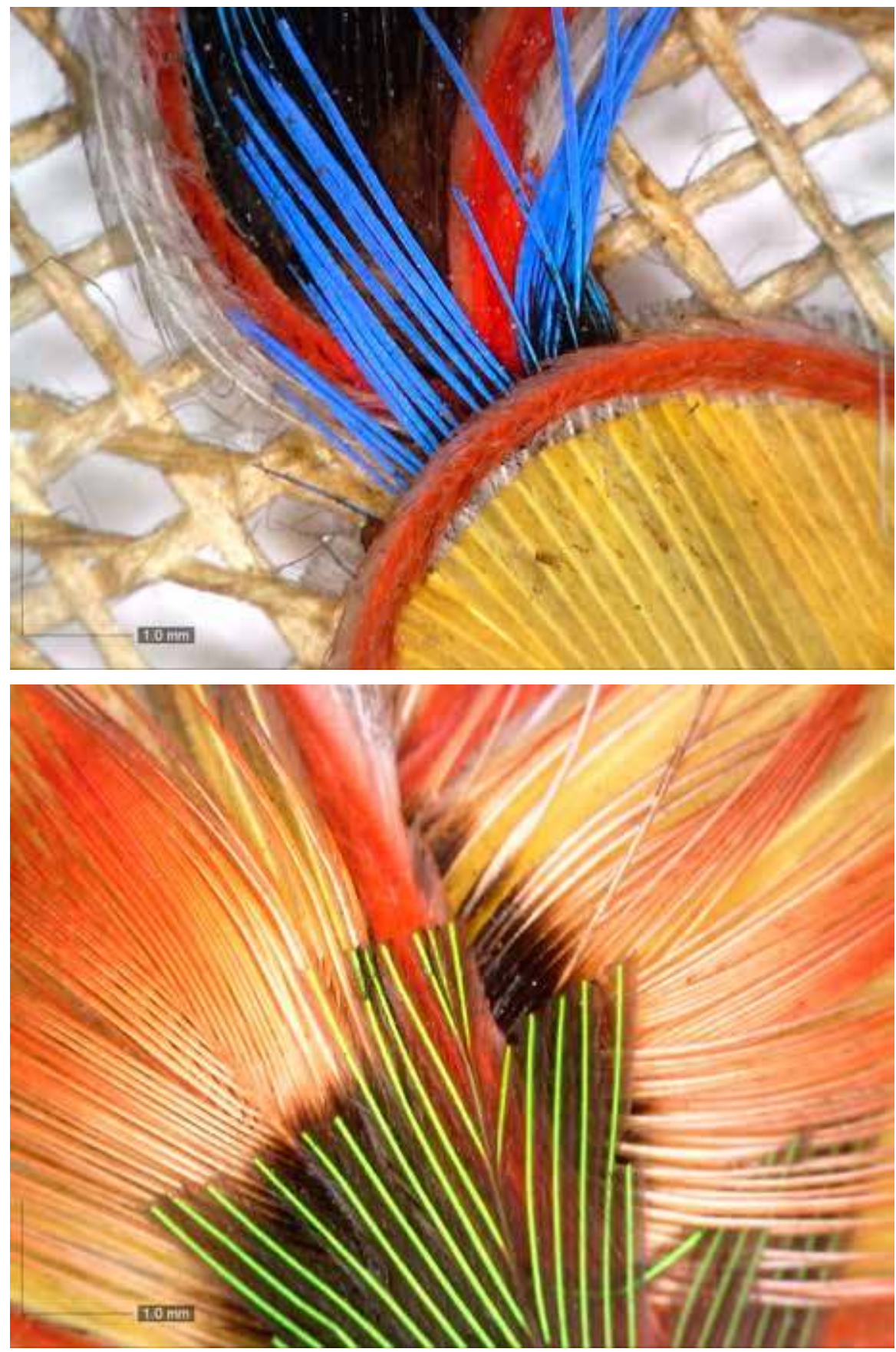

Figure 3.15a-b: The Messel feather fan. South American and Dutch origin, ca. 1665, detail of Fig. 3.14: Showing vibrantly coloured feather mosaics of flowers. Dino-Lite USB microscope AM7013MZT. Image (c) Stefan Hanß. 
fans were widely used to stage flirtations. ${ }^{148}$ Artisans enhanced such resonances through the application of liquids, heat, air, perfumes, dyestuffs, jewels, and the very arrangement and choice of feathers. On the one hand, feathers were starched to make them resistant to potential damage after rough handling. On the other hand, feather-workers deliberately crafted fans' softness by using several layers and, later on, altogether hundreds of feathers for panaches and fans. In the 1550s, Parisian feather-worker Thomas Flache surely decided to process the feathers of cranes due to their very material characteristics: their solid lower parts made crane feathers easy to fix to handles and guaranteed the feathers' stability while being handled; the feathers' upper part with their defined barbs, however, is of downy appearance, which attracts tactile engagement. ${ }^{149}$ Through their expertise in making, feather-workers extended and instantiated sensorial experiences. These artisans' skills crafted objects whose material properties - through interaction with bodily movements - enacted affective fields, shaped sensorial engagement, and stimulated emotional responses. Feather-workers helped crafting materialized identities.

\section{Crafting Affective Matter}

This chapter charted the hitherto unknown history of early modern European artisans who specialized in trading, processing, and manufacturing feathers. Archaeologists' theoretical approaches to material culture and their attunement to questions of material affordances, sensorialities, material engagement, and assemblage theory, I argued, are particularly useful to discuss the vibrancy of early modern featherwork. As globally traded commodities, feathers shaped commerce and consumption by generating styles and desires. They caused economic entrepreneurship that manifested in the formation of specialized guilds, female industriousness, supra-regional networks, and craft specialization. Such developments further stimulated cultures of tastes by making a huge spectrum of featherwork available for a diversified market of knowledgeable buyers in cities and courts alike. In that sense, early modern featherworking and feather-trading commerce has to be considered both a result and a driving force of the global consumerism that responded to materials' striking properties and thereby transformed material and aesthetic lives in early modern Europe..$^{150}$

This observation should lead to a reconsideration of the cross-cultural dynamics of the material Renaissance. Thus far, historians have addressed the artisanship of

148 Beatriz Marín-Aguilera, “(De)Orientalising Spain: The ‘Other' from Within,” Arkeogazte 6 (2016): 83f. $149 \mathrm{AN}, \mathrm{MC} / \mathrm{ET} / \mathrm{III} / 308$ (1558/01/28).

150 Lemire, Global Trade. 
New World featherwork on the one hand and their collection in sixteenth-century Europe on the other. ${ }^{151}$ This approach constructs a cultural dichotomy between indigenous production/ritual usage versus European perception/representation. ${ }^{152}$ By exploring the unknown material worlds of Dutch, English, French, German, Italian, and Spanish feather-workers, this chapter questions the traditional story of Europeans' passive perception of American featherwork. An object-centred approach is crucial to address European and non-European artefacts on the same analytical level: it charts a story of the flows of materials, things, and knowledge that connected early modern European artisans with the wider Atlantic, Mediterranean, and Asian worlds.

I studied featherworking in terms of artisans' material engagement - as the embodied making skills and cognitive knowledge of matter that lent featherwork cultural significance. Artisans' embeddedness within material assemblages with their own distinct affordances shaped the routines and innovations of early modern featherworking. The making of featherwork, understood as artisans' sensorial engagement with material transformation, aimed at the sensoriality of these objects: feather-workers transformed materials in such ways that allowed featherwork to foreground its culturally appreciated characteristics. It was precisely this material engagement that aimed at the enaction of aesthetics, as featherwork also called for certain modes of handling, bodily postures, and sensorial perceptions that were associated with emotional registers like flirtation, gallantry, or chivalry. By crafting featherwork in such ways, artisans positioned their products at the very heart of early modern affective fields: feather-workers made their artefacts efficacious agents that evoked affective resonances and provoked emotional responses.

151 Mariana Françozo, "Beyond the Kunstkammer: Brazilian Featherwork in Early Modern Europe," in Gerritsen and Riello, The Global Lives of Things, 105-127; Mary Norton, "Going to the Birds: Animals as Things and Beings in Early Modernity," in Early Modern Things: Objects and Their Histories, 1500-180o, ed. Paula Findlen (London and New York: Routledge, 2013), 53-83; Carina L. Johnson, Cultural Hierarchy in Sixteenth-Century Europe: The Ottomans and Mexicans (Cambridge: Cambridge University Press, 2011); Alessandra Russo, Gerhard Wolf, and Diana Fane, eds., Images Take Flight: Feather Art in Mexico and Europe, 1400-1700 (Munich: Hirmer, 2015).

$15^{2}$ Cf. Hanß, "Material Encounters.” 


\section{Bibliography}

\section{Unpublished Primary Sources}

Archivo General de Indias, Seville (AGI)

Audiencia de Santa Fe, 987, L.2

Indiferente General, 420, L.8

Archivo General de Palacio, Madrid (AGP)

Administración General, leg.5.26o, exp.1

Sección de expedientes personales, caja 151, expediente 7

Archives Nationales Paris (AN)

$\mathrm{MC} / \mathrm{ET} / \mathrm{II} / 140,152,166,176,179,183$; III/12, 240/A-B, 308, 489; VIII/104, 316, 530, 564, 589,

593, 603, 632, 666; X/8; XI/109; XIX/158; XXII/52; XXIII/123, 477; XXIV/338, 342; XX-

$\mathrm{VII} / 457 ; \mathrm{XXIX/73,} \mathrm{152;XXX/475;XXXIII/24;XXXIV/33;} \mathrm{XLIII/173;} \mathrm{LXXIII/279;} \mathrm{LXXXIV/27;}$

$\mathrm{XCVIII} / 716 ; \mathrm{C} / 31 ; \mathrm{CV} / 587$

$\mathrm{MIC} / \mathrm{Y} / / 115$

$\mathrm{O} / 1 / 34$

Archivio di Stato di Torino, Turin (AST)

Commercio, mazzo 20 da ordin. cat. 4

Archivio di Stato di Venezia, Venice (ASVe)

Giudici di petizion, inventari di eredità, tutele, curatele, oppure richiesti in causa, b. $339 / 4$, n. $53 ; 340 / 5$, n. $55 ; 354 / 19$, n. $39 ; 360 / 25$, n. 79

Archives de la ville de Bruxelles/Archief van de Stad Brussel, Brussels (AVB/ASB)

Registre $\mathrm{n}^{\mathrm{o}} 3426$

Bibliothèque nationale de France, Paris $(\mathrm{BnF})$

ms. fr. 21798

The British Museum, London (BM)

Print \& Drawings, 1891,0713.652, Agostino Carracci, sheet for fan-making, Milan, ca. 1580. Etching, $369 \times 251 \mathrm{~mm}$

Print \& Drawings, E,8.114, Hans Schäufelein, The Wedding Dancers, ca. 1530s. Print, $263 \times 214 \mathrm{~mm}$

Châtelet de Paris

Y//10o, 127, 196 
Germanisches Nationalmuseum Nürnberg, Nuremberg (GNM)

Perg.-Urk.1587/05/05

T1593, 3784

Historisches Museum am Hohen Ufer, Hannover (HM)

L1435f

Landesarchiv Baden-Württemberg, Hauptstaatsarchiv Stuttgart (HStAS)

A 202, vol. 2394, Nr. 4, 5 r

A 256, vols. 81, 85, 86, 87, 89, 91, 93, 95, 96, 97, 107

Royal Collection Trust, UK (RC)

RCIN 913071, Henri Gissey, Louis XIV in the Guise of Apollo, no date (seventeenth century).

Graphite, watercolour, bodycolour, and gold paint on vellum, $304 \times 225 \mathrm{~mm}$

Stadsarchief Antwerpen (Felixarchief), Antwerp (SA)

GA\#4254, $7^{\# 1150}$

Stadtarchiv Leipzig (StadtAL)

LXIV Nr. 46

Staatsarchiv Nürnberg (StAN)

B14/II Nr. 3

E1/1905, Nr. 1:Jornal vnd Schuldtbu[o]ch of Bartholomäus Viatis (1579); Nr. 18

Stadtarchiv Nürnberg, Nuremberg (StadtAN)

A1, Schwabach; 6, Nr. 691

B14/I, Nr. 57, 62, 68, 71, 90, 116, 133, 162, 181, 194; II, Nr. 13, 34, 36; III, Nr. 35

D1, Nr. 18,776

E1/1158, Nr. 1; 8, Nr. 2333/14, 17, 38; 17/II, Nr. 677; 18; 29/I, Nr. 397

F5, Nr. 2; $3 /$ I, III, V

GSI 152 Obj.Nr. 58.725, 58.870, 59.300

$\mathrm{U}_{56}, 58,61,64 \mathrm{af}$.

Stadt- und Staatsbibliothek Augsburg (SUSBA)

$2^{\circ} \operatorname{Cod} 568$

National Archives, Kew (TNA)

PROB 11/34/234, 11/104/348 


\section{Published Primary Sources}

Amman, Jost. Gynceceum, siue theatrvm mvliervm [...]. Frankfurt: Sigmund Feyerabend, 1586.

Bayle-Mouillard, Élisabeth-Félice. Manuel du fleuriste artificiel [...]. Paris: Roret, 1829.

Cennini, Cennino d'Andrea. "Il Libro dell'Arte": The Craftman's Handbook, translated by Daniel V. Thompson Jr. New York: Dover, 2016.

Diderot, Denis, and Jean B. d'Alembert, eds. Encyclopédie ou Dictionnaire raisonné des sciences, des arts et des métiers, vol. 2. Paris: Briasson et al., 1751.

Diderot, Denis, and Jean B. d'Alembert, eds. Encyclopédie ou Dictionnaire raisonné des sciences, des arts et des métiers, vol. 12. Paris: Samuel Fauche, 1765.

Diderot, Denis, and Jean B. d'Alembert, eds. Encyclopédie ou Dictionnaire raisonné des sciences, des arts et des métiers, vol. 8. Paris: Briasson et al., 1771.

Fugger, Wolfgang. Ein nutzlich vnd wolgegrundt Formular, Manncherleÿscho[e]ner schriefften [...]. Nuremberg: Valentin Geißler, 1553.

Hooke, Richard. Micrographia: or some Physiological Descriptions of Minute Bodies made by Magnifying Glasses with Observations and Inquiries thereupon. London:John Martyn, 1665.

Léry, Jean de. History of a Voyage to the Land of Brazil, otherwise called America, translated by Janet Whatley. Berkeley and Los Angeles, CA and Oxford: University of California Press, 1990.

Martyr, Peter (Pietro Martire d'Anghiera). De Orbe Novo Decades I-VIII, edited by Rosanna Mazzacane and Elisa Magoncalda. 2 vols. Genoa: Dipartimento di archeologia, filologia classica e loro tradizioni, 2005 .

Olina, Giovanni P. Vccelliera overo discorso della natvra, e proprieta di diversi vccelli [...]. Rome: Andrea Fei, 1622.

Weigel, Hans. Habitus prceipvorvm popvlorum [...]. Nuremberg: Hans Weigel, 1577.

\section{Secondary Literature}

Arnold, Janet. Queen Elizabeth's Wardrobe Unlock'd: The Inventories of the Wardrobe of Robes prepared in July 1600 [...]. Leeds: British Library, 1988.

Bennett, Jane. Vibrant Matter: A Political Ecology of Things. Durham, NC and London: Duke University Press, 2010.

Bruna, Denis, ed. Fashioning the Body: An Intimate History of the Silhouette. New Haven, CT: Yale University Press, 2015.

Cavallo, Sandra, and Tessa Storey. Healthy Living in Late Renaissance Italy. Oxford: Oxford University Press, 2013.

David, Abraham. "Jewish Involvement in Ostrich Feathers Trade between Egypt and Venice in the 16th Century as Reflected in Documents from the Cairo Genizah." Judaica:Beiträge zum Verstehen des Judentums 74/1-2 (2018): 82-95. 
Eliason, Chad M., and Matthew D. Shawkey. "Decreased Hydrophobicity of Iridescent Feathers: A Potential Cost of Shiny Plumage." Journal of Experimental Biology 214 (2011): 2157-2163.

Emmendörffer, Christoph. "Wunde Welt: Hainhofers Diarium der schwedischen Besatzung Augsburgs." In Wunderwelt: Der Pommersche Kunstschrank, edited by Christoph Emmendörffer and Christof Trepesch, 466-539. Berlin and Munich: Deutscher Kunstverlag, 2014.

Epstein, Stephan R., and Maarten Prak, eds. Guilds, Innovation and the European Economy, 1400-1800. Cambridge: Cambridge University Press, 2009.

Findlen, Paula. "Afterword: How (Early Modern) Things Travel." In The Global Lives of Things: Material Culture of Connections in the Early Modern World, edited by Anne Gerritsen and Giorgio Riello, 241-246. London: Routledge, 2016.

Françozo, Mariana. "Beyond the Kunstkammer: Brazilian Featherwork in Early Modern Europe." In The Global Lives of Things: Material Culture of Connections in the Early Modern World, edited by Anne Gerritsen and Giorgio Riello, 105-127. London: Routledge, 2016.

Gayangos, Pascual de, ed. Cartas y relaciones de Hernan Cortés al Emperador Carlos V. Paris: Imprenta Central de los Ferro-Carriles, 1866.

Gerritsen, Anne, and Giorgio Riello. The Global Lives of Things: Material Culture of Connections in the Early Modern World. London: Routledge, 2016.

Gibson, James J. “The Theory of Affordances." In Perceiving, Acting, and Knowing: Toward an Ecological Psychology, edited by Robert E. Shaw, 127-137. Hillsdale, NJ: Erlbaum, 1977.

Gosden, Chris. "What Do Objects Want?" Journal of Archaeological Method and Theory 12, no. 3 (2005): 193-211.

Green, Nile. "Ostrich Eggs and Peacock Feathers: Sacred Objects as Cultural Exchange between Christianity and Islam." Al-Masāq 18 (2006): 27-66.

Hamilakis, Yannis. Archaeology of the Senses: Human Experience, Memory, and Affect. Cambridge: Cambridge University Press, 2013.

Hamilakis, Yannis, and Andrew M. Jones. "Archaeology and Assemblage." Cambridge Archaeological Journal 27, no. 1 (2017): 77-84.

Hanß, Stefan. "Material Encounters: Knotting Cultures in Early Modern Peru and Spain.” The Historical Journal 62, no. 3 (2019): 583-615.

Hanß, Stefan. "New World Feathers and the Matter of Early Modern Ingenuity: Digital Microscopes, Period Hands, and Period Eyes." In Ingenuity in the Making: Materials and Technique in Early Modern Europe, edited by Alexander Marr, Richard Oosterhoff, and José Ramón Marcaida. Pittsburgh, PA: Pittsburgh University Press, 2021, in press.

Hanß, Stefan. Court and Material Culture in Early Modern Germany: A Sourcebook on the Duke of Württemberg's Payments to Artisans, Stuttgart, 1592-1628. Amsterdam: Amsterdam University Press, forthcoming. 
Hanß, Stefan. "The Material Creativity of Affective Artefacts in the Dutch Colonial World: Imaging and Imagining Early Modern Feather Fans." Current Anthropology (in press).

Hanß, Stefan. "Material Cross-Referencing in the Age of Courtly Consumption: Feathers and the Making of Luxury Experiences at the Early Modern Spanish Court" (forthcoming).

Hanß, Stefan, and Ulinka Rublack. "Knowledge Production, Image Networks, and the Material Significance of Feathers in Late Humanist Heidelberg." Renaissance Quarterly 74, no. 2 (2021): 1-39.

Harrap, B. S., and E. F. Woods. "Species Differences in the Proteins of Feathers." Comparative Biochemistry and Physiology 20 (1967): 449-46o.

Harris, Oliver J. T., and Tim F. Sørensen. "Rethinking Emotion and Material Culture." Archaeological Dialogues 17, no. 2 (2010): 145-163.

Hayward, Maria. Dress at the Court of King Henry VIII: The Wardrobe Book of the Wardrobe of the Robes prepared by James Worsley in December 1516, edited from Harley MS 2284, and his Inventory prepared on 17 January 1521, edited from Harley MS 4217, both in the British Library. Leeds: Maney, 2007.

Hofmann, Cornelia. Das Federzimmer Augusts des Starken. Dresden: Verlag der Kunst, 2003. Horie, C. V. "Fading of Feathers by Light." In gth Triennial Meeting, Dresden, German Democratic Republic, 26-31 August 199o, edited by International Council of Museums Conservation Committee, 431-436. Los Angeles, CA: International Council of Museums Conservation Committee, 1990.

Jegel, August, ed. Alt-Nürnberger Handwerksrecht und seine Beziehungen zu anderen. Nürnberg-Reichelsdorf: Schmidt, 1965 .

Johnson, Carina L. Cultural Hierarchy in Sixteenth-Century Europe: The Ottomans and Mexicans. Cambridge: Cambridge University Press, 2011.

Kushlan, James A., and James A. Hancock. The Herons. Oxford: Oxford University Press, 2005. Lehmann, Ann-Sophie. "The Matter of the Medium: Some Tools for an Art Theoretical Interpretation of Materials." In The Matter of Art: Materials, Technologies, Meanings, 1200-170o, edited by Christy Anderson, Anne Dunlop, and Pamela H. Smith, 21-41. Manchester: Manchester University Press, 2014.

Lemire, Beverly. Global Trade and the Transformation of Consumer Cultures: The Material World Remade, c. 1500-1820. Cambridge: Cambridge University Press, 2018.

Lieb, Norbert. Octavian Secundus Fugger (1549-16oo) und die Kunst. Tübingen: Mohr, 1980.

Malafouris, Lambros. How Things Shape the Mind: A Theory of Material Engagement. Cambridge, MA and London: MIT Press, 2013.

Marcaida López, José Ramón. “El ave del paraíso: historia natural y alegoría.” In Alegorías: imagen y discurso en la España Moderna, edited by María Tausiet, 93-108. Madrid: Consejo Superior de Investigaciones Científicas, 2014.

Marín-Aguilera, Beatriz. “(De)Orientalising Spain: The ‘Other’ from Within.” Arkeogazte 6 (2016): $75^{-89}$. 
Marín-Aguilera, Beatriz. "Inhabiting Domestic Space: Becoming Different in the Early Iron Age Western Mediterranean." Journal of Mediterranean Archaeology 31, no. 1 (2018): 77-100.

Norton, Mary. "Going to the Birds: Animals as Things and Beings in Early Modernity." In Early Modern Things: Objects and Their Histories, 1500-1800, edited by Paula Findlen, 53-83. London and New York: Routledge, 2013.

O'Malley, Michelle, and Evelyn S. Welch, eds. The Material Renaissance. Manchester: Manchester University Press, 2007.

Reckwitz, Andreas. "Affective Spaces: A Praxeological Outlook." Rethinking History 16, no. 2 (2012): 241-258.

Rosenbaum, David A. Knowing Hands: The Cognitive Psychology of Manual Control. Cambridge: Cambridge University Press, 2017.

Rublack, Ulinka. "Matter in the Material Renaissance." Past and Present 219 (2013): 41-85.

Rublack, Ulinka. "Renaissance Dress, Cultures of Making, and the Period Eye." West 86th: A Journal of Decorative Arts, Design History, and Material Culture 23 (2016): 6-34.

Rublack, Ulinka. "Befeathering the European: The Matter of Feathers in the Material Renaissance.” The American Historical Review 126, no. 1 (March 2021): 19-53, https:// doi.org/10.1093/ahr/rhaboo6.

Russo, Alessandra. The Untranslatable Image: A Mestizo History of the Arts in New Spain, 1500-160o. Austin, TX: University of Texas Press, 2014.

Russo, Alessandra, Gerhard Wolf, and Diana Fane, eds. Images Take Flight: Feather Art in Mexico and Europe, 1400-1700. Munich: Hirmer, 2015.

Seibold, Gerhard. Die Viatis und Peller: Beiträge zur Geschichte ihrer Handelsgesellschaft. Cologne: Böhlau, 1977 .

Smith, Pamela H. The Body of the Artisan: Art and Experience in the Scientific Revolution. Chicago, IL: University of Chicago Press, 2004.

Smith, Pamela H., and Tonny Beentjes. "Nature and Art, Making and Knowing: Reconstructing Sixteenth-Century Life-Casting Techniques." Renaissance Quarterly 63 (2010): 128-179.

Swan, Claudia. "Exotica on the Move: Birds of Paradise in Early Modern Holland." Art History 38 , no. 4 (2015): 621-635.

Vlček, Pavel et al., eds. Umělecké památky Prahy, vol. 3. Prague: Academia, 1999.

Von Rohr, Alheidis. "Kleidung eines Patriziers aus Einbeck vom Ende des 16. Jahrhunderts." Waffen- und Kostümkunde 18 (1976): 69-75.

Welch, Evelyn. "Art on the Edge: Hair and Hands in Renaissance Italy." Renaissance Studies 23, no. 3 (2009): 241-268.

Welch, Evelyn. "Scented Buttons and Perfumed Gloves: Smelling Things in Renaissance Italy." In Ornamentalism: The Art of Renaissance Accessories, edited by Bella Mirabella, 13-39. Ann Arbor, MI: University of Michigan Press, 2011.

Zander-Seidel, Jutta. Textiler Hausrat: Kleidung und Haustextilien in Nürnberg von 1500-1650. Munich: Deutscher Kunstverlag, 1990. 
Zander-Seidel, Jutta, ed. In Mode: Kleider und Bilder aus Renaissance und Frühbarock. Nuremberg: Germanisches Nationalmuseum, 2015.

Zimmermann, Heinrich. "Das Inventar der Prager Schatz- und Kunstkammer vom 6. Dezember 1621: nach Akten des K. und K. Reichsfinanzarchives in Wien.” Kunsthistorische Sammlungen des Allerhöchsten Kaiserhauses 25 (1905): XIII-LXXV.

\section{About the Author}

Stefan Hanß is Senior Lecturer at The University of Manchester. His research focuses on early modern material culture and cultural encounters. Current projects cover the history of early modern hair and featherworking. Hanß has been awarded a British Academy Rising Star Engagement Award and a Philip Leverhulme Prize. 



\title{
4. Performing America: Featherwork and Affective Politics
}

\author{
Ulinka Rublack
}

\begin{abstract}
This article analyses feather-work as central material in the culture of a German court around 1600 . Materials afforded meanings, invited specific practices, and thus became agents that "enmeshed" an audience to endorse new social, economic, and political norms. They formed part of an affective culture and habitus, reproduced in similar spaces and atmospheres. Feathers could be part of specific emotional styles and embodied practices. Their appreciation intertwined with specific collecting and media strategies as well as the encounter of the Americas. Artefacts fostered emotional communication and aimed at affective transformation in performances such as those at the Württemberg court. They strongly appealed to tactile sensory engagement as much as to vision as modes of perception.
\end{abstract}

Keywords: Protestant court culture; feathers as artefacts; cultural translation; material culture and the Thirty Years' War; Frederick I of Württemberg

\section{Animated Accessory}

In 1895, Aby Warburg published an article on theatre costume and the beginning of opera at the Medici court. Among the art historian's most interesting finds was a tailor's account book for costumes to stage the famous musical intermezzi during festivities in honour of Christina of Lorraine in $1589 .{ }^{1}$ Two master tailors

1 These intermezzi were staged in-between scenes of the comedy La Pellegrina and their success enabled opera to emerge as an independent genre. Aby Warburg, "Die Theaterkostüme für die Intermedien," in Aby

Burghartz, S., L. Burkart, C. Göttler, U. Rublack, Materialized Identities in Early Modern Culture, 1450-1750: Objects, Affects, Effects. Amsterdam: Amsterdam University Press, 2021 DOI 10.5117/9789463728959_CHO4 
and fifty apprentices had created 286 costumes. The account book noted fabrics and materials for each scene, as well as negotiations about props in relation to their cost. ${ }^{2}$ One decision concerned fifteen sirens, who prominently featured as bird-like creatures endowed with the power of song. Creating their upper garments from real feathers was deemed far too extravagant; instead, canvas was ordered onto which the feathers were painted and then cut out. Finally, these painted feathers were individually glued onto the costumes and assembled alongside papier-mâché breasts and other accessories to create characters. Warburg stressed that account books make for "dry" source material. Yet they indicated the "intensity" of an ambition to create "living memory images" - lebendige Erinnerungsbilder - of the classical age in Florence. These facilitated an emotionally resonant dialogue between antiquity and the present.

This chapter follows Warburg's interest in court festivities and the emotional power of accessories. It analyses the role of featherwork in the 1599 staging of Duke Frederick of Württemberg as "Lady America" as well as the Protestant Union festivals of his son John Frederick. Account books reveal the importance of feather-crafting at this early modern court in Stuttgart, the capital of a land-locked territory in the south-west of Germany. Feather-crafting has long been overlooked as a trade that grew and substantially diversified during the sixteenth century. European interest in Latin-American featherwork has attracted much scholarly attention. Yet the remarkable sixteenth-century diversification of European "be-feathered" head-wear complemented this fascination. ${ }^{3}$ Courts had initially provided a milieu for which noblemen commissioned highly innovative ensembles of dyed ostrich feathers on helmets to compete in tournaments. ${ }^{4}$ By the late sixteenth century, the greater availability of exotic feathers made references to the encounter with the Americas possible in entertainments; however, much like advanced embroidery, the production

Warburg: Werke in einem Band, ed. Martin Trend, Sigrid Weigel, and Perdita Ludwig (Frankfurt-am-Main: Suhrkamp, 2010), 124-167, and his better-known "Sandro Botticellis 'Geburt der Venus' und 'Frühling'," in ibid., 32-38; see also Horst Bredekamp, Image Acts: A Systematic Approach to Visual Agency (Berlin and Boston, MA: De Gruyter, 2018), 253-264.

2 Warburg, "Theaterkostüme," 135.

3 For a recent, major volume on American featherwork see Alessandra Russo, Gerhard Wolf, and Diana Fane, eds., Images Take Flight: Feather Art in Mexico and Europe, 1400-1700 (Munich: Hirmer, 2015). See also Mariana Françozo, "Beyond the Kunstkammer: Brazilian Featherwork in Early Modern Europe," in The Global Lives of Things: Material Culture of Connections in the Early Modern World, eds. Anne Gerritsen and Giorgio Riello (London: Routledge, 2016), 105-127, and for the following see Ulinka Rublack, "Befeathering the European: The Matter of Feathers in the Material Renaissance," The American Historical Review 126, no. 1 (March 2021): 19-53, https://doi.org/10.1093/ahr/rhaboo6, and Stefan Hanß's chapter in this volume. 4 Carnival displays in cities like Nuremberg during the 1520 s and 1530 s experimented with costumes which used layers of cheap silks to imitate parrot feathers, or attached peacock feathers, Hans-Ulrich Roller, Der Nürnberger Schembartlauf: Studien zum Fest- und Maskenwesen des späten Mittelalters (Tübingen: Tübinger Vereinigung für Volkskunde, 1965), 71, 62. 
of intricate feather garments remained costly as well as technically, mentally, and physically extremely demanding. An engagement with such soft, light material required fine motor skills, manual dexterity, and great care, especially when it was sewn or glued. Yet, as Stefan Hanß's contribution in this volume shows, this challenge as well as the graphics, translucency, and movement of feathers made such artefacts enchanting. Their properties and demands on craftsmanship were seen to stimulate subtlety and the imagination. ${ }^{5}$

The 1599 Württemberg spectacle stands out as one of the most original of its time. It used the largest amount of exotic featherwork Europeans had ever seen, was generously funded by the court, and was staged publicly. There was, in other words, an exceptional investment in the use of exotic feathers to achieve mimetic faithfulness. Strikingly, the Württemberg entertainment did not represent America as simple or as inferior to Europe. It has thus previously been discussed - by those interested in early images of America, in the collecting of Americana, and in courtly culture - to the degree that the extant costume drawings for the performance are frequently reproduced. Elke Bujok has demonstrated that Jakob Frischlin's printed report of the occasion allows us to contextualize the images. They were inspired by John White's recent drawings that accompanied Thomas Harriot's travelogue to Virginia, published by Theodor de Bry. ${ }^{6}$ Historians of Württemberg, moreover, have established the immediate political context in which the event needs to be situated as a ritual of power. After prolonged diplomatic relations, Frederick had signed a treaty with Emperor Rudolf II in late January 1599 which, in return for a payment of 400,000 florins, liberated his duchy from its vassalage of Habsburg Austria. This ensured the continuity of the house of Württemberg and Lutheranism. Frederick now relied on his estates to pay this enormous sum. Predictably, the estates proved reluctant. They instantly assembled in Stuttgart in February 1599 and remained in the capital during carnival. Frederick used the licence of a carnival entertainment to demonstrate ducal strength and expectations for the duchy's brilliant future (Figs. 4.1 and 4.2). ${ }^{7}$

Yet we still need to explain why this duke chose to present an image of America and why featherwork should have been even more prominent in the Württemberg

5 See Rublack, "Befeathering the European" and Stefan Hanß's chapter in this volume.

6 Elke Bujok, Neue Welten in europäischen Sammlungen: Africana und Americana in Kunstkammern bis 1670 (Berlin: Reimer, 2004), 14. A digitalized original of the entire description of the tournament and festivities is available: Jakob Frischlin, Beschreibung deß fürstlichen Apparatus, königlichen Auffzugs, heroischen Ingressus und herrlicher Pomp und Solennittet (Frankfurt-am-Main: Joachim Brathering, 1602), 44, http://digital.slub-dresden.de/werkansicht/dlf/65017/1/.

7 For this important contextualization see Sabine Hesse, "Die Neue Welt in Stuttgart: Die Kunstkammer Herzog Friedrich I. und der Aufzug zum Ringrennen am 25. Februar 1599," in Hofkultur um 16oo: Die Hofmusik Herzog Friedrichs I. von Württemberg und ihr kulturelles Umfeld, ed. Joachim Kremer, Sönke Lorenz, and Peter Rückert (Sigmaringen: Thorbecke, 2010), 150-164. 
entertainment than in de Bry's images. As in the case of Florence, account books of craftspeople employed at the Württemberg court detail information of expenditure on featherwork, which has not been analysed in relation to the spectacle. In contrast to the Florentine tailor's records, these suggest that real and costly exotic feathers were used to recreate cloaks, headdresses, and skirts and that they were used alongside authentic artefacts from the Americas. This mimesis of American featherwork facilitated "translational technologies," as feather-workers would have needed to learn to work with exotic feathers, to cut, layer, and assemble them, and to imitate the colour intensity of exotic feathers through dyes. Exquisite stage images (see Figs. 4.1, 4.4-4.7, and 4.9-4.10) likewise underline the importance given to the event and the creation of what I call a "present image," a Jetzt-bild, of a contemporary culture across the Atlantic, rather than a memory image of antiquity.

I draw on Frischlin's report, the stage images, account books, and a broader view of Duke Frederick's reign to argue that the 1599 entertainment should not just be understood in response to the immediate political context of the Treaty of Prague, in which case its subject would have been incidental. Rather, the adaptation of new imagery and information about the New World served as cultural material to propagate a far wider vision of his politics. It advertised the benefits of stateled innovation, knowledge-making, trade, and cultural exchange. It conjured up curiosity and optimism in regard to the future, rather than aesthetic austerity, melancholy, and the apocalyptic fear with which Protestantism is so often equated. The entertainment, in sum, was designed to help enshrine Stuttgart's position among the culturally leading, forward-looking European courts. Feathers as specific materials were integral to how court spectacles were made to function. ${ }^{8}$ They served to make the display persuasive, and hence, in contemporary understandings, alive,

8 For the importance of rhetorical traditions to furnish ideas of aliveness and affect as signs of successful, persuasive art see Caroline van Eck, Classical Rhetoric and the Visual Arts in Early Modern Europe (Cambridge: Cambridge University Press, 2007). In 1550, by contrast, the astonishing staging of a Tupinambá village and battle in Rouen to welcome King Henry II had involved fifty Brazilian natives and 250 local sailors and prostitutes enacting them. Yet the use of accessories had been minimal. Startlingly, therefore, the French actors appeared naked or, perhaps more likely, were dressed in nude costumes, although body paint was used on some figures while the native Tupi could use basic headdresses. This decision may have been related to the expense of costumes, which were financed locally, but which amplified the message. Natural simplicity was contrasted to the wrong kind of ostentatiousness and dissimulation in France, see Michael Wintroub, A Savage Mirror: Power, Identity, and Knowledge in Early Modern France (Stanford, CA: Stanford University Press, 2006), 182; Amy Buono, "Representing the Tupinambá and the Brazilwood Trade in Sixteenth-Century Rouen," in Cultural Exchange between Brazil and France, ed. Regina R. Felix and Scott D. Juall (West Lafayette, IN: Purdue University Press, 2016), 29f. For Buono's argument that the Stuttgart entertainment does stereotype otherness for political purposes see Amy J. Buono, "Their Treasures Are the Feathers of Birds': Tupinambá Featherwork and the Image of America," in Images Take Flight: Feather Art in Mexico and Europe 1400-1700, ed. Alessandra Russo, Gerhard Wolf, and Diane Fane (Munich: Hirmer, 2015), 178-189. 
energizing, and emotionally powerful. The Stuttgart entertainment and a focus on featherwork, therefore, allow us to reflect on the importance of accessories in relation to the encounter with the Americas, which, as a new generation of scholars have shown, was as crucial for the period as its fascination with antiquity. ${ }^{9}$ A combination of textual and artefact-led methodologies can be used to explore how past people responded to a particular material, what kinds of energy they invested in an object, why they did so, and what emotions it might have evoked. ${ }^{10}$ This enables us to address continuities in the visual and rhetorical construction of affective atmospheres through one of the most fragile and delicate objects to be found in the early modern world.

\section{Staging America}

One cold morning in February 1599, over six thousand spectators gathered in the German town of Stuttgart to witness an extraordinary spectacle. It was carnival time, and the duke of Württemberg staged an entertainment that included many of his most respected councillors and officials. As the usual tournaments progressed, Duke Frederick I (1557-1608) led an elaborate, expensive, and meticulously planned procession in which he himself personified Lady America. This was the stately as much as playful manner in which drummers and trumpeters orchestrated the duke's arrival and his transformation into a woman. ${ }^{11}$

In his 1602 report of the event, the court historian and poet Jakob Frischlin highlighted the authenticity of the artefacts, which bore out the considerable investment in the event: Duke Frederick had shown himself in "form, figure, adornment and dress like the queen of America, with naked people, large clubs and clothes from parrots and many colours, none of which had been presented or seen in Swabia." ${ }^{\prime 2}$ America was carried below a canopy to display her "gracefully"

9 For the Medici court see Lia Markey, Imagining the Americas in Medici Florence (University Park, PA: Pennsylvania State University Press, 2016).

10 The efforts invested in creating scenes and personifying figures attempted to do more than merely depict Indians as "dark strangers whose foreignness was amplified [...] by feathers and reinforced by a parrot." See Elizabeth Hill Boone's discussion of Christoph Weiditz's costume images in her "Seeking Indianness: Christoph Weiditz, the Aztecs and Feathered Amerindians," Colonial American Review 26, no. 1 (2017): 49 .

11 "[...] / Pomp/ pim/ pom/ Duke Frederick arrives/ pom/ pim/ pom/ duke Frederick/ Frederick/ Frederick arrives/ he arrives/ he arrives/ America arrives/ arrives/ she arrives/ America arrives/ the queen/ queen/ queen arrives/ she arrives/arrives/ the pimperle pom/the pimperle pom/ pom/ pom/ pom/Vide pomp/ Vide pom/ aso," Bujok, Neue Welten, 44.

12 Ibid., 14; Frischlin, Auffzug, 44. Frischlin's text would have addressed an upper-German audience which by now was extremely knowledgeable about different varieties of Latin American parrots, while 
hanging breasts. Gold pieces had been glued to the nude costume and "shone from afar," just like the crown of blue, green, and red parrot feathers. ${ }^{13}$ Frederick's entertainment was thus markedly different from other court masques - for instance, an "Indian Invention" in Dresden, in which ostrich and parrot feathers were simply attached to European clothing. ${ }^{14}$ As the representation of other nations became one of the most popular features of courtly "shews," the use of authentic costume distinguished aspiring rulers who revealed their true knowledge of other worlds. Stuttgart excelled in producing such costume - although the image produced in connection with the event depicted the duke himself adorned with body-paint and fabric rather than feathers. Both the text and the images produced independent, if overlapping, visual worlds, and it is now impossible to verify whether these images or Frischlin's text were more authentic, as the account of Frederick's attire presents one of several discrepancies. The account books record that Hans Karg, one of the ducal painters, received the considerable sum of 20 florins to document the entertainment on parchment. ${ }^{15} \mathrm{Karg}$ had previously been sent out by the duke to record entertainments elsewhere, such as one at a Fugger wedding in $1591 .{ }^{16} \mathrm{He}$ was, therefore, a valued specialist. This evidence matches the high quality of these surviving, brightly coloured watercolours with tempera and extensive gilding, which named each depicted figure. ${ }^{17}$ The images might well have been shared with other courts.

The visual representation of Frederick was certainly inspired by de Bry's image of the Queen of Florida on the title page of the second volume, printed in 1591, as well as in an enlarged version inside the volume (Fig. 4.2). It depicted her on a throne decorated with fresh, green leaves (Maiengrün), followed by the most

Iberia in this respect had lost its "monopoly of mediating information about the New World and the Old," Renate Pieper, Die Vermittlung einer Neuen Welt: Amerika im nachrichtennetz des Habsburgischen Imperiums 1493-1598 (Mainz: von Zabern, 2000), 271.

13 Bujok, Neue Welten, 18; Frischlin, Auffzug, 50.

14 Claudia Schnitzer, Höfische Maskeraden:Funktion und Ausstattung von Verkleidungsdivertissements an deutschen Höfen der frühen Neuzeit (Tübingen: Niemeyer, 1999), 340.

15 HStAS, A 256, vol. 86, 383v, 384r: "von Ainem Auffzug, so Anno 1599 Im Thiergarten gehalten worden uf pergament zuverfertigen zalt."

16 Werner Fleischhauer, Renaissance im Herzogtum Württemberg (Stuttgart: Kohlhammer, 1971), 96; on Karg see also p. 169. On the Fugger's interest to maintain Augsburg's rank through magnificent displays at weddings and courtly tournaments see Julian Jachmann, "[...] in Ritterspieln und hohem Gebreng fremder nationen erfahren: Feste und Turniere der Fugger im frühneuzeitlichen Augsburg," in Herrschaft - Architektur - Raum: Festschrift für Ulrich Schütte zum 6o. Geburtstag, ed. Stephanie Hahn and Michael H. Sprenger (Berlin: Lukas Verlag, 2008), 261-275.

17 On the other hand, these images were executed on white paper rather than parchment, the writing appears hasty, and Bujok has, therefore, argued that these must have been preparatory stage sketches. If that is true, Karg's images would have been still more refined and are now lost. See Bujok, Neue Welten, 151, for a detailed description of their appearance now and changes. 


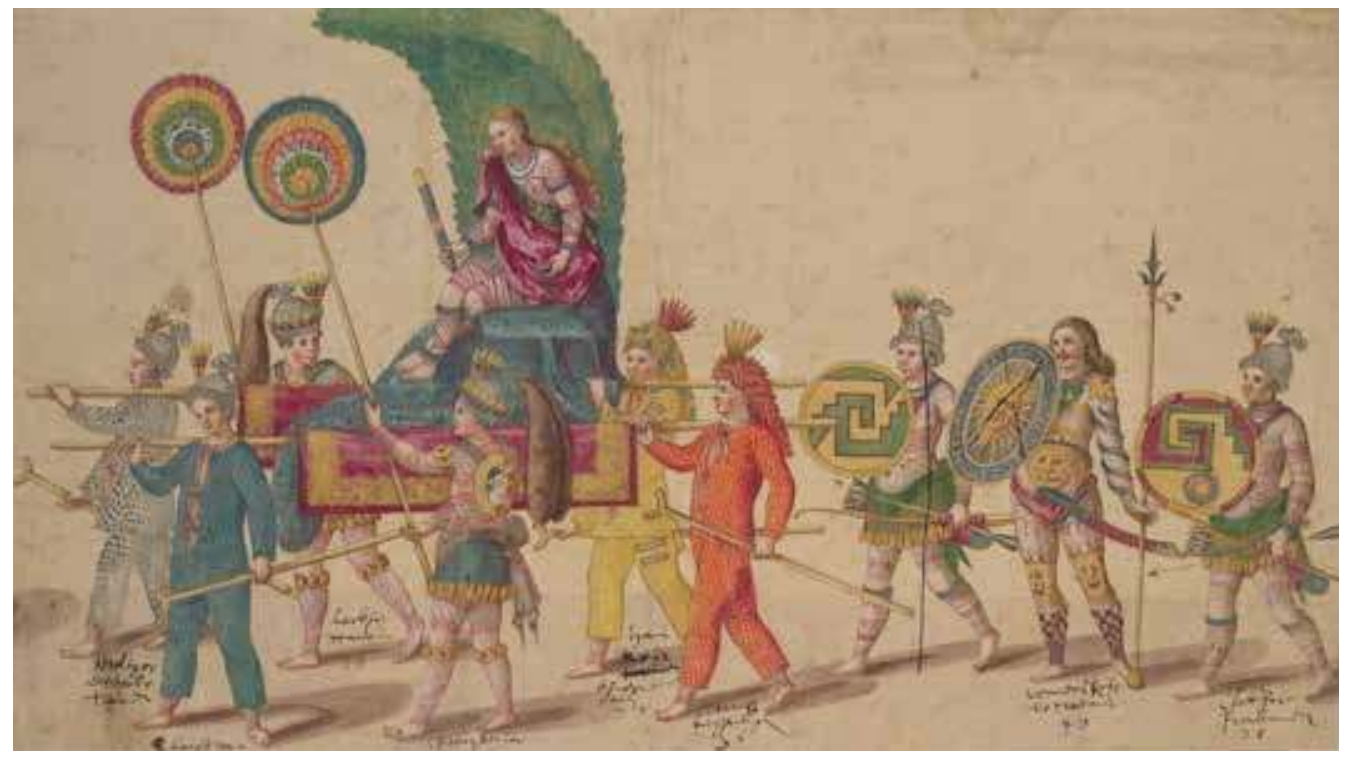

Figure 4.1: Procession at the Württemberg Court in Stuttgart, 1599: The sixth scene with Duke Frederick as Lady America. Watercolour, pigment, and gold on paper, $29.9 \times 53.3 \mathrm{~cm}$. Weimar, Graphische Sammlungen, Klassik Stiftung Weimar, inv. no. KK 207. Image @ Stiftung Weimarer Klassik und Kunstsammlungen/Museen. Photo: Roland Dreßler.

beautiful virgins decorated with pearls. ${ }^{18}$ Yet the watercolour image also suggests that Frederick was surrounded by men clad in featherwork and that the Aztec shields represented particularly prestigious artefacts. ${ }^{19}$ Featherwork was hence staged as artefact that instantiated an authentic experience of America as an equal sister and became even more important in Frischlin's literary commemoration of the event.

The Mexican feather shields were exquisite rarities and two of them survive to this day. ${ }^{20}$ Their complex crafting reveals that they were either pre-Columbian

18 Ibid., 152-157, for a table which details references to de Bry. De Bry also inspired a much smaller staging of America at the Kassel court in 1596, and Bujok points out how it differed from the 1599 Stuttgart entertainment (pp. 157-159). For a discussion of the entertainment in relation to the de Bry depictions see also Maike Christadler, "Indigenous Skins: Indian Costume at the Court of Württemberg," in Visual Representations of Native Americans: Transnational Contexts and Perspectives, ed. Karsten Fritz (Heidelberg: Universitätsverlag, 2012), 13-28; Hesse, Kunstkammer, 159-161.

19 See the seminal comparative discussion in Helen Watanabe-O'Kelly, Triumphall Shews: Tournaments at German-Speaking Courts in their European Context, 1560-1730 (Berlin: Mann Verlag, 1992), 51 and Schnitzer, Höfische Maskeraden.

20 Die Kunstkammer der Herzöge von Württemberg: Bestand - Geschichte - Kontext, 3 vols., exh. cat. (Ulm: Jan Thorbecke, 2017), 1:164-171; Bujok presents a nuanced discussion of the complicated story of their precise provenance, see Bujok, Neue Welten, 112-114. These are extremely rare; only four of them are still extant, see also Hesse, Kunstkammer, 147f.; for a conservation report see Melanie Korn, Die zwei Federschilde des Landesmuseums Württemberg (Stuttgart, April 2015, unpublished thesis, with thanks 


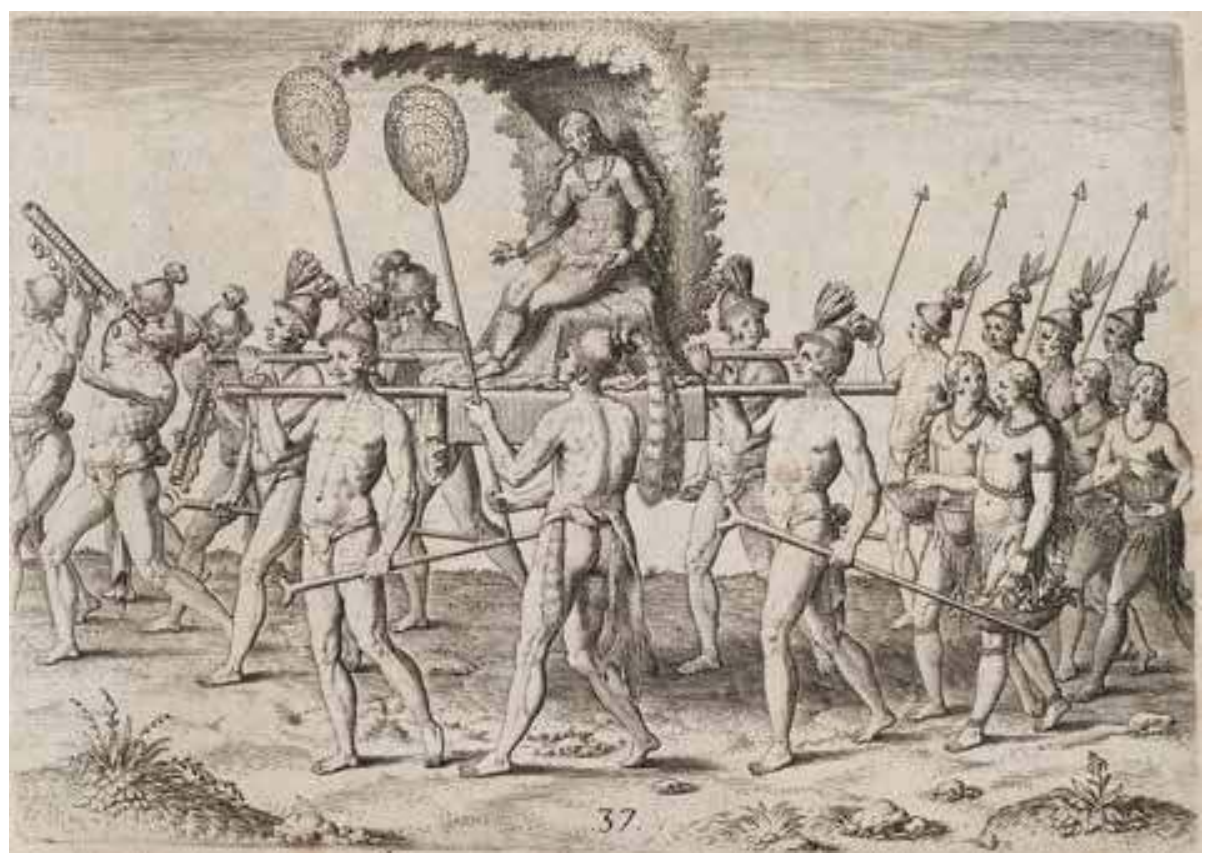

Figure 4.2: Theodor de Bry after Jacques le Moyne de Morgues, The queen-elect is brought to the king. Engraving. In Theodor de Bry, Der ander Theyl, der newlich erfundenen Landtschafft Americæ, Frankfurt am Main: Johann Feyerabendt, 1591, Plate XXXVII. Universitäts-Bibliothek Heidelberg. Image @ UniversitätsBibliothek Heidelberg.

or made shortly after the Spanish conquest (Fig. 4.3). About $25^{\circ}$ reed sticks were connected with two types of plant fibre to serve as a foundation that was secured with leather and wood. Up to eight tiny, vibrantly coloured yellow or red feathers were then skilfully looped with plant fibre around its shaft and tied to two threads, which were sewn to dyed parts of the leather skin. In the centre of the shields, several layers of tiny, gathered feathers in five colours were glued to the foundation so as to compose a striking geometrical pattern of great intricacy. Geometrical patterns on shields would have impressed Europeans as a mathematically conceived, regular, and thus harmonious design. Their making required planning and patience - it was instantly recognizable as a civilizational achievement.

Three beautifully dressed, "courageous" men on horseback led the entertainment to represent Europe. Junker Philip von Lamersheym and Carl Egen, two prominent

to the author for making this available). This close engagement with making can suggest periodizations problematized by Alessandra Russo with reference to the Stuttgart shields in her article "Cortés's Objects and the Idea of New Spain: Inventories as Spatial Narratives," Journal of the History of Collections 23, no. 2 (2011): 246 . 


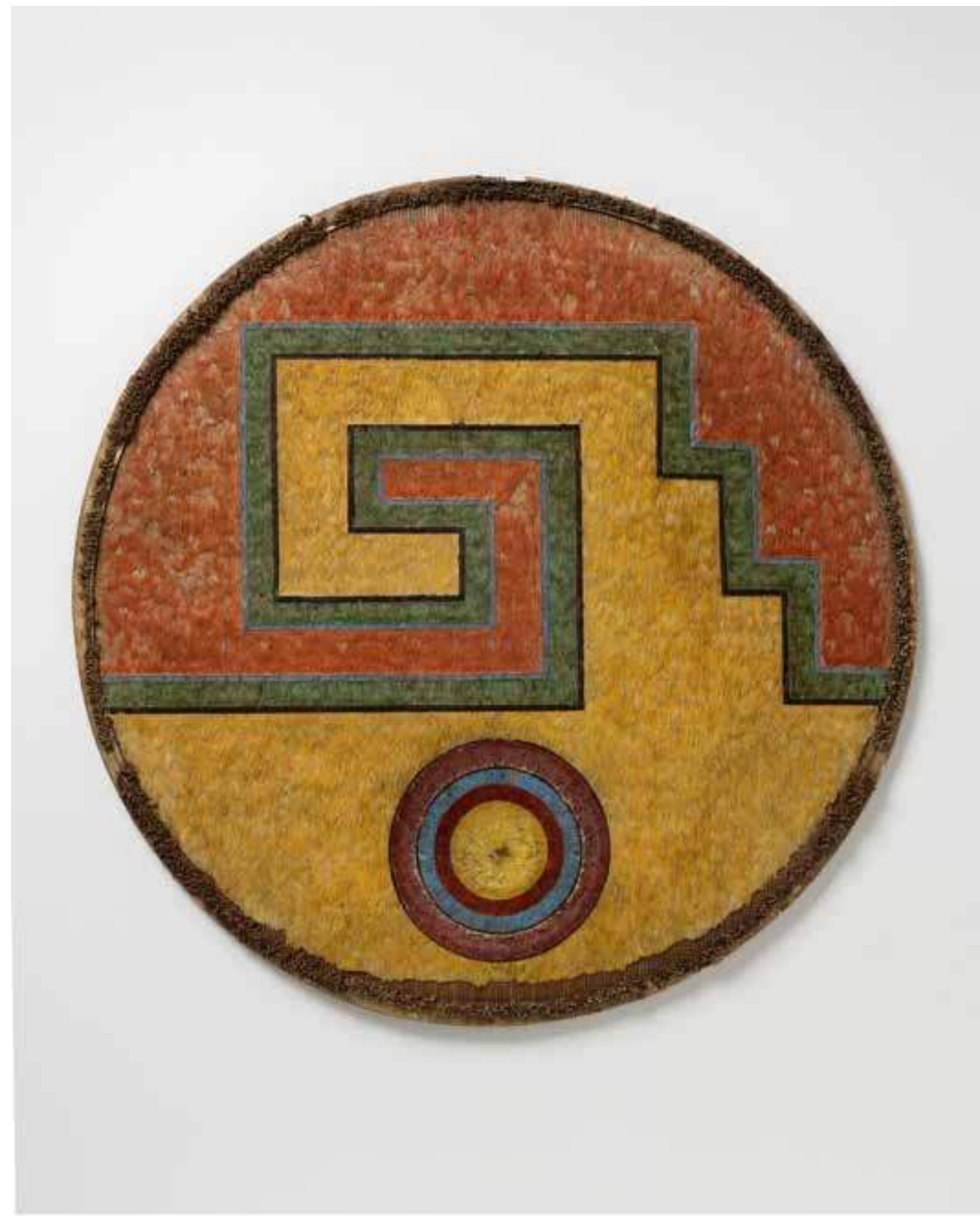

Figure 4.3: Red and Yellow Feather Aztec / Mexica Warrior Shield. Stuttgart, Landesmuseum. Image $\odot$ Landesmuseum Württemberg, Hendrik Zwietasch. 
courtiers, personified Columbus (d. 1506) and Vespucci (d. 1512), whose "shadow," Frischlin wrote, was still felt in Württemberg. They were described as experienced "pilots" to accompany America as she travelled to her sister Europe. In order to emphasize their familiarity with and interest in America, both men, according to Frischlin's text, had been clad with feather cloaks, though here there is a further discrepancy between the preparatory stage images. Frischlin highlighted the strong visual impact of the red, blue, yellow, and light-grey shades of parrot feathers:

Their cloaks were of a motley hue/

Much like a parrot/

Striped red and blue/

Thereafter yellow and pale grey too. Verily it looked passing fair/

As these two walked forward through the air.

Ihr Mäntel waren mancherley/

Von Farben/

als von papengäy/

Rot Striemen uberzwerch/

und blaw/

Darnach auch gelb/

und dann Liechtgraw. Warlich es sahe visierlich schön/

Als vorher giengen diese zween. ${ }^{21}$

The entertainment next presented a feat of mechanical engineering that reflected the duke's own fascination with innovative technologies. Four men, dressed as Indians in long, colourful, elaborate feather cloaks, feather headdresses, and decorated clubs, carried a green tree, a water well, and a cloud. Following de Bry's account of a water-tree on the island of Hierro, the well was presented as a gift that America had found on a Caribbean island. The mechanism showed how rain fell from the cloud into the well, from where a man pumped the water up to the tree for it to drip down again. This was to illustrate how a wondrous natural tree generated drinking water..$^{22}$ The scene also signalled that travel mediated the marvels of God's nature, which he had distributed across the world and which humans could imitate through inventive technologies.

Several of the court and government officials involved in the procession were dressed in skin-coloured leather costumes so as to appear naked. This further underlines the considerable expense of these costumes, which were typically

21 All translations into English are by Pamela Selwyn. Bujok, Neue Welten, 15 .

22 Ibid., 16. 


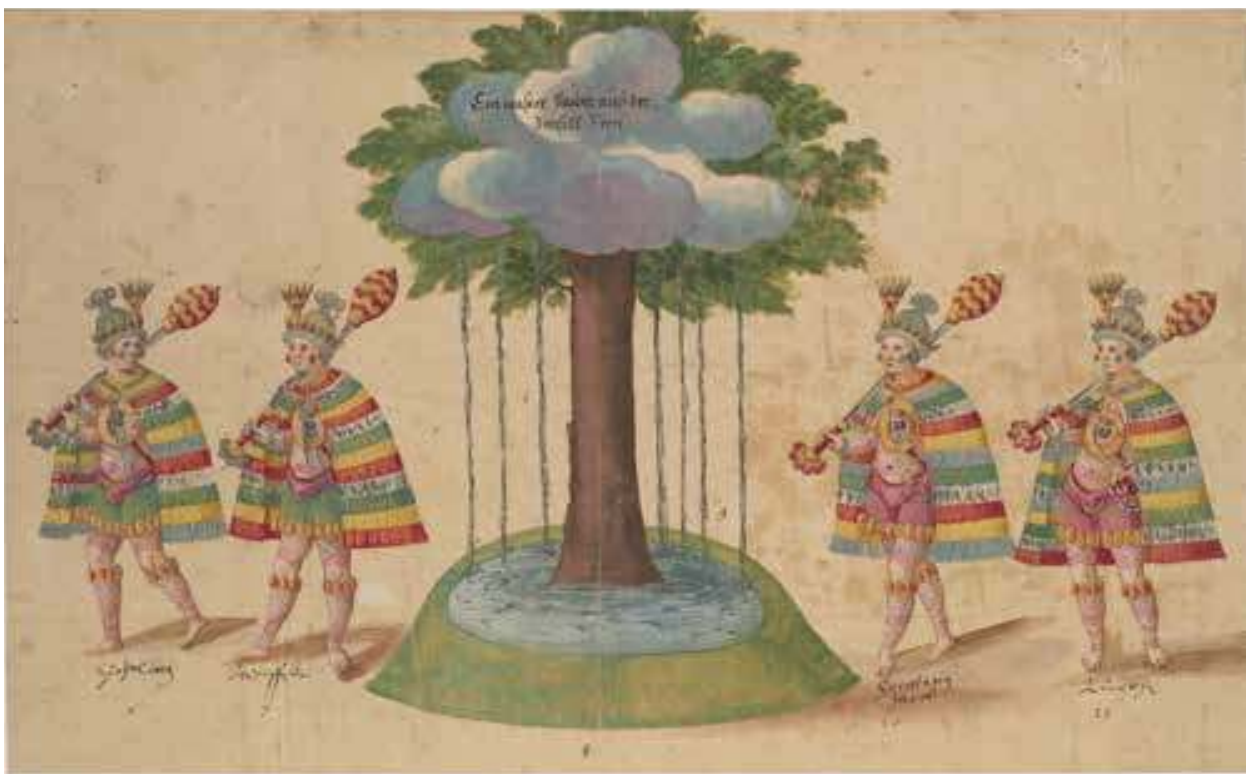

Figure 4.4: Procession at the Württemberg Court in Stuttgart, 1599: The second scene. Watercolour, pigment, and gold on paper, $30.5 \times 49.8 \mathrm{~cm}$. Weimar, Graphische Sammlungen, Klassik Stiftung Weimar, inv. no. KK 203. Image ๑ Stiftung Weimarer Klassik und Kunstsammlungen/Museen. Photo: Roland Dreßler.

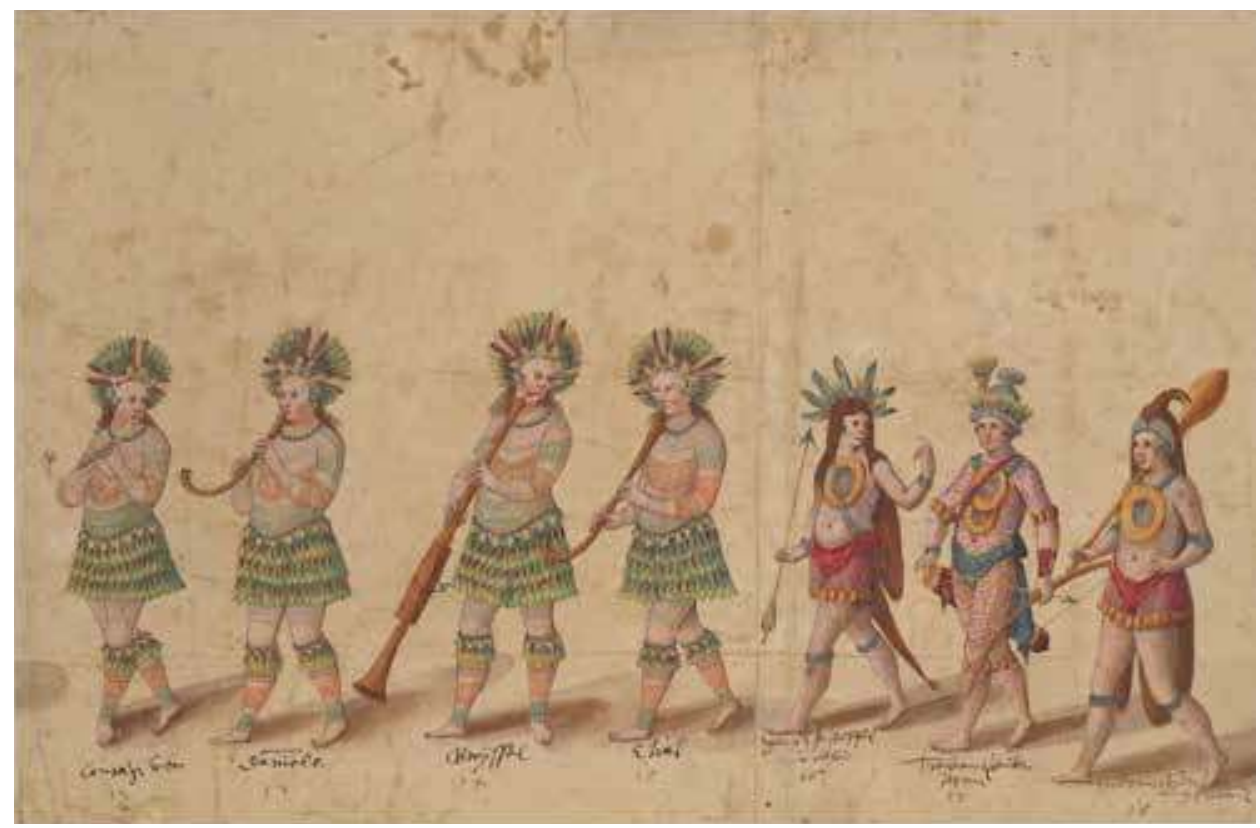

Figure 4.5: Procession at the Württemberg Court in Stuttgart, 1599: The third scene. Watercolour, pigment, and gold on paper, $29.9 \times 45.5 \mathrm{~cm}$. Weimar, Graphische Sammlungen, Klassik Stiftung Weimar, inv. no. KK 204. Image ๑ Stiftung Weimarer Klassik und Kunstsammlungen/Museen. Photo: Roland Dreßler. 


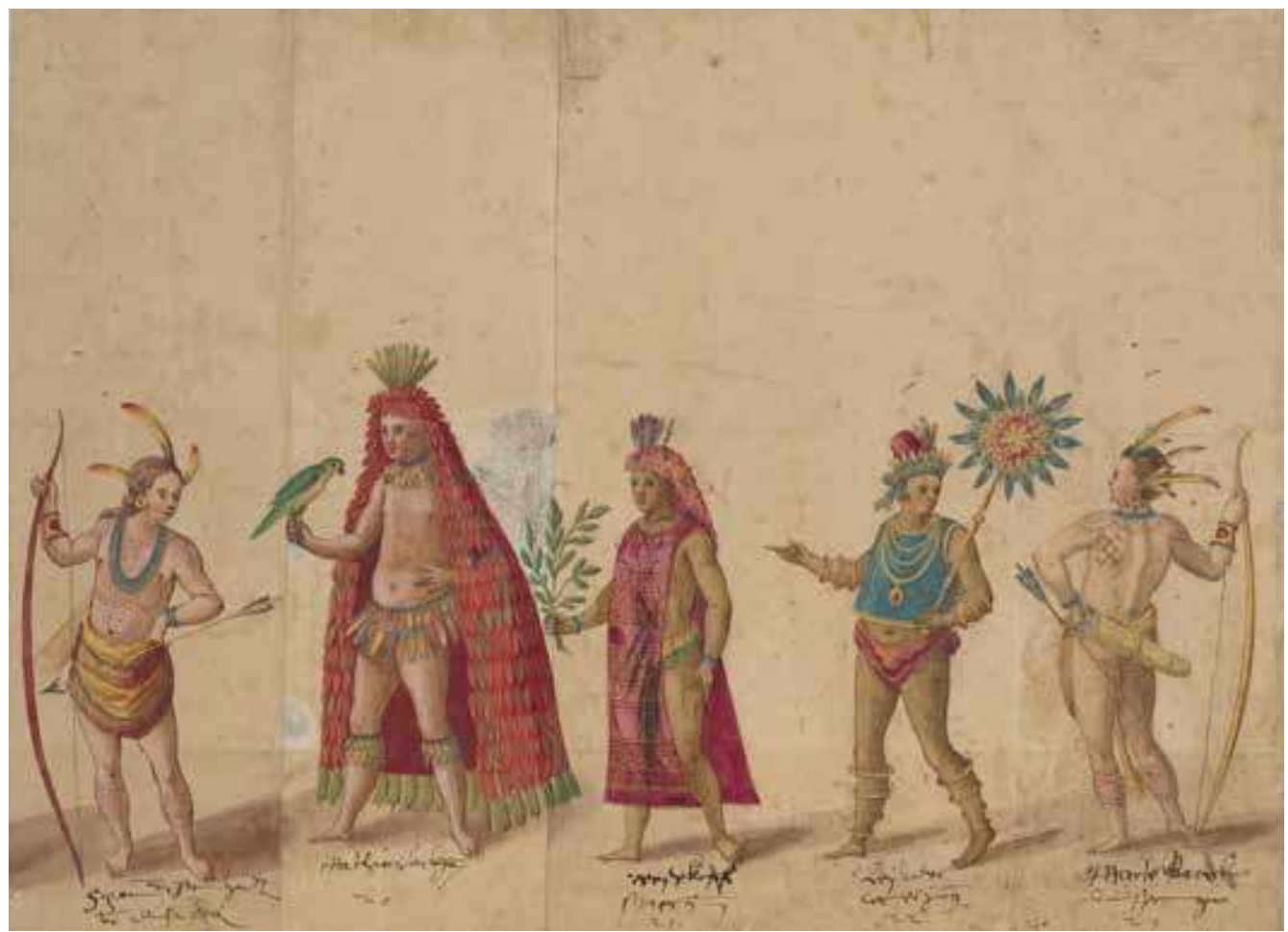

Figure 4.6: Procession at the Württemberg Court in Stuttgart, 1599: The fourth scene. Watercolour, pigment, and gold on paper, $29.8 \times 41.0 \mathrm{~cm}$. Weimar, Graphische Sammlungen, Klassik Stiftung Weimar, inv. no. KK 205. Image $\odot$ Stiftung Weimarer Klassik und Kunstsammlungen/Museen. Photo: Roland Dreßler.

created from cheap fabrics, such as flax or linen. ${ }^{23}$ The men were followed by a group of musicians, representing European traditions, and three guards dressed in feathers.

The following sequence of the procession involved twelve men elaborately dressed as Indians, several of them high-ranking noblemen to orchestrate the arrival of America. One of them held a real parrot and was clad in a spectacular foot-length, red feather cloak. This is likely to have been identical with one of two "cloaks of red and various other colours, parrot feathers, plus one attached hood" mentioned in a 1634 register of Indian dress used for courtly entertainments. ${ }^{24}$

Four men dressed as women, with baskets representing the riches of America through money as well as exotic fruit such as figs, melons, and lemons, ended this part of the procession. ${ }^{25}$

23 On nude costumes in masques see Schnitzer, Höfische Maskeraden, 64, 327.

24 As argued by Bujok, Neue Welten, 160.

25 Two final scenes showed a nobleman carried in a hammock and four women with horses, ibid., $19 f$. 


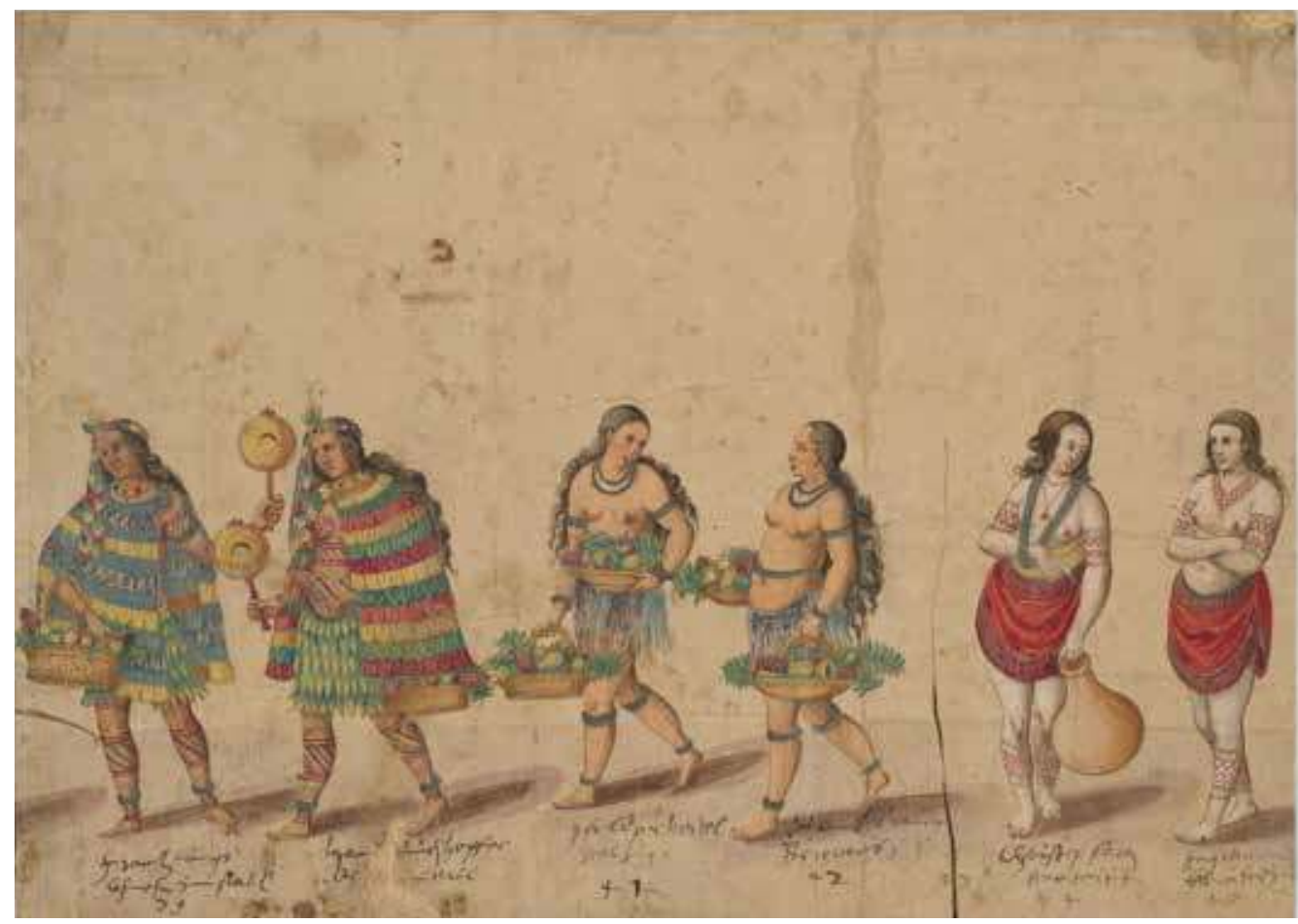

Figure 4.7: Procession at the Württemberg Court in Stuttgart, 1599: The seventh scene. Watercolour, pigment, and gold on paper, $29.8 \times 42.0 \mathrm{~cm}$. Weimar, Graphische Sammlungen, Klassik Stiftung Weimar, inv. no. KK 208. Image ๑ Stiftung Weimarer Klassik und Kunstsammlungen/Museen. Photo: Roland Dreßler.

Julius Caesar and Alexander the Great represented ancient rulers keen to witness America's inexhaustible riches and chart how much Germany had changed. This emphasized that textual knowledge about the classical world could no longer remain the sole guiding line for advancing civilizations who found themselves in a new world. Exchange derived from observing these cultures' notable achievements with one's own eyes (augenscheinlich sehen und erfahren). This empiricist stance invested ethnographic objects, alongside indigenous animals, plants, and people, with significance for knowledge-making.

\section{The Value of Curiosity}

Curiosity tied such knowledge to virtue rather than vice - even in women. Frischlin set out that the procession had been conceived particularly to please the ladies at court: Duchess Sybilla and her praiseworthy ladies-in-waiting, an entourage which resided in a "women's chamber" and was collectively addressed as das 
Frauenzimmer. While tournaments regularly focused on male figures, the ladies would enjoy seeing America as courageous and chivalrous. The procession was thereby presented as emblematic of the exchange desirable between sister continents and the opportunity for mutual benefit. ${ }^{26}$ Duchess Sybilla and her entourage were themselves in turn associated with a particular esteem of novelty and curiosity, as well as with an effect of luminosity:

Thus does (America) aim to please/

Extraordinary before all the other/

Highly esteemed ladies of the chamber/

Eager for something new and rarel

Shimmering in her fine array/

As is seldom seen in these lands.

So möcht (America) auch gefalln/

Weil sie ungwöhnlich für andern alln/

Dem hochlöblichen Frauwenzimmer/

Welchs Fürstlich gzieret her thut schimmern/

Und gern was news und seltsams sicht/

Welchs selten in den Landen gschicht $/{ }^{27}$

Sybilla even owned a piece of jewellery with rubies "made in the Indian manner" - perhaps one described in the account book as depicting two parrots. ${ }^{28}$ Attributes such as shimmering, shining, and "gleaming" repeatedly emphasized the ladies' honour. ${ }^{29}$ Frischlin set out that this February day had been brilliantly sunny, and Duchess Sybilla herself "glistened beautifully like a crystal." ${ }^{30}$ This ideal of "luminescent splendour" was central to sacred art since the Middle Ages - as it was to the embodiment of secular power - and was constituted through accessories. ${ }^{31}$ Courtly dress tried to maximize the light-reflecting properties of its fabrics through the use of silver and gold thread, extremely expensive and difficult to manufacture, as

\footnotetext{
26 See also ibid., 149 f.

27 Frischlin, Auffzug, 27, my emphasis.

28 Fleischhauer, Renaissance, 404; HStAS, A 256, vol. 82, 372v.

29 I owe this point to Regine Maritz's important reading of the role of gender at the Württemberg court and her chapter on court festivities. Regine Maritz, "Gender as a Resource of Power at the Early Modern Court of Württemberg, c. 1580-1630" (PhD diss., University of Cambridge, 2018), 90-125.

30 Frischlin, Auffzug, 38.

31 See Herbert L. Kessler's crucial book Seeing Medieval Art (Toronto: University of Toronto Press, 2011), here 175 and for a wider exploration of this theme, Ulinka Rublack, "Renaissance Dress, Cultures of Making, and the Period Eye," West 86th: A Journal of Decorative Arts, Design History, and Material Culture 23 (2016): $6-34$.
} 
well as through precious, semi-precious, and gilded glass stones. $3^{2}$ Great amounts of money were invested in bejewelled wreaths or belts worn by high-ranking women. Frischlin hence noted that the spears and spurs carried as Zier by male participants had been beautifully gilded with silver and gold, and thus drew further attention to the labour, skill, and cost that had been invested in the event. ${ }^{33}$ The images of the procession suggest that feathers were embellished with powdered gold to heighten their preciousness. A marginal note in Frischlin's texts summarized: $U t$ est natura hominis novitates avida - a reference to Pliny - and translated: Man hört und sicht gern alle tage etwas neuwes: "Everyone enjoys daily hearing and seeing novelties." ${ }^{34}$ His account was printed in Frankfurt-am-Main rather than at the more local Tübingen press, and thus aimed at a broader German literate audience.

\section{The New Cultural Politics of a Lutheran Court}

As this suggests, Frederick was an ambitious and innovative ruler. ${ }^{35} \mathrm{He}$ had previously ruled over Montbelliard, a small territory attached to Württemberg which lay close to France. Here, Frederick defended Lutheranism, offered Huguenots a refuge, and had made available funds for one of Europe's first botanical gardens. Frederick began to rule over the house of Württemberg in 1593. He spearheaded innovation in agri- and viticulture, systematically surveyed fuel and mining resources, developed his interests in alchemy, embarked on ambitious building programmes, installed printing presses, and invested in diplomatic relations with France. ${ }^{36}$ Giovanni Botero's bestselling treatise On the Reason of State, recently published in 1589 , spoke directly to the duke's idea that political power was strengthened by an investment in local natural resources alongside the improvement of domestic manufacturing and trade. Growth hinged upon knowledge about local environments - mineral, plant, and fossil resources, water reserves and climate conditions, good or bad winds. Botero, therefore, had influentially united economics with environmental thinking to propose a new political science which considered human affect as key.

32 Carolin Oster, Die Farben höfischer Körper: Farbattributierung und höfische Identität in mittelhochdeutschen Artus- und Tristanromanen (Berlin: De Gruyter, 2012), 66.

33 Frischlin, Auffzug, 44 and 55 for feathers on horses and gilding.

34 Ibid., 27.

35 See also Ulinka Rublack, The Astronomer and the Witch:Johannes Kepler's Fight for His Mother (Oxford: Oxford University Press, 2015).

36 Nicole Bickhoff, “'Gott kann der Welschen pracht nicht leiden': Hof- und Festkultur unter Herzog Friedrich I. von Württemberg," in Hofkultur um 16oo: Die Hofmusik Herzog Friedrichs I. von Württemberg und ihr kulturelles Umfeld, ed. Joachim Kremer, Sönke Lorenz, and Peter Rückert (Sigmaringen: Thorbecke, 2010), 73 . 
Human curiosity for a variety of goods and spending on new consumables, even luxuries, was to be encouraged, if they were domestically produced. ${ }^{37}$

Frederick wished the duchy's economy to grow through improvements in infrastructure, fortifications, milling, water-supply, mining and metal production, wine, silk, and linen production, as well as the cultivation of new varieties of fruit trees, animal-breeding, and bee-keeping. ${ }^{38}$ The Old Pleasure House, next to the castle, became the site of an ambitious alchemical laboratory. Alchemy involved not only the quest to turn base metal into gold, but was linked to a whole set of beneficial activities of a practical chemical kind, such as the improvement of health through "universal medicine," making sugar, refining salts, and dye, leather, glass, and gunpowder manufacturing. ${ }^{39}$ Hence the accounts register continuous entries for a wealth of materials delivered to the alchemists, which attracted much attention from within the court and involved courtiers and collectors, such as Carl Egen, who took part in the entertainment as Vespucci. ${ }^{40}$ Heinrich Schickhardt, the gifted engineer and architect, was another central figure at the court who accompanied Frederick to Italy and made beautiful drawings of new inventions.

In addition to this ambitious domestic policy, Frederick was determined to turn Württemberg court into an international Protestant power to be reckoned with and relied upon. He put great effort into diplomatic relations with other nations, travelled to see an ageing Elizabeth I, and maintained excellent relations with France to balance the power of the Habsburgs and protect Württemberg from her Catholic neighbour. ${ }^{41}$ Both countries honoured him with high decorations - England awarded him the Order of the Garter and France the Order of St Michael. An integral part of Frederick's international ambitions was the commemoration of his travels, entertainments, and achievements in print. Erhart Cellius, the Tübingen professor of poetry, oratory, and history, stressed the extraordinary medical benefits of alchemical discoveries made under Frederick's patronage as a magnificent art to facilitate a more enjoyable life. ${ }^{42}$

37 It is likely that Frederick would have encountered Botero's ideas through his travels in Italy before they were published in Latin from German printing presses in 1602. For a discussion of his ideas as related to a consideration of affects see Vera Keller, Knowledge and the Public Interest, 1575-1725 (Cambridge: Cambridge University Press, 2015), 38-45.

38 Walter Grube, Der Stuttgarter Landtag 1457-1957: Von den Landständen zum demokratischen Parlament (Stuttgart: Ernst Klett, 1957), 263.

39 Nettesheim (1486-1535) was widely known for his De occulta philosophia, 1531-1533, see William R. Newman, "From Alchemy to 'Chymistry'," in The Cambridge History of Science, vol. 3, ed. Katharine Park and Lorraine Daston (Cambridge: Cambridge University Press, 2006), 502; Tara Nummedal, Alchemy and Authority in the Holy Roman Empire (Chicago, IL: Chicago University Press, 2008), esp. 115, 127.

40 Fleischhauer, Renaissance, 393, describes Egen as an alchemist.

41 On Paludanus's collection see Harold Cook, Matters of Exchange: Commerce, Medicine, and Science in the Dutch Golden Age (New Haven, CT: Yale University Press, 2007), 116-130.

42 Erhard Cellius, Wahrhaffte Beschreibung Zweyer Raisen (Tübingen: Cellische Truckerey, 1603). 
The endorsement of improvement and enjoyment signals an important development within Lutheranism, which has been neglected in much of the historiography so far. It endorsed a positive outlook based on an interest in natural philosophy, travel, innovation, and economic policies. This vision was a world apart from the characteristically fatalist writings of many pastors in the Lutheran orthodox tradition. ${ }^{43}$ Just like Frederick's, several Lutheran princely courts during the later decades of the sixteenth century were active in their broad support of learning for the benefit of society. The Württemberg court was becoming a leading power among these, an intellectual as much as experimental, practical, and ambitious space in which duchess Sibylla built up expertise in herbal medicine and Frederick invested in a significant healing spa. Such practical learning connected them to ideas of positive regeneration by taking the products of the earth - minerals, plants, water, and geo-thermal heat - to improve life on earth. The secrets of nature, and past and present civilizations across the globe could be unlocked to benefit the body politic.

\section{Performing Colour}

Connected to this was an interest in the beauty and transformation of colours, which also inspired the fascination with featherwork. Cellius commented on the new manufacture of advanced wool weaving in the city of Calw. This was one of Frederick's large-scale, state-sponsored economic enterprises and spearheaded cameralist projects linked to the idea of shared pleasures in artificial things profitably produced in a polity open to industry, invention, the mechanical arts, and trade:

They spin/ and weave/ and dye there too

More finely than most others do.

And their pigments in the main

They procure from France and Spain.

Black/ yellow/green/grey/ brown/ red/ blue

43 Thomas Kaufmann, Konfession und Kultur: lutherischer Protestantismus in der zweiten Hälfte des Reformationsjahrhunderts (Tübingen: Mohr Siebeck, 2006), 420-423. On the following see also AnneCharlott Trepp, "Natural Order and Divine Salvation: Protestant Conceptions in Early Modern Germany (1550-1750)," in Natural Law and Laws of Nature in Early Modern Europe:Jurisprudence, Theology, Moral, and Natural Philosophy, ed. Lorraine Daston and Michael Stolleis (Aldershot: Ashgate, 2008), 129-131; Volker Leppin, Antichrist und Jüngster Tag:Das Profil apokalyptischer Flugschriftenpublizistik im deutschen Luthertum 1548-1618 (Gütersloh: Mohn, 1992). On the pluralism of Lutheranism in the seventeenth century see Thomas Kaufmann, Dreißigjähriger Krieg und Westfälischer Friede. Kirchengeschichtliche Studien zur lutherischen Konfessionskultur (Tübingen: Mohr Siebeck, 1998), esp. 149. 
And all admixtures of those hues/

The colours are varied to suit

And now enjoy a high repute.

Like Spanish pink and carmine/

Grass: Swiss: Dark: parrot green.

Gold: sulphur yellow/ fine violet/

And whatever else the plants beget.

With these wares you'll gain renown/

At Strasbourg/ Frankfurt or Nördlingen town.

They bring them there by wagon and cart/

And earn good profits from the start.

Man spint/ man webt/ man färbt alda

So schön als irgendts anderstwa.

Auß Frankreich und Hispanien

Haben sie ihre KunstFarben.

Als schwarz/gelb/grün/graw/ braun/ blaw/ rhot/

Und was jedes für mischung hat/

Daß Farben werden mancherley/

Die jetzund seind im besten geschrey.

Wie Spannisch Leibfarb/ Carmesin/

Gras: Schweitzer: Dunckel: Sittichgrün.

Gold: Schwäbelgäl/ schön Violfarb/

Und wie es gibt durchaus die Garb.

Mit diesen Wahren könnens bstehn/

Zu Straßburg/ Frankfort/ Nördlingen.

Mit Wagen/ Karn führt mans dahin/

Und haben dessen guten Gwin. ${ }^{44}$

Just as travel was praised as mediating technological knowledge through the water-tree from Hierro in the 1599 entertainment, and America was presented as Europe's sister, so the emphasis here lay on the use of French and Spanish dyestuffs, which enabled fashionable innovation. Spannisch Carmesin referred to the deep, scarlet red that cochineal imported by the Spanish from Mexico made so much more accessible. Such global trade was seen to profitably enable new industry in Württemberg's Black Forest to compete at the Frankfurt fair, Strasbourg, and important Franconian fairs. Green was a particularly difficult dye to achieve through vegetables and minerals, which explains Cellius's emphasis on the sophistication 
of the four different kinds of green which the Calw weavers traded in as a response to consumer demand. Profit, therefore, did not have to be a product of selfishness.

Duchess Sibylla owned at least one costume book and Frischlin's 1602 description evoked the deep, vibrant, innovative, and varied colours of Sibyllia's entourage, which could be seen to match the colour of New World feathers:

The ladies of the chamber followed/

Three and twenty shimmering came/

In twos/ then threes/ they walked apace

Their neck-ruffs finely edged with lace

And glistened in every lovely hue/

Their sleeves now snow white and then blue/

Now a grey that was so light/

Now a green/ or red so bright/

Others gleamed in violet tones/

In silvered garb the many went/

To gaze upon this tournament.

Darauff so folgt das Frawenzimmer/

Drey und zwanzig Glieder schimmern/

Giengen allwege zwo/ dann drey/

Ihr Kröser waren schön gespitzt/

Und haben hübsch von Farben glitzt/

Die Ermel waren etwan blaw/

Zum theil schneeweiß/ und dann liechtgraw/

Zum Theil auch grün/ dann etwa rot/

Manche von feyolfarb da gaht/

In silbern Stücken giengen vil/

$\mathrm{Zu}$ sehen dieses Ritterspiel. ${ }^{45}$

The women performed, in other words, particular dye-tones such as violet (feyolfarb), which could now be achieved locally. ${ }^{46}$ This rendered consumption virtuous "personal desires," as Vera Keller shows, could "be harnessed to serve public ends."47

Protestant rulers around 1600 such as Frederick of Württemberg or Moritz of Hesse were thus "prince-practitioners" - open to progressive learning through

45 Frischlin, Auffzug, 39 .

46 Fleischhauer confirms that court dress in Frederick's reign was more vibrant in colour than under his son John Frederick, Renaissance, 338.

47 Keller, Knowledge and the Public Interest, 14. 
practice, discovery, and esteem of the arts and crafts in order to spearhead harmony and progress in their realms. ${ }^{48}$ Frederick even entertained intimate relations with craftswomen - he cultivated affairs with a female house-tailor and a specialized washerwoman, for example. ${ }^{49}$

\section{The Element of Air}

Cellius stressed that God provided everything humans needed on earth, and that Frederick knew how to take hold of these possibilities and thus comprehend the world with his hands (Also begreifet Er die Erd Mit Seiner Hand). This was linked to deep comprehension of the four elements..$^{5}$ Cellius in turn celebrated Frederick as a master of these elements - earth, water, fire, and air. The earth provided plants, minerals, nourishment, and splendid dress, if rightly cultivated, and Frederick had even begun to produce silk locally. He had widened navigation, developed healing spas, and ensured that wells provided clean water. The element of fire was cultivated through managing the duchy's supply of wood and alchemical projects.

Air and winds were another essential element. Fredrick had ensured that the air in the duchy was fresh and well-becoming. Its mountainous regions brought refreshing winds for those who lived in valleys. The territory thus benefited from the right natural climate. This meant that people were enlivened by the air:

'Tis not lazy/ not sluggish/ not dense/ not heavy/

But blows instead towards the mountains.

Banishing foul vapours and damp

Which otherwise harm man and beast.

The air beneath and on the earth/

Therefore serves the common good:

So all the fruits may be their best/

And all that lives may benefit:

Most specially the feathered beasts

For whom the air is all and all.

'Tis why so many game birds gather/

Surpassing the numbers in other lands.

\footnotetext{
48 Bruce T. Moran, The Alchemical World of the German Court: Occult Philosophy and Chemical Medicine in the Circle of Moritz of Hessen (1572-1632) (Stuttgart: Steiner, 1991), 8, 11-12; see also Rublack, The Astronomer. 49 Paul Sauer, Herzog Friedrich I. von Württemberg 1557-1608: Ungestümer Reformer und weltgewandter Autokrat (Munich: Deutsche Verlags-Anstalt, 2003), 171-174.

5o Cellius, Zweyer Raisen, 30.
} 
Nicht faul/ nicht träg/ nicht dick/ nicht schwer/

Sondern geht auff den Bergen her.

Vertreibt bös Dämpff und Feuchtigkeit

Die Menschen und vieh sonst thun Leid.

Der Lufft unter und auff der Erd/

Mit grossem Nutz dahero fehrt:

All früchten desto besser sein/

Und was drin lebet in gemein:

Sonderlich aber Feder Thier

So den Lufft brauchen für und für.

Drumbs auch vil Feder Wildprett hat/

Und vilen Landen weit fürgaht.

Cellius now pointed out that he had himself heard others comment that there was no other country like Württemberg. ${ }^{51}$

This respect for Frederick's environmental politics and the duchy's climate provides an important clue to understand the period's new esteem of feathers as well as birds. As Sandra Cavallo has shown, Italian medical writers increasingly presented air as a "palpable presence," which was defined by its "density and texture as well as by its colour and smell." ${ }^{2}$ This notion is equally reflected in Cellius's notion of "lazy," "heavy" air as harmful and the benefit of good air to dispel humidity and bad vapours. Good air remained invisible, but affected the body and soul, while winds, since antiquity, had been thought of as a "vivid presence." At their best, they stimulated "inner vitality." 53

Feathers in turn would have functioned like a sensor to register the quality of air. Bad air would make them stick and droop through humidity and stagnation, characterized through heaviness and density which at worst upset the mind. Good air possessed its own texture which responded to the fragility of feathers. It was "light, thin, transparent and fresh" as well as mobile. This helped to create cheerfulness and literally a lighter spirit. ${ }^{54}$

Cellius's poem underlines that humidity, in particular, was regarded as a major health hazard for man and animals. An abundance of birds, in turn, with healthy,

51 He ended by once more lauding Frederick as a man who had travelled to see other countries and was known to further develop the advantages of his own, ibid., 35 .

$5^{2}$ Sandra Cavallo, "Health, Air and Material Culture in the Early Modern Italian Domestic Environment," Social History of Medicine 29, no. 4 (2016): 695-716.

53 On the influential Greek discourse see the fascinating chapter on winds in Shigehisa Kuriyama, The Expressiveness of the Body and the Divergence of Greek and Chinese Medicine (New York: Zone Books, 1999), $235,246$.

54 Cavallo, "Health, Air and Material Culture," 704f.; and Sandra Cavallo and Tessa Storey, Healthy Living in Late Renaissance Italy (Oxford: Oxford University Press, 2013). 
glistening, fluttering feathers thus instantiated Württemberg's wise environmental policies and ideal climate for the spiritual and physical benefit of mankind. In addition, birds traversed cultures and were esteemed for the beauty of their colours and iridescent effects. In the alchemical tradition, feathers, moreover, indicated transformation into air and a different spiritual state. An interest in American featherwork, exotic as much as indigenous birds and feather-making, could thus become part of a wider world view and vision of political order. This newly intensified encounter with feathers and birds became an active part of how Europeans could construct symbolic systems with social as much as emotional meanings.

\section{Acquiring a Cabinet}

Frederick's collecting for a cabinet of curiosities was therefore integral to this new cultural politics at the Württemberg court. Johann Jakob Guth von SulzDurchausen (1543-1616) was his appointed chamber-master, a notable collector of curiosities and present at the 1599 procession. Frischlin lauded his intelligence and learning. ${ }^{55}$ In the year before Frederick's death, Sulz's collection - valued 20,00o Imperial florin - was visited by the Augsburg art agent Philip Hainhofer, and contained an unusually large number of 916 ethnographic objects, including clothing, featherwork, and adornments from India..$^{6}$ Guth von Sulz gained prestige by adding to the significance of the Württemberg court and acted as a cultural broker who acquired considerable knowledge about many of his ethnographic novelties, which showed how grass, fibre, teeth, bones, wood, stones, shells, metals, and feathers were used in ingenious ways. His collection included 250 adornments from Virginia and Florida no less, which were depicted in de Bry's work. ${ }^{57}$ Guth thus cultivated an interest in national styles of craftsmanship that an international court could showcase as "intellectual capital" to record and stimulate technical developments. ${ }^{8}$ In addition, Carl Egen, the courtier impersonating Vespucci who was interested in alchemy, repeatedly bought rare and exotic goods at very high prices for the duke at the Frankfurt fair and elsewhere. ${ }^{9}$ The two Aztec shields are very likely to have been in the possession of Niclas Ochssenbach (1562-1626), whom

55 Frischlin, Auffzug, 40. On Guth von Sulz see Werner Fleischhauer, Die Geschichte der Kunstkammer der Herzöge von Württemberg in Stuttgart (Stuttgart: Kohlhammer, 1976).

56 Bujok, Neue Welten, 125; HStAS, A 20a, vol. 4.

57 Bujok, Neue Welten, $127 \mathrm{f}$.

$5^{8}$ The term is Mark Meadow's, see his "Merchants and Marvels: Hans Jakob Fugger and the Origins of the Wunderkammer," in Merchants \& Marvels: Commerce, Science and Art in Early Modern Europe, ed. Pamela H. Smith and Paula Findlen (New York: Routledge, 2002), 193.

59 See, for instance, HStAS, A 256, vol. 97, 362r. 
Frederick had favoured with a position as captain of Tübingen's castle, and who in turn also received objects from Egen. ${ }^{60}$ Frederick showed his own acquisitions to high-ranking Protestant rulers when they visited. In 1602, for instance, Moritz of Hesse noted "beautiful Indian costume made from feathers." ${ }^{61}$

Did Frederick, as much of the literature suggests, acquire many of these artefacts from Bernhardus Paludanus, the Dutch humanist? ${ }^{62}$ Jacob Rathgeb, the ducal secretary, described Frederick's visit of Paludanus's collection when he travelled from Montbelliard and provided an overview of it as a separate booklet of twentyfour pages, which was bound into the account of Frederick's travels. ${ }^{63}$ The visit underlines Frederick's keen interest in natural knowledge, artefacts, and encounter. Amsterdam around 1600 quickly became a hub of global trade in exotica and natural materials, among them birds, featherwork, and clothing. ${ }^{64}$ Alongside England, the Dutch Republic was now a global Protestant power. Frederick made every effort to visit Paludanus on his return from England in 1592, travelling to the Dutch port town of Enkhuizen, seven miles by sea from Amsterdam. ${ }^{65}$

The duke encountered a forty-two-year-old man who had studied medicine in Padua and afterward travelled through Europe, Asia, and Africa. Upon his return to the Dutch Republic, Paludanus had first taken up a position as town physician in Zwolle and then, in 1586, in the port town of Enkhuizen. He collected artefacts and naturalia. Since 1575 , he also kept an unusually extensive album amicorum that included not only the signatures and coats of arms of his many guests, but also about 145 costume figures from different lands (Fig. 4.8). ${ }^{66}$ Paludanus at the time of Frederick's visit, moreover, closely collaborated with Jan Huygen Linschoten (b. 1562), a native of Enkhuizen, and would help him to prepare his pioneering, richly illustrated

\footnotetext{
6 o Bujok, Neue Welten, 112-114.

61 Ibid., 109 .

62 The abundance of featherworks used for the 1599 entertainment might have been lent from the Kassel court, which had recently staged a small procession of America, as well as from the collection of the Tübingen castle-Hauptmann Niclas Ochssenbach. On the Kassel procession see Hartmut Brozinski and Günther Schweikhart, eds., Wilhelm Dilich: Ritterspiele anno 1596 (Kassel: Wenderoth, 1986). On Paludanus see F. W. T. Hunger, "Bernardus Paludanus (Barent ten Broeke) 1550-1633: Zijn verzamelingen en zijn werk," in Itinerario: voyage ofte schipvaert van Jan Huygen van Linschoten naer Oost ofte Portugels Indien 1579-1592, ed. C. P. Burger and F. Hunger, vol. 3 ('s-Gravenhage: Martinus Nijhoff, 1934), 249-268; Roelof van Gelder, "Paradisvogels in Enkhuizen: De relatie tussen Van Linschoten en Bernardus Paludanus," in Souffrir pour parvenir: De wereldd van Jan Huygen van Linschoten, ed. Roelof van Gelder (Haarlem: Uitg. Arcadia, 1998), 30-50.

63 Jacob Rathgeb, Kurtze und Warhaffte Beschreibung der Badenfahrt [...] (Tübingen: Cellius, 1602).

64 Claudia Swan, "Exotica on the Move: Birds of Paradise in Early Modern Holland," Art History 38 , no. 4 (2015): 621-635.

65 The distance is noted in the report by Cellius, Zweyer Raisen, 42.

66 This is held at the National Library of the Netherlands. Marika Keblusek is currently working on Paludanus's album. Frederick's own album amicorum did not contain costume figures.
} 


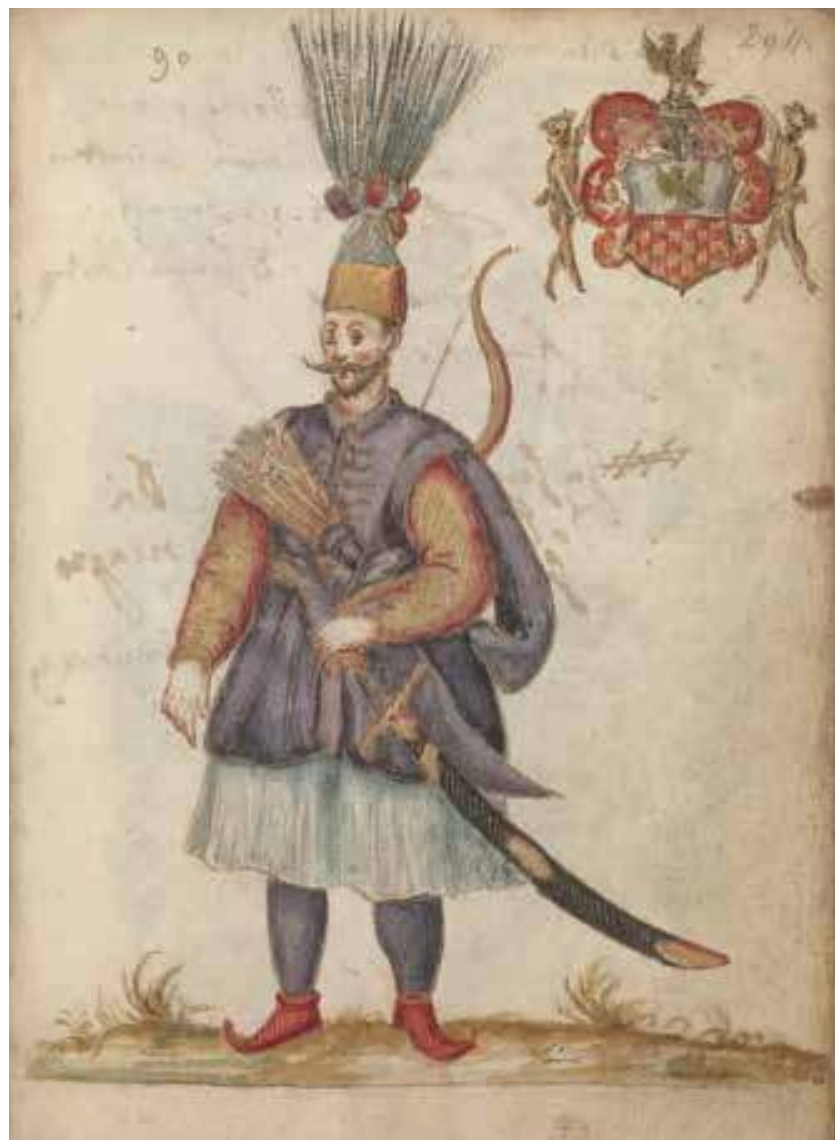

Figure 4.8: Costume image of an Ottoman soldier with a striking feather-headdress. Gouache and brown ink on paper, $15.5 \times 11.5 \mathrm{~cm}$. In album amicorum of Bernardus Paludanus, 1575-1630, fol. 294r. The Hague, Koninklijke Bibliotheek, shelf no. 133 M 63. Image @ KB | National library.

description of his voyage to Goa and Asian countries with which the Portuguese traded. Linschoten's Itinerario was published in $1595^{-96}$ and quickly translated into Latin, English, and French. It stood out for its carefully observed costumes of Portuguese men and women as well as Asians ranging from China to India. ${ }^{67}$

The town of Enkhuizen that Frederick set foot on thus was a microcosm of global knowledge-making in which the claim to first-hand experience through travelling was evidenced through costume, images of costumes, and artefacts as much as writing. This yielded men authority and commodities with which to profitably trade. Linschoten - who was hailed as a "Dutch Magellan" - had brought back his

67 Ernst van den Boogart, Civil and Corrupt Asia: Image and Text in the Itinerario and the Icones ofJan Huygens van Linschoten (Chicago, IL: Chicago University Press, 2003). 
own collection of manuscripts, books, naturalia such as birds of paradise, and artefacts. The former Enkhuizen town physician François Maelsen, as well as the local cartographer Lucas Jansz Waghenaer, belonged to the same Enkhuizen circle of those furnishing knowledge about cultures, which spurred on booming Dutch trade ventures and knowledge-making. ${ }^{68}$

For Frederick, this encounter would have strengthened confidence in an exciting Protestant future. Paludanus had visited Stuttgart in 1581, but it is unlikely that he had then met Frederick, who took over rule in $1593 .{ }^{69}$ Yet the Dutchman's travels through the German lands provided him with useful knowledge about a range of courts and collectors, which helped to demonstrate the advantages of his own collection of coins and minerals, such as different types of sand and stones, as well as plants and animal parts, costume, and handcrafted objects. The lengthy Latin table in Rathgeb's 1602 description of the duke's travels systematically set out the contents of the first ten cases of Paludanus's collection, and this was followed by a summary account of the complete collection in the vernacular as part of the body of the travel account. The collection amounted to 1,440 cases (Kästlin) in eighty-seven drawers (Laden). It was astonishingly comprehensive in naturalia. Six cases alone were filled with 253 types of coral. Rathgeb set out that, as this was "truly a cabinet of wonder," with objects from India and Egypt "and other far away countries which were at hand" and could not easily be brought together again, each piece was thus being described.$^{70}$ Case 63 contained twenty drawers and "foreign birds, including three birds of paradise/ and the clothes made from Brazilian feathers." Case 87, the final case, contained "all sorts of clothes and foreign things from Syria/ Persia/ Armenia/ East and West India/ Turkey/ Arabia/ Muscovy/ etc. in many hundreds." Rathgeb enigmatically ended his account at this point by noting: "all of which I shall put into a case when there is time to do so and send to his highness Duke Frederick." ${ }^{11}$

This passage in the main body of the text has usually been interpreted to indicate that Frederick bought Paludanus's entire collection. More recently, however, Sabine Hesse has argued that this is unlikely, as the Latin inventory itself notes four gifts from Frederick, such as terra sigillata. She argues that the exotica in case 87 were not

68 Ibid., 4-5.

69 Paludanus's entry in Frederick's album amicorum likewise dates from 1602 and supports that the men only met in 1602, see Ingeborg Krekler, Die Handschriften der Württembergischen Landesbibliothek Stuttgart, vol. 3: Stammbücher bis 1625 (Wiesbaden: Harrassowitz, 1999), StB, Nr.9. On Paludanus's career see Cook, Matters of Exchange, 115f., which provides a detailed account of Paludanus's travels in Europe. 70 Rathgeb, Badenfahrt, 132.

71 Cellius, Zweyer Raisen, 156: "Noch eine Laden darinn allerley Kleydungen und fremde sachen/ auß Syria/ persien/Armenien/ Ost und West Indien/ Türkheyen/ Arabien/ Muscovien/ etc zu ettlichen hunderten/ die ich alle mit gelegenheit und zeit/ ein jeglichs in sein kasten stellen soll/ und E.F.Gn. zustellen." 
destined to be sent to Frederick as artefacts but were meant to be incorporated into the systematic order of Paludanus's own collection. She correctly notes, moreover, that Paludanus's inventory was sent to Frederick after the trip had been completed, and in fact after Frederick had risen from ruling over Montbelliard to ruling over Württemberg, as the inscriptions of his gifts indicate..$^{2}$

Yet a third possibility appears to be that not the entire collection, but only the final case with "various clothing and strange things" in their hundreds, was sent to Stuttgart. It was discussed without reference to a number, was not part of the Latin inventory, and was subsequently referred to in German at the very end of Rathgeb's account of the visit. Rathgeb's enigmatic note might well indicate that only this part of Paludanus's collection was transferred to Stuttgart. ${ }^{73}$ As Rathgeb refers to this task, there remains little doubt that either the whole collection or this section was bought by the duke, but Hesse is right to point out that the fact that the Latin inventory shows that ducal gifts had later been incorporated indicates that the main body of the collection is likely to have remained in Enkhuizen. It would have been a strange decision for Paludanus in 1592 to sell off his entire collection, especially since these were the crucial years of his collaboration with Linschoten. On the other hand, when a duke of Pomerania visited Stuttgart in 1602, his tutor noted that Frederick's cabinet "had not so many marvels as foreign rarities, most of which the current duke has bought for a lot of money from doctor Paludanus and among which the most noble pieces cost him around six thousand Thaler." Hence the evidence is far from clear.74

The implication of the possibility that only the unnumbered final case was transferred is twofold. It underlines Frederick's early and distinct interest in possessing authentic foreign dress, including featherwork, which he could then use in entertainments. The inclusion of Paludanus's inventory, moreover, might explain the success of Rathgeb's 1602 publication, prepared in at least five editions, and even more so its success as part of Cellius's 1603 and 1604 editions of Rathgeb's account alongside an account of Frederick's voyage to Italy in 1599, which took place after the Stuttgart entertainment. At least twelve editions of these travel accounts and Cellius's celebratory poem survive. The inventory of Paludanus's collection in Latin would have been of interest to an international audience of art lovers and natural philosophers, and the record of Frederick's gifts for Paludanus's collection prominently positioned him among them.

By 1625, Jakob Bornitz's (1560-1625) treatise On a Sufficiency of Things laid the ground for a political analysis of the role of art and crafts. Its list of notable European

72 Hesse, "Neue Welt in Stuttgart," 146, fn. 16.

73 Rathgeb, Badenfahrt, 156, as above. Paul Sauer also seems to have adopted this interpretation of the text, see his Herzog Friedrich, 145.

74 For Gerschow's report and the unresolved assessments of whether the Paludanus collection formed a major part of Frederick's cabinet see Die Kunstkammer der Herzöge von Württemberg, 104-105, 73-75. 
collections was painstakingly copied down by the pan-European Protestant reformer Samuel Hartlib (160o-1662). This underlines the enduring effect of Frederick's collecting strategy, which linked him to Paludanus, whom Bornitz had likewise himself visited. Major collections, Bornitz noted, were to be found in or at:

The courts of the elector of Saxony

The Landgrave of Hesse

The Grand Duke of Tuscany

The Duke of Württemburg in Stuttgart

The Duke of Bavaria in Münich

and in the home of the doctor Paludanus in Enkhuizen. ${ }^{75}$

As Vera Keller has shown, Bornitz was a leading Lusatian jurist with close connections to Rudolf II's court in Prague. He was engaged in debates about universal reform alongside prominent Württemberg writers such as Christoph Besold and Johann Valentin Andreae. Bornitz provided an early economic theory of how cameralism and artisanal knowledge benefited a body politic spearheaded by intellectually as much as physically engaged rulers. Such engagement manifested itself through travel and hands-on work as well as the way in which he animated a body politic through vital spirits. ${ }^{6}$

Bornitz thus came to theorize the practice of courts, such as in Württemberg under Frederick's rule, and likewise drew on the popular genre of art and recipe books, which described how to achieve dyes, make medicines, or style hair. ${ }^{77} \mathrm{He}$ celebrated humankind's potential for constant innovation and change, the desire for the inexhaustible new, the discovery of new techniques, as well as the recovery of ancient practical knowledge. The jurist endorsed the importance of alchemy and eventually listed an enormous number of things which ought to be seen as the foundation of civil and civilized societies rather than being decried as lamentable luxuries. He lauded Rudolf II's court in Prague for attracting so many foreign craftsmen who perfected nature through art.$^{7}$ The many things Bornitz listed to show "everything art, nature, or learning could furnish" included confectionary or soap-balls, flowers, ribbons, and wreaths, and appeared alongside feathers and

75 Keller, Knowledge and the Public Interest, 172, my emphasis. On Bornitz see also Winfried Schulze's influential article, "Vom Gemeinnutz zum Eigennutz: Über den Normenwandel in der ständischen Gesellschaft der Frühen Neuzeit," Historische Zeitschrift 243 (1986): 591-626.

76 Keller, Knowledge and the Public Interest, offers a pioneering discussion of Bornitz's importance, 95-126.

77 He prominently draws on Balthasar Schnurr's enormous compendium, which kept on being republished throughout the seventeenth century.

78 Keller, Knowledge and the Public Interest, 116-118. 


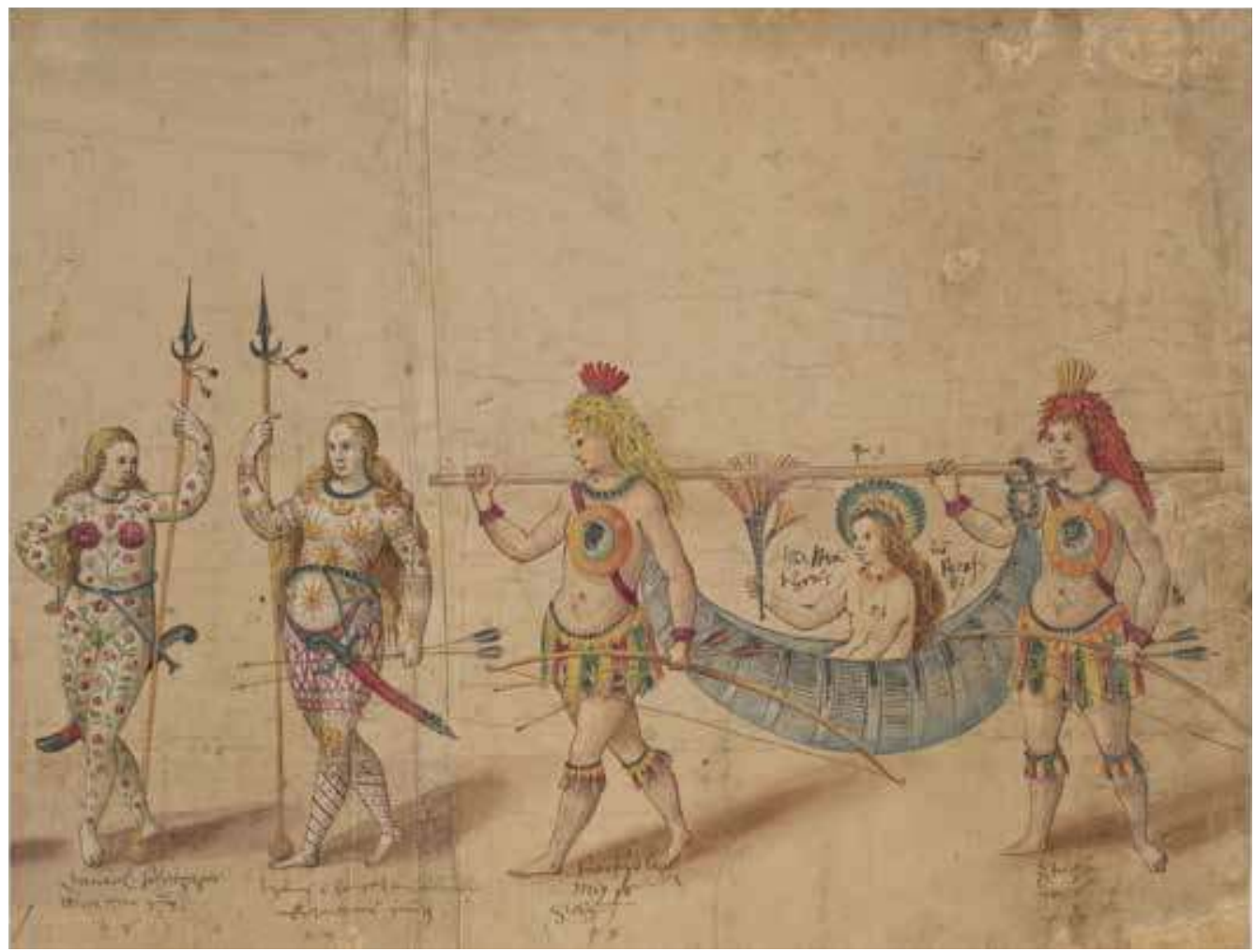

Figure 4.9: Procession at the Württemberg Court in Stuttgart, 1599: The final scene. Watercolour, pigment, and gold on paper, $29.6 \times 38.6 \mathrm{~cm}$. Weimar, Graphische Sammlungen, Klassik Stiftung Weimar, inv. no. KK 209. Image @ Stiftung Weimarer Klassik und Kunstsammlungen/Museen. Photo: Roland Dreßler.

their expert craftsmen, the Federschmucker. ${ }^{79}$ Adapted from the Indies, these subtle, translational objects now served to embellish Europeans.

\section{Spending on Feathers}

This is borne out by the Stuttgart court's annual spending on featherwork, which is exceptionally well documented in the ducal treasury's account books. ${ }^{80}$ The court relied on several long-serving artisans of high quality who practised their

79 Jakob Bornitz, De Rerum Sufficientia in Rep. \& Civitate procuranda [...] (Frankfurt-am-Main: Tampachius and Weissius, 1625), ch. 89, 199, De plumariis.

80 Fleischhauer, Renaissance, 428 . The Landschreibereiakten provide a serial record that is preserved in its entirety - they contain c. 20 pages each year for spending on artisanal work, products, or materials, including spending on the alchemical laboratory. My thanks to Dr Stefan Hanß for transcribing the records for the reigns of Frederick and John Frederick - an edition will be published as Stefan Hanß, Court 
craft with their wives and passed on their knowledge to the next generation. In relation to silk embroidery and featherwork, this required the ability to work with particular ingenuity for festivities, tournaments, and masques. Frederick could draw on the extraordinary expertise of two longstanding colleagues entrusted with such work: the embroiderer Salomon Daubenhauer, who was also trained as an artist and was employed between 1556 and 1609-10; and the feather-worker Hans Dannenritter, employed between 1557 and 16o2, who in addition to working with real or false feathers crafted from wool, also lined head-wear or provided hat-bands and multi-coloured silk ribbons. Daubenhauer and Dannenritter, in addition, jointly kept a shop. ${ }^{81}$ Further featherwork for the court was mostly supplied by one Adam Eßlinger, whose son continued alongside Ludwig Dannenritter after his father's death in 1602, and, between 1612 and 1634, Jakob Unangst. ${ }^{82}$

Expenditure on feathers and head-wear was considerable. In 1595, Hans Dannenritter, for instance, received a total of 921 florins for "feathers and work" carried out to suitably attire the Württemberg delegation for the Regensburg Imperial Diet. $^{83}$ In 1596 , he received over 607 florins in connection with a tournament and masque, as well as a further 25 florins for featherwork supplied to the ladies at court and 4 florins for silk ribbons for those working in the ducal chancellery. ${ }^{84}$ These costs compare to those of a simple silver cup from a Stuttgart goldsmith for 14 florins in 1595-96, or the average price of 204 florins for a golden necklace from Augsburg during the same year. ${ }^{85} \mathrm{~A}$ bird of paradise sourced via Nuremberg cost 100 florins. ${ }^{86}$ In $1595^{-96}$, a group of craftspeople were paid 809 florins specifically for work on entertainments. ${ }^{87}$ Even against this figure, the high cost of Dannenritter's contribution (6o7 florins) in $1596-97$ stands out. ${ }^{88}$

The account book roughly filled the same number of pages listing expenses year after year, which means that it is doubtful that every expense was noted. Moreover, while many of the entries precisely identified which objects had been paid for, others recorded in a summary manner that "Georg Gewandschneider from Nuremberg," a tailor, had been paid 770 florins, or a Frankfurt jeweller 50 florins "for numerous

and Material Culture in Early Modern Germany: A Sourcebook on the Duke of Württemberg's Payments to Artisans, Stuttgart, 1592-1628 (Amsterdam: Amsterdam University Press, forthcoming).

81 Fleischhauer, Renaissance, 234f.

82 Ibid., 428.

83 HStAS, A 256, vol. 81, 332v-333v.

84 HStAS, A 256 , vol. 83,365 r.

85 HStAS, A 256, vol. 82, 370v.

86 HStAS, A 256 , vol. 83,356 r.

87 HStAS, A 256, vol. 82, 378rf.

88 HStAS, A 256, vol. 83, 365r. 
things," while Carl Egen purchased goods worth 674 florins at the Frankfurt fair in $1596-97$, some of which might well have been exotica. ${ }^{89}$

The account books, therefore, cannot serve as a basis for any exact statistical analysis. Yet they clearly suggest that feathers and indigenous featherwork for the entertainment in February 1599 were accumulated and perhaps already used in previous years and relied on a network of intellectuals, dealers, and craftsmen in Nuremberg and Augsburg. Most interestingly, Levinus Hulsius of Nuremberg was paid 216 florins for "several Indian and other things." Hulsius was born in Ghent in 1546 and had sought refuge in Germany in 1583 . He is well known for his interest in mathematical and astronomical instruments, publishing Tycho Brahe, and also trading instruments, many of which promised to improve navigation and thus commercial success. In addition, Hulsius translated travel accounts from Dutch into German, notably an account of East Indian voyages in 1598. Like other travel accounts from his press, these cheap, illustrated quartos were so successful that they complemented de Bry's. ${ }^{90}$ What has gone unnoticed so far is that, just as he dealt in instruments, Hulsius also traded Indian artefacts, which he most likely sourced via Amsterdam or the Frankfurt fair. The brokerage of such artefacts could be interlinked with a wider set of intellectual and economic engagements, rather than simply being a matter of supplying "costume."

Meanwhile, Zachariae Ringswanden, another Nuremberg dealer, received the considerable sum of 209 florins in 1598 just for parrot feathers. At the same time, decorated parrot feathers retailed for about 1 florin in Nuremberg..$^{91}$ Ringswanden was soon asked to send additional parrot feathers for 39 florins, while a Ludwig Heinzeln was reimbursed another 200 florins which he had paid the same dealer..$^{92}$ Very soon after these payments, an Augsburg feather-worker named Augustein Weltz was paid 500 florins for the "masque for the Ringlinrennen," while a number of temporary painters who had been employed on a daily basis for the entertainment received a mere 25 florins. ${ }^{93}$ One parrot had been acquired for 40 florins..$^{94}$ Perhaps because Weltz had been brought in from Augsburg, Hans Dannenritter received only 98 florins for featherwork carried out between July 1596 and February 1598.95

89 HStAS, A 256, vol. 82, 372r; vol. 83, 353r.

90 Michiel van Groesen, The Representation of the Overseas World in the De Bry Collection of Voyages (1590-1634) (Leiden and Boston, MA: Brill, 2008), 346-351.

91 Jutta Zander-Seidel, Textiler Hausrat: Kleidung und Haustextilien in Nürnberg von 1500-1650 (Munich: Deutscher Kunstverlag, 1990), 226.

92 HStAS, A 256, vol. 85, 376v-377r.

93 Ibid., 378r.

94 Ibid., 372v-378r.

95 Ibid., 38 or. 


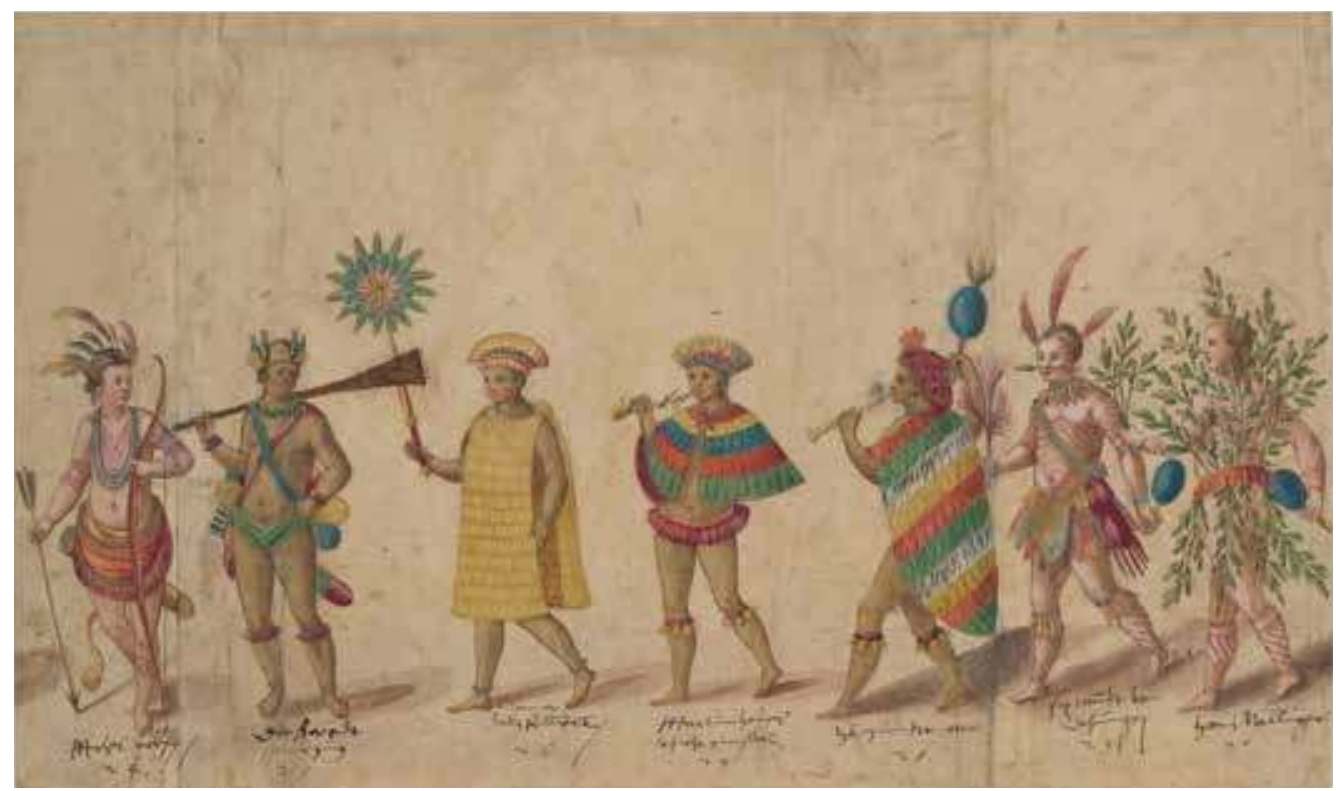

Figure 4.10: Procession at the Württemberg Court in Stuttgart, 1599: The fifth scene. Watercolour, pigment, and gold on paper, $30.0 \times 50.9 \mathrm{~cm}$. Weimar, Graphische Sammlungen, Klassik Stiftung Weimar, inv. no. KK 206. Image $\odot$ Stiftung Weimarer Klassik und Kunstsammlungen/Museen. Photo: Roland Dreßler.

Susanna Mentler from Augsburg, meanwhile, was paid 28 florins for making wigs for the entertainment with "curled human hair." 96

The accounts for 1598-99 indicate that Dannenritter's expertise was reinstated: he was paid 400 florins for featherwork carried out between 28 March 1598 and 12 April 1599, the period which included the February show. ${ }^{97}$ Shortly after, he received 10 florins for five feather tips, while the painter who recorded the entertainment on parchment was paid 20 florins for the task..$^{8}$ During the following year, Carl Egen received 142 florins for "all sorts of Indian things" he had bought for Frederick, while Dannenritter received 132 florins - very much his average pay for routine work carried out at the court. 99 Overall, Dannenritter was nonetheless paid 9,500 florins between 1557 and his death in 1602 - more than 200 florins on average per year just for his work for the duke, which indicates his respectable income. $^{100}$

The account books, in other words, provide evidence that despite the later reports, which emphasized the exotic nature of all feather-costumes used in the

96 Ibid., $384 \mathrm{v}$.

97 HStAS, A 256, vol. 86, 383 r.

98 Ibid., $383 \mathrm{v}, 384 \mathrm{r}$.

99 HStAS, A 256, vol. 87, 362r, 376v, see his salary of 116 florins in 1600 , HStAS, A 256, vol. 88, 379v.

100 On the overall figure see Fleischhauer, Renaissance, 235. 
entertainment, considerable sums of money had also been spent on the skilful German re-crafting of an Indian look. Paludanus's and other original artefacts would have served as models to imitate Indian fibre and textile arts and become more familiar with them. ${ }^{101}$

\section{The Politics of Feathers}

Frederick I of Württemberg unexpectedly died in 1608. His son Johann Friedrich took over rule just as the Protestant Union was founded as a military coalition in a new age of fragile Imperial governance and greater confessional tension. The official description of his marriage festivities with Barbara Sophia of Brandenburg in 1609 argued that Germans had acquired greater experience and ingenuity than other nations through their keen travelling. ${ }^{102}$ John Frederick inherited and added to the cabinet, which he showed off to the young Calvinist ruler Frederick $V$ of the Palatinate and his wife Elizabeth as well as Duke Frederick III of Schleswig-Holstein as important guests in $1616 .{ }^{103} \mathrm{He}$ had been thoroughly socialized into a world view which accorded indigenous featherwork and birds great significance, and in 1607, for instance, had taken back "lots of Indian things" for his father's cabinet when he returned from a trip to the Netherlands. ${ }^{104}$

The duchess and her courtly ladies now spent much more freely on luxuries and attire. Entertainments became ever more lavish. In 1616, the ducal couple celebrated the baptism of their son during one of the new Protestant Union's most formidable festivities. The entertainment focused on Germany's united interests against the threat of over-powerful Catholic Habsburg rule, and emphasized the importance of patriotism. ${ }^{105}$ The notion that Württemberg's virtue could inspire Germany and spread globally was retained, as was the notion of a dialogue with representatives of such nations.

Remarkably, Ferdinand Geizkofler, a leading court politician, appeared as "regent of Madagaskar" with an entourage dressed from top to toe in green- a colour

101 For a brief discussion of separate lists from 1634 that contain indigenous feather costumes for entertainments see Bujok, Neue Welten, 160 .

102 Alexander Schmidt, Vaterlandsliebe und Religionskonflikt:Politische Diskurse im Alten Reich (1555-1648) (Leiden and Boston, MA: Brill, 2007), 336, fn.420.

103 Bujok, Neue Welten, 104; Fleischhauer, Renaissance.

104 Hesse, "Neue Welt in Stuttgart," 143.

105 Schmidt, Vaterlandsliebe, 328-350; Laure Ognois, "Dass ein Cavallier seinen Dienst nicht besser kan anwenden, als denselben dem Vaterland zu nutzen den Unirten zu praesentieren: Politische Instrumentalisierung eines christlichen Ereignisses? Die Festtaufe Friedrich von Württembergs im Jahre 1616," in Union und Liga 16o8, 16og: Konfessionelle Bündnisse im Reich - Weichenstellung zum Religionskrieg, ed. Albrecht Ernst and Anton Schindling (Stuttgart: Kohlhammer, 2010), 227-262. 
associated with renewal, hope, and love. He announced that the people of America, Asia, and Africa all spoke about the virtue and perfection of the Württemberg court. A perfect knight, he declared, was "not only gotten by deeds of prowess," but also "by constancie and faithfulness in Love." This challenged the stereotype of African people as less civilized and more unruly in their desire. ${ }^{106}$

Above all, the masque sought to end dissonance in Germany and achieve concord among "great lords who by their wisedome shall reforme and confirm the old confidence of Germans." ${ }^{\prime 107}$ Virtue, and the stimulation of affects in accordance with a fortuitous constellation of Sagittarius over Stuttgart, was expected to increase the population's love of the German fatherland and freedom. ${ }^{108}$

Feathers, dress, and translucent jewellery now formed an assemblage of accessories that structured perceptions and affects. The lengthy festival description in German and English noted a variety of feathers used and their colours as well as their effects. The Augsburg art agent Hainhofer particularly lauded the joyful, friendly manner of the princess, who spoke many languages, but preferred fluent English and French, wore liberating English dress, danced gracefully, and galloped more energetically than her husband to hunt down five wolves, eighteen rabbits, a fox, and three herons. ${ }^{109}$ "The princess," he noted,

is stacked up with big diamonds, in her hair, on her sleeves, around her neck, on her ears, and especially she wore a diamond collar on her bare chest, (as the ladies now sport the English manner, wide and open at the front), with beautiful large stones (Clainot) which one estimates are worth a kingdom, and the image of this I send to the duke, and in her hair she wore small white feathers. ${ }^{110}$

Before sitting down for lunch, the princes put their hats aside and this gave Hainhofer the opportunity to inspect them alongside a court councillor, who acted as his guide. Johann Friedrich's aigrette of heron feathers, his Raigerbusch, was adorned with a diamond feather and a ribbon of twelve diamonds; Hainhofer established that it was said to have cost the duke 2,00o florins. ${ }^{111}$

Württemberg continued to position itself as a distinguished, international, Anglophone Protestant court, with new forms of dress and an interest in new types

106 Ludwig Krapf and Christian Wagenknecht, eds., Stuttgarter Hoffeste: Texte und Materialien zur höfischen Repräsentation im frühen 17. Jahrhundert, vol. 2 (Tübingen: Max Niemeyer, 1979), 118-122, this is ignored in Schmidt's focus on patriotism.

107 Ibid., 2:100.

108 Ibid., 100-103.

109 Ibid., 331, 342 .

110 Ibid., 328.

111 Ibid., 329 . 
of craft and learning. The fascination with English dress, which had already appealed to Frederick, went so far that Prince Lewis-Frederic of Württemberg himself dressed up as an English lady. The prince had even mastered riding side-saddle. He and his two companions distinguished themselves through their bare necks (instead of wearing more restricting high-necked collars and ruffs) and wore gowns made from

white satin from China (embroidered with) with red and blew flowers, their petticoats of a sea-greene colour: they had in their hand blacke fannes (fans), in summe they were right like English Ladies, sitting a side as ladies are wont to ride and naming themselves by borrowing English names. ${ }^{112}$

The men attired as ladies Darby, Winchester, and Pembroke announced, no less, that "Womankind doe excel mankind as farre as heaven excelleth earth" - women excel men as far as heaven excels earth. ${ }^{113}$ Such expertise continued to manifest itself in alchemical and medical experiment and experience, for the benefit of mankind. Hainhofer thus visited the two laboratories of the ducal pharmacy, which traditionally were operated by the duchess and other women, and were situated next to the rooms for the princess, her ladies, and the smaller and older children. ${ }^{114}$

He also visited the cabinet of curiosities, noting that it contained many "pieces of Schwegler's featherwork." ${ }^{\prime 15}$ Schwegler was a prized artist who fixed feathers onto wax miniatures of birds and supplied the Stuttgart as well as other courts with artificial bird houses or whole miniature farmyards. ${ }^{116}$ The art agent next repeated a visit to one of the most ambitious of Frederick's and John Frederick's cameralist projects, the "silk house," which continued to operate until much of Württemberg was devastated after the battle of Nördlingen during the Thirty Years' War, in 1634. Hainhofer admired the local production of silk, which had been grown in Württemberg and spun and manufactured in Stuttgart into rich velvets and other silks in order to alleviate the burden of costly imports on the population. ${ }^{17}$ This highlighted the virtuous ingenuity of craftspeople who had been lured to Württemberg from Italy and Geneva. ${ }^{118}$

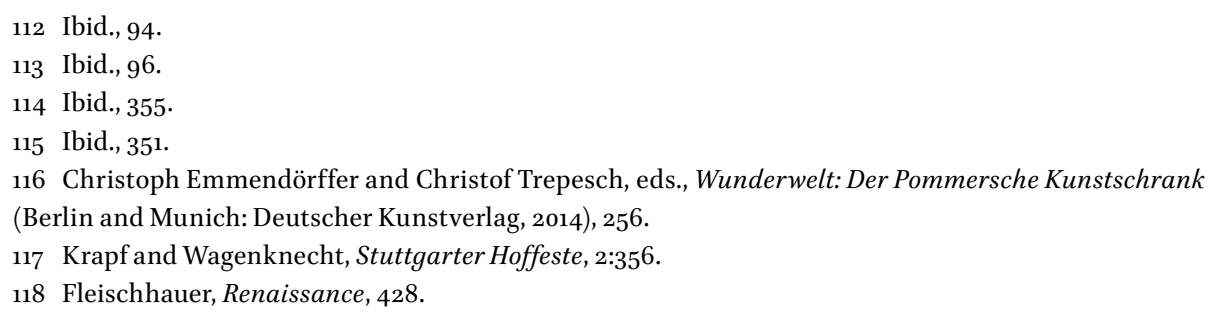


Rudolf Weckherlin dedicated his account of the baptism to Elizabeth Stuart. ${ }^{119}$ "My soul," he enthused, "was amazed with marvell: mine eyes did dazzle: and all my senses were overwhelmed by the majestie, beautie, richesse, and magnificence of those brave Princeses, Princes, Ladies, Lords and Knights."120 Expenditure was once more vast - in 1616-18, more than 7,0oo florins were paid to artisans just for work carried out to prepare the celebrations. ${ }^{121} \mathrm{High}$-quality feathers continued to be costly: in 1618, Jacob Unangst, the Federschmucker, was paid $5^{2}$ florins for just "15 feathers, of different colours." ${ }^{\text {122 }}$

Eyes were "fed" with such pleasant sensations, and Weckherlin thus detailed the apparel of those who partook in the elaborate masque. Here were "bravely apparelled" ancient Romans, "all in white satin, covered with gold and silver, their helmets garnished with great bunches of red, yellow, blew, and white feathers. ${ }^{{ }^{123}}$ An Indian with a "fair cloke of coloured feathers" and a hat made of feathers jumped out of a giant head. ${ }^{124}$ Trojan knights appeared, their "head peeces glistering of gold and silver, and covered with great yellow and white feathers."125 Hector sported a golden helmet on which floated a green and white feather panache. Mercurius and Apollo were adorned with "great bunches of red, white, and yellow feathers," while a Trojan monarch wore a golden helmet "where did waver upon a plume of manie faire colours." ${ }^{\prime 26}$

Frederick $\mathrm{V}$ of the Palatinate was the most noble guest at the baptism and appeared as a dazzling Scipio Africanus, a conqueror whose "sumptuous helmet was over-shadowed by a great wavering bunch of red and white feathers." His horse despised the ground and bore "himself up by his own courage, might and ostentation in a higher element." This was an approximate translation of the German text and emphasized the understanding that feathers and their translucent adornments, such as spangles - small, gilded metal-plates attached to feathers - or jewellery and their movement, instantiated an awe-inspiring, masterful moment of engagement with air as a higher element than earth, performing triumphant magnificence as moral superiority:

119 Ibid., 333f. and through the close diplomatic ties forged between Stuttgart and London, Weckherlin later came to serve the English Crown, arranging masques for Queen Henrietta Maria.

120 Krapf and Wagenknecht, Stuttgarter Hoffeste, 1:18f.

121 HStAS, A 256, vol. 103, 39or, two entries for over 4,000 florins, which summarize the costs and thus make it impossible to gauge how much was paid for feathers and featherwork. Further bills came in during the following year - see for instance a bill for twelve ballet outfits of 142 florins, vol. 104, 338v and 389v, summary costs of 1,884 florins.

122 HStAS, A 256, vol. 104, 389r.

123 Krapf and Wagenknecht, Stuttgarter Hoffeste, 1:20-23.

124 Ibid., 24f.

125 Ibid., $32 \mathrm{f}$.

126 Ibid., 34-36. 
His steed, recognizing and appreciating, as it were, his superhuman encumbrance, kept rearing up and haughtily stamping the earth, prancing with his gleaming adornments and shaking his flying plumes of feathers in the air.

Sein hengst, erkennend gleichsam und schätzend seine übermenschliche bürde, erhub sich derselbingen ohn ablaß und stampffte verächtlich die erden, prachtierte mit seiner schimmernden zier und fliegenden federbuschen in dem luft. ${ }^{127}$

Horses were, of course, likewise adorned with feathers, and their quality was repeatedly emphasized as they could be described as "high feathers," ${ }^{28}$ or "great peacock-feather panaches" to accentuate pride and fallibility. ${ }^{129}$

The running of the ring caused more sensation. Nothing, wrote Weckherlin,

could be seene round [...], but silver, gold, jewels, flowers, feathers, banners, launces and pennons of all colours. The splendour did dazzle the eyes of the beholders, and the richesse did ravish their minds.

This complemented, rather than exactly translated, the German:

Man sahe nichts innerhalb den schrancken ganz herumb, dan silber, gold, edelgestein, und gestickte klaider glänzen, und allerley blumen, federn und fahnen inder luft schweben. Möniglich war mit wunder verzuckt ab dem pomp all dieser newheiten.

Within the ring one saw nought but silver, gold, precious stones, and shimmering embroidered garments, and all manner of flowers, feathers and pennants floating in the air. Many were dazzled by wonderment at the pomp of all these novelties. ${ }^{130}$

The materials and dramaturgy used in the tournament were once more designed to emanate affective transformations in the audience through animated accessories. The "graceful managing" of "bodily behaviour" induced astonishment, awe, and dread through demonstrations of power, as much as hope and pleasure through acts of mercy. ${ }^{131}$

127 Ibid., 48f, my emphasis, and: the beauty of the horses increased his "magnificence and wonder."

128 Ibid., 60.

129 Ibid., 67, 70 .

130 Ibid., $86 f$.

131 Ibid., 88. 


\section{Conclusion}

Duke Frederick's parading as America did not just remain a fleeting vision to present the splendours of his cabinet of curiosities and stage his magnificence. Since 1595, Frederick's court painter and sculptors had worked on a major new portal for the court. It now faced the city of Stuttgart and showed Frederick's and his wife Sibylla von Anhalt's coats of arms surrounded by several life-sized standing and lying "Indian" figures, which represented the 1599 procession. ${ }^{132}$ Frederick's interest in the New World was thus commemorated as public art - Frischlin's description declared that in Stuttgart the new portal could be seen from "everywhere" and all Württembergers needed to understand its significance. ${ }^{133}$

The entertainment, therefore, underlines the necessity to re-orient our understanding of Lutheran court culture in the confessional age. It cannot be understood as insular, frozen in time, or solely as dominated by an affective atmosphere generated by apocalyptic Lutheran sermons. Rather, Frederick used feathers as cultural material and commemorated their use on the gate for all Württembergers in order to propagate the benefits of innovation, empirical knowledge, craft, and cultural exchange. An account of a 1596 entertainment at the Protestant court in Kassel had already innovated by staging America as one among the continents through the use of featherwork, and a printed report followed de Bry's condemnation of Spanish atrocities. ${ }^{134}$ A positive depiction of America as a sister continent thus served as a Protestant programme that fused with a positive vision of global trade and, as the example of the Calvinist Johann Moritz of Nassau Siegen - who had been educated at the Kassel court - would soon bear out in Brazil, the possibility of expanding empire. ${ }^{135}$ The completion of a building programme in 1599 , which

132 Fleischhauer, Renaissance, 274; Frischlin, Auffzug, 44: "Darauff folgt Herzog Friderich/ Der durchleuchtig ließ sehen sich/ Mit seim Auffzug in solcher Gstalt/ Wie auff diß Fürsten Hoffthor gmahlt/ Von neuwen Königlichen Portall/ Zu Stuttgart sihst dus uberall/ Oder wie ich da beschreiben will/ Merkt auff ihr Würtenberger/still" (in translation: Duke Frederick followed/ His Highness let himself be seen/ In an array such as/ that painted on the princely court gate/ of the new Royal Portal/ At Stuttgart you can see it from everywhere/ Or as I choose to describe it/ Württembergers take note).

133 Archival evidence likewise suggests that a new portal was built. On the function of masques in Germany see Schnitzer, Höfische Maskeraden, $358 \mathrm{f}$.

134 Hesse, Kunstkammer, 163; Brozinski and Schweikhart, Wilhelm Dilich, for the positive representation of ingenuity trained/cultivated through craftsmanship to which artefacts testify, transforming humans through acquired skill. For the history of European understanding that practice develops mental as well as manual ability and is therefore a liberal rather than mechanical art, see Marieke M. A. Hendriksen, “'Art and Technique Always Balance the Scale': German Philosophies of Sensory Perception, Taste, and Art Criticism, and the Rise of the Term Technik, ca. 1735-ca. 1835," History of Humanities 2, no. 1 (2017): 201-219.

135 Featherwork from Brazil remained of great value as diplomatic gifts for Protestant leaders during the seventeenth century, after Johann Moritz's return, see Françozo, "Beyond the Kunstkammer," 120. 
erased eleven civic houses in order to create more space for the ducal castle and associated squares, buildings, gardens, and gates, along with Frischlin's account, Cellius's poem, Rathgeb's book, and the images of the 1599 entertainment, all served to bolster a vision of Württemberg's leadership towards a future for which openness to innovation, travel, different cultures, and modern foreign languages in an interconnected global world was vital. ${ }^{136}$ It was a visual as much as material act to transform the mindsets of the estates and population who seemed rooted in their localities and local needs. ${ }^{137}$ Württemberg itself was a leader among the Protestant nations. Featherwork could be staged as an important idiom of this luminous leadership to set off new affective atmospheres. ${ }^{138}$ Objects, vision, and touch were thus increasingly integrated into a concept of political rhetoric that opened up to "new possibilities" through performances. These entertainments were designed to persuade and appeal to reason as much as to transform affects from ungoverned passions into eloquent moral, subtle, and graceful sentiments. ${ }^{139}$ The 1599 entertainment and John Frederick's Protestant Union festivals can in this sense be read as outstanding attempts to animate and transform affects in the body politic. In Stuttgart, these affective atmospheres sought, above all, to stabilize optimism about future discoveries and territorial development, as well as the strength of the Protestant Union on the eve of the Thirty Years' War. ${ }^{140}$

136 See also Christadler, "Indigenous Skins," 24.

137 The core of this interpretation is also supported by Fleischhauer, Renaissance; on the building programme, the role of clothing, dance, festivities, and food see also Nicole Bickhoff, “'Gott kann der Welschen pracht nicht leiden'."

138 Andreas Reckwitz, "Affective Spaces: A Praxeological Outlook," Rethinking History 16, no. 2 (2012): 241-258.

139 See the important work by Mark Greengrass, Governing Passions: Peace and Reform in the French Kingdom, 1576-1585 (Oxford: Oxford University Press, 2007), 367f. and Cornelia Niedermeier, Gedanken-Kleider: Die Allegorisierung des Körpers in Gesellschaft und Theater des 17. Jahrhunderts (Vienna: Universitätsverlag, 2000), 48.

140 For the definition of the term affective culture and habitus see Andreas Reckwitz's pioneering essay, "Affective Spaces," 253-255; on the political importance of the pioneering Protestant Union festivals in Württemberg see Watanabe-O'Kelly, Triumphall Shews. 


\section{Bibliography}

\section{Unpublished Primary Sources}

Landesarchiv Baden-Württemberg, Hauptstaatsarchiv Stuttgart (HStAS)

A 20a, vol. 4

A 256 , vols. 81, 82, 83, 85, 86, 87, 88, 97, 103, 104

\section{Published Primary Sources}

Bornitz, Jakob. De Rerum Sufficientia in Rep. \& Civitate procuranda [...]. Frankfurt-am-Main: Tampachius and Weissius, 1625 .

Cellius, Erhard. Wahrhaffte Beschreibung Zweyer Raisen. Tübingen: Cellische Truckerey, 1603. Dilich, Wilhelm. Historische Beschreibung der Fürstlichen Kindstauff Fräwlein Elisabetha zu Hessen ... Welche im Augusto dess 1596. Jahrs zu Cassel gehalten worden. Kassel, 1598.

Frischlin, Jakob. Beschreibung deß fürstlichen Apparatus, königlichen Auffzugs, heroischen Ingressus und herrlicher Pomp und Solennittet. Frankfurt-am-Main:Joachim Brathering, 1602. http://digital.slub-dresden.de/werkansicht/dlf/65017/1/.

Rathgeb, Jacob. Kurtze und Warhaffte Beschreibung der Badenfahrt [...]. Tübingen: Cellius, 1602.

\section{Secondary Literature}

Bickhoff, Nicole. “'Gott kann der Welschen pracht nicht leiden': Hof- und Festkultur unter Herzog Friedrich I. von Württemberg.” In Hofkultur um 16oo: Die Hofmusik Herzog Friedrichs I. von Württemberg und ihr kulturelles Umfeld, edited by Joachim Kremer, Sönke Lorenz, and Peter Rückert, 73-94. Sigmaringen: Thorbecke, 2010.

Boogart, Ernst van den. Civil and Corrupt Asia: Image and Text in the Itinerario and the Icones ofJan Huygens van Linschoten. Chicago, IL: Chicago University Press, 2003.

Boone, Elizabeth H. "Seeking Indianness: Christoph Weiditz, the Aztecs and Feathered Amerindians." Colonial American Review 26, no. 1 (2017): 39-51.

Bredekamp, Horst. Image Acts: A Systematic Approach to Visual Agency. Berlin and Boston, MA: De Gruyter, 2018.

Brozinski, Hartmut, and Günther Schweikhart, eds. Wilhelm Dilich: Ritterspiele anno 1596. Kassel: Wenderoth, 1986.

Bujok, Elke. Neue Welten in europäischen Sammlungen: Africana und Americana in Kunstkammern bis 1670 . Berlin: Reimer, 2004.

Buono, Amy J. “Their Treasures Are the Feathers of Birds': Tupinambá Featherwork and the Image of America." In Images Take Flight: Feather Art in Mexico and Europe 1400-1700, 
edited by Alessandra Russo, Gerhard Wolf, and Diane Fane, 178-189. Munich: Hirmer, 2015 .

Buono, Amy J. "Representing the Tupinambá and the Brazilwood Trade in Sixteenth-Century Rouen." In Cultural Exchange between Brazil and France, edited by Regina R. Felix and Scott D. Juall, 19-34. West Lafayette, IN: Purdue University Press, 2016.

Cavallo, Sandra. "Health, Air and Material Culture in the Early Modern Italian Domestic Environment." Social History of Medicine 29, no. 4 (2016): 695-716.

Cavallo, Sandra, and Tessa Storey. Healthy Living in Late Renaissance Italy. Oxford: Oxford University Press, 2013.

Christadler, Maike. "Indigenous Skins: Indian Costume at the Court of Württemberg." In Visual Representations of Native Americans: Transnational Contexts and Perspectives, edited by Karsten Fritz, 13-28. Heidelberg: Universitätsverlag, 2012.

Cook, Harold. Matters of Exchange: Commerce, Medicine, and Science in the Dutch Golden Age. New Haven, CT: Yale University Press, 2007.

Die Kunstkammer der Herzöge von Württemberg: Bestand - Geschichte - Kontext, 3 vols., exh. cat. Ulm: Jan Thorbecke, 2017.

Emmendörffer, Christoph, and Christof Trepesch, eds. Wunderwelt: Der Pommersche Kunstschrank. Berlin and Munich: Deutscher Kunstverlag, 2014.

Fleischhauer, Werner. Renaissance im Herzogtum Württemberg. Stuttgart: Kohlhammer, 1971. Fleischhauer, Werner. Die Geschichte der Kunstkammer der Herzöge von Württemberg in Stuttgart. Stuttgart: Kohlhammer, 1976.

Françozo, Mariana. "Beyond the Kunstkammer: Brazilian Featherwork in Early Modern Europe." In The Global Lives of Things: Material Culture of Connections in the Early Modern World, edited by Anne Gerritsen and Giorgio Riello, 105-127. London: Routledge, 2016.

Gerritsen, Anne, and Giorgio Riello, eds. The Global Lives of Things: The Material Culture of Connections in the Early Modern World. London and New York: Routledge, 2016.

Greengrass, Mark. Governing Passions: Peace and Reform in the French Kingdom, 1576-1585. Oxford: Oxford University Press, 2007.

Grube, Walter. Der Stuttgarter Landtag 1457-1957: Von den Landständen zum demokratischen Parlament. Stuttgart: Ernst Klett, 1957.

Hanß, Stefan. Court and Material Culture in Early Modern Germany: A Sourcebook on the Duke of Württemberg's Payments to Artisans, Stuttgart, 1592-1628. Amsterdam: Amsterdam University Press, forthcoming.

Hendriksen, Marieke M. A. “'Art and Technique Always Balance the Scale': German Philosophies of Sensory Perception, Taste, and Art Criticism, and the Rise of the Term Technik, ca. 1735-ca. 1835." History of Humanities 2, no. 1 (2017): 201-219.

Hesse, Sabine. "Die Neue Welt in Stuttgart: Die Kunstkammer Herzog Friedrich I. und der Aufzug zum Ringrennen am 25. Februar 1599." In Hofkultur um 16oo: Die Hofmusik Herzog Friedrichs I. von Württemberg und ihr kulturelles Umfeld, edited by Joachim Kremer, Sönke Lorenz, and Peter Rückert, 139-165. Sigmaringen: Thorbecke, 2010. 
Hunger, F. W. T. "Bernardus Paludanus (Barent ten Broeke) 1550-1633: Zijn verzamelingen en zijn werk." In Itinerario: voyage ofte schipvaert van Jan Huygen van Linschoten naer Oost ofte Portugels Indien 1579-1592, edited by C. P. Burger and F. Hunger, vol. 3, 249-268. 's-Gravenhage: Martinus Nijhoff, 1934.

Jachmann, Julian. “... in Ritterspieln und hohem Gebreng fremder nationen erfahren: Feste und Turniere der Fugger im frühneuzeitlichen Augsburg." In Herrschaft - Architektur Raum: Festschrift für Ulrich Schütte zum 6o. Geburtstag, edited by Stephanie Hahn and Michael H. Sprenger, 261-275. Berlin: Lukas Verlag, 2008.

Kaufmann, Thomas. Dreißigjähriger Krieg und Westfälischer Friede. Kirchengeschichtliche Studien zur lutherischen Konfessionskultur. Tübingen: Mohr Siebeck, 1998.

Kaufmann, Thomas. Konfession und Kultur: lutherischer Protestantismus in der zweiten Hälfte des Reformationsjahrhunderts. Tübingen: Mohr Siebeck, 2006.

Keller, Vera. Knowledge and the Public Interest, 1575-1725. Cambridge: Cambridge University Press, 2015.

Kessler, Herbert L. Seeing Medieval Art. Toronto: University of Toronto Press, 2011.

Korn, Melanie. Die zwei Federschilde des Landesmuseums Württemberg. Stuttgart, April 2015, unpublished conservation report.

Krapf, Ludwig, and Christian Wagenknecht, eds. Stuttgarter Hoffeste: Texte und Materialien zur höfıschen Repräsentation im frühen 17. Jahrhundert, vol. 2. Tübingen: Max Niemeyer, 1979.

Krekler, Ingeborg. Die Handschriften der Württembergischen Landesbibliothek Stuttgart, vol. 3: Stammbücher bis 1625. Wiesbaden: Harrassowitz, 1999.

Kuriyama, Shigehisa. The Expressiveness of the Body and the Divergence of Greek and Chinese Medicine. New York: Zone Books, 1999.

Leppin, Volker. Antichrist und Jüngster Tag:Das Profil apokalyptischer Flugschriftenpublizistik im deutschen Luthertum 1548-1618. Gütersloh: Mohn, 1992.

Maritz, Regine. "Gender as a Resource of Power at the Early Modern Court of Württemberg, c. 1580-1630." PhD diss., University of Cambridge, 2018.

Markey, Lia. Imagining the Americas in Medici Florence. University Park, PA: Pennsylvania State University Press, 2016.

Meadow, Mark. "Merchants and Marvels: Hans Jakob Fugger and the Origins of the Wunderkammer." In Merchants \& Marvels: Commerce, Science and Art in Early Modern Europe, edited by Pamela H. Smith and Paula Findlen, 182-200. New York: Routledge, 2002.

Moran, Bruce T. The Alchemical World of the German Court: Occult Philosophy and Chemical Medicine in the Circle of Moritz of Hessen (1572-1632). Stuttgart: Steiner, 1991.

Newman, William R. "From Alchemy to 'Chymistry'. In The Cambridge History of Science, vol. 3, edited by Katharine Park and Lorraine Daston, 497-517. Cambridge: Cambridge University Press, 2006.

Niedermeier, Cornelia. Gedanken-Kleider: Die Allegorisierung des Körpers in Gesellschaft und Theater des 17. Jahrhunderts. Vienna: Universitätsverlag, 2000. 
Nummedal, Tara. Alchemy and Authority in the Holy Roman Empire. Chicago, IL: Chicago University Press, 2008.

Ognois, Laure. "Dass ein Cavallier seinen Dienst nicht besser kan anwenden, als denselben dem Vaterland zu nutzen den Unirten zu praesentieren: Politische Instrumentalisierung eines christlichen Ereignisses? Die Festtaufe Friedrich von Württembergs im Jahre 1616." In Union und Liga 16o8, 16og: Konfessionelle Bündnisse im Reich - Weichenstellung zum Religionskrieg, edited by Albrecht Ernst and Anton Schindling, 227-262. Stuttgart: Kohlhammer, 2010.

Oster, Carolin. Die Farben höfischer Körper: Farbattributierung und höfische Identität in mittelhochdeutschen Artus- und Tristanromanen. Berlin: De Gruyter, 2012.

Pieper, Renate. Die Vermittlung einer Neuen Welt: Amerika im nachrichtennetz des Habsburgischen Imperiums 1493-1598. Mainz: von Zabern, 2000.

Reckwitz, Andreas. "Affective Spaces: A Praxeological Outlook." Rethinking History 16, no. 2 (2012): 241-258.

Roller, Hans-Ulrich. Der Nürnberger Schembartlauf: Studien zum Fest- und Maskenwesen des späten Mittelalters. Tübingen: Tübinger Vereinigung für Volkskunde, 1965 .

Rublack, Ulinka. The Astronomer and the Witch:Johannes Kepler's Fight for His Mother. Oxford: Oxford University Press, 2015.

Rublack, Ulinka. "Renaissance Dress, Cultures of Making, and the Period Eye." West 86th: AJournal of Decorative Arts, Design History, and Material Culture 23 (2016): 6-34.

Rublack, Ulinka. "Befeathering the European: The Matter of Feathers in the Material Renaissance.” The American Historical Review 126, no. 1 (March 2021): 19-53, https:// doi.org/10.1093/ahr/rhaboo6.

Russo, Alessandra. "Cortés's Objects and the Idea of New Spain: Inventories as Spatial Narratives." Journal of the History of Collections 23, no. 2 (2011): 229-252.

Russo, Alessandra, Gerhard Wolf, and Diana Fane, eds. Images Take Flight: Feather Art in Mexico and Europe, 1400-170o. Munich: Hirmer, 2015.

Sauer, Paul. Herzog Friedrich I. von Württemberg 1557-1608: Ungestümer Reformer und weltgewandter Autokrat. Munich: Deutsche Verlags-Anstalt, 2003.

Schmidt, Alexander. Vaterlandsliebe und Religionskonflikt: Politische Diskurse im Alten Reich (1555-1648). Leiden and Boston, MA: Brill, 2007.

Schnitzer, Claudia. Höfische Maskeraden: Funktion und Ausstattung von Verkleidungsdivertissements an deutschen Höfen der frühen Neuzeit. Tübingen: Niemeyer, 1999.

Schulze, Winfried. "Vom Gemeinnutz zum Eigennutz: Über den Normenwandel in der ständischen Gesellschaft der Frühen Neuzeit." Historische Zeitschrift 243 (1986): 591-626.

Smith, Pamela H., and Paula Findlen, eds. Merchants \& Marvels: Commerce, Science and Art in Early Modern Europe. New York: Routledge, 2002.

Swan, Claudia. "Exotica on the Move: Birds of Paradise in Early Modern Holland." Art History 38 , no. 4 (2015): 621-635. 
Trepp, Anne-Charlott. "Natural Order and Divine Salvation: Protestant Conceptions in Early Modern Germany (1550-1750)." In Natural Law and Laws of Nature in Early Modern Europe:Jurisprudence, Theology, Moral, and Natural Philosophy, edited by Lorraine Daston and Michael Stolleis, 123-142. Aldershot: Ashgate, 2008.

Van Eck, Caroline. Classical Rhetoric and the Visual Arts in Early Modern Europe. Cambridge: Cambridge University Press, 2007.

Van Gelder, Roelof. “Paradisvogels in Enkhuizen: De relatie tussen Van Linschoten en Bernardus Paludanus.” In Souffrir pour parvenir: De wereldd van Jan Huygen van Linschoten, edited by Roelof van Gelder, 30-50. Haarlem: Uitg. Arcadia, 1998.

Van Groesen, Michiel. The Representation of the Overseas World in the De Bry Collection of Voyages (1590-1634). Leiden and Boston, MA: Brill, 2008.

Warburg, Aby. "Die Theaterkostüme für die Intermedien." In Aby Warburg: Werke in einem Band, edited by Martin Trend, Sigrid Weigel, and Perdita Ludwig, 124-167. Frankfurtam-Main: Suhrkamp, 2010.

Warburg, Aby. "Sandro Botticellis 'Geburt der Venus' und 'Frühling'.” In Aby Warburg: Werke in einem Band, edited by Martin Trend, Sigrid Weigel, and Perdita Ludwig, $3^{2-} 3^{8}$. Frankfurt-am-Main: Suhrkamp, 2010.

Watanabe-O'Kelly, Helen. Triumphall Shews: Tournaments at German-Speaking Courts in their European Context, 156o-1730. Berlin: Mann Verlag, 1992.

Wintroub, Michael. A Savage Mirror: Power, Identity, and Knowledge in Early Modern France. Stanford, CA: Stanford University Press, 2006.

Zander-Seidel, Jutta. Textiler Hausrat: Kleidung und Haustextilien in Nürnberg von 1500-1650. Munich: Deutscher Kunstverlag, 1990.

\section{About the Author}

Ulinka Rublack is Professor of Early Modern History at Cambridge University and Fellow of St John's College. In addition to research on Reformation and on gender history, Rublack specializes in the history of dress. Her books on this subject include Dressing Up: Cultural Identity in Renaissance Europe (Oxford University Press, 2010). 



\section{Part 3}

Gold Paint 



\title{
5. Yellow, Vermilion, and Gold: Colour in Karel van Mander's Schilder-Boeck
}

\author{
Christine Göttler
}

\begin{abstract}
This chapter proposes a new interpretation of Karel van Mander's views on colour, as presented in his 1604 Schilder-Boeck, the most important early modern treatise on Netherlandish painting. At the heart of Van Mander's theory of colour lay the creation of a critical vocabulary of art that would do justice to the "Netherlandish" technique of oil painting and assert both its epistemic dimensions and its power to produce affects. Particular attention is given to Van Mander's extensive discussion of the uses of gold and yellow, which has received little attention to date, and to Hendrick Goltzius's pictorial strategies to "materialize" his new identity as a painter that closely paralleled the writing of the Schilder-Boeck.
\end{abstract}

Keywords: alchemy of colour; gold; yellow; oil painting; critical vocabulary of Netherlandish art; foreign and local colour worlds

The painter and poet Karel van Mander (1548-1606), both in his Schilder-Boeck of 1604 and in some of his other writings, frequently refers to the lustre of precious metals and the glow of translucent skin when ruminating about the power of oil painting to imitate the appearance of substances and materials. Throughout the Schilder-Boeck, yellow and vermilion are introduced as the brightest and most splendid of all the colours, both being associated, although in different ways, with alchemy and gold. Whereas yellow and gold share similarities in appearance, the relationship between gold and vermilion, one of the oldest alchemically made artists' pigments, lay in the fact that both were believed to be combinations of

Burghartz, S., L. Burkart, C. Göttler, U. Rublack, Materialized Identities in Early Modern Culture, 1450-1750: Objects, Affects, Effects. Amsterdam: Amsterdam University Press, 2021 DOI 10.5117/9789463728959_CHO5 
sulphur and mercury. ${ }^{1}$ In addition, vermilion and yellow ochre were the principal pigments for the creation of flesh tones or "carnations" ("carnaty"), to use the term Van Mander introduced into the Netherlandish theory of art. ${ }^{2}$ Red vermilion, with its associations with blood and life, is described as the pigment that "makes all the flesh parts glow."3 According to Van Mander, oil painting, while "invented" by Jan van Eyck in Bruges, was brought to new life in Haarlem and Amsterdam, his own two chosen hometowns, in the very years when he was writing the Schilder-Boeck. Using Van Mander's Schilder-Boeck as a central source, this chapter examines the dynamic triangular relationship between yellow, vermilion, and gold, including their sensory affinities and their life-like appearances. ${ }^{4}$

Written by a well-read, widely travelled, and internationally connected practitioner in the graphic and painterly arts, the crucial importance of the SchilderBoeck for the history, theory, and practice of Netherlandish painting cannot be overestimated. ${ }^{5}$ Its six parts consist of a theoretical treatise in verse on the "basic

1 Rutherford J. Gettens, Robert L. Feller, and W. T. Chase, "Vermilion and Cinnabar," in Artists' Pigments: A Handbook of their History and Characteristics, ed. Ashok Roy et al., 4 vols. (Oxford: Oxford University Press, 1986-2007), 2:159-182; Spike Bucklow, Red: The Art and Science of a Colour (London: Reaktion Books, 2016), 70-77; Pamela H. Smith, "Vermilion, Mercury, Blood, and Lizards: Matter and Meaning in Metalworking," in Materials and Expertise in Early Modern Europe: Between Market and Laboratory, ed. Ursula Klein and E. C. Spary (Chicago, IL: University of Chicago Press, 2010), 29-49.

2 Ann-Sophie Lehmann, "Fleshing out the Body: The 'Colours of the Naked' in Workshop Practice and Art Theory, 1400-1600," in Body and Embodiment in Netherlandish Art, ed. Ann-Sophie Lehmann and Herman Roodenburg, Netherlands Yearbook for History of Art $5^{8}$ (Zwolle: Waanders, 2008), 87-109; Lehmann, "Jan van Eyck und die Entdeckung der Leibfarbe," in Weder Haut noch Fleisch: Das Inkarnat in der Kunstgeschichte, ed. Daniela Bohde and Mechthild Fend (Berlin: Gebr. Mann, 2007), 34-35.

3 Karel van Mander, Het Schilder-Boeck waer in Voor eerst de leerlustighe Iueght den grondt der Edel Vry Schilderconst in Verscheyden deelen Wort Voorghedraghen: Daer nae in dry deelen t'leven der vermaerde doorluchtighe Schilders des ouden, en nieuwen tyds; Eyntlyck d'wtlegghinghe op den Metamorphoseon pub. Ovidii Nasonis; Oock daerbeneffens wtbeeldinghe der figueren. Alles dienstich en nut den schilders, Constbeminders, en dichters, oock allen staten van menschen (Haarlem: Paschier van Wesbusch, 1604), fol. 49r: "Maer vermillioen doet al vleeschigher gloeyen" (Grondt, Chapter XII: Van wel schilderen/ oft Coloreren, stanza 29). For Van Mander's Lives of the Netherlandish and German Painters I have been using the very helpful translation by Jacqueline Pennial-Boer and Charles Ford, but occasionally modified it to make it closer to the original Dutch: Karel van Mander, The Lives of the Illustrious Netherlandish and German Painters from the First Edition of the Schilder-boeck (16o3-1604), ed. Hessel Miedema, 6 vols. (Doornspijk: Davaco, 1994-1999), vol. 1. The translations of all other parts of the Schilder-Boeck are mine if not otherwise indicated.

4 On triangular relationships and triads: Rebecca Zorach, The Passionate Triangle (Chicago, IL and London: University of Chicago Press, 2011).

5 For the genesis and the organization of Karel van Mander's Schilder-Boeck and its six parts: Walter S. Melion, Shaping the Netherlandish Canon: Karel van Mander's Schilder-Boeck (Chicago, IL and London: University of Chicago Press, 1991), 15-24; Jeroen Stumpel, "A Note on the Intended Audiences for van Mander's Schilder-Boeck," Simiolus 35, nos. 1-2 (2011): 84-9o; Werner Waterschoot, "Karel van Mander's Schilder-Boeck (1604): A Description of the Book and Its Setting," Quaerendo 13, no. 4 (1983): 260-285. On 
elements" of painting (Den grondt der Edel Vry Schilderconst); three sets of lives dedicated firstly to ancient (Egyptian, Greek, and Roman) painters, secondly to their modern and contemporary Italian counterparts, and thirdly to Netherlandish and German ones; ${ }^{6}$ a commentary on Ovid's Metamorphoses, and finally a Depiction of Figures (Wtbeeldinghe der Figueren), a reference work about the ways in which "the pagans represented their gods" and the meanings they ascribed to animals and certain objects.7 The latter two parts, for which Van Mander designed a separate title page, might not have originally been intended for inclusion. ${ }^{8}$ As indicated by their titles, all six parts were addressed to painters ("schilders") and "lovers of the art of painting" ("schilderconst beminders"). On the basis of his own range of skills, Van Mander recorded and synthesized a tradition of knowledge about artists' materials and procedures that was both of immediate interest to practitioners and helped to shape a growing community of liefhebbers or lovers of the arts. The Schilder-Boeck was widely used within these connected circles of makers and experts, and there is documentary evidence that several copies were owned in Amsterdam and Antwerp, among other cities. ${ }^{9}$

As has been shown by Walter S. Melion and others, Van Mander, in the SchilderBoeck, rather than continuing Giorgio Vasari's historiographic model, redefined the values of the visual arts in order to promote Netherlandish painting as the new leading art form of his own time. In Van Mander's geography of art, Haarlem and Amsterdam are presented as the "new" cities where the alchemy of (oil) painting experienced a powerful revival. In contrast to Italian authors such as Vasari and Giovan Paolo Lomazzo, who considered oil painting as an effeminate art, Van

the publisher, Passchier (Paschier) van Westbusch (Wesbusch): Karel van Mander, Den grondt der edel vry schilder-const, ed. Hessel Miedema, 2 vols. (Utrecht: Haentjens Dekker \& Gumbrecht, 1973), 2:317.

6 Van Mander, Schilder-Boeck, fol. H2r: "Het Leven Der oude Antijcke doorluchtighe Schilders/ soo wel Egyptenaren/ Griecken als Romeynen [...] tot dienst/ nut/ en vemaeck der Schilders/ en alle Constbeminders"; fol. M3r: "Het Leven Der Moderne/ oft dees-tijtsche doorluchtighe Italiaensche Schilders [...] tot groot nut en vermaeck der Schilders/ en Schilder-const beminders"; fol. Bb4r: "Het Leven der Doorluchtighe Nederlandtsche/ en Hooghduytsche Schilders. By een vergadert en beschreven, door Carel van Mander Schilder. Alles tot lust/ vermaeck/ en nut der Schilders/ en Schilder-const beminders."

7 Karel van Mander, Wtlegghingh Op den Metamorphosis Pub. Ovidii Nasonis [...] Seer dienstich den Schilders, Dichters, en Constbeminders, oockyeghelyck tot leering by een gebracht en gheraemt (Haarlem: Paschier van Westbusch, 1604); fol. Q3r: "Wtbeeldinge der Figueren: waer in te sin is/ hoe d'Heydenen hun Goden uytghebeeldt/ en onderscheyden hebben: hoe d'Egyptsche yet beteyckenden met Dieren oft anders/ en eenighe meeninghen te kennen gaven/met noch meer omstandicheden. Alles seer nut den vernuftighen Schilders/ en oock Dichters/ hun Personnagien in vertooninghen/ oft anders/ toe te maken." 8 Melion, Shaping the Netherlandish Canon, 16.

9 Annette de Vries, "Hondius Meets Van Mander: The Cultural Appropriation of the First Netherlandish Book on the Visual Arts System of Knowledge in a Series of Artists' Portraits," in The Artist as Reader: On Education and Non-Education of Early Modern Artists, ed. Heiko Damm, Michael Thimann, and Claus Zittel, Intersections 27 (Leiden and Boston, MA: Brill, 2013), 259-304, especially 300-301, Appendix 1. 
Mander emphasized that the "new" technique required access to hidden knowledge about nature, the kind of knowledge possessed by the Haarlem-based artist Hendrick Goltzius (1558-1616), the hero of his account. In addition, the upsurge of painting in Haarlem and Amsterdam is related as occurring in the "here and now," in other words as a process that had just begun at the actual time of Van Mander's writing and would unfold over many years to come.

Within this conceptual and historical framework, this chapter aims to shed new light on Van Mander's four chapters on colour in Den Grondt, with their numerous links to other chapters of the theoretical treatise and to the Netherlandish Lives. Remarkably, Van Mander's chapters on colour, which drew from both his own expertise and a diverse array of sources, have so far not been discussed in their entirety. In fact, research literature has focused almost exclusively on Chapter Twelve "about how to paint well," which also includes Van Mander's thoughts on flesh colour, while Chapters Thirteen and Fourteen have been judged derivative since they are partially based on heraldic literature. As a consequence, Van Mander's thoughts on gold and yellows have so far attracted little interest. This is all the more surprising since, from the late sixteenth century, gold, with its bright sun-like colour, became a central reference point for thinking about the values of painting, and yellows emerged as the most frequently used colours in oil painting as well as in the glass and ceramic industries. ${ }^{10}$

How were paint and gold, both as artists' materials and as metaphors for artistic creation, described and put into practice by Van Mander and his contemporaries? In what ways did Van Mander's writings assert the position of Netherlandish artists within the expanding early modern world of colour? ${ }^{11}$ Three linked lines of inquiry will be pursued. The chapter starts with a discussion of how Van Mander construed the turn of the century as a radical turning point that sparked a new golden age of Netherlandish art. In Van Mander's usage, "blinckentheyt" refers both to the sheen of oil painting and to the aura of celebrity attached to that art, which underwent

10 Roland Krischel, "Zur Geschichte des venezianischen Pigmenthandels: Das Sortiment des 'Jacobus de Benedictis à Coloribus'," Wallraf-Richartz-Jahrbuch 63 (2002), especially 111-116; Claudio Seccaroni, Giallorino: Storia dei pigmentigialli di natura sintetica. Dal 'vetrio giallo per patre nostro o ambre' al 'giallo di Napoli' (Rome: De Luca, 2006), especially 47-53. See also Michel Pastoureau, Yellow: The History of a Color, trans. Jody Gladding (Princeton, NJ and Oxford: Princeton University Press, 2019).

11 Recent contributions include: Tawrin Baker, Sven Dupré, Sachiko Kusukawa, and Karin Leonhard, eds., Early Modern Color Worlds (Leiden and Boston, MA: Brill, 2015); Magdalena Bushart and Friedrich Steinle, eds., Colour Histories: Science, Art, and Technology in the 17th and 18 th Centuries (Berlin and Boston, MA: De Gruyter, 2015). See also: Eileen Reeves, "The New Sciences and the Visual Arts," in A Companion to Renaissance and Baroque Art, ed. Babette Bohn and James M. Saslow (Chichester: Wiley, 2013), 316-335; Frank Fehrenbach, "Kohäsion und Transgression: Zur Dialektik lebendiger Bilder," in Animationen / Transgressionen: Das Kunstwerk als Lebewesen, Hamburger Forschungen zur Kunstgeschichte 4 (Berlin: Akademie Verlag, 2005), 41-72. 
a rebirth in the Netherlands around 1600 . It then proceeds to offer a close reading of Van Mander's chapters on colour, emphasizing his attempts to create a critical vocabulary of art that would do justice to the qualities and effects of Netherlandish oil painting, its epistemic dimensions, and its power to produce affects. Using some works by Goltzius as its main examples, it ends by exploring the ways in which the Haarlem artist articulated and "materialized" his new identity as a painter and his ability to use colour to animate figures and forms.

\section{Shaping the Life of a Painter-Poet}

In order to better assess Van Mander's writings on colour and painting, a few biographical notes will be helpful. The anonymous biography of Van Mander, included in the posthumous second edition of the Schilder-Boeck of 1618, sheds some light on the range of interests he pursued during his lifetime and in which the writing and producing of plays, including the making of stages, props, and costumes, played a significant role. ${ }^{12}$ It documents the ease with which he moved between the worlds of the visual and literary arts, including drawing, printmaking, and painting on the one hand, and poetry, prose, and drama on the other. Born in Meulebeke in West Flanders into a family of the lesser gentry, Van Mander attended Latin school in Tielt and French school in Ghent where he was apprenticed for a brief time to Lucas de Heere (1534-1584), himself a painter and poet of great learning. ${ }^{13}$ He then continued his apprenticeship in Courtrai and Tournai with Pieter Vlerick (1539-1581) who, as Van Mander noted, had "spent a long time in Venice with Tintoretto," and had also travelled to Rome and Naples; all this gave the young Van Mander a first glimpse of the Italian world of art he would later see for himself. ${ }^{14}$ Back in Meulebeke, Van Mander dedicated himself "more to writing poetry and prose than to painting," also creating several "spelen van sinne" (morality plays), "toneelen" (plays), "tafel-spelen" (interludes during banquets), "refereynen" (refrains), and "liedekens" (songs). ${ }^{15}$

12 Karel van Mander, Het Schilder-Boeckwaerin Voor eerst de Leerlustige Iueght den gront der Edele Vrye Schilderkonst in verscheyden deelen wort voorgedragen (Amsterdam: Jacob Pietersz. Wachter, 1618), fols. Rir-S3v (Karel van Mander, Schilder/ en Poeet). Hessel Miedema, "The Biography of Karel van Mander (1548-16o6)," in Van Mander, The Lives of the Illustrious Netherlandish and German Painters, 2:9-168; Marjolein Leesberg, "Karel van Mander as a Painter," Simiolus 22, nos. 1-2 (1993-94): 5-57; H. Duits, "Het leven van Karel van Mander: Kunstenaarsleven of schrijversbiografie?," De zeventiende eeuw 9 (1993), accessed on 30 November 2020, https://www.dbnl.org/tekst/_zevo01199301_01/_zevoo1199301_01_0012.php.

13 Van Mander, Schilder-Boeck, fols. 255r-256v.

14 Ibid., fol. 25or.

15 Van Mander, Schilder-Boeck 1618, fol. R3r-v. See Bart Ramakers, "Dutch Allegorical Theatre: Traditions and Conceptual Approach,” in Urban Theatre in the Low Countries, ed. Elsa Strietman and Peter Happé (Turnhout: Brepols, 2006), 127-147. 
Between 1573 and 1577 he spent several months in Florence and around three years in Rome, a stay that was instrumental for the formation of his theory of art and particularly his views on colour. During this period, Van Mander acquainted himself with a number of artists involved in the decorative programmes commissioned during the papacy of Gregory XIII and also became friends with Bartholomeus Spranger (1546-1611). ${ }^{16} \mathrm{He}$ painted grotesques and landscapes in fresco for various cardinals - small-scale tasks that, as Van Mander himself observed, the Italians frequently delegated to the Netherlanders, considering themselves to be more accomplished in figural works. ${ }^{17}$ In Den Grondt, Van Mander strongly recommends aspiring painters a visit to Italy to learn "proficient drawing" ("teyckenen zedich") in Rome and "good painting" ("t'wel schilderen") in Venice; but he also paints an ambivalent picture of Rome, calling it a "nest of treachery" ("verradich nest") that might easily cause the downfall of aspiring foreign artists. ${ }^{18}$ His preference for Venetian-Lombard colorito over Vasari's Tuscan-Roman disegno is articulated in the numerous modifications made to Vasari's Vite and in the addition of several biographies of then still living Italian artists including Jacopo Bassano, Federico Zuccari, Federico Barocci, and Jacopo Palma il Giovane, who oriented their art toward newer, "reformed" painterly styles. ${ }^{19}$

On his return to Meulebeke in the final years of the 1570s, Van Mander got married and his wife soon bore him two sons. The religious and political conflicts compelled the young family to leave. ${ }^{20}$ After short sojourns in Courtrai and Bruges, they finally embarked for Holland to settle in "the old and glorious city of Haarlem" in around $1583 .{ }^{21}$ It was in Haarlem that Van Mander first met two men who were to be among his most intimate friends, Goltzius and Cornelis Corneliszoon (1562-1611). The three of them formed an "Academie among themselves" - a loose association of friends of a kind of which there were many in Italy - sharing their interests in the "Italian manner" and in "studying from life."22 The biographer follows up with a list of Van Mander's paintings, his designs for tapestries, damasks, tablecloths, and napkins, his ligatures for glass paintings, as well as his writings. The latter included, alongside the Schilder-Boeck and other texts discussed in this chapter,

16 Van Mander, Schilder-Boeck 1618, fols. R3v-R4r.

17 Ibid., fol. R3v; Van Mander, Schilder-Boeck, fol. 7r (Grondt, Chapter I: Exhortatie, stanza 71).

18 Van Mander, Schilder-Boeck, fol. 7v (Grondt, Chapter I, stanza 75); fol. 6v (stanzas 66-67).

19 Melion, Shaping the Netherlandish Canon, 112-117; Helen Noë, Carel van Mander en Italië: Beschouwingen en notities naar aanleiding van zijn "Leven der dees-tijtsche doorluchtighe Italiaensche Schilders" ('s-Gravenhage: Martinus Nijhoff, 1954).

20 Van Mander, Schilder-Boeck 1618, fol. R4v.

21 Ibid., fol. Siv.

22 Ibid., fol. S2r: "hielden en maeckten onder haer dryen een Academie, om nae 't leven te studeeren/ Karel wees haer de Italiaensche maniere." 
translations into Dutch of Virgil's Bucolica and Georgica, the first ten books of the Iliad (after Hugues Salel's 1545 French version), and Girolamo Benzoni's Historia del Mondo Nuovo, which appeared posthumously in $1610 .{ }^{23}$ Van Mander's interest in Benzoni's popular treatise, with its explicit scorn of the Spanish greed for gold, was certainly also motivated by his Mennonite beliefs. ${ }^{24}$

After living in Haarlem for twenty years, Van Mander retired to "Huis te Zevenbergen," a country house in Noorddorp (north of Haarlem) where, according to his biographer, most of the Schilder-Boeck was penned. ${ }^{25}$ To advertise the Schilder-Boeck he invited some of his closest friends as well as a number of liefhebbers to a play written in their honour and performed inside the local castle. The decoration of the entry gate included "palettes, brushes, and maulsticks as well as other painting tools" woven into festoons which served as a visible statement of the honour due to the art of painting. ${ }^{26}$ In June 1604 Van Mander moved to Amsterdam, where he died in September 1606. His life, like that of many of his contemporaries, was affected by war, migration, and exile. The multi-confessional city of Haarlem, where he settled in the early 1580 s, continued to be the destination for a large number of Flemish immigrants throughout the first years of the seventeenth century, many of them skilled professionals eager to build up new careers. ${ }^{27}$ Van Mander's commitment to turn Haarlem into a new centre of poetry and painting reflected and further promoted the city's growing social and cultural transformation, and the imminent turn of the century gave an impetus to his activities.

The phrase "gulden jaer" appears repeatedly in Van Mander's De Kerck der Deught (The Church of Virtue) of 1600 , a poetic dream-fiction written in alexandrines about the ascent to the Temple of Virtue on Mount Helicon (in Greek mythology the haunt of the Muses), dedicated to Van Mander's painter friend Cornelis Ketel (1548-1616) in Amsterdam. Deught or virtus was a central element of the self-image of the city

23 Miedema, "The Biography of Karel van Mander," 81-84, 100-104.

24 First published in Venice in 1565 , Benzoni's Historia appeared in numerous editions and in German, French, and Latin translations until well into the seventeenth century: Benjamin Schmidt, "'O Fortunate Land!' Karel van Mander, a West Indies Landscape and the Dutch Discovery of America," New West Indian Guide 69 (1995): 5-44.

25 Miedema, "The Biography of Karel van Mander," 86.

26 Van Mander, Schilder-Boeck 1618, fol. S3r: "behangen met groene kruyden/ en kranssen daer in gevlochten/ daer was oock aerdich ingheslingert/ palletten/ pinceelen/ mael-stocken/ en andere Schilder-werck-tuych."

27 Raingard Esser, The Politics of Memory: The Writing of Partition in the Seventeenth-Century Low Countries, Brill's Studies in Intellectual History 208 (Leiden: Brill, 2012), 105-136; Pieter Biesboer, Collections of Paintings in Haarlem, 1572-1745, Documents for the History of Collecting: Netherlandish Inventories 1 (Los Angeles, CA: The Provenance Index of the Getty Research Institute, 2002), 2. Biesboer refers to membership records of the Dutch Reformed Church that list between 1578 and 1609 5,00o immigrants from Ghent, 3,000 from Courtrai, and 12,000 from Antwerp. 
of Haarlem, which had adopted the motto "vicit vim virtus" ("virtue overcomes force") in recognition of the "virtue" displayed by its population during the siege by Spanish troops in 1572-73 and the bloodshed after the forced surrender. ${ }^{28} \mathrm{De}$ Kerck der Deught was included in Den Nederduytschen Helicon of 1610, an anthology of eighty-nine poems initiated by Van Mander and, after his death, put together for publication by Jacob van der Schuere, the head of the Flemish chamber of rhetoric in Haarlem, De Witte Angieren (The White Carnations). ${ }^{29}$ Den Nederduytschen Helicon emerged from the joint efforts of a close-knit circle of writers, rhetoricians, artists, and liefhebbers, the same men and women Van Mander had invited to Zevenbergen to attend his spel, many of them immigrants from Flanders like himself. In both the Schilder-Boeck and the Nederduytschen Helicon, the year 1600 is presented as a "golden year" and a turning point in the history of the city of Haarlem. In the Nederduytschen Helicon, Haarlem is celebrated as the site of the new Helicon, ${ }^{30}$ while in the Schilder-Boeck it is praised for having "brought forth many good spirits in our art" so that the city had now gained the same fame in Holland as was once attributed to Sicyon in Greece, and Florence and Rome in Italy. ${ }^{1}$

\section{Blinckentheyt: The Splendour of Oil Painting}

Van Mander's views on oil painting need to be understood within this larger context of a growing preoccupation with the image and identity of the city, where the practice of art and highly skilled crafts played a central role. In his life of the Haarlem painter Albert van Ouwater, Van Mander refers to "trustworthy evidence" that he had become "an accomplished oil painter very early on," thus indicating that the art of painting in oil was practised in Haarlem not long after its "invention" by

28 Miriam Volmert, Grenzzeichen und Erinnerungsräume: Holländische Identität in Landschaftsbildern des 15.-17.Jahrhunderts, Ars et Scientia 4 (Berlin: Akademie-Verlag, 2013), 110-118; Lisa Rosenthal, "Political and Painterly Virtue in Cornelis Cornelisz. van Haarlem's 'Wedding of Peleus and Thetis' for the Haarlem Prinsenhof," in Virtue: Virtuoso, Virtuosity in Netherlandish Art 1500-170o, ed. Jan de Jong et al., Netherlands Yearbook for History of Art 54 (Zwolle: Waanders, 2003), 172-201.

29 Den Nederduytschen Helicon (Alkmaar:Jacob de Meester, voor Passchier van Westbusch, 1610), 113-121. Bart Ramakers, "As Many Lands, as Many Customs: Vernacular Self-Awareness among the Netherlandish Rhetoricians," in The Transformation of Vernacular Expression in Early Modern Art, ed. Joost Keizer and Todd M. Richardson, Intersections 19 (Leiden and Boston, MA: Brill, 2012), 123-178; Boukje Thijs, De hoefslag van Pegasus: Een cultuurhistorisch onderzoek naar Den Nederduytschen Helicon (161o) (Hilversum: Verloren, 2004).

30 Ramakers, "As Many Lands," 160.

31 Van Mander, Schilder-Boeck, fol. 229r (Ian Mostart, Schildervan Haerlem): "Ghelijck in de Schilder-const plagh gheruchtigh wesen Sicyonien by den Griecken/ en naemaels Florencen en Room by d'Italianen: also is in Hollandt van oudts tijdt oock vermaert gheweest d'oude heerlijcke stadt Haerlem/ die veel goede gheesten in onse Const heeft voortghebracht." 
Jan van Eyck in Bruges..$^{32}$ In his life of Jacques de Gheyn, Van Mander presents oil painting as the "highest art and the most appropriate means to come closer to representing nature in all her parts" or to make art "converge" with life or nature. 33 Van Mander uses similar words in his life of Van Eyck, who, during his investigations into "various kinds of colours," observed that the oil rendered the colours much more "alive, so that they had in themselves a lustre (blinckentheyt) without having to be varnished": "Our art needed this noble invention to approximate, or be more like, nature in her forms." ${ }^{34}$ The mimetic power and high status Van Mander affords to oil painting stands in stark contrast to views expressed by Italian writers on art. Vasari notes that Michelangelo considered oil painting "a woman's art and only fit for lazy, well-to-do people,"35 an opinion also expressed by Giovan Paolo Lomazzo, according to whom colouring in oil was a painting technique "suited for effeminate youths. ${ }^{36}$

In contrast to Giorgio Vasari, who emphasizes the serendipitous nature of Van Eyck's discovery of binding pigments with oil, Van Mander turns the moment of invention into the founding moment of the history of (Netherlandish) art, which "gave birth to a new generation of works" - the works that Van Mander discusses in the lives of the subsequent Netherlandish artists. ${ }^{37}$ In stressing so strongly the "clear resplendent glow" ("schoon blinckende glans") ${ }^{38}$ of oil paints, Van Mander also takes up elements from local sources, such as Lucas de Heere's Ode to the Ghent Altarpiece of 1565 and Dominicus Lampsonius's verses below the portrait of Van Eyck in the Pictorum aliquot celebrium Germaniae Inferioris effigies (Effigies of Some Famous Painters, especially of Lower Germany) of 1572. In the latter, Van Eyck himself appears to be speaking, using the authorial formula "ille ego qui" to announce the

32 Ibid., fol. 205v: "met eenen my verwondert vernomen te hebben uyt geloofweerdighe getuyghnis/ van desen Albert van Ouwater, Schilder van Haerlem/ dat hy so heel vroegh een so constigh Oly-verwe Schilder is geworden."

33 Ibid., fol. 294r: "hem eyndlijck heeft begheven eyghentlijck tot den beolyden Pinceel/ met verwen te wercken en te schilderen/ als wesende het opperste der Const/ en den alder bequaemsten middel/ om de Natuere in allen deelen met uytbeeldinghe ten alder ghelijcksten nae te comen [...] maer bevindende (als vooren verhaelt is) t'schilderen bequaemst/ om t'leven oft de Natuere te verghelijcken/ werdt in hem den Schilder-lust meer en meer crachtigh." Claudia Swan, Art, Science, and Witchcraft in Early Modern Holland:Jacques de Gheyn II (1565-1629) (Cambridge: Cambridge University Press, 2005), especially 29-40. 34 Van Mander, Schilder-Boeck, fol. 199v: “dat d'Oly oock de verwen veel levender maeckten/ en van selfs een blinckentheyt deden hebben/ sonder dat mense verniste [...] Dese edel inventie hehoefde noch onse Const/ om de Natuere in gedaenten nader comen/ oft ghelijcker te worden."

35 Cited from Philip Sohm, "Gendered Style in Italian Art Criticism from Michelangelo to Malvasia," Renaissance Quarterly 48, no. 4 (Winter 1995): 759-808, at 786.

36 Giovan Paolo Lomazzo, Idea of the Temple of Painting, ed. and trans. Jean Julia Chai (University Park, PA: Pennsylvania State University Press, 2013), 104.

37 Van Mander, Schilder-Boeck, fol. 199v.

38 Ibid., fol. 199v. 
transformative potential of his invention: "I am he who first taught to mix joyful colours from the pressed oily seed of flax." ${ }^{39}$ The phrase "colores laetos" (joyful colours) in the first line further signals the energy and vitality associated with colours. Van Mander considers Van Eyck's "invention" as the necessary prerequisite for rendering "reflections and reverberations," an aspect of painting in which Netherlandish artists, according to their Italian colleagues, excelled. "Reflexy-const" is extensively discussed in Chapter Seven of Den Grondt..$^{40}$ Some of the terms and notions employed by Van Mander are indebted to Walther Hermann Ryff's adaptation of the second and third books of Leon Battista Alberti's De Pictura. ${ }^{41}$ But whereas Ryff and Alberti were interested in the study of light and shade as a means to achieve sculptural depth and relief, Van Mander associated "reflexy-const" with the skilful handling of colours ("verwen") and their use as a means to stir the viewer's emotions. Chapter Seven begins with the reflection and reverberation ("weerschijn") of the golden rays ("gulden raepen") of the sun, the "world's soul at the centre of all the planets," through which many colours are spread through the air. ${ }^{42}$ Next, Van Mander evokes the goddess Aurora, whom he associates with the "redness of the evening and morning sky," that causes all things to take on a "red, fiery, glowing colour."43 $\mathrm{He}$ then dedicates several stanzas to a broad discussion of

39 “Ille ego, qui laetos oleo de semine lini| Expresso docui princeps miscere colores." For Poliziano's use of the ille ego formula in an epitaph celebrating the accomplishments of Giotto: Alexander Nagel and Christopher S. Wood, Anachronic Renaissance (New York: Zone Books, 2010), 123-129; Wolf-Dietrich Löhr, "Die Rede der Hand: Giottos O und die Autorschaft des Künstlers bei Polizian und Vasari," in Autorschaft: Ikonen - Stile - Institutionen, ed. Christel Meier and Martina Wagner-Egelhaaf(Berlin: Akademie Verlag, 2011), 163-194.

40 Melion, Shaping the Netherlandish Canon, 60-77; Sven Dupré, "The Historiography of Perspective and reflexy-const in Netherlandish Art," in Art and Science in the Early Modern Netherlands, ed. Eric Jorink and Bart Ramakers, Netherlands Yearbook for History of Art 61 (Zwolle: Wbooks, 2011), 34-61; Philipp Weiss, "We(d)erschijn als Kernbegriff der Diskussion des malerischen Lichtes bei Karel van Mander," in Adfontes!, ed. Claudia Fritsche, Karin Leonhard, and Gregor J. M. Weber (Petersberg: Imhof, 2013), 35-53. 41 Leon Battista Alberti, On Painting and On Sculpture: The Latin Text of De Pictura and De Statua, ed. Cecil Grayson (London: Phaidon, 1972), 85 (libro secondo, 47). I have been using the 1558 edition of the treatise by Walther Hermann Ryff (Gualtherus H. Rivius): Der Architectur furnembsten/notwendigsten/ angehörigen Mathematischen und Mechanischen künst/ eygentlicher bericht (Nuremberg: Gabriel Heyn, 1558), fol. 7or-v: "ist vast notwendig das der Maler guten bericht hab/ welches superficies in yedem ding vom liecht getroffen oder beschattet wirt/ welches jm nit allein auß gutem verstand/ des Geometrischen grunds der Perspectiva/ so die eigentschafft der streimen des gesichts/glastes/ scheins/ widerglast/ gegenscheins/ unnb alles so das liecht schatten/glantz/ durchsichtigkeit scheinender und glitziger streimen betrifft gnugsam demonstriert/ sonder auch von der Natur/ deßgleichen auß yedem ding/ an jm selber gnugsamlichen anzeigt wirdt."

42 Van Mander, Schilder-Boeck, fol. 29r (Grondt, Chapter VII: Van de Reflecty/Reverberaty/teghen-glans oft weerschijn, stanzas 1-2).

43 Ibid., fol. 29r, stanza 4, marginal note: "Aurora, is sowel des avonts rootheyt, als des morgens"; fol. 29v, stanza 6: "Wordense stracx een blosende rootachtich/| Vierich/ en gloyende coleur deelachtich." 
various aspects of the rainbow whose colours - purple, flesh colour, red lake, orange, red, massicot, green, azure and then again purple - he describes by matching them with particular pigments or their mixtures on a painter's palette. ${ }^{44}$ Van Mander emphasizes that "blending colours" is no "waste of time," but rather "useful to learn more about the distinctions in colours and appearances of different kinds of light," and goes on to mention possible scenarios for which the art of depicting reflections is required: "moonlight," "fire," "lighting," "candlelight," and "forges."45

Throughout the Schilder-Boeck, Van Mander uses the terms blinckentheyt, blinckend, and blincken to describe the shine of metals, mirrors, the sun and the stars, and the sparkle of eyes as well as the glow of Van Eyck's oil paintings. ${ }^{46}$ The subtle rays emanating from these bodies directly affect the sense of vision. Blinckentheyt is also used to mean fame, the visibility of a person or deed. In his 1596 poem T'Stadt Haerlems Beeldt Van Mander calls Goltzius the "ornament, light, and honour of our times" ("t'verciersel tlicht en d'eer oock onser tijden"), presenting him as the new Van Eyck, the painter singled out by De Heere and Van Mander himself as the "shining jewel (ornament) of the Netherlands" ("blinckende cieraet van t'Nederlandt"). ${ }^{47}$ Framing the birth of Jan van Eyck in terms of a miracle, Van Mander relates how the event was foreshadowed by a "brilliant and resplendent light" ("claer blinckende licht") arising from the banks of the river Maas. He quotes in full the eulogy by his own teacher, Lucas de Heere, on the Ghent altarpiece painted by the brothers Hubert and Jan van Eyck, which, in an oft-cited passage, called Jan van Eyck's paintings "jewels" and "mirrors" rather than panels, "for it seems as if everything is alive and emerging from the panel."48 The durability of the oil-based colours that, according to De Heere, had not "faded" and "continue to last $[. .$.$] after nearly two hundred years," demonstrated their superiority over$ other painting techniques. ${ }^{49}$

Van Mander's construction of Haarlem and Amsterdam as the new birthplaces of painting was a response to the traditional image of Antwerp as the city of highly

44 Ibid., fol. 30v, stanza 22: "purper/ dan incarnachtich/| Oft lacke wittich/ om wel coloreren// Daer naer orangiachtich/ oft root cieratich/| Dan masticot gheel/ dan groen delicatich/| Dan schoon asuer/ als der Pauwen hals veren/| Achter weder purper." See Ulrike Kern, "Samuel van Hoogstraeten and the Cartesian Rainbow Debate: Color and Optics in a Seventeenth-Century Treatise of Art Theory," Simiolus 36 (2012): 103-114, at 105-106.

45 Van Mander, Schilder-Boeck, fol. 31r, stanza 25: "Want niet dan tijdt-winnen en is de spacy/| Die Schilders in verwe temperen missen."

46 See the entries blinken, blinkeninge, and blinkenisse in the Middelnederlandsch Woordenboek, accessed 1 December 2018, http://gtb.ivdnt.org/search/?owner=onw.

47 Van Mander, Schilder-Boeck, fol. 2o1v.

48 Ibid., fol. 2oir: "Want t'schijnt dat hier al leeft, en uyt de Tafel rijst.| T'sijn spieghels, spieghels zijnt, neen t'zijn geen Tafereelen."

49 Ibid., fol. 2o1v. 
specialized arts and crafts. Around 1600, Van Eyck's invention was brought to new life by a group of painters in the immediate circle of Van Mander, above all Hendrick Goltzius and Cornelis Ketel. Evoking the imagery of birth and reproduction, Van Mander introduces Ketel as an artist "endowed with a productive spirit" who began to experience "various inclinations and desires." ${ }^{\circ 0}$ If in 1595 he had felt the desire to model in clay, in 1599 he had the urge "to paint without brushes, with his hands," and, in 1600, "to paint without hands, with his feet, to see if he could make something of that. ${ }^{\prime 1}$ Ketel performed painting as a bold and unbridled bodily act that drew attention to the dexterity of his hands and feet. His contemporaries apparently compared his inclinations with the "ridiculous, abominable urges such as sometimes happen with pregnant women who crave to eat strange, raw or uncooked foods." Nevertheless, they turned out successful and "no misshapen fruits came forth." ${ }^{2}$

Goltzius's turn to colours, conversely, is described as the result of a long process for which his sojourn in Italy in 1590-91 was a major milestone. Van Mander writes that after his return from Italy, Goltzius had the "handsome Italian paintings firmly impressed in his memory as if in a mirror." ${ }^{n 3} \mathrm{After}$ conveying his impressions of the "glowing flesh parts" ("gloeyende carnatien") and the "glowing shadows" ("gloeyende dipselen") of Italian nudes in words, he began to capture them on paper by colouring, when drawing, the flesh parts with crayons, a technique that he had already practised earlier. ${ }^{54}$ Thus, when he finally took up "brushes and oil paint" in 1600 to create "a small piece on copper" depicting a Christ on the Cross, colour had already preoccupied his thoughts for many years. ${ }^{55}$ In addition, Goltzius's conversion to painting seemed to have cured him of his longstanding melancholy. Perhaps most importantly, the encounter with colour increased general sensitivity towards what was then called the "alchemy of painting," the most material and affective qualities

50 Ibid., fol. 277v: "Gehlijck dan Ketel versierigh van eenen voort-teligen gheest schijnt ghedreven te wesen/ heeft verscheyden voornemens en lusten in hem bevoelt."

51 Ibid., fol. 278r: "In't Jaer 1599 quam hem in den sin eenen lust/ te schilderen sonder Pinceelen metter handt $[. ..] \mathrm{A}[\mathrm{nn}] \mathrm{o} 1600$ werdt hem voor te comen te schilderen sonder handen/ met zijn voeten/ of hy daer van yet te weghe mocht brenghen."

$5^{2}$ Ibid.: "voor eenen belachlijcken wanschapen lust/gelijck gemeen is by eenige bevruchte Vrouwen/ die vreemden/ rouwen/ oft ongekoockten cost to spijse te gebruycken gelusten [...] en datter geen wanschapen vruchten van zijn ghecomen."

53 Ibid., fol. 285v: "hadde de fraey Italische schilderijen als in eenen spieghel soo vast in zijn ghedacht ghedruckt."

54 Ibid.

55 Ibid.: "soo dat hy eyndlijck tot den Pinceelen en Oly-verwe hem heft begheven [...] doch zijns ouderdoms 42. Jaer/ A[nn]o 16oo. Sijn begin was [...] een cleen stucxken op coper." For Goltzius's "first" painting (Christ on the Cross, with Mary, Saint John, and the Magdalen. Copper, $43.3 \times 29.4 \mathrm{~cm}$, Staatliche Kunsthalle Karlsruhe, inv. no. 2854): Lawrence W. Nichols, The Paintings of Hendrick Goltzius (Zwijndrecht, Belgium: Davaco, 2013), 112-114, cat. A-17. 
of the painter's art. Gloeyen, the word employed by Goltzius and Van Mander to describe the glow, radiance, and lustre of successfully rendered flesh tones, is semantically related to blinken. But whereas blinckentheyt was primarily used to refer to the shine and sparkle of metallic or crystalline surfaces, gloeyentheyt connected with the sensations of warmth and heat, evoking the glow of flesh tones (carnations) as well as that of burning coals and hot metals. ${ }^{6}$ While the "first birth" of painting was announced through the resplendent light appearing on the bank of the river Maas, this "second birth" manifested itself, metaphorically and literally, through pregnancy-like symptoms, whether located in the body of the male artist or in his fertile mind. 57

Curiously, the same year that Goltzius reinvented himself as a painter with "een cleen stucxken op coper," Van Mander himself also marked the turn of the century with two signed and dated paintings on copper. Metallic painting supports, usually covered with a preparatory layer, enhanced the jewel-like appearance of oil-based colours, lending them a particular lustre and glow. $5^{8}$ Although Van Mander encouraged aspiring artists to paint on canvas, stone, and copper plates as well, ${ }^{59}$ his own oeuvre consists exclusively of wood-panel paintings, with the notable exception of these two paintings on copper and the large canvas of the 1602 Landscape with the Dance around the Golden Calf. ${ }^{60}$ The two pieces on copper are even more unusual since they are painted on both sides. While each front side shows a scene from biblical or ancient history, the reverse sides feature allegorical or emblematic representations. We do know of copper plates that were subsequently used as painting supports after they had served for engravings, but double-sided paintings on copper are rare. ${ }^{61}$ In the present context, the smaller of

56 Paul Taylor, "The Glow in Late Sixteenth- and Seventeenth-Century Dutch Paintings," in Looking through Paintings: The Study of Painting Techniques and Materials in Support of Art Historical Research, ed. Erma Hermens, Leids kunsthistorisch jaarboek 11 (Baarn and London: de Prom, 1998), 159-178.

57 For the use of reproductive metaphors in art literature: Ulrich Pfisterer, Kunst-Geburten:Kreativität, Erotik, Körper in der Frühen Neuzeit (Berlin: Klaus Wagenbach, 2014), 763-767.

$5^{8}$ Recent literature on paintings on copper includes: Laura Fuster López et al., Paintings on Copper and Other Metal Plates: Production, Degradation and Conservation Issues (València: Universitat Politècnica de València, 2017); Michael K. Komanecky, Copper as Canvas: Two Centuries of Masterpiece Paintings on Copper, 1575-1775, exh. cat., Phoenix Art Museum (New York and Oxford: Oxford University Press, 1999); Christine Göttler, Last Things: Art and the Religious Imagination in the Age of Reform (Turnhout: Brepols, 2010), 335-376.

59 Van Mander, Schilder-Boeck, fol. 7r (Grondt, Chapter I, stanza 72); Achim Stanneck, Ganz ohne Pinsel gemalt (Frankfurt am Main: Peter Lang, 2002), 172-178.

60 Oil on canvas, $98 \times 213.5 \mathrm{~cm}$, Haarlem, Frans Hals Museum. The work is extensively discussed by Van Mander's anonymous biographer: Van Mander, Schilder-Boeck 1618, fol. S2v. Leesberg, "Karel van Mander as a Painter," 12, 28, 36, and 47, no. 4; Melion, Shaping the Netherlandish Canon, 4.

61 Christopher P. Heuer, "A Copperplate for Hieronymus Cock," The Burlington Magazine 149 (2007): 96-99. 


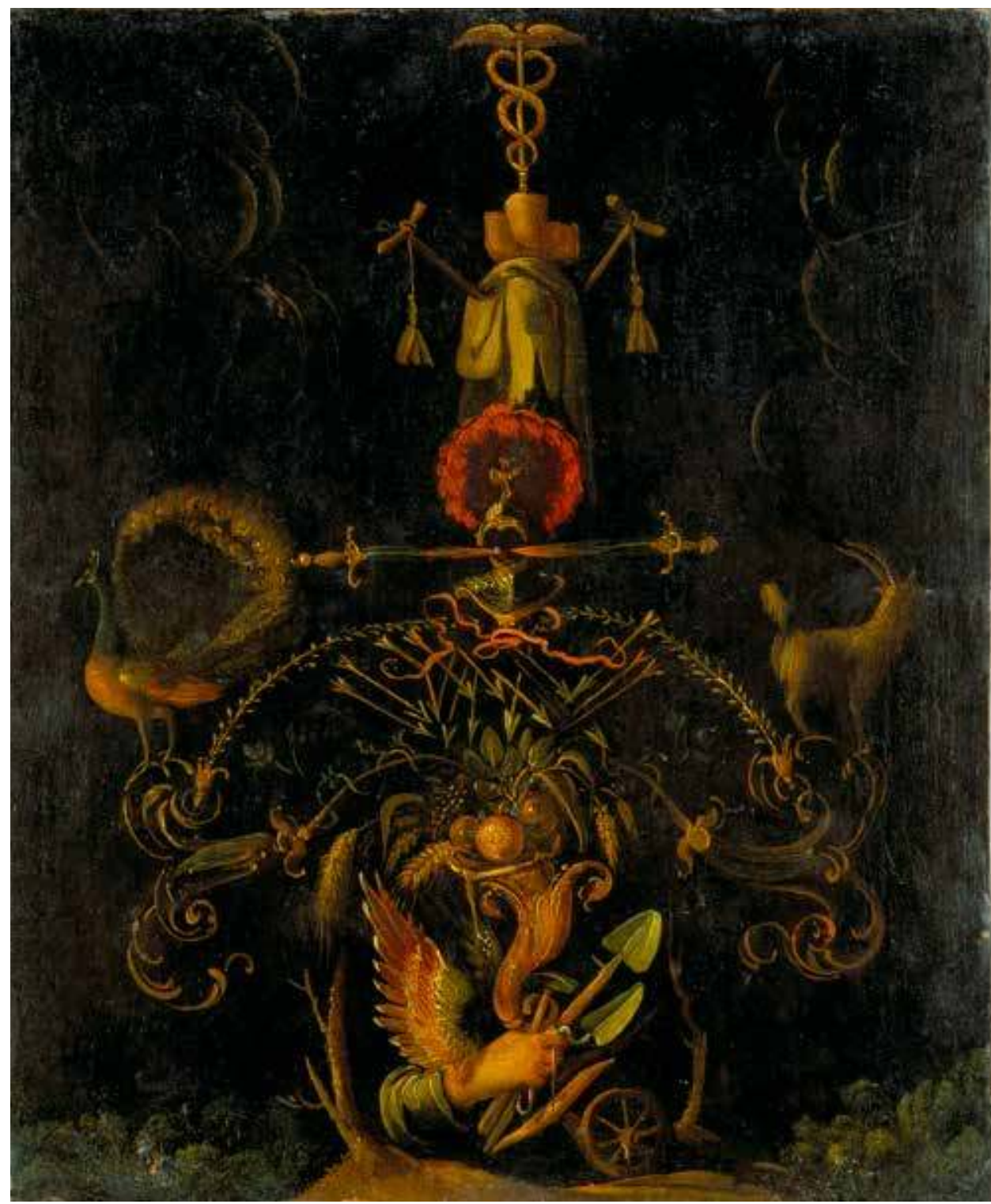

Figure 5.1: Karel van Mander, Emblematic Depiction, 1600 (reverse of Fig. 0.5 - see the "Introduction" to this volume). Oil on copper, $31.1 \times 15.6 \mathrm{~cm}$. Frankfurt am Main, Städel Museum, inv. no. 2088. Image $\odot$ Städel Museum. Photo: U. Edelmann / Artothek.

the two paintings on copper is of particular interest. The front depicts the depravity of humankind before the flood (Genesis $6,5^{-6}$ ), and hence the great turning point in the history of salvation when God, regretting his creation of mankind, decided to wipe all men from the face of the earth, with the exception of Noah and his 
family (see Fig. 0.5) ${ }^{62}$ In the foreground, several men and women engage in leisurely and amorous activities; the gold vessels, jewellery, and furniture underscore the immorality of their environment. The scene stands in stark contrast to that in the background, which shows the construction of the Ark under a darkening sky. The reverse side relates the universal history of salvation to the struggles of an individual's life, as experienced by Van Mander himself (Fig. 5.1). Van Mander's Wtbeeldinghe der Figueren, the last part of the Schilder-Boeck, may provide some help in unravelling the meaning of the emblematic imagery that with its startling yellow, orange, and red colours exercises a powerful impact on the viewer. ${ }^{63}$ Framed by two tree trunks growing from a mound, a winged hand holds a hammer, shovel, and trowel, and, tied by a cord, a plough and a yoke - attributes that stand for agricultural work that themselves lead to a cornucopia of natural riches. A peacock and a billy goat standing on honeysuckle-like blossoms may indicate that prosperity can lead to pride and other sins. ${ }^{64}$ In the central axis between them is a helmet decorated with an unusually elaborate crest in the form of a bird spreading its flaming red feathers into a cloudy sky. Like the arrows aimed at the cornucopia, the two swords with their glowing blades directed against the helmet denote war. War results in poverty and human misery, as symbolized by the ragged coat and the two crutches. Two bent knees, meaning "humble submission," serve as the pedestal for a winged, golden caduceus. The caduceus or Mercury's rod stands in general for "peace and harmony," while in conjunction with a cornucopia, it refers to the abundance that results from harmony. ${ }^{6}$ With its visual and poetic resonances, the composition can be read as a self-aware statement about the continuous cycle of rise and fall that characterizes human life.

\section{Vibrant Vocabularies: The Realm of Colour in Den Grondt}

From here let us proceed to Van Mander's four chapters on colour in Den Grondt. The frequent direct addresses to "aspiring painters" suggest that Den Grondt was

62 The plate was prepared with a thin dark grey underlayer; in addition, a white ground covers the front face. I am deeply indebted to Jochen Sander, Head of German, Dutch, and Flemish Paintings before 180o, and Stephan Knobloch, Head of Conservation, for allowing me to study the painting in the conservation laboratory at the Städel and giving me access to the Städel's documentation of that work. Mirjam Neumeister, Holländische Gemälde im Städel, 1550-180o, vol. 1: Künstler geboren bis 1615, Kataloge der Gemälde im Städelschen Kunstinstitut Frankfurt am Main 8 (Petersberg: Michael Imhof, 2005), 234-243; Leesberg, "Karel van Mander," 33 and 46, no. 1.

63 Hessel Miedema, "Een schilderij van Karel van Mander de Oude (1548-16o6): Een doopsgezinde interpretatie," Doopsgezinde Bijdragen 16 (1990): 113-128.

64 Van Mander, Schilder-Boeck, fol. $131 v$ (Wtbeeldinghe).

65 Ibid., fol. 13ov. 
primarily meant to be read by Netherlandish painters themselves. In the sixteenth century, vernacular verse began increasingly to be used to impart technological knowledge. In Den Grondt, the verse form facilitated memorization and also elevated the art of painting to a higher status. ${ }^{66}$ Dedicated to the art collector and general mint master of the Dutch Republic Melchior Wijntgis, a resident of Middelburg who owned a number of the works discussed in the Schilder-Boeck, Den Grondt includes a preface, several laudatory poems (including four by his painter friend Cornelis Ketel), an exhortation to the reader, plus fourteen chapters covering the subjects of drawing (2), proportion (3), composure (4), composition and invention (5), affects and passions (6), reflections and reverberations (7), landscape (8), animals (9), draperies (10), and, as previously mentioned, colour (11-14). Van Mander pursued his reflections on colour and paints within a variety of cultural and artistic contexts. ${ }^{67}$ He drew both from his own painterly explorations and from previous theories on colour as well as the long tradition of heraldic blazoning. While the main arguments of all four chapters will be presented, the focus of interest is on the most striking and conspicuous colours: vermilion, introduced in Chapter Twelve as the principal pigment for creating "glowing" flesh parts or "flesh colour" (lijfverw); ${ }^{68}$ and yellow, celebrated in Chapter Fourteen for its mimetic proximity to the shine and brightness of gold and to that of the sun's rays, which also appear golden. What constitutes the virtue of Netherlandish oil painting techniques, their power to affect the viewers' bodies and minds?

Chapter Eleven, the first of the chapters on colour, is about "how to sort and combine colours" that "like each other best," a topic that formed part of a larger discussion about sympathetic and antipathetic forces governing the cosmos that was also covered by Alberti, Ryff, and Lomazzo ${ }^{69}$ Van Mander cites Pliny's example of the Greek painter Pausias who, in his paintings, attempted to emulate Glycera, a

66 Christopher Joby, The Dutch Language in Britain (1550-1702): A Social History of the Use of Dutch in Early Modern Britain (Leiden and Boston, MA: Brill, 2015).

67 See most recently: Baker et al., Early Modern Color Worlds; Bushart and Steinle, Colour Histories; Andrea Feeser, Maureen Daly Goggin, and Beth Fowkes Tobin, eds., The Materiality of Color: The Production, Circulation, and Application of Dyes and Pigments, 1400-180o (Farnham: Ashgate, 2012); Ann-Sophie Lehmann, "An Alphabet of Colors: Valcooch's Rules and Emergence of Sense-Based Learning around 1600," in Lessons in Art: Art, Education, and Modes of Instruction since 1500, ed. Eric Jorink, Ann-Sophie Lehmann, and Bart Ramakers, Netherlands Yearbook for History of Art 68 (Leiden: Brill, 2019), 168-203. 68 For the importance of lijfverw in Netherlandish art: Lehmann, "Fleshing out the Body"; Paul Taylor, "Colouring Nakedness in Netherlandish Art and Theory," in The Nude and the Norm in the Early Modern Low Countries, ed. Karolien De Clippel, Katharina van Cauteren, and Katlijne van der Stighelen (Turnhout: Brepols, 2011), 65-79.

69 Van Mander, Schilder-Boeck, fols. 45 r-46v (Grondt, Chapter XI: Van het Sorteren/ en by een schicken der Verwen). Rivius, Architectur, fol. 71r. For Lomazzo's discussion of the "friendships and the enmities" of colours: Barbara Tramelli, Giovanni Paolo Lomazzo's Trattato dell'Arte della Pittura: Color, Perspective and Anatomy (Leiden: Brill, 2017), 85. 
seller of floral wreaths who was able to arrange flowers according to their colours in ten thousand different ways. ${ }^{70} \mathrm{He}$ celebrates Nature, the "wet nurse and mother of painting," for creating flowers in different colours, along with various things that unite all the colours such as "talking parrots, birds, and shells." ${ }^{71} \mathrm{He}$ also refers to the praiseworthy example of Pieter Bruegel, who intersperses garments in different variations of grey with azurite blue or fiery glowing red. $7^{2}$ Van Mander compares the conspicuous vibrancy of these colours to "delightful sayings" ("sin-ghevende Spreuck") scattered through a lengthy speech or story or to the peacocks or "Indian birds" whose bright feathers make them stand out from all other birds. ${ }^{73}$

Chapter Twelve starts with three comparisons between painting and drawing. Stanza One compares drawing to the body and painting to the spirit or soul of man, since "through colour the lifeless lines of drawing begin to stir and come alive, causing them to undergo a resurrection (verweckinghe)."74 Further elaborating on the imagery of awakening, Stanza Two likens drawing to "the clay image of Prometheus, not unpleasant to Minerva, the goddess of the arts" and painting to the "heavenly fire he [Prometheus] stole to his own ruin to add movement to his work; it thus quickly became a Pandora, that is to say the excess of all good things." ${ }^{.75}$ Stanza Three, lastly, relates drawing to the sound of a musical instrument and painting to that of the human voice. ${ }^{7}$ Although for Van Mander drawing and painting are intimately intertwined, in this passage he nonetheless favours the latter over the former since painting breathes life into a work of art. Although colour was frequently likened to the soul in early modern literature on art,77 Van Mander's comparison of painting to the seductive and deceptive Pandora, animated by the heavenly fire, is unique

70 Van Mander, Schilder-Boeck, fol. 45r-v (Grondt, Chapter XI, stanzas 2-3); Pliny, Natural History, vol. 9: Books 33-35, trans. H. Rackham (Cambridge, MA: Harvard University Press, 1952), 352-353 (Book XXXV, 125-126).

71 Van Mander, Schilder-Boeck, fols. 45v-46r (stanza 8): "Natuere [...] van het schilderen voester en moeder."

72 Ibid., fol. 46r (stanza 10): "En onder al dat graeu seer cierlijck bloeyde| Een schoon asuer/ oft root/ dat vyerich gloeyde."

73 Ibid., fol. 46r (stanza 11).

74 Ibid., fol. 46v (Grondt, Chapter XII: Van wel schilderen/ oft Coloreren, stanza 1): "Indien het teyckenen by den Lichame| Te ghelijcken is/ in manier van spreken/| Met zijn verscheyden leden ten betame/| Soo en sal t'schilderen niet onbequame| By den Gheest oft de Siele zijn gheleken:| Want door verwen worden de doode streken| Der teyckeninghen te roeren en leven/| En de rechte verweckinghe ghegheven."

75 Ibid. (stanza 2): "Jae het teyckenen is als t'aerdtsche beelde| Van Prometheus, het welcke Minerven| Goddinne der Consten niet en verveelde// T'schilderen als t'Hemel-vyer/ dat hy steelde// En daer hy mede/ tot zijns selfs verderven/| Zijn werck beweginghe dede verwerven/| En werdt also een Pandora met spoede/| Te weten/ t'overschot van allen goede."

76 Ibid. (stanza 3).

77 Verena Krieger, "Die Farbe als 'Seele' der Malerei: Transformationen eines Topos vom 16. Jahrhundert zur Moderne," Marburger Jahrbuch für Kunstwissenschaft 33 (2006): 91-112. 
and has so far remained largely unexamined. ${ }^{7}$ Jupiter, in order to take revenge for Prometheus's theft of fire, commissioned Vulcan to fashion from earth and water a woman of great beauty and allure who was then endowed with gifts from all the gods and hence named by Mercury as Pandora the "all-gifted" or, alternatively, the "bringer of all gifts." Van Mander uses the figure of Pandora not only to emphasize the affinities between colour and fire, movement and life, but also to underscore colour's ambiguous connotations with abundance, allure, and excess. ${ }^{79}$

The three introductory stanzas set the framework for the remaining chapter. In the following stanzas, Italian and Netherlandish approaches are evaluated against each other in three regards. Van Mander first distinguishes between those who sketch directly onto their panels and apply colour confidently and those who create a final drawing from multiple sketches which is then transferred onto the ground layer of the painting. Although Van Mander considers the first approach as suitable for true masters who, with their "bold way of painting," expand the realm of the arts, he generally favours a more tentative procedure..$^{80}$ Van Mander then modifies Michelangelo's polemical judgement (as transmitted by Vasari) that (Italian) fresco is men's work and (Netherlandish) oil painting women's work by pointing out that the high humidity and rough weather of the north hardly allows for wall painting, and, in addition, the local shell limestone easily develops mildew spots. ${ }^{81} \mathrm{He}$ then discusses two contrasting painterly styles termed "neatness" ("netticheyt") and "roughness" ("rouwicheyt"). ${ }^{82}$ While the neat, precise manner of painting was brought to perfection by such northern European masters as Jan van Eyck, Pieter Bruegel the Elder, Lucas van Leyden, and Albrecht Dürer, painting characterized by rough or loose brushwork was primarily cultivated by Titian in his later works. Although Van Mander admires Titian's loose brushstrokes for their life-like mimetic effects, he considers "neatly painted things" ("nette dingen") the non plus ultra of the painterly arts, that is to say, a standard of perfection that can hardly be surpassed.

78 The exception is: Dora and Erwin Panofsky, Pandora's Box: The Changing Aspects of a Mythical Symbol (Princeton, NJ: Princeton University Press, 1962), 68-69.

79 For a more expanded discussion of Van Mander's use of the Pandora myth: Christine Göttler, "Tales of Transformation: Hendrick Goltzius's Allegory of the (Alchemical) Art in the Kunstmuseum Basel," in Epistemic Images in Early Modern Europe, ed. Christopher Heuer and Alexander Marr, special issue, 21: Inquiries into Art, History, and the Visual 1, no. 2 (2020): 403-444, accessed on 28 November 2020, https:// doi.org/10.11588/xxi.2020.2.76233.

8 o Van Mander, Schilder-Boeck, fols. 46r-47r (stanzas 4-8), at fol. 47r (stanza 6): “Dit mach wel voeghen de Schildersch' Augusten,| Die in Consten toenemen sonder rusten/| En in stout schilderen t'rijcke vermeeren:| Doch al can men aldus vrymoedich leeren| Met de verwe handelen sonder schricken."

81 Ibid., fol. $47 \mathrm{r}-\mathrm{v}$ (stanzas 11-13).

82 Ibid., fol. 48r-v (stanzas 17-26). Melion, Shaping the Netherlandish Canon, 5, 60-63, and passim; Thijs Weststeijn, The Visible World: Samuelvan Hoogstraten's Art Theory and the Legitimation of Painting in the Dutch Golden Age (Amsterdam: Amsterdam University Press, 2008), 219-265. 
A neat, precise manner of painting gives the painted surface a smooth and mirrorlike look which transforms the work of art - literally and metaphorically - into a brilliant gem, feeding the eyes and filling the heart with desire. ${ }^{83}$

Finally, thirteen of the chapter's forty-three stanzas concern the creation of "blossoming" skin or flesh tones - in other words, the refined Lombard-Venetian colorito that was nevertheless reinterpreted by Goltzius and other Netherlandish artists to fit within their own local tradition of painting. It is in these passages that red vermilion is specifically mentioned. ${ }^{84}$ Van Mander strongly advises against heightening with white, a method that will make the "nudes freeze," recommending instead the generous use of vermilion that will make the flesh appear glowing and soft. ${ }^{85}$ When rendering the sunburnt bodies of peasants, shepherds, and other country people, vermilion should be mixed with yellow ochre. ${ }^{86}$ Conversely, the use of lamp black (a pigment made from soot collected from oil lamps) and massicot (a lead-based yellow pigment) should be avoided in flesh tints; ${ }^{87}$ massicot is defined as a "heavy and laborious colour" that "fades in the upper paint layers," and is "difficult to handle because it dries quickly." 88

At the present time even the best examples of Netherlandish flesh paint appear "dry" or "like fish or images of stone" according to Van Mander, whereas the Italians have long achieved a manner of painting that he describes as "poeslijck" and "sacht." 99 Poeslijck corresponds to the Italian morbido (soft, lascivious), as is evidenced by Van Mander's use of the words "seer morbido/ oft poeselich van naeckten" in his description of Maarten van Heemskerck's Triumph of Bacchus and Silenus, a painting that was, incidentally, in the possession of Melchior Wijntgis, the dedicatee of Den Grondt..$^{\circ}$ Van Mander may have been referring here to a passage in Lodovico Dolce's Dialogo della pittura intitolato Aretino, which says that a painter able to imitate the

83 Van Mander, Schilder-Boeck, fol. 48r (stanza 21). For the mirror-like and jewel-like effects of Netherlandish oil painting, see Lucas de Heere's Ode to the Ghent Altarpiece, included in Van Mander's Schilder-Boeck, fol. 201r: "Daert al zijn om te schoonste en rijckste edel juweelen [...] T'sijn spieghels, spieghels zijnt, neen t'zijn geen Tafereelen."

84 Van Mander, Schilder-Boeck, fols. 48v-5or (Grondt, Chapter XII, stanzas 29-41).

85 Ibid., fols. $48 \mathrm{v}-49$ r (stanza 29): "Nu aengaende t'verwen/ laet niet vervriesen| U blos/ noch sos cout oft purperich laten:| Want sulck een lacke wittigh' incarnaten/| Carnaty en can niet lijfverwigh bloeyen/| Maer vermillioen doet al vleeschigher gloeyen." See also ibid., fol. $49 \mathrm{r}$ (stanzas 32 and 33).

86 Ibid., fol. 49 r (stanza 31).

87 Ibid., fol. 49v (stanza 38, marginal note): "Lamp-swart in naeckten te mijden."

88 Ibid., fols. 49v-5or (stanza 41): "Ich meen/ den Masticot meuchdy wel swichten/| En ghebruycken hier toe seer schoonen lichten| Oker [...] Met dees swaer verwe/ verstervich in't hooghen/| En quaet te verwercken/ door t'hastig drooghen." For massicot, see note 114, below.

89 Ibid., fol. 49r-v (stanza 35).

90 Ibid., fol. 246v; Christine Göttler, "Bootsicheyt': Malerei, Mythologie und Alchemie im Antwerpen des frühen 17. Jahrhunderts: Zu Rubens' Silen in der Gemäldegalerie der Akademie der Bildenden Künste in Wien," in Erosionen der Rhetorik? Strategien der Ambiguität in den Künsten der Frühen Neuzeit, ed. 
"smoothness of flesh" can make his paintings "appear alive so that they seem to lack nothing but the breath." ${ }^{\text {91 }}$ As suggested by the emphasis placed by Van Mander on flesh tones and "carnations," the softer, smoother, more sensuous, and more tactile painterly and aesthetic qualities also corresponded to the sensibilities of lovers of (northern) Netherlandish art.

Like Chapter Fourteen, Chapter Thirteen on the origin, nature, and overall power of colour is indebted to one of the most influential heraldic treatises on colour, $L e$ blason des couleurs en armes, livrees et devises, first published in 1505 and then reissued in more than a dozen French and several Italian editions throughout the sixteenth and seventeenth centuries. The first part focuses on the seven heraldic colours - gold, silver, red, blue, black, green, and purple - and their connections to the virtues, metals, and planets; the second part proceeds from an Aristotelian understanding of colours as intermediaries between white and black. ${ }^{92}$ Van Mander begins Chapter Thirteen by asserting that all things have their colour from God, "the most skilful image-maker and painter." He adopts the French treatise's Aristotelian views that colours have their origin in the four elements, ${ }^{93}$ and Aristotle's wellknown statement that colour is "the outermost boundary of the transparency of a body"94 or, as summarized by Van Mander in his own words, "the uppermost cloth

Valeska von Rosen, culturae 4 (Wiesbaden: Harassowitz, 2012), 259-301, at 280-282; Melion, Shaping the Netherlandish Canon, 105-106.

91 Lodovico Dolce, "Dialogo della pittura intitolato l'Aretino," in Trattati d'arte del Cinquecento fra Manierismo e Controriforma, ed. Paola Barocchi, vol. 1 (Bari: Laterza, 1960), 183: "E certo il colorito è di tanta importanza e forza, che, quando il pittore va imitando bene le tinte e la morbidezza delle carni e la proprietà di qualunque cosa, fa parer le sue pitture vive e tali che lor non manchi altro che 'l fiato." See also: Daniela Bohde, “'Le tinte delle carni': Zur Begrifflichkeit für Haut und Fleisch in italienischen Kunstraktaten des 15. bis 17. Jahrhunderts," in Weder Haut noch Fleisch: Das Inkarnat in der Kunstgeschichte, ed. Daniela Bohde and Mechthild Fend (Berlin: Gebr. Mann, 2007), 41-63.

92 In the prologue of the two-part treatise, the author identifies himself as Sicille, a herald in the service of King Alfonso of Aragon and Sicily. While the two parts originated in different circumstances, they have been revised or rewritten for the first printed edition of 1505: Christine Göttler, “'Sicille': Les metaulx en Grec, in Le blason des couleurs en armes, livrees \& devises, 1540?," in Renaissance Invention: Stradanus's Nova Reperta, ed. Lia Markey (Evanston, IL: Northwestern University Press, 2020), 229, cat. 49. See also the commentary by Hessel Miedema: Van Mander, Grondt, ed. Miedema, 6o8-625, 647. For the tradition of heraldic blazoning, see Karin Leonhard, "Painted Gems: The Color Worlds of Portrait Miniature Painting in Sixteenth- and Seventeenth-Century Britain,” in Baker et al., Early Modern Color Worlds, 140-169, especially $156-158$.

93 Van Mander, Schilder-Boeck, fol. 5or (Grondt, Chapter XIII: Van der Verwen oorsprong/natuere/cracht en werckinghe, stanza 1) and fol. $5_{0 v}$ (stanza 4). I have been using: Sicille, Le blason des couleurs en armes, livrees et devises (Paris: P. Menier, 1582), fol. 21r: "Le createur de toutes choses créa toutes couleurs [...] toutes couleurs precedent de la nature des quatre elements."

94 Van Mander, Schilder-Boeck, fol. 5ov (stanza 5): "Verw' is in haer selven d'uyterste claerheyt|Van sulck een lijf/ daer sy ghelijft is binnen/| Jae van des Lichts substanty." Sicille, fol. 21r-v: "Couleur est l'estreme clarté du corps ou elle est incorporee: laquelle est substance de lumiere en elle mesme”; 
or the outermost covering" of all things. ${ }^{95}$ Most of the examples concerning the "marvellous power of colour" are also taken from Le blason des couleurs. Colour instils courage or fear, sadness or joy; it can make things appear ugly or beautiful, base or praiseworthy..$^{6}$ Van Mander supports the general assumption that colours perceived during human and animal pregnancy could alter the appearance of their offspring. ${ }^{97}$ While the maternal imagination is helpless against the power of colour, much virtue is needed from men to resist the temptation of colours, in particular those of fair women ("schoon verwige wijven"). Alexander the Great and the Roman general Scipio Africanus are cited as praiseworthy examples not so much because of their military victories, but rather because they were able to overcome their desires for beautiful women. ${ }^{9}$ Finally, in Van Mander's account, the power of colour also extends to the New World. Citing from his own translation of Benzoni's Mondo nuovo, Van Mander refers to a device documented in the palace of King Atabaliba in Peru consisting of differently coloured cotton cords tied into a variety of knots that served to chronicle the history of the land. 99

While writing the Schilder-Boeck, Van Mander himself produced a painting depicting the "continence" of Scipio Africanus, who, as told by Livy and others, neither took possession of the beautiful female captive allotted to him as part of the booty nor accepted the gold brought by her parents in order to ransom her (Fig. 5.2). ${ }^{100}$ Dated to 1600 , this

Aristotle, "Sense and Sensibilia," in The Complete Works of Aristotle, ed. Jonathan Barnes, 2 vols. (Princeton, NJ: Princeton University Press, 1984), 1:698 (439b, 10-12): "But since the colour is at the extremity of the body, it must be at the extremity of the transparent in the body"; Richard Sorabji, "Aristotle on Colour, Light and Imperceptibles," Bulletin of the Institute of Classical Studies 47 (2004): $129-140$, at 130 .

95 Van Mander, Schilder-Boeck, fol. 50v (stanza 8): "Is t'opperste cleedt en t'uyterste decksel."

96 Ibid., fols. 50v-51r (stanza 9): "Verwe verstout/ en verschrickt de persoonen// Verwe doet verleelijcken oft verschoonen/| Verwe doet verdroeven en verjolijsen/| Verwe doet veel dinghen laken oft prijsen." Sicille, Le blason des couleurs, fol. $22 \mathrm{v}$.

97 Van Mander, Schilder-Boeck, fol. 51r (stanzas 11 and 12). On the susceptibility of the maternal imagination, see most recently: Frances Gage, Painting as Medicine in Early Modern Rome: Giulio Mancini and the Efficacy of Art (University Park, PA: The Pennsylvania State University Press, 2016), 87-119.

98 Van Mander, Schilder-Boeck, fol. 51V (stanza 17, marginal note): "Scipio en Alexander meer gepresen, hun ghemoeden te hebben verwonnen, dan van weghen hum krijchsvictorien."

99 Ibid., fols. 51v-52r (stanzas 19-22). On khipus within a larger context of "knotting cultures": Stefan Hanß, "Material Encounters: Knotting Cultures in Early Modern Peru and Spain," The Historical Journal 62 (2019): 1-33, at 23, accessed 22 January 2019, http://dx.doi.org/10.1017/Soo18246X18000468.

100 Hessel Miedema and Pieter J. J. van Thiel, "De grootmoedigheid van Scipio, een schilderij van Karel van Mander uit 16oo," Bulletin van het Rijksmuseum 26, no. 2 (1978): 51-59; Henk van Os, Jan Piet Filedt Kok, Ger Luijten, and Frits Scholten, Netherlandish Art in the Rijksmuseum, 140o-16oo (Zwolle: Waanders, 2000), 224-225, cat. 97. It is a pleasure to thank Matthias Ubl, Curator of Early Netherlandish Painting at the Rijksmuseum, and the two Paintings Conservators, Lisette Vos and Nienke Woltman, for looking at the two sides of the copper plate with me for an extended period of time. Matthias Ubl kindly provided me with the Rijksmuseum's records of the painting and images of close-up details. 


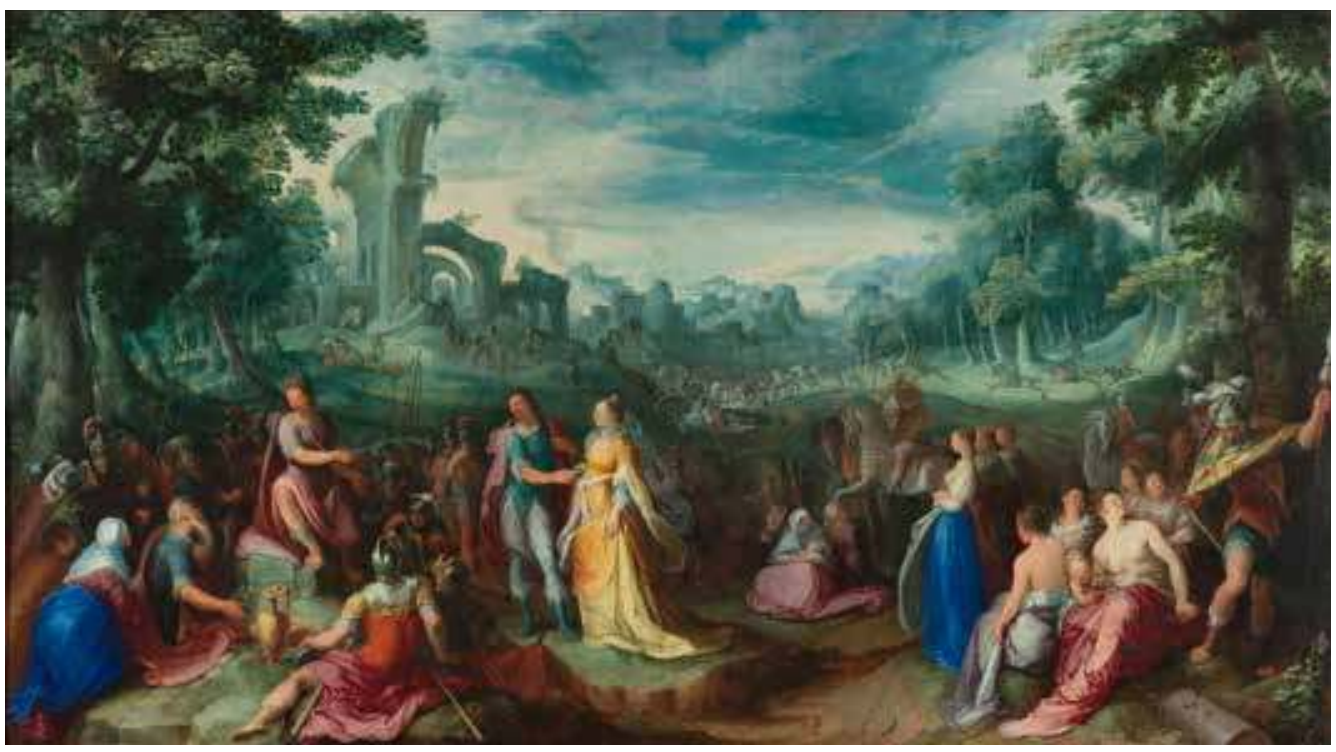

Figure 5.2: Karel van Mander, The Continence of Scipio, 1600 . Oil on copper, $44 \times 79 \mathrm{~cm}$. Amsterdam, Rijksmuseum, inv. no. SK-A-4690. Image ๑ Rijksmuseum.

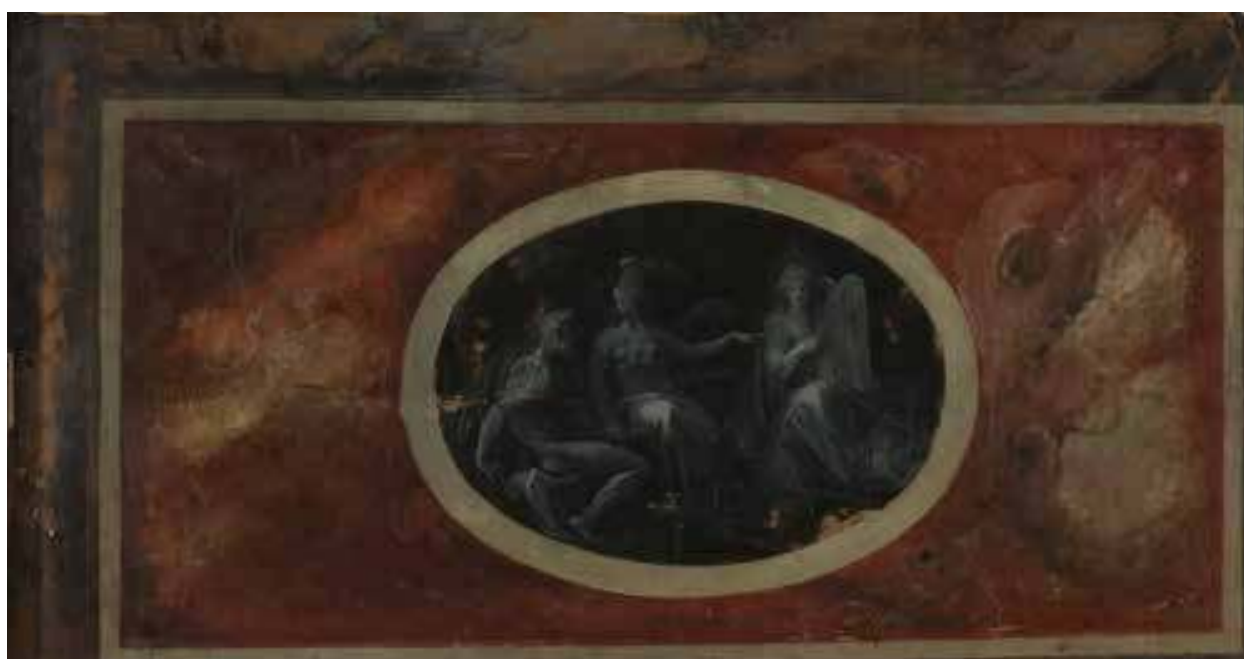

Figure 5.3: Karel van Mander, Allegory of Nature, 1600 (reverse of Fig. 5.2). Oil on copper, $44 \times 79 \mathrm{~cm}$. Amsterdam, Rijksmuseum, inv. no. SK-A-4690. Image @ Rijksmuseum. 
is the larger of the two double-sided paintings on copper that, as mentioned above, marked the turn of the century. The front is a brilliant exercise in colours, textures, and tones, exemplifying Van Mander's interest in merging history and landscape. ${ }^{101}$ Seated on an elevated structure in the left foreground, the youthful conqueror of Carthage gestures with both hands toward the beautiful female captive and her fiancé while turning his head toward the kneeling parents hoping to ransom her with gold. In accordance with the passage in the Schilder-Boeck, Van Mander renders Scipio as an example of male virtue able to resist the allure of colour as perceived both in the beauty of women and the sparkle of gold. To underscore his point, Van Mander shows the woman dressed in a gown of vibrant yellow, the same colour as the gold vessels offered to Scipio for her return. The reverse side of the copper plate demonstrates Van Mander's mastery of painterly deception (Fig. 5.3). Evoking a low relief carved into a dark grey stone, the central oval-shaped scene shows a man guided to multi-breasted Nature, who then directs him to a figure holding the two tablets of the law, perhaps indicating that nature, too, is governed by laws. ${ }^{102}$ The figurative scene appears to be set into a rectangular panel that mimics either red veined marble or scagliola marble, a technique that Van Mander must have encountered during his stay in Florence. Unlike the front, the reverse does not have a ground layer and the metallic surface is occasionally visible through the thin layer of paint. It is thus a stunning example of a bold and fearless approach to painting - as theorized in Chapter Twelve and embodied by Ketel - whereby colour was partially spread with the fingers directly onto the metallic surface or applied with the ball of the hand (Figs. 5.4a-c). ${ }^{103}$

\section{Gold Paint: Van Mander's Yellows}

In contrast to Chapter Twelve which, with its focus on painterly practices, has attracted a number of studies, Chapter Fourteen on the "meaning of colour" has so far received little attention in the art historical literature; its numerous references linking it to other parts of the Schilder-Boeck as well as to other treatises on the significance and symbolism of colour have been largely overlooked. Within the argument of the present chapter, Chapter Fourteen is, however, of particular interest, since twenty-one of the thirty-two stanzas concern gold. Van Mander's verses shift elegantly between gold's material and immaterial qualities and its visible and

101 Melion, Shaping the Netherlandish Canon, 1-12.

102 Weststeijn, The Visible World, 103-104.

103 Paul Vandenbroeck, "Matrix Marmorea: The Sub-Symbolic Iconography of the Creative Energies in Europe and North Africa," in New Perspectives in Iconology: Visual Studies and Anthropology, ed. Barbara Baert, Ann-Sophie Lehmann, and Jenke van den Akkerveken (Brussels: Academic \& Scientific Publishers, 2011), 180-210. 

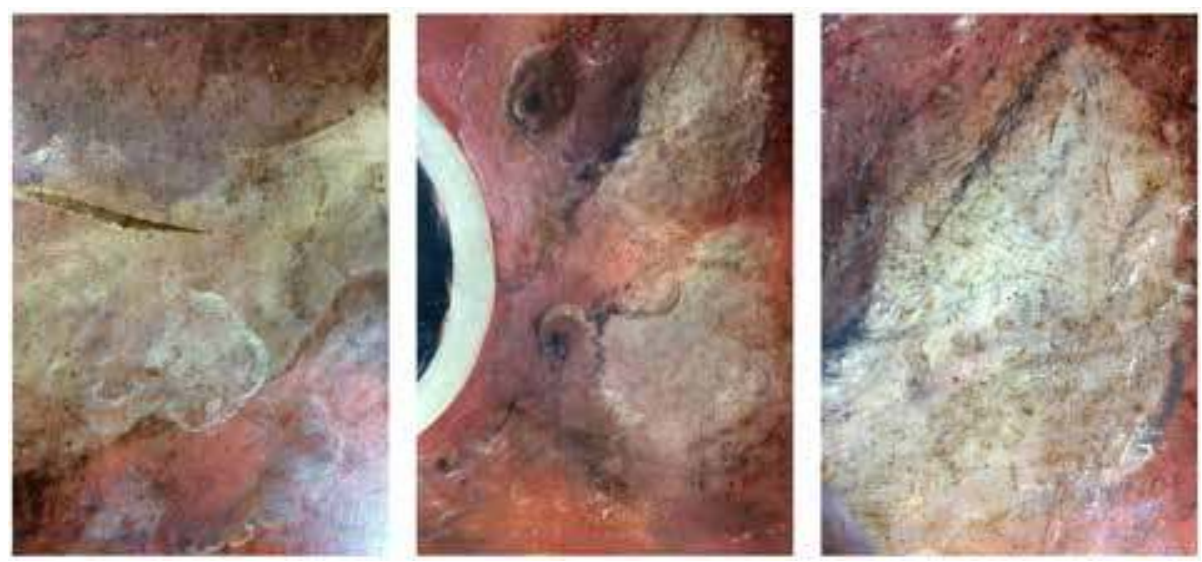

Figures 5.4a-c: Karel van Mander, Allegory of Nature, details of Fig. 5.3: Painted imitation of red-veined stone to the left (Fig. 5.4a) and the right (Figs. 5.4b and c) of the central scene with traces of fingerprints. Photo: Private archive.

invisible effects. His colour hierarchy - granting first place and most of the space to gold/yellow (stanzas 1-21), followed by silver/white (22-23) and then red, blue, green, purple, and black (stanza 24) - is taken from the heraldic literature. On the one hand, yellow is considered the "most splendid" ("t'heerlijckst") among all the colours, since it expresses the "fair colour of gold" ("schoon Goudt-verw"), the most noble of all the metals, as well as that of the sun, whose powerful rays resemble gold. ${ }^{104}$ On the other hand, gold is introduced as the metal that "feeds, but far from saturates, men's greedy senses craving for more" and that has always harmed humankind. ${ }^{105}$ Van Mander continues with two common etymologies of gold. Whereas Isidore of Seville argued that the Latin word aurum came from the Latin aura, signifying splendour, Hippocrates claimed that aurum derived from the goddess Aurora. In reference to Homer, Van Mander calls Aurora "saffron-coloured and glowing" ("safferanich en gloeyend"), certainly because of the glowing light she spreads across the world at dusk and dawn. ${ }^{106}$ The use of gold is considered particularly appropriate in a royal context as a means to express status and wealth; Van Mander mentions golden

104 Van Mander, Schilder-Boeck, fol. 52v (Grondt, Chapter XIV: Bediedinghen der Verwen/watter mede beteykent can worden, stanza 1).

105 Ibid., fol. $52 \mathrm{v}$ (stanza 2).

106 Ibid., fol. 52v (stanzas 4-5). For Van Mander's sources: Van Mander, Grondt, ed. Miedema, 2:616-617. The saffron-coloured dress of Aurora is mentioned by Homer, Iliad, 19.1: Les XXIIII Livres de l'Iliade d'Homere, trans. Hugues Salel (Rouen: Jacques Begne, 1605), 298: "L'Aurore ayant l'habit de couleur de saffran." Van Mander translated the first twelve books of the Iliad from Salel's French translation: De eerste 12 boecken vande Ilyadas, trans. Karel van Mander (Haarlem, 1611). Van Mander, Schilder-Boeck, fol. 29r-v (Grondt, Chapter VII: Van de Reflecty, stanzas 4-6). 
regalia such as sceptres and crowns as well as all kinds of cloth embroidered or interwoven with gold thread, the latter, supposedly, invented by King Attalus (III) of Pergamon, as well as the "golden-yellow shine" of Solomon's Temple. ${ }^{107}$

Van Mander then comments on a crucial difference between ancient and contemporary painters. Whereas the former only knew four colours and, among the yellows, only used "yellow ochre," the latter had, in addition to yellow ochre, four more kinds of yellow, namely massicot, schiet-gheel, and two kinds of orpiment. ${ }^{108}$ Yellows were among the most widely used pigments in early modern Europe, ochres being the earliest known colours used by humans for painting. ${ }^{109}$ Cennino Cennini, in his Libro dell'arte of about 1400, lists among the yellow pigments yellow ochres, giallorino, orpiment, realgar, saffron, and arzica. ${ }^{110}$ Of these, ochres were described as natural pigments, ${ }_{111}^{111}$ giallorino (the Italian name for lead-tin yellow) as "a pigment, which is manufactured, but not by alchemy,"12 and orpiment as "made by alchemy."13 While there is no evidence that Van Mander knew the Libro dell'arte, which contained little information about painting with oil, Cennini's observations are nonetheless revealing in that they shed light about how pigments were described and perceived.

But what about the four other yellows - massicot, schiet-gheel, and two kinds of orpiment - that Van Mander claims were not known to ancients? Lead-tin yellow $\left(\mathrm{Pb}_{2} \mathrm{SnO}_{4}\right)$, called massicot or masticot in northern European and giallolino or giallorino ("little yellow") in Italian sources, was one of the most frequently used pigments in European paintings from the fifteenth to the seventeenth centuries. ${ }^{114}$

107 Van Mander, Schilder-Boeck, fol. 53r (stanzas 7-9): “Moste dat louter gulde gheel daer blincken” (stanza $9)$.

108 Ibid., fol. 53v (stanza 15): “Masticot/ schiet-gheel/ en twee Oprementen.” John Gage, “A Locus Classicus of Colour Theory: The Fortunes of Apelles," Journal of the Warburg and Courtauld Institutes 44 (1981):1-26. In addition to yellow ochre, Pliny also lists orpiment and realgar in Book 35 of his Natural History. For Pliny's pigments: Mark Bradley, Colour and Meaning in Ancient Rome (Cambridge: Cambridge University Press, 2009), 94-100.

109 For the use of ochre, lead-tin yellow, yellow lake, orpiment, and realgar by Giovanni Bellini and other Venetian painters: Paul Hills, Venetian Colour: Marble, Mosaic, Painting and Glass 1250-1550 (New Haven, CT and London: Yale University Press, 1999), 140-150.

110 Lara Broecke, Cennino Cennini's Il libro dell'arte: A New English Translation and Commentary with Italian Transcription (London: Archetype Publications, 2015), 70-77.

111 Ibid., 70-72.

112 Ibid., 72: "ti dico sia colore/ artificiato manon darchimia." According to Broecke, Cennini's giallorino was produced from yellow glass.

113 Ibid., 73: "questo tal colore e artificiato effatto/ darchimia."

114 Seccaroni, Giallorino, especially 92-121; Hermann Kühn, "Lead-Tin Yellow," in Roy et al., Artists' Pigments: A Handbook, 2:83-112; Rosamond D. Harley, Artists' Pigments c. 16oo-1835 (London: Butterworth Scientific, 1982), 85-86; William Jervis Jones, Historisches Lexikon deutscher Farbbezeichnungen, 5 vols. (Berlin: Akademie Verlag, 2013), 4:1841-1843; Nicholas Eastaugh, Valentine Walsh, Tracey Chaplin, and Ruth Siddall, The Pigment Compendium: A Dictionary of Historical Pigments (Oxford: Butterworth-Heinemann, 2008), 238-239. 


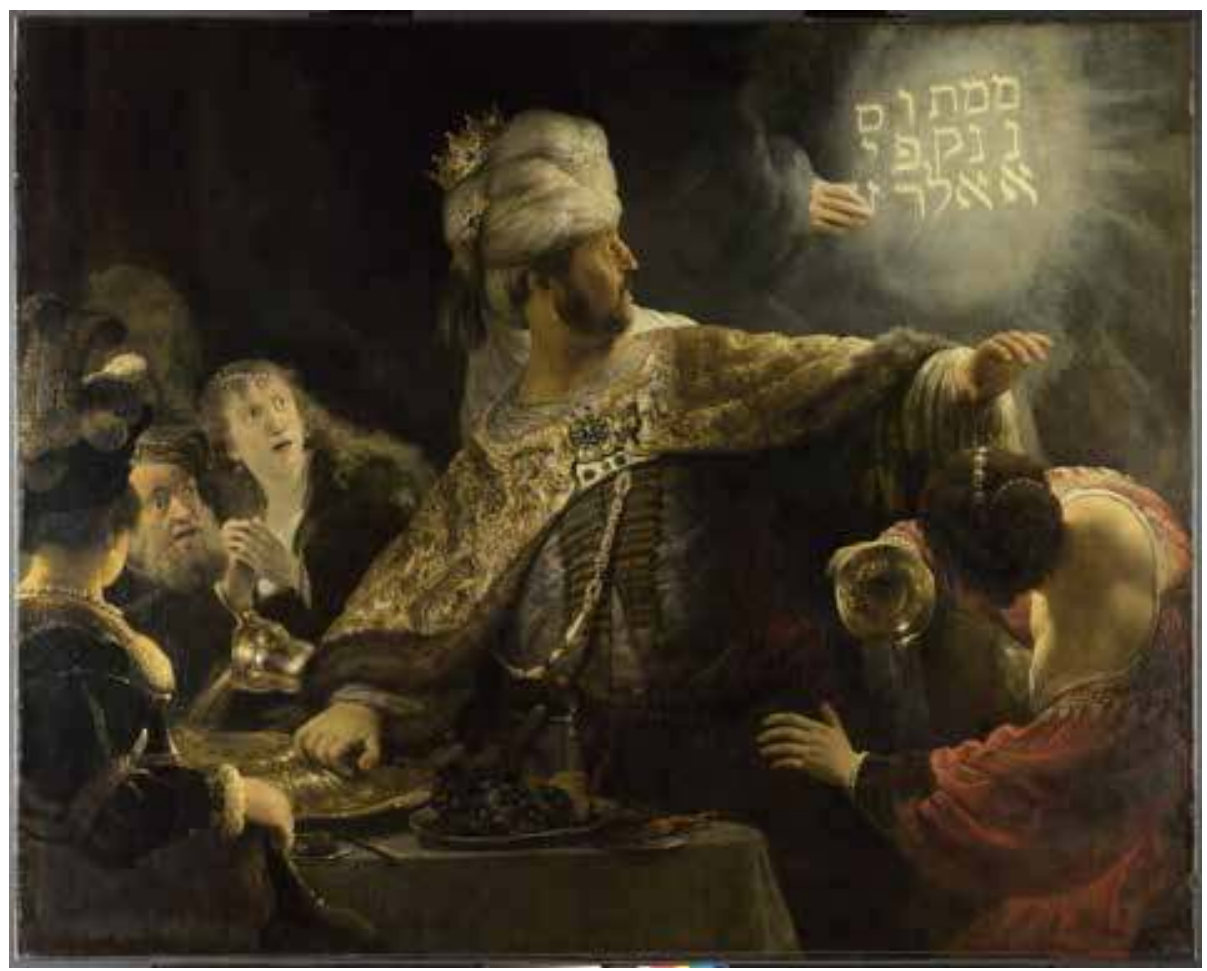

Figure 5.5: Rembrandt, Belshazzar's Feast, about 1636-38. Canvas, $167.6 \times 209.2 \mathrm{~cm}$. London, The National Gallery, NG 6350. Image $\odot$ The National Gallery, London.

The popularity of massicot or giallolino in the late sixteenth century is also shown by the fact that Richard Haydocke, in his 1598 translation of Lomazzo's Trattato dell'arte de la pittura, only mentions "yeallowe of the Flaunders fornace and of Almany, commonly called masticot" among the "matters of yeallowe."15 Lomazzo himself counts among the yellows "il gialolino di fornace di Fiandra, \& di Alamagna, \& l'oropimento oscuro, \& l'ocrea."16 Van Mander considers masticot gheel one of the colours of the rainbow. ${ }^{117}$ While he discourages its use for flesh tones, he recommends it, in combination with orange-coloured minium (meny), for the rendering of golden ornaments. ${ }^{118}$ An impressive example of the powerful effects of this bright yellow

$115 \mathrm{R}[\mathrm{ich}$ ard] $\mathrm{H}[$ aydock], A Tracte Containing the Artes of Curious Paintinge, Carvinge and Building (Oxford: Joseph Barnes for R[ichard] H[aydock], 1598), 99.

116 Gio. Paolo Lomazzo, Trattato dell'arte de la pittura (Milan: Paolo Gottardo Pontio, 1584), 191.

117 Van Mander, Schilder-Boeck, fol. $30 v$ (Grondt, Chapter VII: Van de Reflecty, stanza 22).

118 Ibid., fol.53v (Grondt, Chapter XIV, stanza 16). For minium or meny: Elizabeth West Fitzhugh, "Red Lead and Minium," in Roy et al., Artists'Pigments: A Handbook, 1:109-139; Joe Kirby, "Glossary," in Trade in Artists'Materials: Markets and Commerce in Europe to 17oo, ed. Jo Kirby, Susie Nash, and Joanna Cannon (London: Archetype Publications, 2010), 457 (under "Read lead"). 


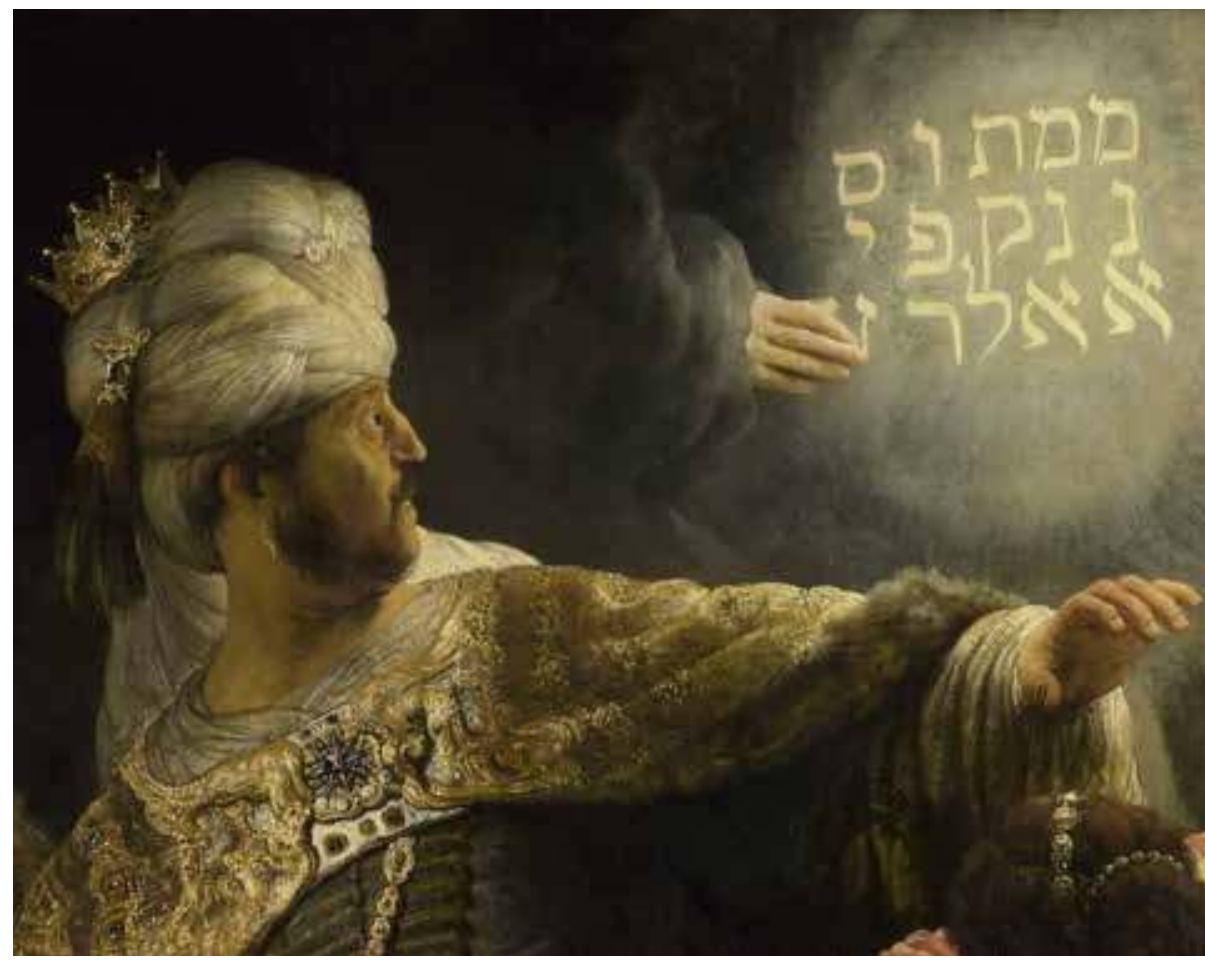

Figure 5.6: Rembrandt, Belshazzar's Feast, detail of Fig. 5.5: Both the gold lettering and the light yellow accents on the embroidery were made with lead-tin yellow.

pigment is Rembrandt's Belshazzar's Feast, where lead-tin yellow is used both for the golden letters of the inscription on the wall and the sparkling embroidery of the king's cloak, the latter painted in an unusually thick impasto (Figs. 5.5 and 5.6). ${ }^{119}$

Sharing Van Mander's ambivalent thoughts about massicot, Willem Beurs, in De groote waereld in't kleen geschildert of 1692, observed that the pigment was "tedious to handle" and may cause blackening; he suggested trying Konings-geel (king's yellow or orpiment) instead. ${ }^{120}$ According to Beurs, massicot was used frequently in landscape paintings, an observation confirmed by a recipe recorded by Theodore Turquet de Mayerne (1573-1655) about how to accentuate the multiple planes of a

119 David Bomford, Jo Kirby, Ashok Roy, Axel Rüger, and Raymond White, eds., Art in the Making: Rembrandt, exh. cat. National Gallery, London (London: National Gallery, 2006), 110-117, cat. 8; Ashok Roy and Jo Kirby, "Rembrandt's Palette," in Bomford et al., Art in the Making: Rembrandt, at 38-39. 120 Wilhelmus Beurs, De groote waereld in't kleen geschildert (Amsterdam: Johannes and Gillis Janssonius van Waesberge, 1692), 13: "De Mastikot is veel in gebruik by de landschap-schilders [...] dog uit oorzaak van zijne grofheid, moejelijkheid van behandelen, en om datze met verloop van tijd swart werd, is't niet raadzaam, die veel te gebruiken, en men kan zig voorzigtiger aan Konings-geel houden." 
landscape with different yellows - massicot, yellow ochre, and schitgeel. ${ }^{121}$ Schietgheel or schitgeel, called Schüttgelb or Scheissgelb in German, and "pinke yellow" in English sources, was a yellow lake pigment extracted from plants including common or "purging" buckthorn (rhamnus cathartica). ${ }^{122}$ A note added by the translator to the English edition of Crispijn de Passe's A Garden of Flowers (Den Blom-Hof) of 1615 states that he had replaced "the couleure which the dutchmen call Schijt-geel [and which] signifieth a shitten yellow" with "sad yellow," in order not to offend "modeste eares." ${ }^{\prime 23}$ The Dutch name may allude to the colour's resemblance to excrement or, perhaps rather, the laxative effects of buckthorn. Nevertheless, Willem Goeree, in Verlichtery-kunde, oft recht gebruyck der Water-Verwen of 1670, noted that bruyne schijt-geel, when mixed with oil, resulted in a "glowing transparent colour."124

Of particular interest within the argument of Chapter Fourteen are Van Mander's "two kinds of orpiment," referring to yellow $\left(\mathrm{As}_{2} \mathrm{~S}_{3}\right)$ and red arsenic sulphide $\left(\mathrm{As}_{4} \mathrm{~S}_{4}\right)$, the latter also called realgar or red orpiment. ${ }^{125}$ Orpiment and realgar were alchemically produced and known to be extremely poisonous, although also used in small doses as remedies. In allusion to their associations with transmutational alchemy, they were also called "the two kings." ${ }^{\text {"26 }}$ Several authors commented on the lustrous golden colour of the bright yellow mineral substance, literally called "gold paint" or auripigmentum. According to Cennini, orpiment "has a more beautiful yellow colour, resembling gold, than any pigment there is. ${ }^{127}$ Aware of its toxicity, he reminded his readers to "watch that you do not spatter your mouth with it lest it does you harm." Lomazzo calls "burnt orpiment" the "colour of gold" and

121 Artechne Database: History of Technique in the Arts, 1500-1950, accessed on 23 July 2019, http://artechne. hum.uu.nl/node/94979 (Mayerne Manuscript Ms. Sloane 2052, fols. 13v-14r); John Gage, Colour and Culture: Practice and Meaning from Antiquity to Abstraction (London: Thames and Hudson, 1993), 167.

122 Harley, Artists' Pigments c. 16oo-1835, 97-101; Kirby, "Glossary," 453-454 (under “Lake, yellow”); Eastaugh, Pigment Compendium, 150 (under “Dutch pink”); Jones, Historisches Lexikon, 5:2508-2510.

123 Crispijn de Passe, A Garden of Flowers, Wherein Very Lively is Contained a True and Perfect Discription of Al the Flowers Contained in These Foure Following Bookes. As also the Perfect True Manner of Colouringe the Same (Utrecht: Salomon de Roy, for Crispijn de Passe, 1615), at the end of the treatise: "The translator to the Readers, or Practitioners."

124 Wilhelmus Goeree, Verlichtery-kunde, oft recht gebruyck der Water-Verwen, 2nd ed. (Middelburg: Wilhelmus Goeree, 1670), 12: "maer inde Oly-Verwen geeft de beste, een Gloeyent doorschijnigh Colorijt, na den Bruyn-geelen aerdende."

125 Elizabeth West Fitzhugh, "Orpiment and Realgar," in Roy et al., Artists' Pigments: A Handbook, 3:47-80; Harley, Artists' Pigments c. 16oo-1835, 87-88; Kirby, “Glossary," 456 (orpiment) and 457 (realgar); Jones, Historisches Lexikon, 2:300-301 (“Auripigment"); ibid., 4:1993-1994 (“Operment"); ibid., 4:2166-2168 ("Rauschgelb"); ibid., 4:2169 ("Realgar"); Eastaugh, Pigment Compendium, 291-292 ("Orpiment") and 324-325 ("Realgar").

126 Harley, Artists' Pigments c. 16oo-1835, 88.

127 Broecke, Cennino Cennini's Il libro dell'arte, 73-74: "ede di color piu vago giallo resimigliante/ all oro che color che sia." 
defines it as "the alchemy of the Venetian painters."128 Indeed, large quantities of orpiment including red orpiment (oropimento rosso) are documented in the shops of sixteenth-century Venetian colour sellers (vendecolori), as Krischel has noted. ${ }^{129}$ However, Netherlandish painters, too, made use of "gold paint." Orpiment was used in Peter Paul Rubens's Massacre of the Innocents of about 1610 (The Art Gallery of Ontario), ${ }^{130}$ while the Swiss-born English court physician Theodore Turquet de Mayerne (1573-1655) recorded that Anthony van Dyck described it as "the most beautiful yellow one can imagine." ${ }^{\prime 13}$ If one believes Van Mander's account, Goltzius himself (whose very name is associated with gold) had, as a child, been exposed to this toxic substance, enduring the mishap that Cennini had warned about: "His father mistakenly or unwittingly let him put orpiment in his mouth, which the father scraped out again as best as he could."132

It is in the context of the wide availability of "glowing" yellow pigments that Van Mander challenges the aspiring painter to use non-metallic gold paints to capture the sparkling appearances of objects made of gold. Although he is reluctant to entirely prohibit the use of "real" gold, he cites Ryff, who (following Alberti) criticizes the use of gold leaf within the pictorial space but enthusiastically recommends it for the frame, which should not only be decorated with gold and silver, but also with precious stones. ${ }^{133}$ Van Mander's mention of the five yellows opens a window into the growing market for pigments and paints in which Amsterdam, alongside Venice and Antwerp, began to play an increasingly important role. ${ }^{134}$ With the less frequent use of gold leaf, the production of bright yellows and oranges increased, as did the taste for them. ${ }^{135}$ Similarly, the boom in the manufacture of red vermilion both responded to and fuelled a widely shared interest in lijfverw.

128 Lomazzo, Trattato dell'arte, 191: “l'oropimento arso, il quale si dice color d'oro. E questo è l'alchimia de i pittori Venetiani."

129 Krischel, "Zur Geschichte des venezianischen Pigmenthandels," 112-114.

130 Eastaugh, Pigment Compendium, 291.

131 Mansfield Kirby Talley, Portrait Painting in England: Studies in the Technical Literature before 1700 (London: Paul Mellon Centre for Studies in British Art, 1981), 113-114.

132 Van Mander, Schilder-Boeck, fol. 282r: "geschiedet dat zijn Vader door ongeluck oft onbewist hem hiet steken in de mondt Orpriment/ oft Aurapigmentum, het welck den Vader ten besten hy mocht weder uyt crabbe."

133 Ibid., fol. 54r (Grondt, Chapter XIV, stanzas 20-21); Rivius, Architectur, fol. 71r-v.

134 For the well-developed pigment market in the northern Netherlands in the early seventeenth century: Jo Kirby, “The Painter's Trade in the Seventeenth Century: Theory and Practice," National Gallery Technical Bulletin 20 (1999): 5-49, at 31. For Antwerp: Filip Vermeylen, "The Colour of Money: Dealing in Pigments in Sixteenth-Century Antwerp," in Kirby, Nash, and Cannon, Trade in Artists' Materials, 356-365.

135 Hills, Venetian Colour, 147, 153. On the rarity of yellow pigments at the Burgundian court: Susie Nash, “'Pour couleurs et autres choses prise de lui ...': The Supply, Acquisition, Cost and Employment of Painters' Materials at the Burgundian Court, c. 1375-1419," in Kirby, Nash, and Cannon, Trade in Artists' Materials, $97-182$, at $15^{1-153}$. 
In the remaining part of Chapter Fourteen, Van Mander follows Le blason de couleurs, in discussing the meanings of the seven heraldic tinctures (gold, silver, red, blue, green, purple, and black) in the blazoning of coats of arms (stanza 24), connecting them with various series of sevens including the planets, days of the week, virtues, and the ages of man (stanzas $25^{-28}$ ); he concludes with comparisons of the four colours with the four humours, the four elements, and the four seasons. At the end of the chapter, the author "washes his soiled hands" in order to bid farewell to his readers. ${ }^{136}$ The humorous gesture points to the hands-on knowledge of pigments and paints required from a practising artist eager to create paintings that engage and enchant their viewers.

According to Van Mander, it was Goltzius who, by continually transforming his own work, brought Netherlandish art to a new perfection. In Chapter Seven on reflections and reverberations in Den Grondt, Van Mander states that Goltzius, accustomed by nature to drawing and engraving, revealed himself as "the only phoenix with golden feathers" after having finally taken to painting. ${ }^{137}$ In the marginal note, Van Mander refers to Pliny's account of the phoenix at the beginning of Book Ten on the "Nature of Birds" in the Natural History, which he cites in considerable detail in the Wtbeeldinghe der Figueren. ${ }^{138}$ Pliny emphasizes the rareness and uniqueness of the phoenix from Arabia, "famous before all others [...] the only one in the whole world and hardly ever seen"; the fabulous bird is "large as an eagle" and has "a gleam of gold round its neck and all the rest of it is purple, but the tail blue picked out with rose-coloured feathers." ${ }^{139}$ The resurrected phoenix with its golden and purple-coloured plumage occasionally served as a symbol for the philosopher's stone, itself associated with either a saffron-like or a reddish colour. ${ }^{140}$ Radiant in the manner of gold or the sun, the phoenix was also an apt simile for Goltzius, whose turn to painting in around 1600 inaugurated a new golden age in the history of Netherlandish art.

136 Van Mander, Schilder-Boeck, fol. 55r (stanza 30): “Van de welck' ich nu/ mijn bekrosen handen| Ghewasschen hebbende/ wil hier uyt scheyden."

137 Ibid., fol. 33r (Grondt, Chapter VII: Van de Reflecty, stanza 47): "D’ander heeft Natuer gants willen aenwennen| Linearis en Clypeus practijcken// Eyndlijck oock Picturams, end'hem doen kennen| Voor eenighen Phoenix met goltsche pennen/| En wat metael sal t'eenich golt niet wijcken/| Oft wat licht d'eenighe Sonne ghelijcken/| Dien hy eenich is toeghewijdt bequame// En draeght van den Victory-boom den name."

138 Van Mander, Schilder-Boeck, fol. 120r-v (Wtbeeldinghe der Figueren).

139 Pliny, Natural History, vol. 3: Books 8-11, trans. H. Rackham (Cambridge, MA: Harvard University Press, 1940), 292-295 (Book X, 3).

140 For Michael Maier's poem on the "resurrected phoenix" (Cantilenae intellectuals [...] de Phoenice redivivo, 1622): Didier Kahn, "Alchemical Poetry in Medieval and Early Modern Europe: A Preliminary Survey and Synthesis. Part I-Preliminary Survey," Ambix 57 (2010): 249-274, here 273-274. 


\section{A Phoenix with Golden Feathers: Goltzius's Fiery Art}

Goltzius's "pen work" in the Philadelphia Museum of Art perhaps best represents the artist's unique ability to combine graphic and painterly techniques in ways that captivate the viewers' imagination (Fig. 5.7). ${ }^{141}$ Produced at some point between 1599 and 1602, it is in all probability identical with the one described by Van Mander as "drawn with the pen on a fairly large prepared canvas" and representing "a nude female figure with a laughing satyr nearby."142 On a canvas prepared with a bluish-grey ground, Goltzius recreated, with a pen, the curved lines and crosshatching that had become the very trademark of his art as an engraver. In imitation of his engraving technique, Goltzius even dotted the lozenges formed by the crossing lines to enhance the effects of light and shade. He then continued with the brush, putting "a little colour here and there on the flesh parts" before varnishing the work. ${ }^{143}$ Lawrence W. Nichols has rightly emphasized the bold application of oil paint culminating in the yellow-orange-red flame of Cupid's torch. ${ }^{144}$ Painted with lead-tin yellow, vermilion, red lake, and lead-white, the love god's torch radiates a golden glow over the bodies of the mythological figures, causing them to come alive in the minds of the viewers. The same heavenly fire of love was used by Prometheus to animate the statue of Pandora, as indicated by Van Mander in the first stanzas of Chapter Twelve, cited above. Van Mander mentions that when the Holy Roman Emperor Rudolf II came into possession of that work, he "wondered about how it was done" and sought in vain the advice of art experts. This parallels his discussion of the response Van Eyck's oil paintings provoked among other artists and collectors: they did not know how "such a new manner of painting" was achieved. ${ }^{145}$

Van Mander and his contemporaries frequently explored alchemical metaphors to articulate the affective and transformative power of colour. ${ }^{146}$ In The Dialogue between Art-Loving Heart and Ardour to Art on the Death of the Artful Hendrick Goltzius (T'samen-spraec tusschen Konst-lievigh Hert end' Yverigh tot Konst) of 1617, the deceased

141 My discussion is largely based on the excellent analysis in Lawrence W. Nichols, "The 'Pen Works' of Hendrick Goltzius," Philadelphia Museum of Art Bulletin 88, nos. 373-374 (Winter 1992): 1-57.

142 Van Mander, Schilder-Boeck, fol. 285r.

143 Ibid.

144 Nichols, “The 'Pen Works' of Hendrick Goltzius," 20-22 and 49, note 80.

145 Van Mander, Schilder-Boeck, fol. 202r (Van Eyck); fol. 285r (Goltzius).

146 Weststeijn, The Visible World, 220-222; Thijs Weststeijn, “Painting's Enchanting Poison': Artistic Efficacy and the Transfer of Spirits," in Sprits Unseen: The Representation of Subtle Bodies in Early Modern European Culture, ed. Christine Göttler and Wolfgang Neuber, Intersections 29 (Leiden and Boston, MA: Brill, 2007), 141-178; Christine Göttler, "Vulcan's Forge: The Sphere of Art in Early Modern Antwerp," in Knowledge and Discernment in the Early Modern Arts, ed. Sven Dupré and Christine Göttler (London and New York: Routledge, 2017), 52-87. See also David Brafman, "The Putrid and the Pure: Colour-Theory of a Baroque Neapolitan Alchemist," in Bushart and Steinle, Colour Histories, 243-26o; James Elkins, What Painting Is: How to Think about Oil Painting, Using the Language of Alchemy (New York and London: Routledge, 1999). 


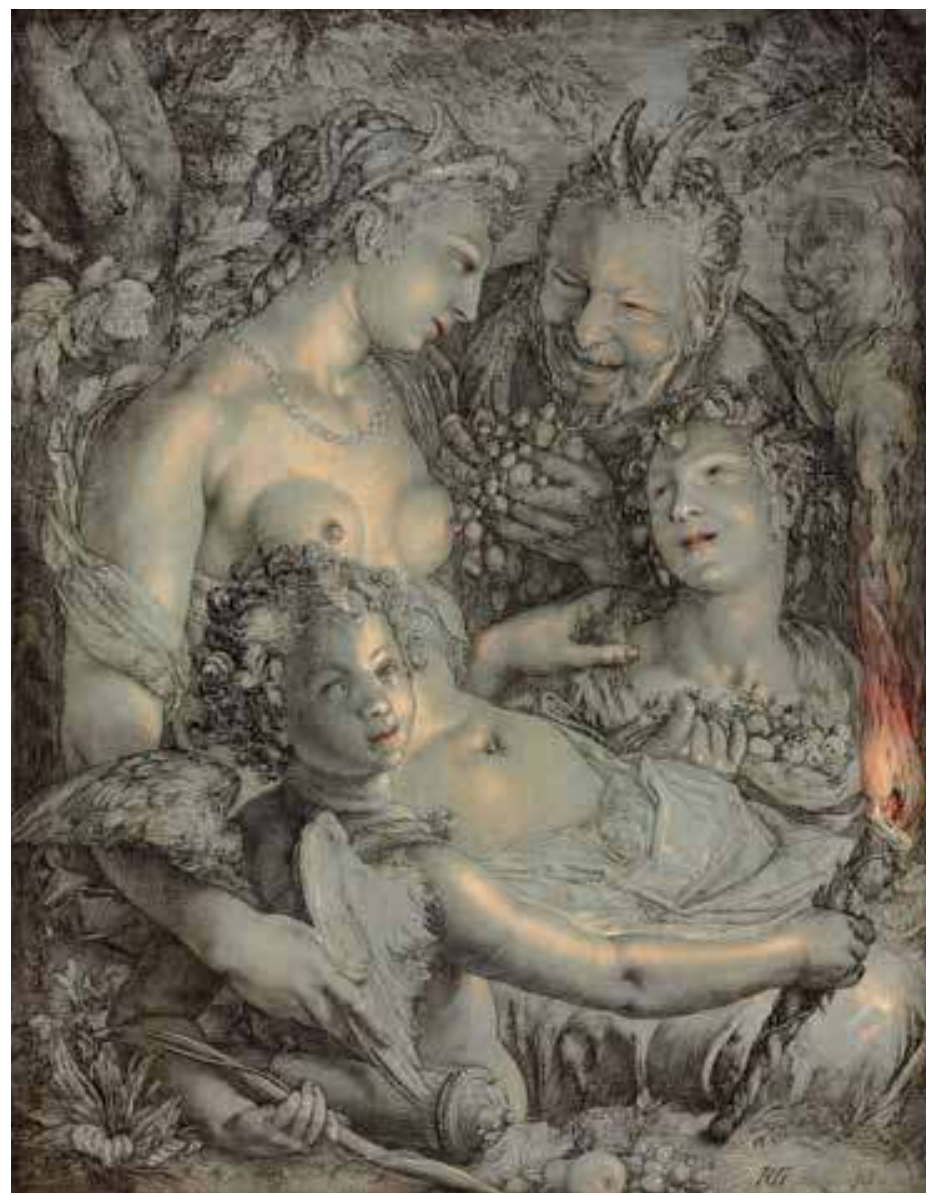

Figure 5.7: Hendrick Goltzius, Without Ceres and Bacchus, Venus Would Freeze (Sine Cerere et Libero friget Venus), 1599-1602. Pen and brown ink, brush and oil, on blue-grey prepared canvas, $105.1 \times 80.0 \mathrm{~cm}$. Philadelphia, Philadelphia Museum of Art, inv. no. 1990-100-1. Image @ Philadelphia Museum of Art. Purchased: The Mr. and Mrs. Walter H. Annenberg Fund for Major Acquisitions, the Henry P. Mcllhenny Fund in memory of Frances P. Mcllhenny, and other Museum funds.

artist is introduced as "a searcher for the philosopher's stone," seen as such "by many alchemists, talented in three languages," that is to say drawing, engraving, and painting. ${ }^{147}$ The Dialogue suggests that Goltzius's art outshone the finest and purest gold, and that his name would make Ophir's gold (considered to be particularly pure) look bad. ${ }^{148}$ As indicated above, the imagery of gold played a significant role in the

147 Cited from Nichols, The Paintings of Hendrick Goltzius, 315: "een ondersoecker der Philosophalen Steen| Wiert hy bevonden oock boven veel Alchimisten.| Met Spraken dry begaeft.”

148 Cited from ibid., 316: "Soo dat den Name GOLTZ hy waerlijck droegh ten rechten/|Ja mach hy Ophiers Goldt gheleken zijn ten slechten/| Doch socht Eer Boven Golt, met scheerp zin-rijck verstant." 


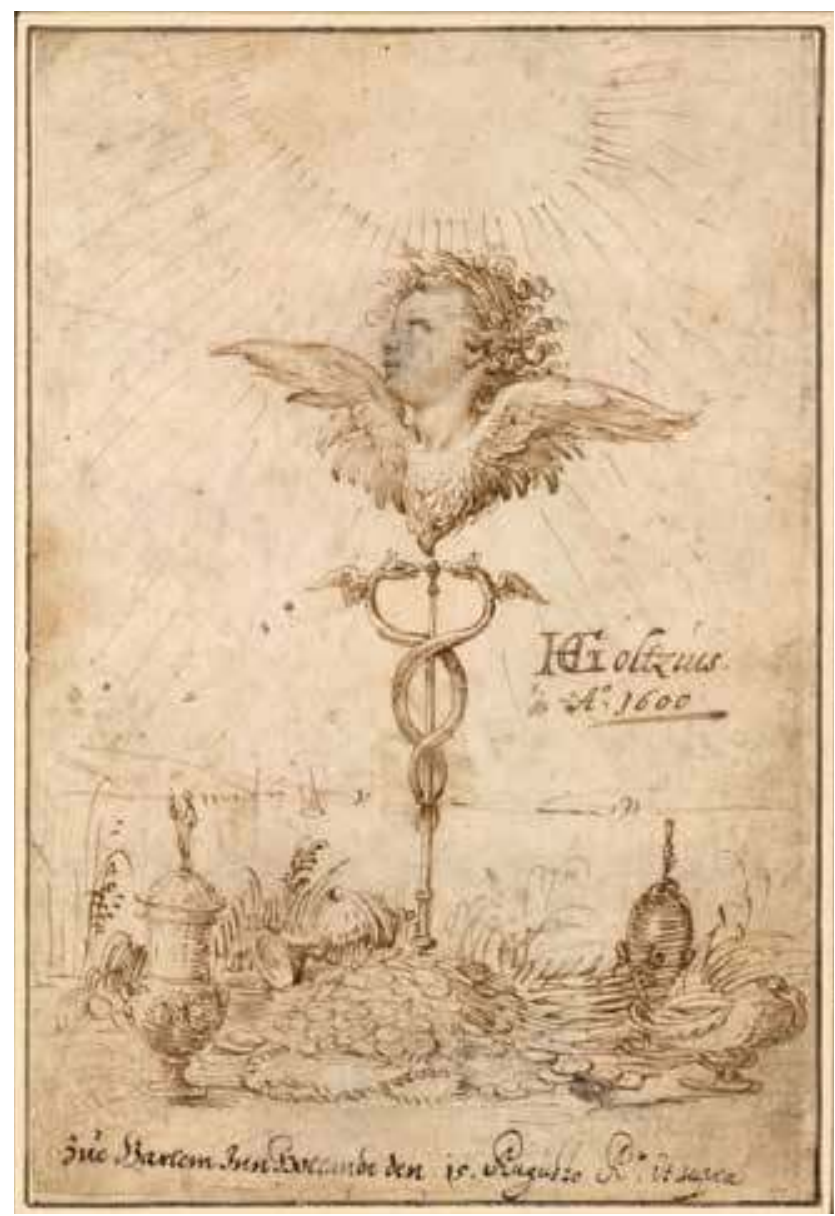

Figure 5.8: Hendrick Goltzius, "Eer boven Gold" (Honour above gold), 1600. Pen in brown ink, $18.4 \times 12.4 \mathrm{~cm}$. Vienna, The Albertina Museum, inv. no. 8076. Image $\odot$ The Albertina Museum.

fashioning and self-fashioning of Goltzius as a painter. In De Kerck der Deught of 16oo, Van Mander, alluding to Goltzius's fragile health, writes that the "golden spirit" ("gulden gheest") of his "golden friend" ("gulden vriendt") does not have an "iron body" ("ijserich lichaem"), thus playing upon the differences between the softness and malleability of gold and the strength and hardness of iron. ${ }^{149}$ Goltzius's own motto and emblem Eer boven golt ("Honour above gold"), first documented in 1600 , appears to have been motivated by his shift to the medium of oil painting. ${ }^{15^{0}}$ In these drawings, mostly produced for alba amicorum, the wand of Mercury with its two intertwined (and

149 Cited from ibid., 276.

150 Nichols, The Paintings of Hendrick Goltzius, 43-44; Larry Silver, "Goltzius, Honor, and Gold," in Habitus: Norm und Transgression in Bild und Text, ed. Tobias Frese and Annette Hoffmann (Berlin: Akademie Verlag, 2011), 315-330. 

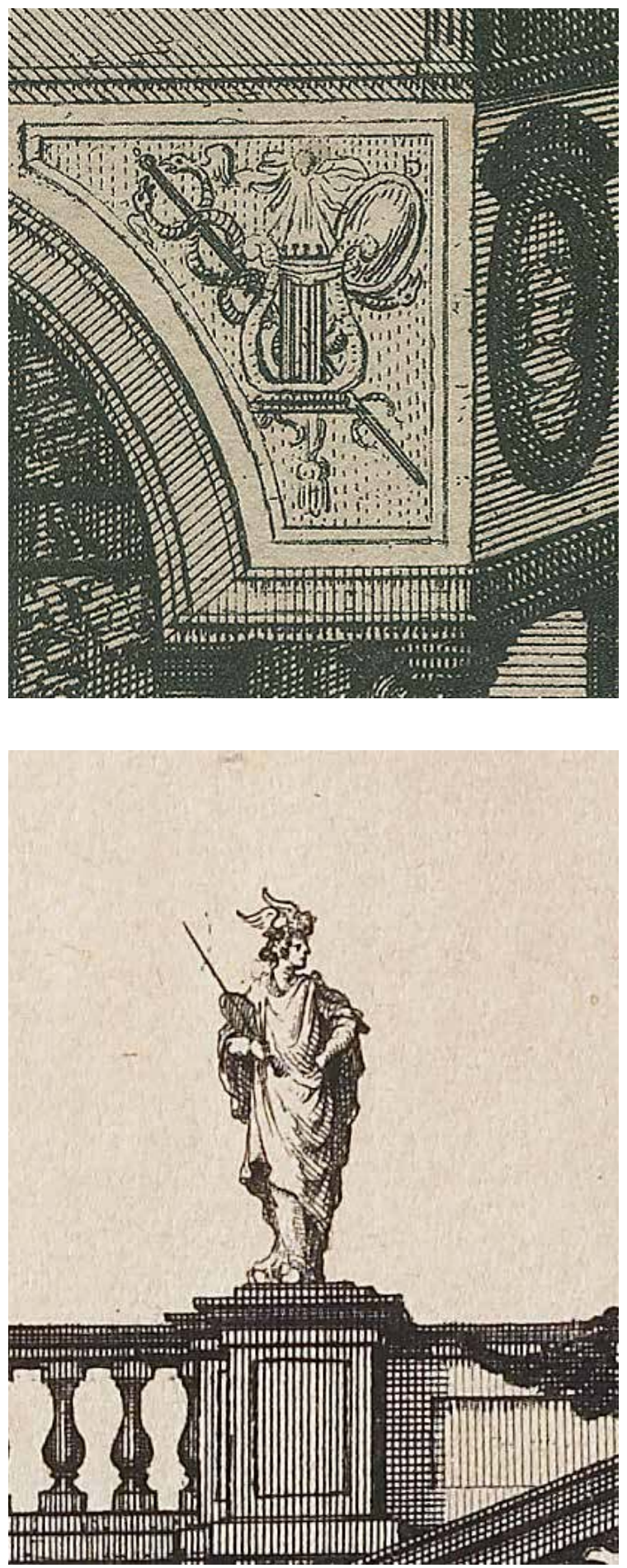

Figure 5.9: The emblems of the painterly arts, painted or carved by Peter Paul Rubens on a spandrel of his garden loggia. Detail from: Jacobus Harrewijn after Jacques van Croes, View of the Garden of the Rubenshuis, 1692. Engraving. Antwerp, Museum Plantin-Moretus, inv. no. PK.OP.17875. Image ๑ Collectie Stad Antwerpen, Museum Plantin-Moretus.
Figure 5.10: Mercury with maulstick on top of the garden screen. Detail from Jacobus Harrewijn after Jacques van Croes, View of the Courtyard of the Rubenshuis. Engraving. Antwerp, Museum Plantin-Moretus, inv. no. PK.OP.17876. Image @ Collectie Stad Antwerpen, Museum Plantin-Moretus. 


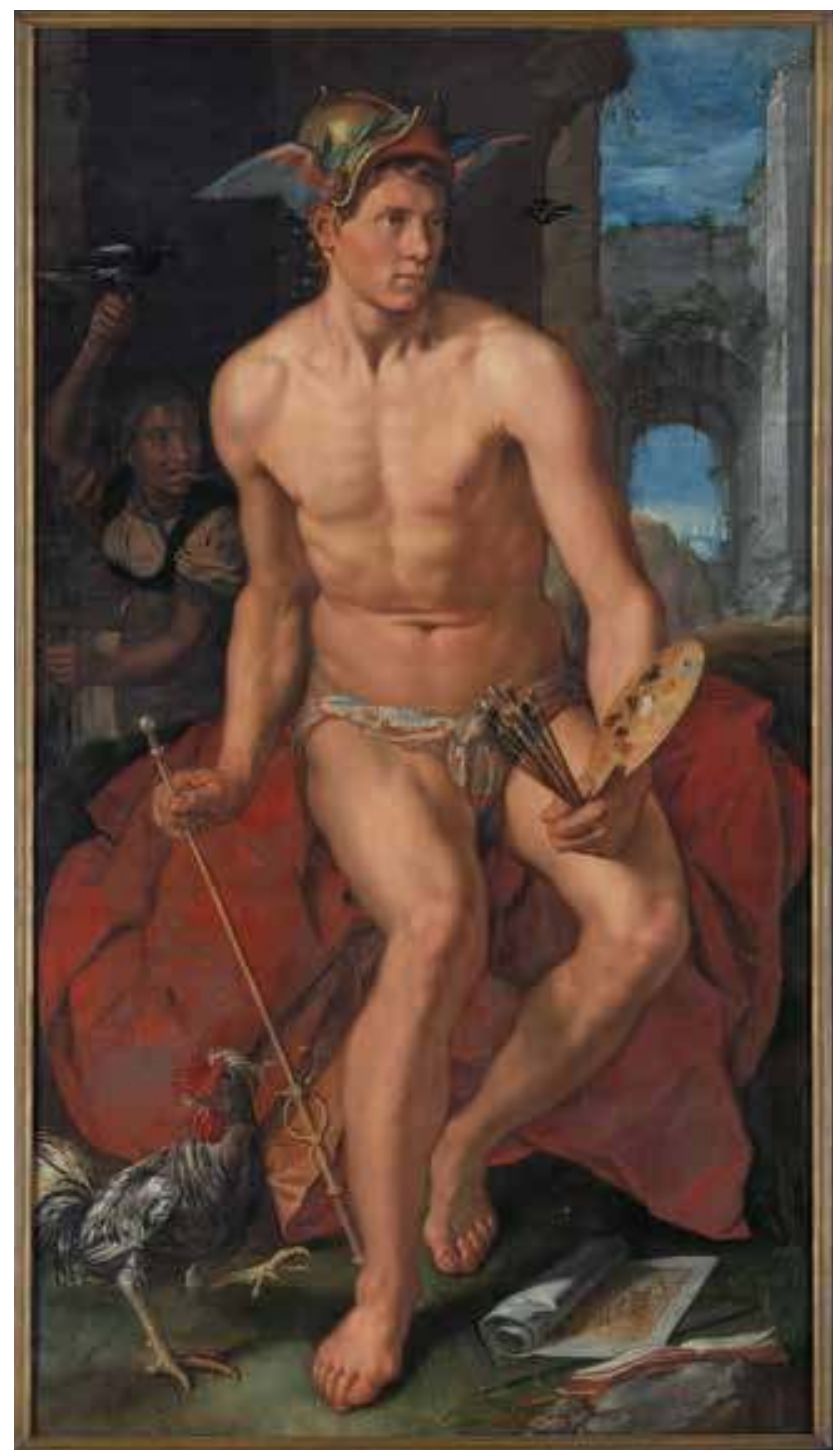

Figure 5.11: Hendrick Goltzius, Mercury, 1611. Oil on canvas, $214 \times 120 \mathrm{~cm}$. Haarlem, Frans Hals Museum, on long-term loan from the Royal Cabinet of Paintings, Mauritshuis, The Hague, inv. no. 44. Image $\odot$ Frans Hals Museum, photo: René Gerritsen.

occasionally winged) serpents serves as a "magic" tool mediating between material and symbolic riches and converting gold, represented by a heap of coins, a chain, and several "golden" vessels, into honour and distinction, represented by the head of a winged cherub or cupid, called by Van Mander lof-geest (spirit of praise) (Fig. 5.8). ${ }^{15^{1}}$

The art historical literature has so far overlooked the fact that in 1600 both Van Mander and Goltzius were designing emblematic images that prominently featured

151 Van Mander, Schilder-Boeck, fol. 286r. 


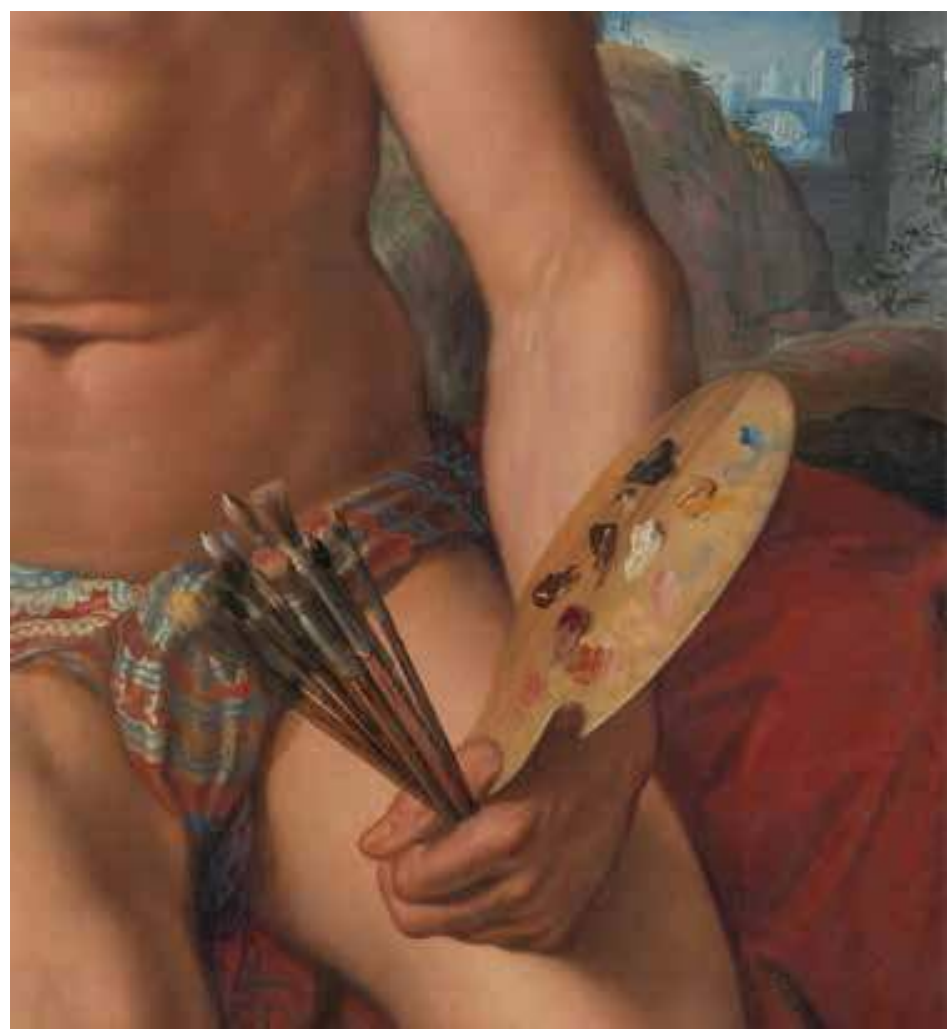

Figure 5.12: Hendrick Goltzius, Mercury, detail of Fig. 5.11: Full of wit and sexual innuendo, the detail playfully alludes to the potency of Goltzius's brushwork.

a caduceus (see Fig. 5.1 and Fig. 5.8). Indeed, for Goltzius and his contemporaries, Mercury's staff primarily symbolized the power and eloquence of painting. The emblems of the painterly arts, drawn, carved, and painted by Peter Paul Rubens on the loggia of his Antwerp house - most probably between 1618 and 1621 - also included a caduceus (Fig. 5.9), while the actual statue of Mercury that appeared on top of the garden screen was equipped with maulstick, palette, and brushes instead of the staff(Fig. 5.10).152 Goltzius himself included the figure of Mercury in his Danaë of 1603, praised by Van Mander for the flesh tones and the "glowing face" of the old woman. ${ }^{153}$ The painting sexualizes the imagery of Goltzius's motto and also brings out the alchemical affinities between vermilion and gold. In Goltzius's life-size painting of Mercury of 1611, the protector of all artists appears as an unabashed male nude holding in his left hand a palette and

152 Jeffrey M. Muller, "Rubens's Emblem of the Art of Painting," Journal of the Warburg and Courtauld Institutes 44 (1981): 221-222.

153 Van Mander, Schilder-Boeck, fol. 286r. Nichols, The Paintings of Hendrick Goltzius, 136-140, cat. A-33. 


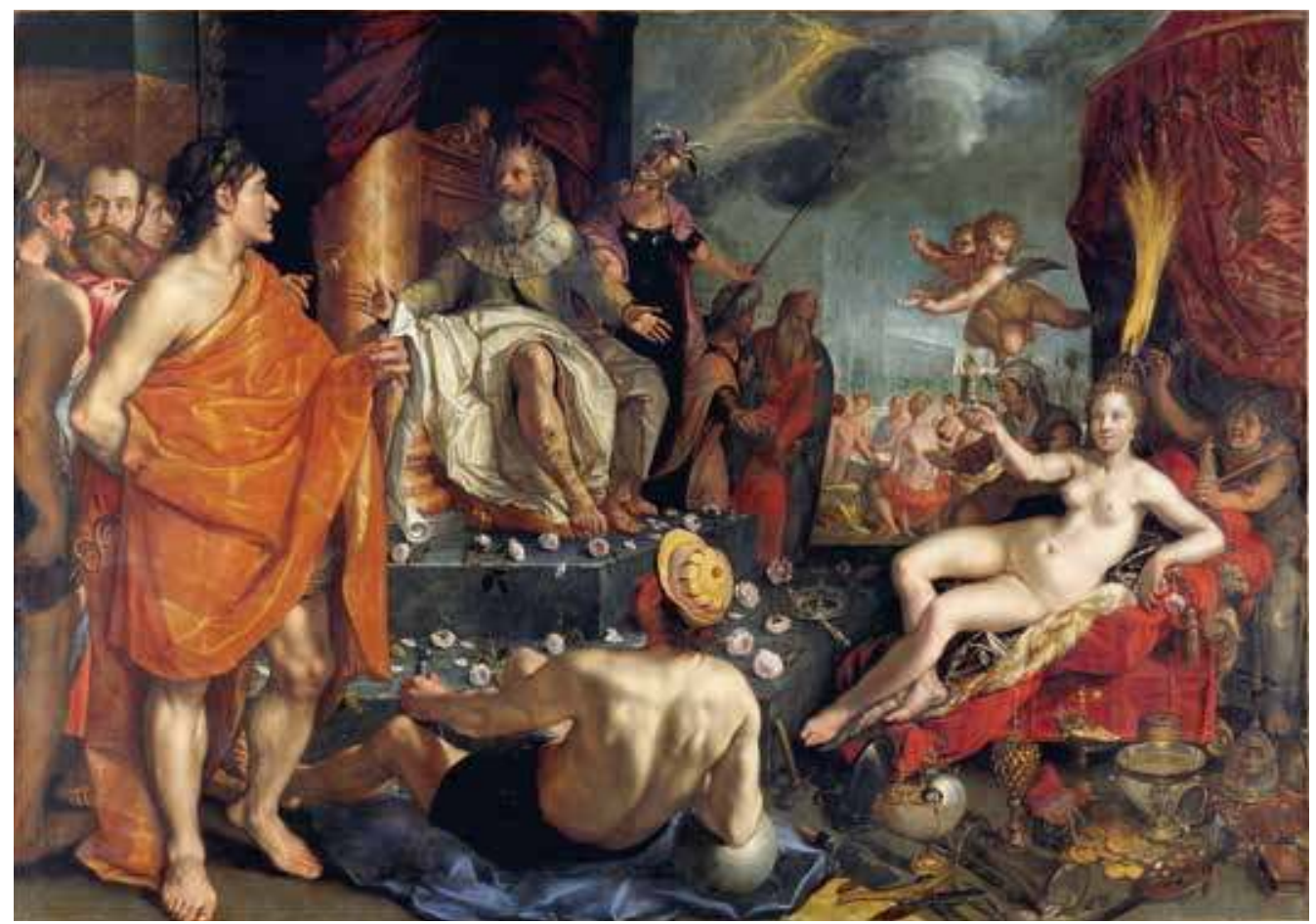

Figure 5.13: Hendrick Goltzius, Allegory of the Arts, 1611 . Oil on canvas, $181.0 \times 256.8 \mathrm{~cm}$. Basel, Kunstmuseum Basel, Birmann-Sammlung 1859, inv. no. 252. Image @ Kunstmuseum Basel.

several brushes, and in his right hand a winged caduceus that might have also been used as a maulstick to steady his hand (Fig. 5.11). ${ }^{154}$ The multi-coloured wings of his laurel-crowned helmet evoke the beautifully feathered birds mentioned by Van Mander as examples of Nature's rich gifts, while the god's small loincloth accentuates rather than covers his private parts. Shown right in front of these are the tips of the brushes, already loaded with some of the pigments prepared on the palette. The palette holds the paints obviously used to create the luminous flesh tones of the Mercury figure that had certainly arrested the eyes of period viewers (Fig. 5.12). ${ }^{155}$

Finally, Goltzius's largest and perhaps most enigmatic painting, the Allegory of the Arts of 1612 in the Kunstmuseum Basel, which also includes a self-portrait among the onlookers on the left, directly references the processes of alchemical and painterly transformation (Fig. 5.13). ${ }^{156}$ The subject of the painting has recently been identified

154 Nichols, The Paintings of Hendrick Goltzius, 149-152, cat. A-39.

155 For the palette as the site of the painter's creation and self-articulation: Philipp Sohm, "Palettes as Signatures and Encoded Identities in Early-Modern Self Portraits," Art History 40 (2017): 994-1025. 156 Göttler, "Tales of Transformation: Hendrick Goltzius's Allegory of the (Alchemical) Arts in the Kunstmuseum Basel." 


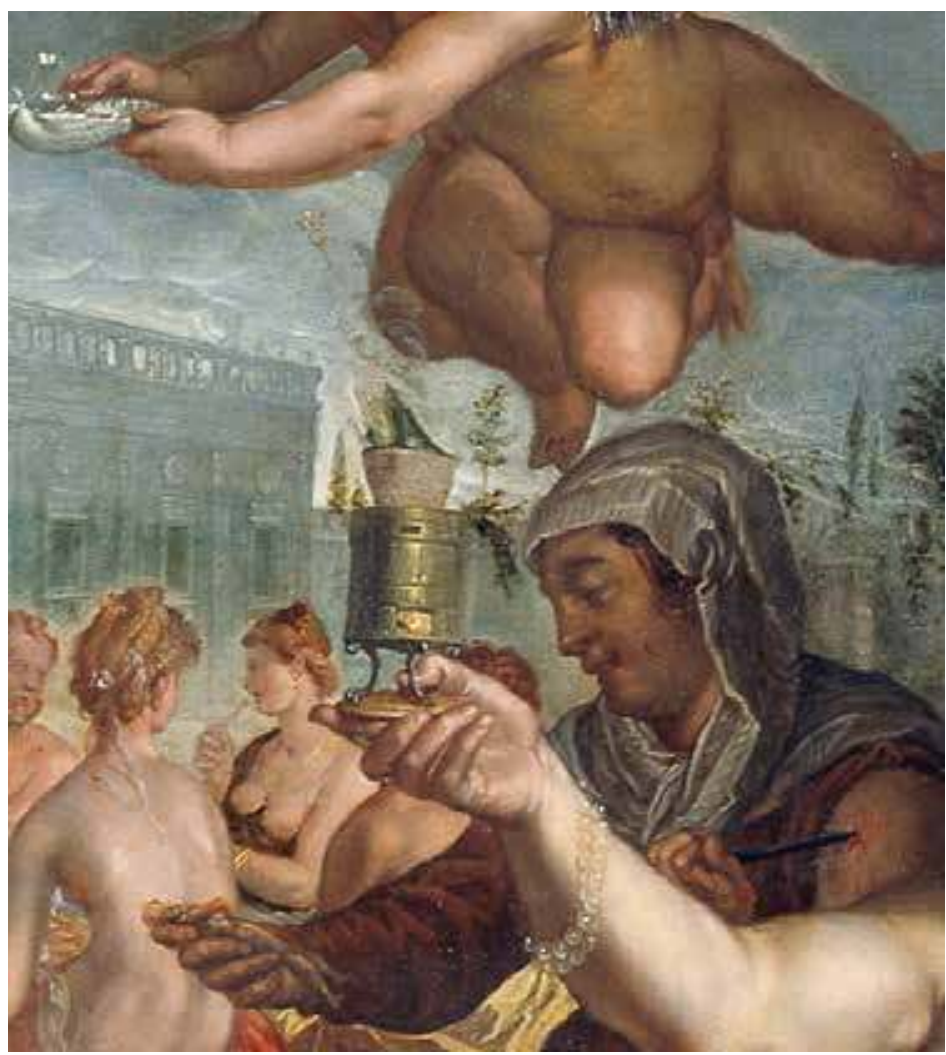

Figure 5.14: Hendrick Goltzius, Allegory of the Arts, detail of Fig. 5.13: Golden caduceus escaping from the furnace held by the Venus-like figure.

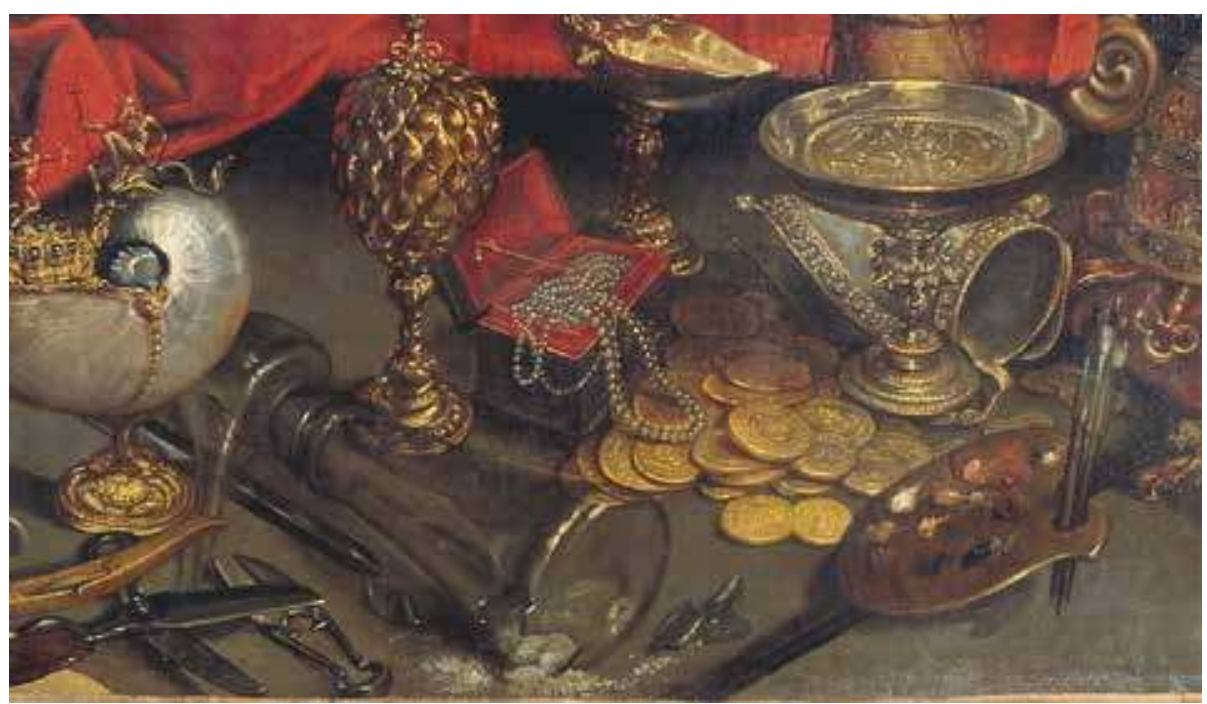

Figure 5.15: Hendrick Goltzius, Allegory of the Arts, detail of Fig. 5.13: An alchemist's alembic and the painter's palette. 
as Mercury presenting Pandora to Prometheus's brother Epimetheus. Mercury is represented as a laurel-crowned man in a bright red chlamys holding a caduceus. Pandora, as mentioned above, is likened by Van Mander to painting's abundance and allure. Allure certainly characterizes the enthroned female nude with her Venus-like features and regal headdress, possibly made of two birds of paradise with their sparkling gold-coloured tail feathers. With her right hand she is holding up a small alchemical furnace from which, in a cloud of smoke, a tiny golden winged caduceus escapes, which may be understood as a witty reference to Goltzius's metamorphic self (Fig. 5.14). In the lower right corner - close to the viewer's space - a broken alembic and a palette prepared for use are shown next to each other (Fig. 5.15). The palette holds the same pigments that may have been used to build up the layers of this painting (lead-white, lead-tin yellow, red lake, scarlet vermilion, ochres, and blue and black pigments), and which is dominated mostly by red, yellow, and orange tones. The curious juxtaposition would have challenged period viewers to reflect on the ambiguous relationship between "living" and "dead" materials, the alchemy of painting, and the alchemy of gold. The subject might have been stimulated by Van Mander's own thoughts about the mercurial power of colour that this chapter has attempted to explore; intended to provoke an immediate and affective response, colour linked material and immaterial realms as well as the worlds of knowledge and deceit.

\section{Conclusion}

As I have shown in this chapter, Haarlem's renewal through the arts was a shared project undertaken by a group of people (most of them Flemish immigrants) who moved seamlessly between the worlds of poetry, painting, and theatre, and brought with them a wide range of knowledge and skills as well as sensibilities with regard to visual, textual, verbal, and material cultures. In the Schilder-Boeck, Van Mander presented the re-emergence of oil painting in Haarlem at the turn of the century as a second turning point in the history of Netherlandish art that further developed Van Eyck's "invention" through the assimilation of specific Italian experiences - such as the tactile softness of Correggio's and Titian's flesh colours - into a long "local" or, rather, Netherlandish tradition and culture of painting that was distinguished by its vivid colours and its mastery in the rendering of glowing surfaces and reflective lights: the "art of painting reflections."

The innovative thrust of Van Mander's art historical and literary project corresponded to a new code or style in the pictorial arts that allowed for the coding and encoding not only of the iconographic but also of material qualities and processes. In contrast to Vasari, who regarded oil painting as a technique that required laborious preparations but then worked almost of its own accord, requiring 
little intervention from the artist, ${ }^{157}$ Van Mander presented the works by Van Eyck, Goltzius, and other Netherlandish artists as the fruit of intensive material and epistemic research into the properties and effects of colours and paints. He thus staged the Netherlands as the site of a new culture or a new "alchemy" of colour that would finally supersede and replace what had been, until then, the authoritative colour world of Venice. Referred to by him as "handeling," Van Mander understood painting practices as "painterly acts" or approaches to painting involving hands and minds, emerging from a deep knowledge of artistic media and tools and their effects on the viewer. ${ }^{158}$ Perhaps most importantly, as a result of the endeavours of Van Mander and his friends, a new vocabulary was established to talk about the values, achievements, and unique qualities of Netherlandish paintings, including their visual and tactile allure with references to the material and immaterial realms. Formed from a variety of foreign and local sources, and old and new kinds of knowledge, this new language of art moved across borders and established Netherlandish painting, again to use Van Mander's words, as "a noble, exceptionally illustrious and virtuous practice that does not need to yield to any natural or liberal art." 159

\section{Bibliography}

\section{Published Primary Sources}

Alberti, Leon Battista. On Painting and On Sculpture: The Latin Text of De Pictura and De Statua, edited by Cecil Grayson. London: Phaidon, 1972.

Aristotle. "Sense and Sensibilia." In The Complete Works of Aristotle, edited by Jonathan Barnes, 2 vols., vol. 1, 693-713. Princeton, NJ: Princeton University Press, 1984.

157 Giorgio Vasari, Le vite de' più eccellenti pittori, scultori e architettori nelle redazioni del 1550 e 1568 , ed. Rosanna Bettarini and Paola Barocchi, 8 vols. (Florence: Sansoni, 1966-1987), 1:132-133 (“Cap. XXI. Del dipingere a olio in tavola e su tele"): "Questa maniera di colorire accende più i colori né altro bisogna che diligenza et amore, perché l'olio in sé si reca il colorito più morbido, più dolce e dilicato e di unione e sfumata maniera più facile che li altri, e mentre che fresco si lavora, i colori si mescolano e si uniscono l'uno con l'altro più facilmente." English translation cited from Vasarion Technique, trans. Louisa S. Maclehose, ed. G. Baldwin Brown (New York: Dover Publications, 1960), 230.

158 For the notion of "handeling": Yannis Hadjinicolaou, Denkende Körper-Formende Hände: Handeling in Kunst und Kunsttheorie der Rembrandtisten (Berlin and Boston, MA: De Gruyter, 2016); Horst Bredekamp, Image Acts: A Systematic Approach to Visual Agency (Berlin: De Gruyter, 2018); for "material acts," see Ulinka Rublack's chapter in this volume.

159 Van Mander, Schilder-Boeck, fol. *4v (Voor-reden): “te bekennen/ onse Schilder-const te zijn een edel uytnemende heerlicke deughtsaem oeffeninghe/ die voor geen ander Natuerlijcke/ oft vry Consten te wijcken heeft." 
Beurs, Wilhelmus. De groote waereld in't kleen geschildert. Amsterdam:Johannes and Gillis Janssonius van Waesberge, 1692.

Broecke, Lara. Cennino Cennini's Il libro dell'arte: A New English Translation and Commentary with Italian Transcription. London: Archetype Publications, 2015.

Den Nederduytschen Helicon. Alkmaar: Jacob de Meester, voor Passchier van Westbusch, 1610.

De Passe, Crispijn. A Garden of Flowers, Wherein Very Lively is Contained a True and Perfect Discription of Al the Flowers Contained in These Foure Following Bookes. As also the Perfect True Manner of Colouringe the Same. Utrecht: Salomon de Roy, for Crispijn de Passe, 1615.

Dolce, Lodovico. “Dialogo della pittura intitolato l'Aretino." In Trattati d'arte del Cinquecento fra Manierismo e Controriforma, edited by Paola Barocchi, vol. 1, 141-206. Bari: Laterza, 1960.

Goeree, Wilhelmus. Verlichtery-kunde, oft recht gebruyck der Water-Verwen, and ed. Middelburg: Wilhelmus Goeree, 1670.

$\mathrm{H}$ [aydock], R[ichard]. A Tracte Containing the Artes of Curious Paintinge, Carvinge and Building. Oxford: Joseph Barnes for R[ichard] H[aydock], 1598.

Homer. Les XXIIII Livres de l'Iliade d'Homere, translated by Hugues Salel. Rouen: Jacques Begne, 1605 .

Homer. De eerste 12 boecken vande Ilyadas, translated by Karel van Mander. Haarlem, 1611. Lomazzo, Gio. Paolo. Trattato dell'arte de la pittura. Milan: Paolo Gottardo Pontio, 1584.

Lomazzo, Giovan Paolo. Idea of the Temple of Painting, edited and translated by Jean Julia Chai. University Park, PA: Pennsylvania State University Press, 2013.

Pliny. Natural History, vol. 3: Books 8-11, translated by H. Rackham. Cambridge, MA: Harvard University Press, 1940.

Pliny. Natural History, vol. 9: Books 33-35, translated by H. Rackham. Cambridge, MA: Harvard University Press, $195^{2}$.

Ryff, Walther Hermann (Gualtherus H. Rivius). Der Architectur furnembsten/notwendigsten/ angehörigen Mathematischen und Mechanischen künst/ eygentlicher bericht. Nuremberg: Gabriel Heyn, 1558 .

Sicille. Le blason des couleurs en armes, livrees et devises. Paris: P. Menier, 1582.

Van Mander, Karel. Het Schilder-Boeck waer in Voor eerst de leerlustighe Iueght den grondt der Edel Vry Schilderconst in Verscheyden deelen Wort Voorghedraghen: Daer nae in dry deelen t'leven der vermaerde doorluchtighe Schilders des ouden, en nieuwen tyds; Eyntlyck d'wtlegghinghe op den Metamorphoseon pub. Ovidii Nasonis; Oock daerbeneffens wtbeeldinghe der figueren. Alles dienstich en nut den schilders, Constbeminders en dichters, oock allen staten van menschen. Haarlem: Paschier van Wesbusch, 1604.

Van Mander, Karel. Wtlegghingh Op den Metamorphosis Pub. Ovidii Nasonis [...] Seer dienstich den Schilders, Dichters, en Constbeminders, oockyeghelyck tot leering by een gebracht en gheraemt. Haarlem: Paschier van Westbusch, 1604.

Van Mander, Karel. Het Schilder-Boeck waerin Voor eerst de Leerlustige Iueght den gront der Edele Vrye Schilderkonst in verscheyden deelen wort voorgedragen. Amsterdam: Jacob Pietersz. Wachter, 1618. 
Van Mander, Karel. Den grondt der edel vry schilder-const, edited by Hessel Miedema, 2 vols. Utrecht: Haentjens Dekker \& Gumbrecht, 1973.

Van Mander, Karel. The Lives of the Illustrious Netherlandish and German Painters from the First Edition of the Schilder-boeck (1603-1604): Preceded by the Lineage, Circumstances and Place of Birth, Life and Works of Karel van Mander, Painter and Poet and likewise his Death and Burial, from the Second Edition of the Schilder-boeck (1616-1618), with an Introduction and Translation, edited by Hessel Miedema, 6 vols. Doornspijk: Davaco, 1994-1999.

Vasari, Giorgio. Le vite de' più eccellenti pittori, scultori e architettori nelle redazioni del 1550 e 1568, edited by Rosanna Bettarini and Paola Barocchi, 8 vols. Florence: Sansoni, 1966-1987.

Vasari on Technique, translated by Louisa S. Maclehose, edited by G. Baldwin Brown. New York: Dover Publications, 1960.

\section{Secondary Literature}

Artechne Database: History of Technique in the Arts, 1500-1950. Accessed on 23 July 2019. http://artechne.hum.uu.nl/node/94979.

Baker, Tawrin, Sven Dupré, Sachiko Kusukawa, and Karin Leonhard, eds. Early Modern Color Worlds. Leiden and Boston, MA: Brill, 2015.

Biesboer, Pieter. Collections of Paintings in Haarlem, 1572-1745. Documents for the History of Collecting: Netherlandish Inventories 1. Los Angeles, CA: The Provenance Index of the Getty Research Institute, 2002.

Bohde, Daniela. "Le tinte delle carni': Zur Begrifflichkeit für Haut und Fleisch in italienischen Kunstraktaten des 15. bis 17. Jahrhunderts." In Weder Haut noch Fleisch: Das Inkarnat in der Kunstgeschichte, edited by Daniela Bohde and Mechthild Fend, 41-63. Berlin: Gebr. Mann, 2007.

Bomford, David, Jo Kirby, Ashok Roy, Axel Rüger, and Raymond White, eds. Art in the Making: Rembrandt. Exh. cat. National Gallery, London. London: National Gallery, 2006.

Bradley, Mark. Colour and Meaning in Ancient Rome. Cambridge: Cambridge University Press, 2009.

Brafman, David. "The Putrid and the Pure: Colour-Theory of a Baroque Neapolitan Alchemist." In Colour Histories: Science, Art, and Technology in the 17th and 18th Centuries, edited by Magdalena Bushart and Friedrich Steinle, 243-26o. Berlin and Boston, MA: De Gruyter, 2015 .

Bredekamp, Horst. Image Acts: A Systematic Approach to Visual Agency. Berlin: De Gruyter, 2018.

Bucklow, Spike. Red: The Art and Science of a Colour. London: Reaktion Books, 2016.

Bushart, Magdalena, and Friedrich Steinle, eds. Colour Histories: Science, Art, and Technology in the 17th and 18th Centuries. Berlin and Boston, MA: De Gruyter, 2015.

De Vries, Annette. "Hondius Meets Van Mander: The Cultural Appropriation of the First Netherlandish Book on the Visual Arts System of Knowledge in a Series of Artists' 
Portraits." In The Artist as Reader: On Education and Non-Education of Early Modern Artists, edited by Heiko Damm, Michael Thimann, and Claus Zittel, 259-304. Intersections 27. Leiden and Boston, MA: Brill, 2013.

Duits, H. "Het leven van Karel van Mander: Kunstenaarsleven of schrijversbiografie?" De zeventiende eeuw 9 (1993). Accessed on 30 November 2020. https://www.dbnl.org/ tekst/_zevoo1199301_01/_zevoo1199301_01_0012.php.

Dupré, Sven. "The Historiography of Perspective and reflexy-const in Netherlandish Art." In Art and Science in the Early Modern Netherlands, edited by Eric Jorink and Bart Ramakers, 34-61. Netherlands Yearbook for History of Art 61. Zwolle: Wbooks, 2011.

Eastaugh, Nicholas, Valentine Walsh, Tracey Chaplin, and Ruth Siddall. The Pigment Compendium: A Dictionary of Historical Pigments. Oxford: Butterworth-Heinemann, 2008.

Elkins, James. What Painting Is: How to Think about Oil Painting, Using the Language of Alchemy. New York and London: Routledge, 1999.

Esser, Raingard. The Politics of Memory: The Writing of Partition in the Seventeenth-Century Low Countries. Brill's Studies in Intellectual History 208. Leiden: Brill, 2012.

Feeser, Andrea, Maureen Daly Goggin, and Beth Fowkes Tobin, eds. The Materiality of Color: The Production, Circulation, and Application of Dyes and Pigments, 1400-180o. Farnham: Ashgate, 2012.

Fehrenbach, Frank. "Kohäsion und Transgression: Zur Dialektik lebendiger Bilder.” In Animationen / Transgressionen:Das Kunstwerk als Lebewesen. Hamburger Forschungen zur Kunstgeschichte 4, 41-72. Berlin: Akademie Verlag, 2005.

Fuster López, Laura, et al. Paintings on Copper and Other Metal Plates: Production, Degradation and Conservation Issues. València: Universitat Politècnica de València, 2017.

Gage, Frances. Painting as Medicine in Early Modern Rome: Giulio Mancini and the Efficacy of Art. University Park, PA: The Pennsylvania State University Press, 2016.

Gage, John. "A Locus Classicus of Colour Theory: The Fortunes of Apelles." Journal of the Warburg and Courtauld Institutes 44 (1981): 1-26.

Gage, John. Colour and Culture: Practice and Meaning from Antiquity to Abstraction. London: Thames and Hudson, 1993.

Gettens, Rutherford J., Robert L. Feller, and W. T. Chase. "Vermilion and Cinnabar." In Artists' Pigments: A Handbook of their History and Characteristics, 4 vols., edited by Ashok Roy et al., vol. 2, 159-182. Oxford: Oxford University Press, 1986-2007.

Göttler, Christine. Last Things: Art and the Religious Imagination in the Age of Reform. Turnhout: Brepols, 2010.

Göttler, Christine. “'Bootsicheyt': Malerei, Mythologie und Alchemie im Antwerpen des frühen 17. Jahrhunderts: Zu Rubens' Silen in der Gemäldegalerie der Akademie der Bildenden Künste in Wien." In Erosionen der Rhetorik? Strategien der Ambiguität in den Künsten der Frühen Neuzeit, edited by Valeska von Rosen, 259-301. Culturae 4. Wiesbaden: Harassowitz, 2012. 
Göttler, Christine. "Vulcan's Forge: The Sphere of Art in Early Modern Antwerp.” In Knowledge and Discernment in the Early Modern Arts, edited by Sven Dupré and Christine Göttler, 52-87. London and New York: Routledge, 2017.

Göttler, Christine. “'Sicille': Les metaulx en Grec, in Le blason des couleurs en armes, livrees \& devises, 1540?” In Renaissance Invention: Stradanus's Nova Reperta, edited by Lia Markey, 229. Evanston, IL: Northwestern University Press, 2020.

Göttler, Christine. "Tales of Transformation: Hendrick Goltzius's Allegory of the (Alchemical) Art in the Kunstmuseum Basel." In Epistemic Images in Early Modern Europe, edited by Alexander Marr and Christopher P. Heuer, special issue, 21: Inquiries into Art, History, and the Visual 1, no. 2 (2020): 403-444. Accessed on 28 November 2020. https://doi. org/10.11588/xxi.2020.2.76233.

Hadjinicolaou, Yannis. Denkende Körper - Formende Hände: Handeling in Kunst und Kunsttheorie der Rembrandtisten. Berlin and Boston, MA: De Gruyter, 2016.

Hanß, Stefan. "Material Encounters: Knotting Cultures in Early Modern Peru and Spain." The Historical Journal 62 (2019): 1-33. Accessed on 22 January 2019. http://dx.doi.org/10.1017/ Soo18246X18000468.

Harley, Rosamond D. Artists' Pigments c. 160o-1835. London: Butterworth Scientific, 1982. Heuer, Christopher P. “A Copperplate for Hieronymus Cock.” The Burlington Magazine 149 (2007): 96-99.

Hills, Paul. Venetian Colour: Marble, Mosaic, Painting and Glass 1250-1550. New Haven, CT and London: Yale University Press, 1999.

Joby, Christopher. The Dutch Language in Britain (1550-1702): A Social History of the Use of Dutch in Early Modern Britain. Leiden and Boston, MA: Brill, 2015.

Jones, William Jervis. Historisches Lexikon deutscher Farbbezeichnungen, 5 vols. Berlin: Akademie Verlag, 2013.

Kahn, Didier. "Alchemical Poetry in Medieval and Early Modern Europe: A Preliminary Survey and Synthesis. Part I-Preliminary Survey." Ambix 57 (2010): 249-274.

Kern, Ulrike. "Samuel van Hoogstraeten and the Cartesian Rainbow Debate: Color and Optics in a Seventeenth-Century Treatise of Art Theory." Simiolus 36 (2012): 103-114.

Kirby, Jo. "The Painter's Trade in the Seventeenth Century: Theory and Practice." National Gallery Technical Bulletin 20 (1999): $5^{-49}$.

Kirby, Jo. “Glossary.” In Trade in Artists' Materials: Markets and Commerce in Europe to 170o, edited by Jo Kirby, Susie Nash, and Joanna Cannon, 447-461. London: Archetype Publications, 2010.

Kirby, Jo, Susie Nash, and Joanna Cannon, eds. Trade in Artists' Materials: Markets and Commerce in Europe to 170o. London: Archetype Publications, 2010.

Komanecky, Michael K., ed. Copper as Canvas: Two Centuries of Masterpiece Paintings on Copper, 1575-1775. Exh. cat. Phoenix Art Museum. New York and Oxford: Oxford University Press, 1999. 
Krieger, Verena. "Die Farbe als 'Seele' der Malerei: Transformationen eines Topos vom 16. Jahrhundert zur Moderne.” Marburger Jahrbuch für Kunstwissenschaft 33 (2006): 91-112.

Krischel, Roland. "Zur Geschichte des venezianischen Pigmenthandels: Das Sortiment des 'Jacobus de Benedictis à Coloribus'." Wallraf-Richartz-Jahrbuch 63 (2002): 93-158.

Kühn, Hermann. "Lead-Tin Yellow." In Artists' Pigments: A Handbook of their History and Characteristics, 4 vols., edited by Ashok Roy et al., vol. 2, 83-112. Oxford: Oxford University Press, 1986-2007.

Leesberg, Marjolein. "Karel van Mander as a Painter." Simiolus 22, nos. 1-2 (1993-1994): 5-57.

Lehmann, Ann-Sophie. “Jan van Eyck und die Entdeckung der Leibfarbe." In Weder Haut noch Fleisch: Das Inkarnat in der Kunstgeschichte, edited by Daniela Bohde and Mechthild Fend, 21-40. Berlin: Gebr. Mann, 2007.

Lehmann, Ann-Sophie. "Fleshing out the Body: The 'Colours of the Naked' in Workshop Practice and Art Theory, 1400-160o." In Body and Embodiment in Netherlandish Art, edited by Ann-Sophie Lehmann and Herman Roodenburg, 87-109. Netherlands Yearbook for History of Art 58. Zwolle: Waanders, 2008.

Lehmann, Ann-Sophie. "An Alphabet of Colors: Valcooch's Rules and the Emergence of Sense-Based Learning around 160o." In Lessons in Art: Art, Education, and Modes of Instruction since 150o, edited by Eric Jorink, Ann-Sophie Lehmann, and Bart Ramakers, 168-203. Netherlands Yearbook for History of Art 68. Leiden: Brill, 2019.

Leonhard, Karin. "Painted Gems: The Color Worlds of Portrait Miniature Painting in Sixteenth- and Seventeenth-Century Britain." In Early Modern Color Worlds, edited by Tawrin Baker, Sven Dupré, Sachiko Kusukawa, and Karin Leonhard, 140-169. Leiden and Boston, MA: Brill, 2015 .

Löhr, Wolf-Dietrich. "Die Rede der Hand: Giottos O und die Autorschaft des Künstlers bei Polizian und Vasari.” In Autorschaft: Ikonen - Stile - Institutionen, edited by Christel Meier and Martina Wagner-Egelhaaf, 163-194. Berlin: Akademie Verlag, 2011.

Melion, Walter S. Shaping the Netherlandish Canon: Karel van Mander's Schilder-Boeck. Chicago, IL and London: University of Chicago Press, 1991.

Middelnederlandsch Woordenboek. Accessed on 1 December 2018. http://gtb.ivdnt.org/ search/?owner=onw.

Miedema, Hessel. "Een schilderij van Karel van Mander de Oude (1548-16o6): Een doopsgezinde interpretatie.” Doopsgezinde Bijdragen 16 (1990): 113-128.

Miedema, Hessel. "The Biography of Karel van Mander (1548-1606).” In Karel van Mander, The Lives of the Illustrious Netherlandish and German Painters from the First Edition of the Schilder-boeck (1603-1604): Preceded by the Lineage, Circumstances and Place of Birth, Life and Works of Karel van Mander, Painter and Poet and likewise his Death and Burial, from the Second Edition of the Schilder-boeck (1616-1618), edited by Hessel Miedema, 6 vols., vol. 2, 9-168. Doornspijk: Davaco, 1994-1999. 
Miedema, Hessel, and Pieter J. J. van Thiel. "De grootmoedigheid van Scipio, een schilderij van Karel van Mander uit 16oo." Bulletin van het Rijksmuseum 26, no. 2 (1978): 51-59.

Muller, Jeffrey M. "Rubens's Emblem of the Art of Painting." Journal of the Warburg and Courtauld Institutes 44 (1981): 221-222.

Nagel, Alexander, and Christopher S. Wood. Anachronic Renaissance. New York: Zone Books, 2010.

Nash, Susie. "'Pour couleurs et autres choses prise de lui ...': The Supply, Acquisition, Cost and Employment of Painters' Materials at the Burgundian Court, c. 1375-1419." In Trade in Artists' Materials: Markets and Commerce in Europe to 170o, edited by Jo Kirby, Susie Nash, and Joanna Cannon, 97-182. London: Archetype Publications, 2010.

Neumeister, Mirjam. Holländische Gemälde im Städel, 1550-180o, vol. 1: Künstler geboren bis 1615. Kataloge der Gemälde im Städelschen Kunstinstitut Frankfurt am Main 8. Petersberg: Michael Imhof, 2005.

Nichols, Lawrence W. “The 'Pen Works' of Hendrick Goltzius.” Philadelphia Museum of Art Bulletin 88, nos. 373-374 (Winter 1992): 1-57.

Nichols, Lawrence W. The Paintings of Hendrick Goltzius. Zwijndrecht, Belgium: Davaco, 2013. Noë, Helen. Carel van Mander en Italië: Beschouwingen en notities naar aanleiding van zijn "Leven der dees-tijtsche doorluchtighe Italiaensche Schilders.”'S-Gravenhage: Martinus Nijhoff, 1954.

Panofsky, Dora and Erwin. Pandora's Box: The Changing Aspects of a Mythical Symbol. Princeton, NJ: Princeton University Press, 1962.

Pastoureau, Michel. Yellow: The History of a Color, translated by Jody Gladding. Princeton, NJ and Oxford: Princeton University Press, 2019.

Pfisterer, Ulrich. Kunst-Geburten: Kreativität, Erotik, Körper in der Frühen Neuzeit. Berlin: Klaus Wagenbach, 2014.

Ramakers, Bart. "Dutch Allegorical Theatre: Traditions and Conceptual Approach." In Urban Theatre in the Low Countries, edited by Elsa Strietman and Peter Happé, 127-147. Turnhout: Brepols, 2006.

Ramakers, Bart. "As Many Lands, as Many Customs: Vernacular Self-Awareness among the Netherlandish Rhetoricians." In The Transformation of Vernacular Expression in Early Modern Art, edited by Joost Keizer and Todd M. Richardson, 123-178. Intersections 19. Leiden and Boston, MA: Brill, 2012.

Reeves, Eileen. "The New Sciences and the Visual Arts." In A Companion to Renaissance and Baroque Art, edited by Babette Bohn and James M. Saslow, 316-335. Chichester: Wiley, 2013.

Rosenthal, Lisa. "Political and Painterly Virtue in Cornelis Cornelisz. van Haarlem's 'Wedding of Peleus and Thetis' for the Haarlem Prinsenhof." In Virtue: Virtuoso, Virtuosity in Netherlandish Art 1500-1700, edited by Jan de Jong et al., 172-201. Netherlands Yearbook for History of Art 54. Zwolle: Waanders, 2003. 
Roy, Ashok et al., eds. Artists' Pigments: A Handbook of their History and Characteristics, 4 vols. Oxford: Oxford University Press, 1986-2007.

Roy, Ashok, and Jo Kirby. "Rembrandt's Palette." In Art in the Making: Rembrandt, edited by David Bomford, Jo Kirby, Ashok Roy, Axel Rüger, and Raymond White, 35-47. Exh. cat. National Gallery, London. London: The National Gallery, 1998.

Schmidt, Benjamin. “'O Fortunate Land!' Karel van Mander, a West Indies Landscape and the Dutch Discovery of America." New West Indian Guide 69 (1995): 5-44.

Seccaroni, Claudio. Giallorino: Storia dei pigmenti gialli di natura sintetica. Dal "vetrio giallo per patre nostro o ambre" al "giallo di Napoli." Rome: De Luca, 2006.

Silver, Larry. "Goltzius, Honor, and Gold." In Habitus: Norm und Transgression in Bild und Text, edited by Tobias Frese and Annette Hoffmann, 315-330. Berlin: Akademie Verlag, 2011.

Smith, Pamela H. "Vermilion, Mercury, Blood, and Lizards: Matter and Meaning in Metalworking." In Materials and Expertise in Early Modern Europe: Between Market and Laboratory, edited by Ursula Klein and E. C. Spary, 29-49. Chicago, IL: University of Chicago Press, 2010.

Sohm, Philip. "Gendered Style in Italian Art Criticism from Michelangelo to Malvasia." Renaissance Quarterly 48, no. 4 (Winter 1995): 759-808.

Sohm, Philipp. "Palettes as Signatures and Encoded Identities in Early-Modern Self Portraits." Art History 40 (2017): 994-1025.

Sorabji, Richard. "Aristotle on Colour, Light and Imperceptibles." Bulletin of the Institute of Classical Studies 47 (2004): 129-140.

Stanneck, Achim. Ganz ohne Pinsel gemalt. Frankfurt am Main: Peter Lang, 2002.

Stumpel, Jeroen. "A Note on the Intended Audiences for van Mander's Schilder-Boeck." Simiolus 35, nos. 1-2 (2011): 84-90.

Swan, Claudia. Art, Science, and Witchcraft in Early Modern Holland:Jacques de Gheyn II (1565-1629). Cambridge: Cambridge University Press, 2005.

Talley, Mansfield Kirby. Portrait Painting in England: Studies in the Technical Literature before 170o. London: Paul Mellon Centre for Studies in British Art, 1981.

Taylor, Paul. "The Glow in Late Sixteenth- and Seventeenth-Century Dutch Paintings." In Looking through Paintings: The Study of Painting Techniques and Materials in Support of Art Historical Research, edited by Erma Hermens, 159-178, Leids kunsthistorisch jaarboek 11. Baarn and London: de Prom, 1998.

Taylor, Paul. "Colouring Nakedness in Netherlandish Art and Theory." In The Nude and the Norm in the Early Modern Low Countries, edited by Karolien De Clippel, Katharina van Cauteren, and Katlijne van der Stighelen, 65-79. Turnhout: Brepols, 2011.

Thijs, Boukje. De hoefslag van Pegasus: Een cultuurhistorisch onderzoek naar Den Nederduytschen Helicon (1610). Hilversum: Verloren, 2004.

Tramelli, Barbara. Giovanni Paolo Lomazzo's Trattato dell'Arte della Pittura: Color, Perspective and Anatomy. Leiden: Brill, 2017. 
Vandenbroeck, Paul. "Matrix Marmorea: The Sub-Symbolic Iconography of the Creative Energies in Europe and North Africa." In New Perspectives in Iconology: Visual Studies and Anthropology, edited by Barbara Baert, Ann-Sophie Lehmann, and Jenke van den Akkerveken, 180-210. Brussels: Academic \& Scientific Publishers, 2011.

Van Os, Henk, Jan Piet Filedt Kok, Ger Luijten, and Frits Scholten, eds. Netherlandish Art in the Rijksmuseum, 1400-16oo. Zwolle: Waanders, 2000.

Vermeylen, Filip. "The Colour of Money: Dealing in Pigments in Sixteenth-Century Antwerp." In Trade in Artists' Materials: Markets and Commerce in Europe to 1700, edited by Jo Kirby, Susie Nash, and Joanna Cannon, 356-365. London: Archetype Publications, 2010.

Volmert, Miriam. Grenzzeichen und Erinnerungsräume: Holländische Identität in Landschaftsbildern des 15.-17. Jahrhunderts. Ars et Scientia 4. Berlin: Akademie-Verlag, 2013.

Waterschoot, Werner. "Karel van Mander's Schilder-Boeck (1604): A Description of the Book and Its Setting." Quaerendo 13, no. 4 (1983): 26o-285.

Weiss, Philipp. "We(d)erschijn als Kernbegriff der Diskussion des malerischen Lichtes bei Karel van Mander." In Ad fontes!, edited by Claudia Fritsche, Karin Leonhard, and Gregor J. M. Weber, 35-53. Petersberg: Imhof, 2013.

West Fitzhugh, Elizabeth. "Red Lead and Minium." In Artists' Pigments: A Handbook of their History and Characteristics, 4 vols., edited by Ashok Roy et al., vol. 1, 109-139. Oxford: Oxford University Press, 1986-2007.

West Fitzhugh, Elizabeth. “Orpiment and Realgar." In Artists' Pigments: A Handbook of their History and Characteristics, 4 vols., edited by Ashok Roy et al., vol. 3, 47-8o. Oxford: Oxford University Press, 1986-2007.

Weststeijn, Thijs. "Painting's Enchanting Poison': Artistic Efficacy and the Transfer of Spirits." In Sprits Unseen: The Representation of Subtle Bodies in Early Modern European Culture, edited by Christine Göttler and Wolfgang Neuber, 141-178. Intersections 29. Leiden and Boston, MA: Brill, 2007.

Weststeijn, Thijs. The Visible World: Samuel van Hoogstraten's Art Theory and the Legitimation of Painting in the Dutch Golden Age. Amsterdam: Amsterdam University Press, 2008. Zorach, Rebecca. The Passionate Triangle. Chicago, IL and London: University of Chicago Press, 2011.

\section{About the Author}

Christine Göttler, Professor emerita of Art History at the University of Bern, specializes in the art of early modern Europe, with a focus on the Netherlands. She has published widely on collecting practices, historical aspects of artists' materials, and the imagery of solitude. Her current projects explore Peter Paul Rubens's engagement with Antwerp's global world and the relationship between landscape and nature. 


\title{
6. Shimmering Virtue: Joris Hoefnagel and the Uses of Shell Gold in the Early Modern Period
}

\author{
Michèle Seehafer
}

\begin{abstract}
While there is a rich literature on the use of gold leaf in painting, its powdered form known as shell gold, a pigment applied with brushes, has received far less attention. This chapter provides a historical overview of this exclusive painters' material and focuses on two artworks by the Antwerp miniaturist Joris Hoefnagel (1542-160o) that specifically demonstrate the use of shell gold as a mediating material. Each painting exemplifies how Hoefnagel fashioned his artistic virtuosity through the use of shell gold and through visual references to this material. Additionally, two historical shell-gold recipes have been reconstructed to enhance the understanding of the material and provide a glimpse into the practitioner's own physical involvement.
\end{abstract}

Keywords: shell gold; Joris Hoefnagel; material culture studies; materiality; virtuosity; reconstruction

Stimulated by the material turn, which aims to investigate specific materials in all their nuances, researchers have paid great attention to the element of gold. However, this material has mainly been examined in relation to its solid form or to the different ways in which it can be imitated. ${ }^{1}$ Far less attention has been given to its liquid form,

1 More recent contributions on gold include: Rebecca Zorach, Blood, Milk, Ink, Gold: Abundance and Excess in the French Renaissance (Chicago, IL and London: University of Chicago Press, 2005); Agnes Husslein-Arco and Thomas Zaunschirm, eds., Gold: Von der Antike bis zur Moderne, exh. cat. (Munich and Vienna: Hirmer, 2012); Rebecca Zorach and Michael W. Phillips Jr., Gold (London: Reaktion Books,

Burghartz, S., L. Burkart, C. Göttler, U. Rublack, Materialized Identities in Early Modern Culture, 1450-1750: Objects, Affects, Effects. Amsterdam: Amsterdam University Press, 2021 DOI 10.5117/9789463728959_CHo6 
shell gold, which during the early modern period was a well-known painters' material. ${ }^{2}$ Shell gold, produced from gold leaf, stands at the threshold of transforming gold from a solid into a liquid state. This chapter explores the potential of shell gold, its material properties, and symbolic significance by focusing on some selected works by one of the most renowned sixteenth-century miniature painters, the Antwerp artist Joris Hoefnagel (1542-1600). In the Schilder-Boeck of 1604, Karel van Mander (1548-1606) writes that Hoefnagel was urged by his parents to become "a merchant, in contradiction to his nature: for although his entire or utmost inclination was turned towards the art of painting they would not permit the boy [...] to do what Mother Nature continually insisted, and from which he could not refrain."3 Van Mander goes on to describe how, when Hoefnagel did not have any paper to hand, he would draw in sand or dust on the floor with his finger or a stick or a piece of chalk. While implicitly referring to Hoefnagel's irrepressible imagination and his unrestrained will to draw, Van Mander simultaneously emphasizes Hoefnagel's affinity for handling and experimenting with various materials. ${ }^{4}$ In addition, Van Mander describes him as a "very learned man and good poet," also noting that he was very "accomplished in Latin," a biographical fact that also informed his artistic practice, as will be shown. ${ }^{5}$

Born in Antwerp into the wealthy family of Jacob Hoefnagel (1509/10-1579) and his wife Elisabeth Vezelaer (d. 1595) in 1542, Joris was educated as a merchant in the family's business where he dealt mostly with luxury goods and especially with jewels. ${ }^{6}$ He therefore came into contact with the physical characteristics of precious materials and small-scale objects at a young age. With this in mind, it

2016); Anna Degler and Iris Wenderholm, "Der Wert des Goldes - der Wert der Golde: Eine Einleitung," Zeitschrift für Kunstgeschichte 79, no. 4 (2016): 443-460.

2 Nigel Morgan, "Painting with Gold and Silver," in Colour: The Art and Science of Illuminated Manuscripts, exh. cat., ed. Stella Panayotova (London and Turnhout: Harvey Miller, 2016), 193, 195.

3 Karel van Mander, The Lives of the Illustrious Netherlandish and German Painters from the First Edition of the Schilder-boeck (1603-1604): Preceded by the Lineage, Circumstances and Place of Birth, Life and Works of Karel van Mander, Painter and Poet and likewise his Death and Burial, from the Second Edition of the Schilder-boeck (1616-1618), ed. Hessel Miedema, 6 vols. (Dornspijk: Davaco, 1994-1999), 1:308-309 (fol. 262v): “Ouders, die hem tot de Coopmanschap, tegen de natuere worstelende, aendronghen: want zijn gantsche oft aldermeeste gheneghentheyt tot de Schilder-const streckende, niet mochten lijden, [...] t'gene hem de Moeder natuere stadich gheboodt, en niet laten en con."

4 On Van Mander and his comments on colour, see the chapter by Christine Göttler in this volume.

5 Van Mander, Lives, 1:308-309 (fol. 262v): "een seer gheleert Man, en een goet Poeet geworden"; 1:310-311 (fol. 263r): “dapper in zijn Latijn.”

6 Hoefnagel's mother, too, came from a family of merchants and jewellers - her father was at one time the master of the Antwerp mint: S. Killermann, "Georg Hoefnagel," Allgemeines Künstlerlexikon Online, accessed on 28 August 2018, https://www.degruyter.com/view/AKL/_oo106351T; Thea Vignau-Wilberg, Joris and Jacob Hoefnagel: Art and Science around 1600 (Berlin: Hatje Cantz, 2017), 20-21, 44. Hoefnagel was not the only merchant who became an artist: Martin Warnke, Der Hofkünstler: Zur Vorgeschichte des modernen Künstlers, 2nd ed. (Cologne: DuMont, 1996), 211. 
is not surprising that Hoefnagel eventually combined his interests in material preciousness, miniature aesthetic, and painting by becoming a specialist painter of the so-called verlichteryen: small-scale illuminations in gouache on parchment. ${ }^{7}$ This chapter focuses on two miniature paintings from Joris Hoefnagel's large oeuvre that specifically demonstrate the application of shell gold as a mediating material. It will be argued that in these miniatures, Hoefnagel not only prominently fashioned himself as a painter of small-scale formats, but at the same time also underlined his awareness of being a member of a larger group: that of the miniature painters. ${ }^{8}$ Coming from Antwerp - a city where the painters' guilds had a high status and collaborations among artists were commonplace - Hoefnagel's need to identify himself as a member of this group in his works was probably due to the fact that he lacked this affiliation in reality: during his lifetime he was never a member of a painters' guild and was a self-declared autodidact. ${ }^{9}$ That he nevertheless understood himself as part of a wider, border-crossing network, which was also perceived by others as such, is echoed in a poem by his friend Johannes Vivianus (ca. 1520-1598) for the album amicorum of Johannes Rademacher, their common friend. Written in the voice of Hoefnagel and commenting on a miniature by the well-known Italian miniaturist Giulio Clovio (1498-1578), the verses say: “[...] and, as you [Clovio] precede me, I [Hoefnagel] worship your genius as my teacher and follow in your footsteps." ${ }^{10}$

Hoefnagel asserted his artistic self and his affiliation towards miniature painters in three ways. First, by prominently depicting his own working tools; second, by

7 Van Mander, Lives, 5:11; Thea Vignau-Wilberg, “Joris Hoefnagels Tätigkeit in München,” Jahrbuch der Kunsthistorischen Sammlung in Wien 81 (1985): 103; Vignau-Wilberg, "Joris Hoefnagel und die Freiheit des hofgeschützten Künstlers," in München - Prag um ı6oo, ed. Beket Bukovinská and Lubomír Konečný (Prague: Artefactum, 2009), 126. On the parallels between miniature paintings and goldsmiths' work: Karin Leonhard, "Painted Gems: The Color Worlds of Portrait Miniature Painting in Sixteenth- and Seventeenth-Century Britain,” in Early Modern Color Worlds, ed. Tawrin Baker, Sven Dupré, Sachiko Kusukawa, and Karin Leonhard, special issue, Early Science and Medicine 20, no. 4/6 (2015): 428-457.

8 Francesca Terrenato, "The Shaping of Individual and Collective Identities in Vasari's and Van Mander's Lives of Artists," Fragmenta 3 (2009): 127-146; Hannah Chapelle Wojciehowski, Group Identity in the Renaissance World (Cambridge: Cambridge University Press, 2011).

9 For the importance of the guild in Antwerp: Natasja Peeters, "The Guild of Saint Luke and the Painter's Profession in Antwerp between c. 1560 and 1585: Some Social and Economic Insights," in Envisioning the Artist in the Early Modern Netherlands, ed. H. Perry Chapman and Joanna Woodall, Netherlands Yearbook for History of Art 59 (Zwolle: Waanders, 2009): 136-163; Natasja Peeters, "A Guild's Eye View on Art: Artists and the Corporate World in Antwerp (ca. 1550-1600)," in The Artist between Court and City (1300-16oo)/L'artiste entre la cour et la ville/Der Künstler zwischen Hof und Stadt, ed. Dagmar Eichberger, Philippe Lorentz, and Andreas Tacke, artifex: Quellen und Studien zur Künstlersozialgeschichte (Petersberg: Michael Imhof, 2017), 189-201.

10 “[...] geniumque magistrum / Te praeeunte sequens, vestigia semper adoro." Cited from Vignau-Wilberg, Joris and Jacob Hoefnagel, 16. Giulio Clovio's position as a miniature painter was offered to Hoefnagel by Cardinal Alessandro Farnese in 1578. Van Mander, Lives, 1:310-311 (fol. 263r). 
demonstrating his virtuoso painting skills; and third, by the extensive usage of shell gold, not only for drawing and painting, but also for writing. Hoefnagel not only used shell gold in large quantities but also referred to it visually and iconographically, depicting the pigment in its natural container - a unique reference to his own working process that has so far not received attention in art historical research, and which is foregrounded in this chapter. To better understand how shell gold was produced at this time and how this "vibrant" material could foster ideas about the shaping of an artist's identity, two historical recipes have been reconstructed; the results of this material reconstruction will be presented towards the end of the chapter. ${ }^{11}$

\section{(Un)Natural Shimmer: Shell Gold}

Due to their durability, shells had been used to hold pigments since antiquity. We thus frequently find representations of medieval painters and illuminators showing pigments being kept either in flat containers or in shells. ${ }^{12}$ The technique of creating shell gold, also known as powdered gold or gold paint, involved grinding up gold leaf, or the remnants of it, into a fine powder and mixing this with a binder material - transforming the gold from a solid to a liquid state. ${ }^{13}$ Even though there are some recipes that mention shells being used as a mortar for grinding gold leaf or as the vessel in which it was stirred, the name comes primarily from their storage function, as the paint comes away easily from the shiny, flat surface of the shell. ${ }^{14}$

\footnotetext{
11 Jane Bennett, Vibrant Matter: A Political Ecology of Things (Durham, NC and London: Duke University Press, 2010), xvi.

12 Helen Howard, "Shells as Palettes and Paint Containers in England," in Medieval Painting in Northern Europe: Techniques. Analysis. Art History, ed. Jilleen Nadolny (London: Archetype, 2006), 202-214; Kevin Danti and Richard L. Zettler, "Shell Vessels and Containers," in Treasures from the Royal Tombs of Ur, ed. Richard L. Zettler and Lee Horne (Philadelphia, PA: University of Pennsylvania Museum of Archaeology and Anthropology, 1998), 143. In a cave in South Africa, researchers discovered a 100,000-year-old shell with a red pigment in it: Stephanie Pappas, "Oldest Human Paint-Making Studio Discovered in Cave," Live Science, 13 October 2011, https://www.livescience.com/16538-oldest-human-paint-studio.html. Using shells as containers was by no means solely a European phenomenon. Indian painters also stored their pigments in shells: Eberhard Fischer, "The Technique of Indian Painters: A Short Note," in Masters of Indian Paintings, ed. Milo C. Beach, Eberhard Fischer, and B. N. Goswamy, 2 vols. (Zurich: Artibus Asiae Publisher, 2011), 2:795. 13 Or Schiffleingold in German recipes, see e.g. Johannes Kunckel, Der Curieusen Kunst- und Werck-Schul [...] (Nuremberg: Johann Friedrich Rüdiger, 1732), 352. Michèle Seehafer, "Shell Gold - Production, Usage, and Handling of a Historical Artisanal Technique (including a hands-on experiment)," 3 February 2017, https://www.materializedidentities.com/single-post/2017/02/03/Shell-Gold-\%E2\%80\%93-ProductionUsage-and-Handling-of-a-Historical-Artisanal-Technique-including-a-hands-on-experiment.

14 Morgan, "Painting," 193; Albert Knoepfli and Oskar Emmenegger, Wandmalerei bis zum Ende des Mittelalters (Stuttgart: Reclam, 1990), 111. There is even a European shell that received its name from the practice of storing painters' pigments in it: Bayerisches Landesamt für Umwelt, "Artensteckbrief:
} 
In medieval manuscripts illuminare - the Latin word for "to give light" - designates the making of beams of divine light for which customarily (shell) gold was used. ${ }^{15}$ Long into the early modern period, shell gold was primarily used for illuminating manuscripts and the ornamentation of scripts, ${ }^{16}$ although the term "shell gold" began to appear more frequently in recipe books only towards the end of the seventeenth century. Nevertheless, the Leyden papyrus (ca. 250 BCE) had already mentioned a mixture of gold particles or gold leaf and a binder. ${ }^{17}$ There are many different recipes, especially concerning the type of binder material and the method of grinding gold. Binding materials such as gum arabic, egg-white - the adhesive known as "glair" - and warm fish glue are all mentioned. Theophilus Presbyter, in De diversis artibus, written in the early twelfth century, recommends boiling the bladders of sturgeons until the whole mixture becomes sticky. He also advises grinding gold in a mortar for several hours. ${ }^{18}$ The painter and writer Cennino Cennini, on the other hand, in his Libro dell'Arte of about 1400, recommends placing gold leaf on a stone and grinding it into tiny flakes with a pestle. He suggests using either glair or gum arabic as the binding agent. ${ }^{19}$ Other treatises mention sea salt, honey, vinegar, or even mercury to grind the gold leaf, which are then separated again by sieving with water. ${ }^{20}$ The recipe on how "to write gold out of a pen" in the so-called Augsburger Kunstbüchlin of 1535 recommends mixing honey and sea salt in order to grind the gold leaf into a powder; as will be shown, this was an effective and relatively quick method, as the salt granules break up the gold leaf easily. ${ }^{21}$ After the shell gold had been applied, it could be brightened - like gold leaf - with a burnisher. ${ }^{22}$ It is quite easy to distinguish shell gold from gold-leaf gilding with the

Malermuschel (unio pictorum)," accessed on 6 May 2018, http://fisch.wzw.tum.de/fileadmin/_migrated/ content_uploads/Merkblatt_Malermuschel.pdf.

15 Michelle P. Brown, Understanding Illuminated Manuscripts: A Guide to Technical Terms (Malibu, CA: J. Paul Getty Museum in association with The British Library, 1994), 69; Morgan, "Painting," 193.

16 Morgan, "Painting," 193.

17 Edmund Oskar von Lippmann, Entstehung und Ausbreitung der Alchemie (Berlin: Julius Springer, 1919), 8.

18 Kathleen P. Whitley, The Gilded Page: The History and Technique of Manuscript Gilding (London and New Castle, DE: British Library and Oak Knoll Press, 200o), 181.

19 Cennino Cennini, The Book of the Art of Cennino Cennini: A Contemporary Practical Treatise on Quattrocento Painting, trans. and ed. Christiana J. Herringham (London: George Allen, 1899), 138-139.

20 Morgan, "Painting," 193-195; Whitley, The Gilded Page, 181-183.

21 Anonymous, Kunstbüchlin, gerechten gründtlichen gebrauchs aller kunstbaren Werckleut (Frankfurt am Main: Christian Egenolph, 1535), 13b: “Golt aus der Feder zu schreiben.” For a detailed study of the Augsburger Kunstbüchlin and the genre of Kunstbüchlein in general: Ernst Striebel, "Das Augsburger Kunstbuechlin von 1535: Eine kunsttechnologische Quellenschrift der deutschen Renaissance” (Master's thesis, Technische Universität München, 2007).

22 The Liber illuministarum mentions the teeth of wolves, bears, or horses as burnishers. Anna Bartl, Christoph Krekel, Manfred Lautenschlager, and Doris Oltrogge, Der "Liber illuministarum" aus Kloster 
naked eye, as tiny particles are visible in the paint. ${ }^{23}$ As shell gold was an expensive material requiring a large amount of gold leaf - the Liber illuministarum contains a recipe where twenty to twenty-four gold leaves must be ground up - several recipes exist for gold-like paints in which other materials were substituted for gold. One example is "mosaic gold," also known as aurum musicum or purpurina, which was made from a mixture of tin, mercury, sulphur, and sal ammoniac. ${ }^{24}$ Occasionally, metallic substitutes such as copper rust, tin, and mercury were combined with animal, vegetable, or mineral substances to imitate the vibrancy of real gold. There are also recipes that recommend mixing finely ground rock crystal with saffron to produce a gold equivalent. ${ }^{25}$

The field of application for shell gold is large, a circumstance already noted by Cennini who stated that shell gold could be applied "on pictures, panels, parchment, or walls, or on anything you please." ${ }^{26}$ Shell gold was needed when fine lines had to be drawn, or filigree letters written, or small areas decorated - tasks that would be difficult or impossible to accomplish with gold leaf. It was employed practically everywhere - in panel paintings, on linen, or on wood; in drawings, manuscripts, frescoes, frames, and wooden sculptures; and on objects made out of glass or porcelain. ${ }^{27}$ The medallist and miniaturist Matteo de' Pasti referred to shell gold in a 1441 letter addressed to Piero di Cosimo de' Medici: "Since being in Venice I have learnt something which could not be more suited to the work I am doing for you, a technique of using powdered gold like any other colour." ${ }^{28}$ The use of powdered gold was popular in Venetian workshops in de' Pasti's day, favoured by panel painters and illuminators alike. ${ }^{29}$ De' Pasti went on to say that he had already begun working with this new technique, describing its effects as something that "you will never

Tegernsee: Edition, Übersetzung und Kommentar der kunsttechnologischen Rezepte (Stuttgart: Franz Steiner, 2005), 737. The Augsburger Kunstbüchlin states that the paint, once dried, should be polished with a tooth. Anonymous, Kunstbüchlin, 13b: "lass trucknen und poliers mit dem zan."

23 Morgan, "Painting," 195.

24 Bartl et al., Liber illuministarum, 6o-63; Morgan, "Painting," 197-198; Thomas Brachert, Lexikon historischer Maltechniken: Quellen, Handwerk, Technologie, Alchemie (Munich: Callwey, 2001), 32.

25 Vera Trost, Gold-und Silbertinten: Technologische Untersuchungen zur abendländischen Chrysographie und Argyrographie von der Spätantike bis zum hohen Mittelalter (Wiesbaden: Harrassowitz, 1991), 34-35, 285.

26 Cennini, Book of the Art, 138. Ames-Lewis assumes that Cennini recorded his recipe of shell gold during the 1390 s when he was in the Veneto region. Most probably the technique reached Florence from there: Francis Ames-Lewis, "Matteo de' Pasti and the Use of Powdered Gold," Mitteilungen des Kunsthistorischen Institutes in Florenz 28, no. 3 (1984): $35^{2}$.

27 In the Song period (96o-1279), Chinese artists used shell gold in techniques such as miaojin ("painting in gold") and tianqi ("filled-in lacquer"): Gerald W. R. Ward, The Grove Encyclopedia of Materials and Techniques in Art (Oxford: Oxford University Press, 2008), 233.

28 Ames-Lewis, "Matteo de' Pasti," 352; D. S. Chambers, Patrons and Artists in the Italian Renaissance (London and Basingstoke: Macmillan, 1970), 94-95.

29 Ames-Lewis, “Matteo de' Pasti," 352. 
have seen [...] before." ${ }^{\prime 30} \mathrm{He}$ evidently appreciated this "new" material as something unique and extraordinary, which was as easy to apply as a normal colour. One of the most prominent later Florentine examples of its use is Sandro Botticelli's The Birth of Venus, produced around 1486, where parts of Venus's hair are rendered in shell gold, giving it a deeper glimmer. ${ }^{31}$

Karel van Mander mentions shell gold in the life of Hans Holbein (1497/1498-1543), arguing that the German artist was first introduced to the technique of verlichterije by Lucas Horenbout (1490/1495-1544) when he was at the court in England where "he immediately grasped it just by seeing the method applied." ${ }^{22}$ According to Van Mander, Holbein employed shell gold in the Triumph of Riches for the Great Hall of the Steelyard in London, where "all the clothing or drapery is in grisaille, with the edges and the adornments drawn with powdered gold." ${ }^{33}$ Miniaturists in the early modern period, among them Giulio Clovio, or later Nicholas Hilliard (ca. 1547-1619), seem to have been very experienced with shell gold, and Joris Hoefnagel likewise used this material quite extensively in his works. The two miniatures by Hoefnagel discussed in this chapter both functioned as gifts with, however, very different purposes and aims. Whereas the Allegory of the Rule of Duke Albert $V$, created at the very beginning of Hoefnagel's career as a painter, was meant to attract the favour of a high-ranking ruler, the Allegory for Abraham Ortelius, created almost twenty years later, can be understood as a meditation on the friendship between two equals as well as two equal arts. Both works, moreover, explicitly refer to the generous use of shell gold, the precious artist's material that so profoundly characterized and shaped this artist's career.

\section{A Hand Guided by Nature: The Allegory for Albert V}

As mentioned above, Joris Hoefnagel was trained in his family's business dealing in luxury materials and precious stones. As a young merchant with financial security, Joris produced a number of drawings of cityscapes during his business travels on behalf of his family that had a special emphasis on customs, human activities,

30 Chambers, Patrons and Artists, 95.

31 Rolf E. Straub, “Tafel- und Tüchleinmalerei des Mittelalters," in Reclams Handbuch der künstlerischen Techniken, ed. Hermann Kühne, Heinz Roosen-Runge, Rolf E. Straub, and Manfred Koller, 3 vols. (Stuttgart: Reclam, 1984), 1:240. Andrea Mantegna as well as Giovanni and Jacopo Bellini used shell gold as recently mentioned in an exhibition catalogue, see Caroline Campbell et al., eds., Mantegna \& Bellini: Meister der Renaissance, exh. cat. (Munich: Hirmer, 2018).

32 Van Mander, Lives, 3:120-121; 1:148-149 (fol. 222v).

33 Ibid., 1:148-149 (fol. 222v): "en alle de cleederen oft draperije, van wit en swart: de boordekens en cieraten met schelp-gout getrocken wesende.” 
handcrafts, and goods, thus clearly demonstrating his interest in the observation of nature and human behaviour that would also define his subsequent artistic undertakings. ${ }^{34}$ According to Van Mander, Hoefnagel left Antwerp for Italy in 1577 due to the financial difficulties of his family resulting from the "Spanish Fury" - the invasion and sack of the city by Spanish soldiers. ${ }^{35} \mathrm{He}$ was accompanied by his friend Abraham Ortelius (1527-1598), the famous cartographer and antiquarian. ${ }^{36}$ The two reached Augsburg in early October where they visited the renowned collections of the merchant Marx Fugger (1529-1597) and the physician Adolf Occo III (1524-16o6). Having received letters of introduction from both men, Hoefnagel and Ortelius travelled onwards to Munich hoping to receive access to the Kunstkammer of Duke Albert V. ${ }^{37}$ Although recommended by Fugger as an "excellent painter, who will show your Serene Highness several pieces of art, which indeed will, in my opinion, adorn the Kunstkammer well," Hoefnagel seems to have hesitated to present himself as such in front of the duke, as he understood himself nevertheless first and foremost as a merchant - a self-perception challenged by his friend Ortelius. ${ }^{38}$ Van Mander emphasizes the crucial role played by Ortelius in encouraging Hoefnagel to change or broaden his career:

While they were at their inn the Duke sent to ask, via his steward or another gentleman, what Hoefnaghel wanted for that small miniature of the little animals, since he did not want to let go of the portraits. Hoefnaghel, who had never passed

34 Marjorie Lee Hendrix, “Joris Hoefnagel and the 'Four Elements': A Study in Sixteenth-Century Nature Painting" (PhD diss., Princeton University, 1984), 47.

35 Van Mander, Lives, 1:308-309 (fol. 262v).

36 Ortelius was often also called an "antiquarian" by his friends and acquaintances: Tine Luk Meganck, Erudite Eyes: Friendship, Art and Erudition in the Networks of Abraham Ortelius (1527-1598) (Leiden and Boston, MA: Brill, 2017), 19. Several sketches, which later became primary sources for the engravings for Braun and Hogenberg's Civitates orbis terrarum, confirm their shared experience since Hoefnagel inserted himself and Ortelius as staffage or repoussoire figures: Jessica Chiswick Robey, "From the City Witnessed to the Community Dreamed: The Civitates Orbis Terrarum and the Circle of Abraham Ortelius and Joris Hoefnagel" (PhD diss., University of California Santa Barbara, 2006), 253-26o; Lucia Nuti, "The Mapped Views by Georg Hoefnagel: The Merchant's Eye, the Humanist's Eye," Word \& Image 4, no. 2 (1988): 545-570; Marisa Anne Bass, Insect Artifice: Nature and Art in the Dutch Revolt (Princeton, NJ and Oxford: Princeton University Press, 2019), 69-74.

37 Thea Vignau-Wilberg, "Joris Hoefnagel, The Illuminator," in Mira Calligraphiae Monumenta: A Sixteenth-Century Calligraphic Manuscript, ed. Lee Hendrix and Thea Vignau-Wilberg (Malibu, CA: The J. Paul Getty Museum, 1992), 18-19. The two letters are published in Dorothea Diemer, Peter Diemer, Lorenz Seelig, Peter Volk, and Brigitte Volk-Knüttel, eds., Die Münchner Kunstkammer, 3 vols., Bayerische Akademie der Wissenschaften 129 (Munich: Verlag der Bayerischen Akademie der Wissenschaft, 2008), $3: 363-364$.

38 Diemer et al., Münchner Kunstkammer, 3:363: "furtreffenlicher Maler, der wirdt Eur Fürstlichen Durchlaucht etliche Kunststuckh von gemählen zaigen, welche derselben KunstCamer meins erachtens wol wurden zieren." Van Mander, Lives, 5:12. 
himself off as a painter, and who had also never let it be understood that he could do anything of that kind, hesitated to ask anything for it; but Ortelius, who gave him encouragement, asked on his behalf for a hundred gold crowns which the Duke gave him straight away with the request that he would remain in his service. ${ }^{39}$

It seems that it was the cartographer who pushed his young friend into accepting his "fate" as a painter.$^{40}$ In addition, the considerable sum of one hundred gold crowns awarded by a patron known for his judgement and taste emphasizes the potential lucrativeness of an artistic career. ${ }^{4}$ Following the call of his talent, Hoefnagel subsequently was appointed as court painter to the dukes of Bavaria, first serving Albert V and then, from 1579 onwards, Wilhelm V. He was listed in the courtly accounts among the "valets de chambre, officers and similar persons"; ${ }^{2}$ yet he received a much lower salary than other painters at the Wittelsbach court since, as an artist "exempted by court," he was also able to execute works for other patrons. 43

Created in 1579, Hoefnagel's Allegory of the Rule of Duke Albert V of Bavaria was intended as a gift in honour of Duke Albert V (Fig. 6.1). ${ }^{44}$ Painted on high

39 Van Mander, Lives, 1:308-311 (fols. 262v-263r): "Doe sy in hun Herbergh waren, sondt den Hertogh door zijn Hofmeester, oft ander Heer vraghen, wat Hoefnaghel begheerde voor dat Verlichteryken van de beestgens, dewijl hy de tronikens niet wouw quijt wesen. Hoefnaghel, die hem noyt had uytghegheven voor een Schilder, noch laten voorstaen yet te connen, was schromigh daer van yet te willen eysschen: Dan Ortelius hem moet ghevende, eyschte self voor hem een hondert gouden Croonen, die dem den Hertogh stracx heeft gegeven, en begheert dat hy daer in zijnen dienst soude blijven [...]."

40 Ibid., 5:18.

41 This appears to be a standardized payment as in 1599 Hans van Aachen also received for two paintings one hundred gold crowns by the Duke of Saxony: Warnke, Hofkünstler, 154. Van Mander also stated that Hoefnagel received "a golden chain worth a hundred golden crowns" from Archduke Ferdinand in Innsbruck: Van Mander, Lives, 1:310-311 (263r).

42 "Cammerdiener, Officier und dergleichen Person": Vignau-Wilberg, "Joris Hoefnagels Tätigkeit in München," 115 .

43 "hofbefreit": Vignau-Wilberg, "Joris Hoefnagel und die Freiheit des hofgeschützten Künstlers," 125-129; Vignau-Wilberg, Joris and Jacob Hoefnagel, 36; Jürgen Zimmer, "München und Prag um 16oo: Soziokulturelle Aspekte der Hofkunst im Vergleich," in Bukovinská and Konečný, München - Prag um 160o, 17-57; Herbert Haupt, "Kammer-, Hof- und hofbefreites Handwerk: Der Versuch einer inhaltlichen Abgrenzung," Jahrbuch der Kunsthistorischen Sammlungen in Wien 85/86 (1989/90): 89-93.

44 Thea Vignau-Wilberg, Joris und Jacob Hoefnagel: Kunst und Wissenschaft um 1600 (Berlin: Hatje Cantz, 2017), 151-152; Thea Wilberg Vignau-Schuurman, Die emblematischen Elemente im Werk Joris Hoefnagels, 2 vols. (Leiden: Universitaire Press, 1969), 1:128; Vignau-Wilberg, "Joris Hoefnagels Tätigkeit in München"; Diemer et al., Münchner Kunstkammer, 2:893; Bass, Insect Artifice, 31-33; Edmund Schilling, "Zwei Landschaftszeichnungen des Georg Hoefnagel," in Kunstgeschichtliche Studien für Hans Kaufmann, ed. Wolfgang Braunfels (Berlin: Gebrüder Mann, 1956), 233-239. In the early modern period such gifts played an important role especially for persons in privileged positions as they were an expression of their 


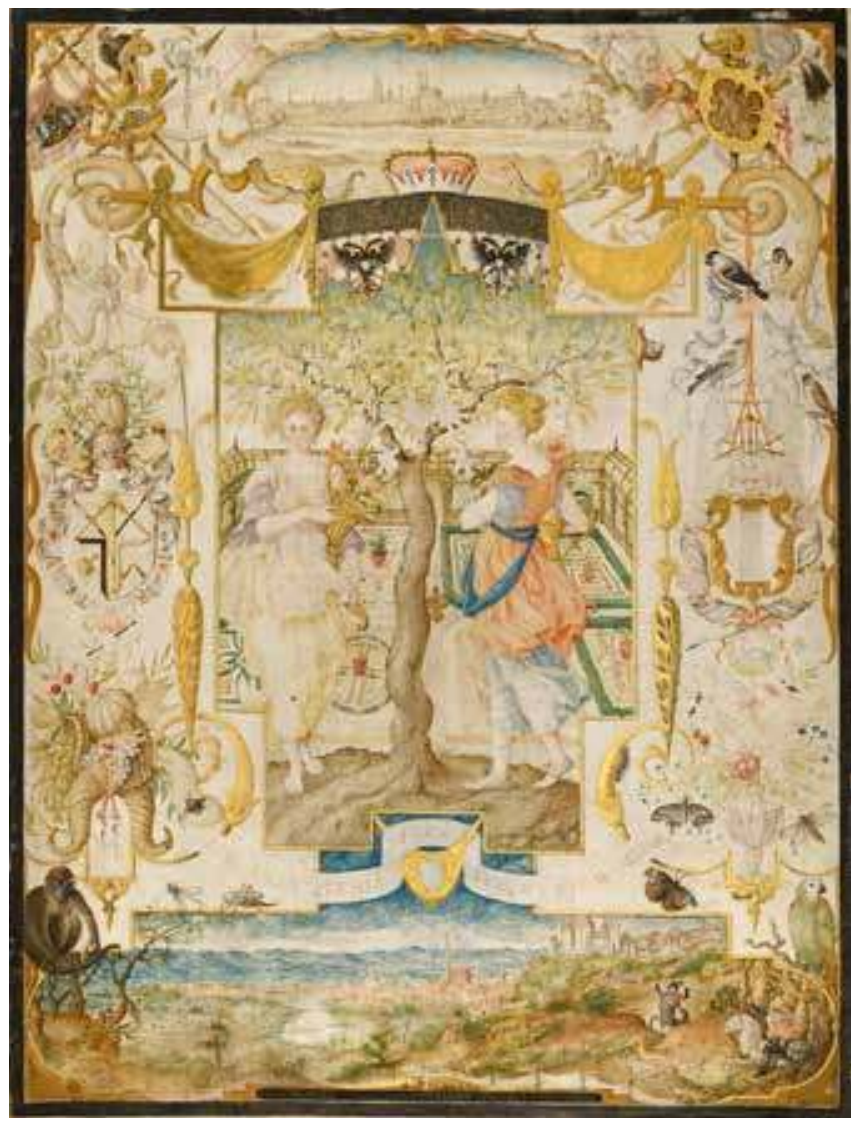

Figure 6.1: Joris Hoefnagel, Allegory of the Rule of Duke Albert V of Bavaria, 1579. Gouache on parchment, $23.5 \times 18.0 \mathrm{~cm}$. Berlin, Kupferstichkabinett der Staatlichen Museen Berlin, inv. no. KdZ 4804. Image $\odot$ Kupferstichkabinett, Staatliche Museen Berlin.

quality parchment that Hoefnagel most likely ordered from Italy, the medium-sized miniature was originally enclosed by an elaborate frame. ${ }^{45}$ Prominently placed in the centre at the bottom of the composition, below the panoramic view of the ducal residence in Landshut and emphasized by its black background, the inscription "invention and work by Joris Hoefnagel guided by nature" plays on the widely used topos of nature as both teacher as well as subject; after all, Hoefnagel never

high status and acted as instruments for their mutual support: Ilana Krausmann Ben-Amos, The Culture of Giving: Informal Support and Gift-Exchange in Early Modern England (Cambridge: Cambridge University Press, 2008), 205; Felicity Heal, The Power of Gifts: Gift-Exchange in Early Modern England (Oxford: Oxford University Press, 2014), 5 .

45 In 1580 Hoefnagel ordered twelve parchments from Italy: Vignau-Wilberg, "Joris Hoefnagels Tätigkeit in München," 117 . 


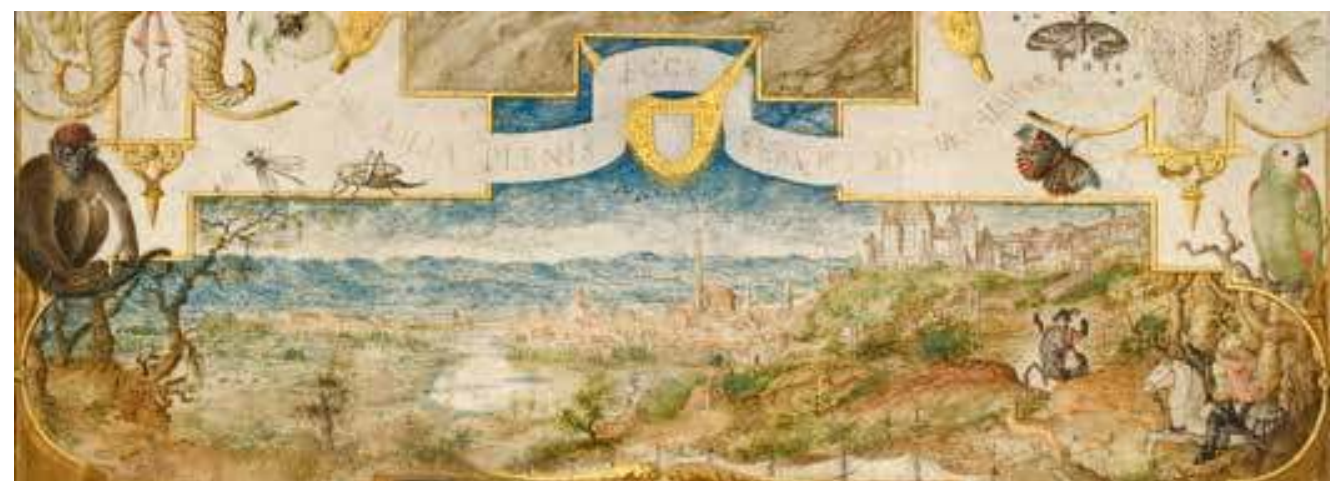

Figure 6.2: Joris Hoefnagel, Allegory of the Rule of Duke Albert V, detail of Fig. 6.1: Panoramic view of Landshut and inscription.

had been formally apprenticed (Fig. 6.2)..$^{46}$ That nature was the major source of inspiration for his artistic creations is also suggested by the landscapes, city views, domestic and foreign animals, as well as flowers shown in this exquisite sheet. Like the Kunstkammer of Albert V, where the collected knowledge of the world was displayed and for which this work was originally intended, the miniature expressed the grandeur of the House of Wittelsbach while at the same time honouring Albert $\mathrm{V}$ as a liefhebber and patron of the arts and paying tribute to his particular interest in precious small-scale works. ${ }^{47}$

The power of the Wittelsbach rule is emphasized by the two city views of the residences in Munich and Landshut, represented in the cartouches at the top and bottom of the composition. ${ }^{48}$ Framed by a delicate golden border and flanked by grotesques, the central image of the composition shows two nymphs holding cornucopias with a laurel tree in their centre (Fig. 6.3). At the very top of the tree appears the golden initial of Albert V, itself crowned by the ducal hat, positioned between two double-headed eagles (Fig. 6.4). On shields

46 “Inventio opusque Georgii Hoefnaglii natura magistra. Monaci A[nn]o 1579." For Hoefnagel's use of the phrases natura magistra or natura sola magistra: Bass, Insect Artifice, 26-28; Marisa Bass, "Patience Grows: The First Roots of Joris Hoefnagel's Emblematic Art," in The Anthropomorphic Lens: Anthropomorphism, Microcosmism and Analogy in Early Modern Thought and Visual Arts, ed. Walter S. Melion, Bret Rothstein, and Michel Weemans, Intersections 34 (Leiden and Boston, MA: Brill, 2014), note 7; Nina Eugenia Serebrennikov, “Imitating Nature/Imitating Bruegel," in Pieter Bruegel, ed. Jan de Jong, Mark Meadow, Herman Roodenburg, and Frits Scholten, Netherlands Yearbook for History of Art 47 (Zwolle: Waanders, 1996), 231; Hendrix, "Joris Hoefnagel and the 'Four Elements'," 29.

47 Diemer et al., Münchner Kunstkammer, 1:59. Hans Fugger emphasized the duke's high standards and expertise regarding precious materials such as stones: Lorenz Seelig, "Die Münchner Kunstkammer," in Diemer et al., Münchner Kunstkammer, 3:55.

48 For the importance of territorial display: Katharina Pilaski Kaliardos, The Munich Kunstkammer: Art, Nature, and the Representation of Knowledge in Courtly Contexts (Tübingen: Mohr Siebeck, 2013). 


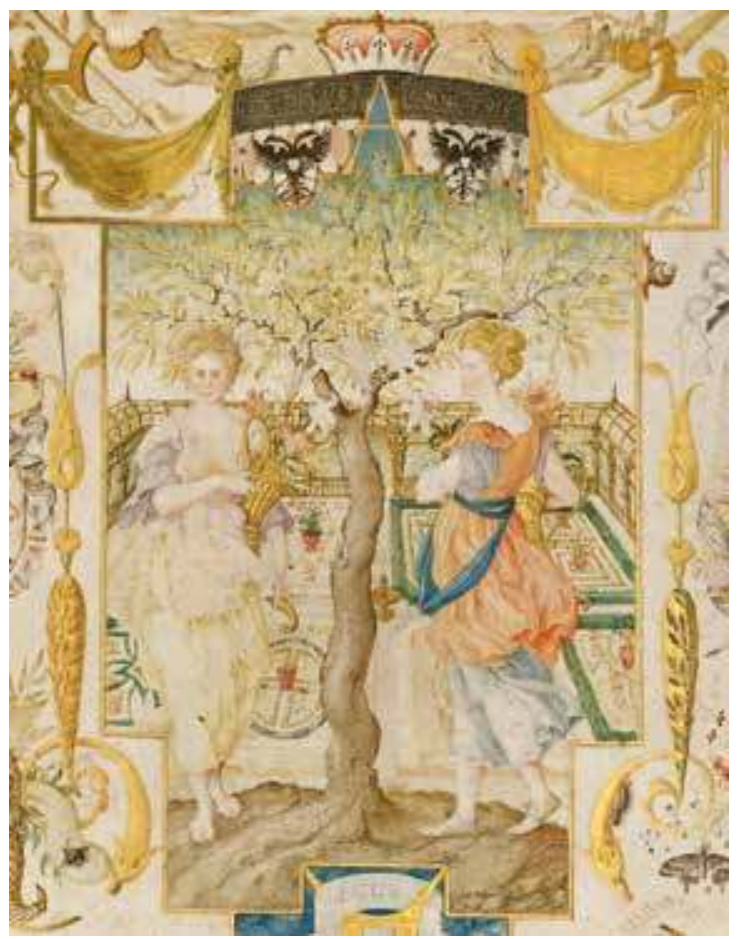

Figure 6.3: Joris Hoefnagel, Allegory of the Rule of Duke Albert V, detail of Fig. 6.1: Central part of the composition with two nymphs.

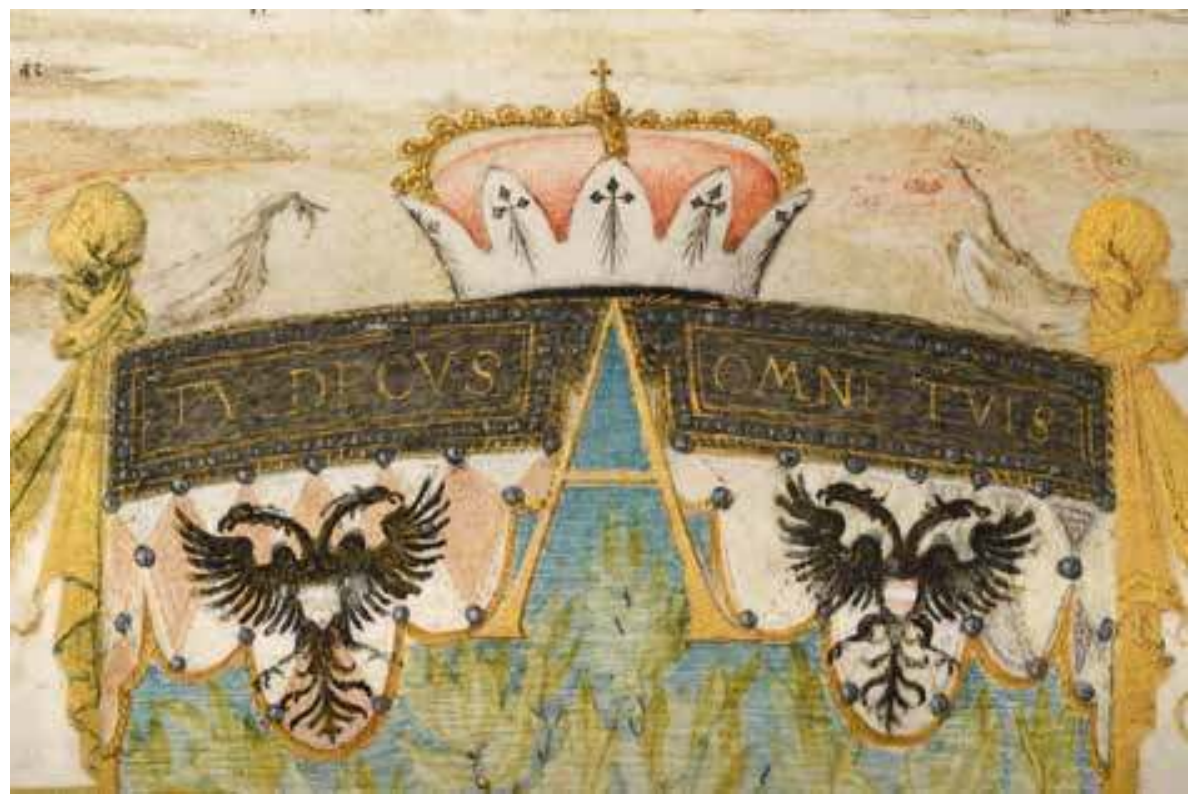

Figure 6.4: Joris Hoefnagel, Allegory of the Rule of Duke Albert V, detail of Fig. 6.1: Golden initial of Albert V, the ducal hat, and the two double-headed eagles. 
attached to their chests, the birds of prey present the coats of arms of the Houses of Habsburg on the right and probably the House of Wittelsbach on the left, which is unfortunately illegible today. It is plausible, however, that this was the case, as the eagles were thus able to allude to the alliance of the two dynasties, referencing their established bond through the marriage of Albert $V$ with Anna of Austria (1528-1590), the daughter of Emperor Ferdinand I (1503-1564), which had taken place in $1546 .{ }^{49}$ Below the ducal hat and thus prominently in the centre of the image, Hoefnagel inserted the first of two citations from Virgil's Eclogues, which he inscribed on a ribbon surrounded by rivets, thus imitating metal work. In this quotation - tu decus omne tuis (you alone give glory to your people) - taken from Eclogues V, 34, he eulogizes the duke and his dynasty as bringers of prosperity and peace..$^{0}$ The second verse undulates along the curved bottom frame of the central images. This one is taken from Eclogues II, $45^{-46}$ and reads tibi lilia plenis ecce ferunt Nymphae calathis (for you the Nymphs bring lilies in heaped-up baskets), referencing the high status of the patron and his successes in leading his state and fostering the arts..$^{5^{1}}$ From the impact Virgil's writings had on Renaissance culture, we can assume that Hoefnagel here wanted to point towards the political and religious struggles of his time, and reassure the audience of his miniature that through the fostering of the arts, a prosperous future was to be achieved..$^{2}$

A possible reason for Hoefnagel to prominently insert quotations from the Eclogues might have been one of Duke Albert's personal mottos - parcere subiectis et debellare superbos (to spare the vanquished and to crush the proud) - which the artist chose to stage in the two upper corners of the sheet. ${ }^{33}$ The motto is taken from the sixth book of Virgil's Aeneid in which Aeneas travels through the underworld and meets the ghost of his father Anchises who then makes his famous prophecy about imperial Rome. In Hoefnagel's miniature, it can be found among trophies of weapons and armour glorifying the military strength of the House of Wittelsbach..$^{54}$ The first half of the famous saying, parcere subiectis, is imbedded in the signum of a standard on the left depicting a lion protecting a lamb (Fig. 6.5), whereas the second half, $e t$

49 Because of this strong reference to the House of Habsburg, one can assume that the initial A could also refer to Albert's wife Anna.

50 Virgil, Eclogues, Georgics, Aeneid I-VI, trans. H. Rushton Fairclough, rev. G. P. Goold, Loeb Classical Library 63 (Cambridge, MA: Harvard University Press, 200o), 56-57 (Book V, 34).

$5^{1}$ Ibid., 34-35 (Book II, 45-46).

$5^{2}$ For Virgil's impact on Renaissance culture: Lukas B. T. Houghton and Marco Sgarbi, eds., Virgil and Renaissance Culture (Tempe, AZ: ACMRS, 2018).

53 Virgil, Eclogues, 592-593 (Book VI, 853); Vignau-Wilberg, “Joris Hoefnagels Tätigkeit in München,” 118.

54 David O. Ross, Virgil's Aeneid: A Reader's Guide (Malden, MA: Blackwell, 2007), 109. 

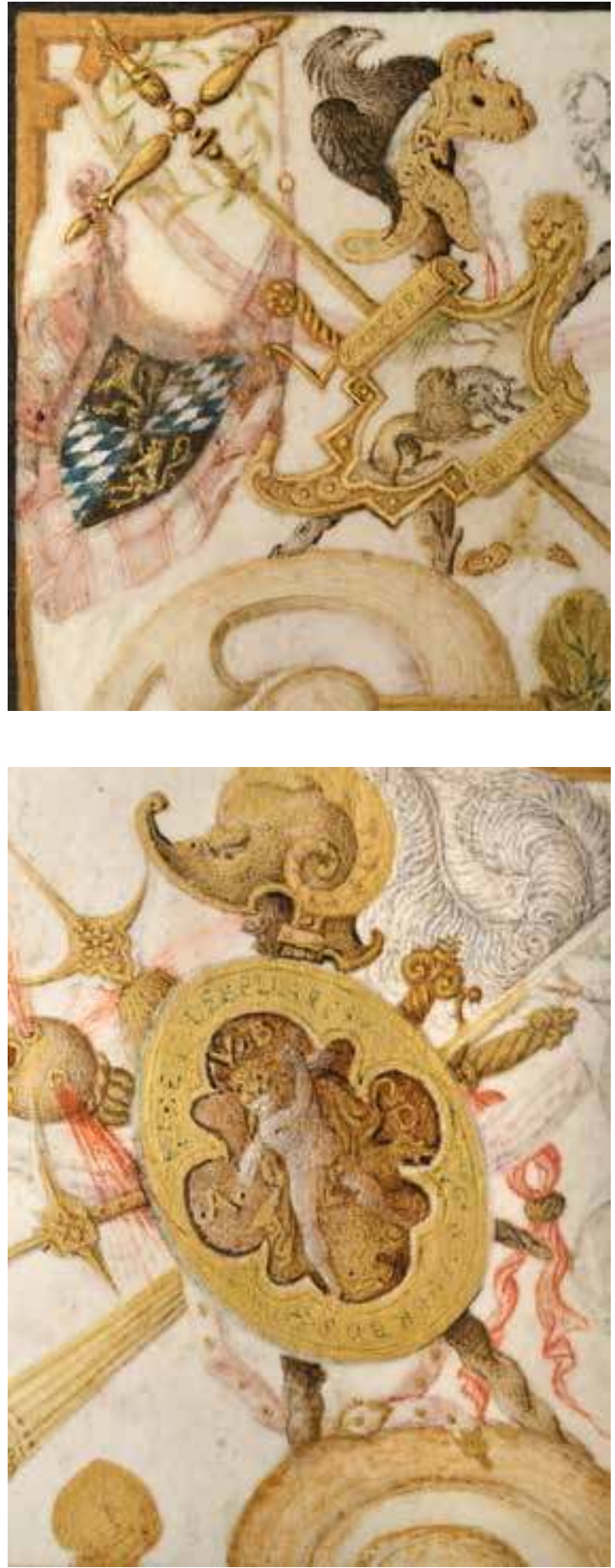

Figure 6.5: Joris Hoefnagel, Allegory of the Rule of Duke Albert V, detail of Fig. 6.1: Signum showing a lion protecting a lamb.

Figure 6.6: Joris Hoefnagel, Allegory of the Rule of Duke Albert V, detail of Fig. 6.1: Shield showing Hercules fighting the Nemean lion. 
debellare superbos, appears on the opposite side in a shield in front of various weapons showing Hercules fighting the Nemean lion (Fig. 6.6). The motto was most probably chosen by Albert for the first time in 1558 to adorn a medal that was modelled after counterparts issued by Charles V, who had also chosen Aeneas as the new forefather of the Habsburg dynasty. ${ }^{55}$ Presenting a lion attacking a bull, Albert's medal refers to the struggles of the Catholic sovereign in suppressing the Reformation. ${ }^{6}$ Hoefnagel's miniature engages with the Counter-Reformation programme of the Wittelsbach, also underlining the strong connections between the dynasties of the Houses of Wittelsbach and Habsburg, staged so prominently in the centre of his work.

The other important theme of the miniature is the fostering of the arts, which also characterized the patronage of the Wittelsbach dukes. The right side, dedicated to music, shows a harp surrounded by a garland of flowers with a banderol containing musical notation and the names Orlando Lassus and Cipriano Rore, two celebrated musicians at the Munich court (Fig. 6.7). ${ }^{57}$ The left side, dedicated to the visual arts and thus Hoefnagel's own profession, features a shield with a wooden hammer, a quill, a pen-knife, a brush, a ruler, two crossed chisels, a pair of compasses, and two squares (Fig. 6.8)..$^{8}$ The shield's pale yellow colour and the curling of its outer edges indicates that Hoefnagel was referring here to parchment as the material for his own miniatures. The helmeted owl, the bird of Pallas Athena, known for her wisdom and handicraft, embodies the artifice and ingenuity of Hoefnagel's work. Resting on a beehive, referring to Hoefnagel's virtue of diligence, and holding in its claw a caduceus or Hermes's staff, the owl also represents the concept of Hermathena, understood as the conjunction of the sciences and arts and frequently employed from the mid-century onwards..$^{59}$ The crucial importance of diligence in

55 Peter Diemer, “Wenig ergiebig für die Alte Pinakothek? Die Gemälde der Kunstkammer," in Diemer et al., Münchner Kunstkammer, 3:173; Walter Cupperi et al., eds., Wettstreit in Erz: Porträtmedaillen der deutschen Renaissance (Berlin: Deutscher Kunstverlag, 2013), 248-249. In the sixteenth century the strong reference to Aeneas was prominently introduced by Charles V and seems to have been adapted by Albert V: Marie Tanner, The Last Descendant of Aeneas: The Hapsburgs and the Mythic Image of the Emperor (New Haven, CT and London: Yale University Press, 1993).

56 For the Counter-Reformation in Bavaria: Philip M. Soergel, Wondrous in His Saints: Counter-Reformation Propaganda in Bavaria (Berkeley, CA: University of California Press, 1993); Alexander J. Fisher, Music, Piety, and Propaganda: The Soundscapes of Counter-Reformation Bavaria (Oxford and New York: Oxford University Press, 2014).

57 Vignau-Wilberg, Joris und Jacob Hoefnagel, 151-152.

$5^{8}$ Marisa Bass argues that the tools are arranged in the shape of a crossbow and bolts, implying that the peaceful arts are "a salvation from the war in his [Hoefnagel's] homeland": Marisa Anne Bass, "Mimetic Obscurity in Joris Hoefnagel's Four Elements," in Emblems and the Natural World, ed. Karl A. E. Enenkel and Paul J. Smith, Intersections 50 (Leiden and Boston, MA: Brill, 2017), 543-544.

59 Günter Irmscher, “'Hermathena' in der Hofkunst Prags und Münchens um 16oo,” in Bukovinská and Konečný, München - Prag um 1600, 85. Bass and Vignau-Wilberg identified the beehive as a helmet: Bass, "Mimetic Obscurity," 543; Vignau-Wilberg, Joris und Jacob Hoefnagel, 151. Nils Büttner, Einführung in die 

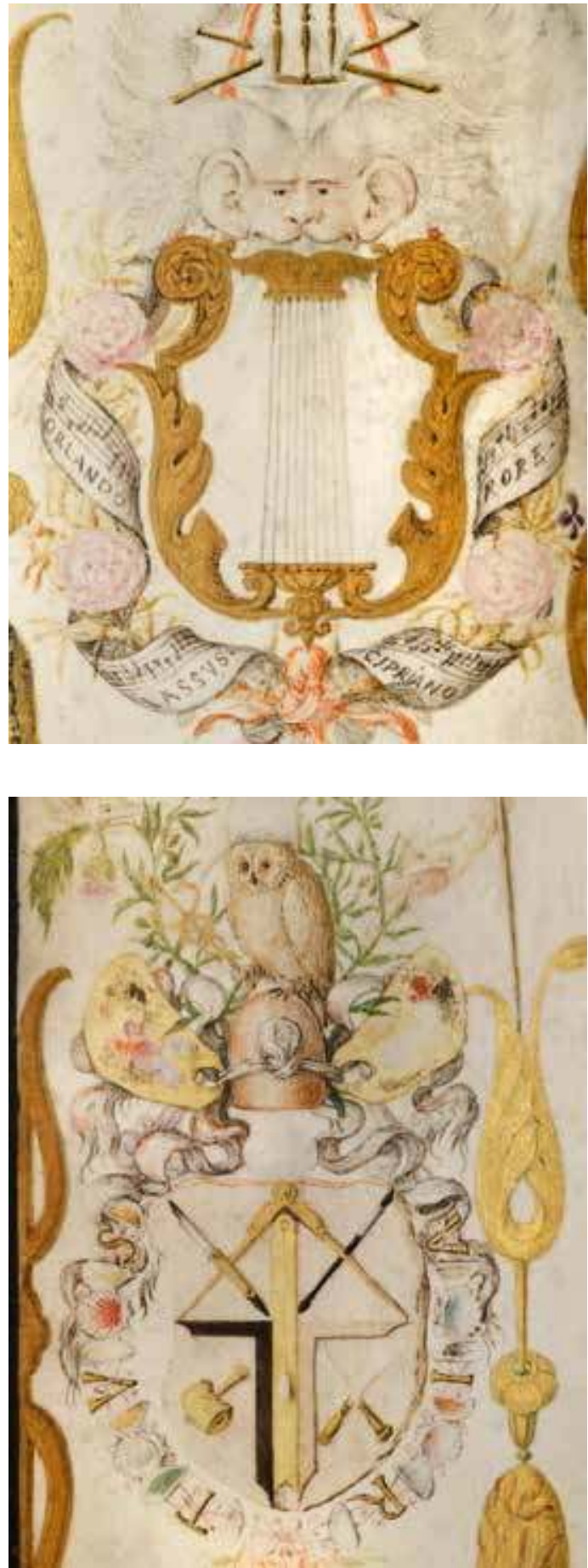

Figure 6.7: Joris Hoefnagel, Allegory of the Rule of Duke Albert $V$, detail of Fig. 6.1: The honouring of the musical arts.
Figure 6.8: Joris Hoefnagel, Allegory of the Rule of Duke Albert V, detail of Fig. 6.1: The honouring of the visual arts. 
Hoefnagel's artistic pursuit is also made evident in that two painters' palettes are attached with a white ribbon to the beehive. ${ }^{60}$ The chain surrounding the shield consists of various shells, each of them filled with a pigment - a reference to the pigments that had apparently been used by Hoefnagel for his very own work of art. ${ }^{61}$ The repeating pattern of the shells is interrupted by six golden letters forming the Latin word virtus.

By prominently inserting the word virtus among his painting tools, Hoefnagel is claiming virtus - and thus being a virtuoso - for himself. Virtuoso describes a person with high intellectual and moral qualities who tackled such themes as art, antiquity, and natural philosophy. Virtuosity thus referred on the one hand to the "artist's performance in physically executing the work," and on the other to the "materially-based property of the entity itself." In the early modern period it was assumed that natural materials such as plants and gems possessed inherent virtuous qualities which were able to protect people or cure them from illnesses. ${ }^{6}{ }_{3}$ These were the basic materials for the production of pigments, which further strengthened the relationship between virtues and the visual arts. ${ }^{64}$ As already mentioned, according to Van Mander, Hoefnagel knew Latin, was educated in literature "for which he also had a good talent," and was characterized by his biographer as a "lively spirit, [who] was learned and very inventive." ${ }^{65}$ Hoefnagel's nephew Christian Huyghens, son of his sister Susanna, notes that he competed with the highest virtues, and there is plausible evidence that Hoefnagel had been part of the Antwerp literati of his time. ${ }^{66}$ A guest book of the library in Munich

frühneuzeitliche Ikonographie (Darmstadt: Wissenschaftliche Buchgesellschaft, 2014), 94; Serebrennikov, "Imitating Nature/Imitating Bruegel," 233; Wilberg Vignau-Schuurman, Die emblematischen Elemente, 1:195. For the owl in general with reference to Hoefnagel: Astrid Zenkert, "The Owl and the Birds: Speeches, Emblems, and Fountains," in Enenkel and Smith, Emblems and the Natural World, 548-6o9.

6o Nicole Hegener, “'Diligentia in minimis maxima': Testament und Nachlaß des 'kleinen Michelangelo' Don Giulio Clovio," in Der Künstler und sein Tod: Testamente europäischer Künstler vom Spätmittelalter bis zum 20. Jahrhundert, ed. Nicole Hegener and Kerstin Schwedes (Würzburg: Königshausen und Neumann, 2012), 105-193; L. C. Cutler, "Virtue and Diligence: Jan Brueghel I and Federico Borromeo," in Virtue: Virtuoso, Virtuosity in Netherlandish Art 1500-1700, ed. Jan de Jong, Dulcia Meijers, Mariët Westermann, and Joanna Woodall, Netherlands Yearbook for History of Art 54 (Zwolle: Waanders, 2003), 202-227.

61 Bass, "Mimetic Obscurity," 543.

62 Joanna Woodall, “In Pursuit of Virtue," in de Jong et al., Virtue, 7, 9.

63 Suzanna Ivanič, "Early Modern Religious Objects and Materialities of Belief," in The Routledge Handbook of Material Culture in Early Modern Europe, ed. Catherine Richardson, Tara Hamling, and David Gaimster (London and New York: Routledge, 2017), 322-337.

64 Woodall, "In Pursuit of Virtue," 17.

65 Van Mander, Lives, 1:308-309 (fol. 262v): "in welcke hy oock goeden geest hadde"; 1:310-311 (263r): "gheestigh, gheleert, en seer vindigh was."

66 “[...] certarunt pietas et virtutes summae reliquae [...]," quoted from Vignau-Wilberg, Joris und Jacob Hoefnagel, 17, note 1. Vignau-Wilberg, "Joris Hoefnagel, The Illuminator," 18-19; Van Mander, Lives, 5:11; 
lists him as Dominus Hoefnagel, implying that he was well-read, since this was a term applied mainly to scholars. ${ }^{67}$

Interestingly, "instruments and equipment for writing and painting" also play a role in Samuel Quiccheberg's Inscriptiones; vel, tituli theatri amplissimi, a treatise on a possible ordering system for a Kunstkammer, written in Munich at Albert's court. ${ }^{68}$ In the third class of objects, alongside various herbs, Quiccheberg lists metals and precious stones, colours, and pigments "for staining, painting, and [...] special containers for oil paints and others for colors mixed with water and gum." ${ }^{\prime 9}$ The fourth class mentions materials for writing and painting such as "vellum, paper, panels, [...] reed pens," as well as "instruments for workshops and laboratories used by the more skilled artisans, such as the tools of sculptors, turners, goldsmiths, [...] and indeed of all artisans whom this world supports in our age." ${ }^{\circ 0}$ Even though the Munich Kunstkammer contained only a few tools that fitted into these categories, it is indeed noteworthy that such tools that "manipulate natural materials into artistic and artisanal works"71 were taken into consideration in the complex arrangement of the early modern Kunstkammer, and were used by Hoefnagel to present himself as the trained wielder of these instruments. ${ }^{72}$

In the Allegory of the Rule of Duke Albert VofBavaria, Hoefnagel employed shell gold lavishly. Shell gold can be discerned in the inscriptions, the leaves of the laurel tree, the cornucopias, the hair accessories of the nymphs, the armour, the shields, the ducal hat, the compasses, the pen-knife, the handle of the chisels, the caduceus, the harp, and in the grotesque decorations. He also refers to its usage in the ornamental chain of shells. ${ }^{73}$ Shell gold is occasionally combined with other pigments, as for example in the skirt of one of the nymphs, where red enhances its luminescent appearance. He was well aware of the fact that shell gold has its own colour nuances, depending on the amount of silver or copper added to it. Silver made colours appear cooler; copper more reddish and warmer. ${ }^{74}$ As an artist "exempted by

\footnotetext{
Meganck, Erudite Eyes.

67 Vignau-Wilberg, “Joris Hoefnagels Tätigkeit in München," 117.

68 Mark Meadow and Bruce Robertson, The First Treatise on Museums: Samuel Quiccheberg's Inscriptiones 1565 (Los Angeles, CA: Getty Research Institute, 2013), 67.

69 Ibid., 67.

70 Ibid., 67-68.

71 Ibid., 21.

72 Diemer et al., Münchner Kunstkammer, 2:565. The 1587 inventory of the Dresden Kunstkammer lists over 10,000 working tools, among them around 400 drawing instruments: Klaus Schillinger, ed., Zeicheninstrumente (Dresden: Staatlicher Mathematisch-Physikalischer Salon, 1990), 2.

73 I thank Dr Michael Roth, Hanka Gerhold, and Katrin Warnecke, Kupferstichkabinett Berlin, for discussing this aspect with me.

74 Anna Bartl and Manfred Lautenschlager, “Die Farben des Goldes: Glanzvergoldung in der Buchmalerei des Mittelalters," in Farbe im Mittelalter: Materialität, Medialität, Semantik, ed. Ingrid Bennewitz and
} 


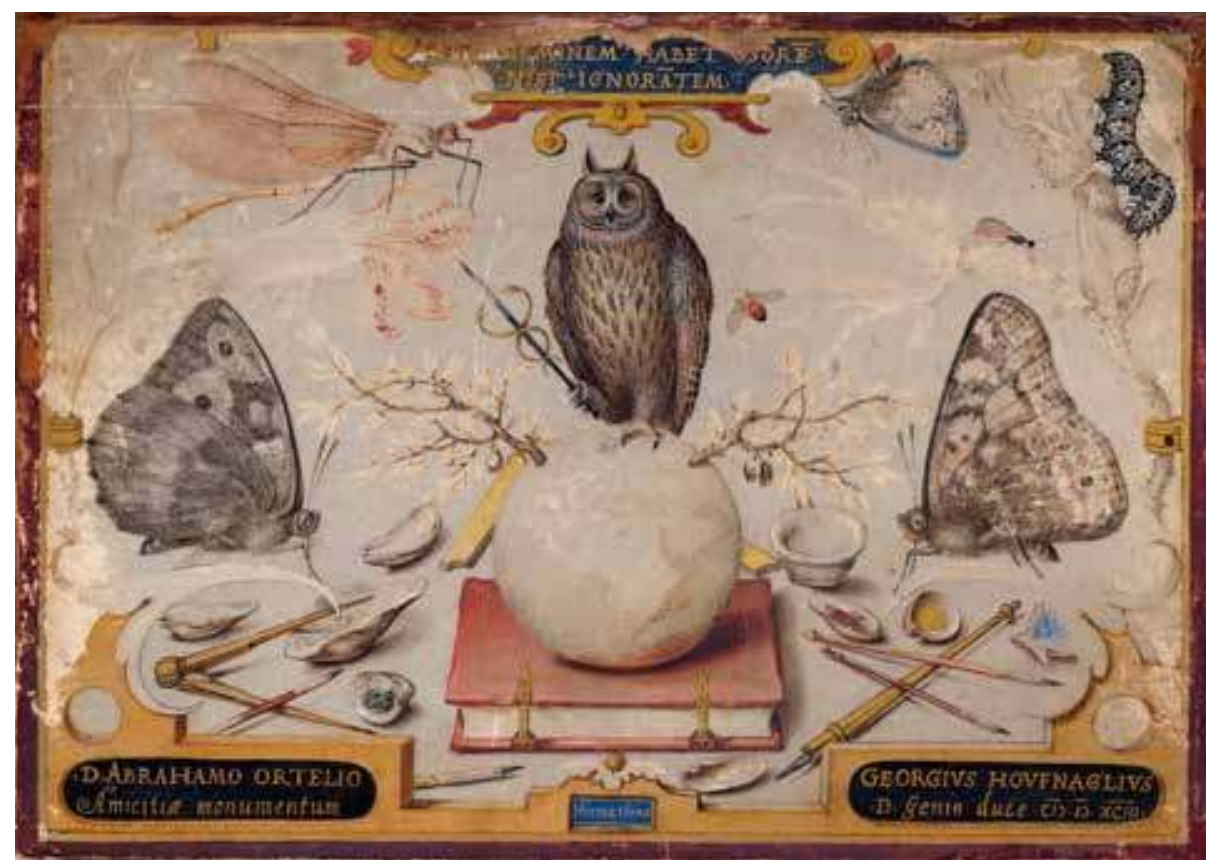

Figure 6.9: Joris Hoefnagel, Allegory for Abraham Ortelius, 1593. Pen and black ink and gouache, heightened with gold on parchment, $11.8 \times 16.5 \mathrm{~cm}$. Antwerp, Museum Plantin-Moretus, Prentenkabinet, inv. no. PK.OT.00535. Image @ Collectie Stad Antwerpen, Museum Plantin-Moretus.

court," Hoefnagel must have purchased his painting supplies on his own; he is not mentioned in the official account book of Wolfgang Pronner, for instance. ${ }^{75}$ From 1586 to 1590 , Pronner listed all the incomes and expenditures of artists' materials at the Munich court, a task that became necessary due to the fact that Wilhelm V was afraid that the materials had not been used for his own commissions. ${ }^{76}$ Pronner himself acquired all his "powdered gold" in nearby Augsburg, and we may assume that Hoefnagel utilized the same sources. Because of its subsequent method of storage, powdered gold was measured in shells, whereas for other pigments the common unit "lot" was used.77

As a result of the Munich court's increasing budgetary restrictions in the early 1590 and the implementation to disclose his professed faith, Hoefnagel began

Andrea Schindler, 2 vols. (Berlin: Akademie, 2011), 1:275.

75 Vignau-Wilberg, "Joris Hoefnagels Tätigkeit in München," 117.

76 Ursula Haller, Das Einnahmen- und Ausgabenbuch des Wolfgang Pronner: Die Aufzeichnungen des "Verwalters der Malerei" Herzog Wilhelms V. von Bayern als Quelle zu Herkunft, Handel und Verwendung von Künstlermaterialien im ausgehenden 16. Jahrhundert (Munich: Siegl, 2005), 12.

77 Gemalen Goldt was listed as Musch, Muschlin, Muschelin, Muschle, or Muschelyn: Haller, Einnahmen-und Ausgabenbuch des Wolfgang Pronner, 213-214. 
to seek another patron. ${ }^{78}$ From 1591 onwards and until his death, Hoefnagel was employed by none other than the Holy Roman Emperor Rudolf II as a painter under court protection for whom he also produced various intricate miniatures. ${ }^{79}$ Created while residing in Frankfurt, the 1593 Allegory for Abraham Ortelius, however, was not part of an official commission but motivated by the twenty-year-long friendship with the man who encouraged him so strongly to become an artist (Fig. 6.9). ${ }^{80}$

\section{A Monument of Friendship: The Allegory for Abraham Ortelius}

In a letter to his friend Ortelius, Hoefnagel hoped that the gift "will not displease" him and that he "desire[d] nothing but art for art," emphasizing once again their shared love for the arts. ${ }^{81}$ Here "the bonds of [...] friendship were what the exchange was supposed to cement," a friendship that during uncertain times offered not only personal intimacy and trust but also financial security and social protection. ${ }^{82}$

In the centre of the composition an owl - the bird of Athena, the goddess of wisdom and handicraft and, as we have seen, a self-referential figure for the artist - is

78 Vignau-Wilberg, Joris and Jacob Hoefnagel, 37-38; Vignau-Wilberg, "Joris Hoefnagels Tätigkeit in München," 149-151; Bass, Insect Artifice, 12.

79 Thea Vignau-Wilberg, "Forti viro omnis locus patria: 'Dem Starken gilt jeder Ort als Vaterland'," in Prag um ı6oo: Kunst und Kultur am Hofe Kaiser Rudolfs II., ed. Jürgen Schultze and Hermann Fillitz, 2 vols., exh. cat. (Freren: Luca, 1988), 2:24.

80 The first proof of their relationship is Hoefnagel's entry in Ortelius's album amicorum from 1574: Abraham Ortelius, Album amicorum, Cambridge, Pembroke College Library MS LC.2.113, 7r-7v, https:// cudl.lib.cam.ac.uk/view/MS-LC-0ooo2-00113/1. For the album see also Joanna Woodall, "For Love and Money: The Circulation of Value and Desire in Abraham Ortelius's Album Amicorum," in Ut Pictura Amor: The Reflexive Imagery of Love in Artistic Theory and Practice, 1500-170o, ed. Walter S. Melion, Michael Zell, and Joanna Woodall, Intersections 48 (Leiden and Boston, MA: Brill, 2017), 649-703; Meganck, Erudite Eyes, 16.

81 Joannes Henricus Hessels (ed.), Abrahami Ortelii (geographi Antverpiensis) et virorum eruditorum ad eundem et ad Jacobum Colium Orteliuanum (Abrahami Ortelii sororis filium) epistulae, cum aliquot aliis epistulis et tractatibus quibusdam ab utroque collectis (1524-1628), 3 vols. (Cambridge: Typis Academiae, 1887), 1:566-567: “[...] nijet anders dan const tegen conste [...]." Although Hessels thinks that Hoefnagel could have meant another miniature painting, Vignau-Wilberg and Popham assume that he was referring to the Allegory of Abraham Ortelius: A. E. Popham, "On a Letter of Joris Hoefnagel," Oud Holland 53, no. 4 (1936): 145-151; Vignau-Wilberg, Joris und Jacob Hoefnagel, 176. The letter mentions that Hoefnagel has already made a miniature painting for Ortelius and has now reworked and supplemented it: Vignau-Wilberg, Joris und Jacob Hoefnagel, 176. For the idea that paintings could also secure friendships: Joseph Leo Koerner, "Freundschaftsbildnisse," in Hans von Aachen (1552-1615): Hofkünstler in Europa, ed. Thomas Fusenig (Berlin and Munich: Deutscher Kunstverlag, 2010), 63-73.

82 Heal, Power of Gifts, 31; for Ortelius's album amicorum and the importance of friendship networks see Jason Harris, “The Practice of Community: Humanist Friendship during the Dutch Revolt," Texas Studies in Literature and Language 47, no. 4 (Winter 2005): 299-325. 
standing on a pedestal-like construction consisting of a book and a terrestrial globe while holding in its claw a brush with two intertwined golden serpents transforming it into a caduceus. The inscription in the oval cartouche in the left-hand corner, $D$ [omino $]$ Abrahamo Ortelio amicitiae monumentum, refers to Ortelius as the dedicatee of this "monument of friendship," which in the cartouche in its right-hand corner, Georgius Houfnaglius D[edit] genio duce 1593, points to Hoefnagel as its creator and also notes that the artist was guided by his genius. ${ }^{83} \mathrm{~A}$ third inscription, Ars neminem habet osorem nisi ignorantem (Art has no enemy except the ignorant ${ }^{84}$ ) might be seen as the motto of the miniature celebrating the friendship between two learned lovers of the arts. While the left-hand side, with the cartographer's compasses, three empty shells and a clam filled with black ink, as well as two brushes with black tips, is dedicated to Ortelius, the right-hand side engages with Hoefnagel himself, showing a mussel with brownish-red, a scallop with blue, and another clam with gold pigments (Fig. 6.10). ${ }^{85}$ In addition, a pen, two brushes of different sizes, and a little bowl are depicted. The whole scene is encompassed by a golden frame to which flowers and various insects such as butterflies, a dragonfly, and a caterpillar seem to be attached. Two olive branches emerge from the globe, which is also framed by two giant butterflies. The caterpillar, dragonfly, and butterflies emphasize nature's transformative powers, qualities that also apply to Hoefnagel's art. ${ }^{86}$ Marisa Bass has suggested that the two butterflies could be read as figurations of Hoefnagel and Ortelius, perhaps hinting towards the transformative power of friendship and certainly also to the ephemerality and transience of life. ${ }^{87}$

The arrangement in the centre of the sheet - the book, the owl, and the caduceusbrush - must thus be understood as ambiguous, consciously oscillating between the various arts and sciences practised by the two learned friends (Fig. 6.11). The book stands for the pursuit of knowledge undertaken by the two men while the

83 Quoted from Bass, Insect Artifice, 253, note 117. Bass dedicated a whole chapter to "monuments of friendship": ibid., 75-100, for the Allegory for Ortelius esp. 94-98.

84 Quoted from Zenkert, "Owl and the Birds," 568.

85 Shells became sought-after collectables and entered princely chambers of curiosities and the collections of humanists and merchants all over Europe in the sixteenth and seventeenth centuries: Karin Leonhard, "Shell Collecting: On 17th-Century Conchology, Curiosity Cabinets and Still Life Painting," in Early Modern Zoology: The Construction of Animals in Science, Literature and the Visual Arts, ed. Karl A. E. Enenkel and Paul J. Smith, 2 vols., Intersections 7 (Leiden and Boston, MA: Brill, 2007), 1:177-214; Leopoldine van Hogendorp Prosperetti, “'Conchas Legere': Shells as Trophies of Repose in Northern European Humanism," Art History 29, no. 3 (2006): 387-413. Shells with gold encrusted inside them were understood as objects worth collecting in their own right. The account book of Archduke Ernest of Austria contains the following entry: "Per 145 muscheln mit goldt, $10 \mathrm{fl} .27 \mathrm{kr}$." Herbert Haupt and Alexander Wied, "Erzherzog Ernst von Österreich (1553-1595): Statthalter der Spanischen Niederlande; Das Kassabuch der Jahre 1589 bis 1595," Jahrbuch des Kunsthistorischen Museums Wien 12 (2010): 234.

86 Wilberg Vignau-Schuurman, Die emblematischen Elemente, 1:174, 177.

87 Bass, Insect Artifice, 95 . 


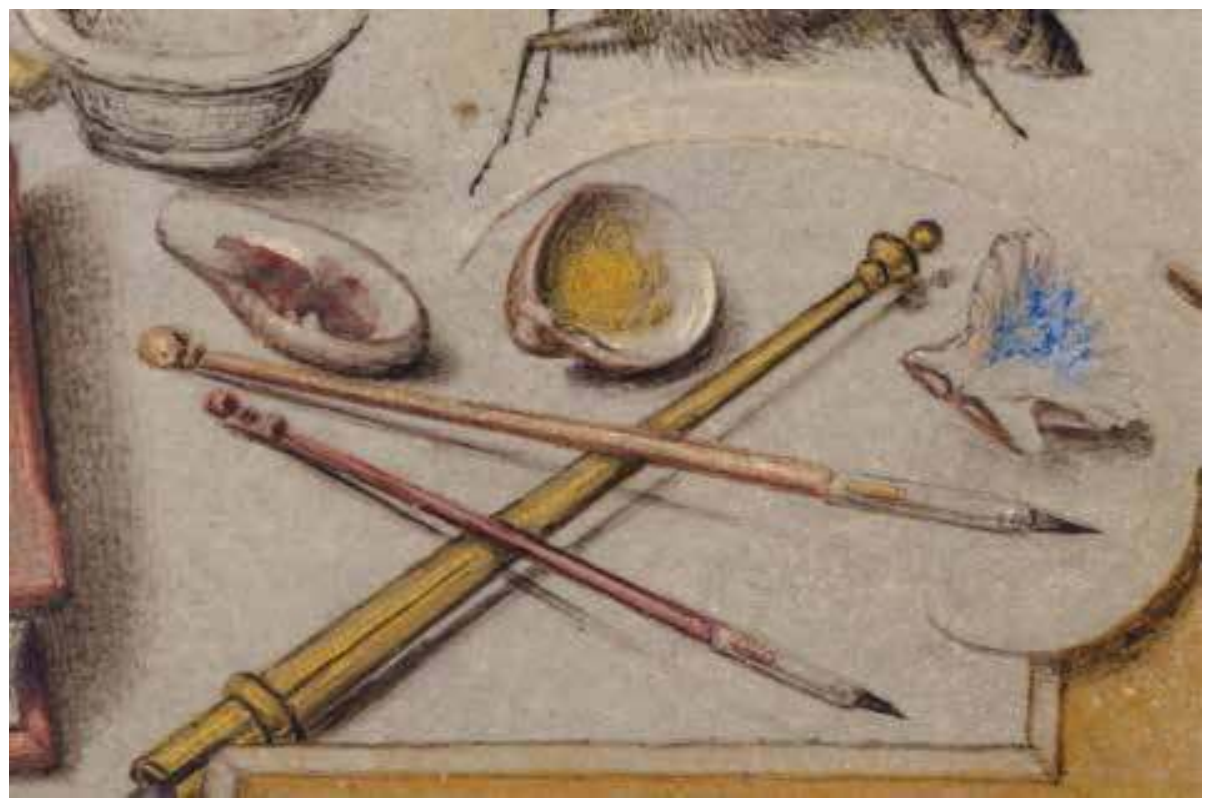

Figure 6.10: Joris Hoefnagel, Allegory for Abraham Ortelius, detail of Fig. 6.9: Sea shells serving as containers for various pigments.

brush-turned caduceus held by the Athenian owl may also emphasize that the arts practised by both Hoefnagel and Ortelius depended on the brush; Ortelius, praised by Petrus Bizarus as an "everlasting ornament [...] educated by Minerva [i.e. Athena]," had begun his career as a colourist of printed maps. ${ }^{89}$ Johannes Radermacher - a humanist, merchant, and close friend of both Ortelius and Hoefnagel - described in a letter to Ortelius's nephew Jacobus Colius how his famous uncle coloured the maps "with so much skill, that they surpassed and supplanted all other maps." Hoefnagel's "monument of friendship" thus visualizes the uniting force of friendship and its power to amalgamate professional interests and ambitions.

In regard to the use of shell gold, Hoefnagel did not merely depict it in its container but again used the material extensively in the overall composition. Shell gold was

88 Hessels, Abrahami Ortelii, 1:75: "ORTELI, patriae tuae, ac tuorum, / Totiusque etiam decus perenne / Orbis, te gremio suo Minerva."

89 Ortelius was listed in the Guild of Saint Luke in 1547 as afsettervan carten: Leon Voet, "Abraham Ortelius and his World," in Abraham Ortelius and the First Atlas: Essays Commemorating the Quadricentennial of his Death, 1598-1998, ed. Marcel van den Broecke, Peter van der Krogt, and Peter Meurer (Houten: HES, 1998$), 15$. 90 Hessels, Abrahami Ortelii, 1:787. Johannes Radermacher was the mentor and longstanding friend of Hoefnagel. In 1589 Hoefnagel dedicated a painting and a miniature to him: Thea Vignau-Wilberg, "Freundschaft für die Ewigkeit:Joris Hoefnagels unbekannte Miniatur für Johannes Radermacher," in Libellus Amicorum: Beket Bukovinská, ed. Lubomír Konečný and Lubomír Slavíček (Prague: Artefactum, 2013), 112-125. 


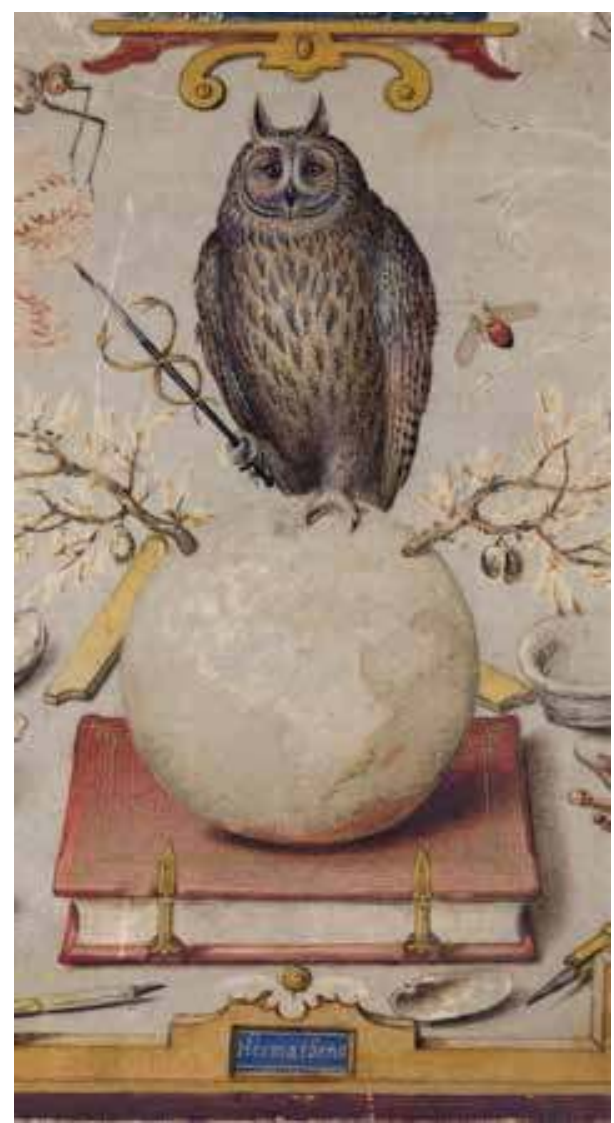

Figure 6.11: Joris Hoefnagel, Allegory for Abraham Ortelius, detail of Fig. 6.9: The owl holding a caduceus with a brush as its central staff.

used for all the inscriptions, the thin frame of the image, the different brushes, the compasses, the filigree ornamentation of the book, and its golden buckles. It was applied in nearly every detail, including the eyes of the owl, the two intertwined serpents of the caduceus as well as the wings of the insects. Shell gold was the principal and certainly the costliest material of miniaturists, who were well aware of its unique qualities and splendour. Edward Norgate (1581-1650) writes that the works of Giulio Clovio are "soe heightned with shell gold as, howe unnaturall soever, gives great beauty." ${ }^{\prime 11}$ Geerard ter Brugge, in his Verlichtery kunst-Boeck, states that "one cannot find a colour that surpasses the gold in splendour and strength."92

92 Quoted from Geerard ter Brugge, Verlichterie-Kunde of recht gebruyck der Water-Verwen [...], ed. and ext. Willem Goeree (Middelburg: Wilhelmus Goeree, 1670), 16: "Dewijle daer geen Verwe en is, die het Gout in kracht en glans kan te boven haelen, soo en salmen het selve nergens alleen aenlegen [...].” 
Unlike objects made of gold that could be melted down, shell gold became irretrievably attached to the surface once put onto the parchment. Within the context of this specific "monument of friendship," shell gold may thus also refer to the durability and strength of friendship as well as to its preciousness and power, as indicated by the "golden" tip of the brush-turned-caduceus held by Athena's owl.93 This creates the illusion that the brush depicted was the one used to paint the image, stressing once more that Hoefnagel understood his hand as being "guided by Nature," nature here being symbolized by the Hermathenian owl. The brush-turned-caduceus, transforming the artist's tool into the principal attribute of Hermes, also alludes to the god as patron of the arts. ${ }^{94}$ It can, however, only be speculated which shell gold recipe Hoefnagel used for his own works and whether he produced the precious pigment himself or relied on the help of an assistant. The reconstruction of two historical recipes outlining how to make shell gold will help us to better understand early modern miniaturists' engagement with this precious material.

\section{Producing Shell Gold: Reconstruction as an Art Historical Method}

By taking as an integral part of their understanding the material out of which works of art including miniatures were made, conservators, historians of science, and art historians have begun to focus more and more on reconstruction as a method of study. ${ }^{95}$ Although quite common in other disciplines such as archaeology, it is only in recent years that reconstruction has become a more accepted tool within

93 There is also a slim brush-turned-caduceus on folio 20 of Georg Bocskay's Book of Writing Patterns (1571/1594) in Vienna. Around 1590 Hoefnagel depicted the figures Hermes and Pallas Athena or their attributes several times: Wilberg Vignau-Schuurman, Die emblematischen Elemente, 1:195-198; Serebrennikov, "Imitating Nature/Imitating Bruegel," 233-234.

94 For Goltzius's engagement with Hermes/Mercury: Christine Göttler, "Tales of Transformation: Hendrick Goltzius's Allegory of the (Alchemical) Arts in the Kunstmuseum Basel," in Epistemic Images in Early Modern Europe, ed. Alexander Marr and Christopher P. Heuer, special issue, 21: Inquiries into Art, History, and the Visual 1, no. 2 (2020): 403-446.

95 Pamela H. Smith and The Making and Knowing Project, "Historians in the Laboratory: Reconstruction of Renaissance Art and Technology in the Making and Knowing Project," Art History, Special Issue: Art and Technology in Early Modern Europe 39, no. 2 (2016): 210-233; Ulinka Rublack, "Renaissance Dress, Cultures of Making, and the Period Eye," West 86th/A Journal of Decorative Arts, Design History, and Material Culture 23, no. 1 (2016): 6-34; Michèle Seehafer, "Interview with Marta Ajmar," 18 June 2018, https:// www.materializedidentities.com/single-post/2018/o6/13/Interview-with-Marta-Ajmar. There are several major research projects where reconstruction plays a significant part in their understanding of a given technique or material and as a source of evidence: The Making and Knowing Project (Columbia University, New York), Recipes and Realities (NICAS, Amsterdam), ARTECHNE (Utrecht University, Utrecht), and Minding Making (Harvard University, Cambridge). 
art history. ${ }^{6}$ Researchers have emphasized the valuable insights gained from personal involvement with specific materials; as stated by Marta Ajmar, "even the first contact [with it] makes you aware of the resistance and potential of the material."97 According to Ajmar, reconstruction also results in a "deep understanding of temporality," especially given the fact that recipes do rarely specify how much time a certain process demands..$^{8}$ Pamela H. Smith has observed that early modern practitioners had a far more "intimate knowing" of materials than historians have nowadays. 99

Therefore, reconstruction allows us to "get closer to historical sensory experiences."100 Active physical engagement with materials or techniques provides more insight into the past than would be possible by simply analysing written sources. ${ }^{101}$ Because reconstruction is partially based on subjective, plausible, but not fully verifiable experiences and interpretations, this method has still not received the attention it deserves in scientific writing. Departing from an understanding of "materials as active components in the conception, production and interpretation of artworks," the final section of this chapter explores the ways in which shell gold can be produced and how this transformation from a solid to a liquid state can be achieved. ${ }^{102}$

With the assistance of Katharina Harsch, a conservator with initial training as a gilder, two different recipes, involving non-toxic ingredients, have been reconstructed. ${ }^{103}$ As shell gold seems to go back to illuminated books, one recipe from the Liber illuministarum of the Tegernsee monastery was selected - one of the major recipe collections in Central Europe, produced around 1500. It is a composite manuscript that brings together in its 231 folios recipes for painting and colour technology, texts on medicine, mathematics, housekeeping, pyrotechnics, metallurgy, alchemy, and

96 Hjalmar Fors, Lawrence M. Principe, and H. Otto Sibum, "From the Library to the Laboratory and Back Again: Experiment as a Tool for Historians of Science," Ambix 63, no. 2 (2016): 86. Erwin Panofsky already considered reconstruction as a suitable tool for art history: Sven Dupré, "Re-enactment in Teaching Art History (Part 1)," Artechne, 21 December 2017, https://artechne.wp.hum.uu.nl/ re-enactment-in-teaching-art-history-part-1/.

97 Seehafer, "Interview with Marta Ajmar."

98 Ibid.

99 Smith and The Making and Knowing Project, "Historians in the Laboratory," 227.

100 Michèle Seehafer, "Interview with Sven Dupré," 2 August 2017, https://www.materializedidentities. com/single-post/2017/08/02/Interview-with-Sven-Dupr\%C3\%A9.

101 Scholars of reconstruction are very well aware of the limits of this method and it cannot be used as a tool for historical accuracy: Fors, Principe, and Sibum, "From the Library to the Laboratory and Back Again," 89; Dupré, "Re-enactment in Teaching Art History (Part 1).”

102 Ann-Sophie Lehmann, "How Materials Make Meaning," in Meaning in Materials, 1400-180o, ed. Ann-Sophie Lehmann, Frits Scholten, and H. Perry Chapman, Netherlands Yearbook for History of Art 62 (Leiden and Boston, MA: Brill, 2013), 7.

103 I would like to thank Katharina Harsch and Franca Mader, both working at the Bern University of the Arts, Conservation and Restoration, for their help during the reconstruction. 
tanning. ${ }^{104}$ It contains various recipes, but the main focus is clearly on illuminating books and how different inks, colours, and binders of various raw materials can be produced and how paper, parchment, and leather can be fabricated and dyed. ${ }^{105}$ The second recipe derives from the widely known Augsburger Kunstbüchlin, published in 1535, which was translated into Dutch as early as 1549 and published under the title Kunst boeck: Nyeulijck wten alchemistischsten gront vergadert. ${ }^{106}$ It is a compilation of various older recipes and includes instructions for metal work, for the production of colour for illuminated manuscripts, for dying various organic materials such as wood, horn, and bone, for testing the purity of precious metals, and for alchemy. ${ }^{107}$

The recipe from the Liber is entitled "How to write with gold or silver."108 To produce shell gold, twenty to twenty-four gold leaves had to be placed on a grinding stone. We were almost immediately confronted with the stickiness of the material, as we were unable to put the leaves down on a glass plate with bare fingers and thus had to use a gilding knife. How thin gold leaf was in former times is elusive, but Cennini stated that from a single gold ducat, one should be able to beat out one hundred leaves. ${ }^{109}$ The second step involved moistening the leaf with vinegar, sprinkling it with salt, and leaving it for an hour. As there were no clear instructions in the recipe about how much vinegar was needed and how to apply it to the leaves, we dripped the vinegar carefully from a brush. From then on, the gold leaves remained on the plate and did not blow away at the slightest movement, as they had before. The pile of gold leaves fell in on itself and the weight of the sea salt encouraged this process. After one hour we began to grind the mixture. Unfortunately, some of the gold leaves stuck so firmly to the plate that it was difficult to remove them. The mixture seemed to be so delicate that we decided to use a gilding knife, rather than a glass muller, for the grinding. After forty-five minutes of grinding, all that was left was a grey, granular mass which had none of the luminous characteristics of gold (Fig. 6.12). We then moved the whole mixture into a mussel shell and filled it up with water to allow it to coalesce. In about an hour, the supernatant water had been drained off, and most of the gold particles had settled on the bottom; nonetheless, a few particles still remained on the surface (Fig. 6.13). This step was repeated several times until there was no vinegar or salt left, by which point the

104 For painting as a kind of alchemy see also the chapter by Christine Göttler in this volume, as well as Göttler, "Tales of Transformation."

105 Bartl et al., Liber illuministarum, 11, 28-48.

106 And republished in 1581 and 1600: Marieke van Delft, "Een alchemistisch boekenraadsel," 29 August 2012, https://www.kb.nl/blogs/boekgeschiedenis/een-alchemistisch-boekenraadsel.

107 Some of the recipes seem to come originally from the Liber illuministarum. The book was quickly translated and published in the Netherlands: Striebel, "Das Augsburger Kunstbuechlin von 1535," 11-12. 108 Bartl et al., Liber illuministarum, 6o-63: "quomodo scribatur cum auro uel argento."

109 Cennini, Book of the Art, 115. 


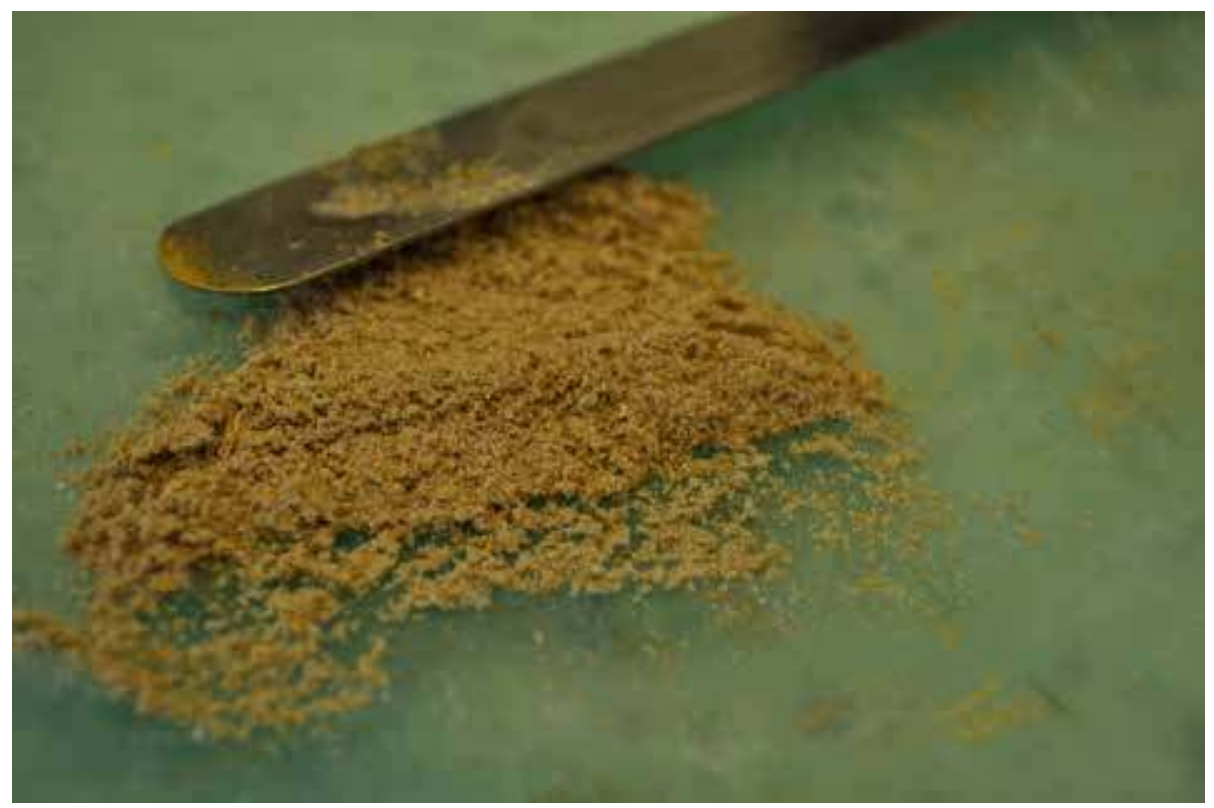

Figure 6.12: Photograph from the reconstruction of the recipe of the Liber illuministarum, showing the grey granular mass after grinding. Image $\odot$ Michèle Seehafer.

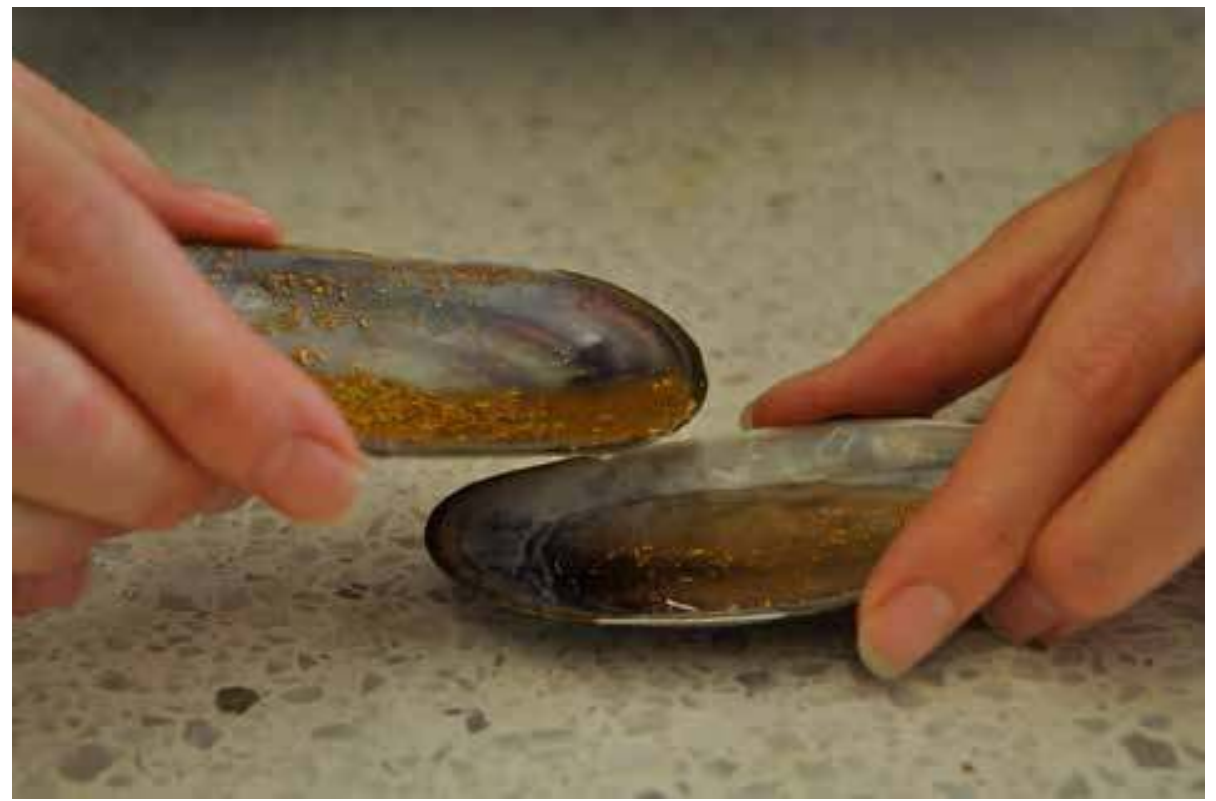

Figure 6.13: Photograph from the reconstruction of the recipe of the Liber illuministarum, showing the pouring off of the water from the mussel shell. Image @ Franca Mader. 
mixture had regained its brilliance. Although the natural shape of the mussel shell appears suitable for draining off the water, this step resulted in a massive loss of material because each time the water was poured out, some gold particles disappeared. The last step was to add gum arabic to the gold mixture and stir it with a wooden stick. It was quite difficult to apply the shell gold to parchment as the gold particles stuck to the brush. It turned out that it was better applied with the tip of a wooden stick. When the paint had been applied and dried, the shimmer was enhanced by polishing it with a burnishing stone.

The recipe from the Kunstbüchlin ("To write gold out of a pen") was structured similarly, but instead of vinegar and sea salt it called for honey and sea salt in "equal measure" (Fig. 6.14). ${ }^{110}$ In contrast to the first recipe it required just one gold leaf to be ground. ${ }^{111}$ It also suggests adding a little ayr wey $\beta$ (the part that settles when you beat the glair) to the mixture before transferring it to a shell. The colour did not change as much, since the stickiness of the honey and glair supported the brilliance of the gold. The recipe then recommended stirring "until no impure substances remain in there," which was interpreted as grinding it until no large pieces of gold leaf were left. But since the next step was to add the gum arabic to the sticky, sweet-smelling mixture, it seemed plausible that, what the author meant by "impure," was to drain the salt and the honey just as in the previous recipe. As before, this step had to be repeated several times. It was evident how much smaller the particles were when produced with the honey, egg-white, and salt mixture. Compared to the first recipe, which required a much larger amount of gold leaf, this one produced a reasonable quantity of shell gold. This second recipe also instructed adding gum arabic to the gold particles at the end and, after application, burnishing it. The exact wording was "temper it with gum arabic" - "to temper" (from Latin temperare) meaning to mix something. In his Treatise Concerning the Arte of Limning, Nicholas Hilliard points to the fragility of shell gold when he explicitly mentions that it "must not be tempered with the finger, but only with the pencil, and with as little gum as will but bind it that it wipe not off with every touch."112 A few years later, Edward Norgate insisted that the pencil used for applying shell gold should only be used for that purpose and not be mixed with other colours, underlining once more the special affinity and appreciation of miniature painters for this delicate material. ${ }^{113}$

In comparison with the first recipe, the second was much easier to apply to parchment because the gold particles were so small (Fig. 6.15). Retrospectively, we

\footnotetext{
110 gleicher schwere: Anonymous, Kunstbüchlin, 13b: "Golt aus der Feder zu schreiben."

111 Today there exists a standard format for gold leaves of $8 \times 8 \mathrm{~cm}$.

112 Nicholas Hilliard, $A$ Treatise Concerning the Arte of Limning together with a More Compendious Discourse Concerning ye Art of Liming by Edward Norgate, ed. R. K. R. Thornton and T. G. S. Cain (Ashington: Mid Northumberland Arts Group, in association with Carcanet New Press, 1981), 99.
}

113 Ibid., 121. 


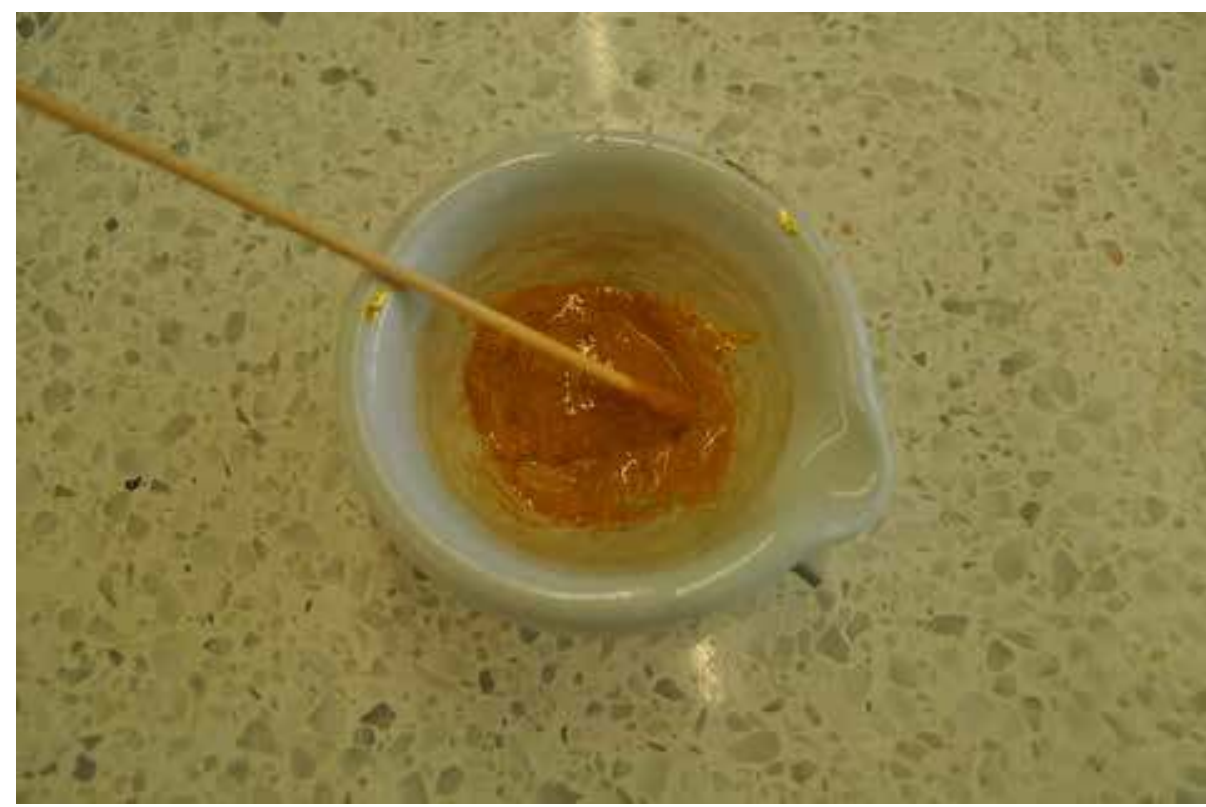

Figure 6.14: Photograph from the reconstruction of the recipe of the Kunstbüchlin, showing the mixture of gold leaf, sea salt, honey, and "ayr weyß." Image $\odot$ Michèle Seehafer.

thought that in the first recipe we should have repeated the grinding process more often, as the resultant paint was clumpy and difficult to apply. That the visual effects of shell gold are strongly linked to the material's properties became clear while reconstructing the first recipe. During this process, the gold was transformed into a non-shimmering and rather sand-like substance and only regained its intricate luminosity and vibrancy as a finished product. Both recipes turned out to require a considerable amount of time as we spent almost seven hours to produce them. The process did not yield very much paint at all and incurred the loss of a large amount of material, which may be why the paint was so expensive, and not just because of its monetary value. ${ }^{114}$

It is striking how many steps in the two recipes demanded active physical involvement of hands and fingers. Lambros Malafouris has pointed out that most artisans can perform things but "do not know how they do it or [...] simply lack the means to express or communicate this," and that in this process, the fingers play an important role. ${ }^{15}$ Several times during the reconstruction we became

114 In Pronner's account book shell-gold shells were listed with a price of 9.5 Kreutzer, compared to shells with silver of 7.5 Kreutzer: Haller, Einnahmen- und Ausgabenbuch des Wolfgang Pronner, 159.

115 Lambros Malafouris, “At the Potter's Wheel: An Argument for Material Agency,” in Material Agency: Towards a Non-Anthropocentric Approach, ed. Carl Knappett and Lambros Malafouris (New York: Springer, 2008), 19 . 


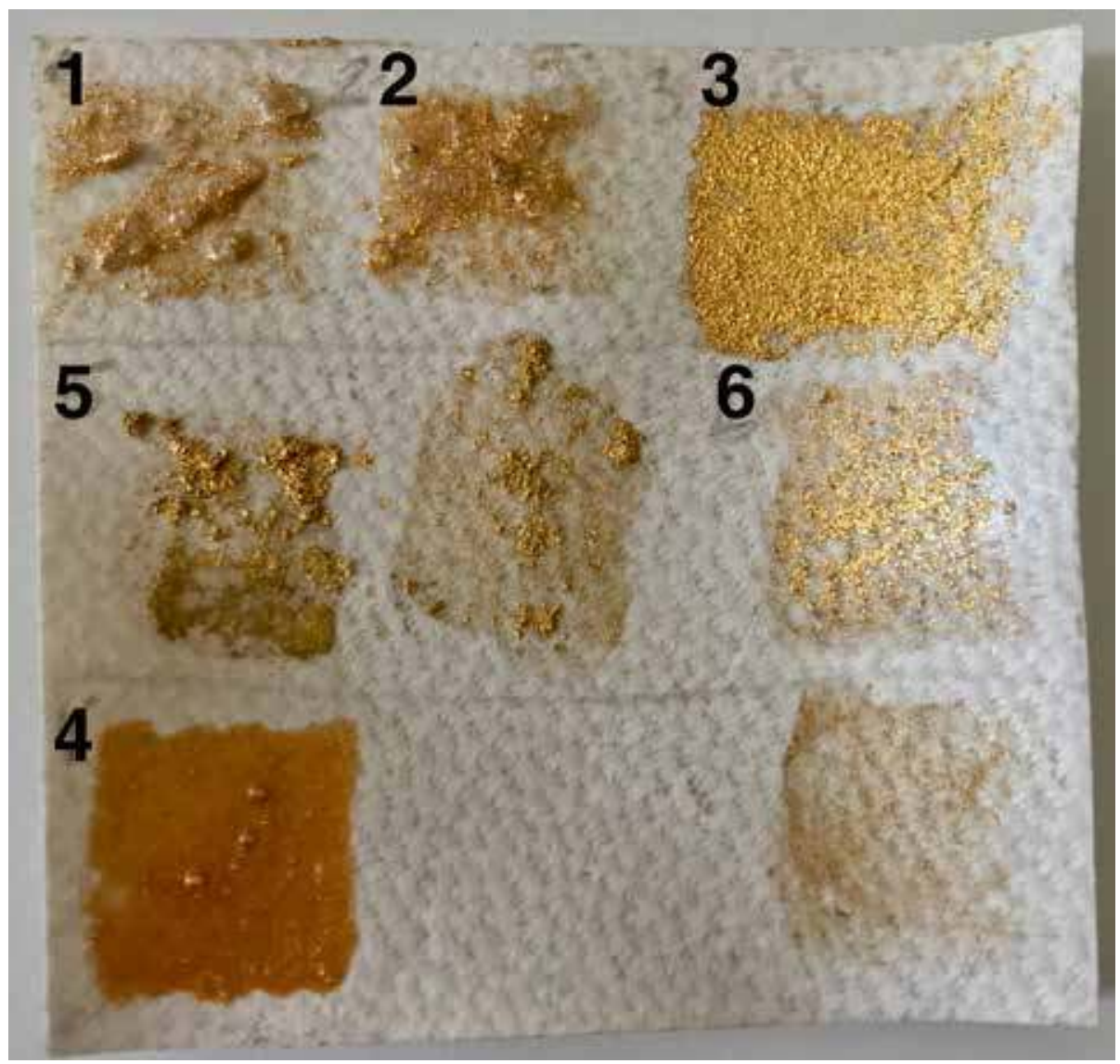

Figure 6.15: Photograph of reconstructed shell-gold paint (nos. 1-3 from the reconstruction of the recipe of the Liber illuministarum and 5-6 from the reconstruction of the recipe of the Kunstbüchlin) and modern pearlescent pigments (no. 4). Image @ Michèle Seehafer.

aware of the fact that, even though the recipe gave clear instructions, several steps were missing, presumably because we lacked both the "embodied knowledge of an artisan" and the years of experience and practice that Joris Hoefnagel or his assistant would have had. ${ }^{116}$ Even though we are not experts in the field of pigment production, the reconstruction gave us a glimpse of the textures and possibilities of the material as well as of its production processes, allowing for a different perspective on Hoefnagel's miniatures and his virtuoso appliance of shell gold. Further still, even seeing the production of this material as a virtuoso act became possible.

116 Pamela H. Smith, The Body of the Artisan: Art and Experience in the Scientific Revolution (Chicago, IL: University of Chicago Press, 2004). 


\section{Conclusion}

As I hope to have shown in this chapter, Hoefnagel connected his work as a miniaturist with the use of liquid gold; he was well aware that such smaller works were generally viewed while being held in the hands and that the movements of viewers even enhanced the shimmering qualities of shell gold. Both the Allegory of the Rule of Duke Albert V of Bavaria and the Allegory for Abraham Ortelius were created as cabinet pieces. In the case of the Allegory for Abraham Ortelius, the parchment was pasted onto a wooden panel, a method that can be observed in some of his other works. ${ }^{117}$ The 1598 inventory of the Munich Kunstkammer states that the Allegory of the Rule of Albert $V$ was at that time surrounded by an elaborate white wooden frame, but it remains unclear if this meant that the miniature painting was hung on a wall. ${ }^{.18}$

Access to these miniatures was generally limited. In Munich, the dukes themselves determined who would receive access based on a recommendation, as was the case with Hoefnagel and Ortelius. ${ }^{119}$ In the case of the Allegory for Abraham Ortelius, it is reasonable to assume that the cartographer showed the sheet only to certain friends. ${ }^{120}$ Viewed and studied close up, these "golden miniatures" stirred viewers' senses and affects, and probably had an engrossing effect over the mind. ${ }^{121}$ Miniature painters frequently used shell gold to enhance the luxuriousness and brilliance of their works. Hoefnagel, extolled by his contemporaries for his humanist

11 Bass, Insect Artifice, 94, 98-99; Vignau-Wilberg, Joris und Jacob Hoefnagel, 13-14; Thea Vignau-Wilberg, "Unbekannte Kabinettminiaturen von Joris Hoefnagel," Jahrbuch der Kunsthistorischen Sammlungen in Wien 85/86 (1989/9o): 73-74. A miniature on parchment dedicated by Hoefnagel to Johannes Radermacher was kept in a special box: Vignau-Wilberg, Joris und Jacob Hoefnagel, 155-156. Cabinet pieces were frequently stored in cupboards, drawers, desks, or even art cabinets. We know that some of Giulio Clovio's works were kept in little cases: Christine Göttler, “Affectionate Gifts: Rubens's Small Curiosities on Metallic Supports," in Munuscula Amicorum: Contributions on Rubens and his Colleagues in Honour of Hans Vlieghe, ed. Katlijne Van der Stighelen (Turnhout: Brepols, 2006), 5 1.

118 Diemer et al., Münchner Kunstkammer, 2:893: "Die ganze dafl umb und umb mit zugwerch, unden her mit einer Poetischen schrifft, alles künstlich und subtil auß weißem holz geschnitten, von handen Mathiesen Schällings Kunstkamerverwallters.” Diemer, “Wenig ergiebig für die Alte Pinakothek," 148.

119 Seelig, "Die Münchner Kunstkammer," 10.

120 For Ortelius's collection: Meganck, Erudite Eyes, 157-163; Nils Büttner, "Abraham Ortelius comme collectionneur," in Abraham Ortelius (1527-1598), cartographe et humaniste, ed. Robert W. Karrow (Turnhout: Brepols, 1998), 168-180; Christine Göttler, "Extraordinary Things: 'Idols from India' and the Visual Discernment of Space and Time, circa 1600," in The Nomadic Object: The Challenge of World for Early Modern Religious Art, ed. Christine Göttler and Mia M. Mochizuki, Intersections 53 (Leiden and Boston, MA: Brill, 2018), 35-73.

121 At court, gold and movement also played an important role in the context of clothing: Timothy McCall, "Brilliant Bodies: Material Culture and the Adornment of Men in North Italy's Quattrocento Courts," I Tatti Studies in the Italian Renaissance 16, no. 1/2 (2013): 445-49o. 


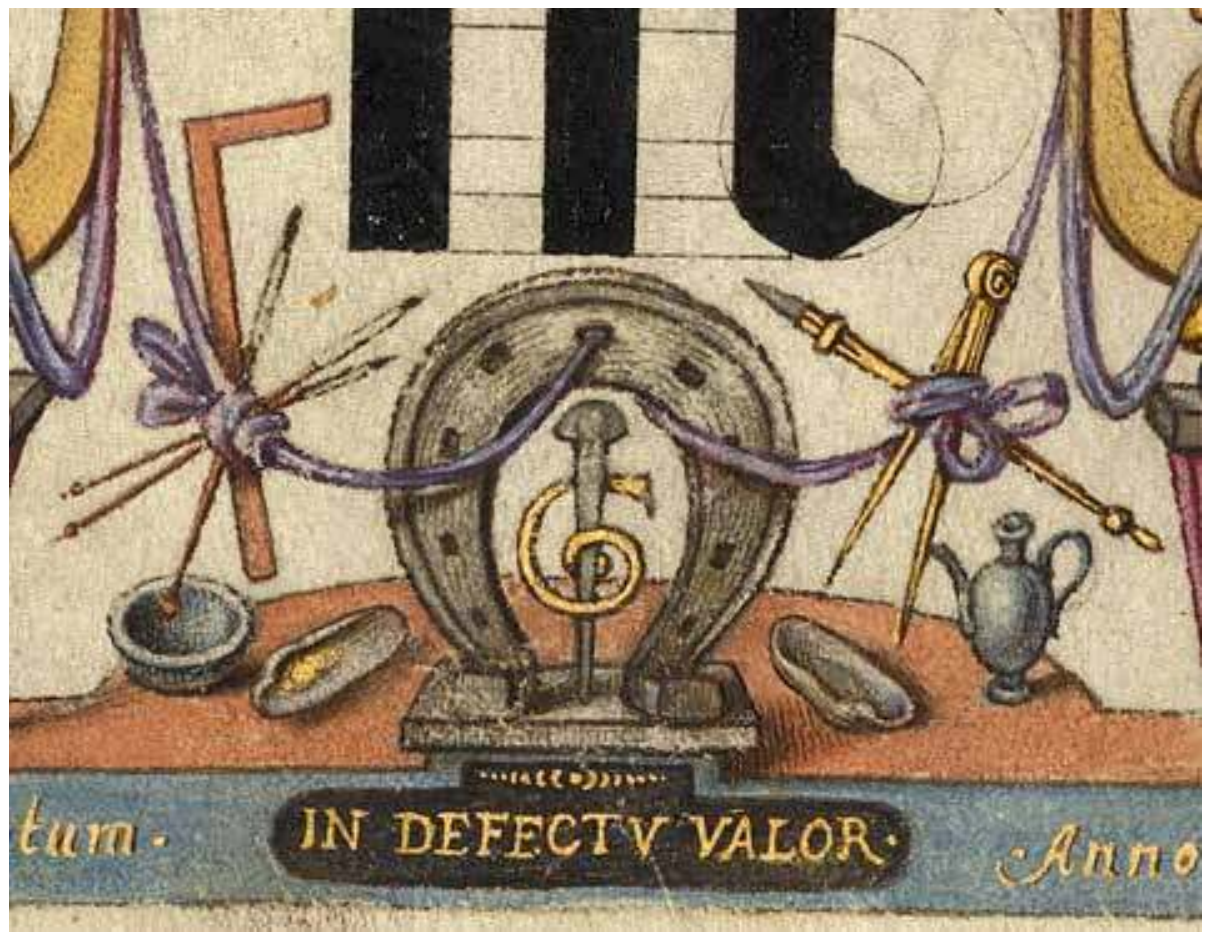

Figure 6.16: Joris Hoefnagel, Guide for Constructing the Ligature ffi, 1591-1596. Watercolours, gold and silver paint, and ink on parchment, $16.6 \times 12.4 \mathrm{~cm}$ (sheet). In Joris Hoefnagel and Georg Bocskay, Mira calligraphiae monumenta, 1561-1562 and 1591-1596, fol. 151v, detail: Painting tools. Los Angeles, J. Paul Getty Museum, shelf. no. Ms. 20 (86.MV.527). Image @ Digital image courtesy of the Getty's Open Content Program / J. Paul Getty Museum, Los Angeles.

knowledge and painterly skills, directly referred to his painting materials and tools in order to articulate his intellectual ambitions and draw attention to the virtue and virtuosity of his own art. Shell gold, the pigment that was the focus of this chapter, embodied, articulated, and enhanced the precious quality of his work. ${ }^{122}$ The allegories for Duke Albert V, his first patron, and for Ortelius, his life-long friend, were not his only works to include such self-reflexive elements in order to comment on the technical and intellectual vibrancy of his art. A miniature in the Mira calligraphiae monumenta (Marvellous Monuments of Calligraphy), executed for Emperor Rudolf II, also includes a shell containing liquid gold (Fig. 6.16). ${ }^{123}$ In addition to his working instruments (a jar, a pot, a square, a pen, three brushes, and

122 Both miniatures have been personally investigated in Berlin and Antwerp to observe the shimmering effects of shell gold when handling the miniatures.

123 Lee Hendrix and Thea Vignau-Wilberg, eds., Mira Calligraphiae Monumenta: A Sixteenth-Century Calligraphic Manuscript (Malibu, CA: The J. Paul Getty Museum, 1992). 
a pair of compasses), Hoefnagel depicted two Hermathenian owls, each holding a brush-turned caduceus and wearing a helmet in the shape of an alchemical alembic. The alembics hint at the emperor's alchemical interests and amalgamate the shared interests of Hoefnagel and his powerful patron in the secrets of nature and art. Furthermore, the reconstruction of two recipes that might have circulated at the time has shed new light on the expansive material knowledge and the skill miniature painters possessed at the time. Lastly, Hoefnagel's virtuoso handling of shell gold highlights only one aspect of his fascinating work. But, as I hope to have shown in this chapter, it opens a window into the ways in which early modern artists used their tools and materials to fashion their professional identities. Studying the virtues of this shimmering material has provided us with a multi-faceted vantage point for thinking about artists' "materialized identities" in the early modern period.

\section{Bibliography}

\section{Unpublished Primary Sources}

Pembroke College Library, Cambridge University

MS LC.2.113: Abraham Ortelius, Album amicorum

\section{Published Primary Sources}

Anonymous. Kunstbüchlin, gerechten gründtlichen gebrauchs aller kunstbaren Werckleut. Frankfurt am Main: Christian Egenolph, 1535.

Cennini, Cennino. The Book of the Art of Cennino Cennini: A Contemporary Practical Treatise on Quattrocento Painting, translated and edited by Christiana J. Herringham. London: George Allen, 1899 .

Henricus Hessels, Joannes, ed. Abrahami Ortelii (geographi Antverpiensis) et virorum eruditorum ad eundem et ad Jacobum Colium Orteliuanum (Abrahami Ortelii sororis filium) epistulae, cum aliquot aliis epistulis et tractatibus quibusdam ab utroque collectis (1524-1628), 3 vols. Cambridge: Typis Academiae, 1887.

Hilliard, Nicholas. A Treatise Concerning the Arte of Limning together with a More Compendious Discourse Concerning ye Art of Liming by Edward Norgate, edited by R. K. R. Thornton and T. G. S. Cain. Ashington: Mid Northumberland Arts Group, in association with Carcanet New Press, 1981.

Kunckel, Johannes. Der Curieusen Kunst- und Werck-Schul [...]. Nuremberg:Johann Friedrich Rüdiger, 1732.

Norgate, Edward. Miniatura or The Art of Limning, edited by Martin Hardie. Oxford: Clarendon Press, 1919. 
Ter Brugge, Geerard. Verlichterie-Kunde of recht gebruyck der Water-Verwen [...], edited and extended by Willem Goeree. Middelburg: Wilhelmus Goeree, 1670.

Van Mander, Karel. The Lives of the Illustrious Netherlandish and German Painters from the First Edition of the Schilder-boeck (1603-1604): Preceded by the Lineage, Circumstances and Place of Birth, Life and Works of Karel van Mander, Painter and Poet and likewise his Death and Burial, from the Second Edition of the Schilder-boeck (1616-1618), with an Introduction and Translation, edited by Hessel Miedema, 6 vols. Dornspijk: Davaco, 1994-1999.

Virgil. Eclogues, Georgics, Aeneid I-VI, translated by H. Rushton Fairclough, revised by G. P. Goold. Loeb Classical Library 63. Cambridge, MA: Harvard University Press, 2000.

\section{Secondary Literature}

Ames-Lewis, Francis. "Matteo de' Pasti and the Use of Powdered Gold." Mitteilungen des Kunsthistorischen Institutes in Florenz 28, no. 3 (1984): 351-362.

Bartl, Anna, Christoph Krekel, Manfred Lautenschlager, and Doris Oltrogge. Der "Liber illuministarum" aus Kloster Tegernsee: Edition, Übersetzung und Kommentar der kunsttechnologischen Rezepte. Stuttgart: Franz Steiner, 2005.

Bartl, Anna, and Manfred Lautenschlager. "Die Farben des Goldes: Glanzvergoldung in der Buchmalerei des Mittelalters.” In Farbe im Mittelalter: Materialität, Medialität, Semantik, edited by Ingrid Bennewitz and Andrea Schindler, 2 vols., vol. 1, 275-282. Berlin: Akademie, 2011.

Bass, Marisa. "Patience Grows: The First Roots of Joris Hoefnagel's Emblematic Art." In The Anthropomorphic Lens: Anthropomorphism, Microcosmism and Analogy in Early Modern Thought and Visual Arts, edited by Walter S. Melion, Bret Rothstein, and Michel Weemans, 145-178. Intersections 34. Leiden and Boston, MA: Brill, 2014. https://doi-org. ep.fjernadgang.kb.dk/10.1163/9789004275034.

Bass, Marisa Anne. "Mimetic Obscurity in Joris Hoefnagel's Four Elements." In Emblems and the Natural World, edited by Karl A. E. Enenkel and Paul J. Smith, 521-547. Intersections 50. Leiden and Boston, MA: Brill, 2017. https://doi.org/10.1163/9789004347076_015.

Bass, Marisa Anne. Insect Artifice: Nature and Art in the Dutch Revolt. Princeton, NJ and Oxford: Princeton University Press, 2019.

Bayerisches Landesamt für Umwelt. "Artensteckbrief: Malermuschel (unio pictorum)." Accessed on 6 May 2018. http://fisch.wzw.tum.de/fileadmin/_migrated/content_uploads/ Merkblatt_Malermuschel.pdf.

Bennett, Jane. Vibrant Matter: A Political Ecology of Things. Durham, NC and London: Duke University Press, 2010.

Brachert, Thomas. Lexikon historischer Maltechniken: Quellen, Handwerk, Technologie, Alchemie. Munich: Callwey, 2001.

Brown, Michelle P. Understanding Illuminated Manuscripts: A Guide to Technical Terms. Malibu, CA: J. Paul Getty Museum in association with The British Library, 1994. 
Büttner, Nils. “Abraham Ortelius comme collectionneur.” In Abraham Ortelius (1527-1598), cartographe et humaniste, edited by Robert W. Karrow, 168-180. Turnhout: Brepols, 1998.

Büttner, Nils. Einführung in die frühneuzeitliche Ikonographie. Darmstadt: Wissenschaftliche Buchgesellschaft, 2014.

Campbell, Caroline, Dagmar Korbacher, Neville Rowley, and Sarah Vowles, eds. Mantegna \& Bellini: Meister der Renaissance. Exh. cat. Munich: Hirmer, 2018.

Chambers, D. S. Patrons and Artists in the Italian Renaissance. London and Basingstoke: Macmillan, 1970.

Chiswick Robey, Jessica. "From the City Witnessed to the Community Dreamed: The Civitates Orbis Terrarum and the Circle of Abraham Ortelius and Joris Hoefnagel." PhD diss., University of California Santa Barbara, 2006.

Cupperi, Walter, Martin Hirsch, Annette Kranz, and Ulrich Pfisterer, eds. Wettstreit in Erz: Porträtmedaillen der deutschen Renaissance. Berlin: Deutscher Kunstverlag, 2013.

Cutler, L. C. "Virtue and Diligence: Jan Brueghel I and Federico Borromeo." In Virtue: Virtuoso, Virtuosity in Netherlandish Art 1500-1700, edited by Jan de Jong, Dulcia Meijers, Mariët Westermann, and Joanna Woodall, 202-227. Netherlands Yearbook for History of Art 54. Zwolle: Waanders, 2003.

Danti, Kevin, and Richard L. Zettler. "Shell Vessels and Containers." In Treasures from the Royal Tombs of Ur, edited by Richard L. Zettler and Lee Horne, 143-146. Philadelphia, PA: University of Pennsylvania Museum of Archaeology and Anthropology, 1998.

Degler, Anna, and Iris Wenderholm. "Der Wert des Goldes - der Wert der Golde: Eine Einleitung." Zeitschrift für Kunstgeschichte 79, no. 4 (2016): 443-46o. https://doi.org/10.1515/ ZKG-2016-0034.

Diemer, Dorothea, Peter Diemer, Lorenz Seelig, Peter Volk, and Brigitte Volk-Knüttel, eds., submitted by Willibald Sauerländer. Die Münchner Kunstkammer, 3 vols. Bayerische Akademie der Wissenschaften 129. Munich: Verlag der Bayerischen Akademie der Wissenschaft, 2008.

Diemer, Peter. "Wenig ergiebig für die Alte Pinakothek? Die Gemälde der Kunstkammer." In Die Münchner Kunstkammer, edited by Dorothea Diemer, Peter Diemer, Lorenz Seelig, Peter Volk, and Brigitte Volk-Knüttel, submitted by Willibald Sauerländer, 3 vols., vol. 3 , 125-224. Bayerische Akademie der Wissenschaften 129. Munich:Verlag der Bayerischen Akademie der Wissenschaft, 2008.

Dupré, Sven. "Re-enactment in Teaching Art History (Part 1)." Artechne, 21 December 2017. https://artechne.wp.hum.uu.nl/re-enactment-in-teaching-art-history-part-1/.

Fischer, Eberhard. "The Technique of Indian Painters: A Short Note." In Masters of Indian Paintings, edited by Milo C. Beach, Eberhard Fischer, and B. N. Goswamy, 2 vols., vol. 2, 793-798. Zurich: Artibus Asiae Publishers, 2011.

Fisher, Alexander J. Music, Piety, and Propaganda: The Soundscapes of Counter-Reformation Bavaria. Oxford and New York: Oxford University Press, 2014. 
Fors, Hjalmar, Lawrence M. Principe, and H. Otto Sibum. "From the Library to the Laboratory and Back Again: Experiment as a Tool for Historians of Science." Ambix 63, no. 2 (2016): 85-97. https://doi.org/10.1080/00026980.2016.1213009.

Göttler, Christine. “Affectionate Gifts: Rubens's Small Curiosities on Metallic Supports.” In Munuscula Amicorum: Contributions on Rubens and his Colleagues in Honour of Hans Vlieghe, edited by Katlijne Van der Stighelen, 47-66. Turnhout: Brepols, 2006.

Göttler, Christine. "Extraordinary Things: 'Idols from India' and the Visual Discernment of Space and Time, circa 16oo." In The Nomadic Object: The Challenge of World for Early Modern Religious Art, edited by Christine Göttler and Mia M. Mochizuki, 35-73. Intersections 53. Leiden and Boston, MA: Brill, 2018.

Göttler, Christine. "Tales of Transformation: Hendrick Goltzius's Allegory of the (Alchemical) Arts in the Kunstmuseum Basel." In Epistemic Images in Early Modern Europe, edited by Alexander Marr and Christopher P. Heuer, special issue, 21: Inquiries into Art, History, and the Visual 1, no. 2 (2020): 403-446. https://doi.org/10.11588/xxi.2020.2.76233.

Haller, Ursula. Das Einnahmen- und Ausgabenbuch des Wolfgang Pronner: Die Aufzeichnungen des "Verwalters der Malerei" Herzog Wilhelms V. von Bayern als Quelle zu Herkunft, Handel und Verwendung von Künstlermaterialien im ausgehenden 16. Jahrhundert. Munich: Siegl, 2005.

Harris, Jason. "The Practice of Community: Humanist Friendship during the Dutch Revolt.” Texas Studies in Literature and Language 47, no. 4 (Winter 2005): 299-325.

Haupt, Herbert. "Kammer-, Hof- und hofbefreites Handwerk: Der Versuch einer inhaltlichen Abgrenzung." Jahrbuch der Kunsthistorischen Sammlungen in Wien 85/86 (1989/90): 89-93.

Haupt, Herbert, and Alexander Wied. "Erzherzog Ernst von Österreich (1553-1595): Statthalter der Spanischen Niederlande; Das Kassabuch der Jahre 1589 bis 1595." Jahrbuch des Kunsthistorischen Museums Wien 12 (2010): 153-275.

Heal, Felicity. The Power of Gifts: Gift-Exchange in Early Modern England. Oxford: Oxford University Press, 2014.

Hegener, Nicole. “Diligentia in minimis maxima': Testament und Nachlaß des 'kleinen Michelangelo' Don Giulio Clovio." In Der Künstler und sein Tod: Testamente europäischer Künstler vom Spätmittelalter bis zum 20. Jahrhundert, edited by Nicole Hegener and Kerstin Schwedes, 105-193. Würzburg: Königshausen und Neumann, 2012.

Hendrix, Marjorie Lee. “Joris Hoefnagel and the 'Four Elements': A Study in SixteenthCentury Nature Painting." PhD diss., Princeton University, 1984.

Hendrix, Lee, and Thea Vignau-Wilberg, eds. Mira Calligraphiae Monumenta: A SixteenthCentury Calligraphic Manuscript. Malibu, CA: The J. Paul Getty Museum, 1992.

Houghton, Lukas B. T., and Marco Sgarbi, eds. Virgil and Renaissance Culture. Tempe, AZ: ACMRS, 2018.

Howard, Helen. "Shells as Palettes and Paint Containers in England." In Medieval Painting in Northern Europe: Techniques. Analysis. Art History, edited by Jilleen Nadolny, with 
Kaja Kollandsrud, Marie Louise Sauerberg, and Tine Frøysaker, 202-214. London: Archetype, 2006.

Husslein-Arco, Agnes, and Thomas Zaunschirm, eds. Gold: Von der Antike bis zur Moderne. Exh. cat. Munich and Vienna: Hirmer, 2012.

Irmscher, Günter. “'Hermathena' in der Hofkunst Prags und Münchens um 16oo.” In München - Prag um 16oo, edited by Beket Bukovinská and Lubomír Konečný, 77-101. Prague: Artefactum, 2009.

Ivanič, Suzanna. "Early Modern Religious Objects and Materialities of Belief." In The Routledge Handbook of Material Culture in Early Modern Europe, edited by Catherine Richardson, Tara Hamling, and David Gaimster, 322-337. London and New York: Routledge, 2017.

Killermann, S. “Georg Hoefnagel.” Allgemeines Künstlerlexikon Online. Accessed on 28 August 2018. https://www.degruyter.com/view/AKL/_oo106351T.

Knoepfli, Albert, and Oskar Emmenegger. Wandmalerei bis zum Ende des Mittelalters. Stuttgart: Reclam, 1990.

Koerner, Joseph Leo. “Freundschaftsbildnisse.” In Hans von Aachen (1552-1615): Hofkünstler in Europa, edited by Thomas Fusenig, with the assistance of Alice Taatgen and Heinrich Becker, 63-73. Berlin and Munich: Deutscher Kunstverlag, 2010.

Krausmann Ben-Amos, Ilana. The Culture of Giving: Informal Support and Gift-Exchange in Early Modern England. Cambridge: Cambridge University Press, 2008.

Lehmann, Ann-Sophie. "How Materials Make Meaning." In Meaning in Materials, 1400-180o, edited by Ann-Sophie Lehmann, Frits Scholten, and H. Perry Chapman, 6-27. Netherlands Yearbook for History of Art 62. Leiden and Boston, MA: Brill, 2013.

Leonhard, Karin. "Shell Collecting: On 17th-Century Conchology, Curiosity Cabinets and Still Life Painting." In Early Modern Zoology: The Construction of Animals in Science, Literature and the Visual Arts, edited by Karl A. E. Enenkel and Paul J. Smith, 2 vols., vol. 1, 177-214. Intersections 7. Leiden and Boston, MA: Brill, 2007.

Leonhard, Karin. "Painted Gems: The Color Worlds of Portrait Miniature Painting in Sixteenth- and Seventeenth-Century Britain." In Early Modern Color Worlds, edited by Tawrin Baker, Sven Dupré, Sachiko Kusukawa, and Karin Leonhard, special issue, Early Science and Medicine 20, no. 4/6 (2015): 428-457.

Malafouris, Lambros. "At the Potter's Wheel: An Argument for Material Agency." In Material Agency: Towards a Non-Anthropocentric Approach, edited by Carl Knappett and Lambros Malafouris, 19-36. New York: Springer, 2008.

McCall, Timothy. "Brilliant Bodies: Material Culture and the Adornment of Men in North Italy's Quattrocento Courts." I Tatti Studies in the Italian Renaissance 16, no. 1/2 (2013): 445-490.

Meadow, Mark, and Bruce Robertson. The First Treatise on Museums: Samuel Quiccheberg's Inscriptiones 1565. Los Angeles, CA: Getty Research Institute, 2013.

Meganck, Tine Luk. Erudite Eyes: Friendship, Art and Erudition in the Networks of Abraham Ortelius (1527-1598). Leiden and Boston, MA: Brill, 2017. 
Morgan, Nigel. "Painting with Gold and Silver." In Colour: The Art and Science of Illuminated Manuscripts, edited by Stella Panayotova, with the assistance of Deirdre Jackson and Paola Ricciardi, 192-219. Exh. cat. London and Turnhout: Harvey Miller, 2016.

Nuti, Lucia. "The Mapped Views by Georg Hoefnagel: The Merchant's Eye, the Humanist's Eye." Word \& Image 4, no. 2 (1988): 545-570. https://doi.org/10.1080/02666286.1988.104 36199 .

Pappas, Stephanie. “Oldest Human Paint-Making Studio Discovered in Cave.” Live Science, 13 October 2011. https://www.livescience.com/16538-oldest-human-paint-studio.html. Peeters, Natasja. “The Guild of Saint Luke and the Painter's Profession in Antwerp between c. 1560 and 1585: Some Social and Economic Insights." In Envisioning the Artist in the Early Modern Netherlands, edited by H. Perry Chapman and Joanna Woodall, 136-163. Netherlands Yearbook for History of Art 59. Zwolle: Waanders, 2009.

Peeters, Natasja. "A Guild's Eye View on Art: Artists and the Corporate World in Antwerp (ca. 1550-1600)." In The Artist between Court and City (1300-160o)/L'artiste entre la cour et la ville/Der Künstler zwischen Hof und Stadt, edited by Dagmar Eichberger, Philippe Lorentz, and Andreas Tacke, 189-201. artifex: Quellen und Studien zur Künstlersozialgeschichte. Petersberg: Michael Imhof, 2017.

Pilaski Kaliardos, Katharina. The Munich Kunstkammer: Art, Nature, and the Representation of Knowledge in Courtly Contexts. Tübingen: Mohr Siebeck, 2013.

Popham, A. E. “On a Letter of Joris Hoefnagel.” Oud Holland 53, no. 4 (1936): 145-151.

Ross, David O. Virgil's Aeneid: A Reader's Guide. Malden, MA: Blackwell, 2007.

Rublack, Ulinka. "Renaissance Dress, Cultures of Making, and the Period Eye." West 86th: A Journal of Decorative Arts, Design History, and Material Culture 23, no. 1 (2016): 6-34. Schilling, Edmund. "Zwei Landschaftszeichnungen des Georg Hoefnagel.” In Kunstgeschichtliche Studien für Hans Kaufmann, edited by Wolfgang Braunfels, 233-239. Berlin: Gebrüder Mann, 1956.

Schillinger, Klaus, ed. Zeicheninstrumente. Dresden: Staatlicher Mathematisch-Physikalischer Salon, 1990.

Seehafer, Michèle. "Shell Gold - Production, Usage, and Handling of a Historical Artisanal Technique (including a hands-on experiment).” 3 February 2017. https://www.materializedidentities.com/single-post/2017/02/03/Shell-Gold-\%E2\%80\%93-Production-Usageand-Handling-of-a-Historical-Artisanal-Technique-including-a-hands-on-experiment. Seehafer, Michèle. "Interview with Sven Dupré.” 2 August 2017. https://www.materializedidentities.com/single-post/2017/08/o2/Interview-with-Sven-Dupr\%C $3 \%$ A9.

Seehafer, Michèle. "Interview with Marta Ajmar." 18 June 2018. https://www.materializedidentities.com/single-post/2018/o6/13/Interview-with-Marta-Ajmar.

Seelig, Lorenz. “Die Münchner Kunstkammer.” In Die Münchner Kunstkammer, edited by Dorothea Diemer, Peter Diemer, Lorenz Seelig, Peter Volk, and Brigitte Volk-Knüttel, submitted by Willibald Sauerländer, 3 vols., vol. 3, 1-114. Bayerische Akademie der Wissenschaften 129. Munich: Verlag der Bayerischen Akademie der Wissenschaft, 2008. 
Serebrennikov, Nina Eugenia. “Imitating Nature/Imitating Bruegel.” In Pieter Bruegel, edited by Jan de Jong, Mark Meadow, Herman Roodenburg, and Frits Scholten, 222-246. Netherlands Yearbook for History of Art 47. Zwolle: Waanders, 1996.

Smith, Pamela H., The Body of the Artisan: Art and Experience in the Scientific Revolution. Chicago, IL: University of Chicago Press, 2004.

Smith, Pamela H., and The Making and Knowing Project. "Historians in the Laboratory: Reconstruction of Renaissance Art and Technology in the Making and Knowing Project." In Art and Technology in Early Modern Europe, special issue, Art History 39, no. 2 (2016): 210-233.

Soergel, Philip M. Wondrous in His Saints: Counter-Reformation Propaganda in Bavaria. Berkeley, CA: University of California Press, 1993.

Straub, Rolf E. "Tafel- und Tüchleinmalerei des Mittelalters." In Reclams Handbuch der künstlerischen Techniken, edited by Hermann Kühn, Heinz Roosen-Runge, Rolf E. Straub, and Manfred Koller, 3 vols., vol. 1, 125-260. Stuttgart: Reclam, 1984.

Striebel, Ernst. "Das Augsburger Kunstbuechlin von 1535: Eine kunsttechnologische Quellenschrift der deutschen Renaissance.” Master's thesis, Technische Universität München, 2007.

Tanner, Marie. The Last Descendant of Aeneas: The Hapsburgs and the Mythic Image of the Emperor. New Haven, CT and London: Yale University Press, 1993.

Terrenato, Francesca. "The Shaping of Individual and Collective Identities in Vasari's and Van Mander's Lives of Artists." Fragmenta 3 (2009): 127-146. https://doi.org/10.1484/J. FRAG.1.102586.

Trost, Vera. Gold- und Silbertinten: Technologische Untersuchungen zur abendländischen Chrysographie und Argyrographie von der Spätantike bis zum hohen Mittelalter. Wiesbaden: Harrassowitz, 1991.

Van Delft, Marieke. "Een alchemistisch boekenraadsel." 29 August 2012. https://www.kb.nl/ blogs/boekgeschiedenis/een-alchemistisch-boekenraadsel.

Van Hogendorp Prosperetti, Leopoldine. ' 'Conchas Legere': Shells as Trophies of Repose in Northern European Humanism." Art History 29, no. 3 (2006): 387-413.

Vignau-Wilberg, Thea. "Joris Hoefnagels Tätigkeit in München." Jahrbuch der Kunsthistorischen Sammlung in Wien 81 (1985): 103-167.

Vignau-Wilberg, Thea. “Forti viro omnis locus patria: 'Dem Starken gilt jeder Ort als Vaterland'." In Prag um 16oo: Kunst und Kultur am Hofe Kaiser Rudolfs II., edited by Jürgen Schultze and Hermann Fillitz, 2 vols., vol. 2, 23-27. Exh. cat. Freren: Luca, 1988.

Vignau-Wilberg, Thea. “Unbekannte Kabinettminiaturen von Joris Hoefnagel.” Jahrbuch der Kunsthistorischen Sammlungen in Wien 85/86 (1989/90): 67-77.

Vignau-Wilberg, Thea. "Joris Hoefnagel, The Illuminator." In Mira Calligraphiae Monumenta: A Sixteenth-Century Calligraphic Manuscript, edited by Lee Hendrix and Thea VignauWilberg, 15-28. Malibu, CA: The J. Paul Getty Museum, 1992. 
Vignau-Wilberg, Thea. “Joris Hoefnagel und die Freiheit des hofgeschützten Künstlers.” In München - Prag um 160o, edited by Beket Bukovinská and Lubomír Konečný, 125-129. Prague: Artefactum, 2009.

Vignau-Wilberg, Thea. "Freundschaft für die Ewigkeit: Joris Hoefnagels unbekannte Miniatur für Johannes Radermacher." In Libellus Amicorum: Beket Bukovinská, edited by Lubomír Konečný and Lubomír Slavíček, 112-125. Prague: Artefactum, 2013.

Vignau-Wilberg, Thea.Joris and Jacob Hoefnagel: Art and Science around 1600 . Berlin: Hatje Cantz, 2017.

Vignau-Wilberg, Thea. Joris und Jacob Hoefnagel: Kunst und Wissenschaft um 1600 . Berlin: Hatje Cantz, 2017.

Voet, Leon. "Abraham Ortelius and his World." In Abraham Ortelius and the First Atlas: Essays Commemorating the Quadricentennial of his Death, 1598-1998, edited by Marcel van den Broecke, Peter van der Krogt, and Peter Meurer, 11-28. Houten: HES, 1998.

Von Lippmann, Edmund Oskar. Entstehung und Ausbreitung der Alchemie. Berlin: Julius Springer, 1919.

Ward, Gerald W. R. The Grove Encyclopedia of Materials and Techniques in Art. Oxford: Oxford University Press, 2008.

Warnke, Martin. Der Hofkünstler: Zur Vorgeschichte des modernen Künstlers, 2nd ed. Cologne: DuMont, 1996.

Whitley, Kathleen P. The Gilded Page: The History and Technique of Manuscript Gilding. London and New Castle, DE: British Library and Oak Knoll Press, 2000.

Wilberg Vignau-Schuurman, Thea. Die emblematischen Elemente im WerkJoris Hoefnagels, 2 vols. Leiden: Universitaire Press, 1969.

Wojciehowski, Hannah Chapelle. Group Identity in the Renaissance World. Cambridge: Cambridge University Press, 2011.

Woodall, Joanna. "In Pursuit of Virtue." In Virtue: Virtuoso, Virtuosity in Netherlandish Art 1500-1700, edited by Jan de Jong, Dulcia Meijers, Mariët Westermann, and Joanna Woodall, 6-25. Netherlands Yearbook for History of Art 54. Zwolle: Waanders, 2003. Woodall, Joanna. "For Love and Money: The Circulation of Value and Desire in Abraham Ortelius's Album Amicorum." In Ut Pictura Amor: The Reflexive Imagery of Love in Artistic Theory and Practice, 1500-1700, edited by Walter S. Melion, Michael Zell, and Joanna Woodall, 647-703. Intersections 48. Leiden and Boston, MA: Brill, 2017. https://doi-org. ep.fjernadgang.kb.dk/10.1163/9789004346468_oo2.

Zenkert, Astrid. “The Owl and the Birds: Speeches, Emblems, and Fountains." In Emblems and the Natural World, edited by Karl A. E. Enenkel and Paul J. Smith, 548-609. Intersections 50. Leiden and Boston, MA: Brill, 2017.

Zimmer, Jürgen. "München und Prag um 16oo: Soziokulturelle Aspekte der Hofkunst im Vergleich.” In München - Prag um 16oo, edited by Beket Bukovinská and Lubomír Konečný, 17-57. Prague: Artefactum, 2009. 
Zorach, Rebecca. Blood, Milk, Ink, Gold: Abundance and Excess in the French Renaissance. Chicago, IL and London: University of Chicago Press, 2005.

Zorach, Rebecca, and Michael W. Phillips Jr. Gold. London: Reaktion Books, 2016.

\section{About the Author}

Michèle Seehafer received her PhD in Art History from the University of Bern. In her dissertation she investigates unique courtly collection rooms in early modern Denmark with a specific emphasis on material and materiality while also focusing on visual culture, technology, global trade, and strategies of political representation and self-formation. 



\section{Part 4}

Veils 



\title{
7. “Fashioned with Marvellous Skill": Veils and the Costume Books of Sixteenth- Century Europe
}

\author{
Katherine Bond
}

\begin{abstract}
Veils were indispensable garments in the wardrobes of women throughout sixteenth-century Europe. Costume imagery provides a springboard for analysing the sensorial typologies that manifested around lightweight, transparent, and translucent veils and those that were heavy and densely woven. Contextualizing the extraordinary variety of veil textiles produced and consumed at this time, the chapter investigates the enterprise of dedicated veil-makers in the manufacturing and commercial hubs of Florence and Seville. The material qualities of different veiling textiles gave rise to popular sensibilities and localized communities of taste. A case study on women's headdresses in the northern regions of Spain and the Basque country concludes the chapter, demonstrating an enthusiastic veiling culture based upon industry, creativity, and kinship.
\end{abstract}

Keywords: veils; costume books; textiles; silk; fashion; beauty

\section{The Idiosyncratic Veil}

In his autobiography, the precocious Italian sculptor and goldsmith Benvenuto Cellini (1500-1571) recalled an occasion on which he used a gauze veil to present a bronze statue of Jupiter to Anne de Pisseleu d'Heilly, the duchess d'Etampes and mistress of the king of France. ${ }^{1}$ Draping the gauze veil over a section of the statue

1 Benvenuto Cellini, The Autobiography of Benvenuto Cellini, trans. J. Addington Symonds (New York: Reynolds Publishing Company, 1910), 340.

Burghartz, S., L. Burkart, C. Göttler, U. Rublack, Materialized Identities in Early Modern Culture, 1450-1750: Objects, Affects, Effects. Amsterdam: Amsterdam University Press, 2021

DOI 10.5117/9789463728959_CHO7 
"with elegance and delicacy [...] [and] with the view of augmenting its majesty," Cellini offended the sensibilities of the duchess when he lifted the veil only to reveal the God's "handsome genital members."2 Cellini's comment reveals a purpose to the semi-transparent veil that is typically overlooked when considering the uses of veils in early modern times. The veil not merely stood as a screen with which to conceal and reveal, but added a beauteous dimension to what lay beneath, enhancing the statue's "majesty" or inherent splendour.

In its broadest sense, the word "veil" is defined as a covering. Much like today, early modern Europeans also understood the term as a verb meaning to disguise or conceal and as a noun to refer to a (covering) piece of cloth, including such things as curtains, shrouds, and awnings. Veils served in liturgical practice, particularly in a Catholic context where they were used in rituals pertaining to the concealment and revelation of devotional objects. They also provided curtains for art objects and, like the outer wings of a triptych panel, pertained to the spectacle of unveiling for special occasions or for a privileged viewership, as the Cellini episode demonstrates. ${ }^{3}$ This chapter focuses on veils as items of women's headwear. ${ }^{4}$ The overlooked role veils played as an enhancer (of beauty, honour etc.), a role that took veils beyond merely functioning as a cover, is worth further exploration considering that they were a principal component of women's dress throughout sixteenth- and seventeenth-century Europe and are conspicuous in the period's costume books for upholding regional idiosyncrasies and social identities. ${ }^{5}$

2 Ibid., 340.

3 On the drama of revelation, see Patricia Simons, "The Visual Dynamics of (Un)veiling in Early Modern Culture," in Visual Cultures of Secrecy in Early Modern Europe, ed. Timothy McCall, Sean Roberts, and Giancarlo Fiorenza (Kirksville, MO: Truman State University Press, 2013), 38.

4 As an article of women's dress, the veil was not unilaterally a hair-cover or adornment, since veil-cloths were also worn around the waist, chest, and shoulders. Moreover, the distinction between veils and mantles is not clear-cut, since both could drape around the head, shoulders, and body more generally, and were manufactured in diverse lengths from both light- and heavy-weight textiles. This chapter examines veils as items of women's headwear. Assorted cloth-based hair-covers existed in early modern Europe including "hoods," "bonnets," "coifs," and "caps." In the following, the term veil encompasses those headdresses which were not permanently tailored, but which remained lengths of cloth arranged around the head with temporary fixtures.

5 Women's veils have become a lively topic of scholarship in the last decade. Many recent works have stressed the long tradition of women's veiling in European Christian societies, particularly in light of contemporary political debates about Muslim women's veiling in Europe: see Maria Guiseppina Muzzarelli, A capo coperto. Storie di donne e di veli (Bologna: il Mulino, 2016); Susanna Burghartz, "Covered Women? Veiling in Early Modern Europe," History Workshop Journal 8o (2015): 1-32; Gabriella Zarri, ed., Velo e Velatio: Significato e Rappresentazione nella cultura figurative dei secoli XV-XVII (Rome: Edizioni di Storia e Letteratura, 2014); Eugenia Paulicelli, "From the Sacred to the Secular: The Gendered Geography of Veils in Italian Cinquecento Fashion," in Ornamentalism: The Art of Renaissance Accessories, ed. Bella Mirabella (Ann Arbor, MI: University of Michigan Press, 2011), 40-58. 
In their most basic material form, veils constitute detached lengths of cloth, which might incorporate a range of material fibres and manufacturing processes. They maintain a draping function that conjointly plays with the properties of weight, transparency, opacity, luminosity, and plasticity, qualities which provoke manifold sensorial responses informed by the values and concepts of different societies in different eras. In sixteenth- and seventeenth-century Europe, veils were a wardrobe staple variably used by women as kerchiefs to cover the shoulders and chest, and as headwear to enclose or ornament the hair, face, neck, and back. As headwear, veils connoted decorum and signalled women's passage through different life stages. Nuns "took the veil" as a gesture of their commitment to Christ and their membership of a religious order. In the Christian tradition, following the advice of St Paul, married women were expected to veil their hair as a sign of subservience to their husbands, while widows used veils to demonstrate their humility. ${ }^{6}$ Although their performative function in the service of social roles is without question, veils were also ornamental and are depicted in early modern visual culture arranged into sculpturesque forms, draped around coifs, headbands, and tiaras, and paired with lavish hairstyles.

Veils were thus not merely commonplace items signalling age, sexuality, marital status, or social position. These traditional garments were also objects of beauty, fashionability, virtue, and vehicles of creativity. Veils not only enchanted, as Cellini's example shows, but precipitated an emotional register from sexual attraction and admiration to humility and communal belonging. Materiality is at the heart of this affective range. It is easy to forget materiality when dealing with visual culture, and this is particularly so with costume books, whose archetypal figures invite readers to view garments as semiotic codes for social types. But besides being an excellent source for the staggering variety of veils popularly adopted by women of all nations and life stages, costume books also highlight that items of dress materialized group sentiments and sensibilities. It is worth considering how and why veils became invested with social meanings. In many ways, the answer lies in the symbiotic relationship between matter and the human body. Diversity in material qualities gave rise to differing effects that lay at the threshold of the body and its environs. Weight and fibre density impacted the drape, handle, and light-transmission of veils for instance, negotiating their affective resonances for wearers and observers alike. The malleability of veil-cloths meanwhile, encouraged experimentation with drape and a wide range of impermanent fixtures. Veils could be manipulated into manifold forms and shapes, informing regionalized communities of taste and materializing local identities.

The sixteenth-century's flourishing output of costume books and albums consequently paid close attention to idiosyncratic veils and headdresses as a gauge 
of place and identity, as did contemporary travellers. One keen observer of the period was the Burgundian wardrobe master and chronicler Laurent Vital, whose account of the voyages of the Habsburg princes Charles and Ferdinand between 1517 and 1518 contains vivid descriptions of foreign dress, including of women's linen headdresses and hats made from rushes observed in Kinsale, Ireland and the "strange" veils of the local women in Asturias, Spain.7 From the long, floaty veils of Italy, fitted veils and hoods (Steuchlein) of the German lands, to the horn-shaped headdresses of northern Spain, veils were produced in all shapes and sizes, isolated by costume books as part of their visualization of geographies of taste and culture.

Produced in manuscript and print, costume works burst onto the visual media scene in the first half of the sixteenth century, their ethnographic appeal rooted in the era's sensitivity to dress cultures and the "materialization" of identities. Informing much of my discussion is the 1590 costume book of Venetian-based artist Cesare Vecellio, his celebrated De gli habiti antichi et moderni di diverse parti del mondo (On Clothing, Ancient and Modern, of Various Parts of the World). Vecellio's magnum opus was the self-proclaimed result of decades' worth of research involving discussions with travellers and merchants, and the exhaustive study of travel accounts, ethnographic texts, local artworks, and older costume books and drawings. ${ }^{8}$ With its discursive textual dialogue, Vecellio's work is an unparalleled source for gathering information about the sorts of textiles, methods of arrangement, and societal values associated with women's veils in his time. Other examples cited come from Jean Jacques Boissard's lavish publication Habitus variarum orbis gentium [...] (The costumes of the various peoples of the world: Mechelen, 1581) and a selection of hand-painted, sixteenth-century costume albums that superbly capture the composition and material effects of contemporary women's headwear.

The chapter unfolds by examining how veils were produced and traded in early modern Europe, comparing the industry of two quite different groups of professional veil-makers in early sixteenth-century Seville and early seventeenth-century Florence. The range of veil textiles available to consumers was boundless. An examination of the uses, affects, and meanings of delicate, translucent veils gives way to a consideration of how drape and malleability affected veils' different performances

7 Laurent Vital, "Relation du premier voyage de Charles-Quint en Espagne," in Collection des voyages des souverains des Pays-Bas, ed. M. Gachard, vol. 3 (Brussels: F. Hayez, 1881). In 1518 the ship transporting Ferdinand I to the Low Countries from Spain encountered a storm in the Bay of Biscay. Blown off course, the ship's crew landed in Kinsale, Cork, where Vital narrated a lively encounter with the locals: Hiram Morgan, Ireland 1518: Archduke Ferdinand's Visit to Kinsale and the Dürer Connection (Cork: Crawford Art Gallery, 2015).

8 Cesare Vecellio, Cesare Vecellio, Habiti Antichi et Moderni: The Clothing of the Renaissance World, ed. and trans. Margaret F. Rosenthal and Ann Rosalind Jones (London and New York: Thames and Hudson, 2008), 23-25. All subsequent quotations from Vecellio are drawn from this English translation. 
and applications. The chapter concludes with a case study on women's headdresses in the northern peninsula of Spain, and Basque Spain and France, investigating the veil as an integral garment to the formation of community identity. As well as using the rich visual and textual source material from sixteenth-century costume series, this chapter looks to travellers' accounts, popular literature, wardrobe inventories, dowries, and workshop account books to highlight the degree to which women's hair-veils were socially significant textiles.

\section{Materializing the Veil: Textile Production and Trade}

Across sixteenth- and seventeenth-century Europe, a variety of textiles popularly used for veiling were manufactured, traded, and merchandised - distinctive in their fibre, weave density, transparency level, weight, pliability, colour, and ornamental design. In terms of fibres, linen and silk were the mainstays for veiling textiles. Smooth, strong, cool, and absorbent, linen fibres were popular for textiles worn directly against the skin and hair. Able to withstand bleaching agents, linens were appropriate for everyday wear and regular laundering and were fundamental to early modern hygiene practices. ${ }^{9}$ Silk filaments, the protein fibres extracted from the cocoons of silkworms, could be woven into lightweight, luminous textiles. When the outer layer of waxy sericin covering raw silk is washed away, the surface of silk filaments becomes smooth and, at a cross-sectional view, triangular in shape. This forms a natural, light-refracting prism, making silk highly lustrous. ${ }^{10}$ Light but strong, with excellent elasticity, woven silk also maintains exceptional drape and tactility. Cotton and wool were also used for veils; pockets of production around Spain and Italy specialized in the weaving of light cotton veils for instance, while wool fibres were typically mixed with linen or silk to produce more robust drapes. ${ }^{11}$

The methods used to spin or twist fibres, the number of filaments in a thread, which sorts of thread were used for the warp or the weft, and the patterns of weave structures all ensured wide differences in textiles' quality and handling. Rich regional vocabularies attest to a widespread sensibility for textile diversities. Like

9 Susan Vincent, "From Cradle to the Grave: Clothing the Early Modern Body," in The Routledge History of Sex and the Body: 1500 to the Present, ed. Sarah Toulalan and Kate Fisher (London: Routledge, 2013 ), 167.

10 Mary Schoeser, Silk (New Haven, CT: Yale University Press, 2007), 117.

11 Milan, Perugia, and surrounding Umbrian towns had woven cotton veils since the fourteenth century. See Maria Luciana Buseghin, "Uno sguardo sul velo dal medioevo all'età contemporanea: veletti, 'tovagli', panni” and Maria Paola Zanoboni, “Pro trafegando in exercitio seu arte veletarum': Tipologia e produzione dei veli nella Milano del secondo quattrocento," in Il velo in area mediterranea fra storia e simbolo: tardo medieval - prima Età moderna, ed. Maria Giuseppina Muzzarelli, Maria Grazia Nico Ottaviani, and Gabriella Zarri (Bologna: il Mulino, 2014), 381-394 and 123-138 respectively. 
many of his contemporaries, Cesare Vecellio was conversant about the provenance, quality, and application of different types of cloth. No less than twelve types of textiles are identified in his descriptions of veils, including cambrai (cambric: a very fine linen), ormesino (a lightweight, inexpensive silk taffeta), renso (a lightweight linen, originally associated with Reims), and velo (a fine Italian gauze, usually of silk but occasionally cotton). ${ }^{12}$ Seventeenth-century Dutch inventories demonstrate the comparable dominance of Armosijn (ormesino) and Kameriksdoek (cambric), as well as Bourat (buratto), a silk and wool blend with a matte surface, and Floer, a sheer silk crepe. ${ }^{13}$ In Spain, meanwhile, the northern Basque regions excelled in the production of beatilla, a very fine linen used for veiling. Velillo, a silk gauze, was also popular, as was espumilla (crepe), a textile manufactured in silk, linen, and cotton, distinguished by its crimped surface.

Ranging from soft to crisp, matte to shiny, circulating veil textiles serviced women's changing needs and aspirations in societies that cultivated a discernment for the subtle material differences each maintained and the affective sensibilities they extended to the body. In some cities, these textiles were the trade of professional veil-makers, specialist artisans who conducted businesses both manufacturing and/ or trading in lightweight textiles for veils, collars, and other small-scale, intimate garments. Veil-makers' presence in Seville and Florence in the sixteenth and seventeenth centuries is particularly well documented. In 1527 the Seville authorities published their first edition of the Ordenanças de Sevilla, a compilation of the city's manifest guild regulations. ${ }^{14}$ The veil-makers (los toqueros) issued a collection of directives to standardize and maintain the quality of veiling textiles manufactured and traded in Seville. ${ }^{15}$ The veil-makers of Florence (ivelettai), meanwhile, kept exhaustive account books spanning the late sixteenth and early seventeenth centuries recording their day-to-day transactions with suppliers and customers. ${ }^{16}$ These sources peer into the trading practices, wares, and clientele of early modern veil-makers and bring to life the abundant makes, materials, and market for veils.

The Seville veil-makers specialized in the weaving of light textiles, particularly silks, as well as the manufacture of finished veil-cloths. They maintained workshops

12 Vecellio, Habiti, 584, 589, 593 .

13 On seventeenth-century Dutch wardrobes, see Marieke de Winkel, Fashion and Fancy: Dress and Meaning in Rembrandt's Paintings (Amsterdam: Amsterdam University Press, 2006), 352.

14 These ordinances were republished without alteration in 1632.

15 Ordenanças de Sevilla: que por su original, son aora nveuamente impressas [...] (Seville: Andres Grande, 1632), 191r-194V.

16 ASF, LCF 933-34, 1844-98, 4198. On the Florentine velettai: Chia-Hua Yeh, "Material Culture of Head Coverings in Early Modern Florence," in Muzzarelli, Ottaviani, and Zarri, Il velo, 139-154 and Evelyn Welch, "Art on the Edge: Hair and Hands in Renaissance Italy," Renaissance Studies 23, no. 2 (June 2009): 241-268. 
with specialist looms and were supplied threads by the city's silk-workers (sederos) amongst others. Although the ordinances occasionally refer to shop premises, the veil-makers' goods were largely traded by other merchants, especially by jewellers (joyeros). ${ }^{17}$ Their concentration on the weaving of veil textiles set them apart from the Florentine velettai, who mostly relied on suppliers from inside and outside of the city who managed the weaving. The velettai focused on the commercial side of their businesses, running well-stocked shops and servicing important patrons' wardrobes while maintaining a hand in the production of finished goods that complemented their textile sales.

The Seville veil-makers ran a highly regulated trade. Guild masters elected overseers responsible for performing spontaneous checks on those weaving veils, scrutinizing not only those from within their own ranks, but also widows making veils at home. ${ }^{18}$ The commune's output was obliged to conform to standardized thread types, loom set-ups, weave measurements, and fabric widths. Approved textiles - measured against the overseers' yardsticks - were stamped with a seal, while in dramatic fashion, those that did not measure up were to be publicly burned, setting "an example to all who see it."19 The city authorities supported these measures, concerned that "many collusions and falsehoods" had made textiles narrow and diminished, causing "damage to the Republic" and hindering its capacity to profit from the veil-makers' trade. ${ }^{20}$

The Seville veil-makers' concern for uniformity stands in opposition to the enterprises of their Florentine peers, who offered their customers a rich assortment of textiles and haberdashery supplies sourced from far and wide. Between 1612 and 1623, veil-maker Francesco Donati sustained business relationships with makers, traders, and merchants based in Pisa, Siena, Bologna, Milan, and Livorno, sending and receiving huge quantities of textiles such as renso, velo, buratto, taffeta, and retino (tulle). These textiles passed through his business transformed into ready-to-wear garments or sold at smaller lengths. In May 1621 for example, Donati received from his regular Milanese supplier Alessandro Cella large bolts of retino, "black serge," "black renso," and "black buratto from Lyon." ${ }^{.12}$ In December of the same year, he sold Florentine resident Tommaso di Franco four "pretty net veils" ornamented with silver (likely using retino of the sort sourced from Milan), seventeen Bolognese-style veils, and eight braccia of velo crespo (silk crepe) to be made into coifs. ${ }^{22}$

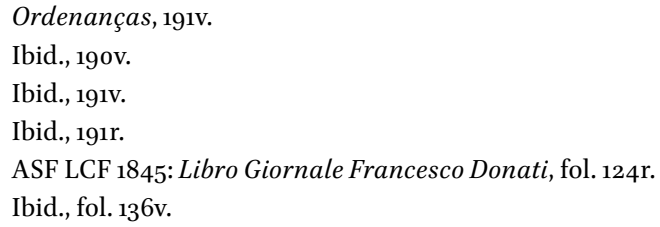


In the early years of his business, Donati had set up shop with the veil-maker Simone Quarenghi. The female workforce in Florence's many convents provided the pair with an important source of labour and supply, recorded in their self-titled Libro dimonachi. ${ }^{23}$ As Sharon T. Strocchia has examined, nuns played an active role in the city's textile industry and were paramount in expanding its silk production. ${ }^{24}$ Textile work supported convent incomes as many maintained textile workshops within their walls where spinning, weaving, sewing, and embroidery took place. ${ }^{25}$ Along with conducting their own labour, nuns were involved in brokerage, consigning low-paid textile work to local laywomen on behalf of dealers and merchants. ${ }^{26}$ The veil-makers' Libro di monachi does not treat nuns as anonymous workers for their respective convents; remarkably, individual nuns are named and compensated personally. It is unclear whether the textiles they supplied were personally woven or consigned by each named sister, however it is certain that these individuals maintained their own cache within the manufacturing chain and together supplied the veil-makers with sundry goods.

Particularly prolific was sister Lorenza, a member of Florence's wealthy Buondelmonti family and the convent of San Matteo in Arceti, who between December 1602 and May 1603 furnished Donati and Quarenghi with twenty-three lengths of fabric. ${ }^{27}$ Among these veil textiles were large numbers of quadrotti bianchi (squares of white linen) and silk velo supplied in black, white, and crimped. Sister Cornelia of Santa Chiara's supply was even more varied. In 1602 her output ranged from basic linen cloth (pannolino) and fine renso linen to silk crepe and gold-embellished, bridal kerchiefs (fazzoletti).$^{28}$ She even brokered a number of her peers' labour, offering the veil-makers "velo by Sister Isabella" and "renso by Sister Massimella." ${ }^{29}$ Many laywomen weaving veil textiles sidestepped the convents altogether and sold directly to veil-makers. Operating in the first decades of the seventeenth century, the veil-maker Giovanpietro Caglionni obtained ample quantities of fabrics from women (and men) about the city, some of whom worked as sub-contractors since they were paid not only for their finished textiles, but also for their labour at the loom..$^{30}$

ASF LCF 4198: Libro di monachi.

24 Sharon T. Strocchia, Nuns and Nunneries in Renaissance Florence (Baltimore, MD and London: Johns Hopkins University Press, 2009), 111-151.

25 Ibid., 113, 116-117, 126.

26 Ibid., 118-119.

27 ASF LCF 4198: Libro dimonachi, fol. $20 \mathrm{v}$.

28 Ibid., 2 r.

29 Ibid.

30 ASF LCF 933: Libro di ricordo, see for instance fol. 144r. Caglionni pays "Alessandra" for tanti posti adare al spollio. 
Where those involved in the making and selling of veils in early seventeenthcentury Florence enjoyed a measure of creative freedom, a century earlier, makers in Seville faced strict regulations aimed at producing controlled, ready-to-wear veils that would be "perfect and profitable to the Republic."31 The guild's guidelines disclose the material knowledge and craft expertise that enabled different kinds of veils and veil textiles to reach the marketplace. Linen and cotton veils (plain headcloths called trapos de cabeza) were to be woven with a uniform width of $7 / 8$ ths of a vara (yard), presumably cut into uniform lengths and individually hemmed..$^{2}$ The manufacture of silk veils was more convoluted and particular emphasis was placed on the quality of thread weavers used. The finest threads were those reeled from the cocoons in single, unbroken filaments as opposed to those using waste silk - the leftover, broken fibres after cocoon fragmentation, which had to be combed and spun like wool fibres, producing weaker, coarser threads. ${ }^{33}$ A number of textiles the Seville veil-makers specialized in took advantage of "Morisco" silk threads (sedas Moriscas), threads that had been thrown (twisted) no less than two times by hand using a device called an alparguale. ${ }^{34}$ These threads had to have been "put into the cauldrons to boil," meaning much of the sericin residue had been melted off, "because such [threads] are perfect."35 For the weaving of los velos, standard silk veils, the ordinances promoted silk threads twisted on special spinning machines (los tornos, known as filatoi in Italian), a technology that enabled tighter and stronger twists but could diminish shine and softness. The Seville guild's emphasis on threads made from unbroken, boiled silk is in standing with the protections governments and guilds enacted in Italy throughout the sixteenth century, attempting to combat the short-cuts of entrepreneurial weavers and the increasing manufacture of cheaper, less durable cloths. ${ }^{36}$

Treatment methods involving water were important to the guild to distinguish two very similar varieties of veils: the so-called espumillas ("foam" veils) and the tocas de Reina ("Queen's veils"). These were evidently similar in appearance, since regulators were most troubled that espumillas were being applied a special treatment "making them appear as the aforesaid tocas de Reina," misleading purchasers about the type of veil they had bought. ${ }^{37}$ The preparation of the "Queen's veils," which

31 Ordenanças, 192r.

32 Ibid.

33 Luca Molà, The Silk Industry of Renaissance Venice (Baltimore, MD and London: Johns Hopkins University Press, 2000), 164-165.

34 These cloths were named lino de Paris, tela de seda cocha, and tela de filiseda.

35 Ordenanças, $191 v$.

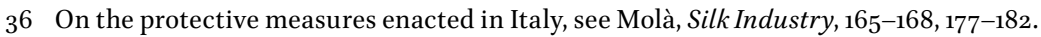

37 Ordenanças, 193r. In his appendix to a volume containing fifteenth-century treatises issued by Florence's Arte della seta, Girolamo Gargiolli notes that in Naples, "spumiglia" was the local term for velo 
were higher in thread density than their counterparts, involved immersing each finished veil in a bath (duchas de seda blanca) no less than four times..$^{8}$ These baths were likely part of an intensive degumming process wherein any leftover sericin in the veils was removed in hot, soapy water, transforming the yellow of the raw silk fibres into a lustrous white..$^{39}$ The espumilla veils, conversely, were to be soaked (adobadas) but not to have "entered the cauldron."40 Presumably this means that they were not boiled in hot water, as the Queen's veils were, but were immersed in a cooler solution. The intention was likely to retain more of the gummy sericin, a key ingredient for the rigidity of a crisp silk gauze like organza. ${ }^{41}$

Many technological and ornamental applications were applied to veils outside of the weavers' workshops. Customers who frequented the Florentine veil-makers' shops could purchase from the wide range of decorative trimmings they traded alongside textiles. Ribbons, cords, braids, buttons, fringes, and spangles were just some of the ornaments that might elevate one's veil into a fashionable, coordinated accessory. The Medici wardrobe inventories record that in February 1619, the archduchess Maria Maddalena received a mantle of silk velo embellished with pearls "on the occasion of a Comedy," fashioned by a certain Tommaso Salvatico, most likely a veil-maker. ${ }^{42}$ German women were particularly fond of trimmings, which were detailed in dowries and wardrobe inventories to have adorned all manner of headwear. In 1524, the noblewoman Magdalena of Saxony brought an enormously rich wardrobe of goods to her marriage with Joachim II Hector, the future Elector of Brandenburg. Listed beneath a total of ninety assorted veil components are black velvet bindings (swarz Samatbinden) ornamented with pearl trims and gold embroidery, probably used to secure the veil to the head. ${ }^{43}$ Between an assortment of embellished coifs were also recorded quantities of trims set with pearls and embroidered with vines and fig motifs, and Flammern (little flames, probably sequins) "for head-jewels." ${ }^{\text {44 }}$

A lively production and trade in veils destined for women's wardrobes existed across sixteenth- and seventeenth-century Europe. The manifold products consumed

regino, suggesting that the two textile varieties were relatively interchangeable. Girolamo Gargiolli, L'Arte della seta in Firenze: Trattato del secolo XV [...] (Florence: G. Barbèra, 1868), 209, 332.

38 Ordenanças, 193 r.

39 It would have been beneficial to retain some sericin on the silk threads during weaving to protect fibres from abrasion: R. R. Franck, Silk, Mohair, Cashmere and Other Luxury Fibres (Amsterdam: Elsevier, 2001), 29.

40 Ordenanças, 192v-193r.

41 Franck, Luxury Fibres, 31.

42 ASF GM 358: Medici libri di vestiti, fols. 48v-49r.

43 As reproduced in Georg Schuster and Friedrich Wagner, Die Jugend und Erziehung der Kurfürsten von Brandenburg und Könige von Preussen (Berlin: Hoffmann, 1906), 549.

44 Ibid., 547 . 
- woven from diverse fibres, prepared with different treatments, available in various colours, widths, and lengths, and ornamented with assorted trimmings - show the degree to which veils were valued for their material distinctions. Much social energy was expended in the manufacture and consumption of veils, highlighting that they functioned not merely within a semiotic system signalling a woman's age, marital identity, or social role. The veil's ability to signpost these identifications was inseparable from the rich, material world within which these garments were embedded. In the following analyses of veils depicted in the period's costume books, I will demonstrate that to best understand veils' social meanings requires foregrounding the material qualities for which they were prized and the affective resonances they evoked.

\section{Fine and Translucent}

Costume books indicate that the weight and density of veils were of great consequence to contemporaries. The tactile confrontation between the human body and the threads of a gossamer cloth evoked an aesthetic connecting delicacy, lustre, translucency, and rippling movement with the allure of youthful beauty. Luca Molà has shown that technological developments in spinning and weaving in fifteenth- and sixteenth-century Italy, including the Bolognese invention of the hydraulic silk spinning machine, which twisted silk filaments with an unsurpassed level of precision, accounted for the dramatic increase in the lightness of silk cloths the country produced. ${ }^{45}$ Across Europe, experimentations with waste silks, raw silks, and the mixing of different fibres, as well as the decreasing number of warp threads used during silk weaving, point to an emerging market for cheaper textiles appreciative of delicacy over substance. ${ }^{46}$ Such was this shift that by the seventeenth century, the Venetian Senate, for example, no longer imposed minimum warp densities on lighter-weight silk textiles, sacrificing durability to attain ever finer, threadbare cloths.

This appetite for ultra-fine veils is prominent in Vecellio's costume book, which describes myriad examples throughout the work as "thin," "very thin," "delicate," "light," and "transparent." Women of foreign nations such as the Low Countries and the German Lands are characterized wearing veils of notably fine textiles such as ormesino, renso, or cambric; however, it is in Vecellio's descriptions of Italy, and especially Venice, where he is at most pains to stress how "very thin" the veils are. ${ }^{47}$ Adopted by courtesans, domestic servants, and noble brides, the 
diffusion of fine veils in Vecellio's corpus registers the range of qualities and price points available, as was indicated in the Florentine veil-makers' account books. By analysing the social context of these veil-wearing figures, it becomes apparent that the period's taste for fine, diaphanous veiling textiles is intimately associated with the concurrent aesthetic for delicacy, brightness, and luminosity, attributes that helped conceptualize beauty in contemporary thought.

Characterizing the dress of "Gentlewomen in Venetian Outposts and Territories," Vecellio recalls the outfit he once saw worn by "the famous Gussona," the daughter of the renowned naval commander Agostino Barbarigo (1518-1571) (Fig. 7.1). Gussona, who "shone in a most sumptuous gown," was remembered by Vecellio to have worn a veil "of thin, transparent gold silk, bordered all around with gold lace."48 "Its ground was white," he notes, also commenting that she wore the veil when outdoors. Her fine silk veil, sheer and luminous with its white ground, interwoven with gold thread, must have gleamed in the sunlight. Gussona's radiance was augmented only further, Vecellio remarks, by her "indescribable modesty and other rare qualities," an observation linking her glistening appearance to the goodness of her internal character. ${ }^{49}$

In his study of fifteenth-century Italian culture, Timothy McCall identified that the qualities of light - brilliance, luminosity, and lustre - were highly prized in the Renaissance Italian aesthetic. $5^{\circ}$ McCall's case study focused on light as a quality in men's fashion, demonstrating that the Italian princely body emanated political charisma and authority through glittering sartorial displays. Honorific titles affirming princely nobility frequently drew from light-enhancing vocabulary such as illustrisimus and spettabilis, exemplifying, argues McCall, how subjects' visual attention should be captured by and directed towards their lord. ${ }^{11}$ The language of splendour likewise negotiated Vecellio's perception and admiration of Gussona's feminine beauty and high status. The light-reflective properties of fine, translucent veils, then, participated in a shared aesthetic for luminosity that was as significant for women's construction of prestige as it was for men's. ${ }^{2}$

The way Vecellio's attention was captured by the gleaming properties of Gussona's silk gown and veil recalls the words of the writer and Lateran canon Tommaso Garzoni (1549-1589) in his accolades on silk and its myriad uses: "The noblewomen,

48 Ibid., 187 .

49 Ibid.

50 See Timothy McCall, "Brilliant Bodies: Material Culture and the Adornment of Men in North Italy's Quattrocento Courts," I Tatti Studies in the Italian Renaissance 16, no. 1/2 (2013): 445-490.

51 Ibid., 446.

$5^{2}$ This has also been identified by Regine Maritz in her analysis of the language of shimmer and shine at the Württemberg court: Regine Maritz, "Gender as a Resource of Power at the Early Modern Court of Württemberg, c. 1580-1630" (PhD diss., University of Cambridge, 2018), 119-120. 


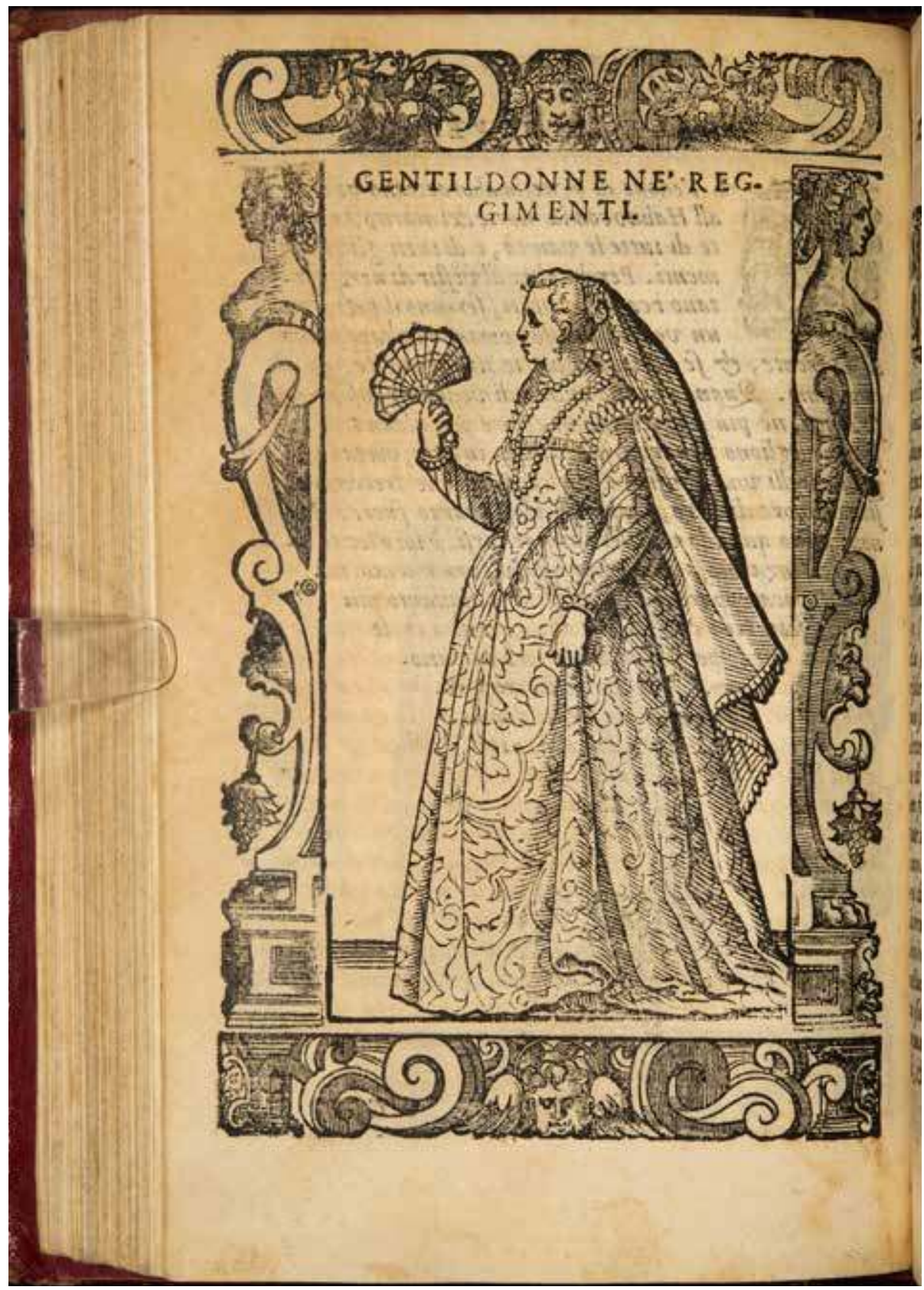

Figure 7.1: Cesare Vecellio, Gentildonne ne' Regimenti. Woodcut, $16.7 \times 12.5 \mathrm{~cm}$. In Cesare Vecellio, Degli habiti antichi, et moderni di diverse parti del mondo, Venice: Damian Zenaro, 1590, plate 135. Gentlewomen in Venetian Outposts and Territories. Düsseldorf, Universitäts- und Landesbibliothek Düsseldorf, inv. no. H 32. Image ๑ Universitäts- und Landesbibliothek Düsseldorf. 
above all, are they not a thousand times more graceful and lovely with their clothes of silk studded with gold and precious stones? Do not their beautiful faces glisten twice as much under white silk?"53 In this passage, beauty and grace in the female body is measured by radiance. The light-reflective qualities of silk garments, gemstones, and white silk veils enchant the bystander, whose dazzled senses perceive the loveliness of the woman beneath. Enchantment calls to mind a range of interpretations, most usefully the political theorist and philosopher Jane Bennett's consideration of enchantment as a deeply affective and transitory, bodily state, a "sensuous condition" of "intense engagement with the world. ${ }^{44}$ The light-refracting properties of glistening veils, the collective work of expert spinners and weavers, enchanted admirers by luring the eye and moving the senses. Consequently, translucent veils were drawn into the poetic language of the Italian Renaissance and its allegorical conceptualization of light.

Since light was associated with beauty and nobility, the luminescence of glittering clothing amplified the inherently radiant subject, whose body was itself the main source of light. Florentine noblewoman Lucrezia Tornabuoni (1427-1482) invoked the veil to this effect in her religious verse about the life of Saint John the Baptist. Describing Salome as she appeared at Herod's banquet, dressed in "a white veil, adorned with jewels" that "did not cover her beauty," Tornabuoni imagines her to resemble the sun among the stars..$^{55}$ Salome's veil is imagined not as a device that conceals or reveals but as a garment elevating her power to enchant by enhancing her luminosity. In this example beauty and light, normally associated with virtue, are unusually associated with the morally ambiguous character of an enchantress who puts the affective powers of her veil to full use. Internal light was more commonly used in contemporary rhetoric to symbolize divine goodness. In a lyric poem composed by Isabella Cervoni to mark the marriage of Marie de' Medici to Henri IV of France in 16oo, the poet addresses Marie saying:

So bright a ray shines in you, Lady, of the vast beauty of God, and such a light issues forth from it to our eyes that he who is privileged to gaze on you sees the true fountain from which there descends to us the eternal light of the heavenly cloisters..$^{6}$

53 Tommaso Garzoni translated and cited in Molà, Silk Industry, 89 .

54 Jane Bennett, The Enchantment of Modern Life: Attachments, Crossings, and Ethics (Princeton, NJ: Princeton University Press, 2016), 111.

55 Extract from Vita di Sancto Giovanni Baptista, translated and cited in Maria Grazia Pernis and Laurie Schneider Adams, Lucrezia Tornabuoni De'Medici and the Medici Family in the Fifteenth Century (New York and Oxford: Peter Lang, 2006), 131.

56 Isabella Cervoni $\left(1600, \mathrm{C}_{3} \mathrm{v}-\mathrm{D}_{3} \mathrm{v}\right)$ reproduced in Virginia Cox, Lyric Poetry by Women of the Italian Renaissance (Baltimore, MD and London: Johns Hopkins University Press, 2013), 301. 
The body of the virtuous noblewoman reflected God's "eternal light," and the spectator was anticipated to be suitably dazzled in her presence.

Light and lustre were also understood to arouse sensations of love. In Baldassare Castiglione's The Book of the Courtier (1528), the scholar Pietro Bembo elaborates on this idea saying:

I shall speak of the kind of beauty I now have in mind, which is that seen in the human body and especially the face and which prompts the ardent desire we call love; and we shall argue that this beauty is an influx of the divine goodness which, like the light of the sun, is shed over all created things but especially displays itself in all its beauty when it discovers and informs a countenance which is well proportioned and composed of a certain joyous harmony of various colours enhanced by light and shadow and by symmetry and clear definition. This goodness adorns and illumines with wonderful splendour and grace the object in which it shines, like a sunbeam striking a lovely vase of polished gold set with precious gems. And thus it attracts to itself the gaze of others, and entering through their eyes it impresses itself upon the human soul, which it stirs and delights with its charm, inflaming it with passion and desire. ${ }^{57}$

In Bembo's eloquent interpretation, the divine goodness emanating from a beauteous face had its own inherent shine - "a ray of the supernatural" as Bembo elsewhere called it - that attracted an observer's gaze; however, the face's natural pallor and countenance were crucially "enhanced by light and shadow." 58

When Garzoni imagined the amplified radiance of noblewomen's faces underneath their translucent silk veils, he must have envisioned the beguiling display of shifting light and shadow that sheer textiles performed upon the face and skin. In Jean Jacques Boissard's costume book of 1581 , a young noblewoman of Padua pulls a lightly crimped veil down over her face (Fig. 7.2). This figure's veil, rendered here as characteristic of the young maidens of the city, is portrayed not as a garment to protect one's modesty so much as an ornamental veneer that attracts vacillating light and shade through its semi-transparency and drape, drawing attention to the features beneath. In a satirical French source of 1632, modish Parisians were advised that they could attract admirers by wearing "sheer crepe to give shadow to the face."59 French contemporaries even understood the term ombre to mean

57 Baldassare Castiglione, The Book of the Courtier, ed. and trans. George Bull (Cambridge: Penguin Classics, 2011), 325-326.

58 Ibid., 334.

59 De Winkel, Fashion and Fancy, 71. 


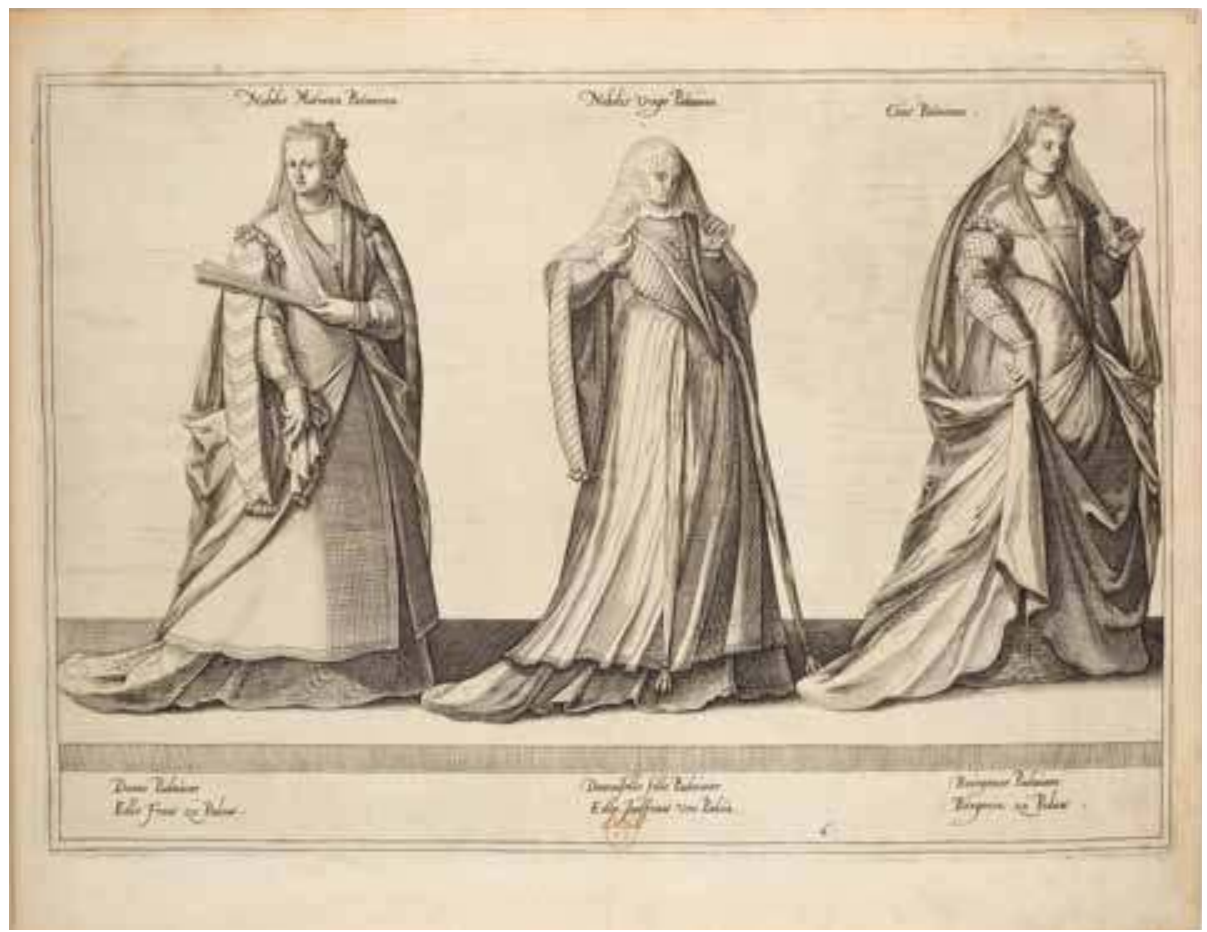

Figure 7.2: Jean Jacques Boissard, Women of Padua. Engraving on paper, $27.9 \times 76.5 \mathrm{~cm}$. In Habitus variarum orbis gentium. Habitz de nations estranges. Trachten mancherley Völcker des Erdskreytz, Mechelen: Caspar Rutz, 1581, fol. 15. Paris, Bibliothèque nationale de France, inv. no. 4-OB-25. Image $\odot$ Bibliothèque nationale de France.

not only "shadow" but also "a veil." ${ }^{\text {"0 }}$ Vecellio informs his readers that in Bologna, a leading centre for the production of silk velo, it was customary for noble-maidens heading to church to wear floor-length silk veils "which they pull over their faces, covering themselves in a beautiful way." ${ }^{\prime 61}$ These veils are portrayed sheer enough to see the shadowed facial features of the woman beneath, while a series of hatched lines suggest the veil's light reflection and fluid drape (Fig. 7.3). These congregate over the woman's eye, which peers out flirtatiously with an arched brow.

Since this play of light could elicit enchantment in spectators, one's veil needed to be suitably reflective. The Florentine silk guild, the Arte della Seta, had cited luzenti (lustrous) veils in their provisions since the mid-fifteenth century. ${ }^{62}$ The natural lustre of silk was enhanced with a variety of experimental treatments. One of the

6o According to the definition in English lexicographer Randle Cotgrave's French to English dictionary: Randle Cotgrave, A dictionarie of the french and english tongues (London: Adam Islip, 1611).

61 Vecellio, Habiti, 251.

62 Elisa Tosi Brandi, "Il velo Bolognese nei secoli xiv-xvi. Produzione e tipologie," in Muzzarelli, Ottaviani, and Zarri, Il velo, 301. 


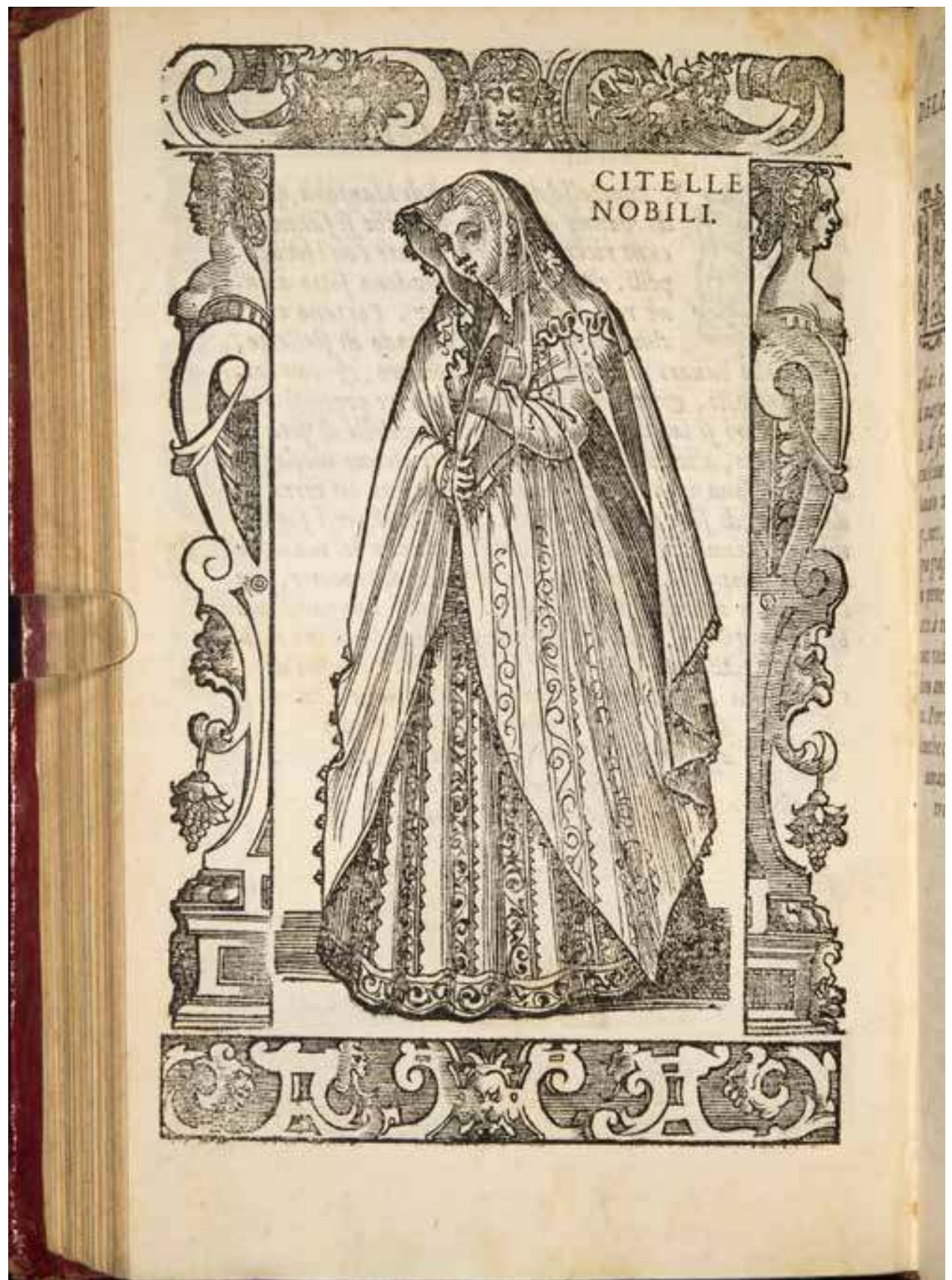

Figure 7.3: Cesare Vecellio, Citelle Nobili. Woodcut, $16.7 \times 12.5 \mathrm{~cm}$. In Cesare Vecellio, Degli habiti antichi, et moderni di diverse parti del mondo, Venice: Damian Zenaro, 1590, plate 199. Noble Girls of Bologna Going from Home to Church. Düsseldorf, Universitäts- und Landesbibliothek Düsseldorf, inv. no. H 32. Image $\odot$ Universitäts- und Landesbibliothek Düsseldorf. 
guild's specialities, a veil textile called velodiacciato, was defined to have "great lustre given to it with a hot iron." ${ }^{63}$ In 1593 a "secret" method for returning the shine to old and dull silk veils was patented in Venice by the Bolognese entrepreneur Castellano di Solimei ${ }^{64}$ Involving beating the veil with a paste made from gum arabic, stretching it, and leaving it to dry, Solimei's strategy and his desire to protect it confirms the value of shine for Italian women, for whom the use of translucent silk veils was widespread. Costume books affirm that veils of this sort were considered especially characteristic of the Italian peninsula. A particularly expressive example worn by a Venetian noblewoman exists in a jewel-like costume album produced in Augsburg in 1580 (Fig. 7.4) ${ }^{65}$ The veil's surface shine is carefully portrayed with a thin wash of white gouache, the reflective surface of its lightly crimped silk defined with crisp, bright lines, augmenting the wearer's pearly visage. Veils draped over the face like this not only dazzled through their translucency, but also accentuated a pale complexion, decisive in the period's beauty standards.

Unlike the gleam of polished armour or golden chains, a veil's shimmer arose from a distinctly delicate surface. Comparatively flimsy in weight, the "very thin" veils cited by Vecellio captured a fragile beauty associated with the feminine aesthetic. The pursuit of ever finer textiles was endeavoured across Europe, with certain regions gaining a reputation for this industry. In Spain the finest linen cloths were manufactured and exported out of the Basque lands. Speaking of the territory of Gipuzkoa, the chronicler Esteban de Garibay (1533-16oo) related, "This land abounds with a great amount of linen, especially [used] for women's heads, which in many parts of Castille are called beatillas, of which the best are worked in the Azpeytia and Azcoytia villages, much more delicate and of better colour than those of Heibar." ${ }^{\prime 66}$ Woven as a gauze with a very loose weft, beatilla was so delicate that it inspired the enlightenment-era philosopher Gaspar Melchor de Jovellanos (1744-1811) to pen a verse describing it as a "cobweb cloth" so thin that a woman's veil made from the stuff could fit inside half a chestnut. ${ }^{67}$ This descriptor had a wide diffusion. The Florentine veil-maker Francesco Donati traded a type of cloth named ragnola ("spider's web" cloth), while Thomas Coryat, an English traveller

63 Gargiolli wrote this definition in the appendix to his nineteenth-century study of the guild's Renaissance treatises, see Gargiolli, L'Arte della seta, $33^{2}$.

64 Molà, Silk Industry, 198.

65 Lipp-OZ 2, Lipperheidesche Kostümbibliothek. See Adelheid Rasche, "Die Bilderhandschrift Lipp-OZ 2 von 1580. Ein Trachtenbuch aus dem Fugger-Umkreis," in Die Kultur der Kleider. Zum hundertjährigen Bestehen der Lipperheideschen Kostümbibliothek, ed. Adelheid Rasche (Berlin: SMPK, Kunstbibliothek, 1999), 23-36. The album is a coloured copy after the designs of Jean Jacques Boissard's earlier pen-and-ink "Trachtenbuch" (Cod. Oct. 193, Herzogin Anna Amalia Bibliothek).

66 As cited in Jose Antonio Azpiazu Elorza, La historia desconocida del lino vasco (Donostia: Ttaarttalo, 2006), 12.

67 As cited in ibid., 109. 


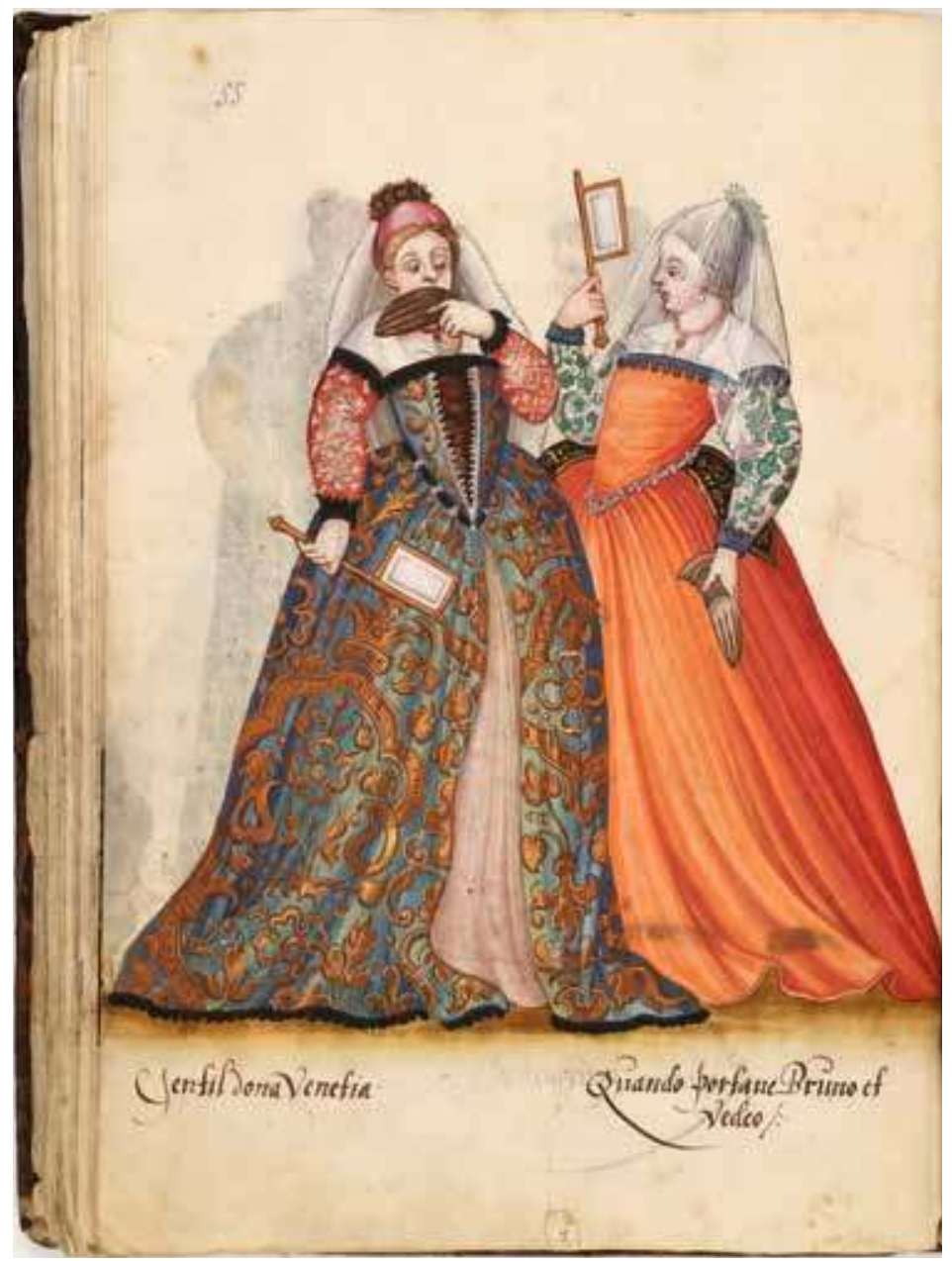

Figure 7.4: (After Jean Jacques Boissard), Venetian Gentlewomen. Gouache on paper. In Trachtenbuch. Darinen viller Volckher unnd Nationen Klaidung [...], 1580, ill. 55. Berlin, Lipperheidesche Kostümbibliothek, inv. no. Lipp Aa 20. Image @ Lipperheidesche Kostümbibliothek.

to Venice in 1608 , described the "slight" linen he observed women covering their shoulders with as a "cobwebbe lawne" or other "thinne stuffe." ${ }^{68}$ Since it was a textile through which the "beholder might plainly see," Coryat considered it an unseemly fashion, ministering to wanton desires. ${ }^{69}$

68 ASF LCF 1848: Libro di vendite e riscossione, 1626, fols. 33, 171; Thomas Coryate, Coryat's crudities: hastily gobled up in five moneths travells in France, Savoy, Italy, Rhetia commonly called the Grisons country, Helvetia alias Switzerland, some parts of high Germany and the Netherlands (Glasgow: James Maclehose and Sons, 1905), 398.

69 Coryate, Crudities, 398. 
Veil-makers and wearers experimented with assorted enterprising methods to create dynamic surface effects. Crimped or crinkled veils - described as increspati in Italian - were particularly modish across Europe and are shown by Vecellio to have been popular among his kinswomen. Venetian maidens, he relates, wear a veil called a cappa "of very delicate silk, very full and ample, thick and staccato [crimped], and of great value, which covers their face so that they are unseen but can see others." ${ }^{\circ}$ Unlike the book's portrayal of the Bolognese maiden, whose glistening face was visible beneath her transparent veil, the Venetian maiden's features are mostly obscured through the "thick" ripples of the "delicate" crimped silk (Fig. 7.5). Crimping, therefore, added textural volume, creating an anomaly whereby the fine, fragile textile concurrently enacted a shield. The threshold of the "thick" veil distorted and decentred the gaze of the spectator, who at times might catch a glimpse of the woman beneath.

Crimped veils were realized with various techniques. The crepe textiles velo crespo and espumilla were popular veil varieties with a light crimp already woven into them. This was achieved using tightly twisted threads for the weft, their elasticity puckering the surface ${ }^{71}$ Such was the importance of using threads with the right torsion, that in 1573 , silk spinners in Toledo were issued royal ordinances dictating the precise measures and twist density for warp and weft threads destined to be woven into espumilla..$^{2}$ To increspare, that is, to create larger crinkles or ripples, was a different procedure documented in Italy. In fifteenth-century Milan, a method of rippling cotton veils was developed using a special iron. ${ }^{73}$ Migrant artisans brought the technique to Venice in the sixteenth century where it was applied to silk veils. Unfortunately, the process rendered the silk exceptionally fragile and prone to wear and tear; thus, in 1573, disgruntled silk-workers complained to the authorities, insisting that the "ancient" method still used by Venetian women to crimp silk with the palm of one's hand was preferable. ${ }^{74} \mathrm{~A}$ recorded Bolognese method was far more complex and involved boiling veils in a solution of water and bile, before being dried and sized for support. The veils were then laid out over beams and heated for several hours before being folded (into pleats) and rolled up on a sheet of paper. ${ }^{75}$

\footnotetext{
70 Vecellio, Habiti, 177.

71 Lou Taylor, Mourning Dress: A Costume and Social History (Abingdon: Routledge, 2010), 170-172; Girolamo Vittori, Tesoro de las tres lenguas francesa, italiana, y Española (Antwerp: Corneille Lectin, 1614); Tosi Brandi, “Velo Bolognese," 296; Gargiolli, L’Arte della seta, 332.

72 Real Academia de la Historia (Spain), Colección de documentos inéditos para la historia de España y sus Indias, vol. 15 (Madrid: Academia de la Historia, 1849), 372.

73 Zanoboni, "Pro trafegando," 130.

74 Ibid., 130.

75 Tosi Brandi, “Velo Bolognese," 297; Muzzarelli, Capo coperto, 171-172.
} 


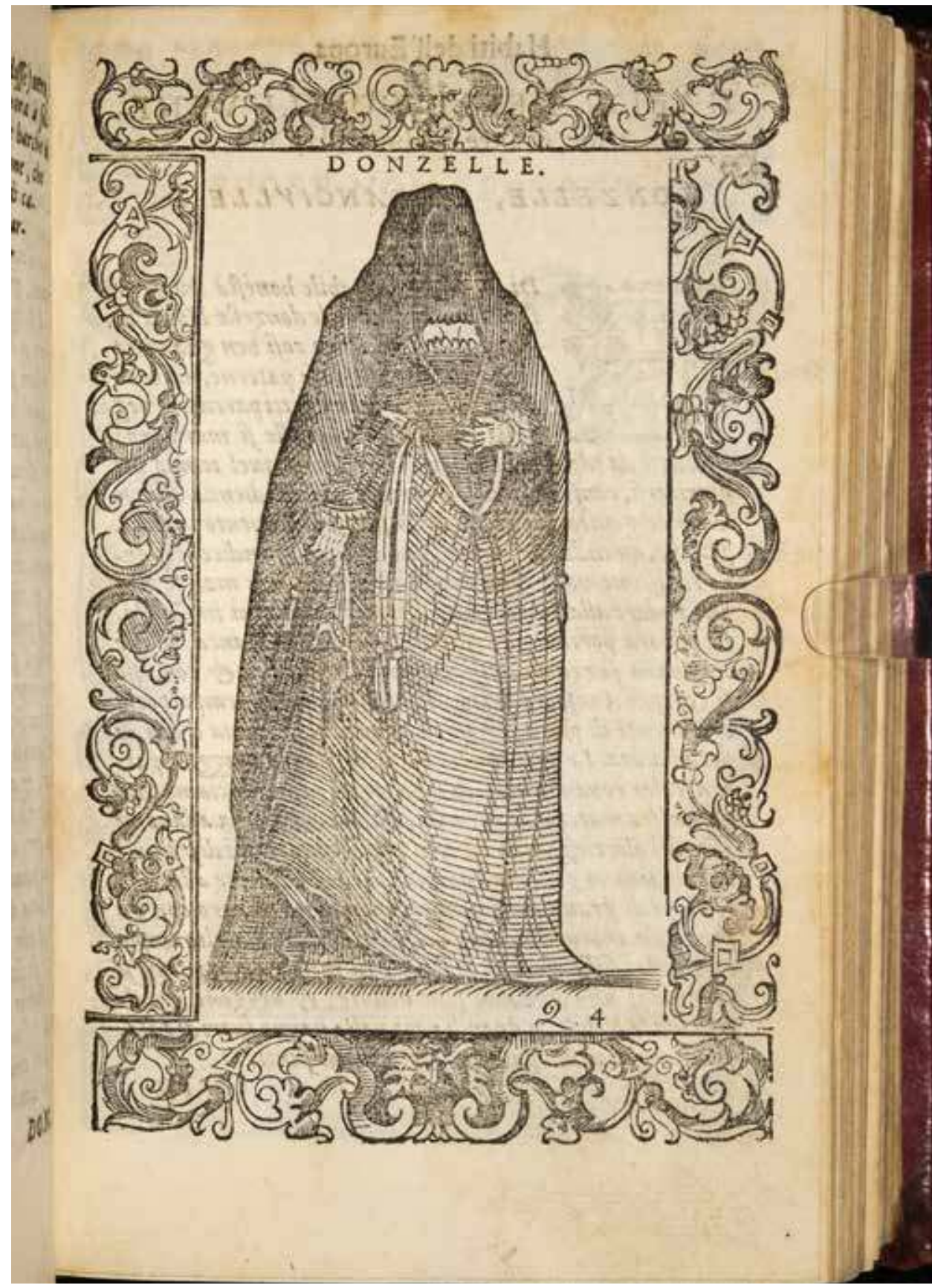

Figure 7.5: Cesare Vecellio, Donzelle. Woodcut, $16.7 \times 12.5$. In Cesare Vecellio, Degli habiti antichi, et moderni di diverse parti del mondo, Venice: Damian Zenaro, 1590, plate 125. Maidens and Girls of Venice. Düsseldorf, Universitäts- und Landesbibliothek Düsseldorf, inv. no. H 32. Image @ Universitäts- und Landesbibliothek Düsseldorf. 
In Castiglione's The Courtier, Pietro Bembo elaborated that beauty was ultimately incorporeal, and was diminished when fused with "base and corruptible matter." ${ }^{76}$ The mass-warping sensation enacted by a rippling veil was to exalt the fragmented face beneath, helping it attain a level of beauty Bembo considered most perfect when "completely separated from matter." 77 In 1608 this feature of the Venetian crimped cappa enthralled Thomas Coryat, who desired to gaze upon the faces of Venice's young women:

It is the custome of these maydes when they walke in the streetes, to cover their faces with their vailes, $[. .$.$] the stuffe being so thin and slight, that they may easily$ looke through it. For it is made of a pretty slender silke, and very finely curled: so that because she thus hookwinketh her selfe, you can very seldome see her face at full when she walketh abroad, though perhaps you earnestly desire it, but only a little glimpse thereof. Now whereas I said before that onely maydes doe weare white vailes, and none else, I meane these white silke curled vayles, which (as they told me) none doe weare but maydes..$^{7}$

According to Coryat, these "curled" white veils signalled maidenhood, affirming, as Vecellio's costume book does, how different veils marked out and codified the life stages of women around the city. Traversing the streets, Coryat's senses were sharpened to an affective typology that associated delicate, form-fragmenting crimped veils with youthful beauty.

\section{Drape and Malleability}

Contemporaries paid close attention to how veils draped, hung, or wrapped around the head and body, turning the textile to diverse effects. The fluidity or stiffness of veil textiles, therefore, was decisive to their function and range of affective resonances. The buoyancy of lightweight veils particularly intrigued Vecellio, who noted the effect of wind upon veils worn in Italy no fewer than seven times. Around Parma, he informs readers, peasant and artisan girls place a "pretty veil" atop their coiffures, and since "it is very long at the end, they let it flutter in the wind" (Fig. 7.6)..$^{79}$ Other women from around Parma and Lombardy are said to suspend from their hairstyles "a little veil striped with gold and lace, fluttering in

76 Castiglione, Courtier, 334.

77 Ibid.

78 Coryate, Crudities, 398.

79 Vecellio, Habiti, 244. 


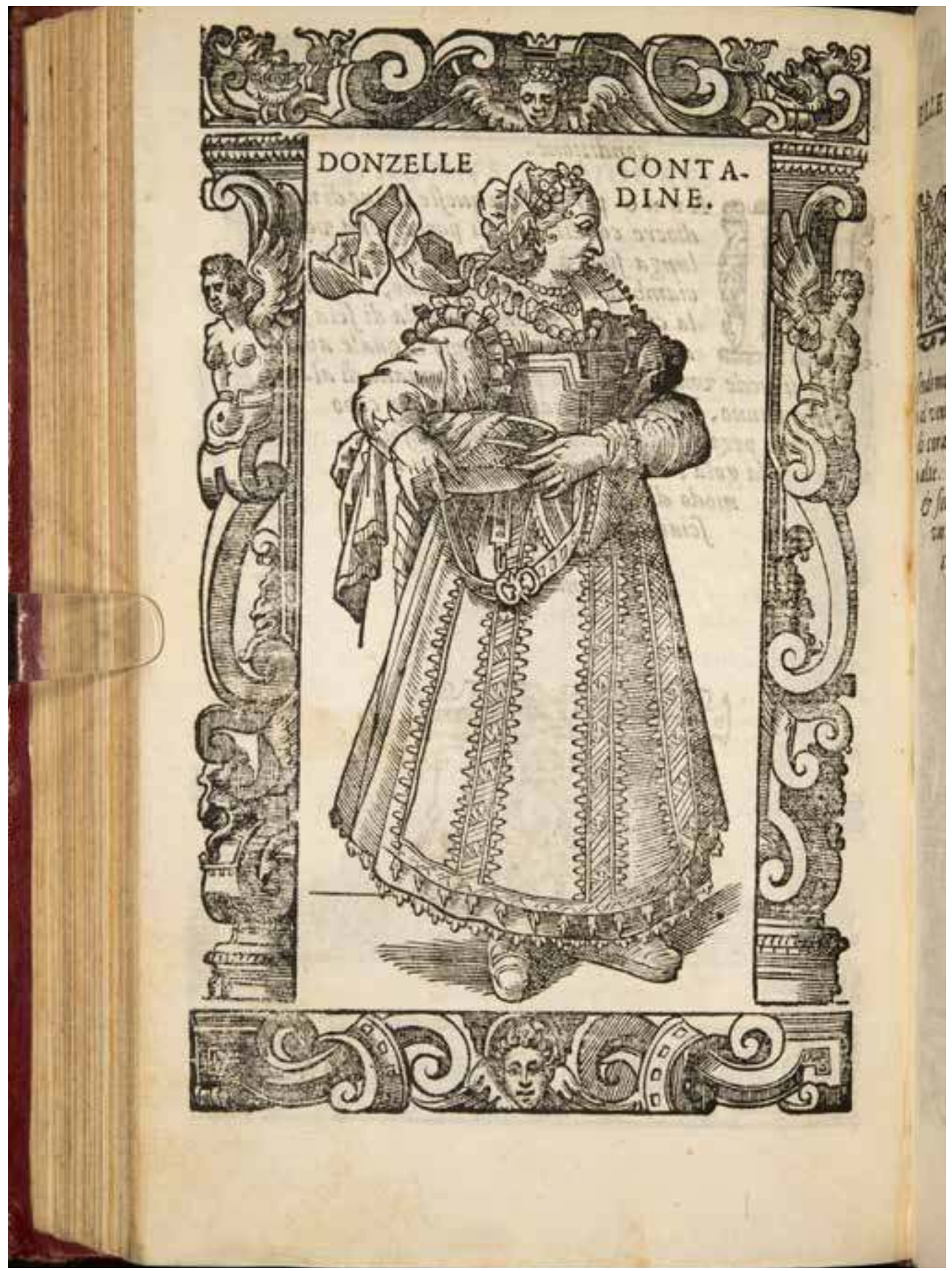

Figure 7.6: Cesare Vecellio, Donzelle Contadine. Woodcut, $16.7 \times 12.5 \mathrm{~cm}$. In Cesare Vecellio, Degli habiti antichi, et moderni di diverse parti del mondo, Venice: Damian Zenaro, 1590, plate 192. Girls of the Peasantry and Artisan Class in Parma. Düsseldorf, Universitäts- und Landesbibliothek Düsseldorf, inv. no. H 32. Image $\odot$ Universitäts- und Landesbibliothek Düsseldorf. 
the breeze"; meanwhile, their compatriots in Mantua wear silk veils which they "let flutter in the breeze down to their shoulders. ${ }^{n 00}$ Vecellio emphasizes the rippling animation of the veils, demonstrating his appreciation for the materiality (and not simply the form) of clothing. Although fixed in static woodcuts, his veils relay a vibrant world of active matter.

The crackling energy of the veil-cloth worn by the Parma countrywoman, whipped mid-air by a wind gust, accentuates the expressiveness of cloth, an aesthetic savoured by contemporary artists. In her discussion of drapery's pictorial appeal, Anne Hollander summarized that "representational art has always dwelt on the fascinating capacity of cloth to bunch, stretch, hang, or flutter, to be smooth or unsmooth under different circumstances. ${ }^{181}$ Addressing characteristics of drapery in Northern Renaissance painting, Hollander drew attention to the "nervous" energy of cloth - agitated not so much by wind, as by its own dynamic force. ${ }^{82}$ This interpretation recalls Aby Warburg's accessories-in-motion (bewegtes Beiwerk) that through their intensity and momentum, independently tap into affects and energies. As Warburg identified, art from Antiquity to the Renaissance appreciated moving drapery for its ability to express fleeting, ephemeral moods independent from human action and subjectivity. The activity of wind and cloth registers such a moment, undermining the "default grammar of agency" that Jane Bennett laments has long assigned "activity to people and passivity to things." ${ }^{83}$

Despite the Renaissance esteem for human-led manipulation of matter, the elemental qualities of materials and the sensorial discernment of these qualities were admired and interrogated. ${ }^{84}$ The aerodynamic spaces between loosely woven threads mobilized veils' ascendency out of a state of inertia; even more, they substantiated the colliding energies and material vitality to which contemporaries were attuned. Veils' buoyancy was mediated by their textile properties; that is, their fibre and thread type, weave, and weight. Silk's natural elasticity was conducive here, as well as the decreasing thread density of popular veil textiles. Vecellio notes that middle-class women in Lombardy covered their hair with black ormesino, a cheap and lightweight silk fabric that they "let fall down behind them and blow in the wind." ${ }^{85}$ Although animated by air-flows, he indicates that these veils were

80 Ibid., 240, 248.

81 Anne Hollander, Seeing through Clothes (Berkeley, CA and London: University of California Press, 1993), 1.

82 Ibid., 20-21.

83 Jane Bennett, Vibrant Matter: A Political Ecology of Things (Durham, NC: Duke University Press, 2010), 119.

84 See Ulinka Rublack, "Matter in the Material Renaissance," Past \& Present 219 (2013): 44; Rublack, "Renaissance Dress, Cultures of Making, and the Period Eye," West 26th 23, no. 1 (2016): 9.

85 Vecellio, Habiti, 243 . 
knowingly manoeuvred by their wearers to catch the breeze, just like those worn by noblewomen in Verona, which were pinned "into so many loops" upon their braids so that "when they catch the wind, they stand up like a crest and look very elegant." ${ }^{86}$

Of course, it was not always desirable for the movement or glisten of one's veil to attract attention. In the seventeenth-century Dutch Republic for instance, Marieke de Winkel notes that mourning dress substituted popular shiny, silk fabrics for heavier black woollens with matte surfaces ${ }^{87}$ Denser veils were taken up by widows for example, which, when draped around the hair and torso, precipitated a sensory and bodily transformation over the enveloped wearer. Vecellio shows us that in Italy, the widow's veil ideally enacted a postural change that elicited a feeling of grief and social exclusion. In Rome widows of the nobility, with their full-length veils made of the wool-and-silk-blend buratto, are recounted to "dress in a way that shows great chastity and sorrow for their dead husbands, so that, considering their demeanour, one would say they seem more like nuns than laywomen." ${ }^{88}$ Venetian widows, explains Vecellio, fastened "a very thick veil over their breast," and wore their cappa "low on their foreheads." In this way, he affirms, "they go through the streets sadly, and with lowered heads" (Fig. 7.7). ${ }^{89}$

These descriptions express the weight - both physical and emotional - that veils and mantles were supposed to bear upon widows' bodies, compelling their heads and shoulders downwards and curtailing how socially accessible they seemed to passers-by. Although not of especially heavy textiles, the buratto and silk veils Vecellio notes were more substantial than the "very thin" semitransparent textiles that proliferate elsewhere in his book. Vecellio's sheltered Italian widows are depicted in line with contemporary prescriptive thought, which firmly emphasized comportment, particularly the downward gaze..$^{9}$ In 1491 the Dominican preacher Savonarola $\left(145^{2-1498)}\right.$ penned a conduct book for widows in which he stressed that their dress and bearing must "indicate mortification and sadness":

Thus she must restrain her eyes everywhere so that they do not see vain things, especially in church or in public places, otherwise she will be a source of scandal [...] Thus a widow must always in every place and especially in the presence of men, lower her eyes and keep them lowered to the earth. ${ }^{91}$

86 Ibid., 262.

87 De Winkel, Fashion and Fancy, 70.

88 Vecellio, Habiti, 8 .

89 Ibid., 186.

90 Alison Levy, Re-membering Masculinity in Early Modern Florence: Widowed Bodies, Mourning and Portraiture (Aldershot: Ashgate, 2006), 66-67.

91 Girolamo Savonarola's Libro della vita viduale, translated and cited in ibid., 66. 


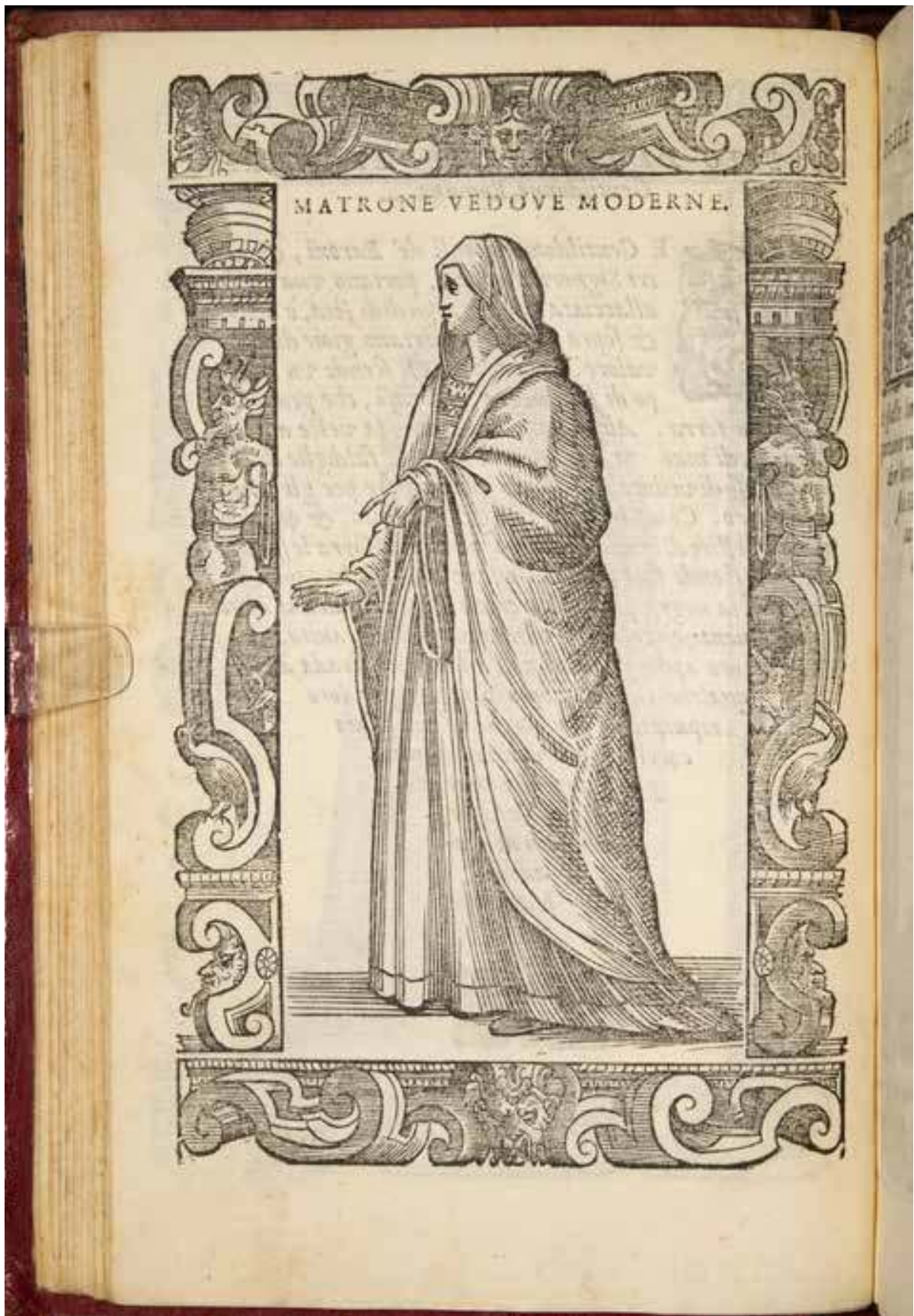

Figure 7.7: Cesare Vecellio, Matrone Vedove Moderne. Woodcut, $16.7 \times 12.5 \mathrm{~cm}$. In Cesare Vecellio, Degli habiti antichi, et moderni di diverse parti del mondo, Venice: Damian Zenaro, 1590, plate 29. Noble Widows of Modern Rome. Düsseldorf, Universitäts- und Landesbibliothek Düsseldorf, inv. no. H 32. Image @ Universitäts- und Landesbibliothek Düsseldorf. 
The veil's role to disrupt the libidinous gaze of both the widow and her male observers is neatly explained in Silvio Antoniano's On the Christian education of youth (Verona, 1583):

The veil, often fully pulled before the face, as it should be worn, is like a shield for the eyes and has the effect of making the sight of the wearer more focused and not allowing it to look curiously here and there [...] Tertullian calls it a helmet of the virgins and a shield against darts and temptations..$^{2}$

When correctly pulled over the forehead, the veil's hood-like shape intended to enshroud the widow and obscure her vision, hampering distraction by external temptations. The denser the textile, the better the veil would affect the widow's countenance and promote internal contemplation.

As Levy affirms, widowhood was a destabilizing source of female autonomy with possibilities for financial and social independence. ${ }^{93}$ Widows' veils also staged a woman's passage through mourning and could be manipulated to signal an interest to re-enter the marriage market. According to Vecellio, Venetian widows would reveal more of their hair from beneath their veils "when they decide to marry again."94 Women handled their veils to "inform others of their intentions," as Vecellio put it. These were not arbitrary codes, however, and were vested in the affective resonances of cloth. ${ }^{95}$ The sensation of a vast, pliable veil enshrouding the body provided a defensive barrier in a cultural milieu that, following Galenic medical principles, considered the skin to be porous and susceptible to foreign, malignant forces. ${ }^{96}$

The malleability enabling a lightweight veil to catch the breeze or a heavier textile to envelop bodies with formidable drape also lent itself to the modelling of diverse forms. The extraordinarily varied compositions of veils seen to shift from region to region in contemporary costume books invite consideration of the processes of preparing and arranging veils for headwear. Veils were not simply put on like a cap and Vecellio's regular use of active verbs like "arrange," "fold," "pin," "attach," "wrap," and "shape" underscore the tactile confrontation veils invited, as dressers wrestled cloth into desired shapes.

Various tools and techniques were required. It was firstly important to launder veils appropriately before use. The 1486 household inventory of Nuremberg

92 Silvio Antoniano, Dell'educazione Cristiana e politica de figliuoli (Florence: Casa di Correzione, 1852, orig. Verona ed. 1584), 388.

93 Levy, Re-membering Masculinity, 61, 66.

94 Vecellio, Habiti, 186.

95 Ibid., 186.

96 Isabelle Paresys, "The Body," in A Cultural History of Dress and Fashion in the Renaissance, ed. Elizabeth Currie (London: Bloomsbury Academic, 2017), 69. 
patricians Konrad and Katherina Imhoff, for example, documents that inside a cupboard storing Katherina's veils (a wieldy, folded style called the Sturz) was also a so-called Sturz-press, as well as soap, sponges, and starch "to [form the] Sturz." ${ }^{\prime 97}$ Such items not only served to maintain one's veil, but also offered the opportunity for originality since they enabled shapes and designs to be made afresh. Iris Sturtewagen also notes the highly specialized nature of laundering apparatuses in fifteenth- and sixteenth-century Bruges, used to wash, bleach, starch, polish, iron, and press linens into submission, including a "little laundry tub for kerchiefs," as well as two iron crepe presses and one "linen bonnet press" for the pleating and setting of veils. ${ }^{8}$ To maintain their form, many styles were fixed with heat and starch, in many cases also underpinned by supporting caps, frames, and mounts. Remarking on the dress of women in Brabant, Vecellio describes "[...] they wear a thin, high mantle lined with wool, which they pin above their foreheads; then, with a copper wire or circlet of wool, they shape it into a large curve." ${ }^{99}$ Multidimensional effects were achieved through folding, pinning, and layering, and veils were often composed in tandem with hairnets, caps, and coifs. During his travels around Germany in 1517, the Italian ecclesiast Antonio de Beatis observed that the "wealthy and upper class women wear a sort of very wide folded cloth on their heads, and over this a closely woven veil of delicate samite of the purest white [...] which is secured and arranged in certain folds giving a most majestic appearance."100

The sculptural quality of cloth and its ability, through manipulation, to maintain rigid shapes as readily as a soft drape is also highlighted in the period's costume images of diverse cloth headdresses. Boissard's costume book is one of many that is strikingly attentive to these qualities. Its depiction of women from Verdun, northeast France, is a compelling example. The women's veil-cloths, supported on a solid frame projecting skyward, are folded into crisp, wrinkle-free triangular points - an architectural feat achieved, no doubt, with the assistance of heat, steam, and starch (Fig. 7.8).

Across the book, groups of three figures from the same location are positioned side by side, sometimes appearing engaged in conversation. A figure's clothing can be analysed in relation to what is worn by their nearest kinsman or -woman, presenting dress as a subject of exchange and dialogue within communities. It has been said that costume books attempted to resist the troublesome reality that

97 Jutta Zander-Seidl, "Das erbar gepent: Zur ständischen Kleidung in Nürnberg im 15. und 16. Jahrhundert," Waffen- und Kostümkunde 27 (1985): 121.

98 Iris Sturtewagen, "All Together Respectably Dressed" (PhD diss., University of Antwerp, 2016), 94-95. 99 Vecellio, Habiti, 414.

100 Antonio de Beatis, The Travel Journey of Antonio de Beatis: Germany, Switzerland, the Low Countries, France and Italy, 1517-1518, trans. J. R. Hale (London: Hakluyt Society, 1979), 80. 


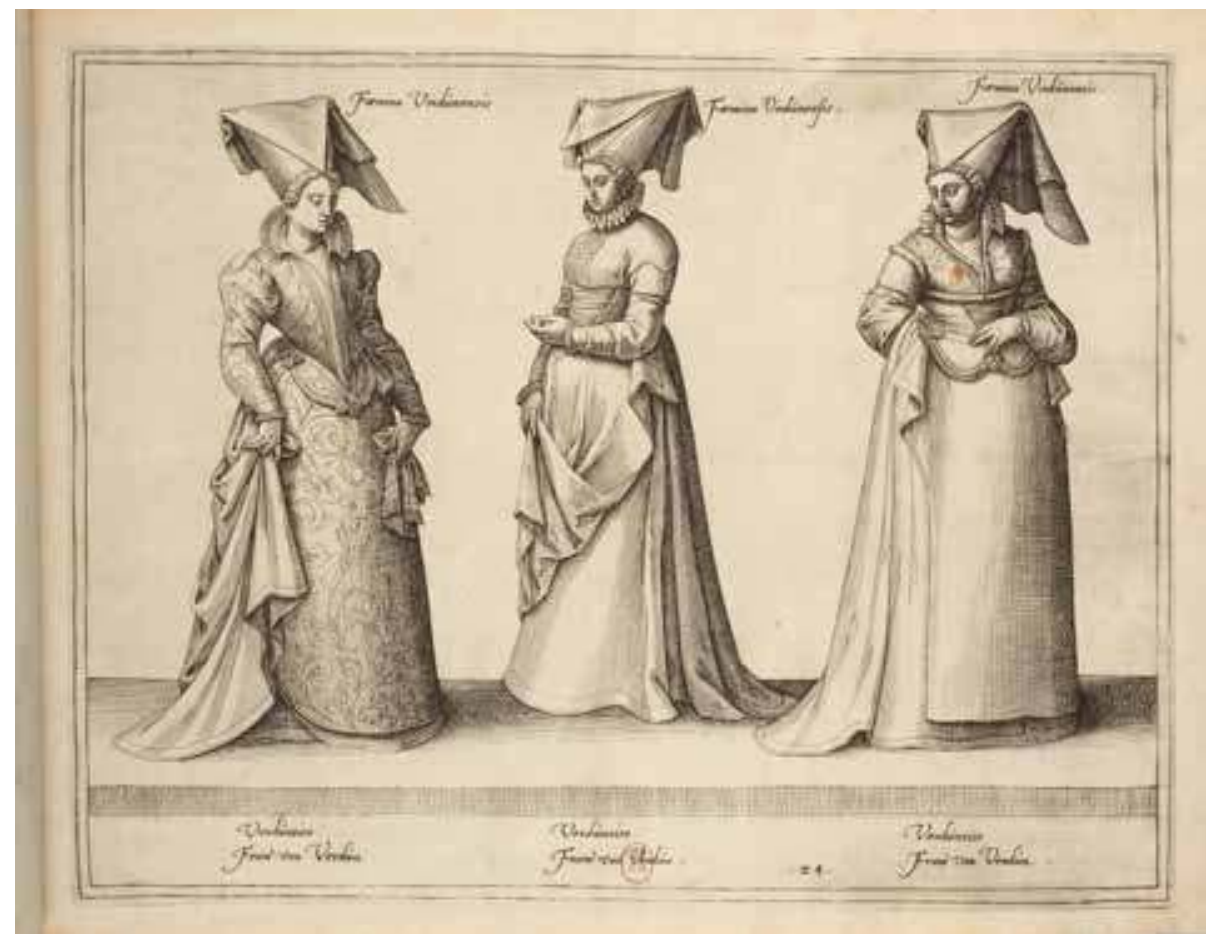

Figure 7.8: Jean Jacques Boissard, Women of Verdun. Engraving on paper, $27.9 \times 76.5 \mathrm{~cm}$. In Habitus variarum orbis gentium. Habitz de nations estranges. Trachten mancherley Völcker des Erdskreytz, 1581, fol. 31. Paris, Bibliothèque nationale de France, inv. no. 4-OB-25. Image $\odot$ Bibliothèque nationale de France.

fashions constantly changed. ${ }^{101}$ But the social influences that compelled people to try new modes and construction methods is hinted at in these moments of gesticulation, reminding readers of the ease with which fashion trends moved through social circles. Evelyn Welch points to the lively interest and exchange in headdress styles among female courtiers in early sixteenth-century Lombardy, noting that Isabelle d'Este of Mantua was credited in 1509 for having disseminated to Milan "a new type of silk headdress, a notable invention of your ladyship."102 In 1523, Bona Sforza, queen of Poland, wrote to Isabella imploring the marchioness to "let us know when some new style of binding the head happens and to send us something that is pretty [...] for we are sure you never miss anything as your Ladyship is the source and origin of all the loveliest fashions in Italy."103

101 See Ann Rosalind Jones, "'Worn in Venice and throughout Italy': The Impossible Present in Cesare Vecellio's Costume Books," Journal of Medieval and Early Modern Studies 39, no. 3 (2009): 511-544.

102 From a letter of Eleanora Ruscha, Countess of Correggio, translated and cited in Welch, "Art on the Edge," 250.

103 From a letter of Bona Sforza, queen of Poland, translated and cited in ibid., 254. 
In a world of ever-changing fashions, veils benefitted from their adaptability, meaning transformation and reuse was permissible. They could be pinned in manifold ways taking on a range of meanings and uses; worn on the head one day, the same textile could potentially be a shoulder cover or breast cloth the next. Chia-Hua Yeh has shown that in inventories from the late sixteenth-century Florentine court, the sciugatoio (towel/ handkerchief/ shawl) appears as an all-purpose cloth that might adorn the chest (sciugatoio da pettinare) or the head (sciugatoio da capo/ da portare in testa). ${ }^{104}$ Early modern garments were commonly fastened together with the use of removable pins as opposed to permanent, stitched seams. If a length of cloth was able to be modelled into a certain shape without needing to cut or stitch it, it could be used on another occasion to make a different composition. Knowing how to arrange and pin cloth into temporary fixtures went beyond the achievement of striking aesthetic looks. Indeed, it was a matter of economic frugality at a time when the disposal of fabric was ideally avoided. Welch notes the contemporary concern for the reuse and adaptation of textiles as they were a visible sign of capital investment and had the potential to be redeemed as necessary. ${ }^{105}$

\section{The Tocados of Northern Spain}

The skills needed to compose veils that were "dexterously arranged" or "fashioned with marvellous skill," were a matter of communal significance. ${ }^{106}$ The following case study considers veiling as an emblem of community identity in the northern territories of Spain stretching around the Bay of Biscay and into the Basque provinces of France. ${ }^{107}$ Many costume series seized upon the rich variety of cloth compositions worn by women in these parts, depicting the assorted styles for folding, tucking, twisting, and binding veil-cloths that fed into the peninsula's unique sartorial character (Fig. 7.9). Together these headdresses (tocados) contributed to a shared aesthetic for dramatic volume, height, and contour that captured the imagination of foreign travellers.

104 Yeh, "Head Coverings," 142.

105 Evelyn Welch, "New, Old and Second-Hand Culture: The Case of the Renaissance Sleeve," in Revaluing the Renaissance, ed. Gabriele Neher and Rupert Shepherd (London: Routledge, 2017), 107-108.

106 Vecellio, Habiti, 421, 483.

107 This culture has been documented in Spanish ethnographic scholarship since the early twentieth century: Julio de Urquijo, "Sobre el tocado corniforme de las mujere vascas," Revista Internacional de Estudios Vascos 12 (1922): 570-581; Julio Caro Baroja, "El tocado antiguo de las mujeres vascas (un problem de etnografia)," Atlantis 15 (1936-1940): 33-71; J. M. Gomez-Tabanera, “Del tocado 'corniforme' de las mujeres asturianas en el siglo XVI," El Basilisco 5 (November-December 1978): 39-82; Herminia Menéndez de la Torre and Eduardo Quintana Loché, "Indumentaria popular asturiana en el siglo XVI," Revista de Folklore 306 (2006): 213-216. 


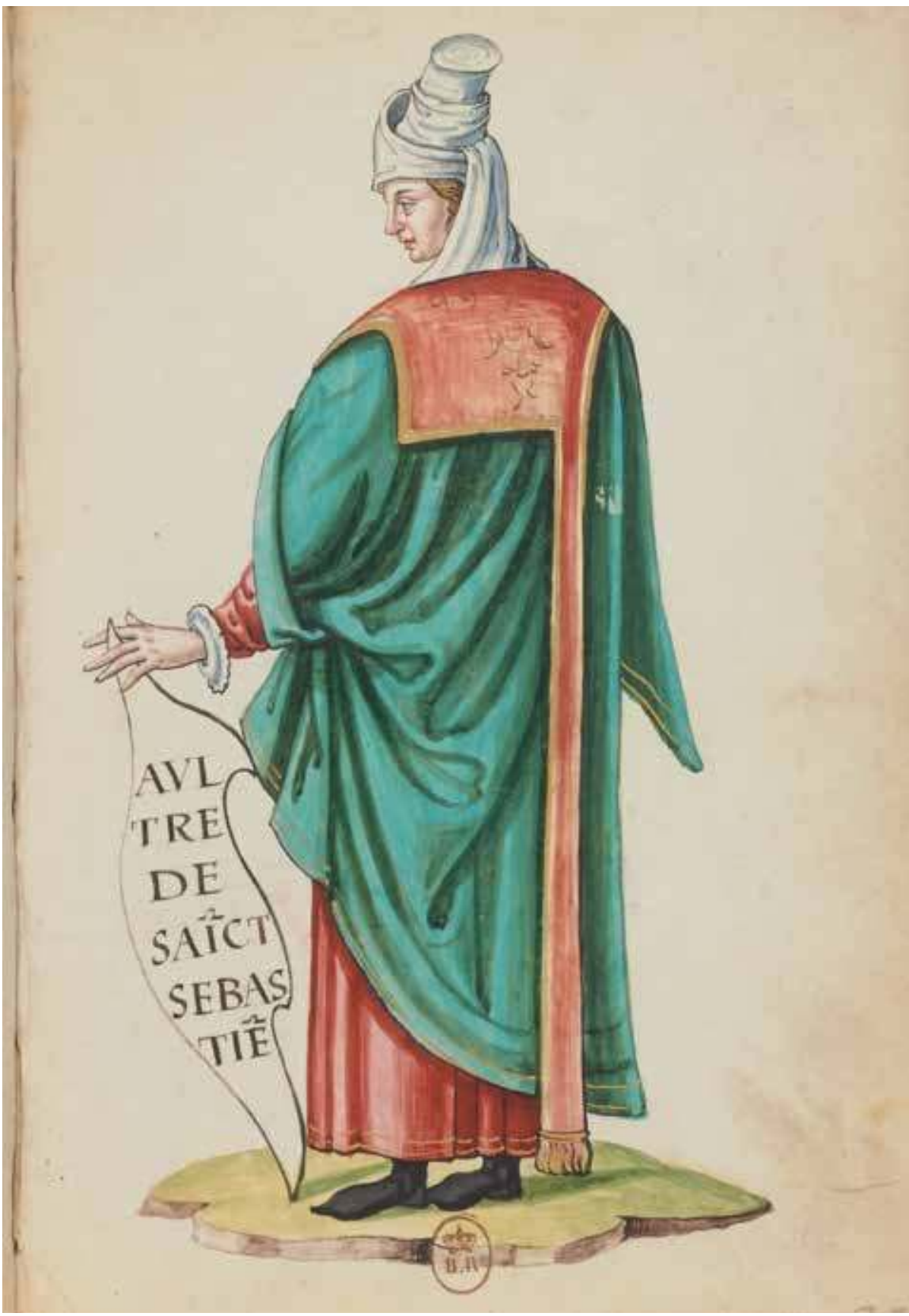

Figure 7.9: Woman of San Sebastián. Pen and ink, gouache, watercolour, and gold on paper. In Costumes de femmes de diverses contrées, sixteenth century, ill. 24. Paris, Bibliothèque nationale de France, inv. no. RESERVE 4-OB-23. Image @ Bibliothèque nationale de France. 
When the Burgundian nobleman Antoine Lailang passed through the Basque lands in 1502, he commented on the beautiful women who, instead of wearing bonnets, wore headdresses "of twenty or thirty ells of cloth. ${ }^{{ }^{108}}$ The Burgundian chamberlain Laurent Vital made similar observations as he journeyed through the region as part of the entourage delivering the young future Charles V to Spain. Landing in Asturias in September 1517, Vital was struck by the women whose "headdresses are strange, and so high and long [...] quite pagan in fashion."109 The headdresses Vital witnessed in Villaviciosa reminded him of beehives or "large baskets of cherries." Flemish ambassador Lambert Wyts was equally astonished by these veils during his travels around Spain in 1571, declaring that Basque women were "adorned in a strange manner, for they wear a headdress shaped like a pyramid that is best compared to a swaddled child." ${ }^{100}$ Immense and towering, the veils are characterized to employ a good deal of yardage. They were, Vital had been told by his landlady, "very painful to wear and very expensive for the large amount of fabric they use in them." ${ }^{\prime 11}$

In his history of the Basque linen trade, José Antonio Azpiazu Elorza reads the quantity of cloth used in the region's headdresses as a marker of social status. ${ }^{112}$ In the Gipuzkoan village of Azpeitia, the deceased María Juan de Auztegui left in her will a tocado of thirteen varas, while her neighbour Domenja de Eguibar bequeathed seven headdresses of eleven varas each. ${ }^{113}$ Since the Spanish $v$ ara (yard) equated to $837 \mathrm{~mm}$, these women's veils measured between nine to eleven metres in length, a ponderous amount to rest on the head. These were not even the most spectacular in volume. A decade later, fellow Gipuzkoan María Joango de Ganbara was recorded to have possessed a "new" woman's tocado thirty varas in length. ${ }^{114}$ The use of thirty yards of cloth, equivalent to twenty-five metres, constituted spectacular consumption. This veil probably used a very fine linen like the "cobweb" cloth beatilla. ${ }^{115}$ In a costume album in the collection of the national library of Spain, a depiction of women from Astorga demonstrates one method for containing such a quantity of cloth (Fig. 7.10). The artist portrays the fabric arranged into a thick concertina fold, encapsulated inside a fat tube of cloth and bent over the crown

108 De Urquijo, "Tocado corniforme," 572-573.

109 Vital, "Premier voyage," 94.

110 As cited in Azpiazu Elorza, Lino vasco, 101.

111 Vital, "Premier voyage," 95.

112 Azpiazu Elorza, Lino vasco, 101.

113 Ibid., 106.

114 Archivo Histórico de Protocolos de Gipuzkoa (AHPG), 289: 2/oo1623. Reproduced in Iñaki Azkune Mendia, Zestoaren historia (1): historiaurretik 1544. urtera arte (electronic resource) (Donostia-San Sebastián, 2016), VIII 1541, Agiritegia, 319. https://www.zestoa.eus/eu/zestoaren-historia-1-.

115 Azpiazu Elorza, Lino vasco, 103. 


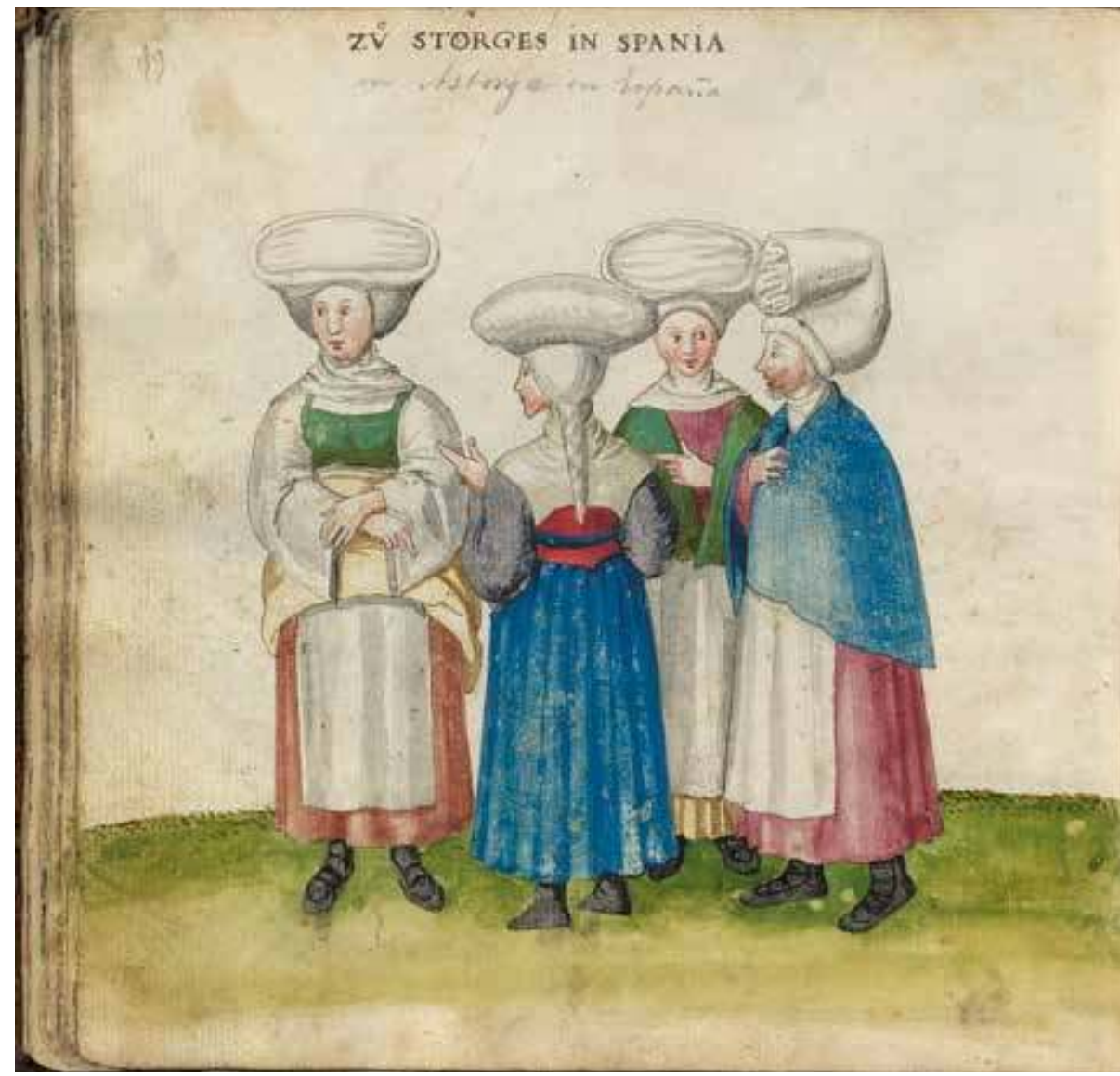

Figure 7.10: Women from Astorga, Spain. Pen, ink, and gouache on paper, $20 \times 20 \mathrm{~cm}$. In Códice de Trajes, ca. 1550, ill. 19. Madrid, Biblioteca Nacional de España, inv. no. Res/285. Image ๑ Biblioteca Nacional de España.

of the head. ${ }^{116}$ Azpiazu Elorza argues that the linen tocados used represented a socially recognized investment and thus owning large numbers demonstrated material abundance. ${ }^{17}$ One Mutriku villager held six in her dowry in 1575 , while a fellow resident was able to bring a total of ten to hers in 1636 . Both women's dowries, by contrast, contained just four shirts apiece. ${ }^{118}$ These headdresses were not only financial assets of valuable yardage, however. The effort that went into

116 The “Códice de Trajes," Res/285 is a contemporaneous copy after Christoph von Sternsee's mid sixteenth-century costume album, housed in the Museo Stibbert, Florence ("Costumes of the time of Charles V, Emperor of the Holy Roman Empire, and King of Spain, of costumes of all nations of the world, circa 1540," ca. 1548-1549. Cat. 2025). On this album, see Katherine Bond, "Mapping Culture in the Habsburg Empire: Fashioning a Costume Book in the Court of Charles V," Renaissance Quarterly 71 (2018): 530-579. 117 Azpiazu Elorza, Lino vasco, 105. 118 Ibid., 98. 
their artful arrangement suggests a clothing culture that took pride in the output of a female-dominated linen industry.

Local economies were upheld by the Basque linen trade and the textile wielded particular social significance. In 1625 the cleric Lope Martínez Isasti recounted in his history of Gipuzkoa that his kinswomen were

[...] very much given to agriculture, and among other things to flax, so that they sow and take in a great quantity of it, and they spin and weave it with particular care; and thus the land is provided with delicate linen, and white clothing, providing headdresses, beatillas and other kinds of linens to much of Spain. ${ }^{19}$

María de Garibay of Oñati was one such industrious woman. Her will reveals ownership of several looms and instruments, and documents transactions with female weavers in her employ. No less than twelve tocados were recorded in her possession at the time of her death in $1594 .{ }^{120}$ The commercial acumen and technical skills women held in these parts was a source of regional pride. Managing the production of linen from sowing flax seeds to trading finished cloth, women positioned their art and industry squarely upon their heads, where it proved the final confirmation of their craft.

The versatility of malleable cloth encouraged experimentation with form, vividly expressed in an early sixteenth-century, French-produced costume series of Basque women. A veil resembling a basket with handles, for example, is modelled by a woman characterizing the town of Saint-Jean-Pied-de-Port, at the foothills of the Pyrenees (Fig. 7.11). Such styles were recognized by the imaginative descriptive terms applied to them in the records. Headdresses described as "stalactites" in the promised dowry of María Juana de Aguirre in 1578 leave little doubt to their tapering, conical form. ${ }^{121}$ Since styles diverged from one town to the next, they were conspicuous and idiosyncratic for foreign travellers, particularly in a region hosting the well-trodden pilgrimage route to Santiago de Compostela. The pervasive fashion for twisted, horn-shaped tocados - illustrated at length in the Trachtenbuch (costume book) of travelling German artist Christoph Weiditz - was particularly commented on, occasionally inviting phallic references from incredulous travellers (Fig. 7.12). When Arnold von Hauff of the town of Bedburg, near Cologne, made his pilgrimage in 1499, he noted that the women in the Basque province of Gascony on the frontier with Spain wore "a twisted horn with cloths of canvas on their heads,

119 Lope Martinez de Isasti, Compendio historial de la provincia de Guipúzcoa, por Lope de Isasti en el año de 1625 (San Sebastián: Ignacio Ramon Baroja, 1850), 149.

120 Azpiazu Elorza, Lino vasco, 105.

121 Ibid. 


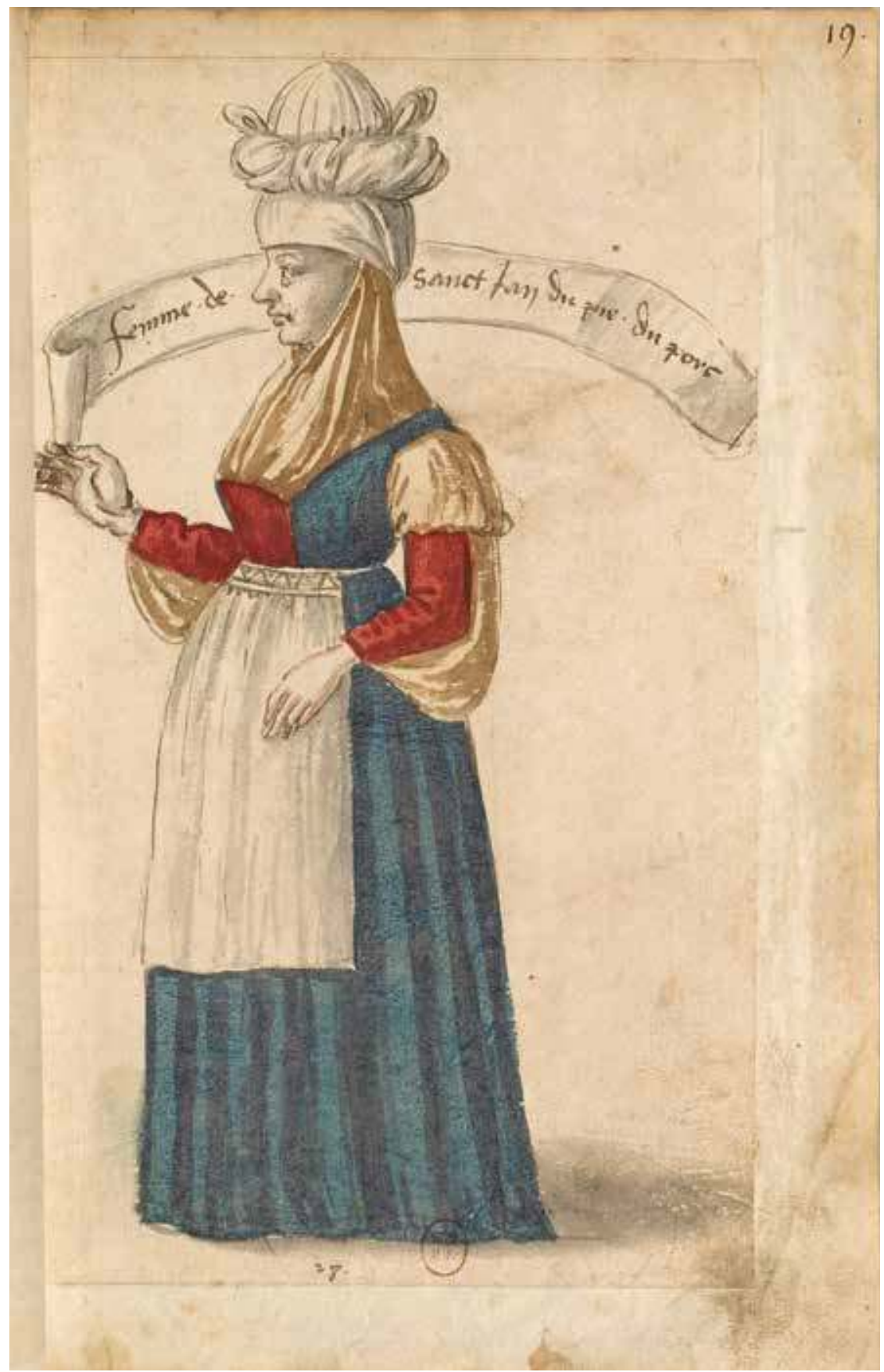

Figure 7.11. Woman from Saint-Jean-Pied-de-Port. Pen, ink, and gouache on paper. In Recueil. Costumes de Femmes de diverses contrées, late fifteenth century, ill. 19. Paris, Bibliothèque nationale de France, inv. no. RESERVE OB-55-4. Image $\odot$ Bibliothèque nationale de France. 


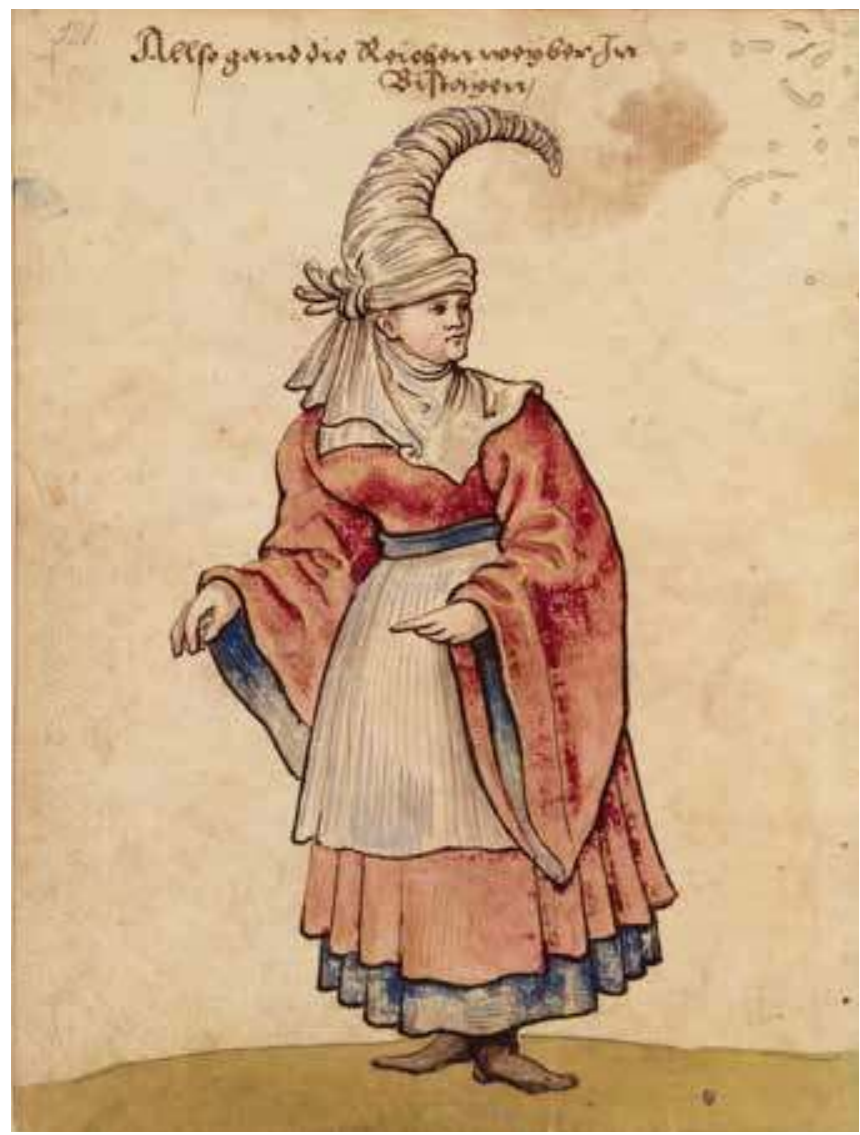

Figure 7.12: Christoph Weiditz, Wealthy Women in Biscay. Pen and gouache, gold and silver, $15 \times 20 \mathrm{~cm}$. In Christoph Weiditz, Trachtenbuch, Augsburg, 1530-1540, ill. 121. Nuremberg, Germanisches Nationalmuseum, inv. no. Hs 22474. Image @ Germanisches Nationalmuseum.

longer than two hand-spans. ${ }^{122}$ In Ribadesella, Asturias, Vital remarked that “[...] it seemed as if they [the women] had planted on their heads [...] those things with which men make children, and it is the most devilish adornment that has ever been seen." ${ }^{123}$ The English physician Andrew Boorde meanwhile, recounting his pilgrimage to St James's shrine in 1532, observed that women along the route wore "thinges [that] standeth vpon theyr hed, within ther kerchers [kerchiefs], lyke a codpiece." ${ }^{.124}$

122 Von Hauff cited by De Urquijo, "Tocado corniforme," 570.

123 Vital, "Premier voyage," 97.

124 Andrew Boorde, The Fyrst Boke of the Introduction of Knowledge [...], ed. Frederick James Furnivall (London: N. Trübner, 1870), 1999 . 
We might dismiss these comparisons as the crude fantasies of culturally insensitive travellers; however, even within their own societies, the veils' position was debated. Vital narrates having sought the testimony of locals in Ribadesella to learn more about the "devilish" headwear he found so fascinating. One old man declared that they were introduced in the distant past by the reigning king of Castile to punish women's resistance to Christianity. Accordingly, the burdensome veils hanging over their foreheads made it "known that they are women." ${ }^{25}$ Vital's landlady, meanwhile, explained "that they carried these ornaments with regret" not only because of the expense of the large amount of cloth they consumed, but also because "in times of great heat, [the tocado] weighs them down and greatly fatigues them." ${ }^{126}$ Convinced to intervene, Vital recounts explaining the women's situation to Charles and his Flemish lords who apparently "burst out laughing, saying that the ornaments were cheerful and of great novelty."127

Interpretations of the phallic symbolism of horn-shaped headdresses even thrived among those familiar with Basque culture. Michel de Montaigne (1533-1592), for instance, who hailed from Guyenne, bordering Gascony, commented that "the married women near my place twist their headscarves into the shape of one [the male sexual organ] to revel in the enjoyment they derive from it; then on becoming widows they push it back and bury it under their hair."128 Sharing this notion was the infamous demonologist Pierre de Lancre (1553-1631), who in 1609 subjected Basque villagers in Labourd to terrifying witch trials. De Lancre considered married women's "spiked" headdresses wholly indecent, claiming that they "testified to their desire" since widows wore theirs flat to demonstrate they lacked husbands. ${ }^{129}$ By the late sixteenth and early seventeenth centuries, the tocado had become a moral issue in the inflamed religious atmosphere of the counter-Reformation. In 1600 in the town of Lesaka, Navarre, the visiting bishop of Pamplona decreed that on pain of excommunication, "the women who wear tocados with those tall figures, the kind which everyone understands means the [wearers] are not decent or honourable women, may not enter the church with these figures, and must at least shape them in a different way to enter the church."130

These testimonies reveal more about changing societal attitudes towards sexuality than they do about the social and material value that women continued to

125 Vital, "Premier voyage," 99.

126 Ibid., 98 .

127 Ibid.

128 Michel de Montaigne, The Essays of Michel de Montaigne, trans. and ed. M. A. Screech (London: Allen Lane, 1991), 969.

129 Pierre de Lancre, On the Inconstancy of Witches: Pierre de Lancre's Tableau de l'inconstance des Mauvais Anges et Demons (1612) (Tempe, AZ: ACRMS, 2006), 62.

130 As cited in Caro Baroja, "El tocado antiguo," 43. 
invest in their veils from the Basque country to Galicia. Women in Bayonne, De Lancre wrote, testified that it took "half a day to whiten them well and to arrange and put them on correctly."131 These efforts indicate the depth of social meaning and group participation they fostered for women in communities recorded to have kept "moulds," "bodies," and special needles for transforming veils into elaborate headdresses - a task involving dexterous hands, a starching agent, and many pins. ${ }^{132}$ Subsequently, it is difficult to assess whether the disillusionment expressed by Laurent Vital's hostess was very widespread. Costume series certainly capture how unwieldy these veils could be and how heavy and uncomfortable they might have felt after prolonged wear, not to mention the accompanying social pressure to finance their tremendous yardage. Despite this, the variation of headdress styles costume books show to have existed document a culture in which the efforts women took to compose new-fangled guises in cloth awarded them social distinction.

The methods for making these compositions are now obscured, although Vecellio's suppositions are useful. Discussing a tocado attributed to a woman of Santander, Vecellio isolates a supporting hat of "felt or velvet, high enough that she can wrap a large piece of very thin renso or a silk sash around it."133 Plebeian women in Biscay meanwhile wear a headdress "of felt or white wool [...] stiffened with small wood or copper hoops." ${ }^{\prime 34}$ The last type he mentions - a conical, twisted number - is described as velvet, "quite tall and pointed at the tip, which these women put on their heads and narrow or widen as required by loosening or tightening a band of silk at the base."135 Although it is surprising that Vecellio mentions linen (renso) only once, it is possible that linen veil-cloths were layered over textile bases. It is interesting to note moreover, that María Juana de Aguirre's "stalactite" headdresses were recorded to have been of velvet (estalquias de terciopelo)..$^{136}$ Based on earlier recycled imagery, Vecellio's textual descriptions of Basque headwear probably represent his interpretation of the imagery rather than authentic knowledge of the region's dress practices. Nonetheless, his input expresses the layers and stages that went into fashioning these pieces, suggesting the assistance of supporting moulds and frames documented in contemporary dowries, and the versatility of the veil-cloths to be narrowed, widened, loosened, or tightened by their wearers into certain shapes. The labour that went into preparing them was such that women

131 De Lancre, Witches, 61.

132 Azpiazu Elorza, Lino vasco, 104, 111; Archivo de la Real Chancillería de Valladolid, Pleitos civiles. Varela. Pleitos fenecidos, 1974/2. Reproduced in Azkune Mendia, II 1501-1520, Agiritegia, 352, 427.

133 Vecellio, Habiti, 339 .

134 Ibid., 342.

135 Ibid., 341.

136 Azpiazu Elorza, Lino vasco, 111. 
did not necessarily make them up afresh with each wear. The 1541 testament of Ana Lizarraras of Arroa implies that these headdresses could be stored in their composed state: "To Maria Joanez, my niece [...] I send my silk tocado, everything as it is prepared (adreçado), to Maria San Joan de Echeuerria, I send a toca that was set earlier." ${ }^{\prime 37}$ The creative opportunities offered by the setting process can only be imagined, following the testimony of Venetian ambassador Andrea Navagero, who observed women's headwear in Gipuzkoa in 1526:

In this region the women wear a very capricious headdress: they wrap it with cloth almost in the Turkish style, but not in the shape of a turban, but a hood, and they make it so narrow by twisting it to the tip, and make it resemble the chest, neck and beak of a crane; this same headdress is spread all over Gipuzkoa where types of crests are made in a thousand whimsical shapes, making them resemble different things. ${ }^{138}$

The tocados stretching around the Bay of Biscay were unlikely to have been a matter of whimsy to their wearers, however, who sourced societal recognition from their veils and embraced the process of fashioning them.

\section{Conclusion}

Throughout early modern Europe, women's veils were neither trivial nor mundane, but aroused the senses, galvanized social values, and shaped identities through their wide spectrum of material properties. The period witnessed an increasing emphasis on innovations in textile production, leading to diversities in the surface tactility, drape, and transparency of fabrics available in the marketplace. In the cities of Florence and Seville, these were the trade of professional veil-makers. The fibre content, density, and weight of veiling textiles delivered different effects including light reflection, form fragmentation, and buoyancy on the one hand, and obscurity and bulk on the other. An admiration for ever finer linens, cottons, and silks popularly used for veiling fed into the period's notions of what constituted feminine beauty. The dazzling properties of diaphanous, translucent silk gauzes for example, amplified the much-desired luminosity of their wearers. Through their ability to "flutter," delicate, feather-weighted veils were attractive and enlivening, while more substantial veils affected bodily comportment and gaze.

137 AHPG, 147: 2/001613. Reproduced in Azkune Mendia, VIII 1541, Agiritegia, 565-566.

138 As cited in Carmen Bernis, Indumentaria española en tiempos de Carlos V (Madrid: Instituto Diego Velazquez, 1962), 71 . 
The plasticity of the textiles used for veiling, along with temporary fixtures like pins, frames, and moulds, enabled veil-cloths to be modelled into what were, at times, the most architectural of compositions. The diverse forms veils took across different regions of Europe captured the attention of travellers and artists and entered into the period's costume books and albums. Here they did not simply signal women's marital status, but tapped into the affective, social, and economic value of different textiles and the processes involved in their transformation. In northern Spain and the Basque lands, making elaborate headdresses from large lengths of cloth was a labour of love. If we are to believe the witch-hunting jurist De Lancre, their forms could take half a day to achieve. This is by no means inconceivable, following the imposing and complicated designs visualized in many contemporary costume series. Veiling practices like these were embedded within local communities, supporting shared aesthetics and group identities that shifted from region to region. Veils thus stood out as markers of place and identity, making them the perfect garment to be elaborated on in costume series. By analysing their lively descriptions and rich illustrations, it is apparent that veils animated and invigorated social relationships in the communities that created them and materialized the identities of the women who made and wore them.

\section{Bibliography}

\section{Unpublished Primary Sources}

Archivio di Stato Firenze (ASF)

GM 358: Medici libri di vestiti

LCF 933: Libro di ricordo

LCF 1845: Libro Giornale Francesco Donati

LCF 1848: Libro di vendite e riscossione

LCF 4198: Libro di monachi

\section{Published Primary Sources}

Antoniano, Silvio. Dell'educazione Cristiana e politica de figliuoli. Florence: Casa di Correzione, $185^{2}$, orig. Verona ed. 1584 .

Azkune Mendia, Iñaki. Zestoaren historia (1): historiaurretik 1544. urtera arte (electronic resource). Donostia-San Sebastián, 2016. https://www.zestoa.eus/eu/zestoaren-historia-1-.

Boissard, Jean Jacques. Habitus variarum orbis gentium. Habitz de nations estranges. Trachten mancherley Völcker des Erdskreytz. Mechelen: Caspar Rutz, 1581.

Boorde, Andrew. The Fyrst Boke of the Introduction of Knowledge [...], edited by Frederick James Furnivall. London: N. Trübner, 1870. 
Castiglione, Baldassare. The Book of the Courtier, edited and translated by George Bull. Cambridge: Penguin Classics, 2011.

Cellini, Benvenuto. The Autobiography of Benvenuto Cellini, translated by J. Addington Symonds. New York: Reynolds Publishing Company, 1910.

Coryate, Thomas. Coryat's crudities: hastily gobled up in five moneths travells in France, Savoy, Italy, Rhetia commonly called the Grisons country, Helvetia alias Switzerland, some parts of high Germany and the Netherlands. Glasgow: James Maclehose and Sons, 1905.

Cotgrave, Randle. A dictionarie of the french and english tongues. London: Adam Islip, 1611. De Beatis, Antonio. The Travel Journey of Antonio de Beatis: Germany, Switzerland, the Low Countries, France and Italy, 1517-1518, translated by J. R. Hale. London: Hakluyt Society, 1979.

De Lancre, Pierre. On the Inconstancy of Witches: Pierre de Lancre's Tableau de l'inconstance des Mauvais Anges et Demons (1612). Tempe, AZ: ACRMS, 2006.

De Montaigne, Michel. The Essays of Michel de Montaigne, translated and edited by M. A. Screech. London: Allen Lane, 1991.

Martinez de Isasti, Lope. Compendio historial de la provincia de Guipúzcoa, por Lope de Isasti en el año de 1625. San Sebastián: Ignacio Ramon Baroja, 1850.

Ordenanças de Sevilla: que por su original, son aora nveuamente impressas [...]. Seville: Andres Grande, 1632.

Real Academia de la Historia (Spain). Colección de documentos inéditos para la historia de Españay sus Indias, vol. 15. Madrid: Academia de la Historia, 1849.

Vecellio, Cesare. De gli habiti antichi, et moderni di diverse parti del mondo libri due. Venice: Damian Zenaro, 1590.

Vital, Laurent. "Relation du premier voyage de Charles-Quint en Espagne." In Collection des voyages des souverains des Pays-Bas, edited by M. Gachard, vol. 3. Brussels: F. Hayez, 1881.

Vittori, Girolamo. Tesoro de las tres lenguas francesa, italiana, y Española. Antwerp: Corneille Lectin, 1614 .

\section{Secondary Literature}

Azpiazu Elorza, Jose Antonio. La historia desconocida del lino vasco. Donostia: Ttaarttalo, 2006.

Bennett, Jane. Vibrant Matter: A Political Ecology of Things. Durham, NC: Duke University Press, 2010.

Bennett, Jane. The Enchantment of Modern Life:Attachments, Crossings, and Ethics. Princeton, NJ: Princeton University Press, 2016.

Bernis, Carmen. Indumentaria española en tiempos de Carlos V. Madrid: Instituto Diego Velazquez, 1962.

Bond, Katherine. "Mapping Culture in the Habsburg Empire: Fashioning a Costume Book in the Court of Charles V." Renaissance Quarterly 71 (2018): 530-579. 
Burghartz, Susanna. “Covered Women? Veiling in Early Modern Europe." History Workshop Journal 80 (2015): 1-32.

Buseghin, Maria Luciana. "Uno sguardo sul velo dal medioevo all'età contemporanea: veletti, 'tovagli', panni." In Ilvelo in area mediterranea fra storia e simbolo: tardo medieval - prima Età moderna, edited by Maria Giuseppina Muzzarelli, Maria Grazia Nico Ottaviani, and Gabriella Zarri, 381-394. Bologna: il Mulino, 2014.

Caro Baroja, Julio. "El tocado antiguo de las mujeres vascas (un problem de etnografia)." Atlantis 15 (1936-1940): 33-71.

"Costumes of the time of Charles V, Emperor of the Holy Roman Empire, and King of Spain, of costumes of all nations of the world, circa 1540." ca. 1548-1549, Cat. 2025. Museo Stibbert, Florence.

Cox, Virginia. Lyric Poetry by Women of the Italian Renaissance. Baltimore, MD and London: Johns Hopkins University Press, 2013.

De Urquijo, Julio. "Sobre el tocado corniforme de las mujere vascas." Revista Internacional de Estudios Vascos 12 (1922): 570-581.

De Winkel, Marieke. Fashion and Fancy: Dress and Meaning in Rembrandt's Paintings. Amsterdam: Amsterdam University Press, 2006.

Franck, R. R. Silk, Mohair, Cashmere and Other Luxury Fibres. Amsterdam: Elsevier, 2001.

Gargiolli, Girolamo. L'Arte della seta in Firenze: Trattato del secolo XV [...]. Florence: G. Barbèra, 1868.

Gomez-Tabanera, J. M. “Del tocado 'corniforme' de las mujeres asturianas en el siglo XVI.” El Basilisco 5 (November-December 1978): 39-82.

Hollander, Anne. Seeing through Clothes. Berkeley, CA and London: University of California Press, 1993 .

Jones, Ann Rosalind. “Worn in Venice and throughout Italy': The Impossible Present in Cesare Vecellio's Costume Books." Journal of Medieval and Early Modern Studies 39, no. 3 (2009): 511-544.

Levy, Alison. Re-membering Masculinity in Early Modern Florence: Widowed Bodies, Mourning and Portraiture. Aldershot: Ashgate, 2006.

Maritz, Regine. "Gender as a Resource of Power at the Early Modern Court of Württemberg, c. 1580-1630." PhD diss., University of Cambridge, 2018.

McCall, Timothy. "Brilliant Bodies: Material Culture and the Adornment of Men in North Italy's Quattrocento Courts." I Tatti Studies in the Italian Renaissance 16, no. 1/2 (2013): 445-490.

Menéndez de la Torre, Herminia, and Eduardo Quintana Loché. "Indumentaria popular asturiana en el siglo XVI." Revista de Folklore 306 (2006): 213-216.

Molà, Luca. The Silk Industry of Renaissance Venice. Baltimore, MD and London: Johns Hopkins University Press, 2000.

Morgan, Hiram. Ireland 1518: Archduke Ferdinand's Visit to Kinsale and the Dürer Connection. Cork: Crawford Art Gallery, 2015. 
Muzzarelli, Maria Giuseppina. A capo coperto. Storie di donne e diveli. Bologna: il Mulino, 2016. Muzzarelli, Maria Giuseppina, Maria Grazia Nico Ottaviani, and Gabriella Zarri, eds. Il velo in area mediterranea fra storia e simbolo: tardo medieval - prima Età moderna. Bologna: il Mulino, 2014.

Paresys, Isabelle. "The Body." In A Cultural History of Dress and Fashion in the Renaissance, edited by Elizabeth Currie, 57-74. London: Bloomsbury Academic, 2017.

Paulicelli, Eugenia. "From the Sacred to the Secular: The Gendered Geography of Veils in Italian Cinquecento Fashion." In Ornamentalism: The Art of Renaissance Accessories, edited by Bella Mirabella, 40-58. Ann Arbor, MI: University of Michigan Press, 2011.

Pernis, Maria Grazia, and Laurie Schneider Adams. Lucrezia Tornabuoni De' Medici and the Medici Family in the Fifteenth Century. New York and Oxford: Peter Lang, 2006.

Rasche, Adelheid. "Die Bilderhandschrift Lipp-OZ 2 von 1580. Ein Trachtenbuch aus dem Fugger-Umkreis.” In Die Kultur der Kleider. Zum hundertjährigen Bestehen der Lipperheideschen Kostümbibliothek, edited by Adelheid Rasche, 23-36. Berlin: SMPK, Kunstbibliothek, 1999.

Rublack, Ulinka. "Matter in the Material Renaissance." Past \& Present 219 (2013): 41-85.

Rublack, Ulinka. "Renaissance Dress, Cultures of Making, and the Period Eye." West 26th 23, no. 1 (2016): 6-34.

Schoeser, Mary. Silk. New Haven, CT: Yale University Press, 2007.

Schuster, Georg, and Friedrich Wagner, Die Jugend und Erziehung der Kurfürsten von Brandenburg und Könige von Preussen. Berlin: Hoffmann, 1906.

Simons, Patricia. "The Visual Dynamics of (Un)veiling in Early Modern Culture." In Visual Cultures of Secrecy in Early Modern Europe, edited by Timothy McCall, Sean Roberts, and Giancarlo Fiorenza, 24-53. Kirksville, MO: Truman State University Press, 2013.

Strocchia, Sharon T. Nuns and Nunneries in Renaissance Florence. Baltimore, MD and London: Johns Hopkins University Press, 2009.

Sturtewagen, Iris. “All Together Respectably Dressed." PhD diss., University of Antwerp, 2016. Taylor, Lou. Mourning Dress: A Costume and Social History. Abingdon: Routledge, 2010.

Tosi Brandi, Elisa. "Il velo Bolognese nei secoli xiv-xvi. Produzione e tipologie." Il velo in area mediterranea fra storia e simbolo: tardo medieval - prima Età moderna, edited by Maria Giuseppina Muzzarelli, Maria Grazia Nico Ottaviani, and Gabriella Zarri, 289-306. Bologna: il Mulino, 2014.

Vecellio, Cesare. Cesare Vecellio, Habiti Antichi et Moderni: The Clothing of the Renaissance World, edited and translated by Margaret F. Rosenthal and Ann Rosalind Jones. London and New York: Thames and Hudson, 2008.

Vincent, Susan. "From Cradle to the Grave: Clothing the Early Modern Body." In The Routledge History of Sex and the Body: 1500 to the Present, edited by Sarah Toulalan and Kate Fisher, 163-178. London: Routledge, 2013.

Welch, Evelyn. "Art on the Edge: Hair and Hands in Renaissance Italy." Renaissance Studies 23, no. 2 (June 2009): 241-268. 
Welch, Evelyn. "New, Old and Second-Hand Culture: The Case of the Renaissance Sleeve." In Revaluing the Renaissance, edited by Gabriele Neher and Rupert Shepherd, 101-120. London: Routledge, 2017.

Yeh, Chia-Hua. "Material Culture of Head Coverings in Early Modern Florence." In Il velo in area mediterranea fra storia e simbolo: tardo medieval - prima Età moderna, edited by Maria Giuseppina Muzzarelli, Maria Grazia Nico Ottaviani, and Gabriella Zarri, 139-154. Bologna: il Mulino, 2014.

Zander-Seidl, Jutta. "Das erbar gepent: Zur ständischen Kleidung in Nürnberg im 15. und 16. Jahrhundert." Waffen- und Kostümkunde 27 (1985): 119-140.

Zanoboni, Maria Paola. "Pro trafegando in exercitio seu arte veletarum': Tipologia e produzione dei veli nella Milano del secondo quattrocento." In Ilvelo in area mediterranea fra storia e simbolo: tardo medieval - prima Età moderna, edited by Maria Giuseppina Muzzarelli, Maria Grazia Nico Ottaviani, and Gabriella Zarri, 123-138. Bologna: il Mulino, 2014.

Zarri, Gabriella, ed. Velo e Velatio: Significato e Rappresentazione nella cultura figurative dei secoli $X V-X V I I$. Rome: Edizioni di Storia e Letteratura, 2014.

\section{About the Author}

Katherine Bond is an Irish Research Council postdoctoral fellow at the School of History, University College Cork. Originally from New Zealand, she holds a PhD from the University of Cambridge on the subject of sixteenth-century costume albums. Her research interests comprise early modern dress, ethnography, and visual culture. 


\title{
8. Moral Materials: Veiling in Early Modern Protestant Cities. The Cases of Basel and Zurich
}

\author{
Susanna Burghartz
}

\begin{abstract}
Throughout the early modern period, veils remained a common garment for women all over Europe. This chapter deals with the economy of veil production, changing fashions of veil wearing, and political identity struggles surrounding the question of the church veil in the Swiss textile cities of Basel and Zurich. The site of a moral battleground, the church veil reveals, in particular, how much attentiveness certain Protestant cultures paid to material issues. Alongside a variety of other sources, analysis of an extant church veil at the Swiss National Museum allowed for the inclusion of hands-on methods from dress history, considerably sharpening our attention to embodied experiences and the emotional effects of dress codes and their regulation.
\end{abstract}

Keywords: veils; embodied methodology; Protestant material culture; fashion; Protestant dress politics

"Sturz, (the), calyptra, a highly starched and precious veil of delicate linen, which some forty years ago the women of Basel and Strasbourg used to conceal all but their eyes and noses." The Basel theologian and philologist Johann Jacob Spreng, writing in the mid-eighteenth century, began the entry on church veils in the largest but never published German-speaking dictionary of his day with this description. ${ }^{1}$ His

1 Johann Jacob Spreng collected the material for his (unpublished) 95,ooo-entry dictionary between 1740 and 1768. See Heinrich Löffler, “J.J. Sprengs Allgemeines deutsches Glossarium'. Das Original, seine Geschichte und seine Edition," Sprachspiegel 74, no. 3 (2018): 66-73, here 68.

Burghartz, S., L. Burkart, C. Göttler, U. Rublack, Materialized Identities in Early Modern Culture, 1450-1750: Objects, Affects, Effects. Amsterdam: Amsterdam University Press, 2021 DOI 10.5117/9789463728959_CHo8 
negative view of this article of clothing was tantamount to a break with tradition, since church veils covering the head and face except for the eyes had been common in Basel for centuries:

Unmarried women wore this Gothic monstrosity down to their ruffs; wives, however, had a long strap of the same cloth hanging down (the back), and whenever they wished to speak, which naturally was quite often, they had to pull the stiff fabric away from their mouths like a shield. Fortunately, they were only compelled to wear this whilst in mourning or church. ${ }^{2}$

Hoods, veils, and barbettes are key components of European clothing and fashion history. Their specific history is characterized by an enormous continuity of basic traits with simultaneous changes of fashion surrounding the concrete details. Within this history, the occasionally charged relationships between economic practices and social interests, moral and gender politics, materiality, and corporeal affects and emotions were constantly being renegotiated. In the process, the veil became a screen upon which gender relations and status inequalities as well as relations of production or trade could be projected. ${ }^{3}$ It simultaneously served as a medium for handling conflicts of interest in the framework of sumptuary laws, body politics, and debates about luxury. Taking the examples of Basel and Zurich, I shall explore this history between 1500 and 1800 .

\section{Form and Material: Transparency around 1500}

The burgher milieu of southern German and Swiss cities saw a change in female fashion around 1500, as transparent veils became part of popular headwear. They could be combined with a tight-fitting hood, known as a Bündlein, or with the traditional opaque veils familiar to us from numerous drawings of this period by Albrecht Dürer (Fig. 8.1). Dürer's elegant woman of Nuremberg wears a Sturz over her hood. This form of veil was marked by heavy and voluminous material and the artful pleating of the starched fabric. The fashionable veil that Dürer depicted about five years earlier in a drawing of two elegantly dressed women of Nuremberg and Venice is very different in material and form (Fig. 8.2). ${ }^{4}$ Here we see the ways in which light veils were used: while the sheer veil worn in combination with a close-fitting

2 Idioticon Rauracum oder Baseldeutsches Wörterbuch von 1768. Johann Jakob Spreng, ed. Heinrich Löffler. Edition of manuscript AA I 3, Universitätsbibliothek Basel (Basel: Schwabe Verlag, 2014), 166.

3 Joan Wallach Scott, The Politics of the Veil (Princeton, NJ: Princeton University Press, 2007), 10.

4 Jutta Zander-Seidel, "Das erbar gepent. Zur ständischen Kleidung in Nürnberg im 15. und 16. Jahrhundert," in Waffen- und Kostümkunde 27 (1985):119-140, 125. 


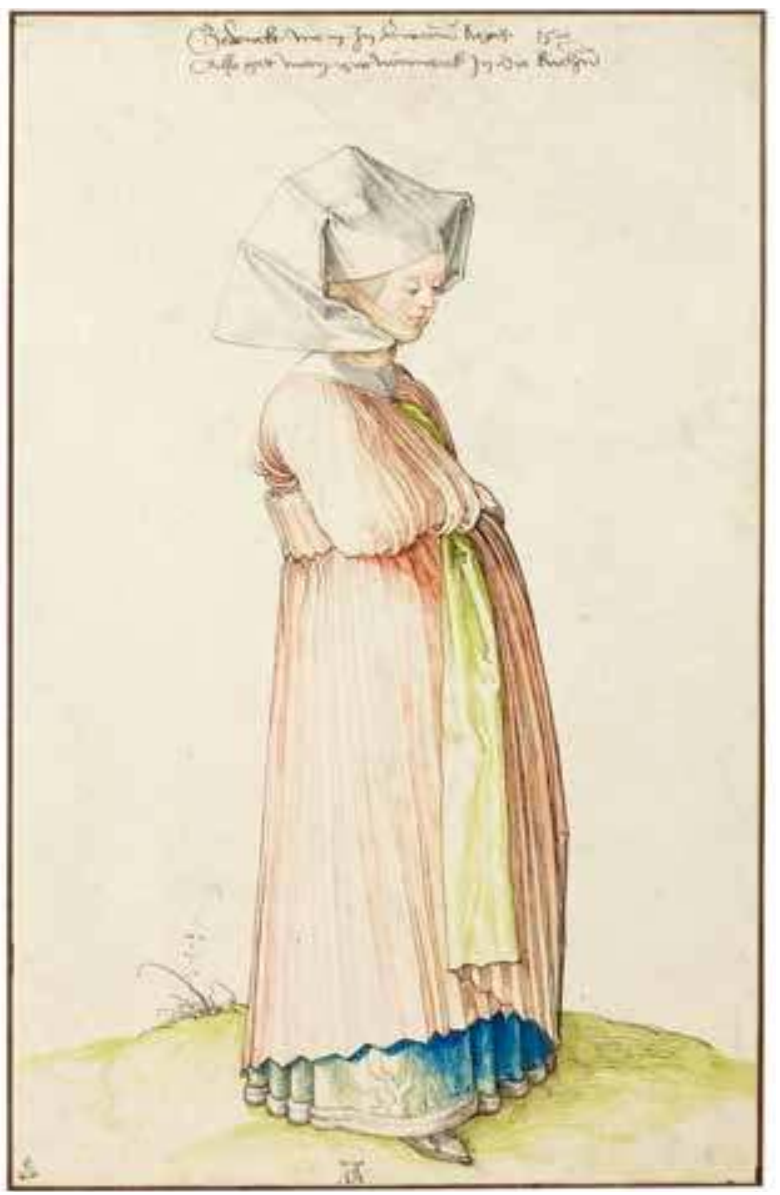

Figure 8.1: Albrecht Dürer, $A$ Woman of Nuremberg Dressed for Church, 1500. Pen in black-grey ink and watercolour, $32 \times 20.4 \mathrm{~cm}$. Vienna, The Albertina Museum, inv. no. 3069. Image () The Albertina Museum, Vienna.

hood covers the forehead of the Nuremberger to the left, the transparent head veil worn by the young Venetian on the right falls to her shoulders like a cloak.

Another drawing of 1527 by Dürer shows how elaborate, complicated, and artful the pleating of the church veil must have been. A 1588 inventory describes it as "Three Old Sturz[-wearing] Women" and provides front, side, and back views of the pleated veil. ${ }^{5} \mathrm{~A}$ Nuremberg inventory of 1486 reveals the elaborate preparation needed to pleat the fabric successfully. It lists a small cupboard containing "a Sturz press with several Sturzes, and also soaps, sponges, starch [...] and other small items." ${ }^{n}$ This suggests

5 Jutta Zander-Seidel, "Ständische Kleidung in der mittelalterlichen und frühneuzeitlichen Stadt," in Terminologie und Typologie mittelalterlicher Sachgüter: Das Beispiel Kleidung, international round table, Krems an der Donau, 6 October 1986 (Vienna: Verlag der Österreichischen Akademie der Wissenschaften, 1988), 59-75, 63 .

6 Zander-Seidel, “Das erbar gepent," 121. 


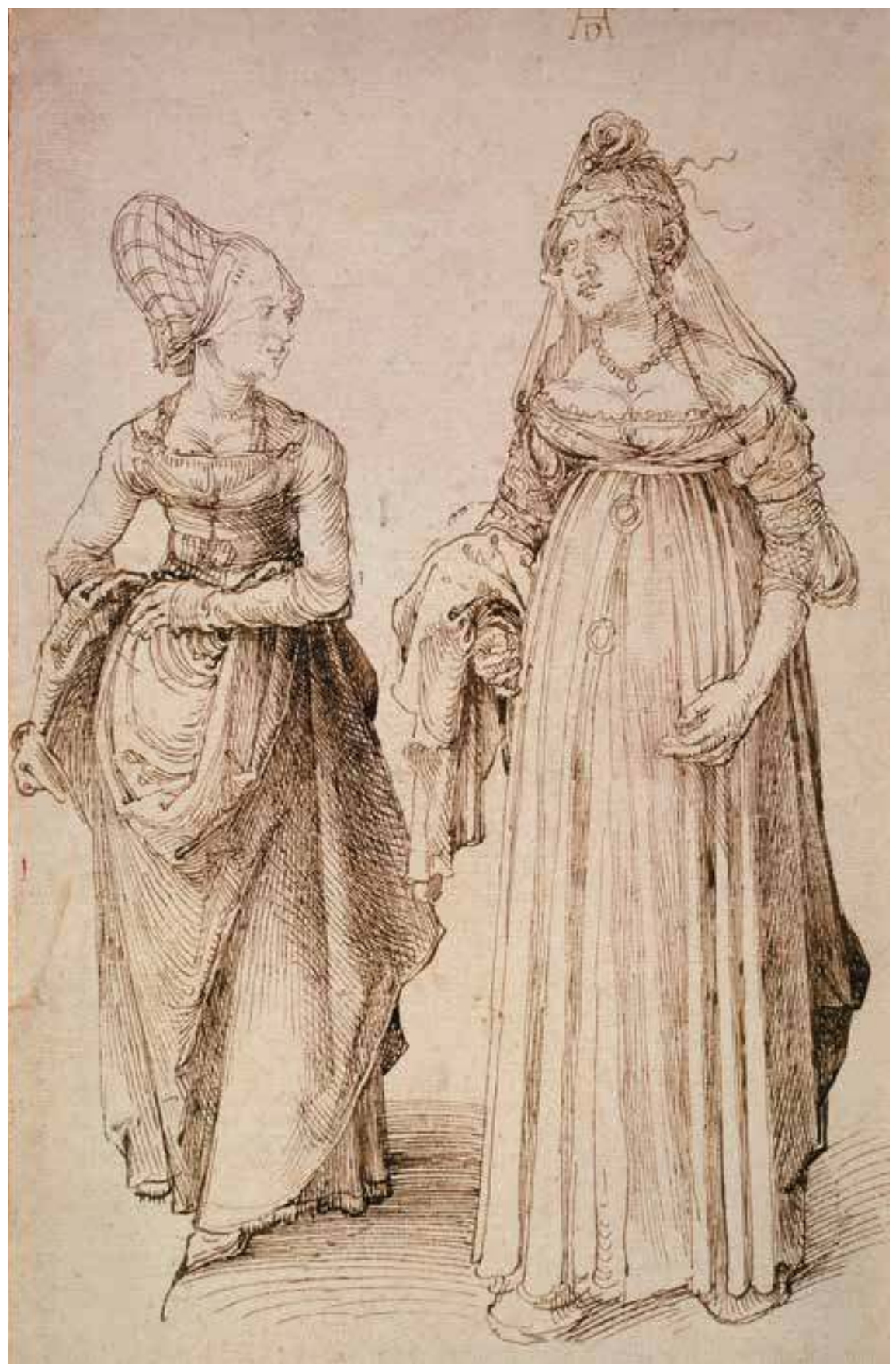

Figure 8.2: Albrecht Dürer, Women of Nuremberg and Venice, ca. 1495. Pen in dark-grey brown ink on paper, $24.5 \times 15.9 \mathrm{~cm}$. Frankfurt am Main, Graphische Sammlung Städelsches Kunstinstitut, inv. no. 696. Image ๑) bpk / Städel Museum / Ursula Edelmann. 
that the Sturz was specially washed with soap, starched, and then brought into shape using a press. In Nuremberg, the Sturz consisted of two components: a close-fitting, tied hood covered with an ample piece of pleated fabric. This form of headwear was reserved for women of the upper classes in Nuremberg, but was also obligatory until $1522 .{ }^{7}$ Thus in the early sixteenth century, the Sturz was at once compulsory and a social privilege for a clearly demarcated group in the city. ${ }^{8}$ However, from 1515 Nuremberg's patrician women fought against the obligatory Sturz and argued against the "hideous headdress" they had to wear to balls and apparently found obsolete and unfashionable. ${ }^{9}$ Shortly thereafter, in 1518 , the women of Augsburg managed to free themselves from the obligatory Sturz against the will of the town council, with the help of Emperor Maximilian; thereby adopting the new aristocratic fashion: the Bündlein. ${ }^{10}$ Some ten years later, a Nuremberg pro-Reformation pamphlet of 1529 reinterpreted the Bündlein as a signal for the Reformation and sign of Protestant faith.

This background lends additional layers of meaning to two pictures featuring different forms of veiling created by Hans Holbein during the restless Reformation era in Basel. Like the women of Nuremberg, those in Basel also kept up with fashion, as Holbein's costume study of 1523 suggests (Fig. 8.3). It depicts a richly attired woman in a Bündlein, veil, and Schwenkel, a long strip of fabric that took up the pattern of the hood and paired voluminous material with an elegant sweep. In this way, the new veil fashion combined movement with translucency and volume.

In his famous Madonna, painted around $15^{26}$ for the Basel mayor Jakob Meyer zum Hasen, Holbein combined the old and new forms of veiling in the depiction of the donor's family (Fig. 8.4). Magdalena Bär, Meyer zum Hasen's late wife, wears the traditional church Sturz with a wimple: a folded white hood and a band covering the chin. After returning from London in 1528 , Holbein repainted the image, now depicting Dorothea Kannengießer, the mayor's second wife, in a more fashionable form of hood with a sheer veil over her forehead and an Umbschläglin (head-cloth) that left her chin largely uncovered. The headwear of the two wives of the homo novus Jakob Meyer zum Hasen, the first guild member to be elected mayor of Basel, embody the social ambitions of a parvenu family who oriented themselves towards the aristocracy or urban patriciate. In the tense, and for Meyer zum Hasen, extremely difficult Reformation years, they may be read as an attempt to display both tradition and fashionability through headdress forms. In light of the Nuremberg pamphlet,

$7 \quad$ When the Bündlein replaced the Sturz as the new respectable church head covering, the council spoke explicitly of allowing "another headdress" "instead of the Sturtz, which is in keeping with propriety and creates quite a difference to other women." Zander-Seidel, "Ständische Kleidung," 64.

8 This is evident from cases from 1459 and 1482 as well as a general ban by the Nuremberg town council in 1514. Zander-Seidel, "Das erbar gepent," 119.

9 Ibid., 126.

10 Ibid., 126-127. 


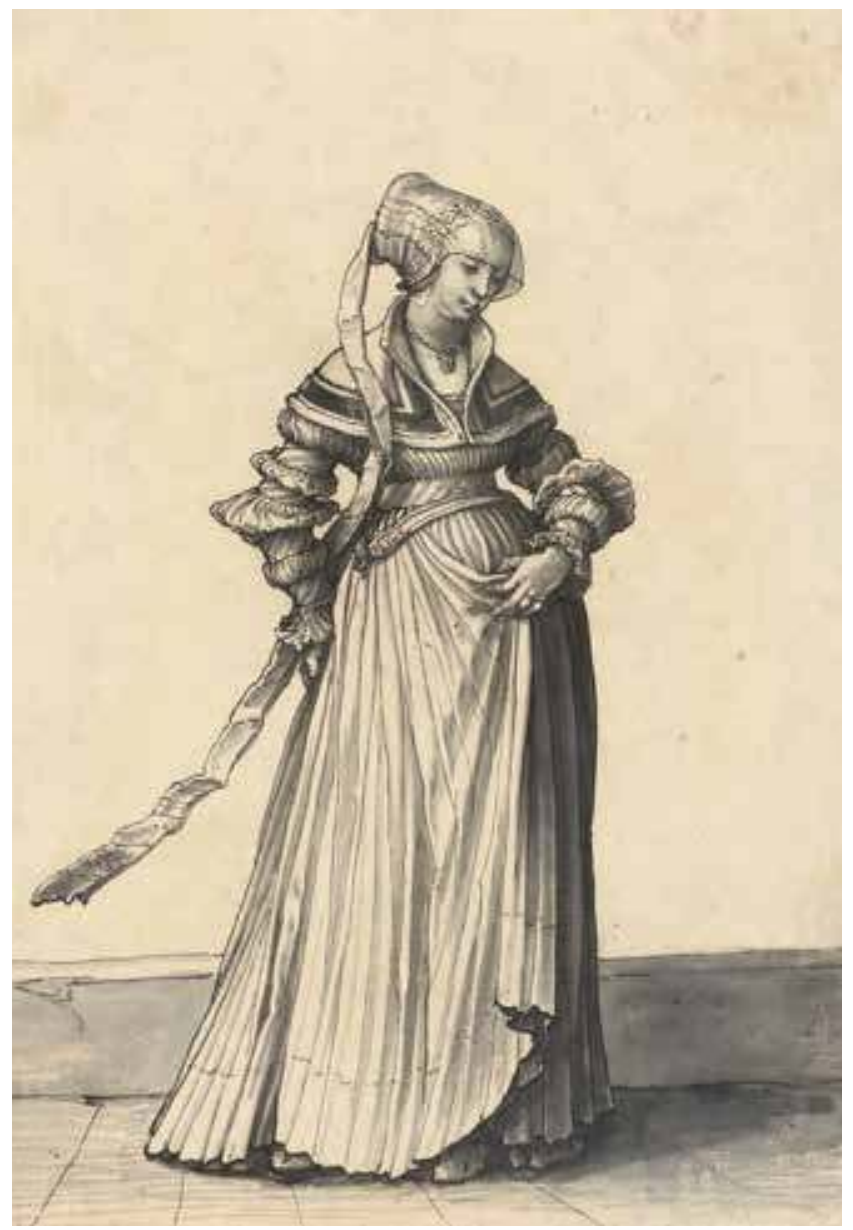

Figure 8.3: Hans Holbein the Younger, A Woman of Basel Turned to the Right, ca. 1523. Pen and brush in black ink, grey wash, $29.0 \times 19.7 \mathrm{~cm}$. Basel, Kupferstichkabinett, Amerbach-Kabinett 1662, Kunstmuseum Basel, inv. no. 1662.142. Image @ Kunstmuseum Basel.

the repainting might be seen as an attempt to avoid making a clear political or confessional fashion statement. ${ }^{.1}$ As the examples from Basel and Nuremberg show, changing fashions and social upheaval could be closely intertwined.

Moreover, an examination of Dürer's and Holbein's depictions of veils reveals the breadth of veiling materials - and significance of the transparent veil in particular

11 Jutta Zander-Seidel, "Des Bürgermeisters neue Kleider," in Hans Holbeins Madonna im Städel, ed. Bodo Brinkmann, exh. cat. (Petersberg: M. Imhof, 2004), 55ff. See also Jochen Sander, "Die 'Darmstädter Madonna'. Entstehungsgeschichte von Holbeins Madonnenbild für Jakob Meyer zum Hasen," in ibid., 33-43, here 39-40, esp. n. 13 . 


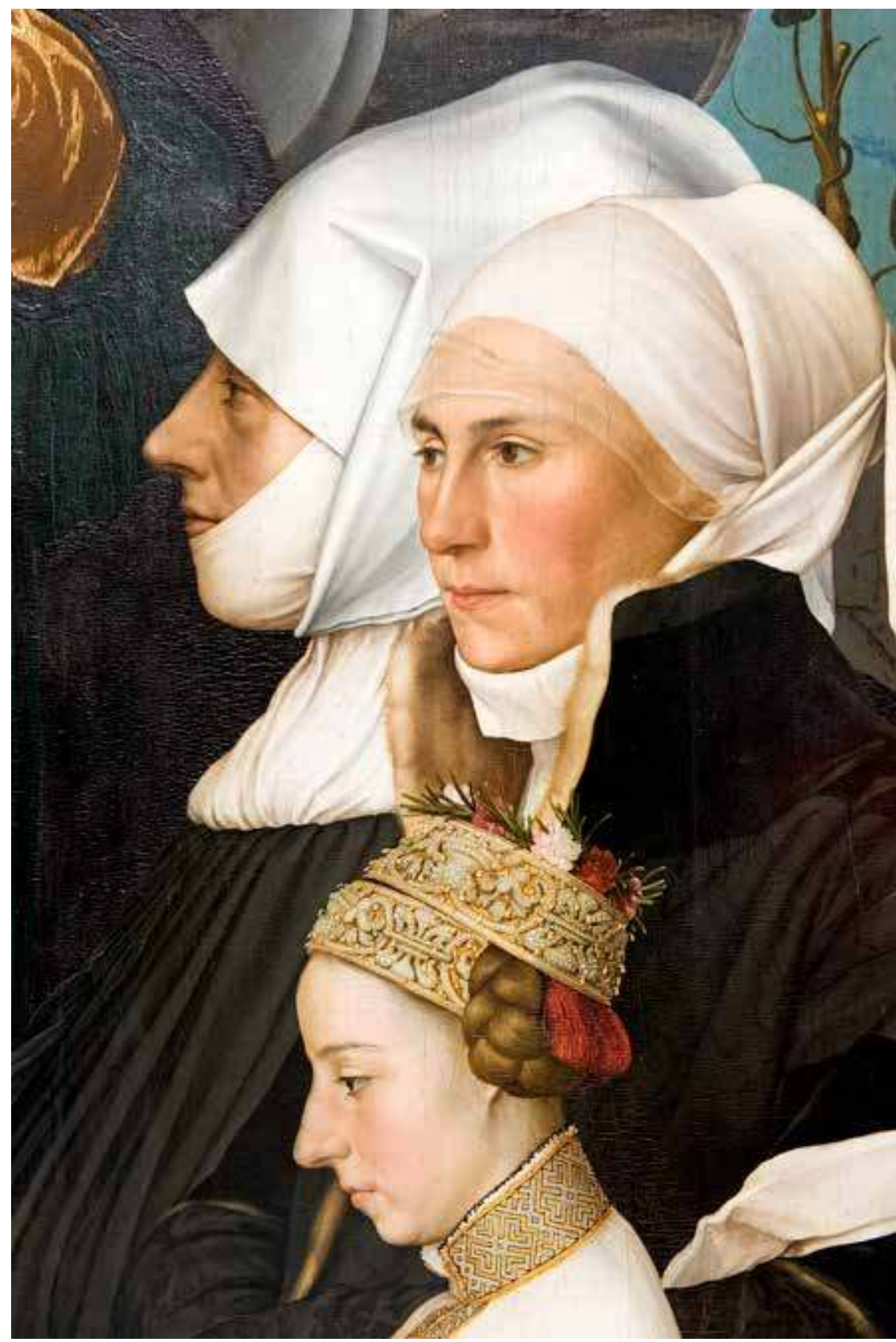

Figure 8.4: Hans Holbein the Younger. Madonna des Bürgermeisters Jakob Meyer zum Hasen ('Schutzmantelmadonna'), 1525/26 and 1528. Oil on limewood, $146.5 \times 102 \mathrm{~cm}$, detail: At left Magdalena Bär, late wife of Jakob Meyer zum Hasen, at right Dorothea Kannengiesser, second wife of Jakob Meyer zum Hasen and daughter Anna. Sammlung Würth, inv. no. 14910. Image @ Sammlung Würth. Photo: Philipp Schönborn, München. 
- in southern German urban fashion around 1500. In the late Middle Ages, Italian painters like Sandro Botticelli, Piero della Francesca and Bonifacio Bembo had already depicted extremely sheer, delicate veils covering noblewomen's coifs. ${ }^{12}$ The divided hennin, with its fine, gauzy veil draped over the cones, epitomized Burgundian court fashion. The veil's sheerness emphasized its preciousness and refinement. This fashionable trend also influenced depictions of the Virgin Mary's veil, as in Joos van Cleve's early sixteenth-century Holy Family, which shows Mary in a sheer wimple based on Italian models. At first sight, the opaque church coif compared against the sheerness of secular veil fashions depicted in Dürer and Holbein suggests that the non-transparent covering of head and hair was intended to guarantee the wearer's propriety, while transparent veils evoked luxury and erotic allure. The example of Mary's sheer veil, in contrast, shows unmistakeably that transparency could also stand for purity and thus become a symbol of respectability. ${ }^{13}$ An examination of the visual veil discourse around 1500 , with its profound interest in materials, thus uncovers a fundamental ambivalence between concealment and revelation. In the decades and centuries that followed, this tension led to discussions in various European societies about the proper form and meaning of head, and above all facial, veiling. ${ }^{14}$

\section{Veil Economies: Production and Trade in Basel and Zurich}

Pictorial sources, inventories, and sumptuary laws reveal the omnipresence of veils as female headwear throughout Europe around 1500. We know that by the thirteenth and fourteenth centuries, a whole range of veil stuffs of varying density and weight, some of exceptional delicacy, ${ }^{15}$ were being woven in Bologna, the most important centre for veil production in Italy, from where they were exported as

\footnotetext{
12 Maria Guiseppina Muzzarelli, A capo coperto. Storie di donne e di veli (Bologna: il Mulino, 2016), passim; Maria Paola Zanoboni, "Pro trafegando in exercitio seu arte veletarum': Tipologia e produzione dei veli nella Milano del secondo Quattrocento," in Il velo in area mediterranea fra storia e simbolo, ed. Maria Giuseppina Muzzarelli, Maria Grazia Nico Ottaviano, and Gabriella Zarri (Bologna: il Mulino, 2014), 123-138.

13 Cf. examples since the fourteenth century in Muzzarelli, A capo coperto; for Italy, see Paul Hills, Veiled Presence: Body and Drapery from Giotto to Titian (New Haven, CT: Yale University Press, 2018).

14 For sixteenth-century Italy, see Eugenia Paulicelli, "From the Sacred to the Secular: The Gendered Geography of Veils in Italian Cinquecento Fashion," in Ornamentalism: The Art of Renaissance Accessories, ed. Bella Mirabella (Ann Arbor, MI: University of Michigan Press, 2011), 40-58; for Spain, see Laura R. Bass and Amanda Wunder, "The Veiled Ladies of the Early Modern Spanish World: Seduction and Scandal in Seville, Madrid, and Lima," Hispanic Review 77, no. 1 (Winter 2009): 97-144.

15 Angela Orlandi, "Impalpabili e trasparenti: I veli Bolognesi nella documentazione Datiniana," in Muzzarelli, Ottaviano, and Zarri, Il velo, 307-324, 314-315 mentions gauze veils $85.5 \mathrm{~cm}$ wide and $377.6 \mathrm{~cm}$ long, weighing just $29 \mathrm{~g}$.
} 
far as Milan, Avignon, and Flanders. ${ }^{16}$ North of the Alps, in cities like Cologne, Basel, and Zurich, women were weaving veils, including for the export market. The economic potential of this trade became evident in Basel in 1443, when female, non-guild weavers successfully enforced their right to continue to produce cotton and linen Tüchli (veils), "which mainly belong on women's heads," in the face of opposition from the weavers' guild masters. In order to guarantee quality in future, they were to appoint four experienced women as inspectors. ${ }^{17}$ Thus veil production remained wholly in female hands. In Zurich, too, women's production of silk veils for export to Poland, Swabia, and "other lands" is mentioned as early as $1336 .{ }^{18}$ From the fifteenth century, women there were also weaving cotton cloth outside the guild system. A regulation of 1491 stated that female weavers with their own household in the city were permitted to weave "cotton and other [fibres] into veils and striped cloths, if they are used on the head," unhindered by the weavers' guild. ${ }^{19}$ Thus in Zurich, weaving cotton veils and headscarves was explicitly exempt from guild restrictions. Zurich weavers purchased high-quality cotton originating in the Mediterranean region, especially Cyprus, ${ }^{20}$ from northern Italy ${ }^{21}$ The veils from Basel and Zurich were presumably relatively simple textiles for everyday use, for which a superregional European market already existed in the late Middle Ages. This is also evident from the 1492 complaint of a Cologne citizen, Johann Rinck, who, reporting on his dealings with Zurich cloth merchants, explained that because of their inferior quality, he could no longer accept the veils and headscarves that he had formerly purchased from Zurich traders at the Frankfurt fair and sold on to Brabant and England. ${ }^{22}$

Nevertheless, the commercialization of cottage industry was also successful in the long term and the simple veils produced by Zurich's female weavers continued to find buyers beyond the region in subsequent decades. Thus, the Italian

16 Luca Molà, “I tessuti dimenticati: Consumo e produzione dei veli a Venezia nel Rinascimento," in Muzzarelli, Ottaviano, and Zarri, Il velo, 155-171, 157; Orlandi, “Impalpabili e trasparenti," 320-321.

17 Traugott Geering, Handel und Industrie der Stadt Basel. Zunftwesen und Wirtschaftsgeschichte bis zum Ende des XVII.Jahrhunderts, aus den Archiven dargestellt (Basel: Felix Schneider, 1886), 284-285.

18 Alfred Bürkli-Meyer, Zürcherische Fabrikgesetzgebung vom Beginn des 14. Jahrhunderts an bis zur schweizerischen Staatsumwälzung von 1798 (Zurich: Ulrich \& Co., 1884), 2.

19 Quoted in Oscar Haegi, "Die Entwicklung der zürcher-oberländischen Baumwollindustrie” (PhD diss., Weinfelden, 1925), 6.

20 On the importance of Cypriot cotton for cotton purchases subsidized by the Zurich authorities, see Ulrich Pfister, Die Zürcher Fabriques. Protoindustrielles Wachstum vom 16. zum 18. Jahrhundert (Zurich: Chronos, 1992), 43-44.

21 In Emil Künzle, Die zürcherische Baumwollindustrie von ihren Anfängen bis zur Einführung des Fabrikbetriebes (Zurich: F. Rosenberger, 1906), 7.

22 Werner Schnyder, Quellen zur Zürcher Wirtschaftsgeschichte (Zürich: Rascher, 1937), vol. 2, no. 1526, 899-9oo. 
Protestant refugees of Locarno exported Zurich Tüchli to Bergamo, the main market for raw silk, where they served as a medium of exchange. ${ }^{23}$ According to Ulrich Pfister, this female-dominated trade was an important seed of innovation for the emergence of protoindustrialization in Zurich from the late sixteenth century. In the course of this development, the female weavers at first became increasingly dependent on long-distance merchants, before the ruralization of the trade in the seventeenth century led to "a complete disappearance of independent urban producers." ${ }^{24}$ An ordinance dating to between 1662 and $1670^{25}$ shows that the cloths, which could be used for headdresses and veiling, continued to be exported to Italy, South Tyrol, and as far as Vienna. ${ }^{26}$ As had already been attempted for silk cloth since the late Middle Ages, these cotton textiles also underwent a market differentiation through the production of varying qualities and sizes for different destinations. ${ }^{27}$ All of these products were nevertheless expected to maintain common standards of quality and to use good, fine cotton as a raw material. ${ }^{28}$ The introduction of the spinning wheel led to a clear surge in growth in the 166 os to 168 os, which also occurred in the approximately simultaneous further differentiation of products and the introduction of pile weaving. ${ }^{29}$ In the 1690 , conflicts arose between city and country dwellers because the latter, together with the Huguenots, who were finally expelled in 1699, continued to sell cotton cloth and Löthligarn (fine cotton thread) in the city despite prohibitions. ${ }^{30}$

\footnotetext{
23 Pfister, Fabriques, 39-40.

24 Ulrich Pfister, "Städtisches Textilgewerbe. Protoindustrialisierung und Frauenarbeit in der frühneuzeitlichen Schweiz," in Frauen in der Stadt, ed. Anne-Lise Head-König and Albert Tanner (Zurich: Chronos, 1993), 35-60, 56 .

25 Cf. StaZH A 74.1 7_1620, "Die Tüchli Schleyer, Burath, Beütel, Sayen und Zwilchen fabriques, inn ihr alte güte wie derumb zubringen, und darinnen zuer halten, ist von hiessigen kauff- und handels- Deputierten zu eines jeden fabricanten nachricht volgende ordnung erkändt worden." On the dating of this source to 1662-1670, see Pfister, Fabriques, 64, n. 86.

26 StaZH A 74.18_1620.

27 Ibid., "Alte Ordnung der Schleyer oder deüchli fabrica nebentz merer erleüterung und verbeserung."

\begin{tabular}{lll}
\hline Type / destination & Width & Length \\
\hline "Veils known as cubit wide" & $7 / 8$ cubits $(=52.71 \mathrm{~cm})$ & 24 cubits $(=1,445.76 \mathrm{~cm})$ \\
Italian veils & depending on quality & 26 cubits $(=1,566.24 \mathrm{~cm})$ \\
Stürze & depending on quality & 30 cubits $(=1,807.20 \mathrm{~cm})$ \\
"Austrian veils or Viennese" & $7 / 16$ cubits $(=26.35 \mathrm{~cm})$ & 40 cubits $(=2,409.60 \mathrm{~cm})$ \\
"Tyrolean or German" & $11 / 16$ cubits $(=41.41 \mathrm{~cm})$ & 30 cubits $(=1,807.20 \mathrm{~cm})$ \\
\hline
\end{tabular}

28 Ibid.

29 Pfister, Fabriques, 68.

30 Walter Bodmer, Die Entwicklung der schweizerischen Textilwirtschaft im Rahmen der übrigen Industrien und Wirtschaftszweige (Zürich: Verlag Berichthaus, 1960), 163 .
} 


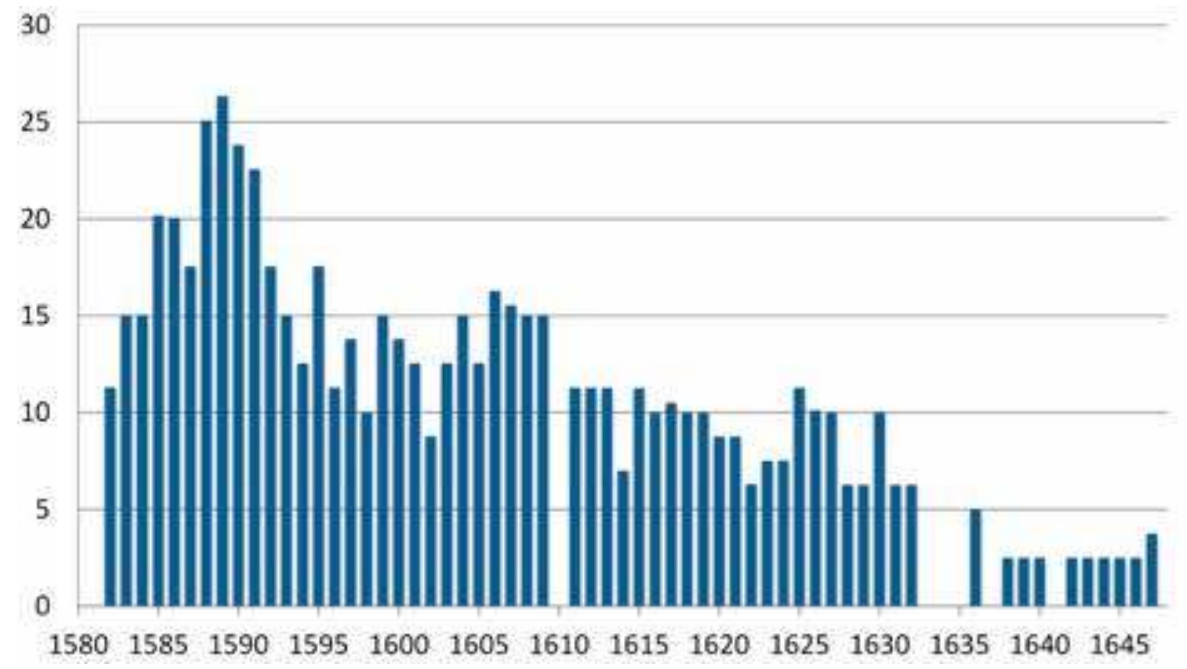

Graph 8.1: Income from fees for veil stalls in Basel 1582-1647 (Source: StaBS Finanz X 4.1)

Around 1700 the cottage weaving industry (Tüchligewerbe) shifted to the production of high-quality textiles, specifically indiennes and mousselines. Löthligarn, a thread spun wet by hand from high-quality cotton, was especially used for these fabrics. Now, though, the cotton was mainly acquired from the Caribbean. ${ }^{31}$ Zurich manufacturing regulations of 1717 , moreover, offer the first mention of wages for the spinners and weavers of fine threads and fabrics being differentiated by quality..$^{2}$

In the textile cities of Basel and Zurich, as we have seen, veil fabrics were already an export product traded by long-distance and wholesale merchants in the late Middle Ages. Veils were also always sold on the local and regional markets. This is evident, for instance, from an analysis of the Basel market stall fees, the Stellgelder, from 1582 to 1648 (Graph 8.1). In the 1580 , there was a sharp rise in stalls selling veils: from nine in 1582 to twenty-one in $1589 .{ }^{33}$ This increase went hand in hand with a revival of veiling from the 1580 s.

Women were comparatively heavily involved in this local trade: between 1582 and 1647 , they represented twenty-two of fifty-four stall holders. Some of them had been conducting business for eight, ten, twelve, or even fifteen years. Finally,

31 Pfister, Fabriques, 67-68.

32 Bürkli-Meyer, Fabrikgesetzgebung, 34-35: The cost of these cotton 7/8-cubit-wide and 40-cubit-long veils was 1 florin for those of simple quality (= 15 Batzen), 20 Batzen for medium, and 24 Batzen for high quality.

33 On the stall fees, see Davina Benkert, "Messbücher und Messrechnungen. Zur Geschichte der Basler Messen bis 1647," in Wiegen, Zählen, Registrieren. Handelsgeschichtliche Massenquellen und die Erforschung mitteleuropäischer Märkte (13.-18.Jahrhundert), ed. Peter Rauscher and Andrea Serles (Innsbruck: Studien Verlag, 2015), 69-9o. I thank Anna Reimann for researching the individual veil stands in the StaBS. 
the presence of individual Zurich veil vendors in Basel between 1585 and 1632 is also remarkable, pointing to commonalities in the two cities' material culture and veiling practices. ${ }^{34}$

\section{Changing Fashions and the Heyday of Veils between 1580 and 1720}

For centuries, hood, veil (Tüchli), and wimple (Umwinderli) were part of every woman's wardrobe. Despite this immense continuity, which defined church garb in particular, women's headwear was also subject to changing fashions. The simultaneous forces of continuity and change can make it hard to pinpoint shifting tastes; however, thanks to unusually rich sources for Basel - four lavishly illustrated albums of the Falkner family from 1574, 1598, 1690, and 1741 - we can follow corresponding changes in fashion over nearly two centuries (Fig. 8.5).35 The quantity of vacillating trends seen in the albums elucidates the growing complaints from Swiss clerics about luxury consumption and their fight to retain the traditional church Sturz, about which we will hear more below.

The first album of 1574 depicts late-medieval Falkner women wearing the wimples and veils typical of the sixteenth century, thus following contemporary fashion. The barett cap, which also emerged in the sixteenth century, was shown as a head-covering for women for the first time in $155^{2 .} .^{36}$ It is noteworthy that none of the women in this album are represented with a veiled face. Basel, it seems, also went through what Jutta Zander-Seidel has called for Nuremberg the "twilight of the hood." 37 By the second album of 1598 , the great majority of wives are depicted up to the end of the volume having gained face veils and wimples, despite adopting all the headwear from the first album unaltered..$^{8}$

34 Concretely, we know of (Hans) Heinrich Bleuler, Stand Bären 1624-28, 1630-32, StaBS Finanz X 4.1. and StaZH A 74.1 14; (Hans) Cunradt Hürt/Hirt, Stand Bären 1630-32, StaBS Finanz X 4.1. StaZH A 74.1 14; Hans Kaspar Wiest/Wüst, Stand Safran 1585-89, 1593, StaBS Finanz X 4.1. and StaZH B VI 2666, B VI 322, B V 43; and of (Hans) Ulrich Ziegler, Stand Bären 1605, 1607-09, StaBS Finanz X 4.1. and StaZH A 26.4.

35 Anna Reimann, "Die Falkner gestalten. Vier Basler Familienbücher als dynamische Wissensspeicher in Bildern" (unpublished MA thesis, University of Basel, 2018).

36 Der Falckner Stammbaum. Stammbuch der Familie Falkner. Angelegt von Niclaus Falkner, Basel 1574, Historisches Museum Basel Inv. 1887.159; Ursula Falcknerin, fol. 16r.

37 Jutta Zander-Seidel, “'Haubendämmerung'. Frauenkopfbedeckungen zwischen Spätmittelalter und früher Neuzeit," in Fashion and Clothing in Late Medieval Europe - Mode und Kleidung im Europa des späten Mittelalters, ed. Regula Schorta and Rainer Christoph Schwinges (Basel: Schwabe Verlag, 2010), 37-43. $3^{8}$ The first in this series was Justina Mieg, who married Sebastian Falkner in 1575. Der Falckner zu Basel Stammbuch. Stammbuch der Familie Falckner. Angelegt von Daniel und Hans Heinrich Falkner, Basel 1598, Historisches Museum Basel, Inv. 1984.279, 28. 


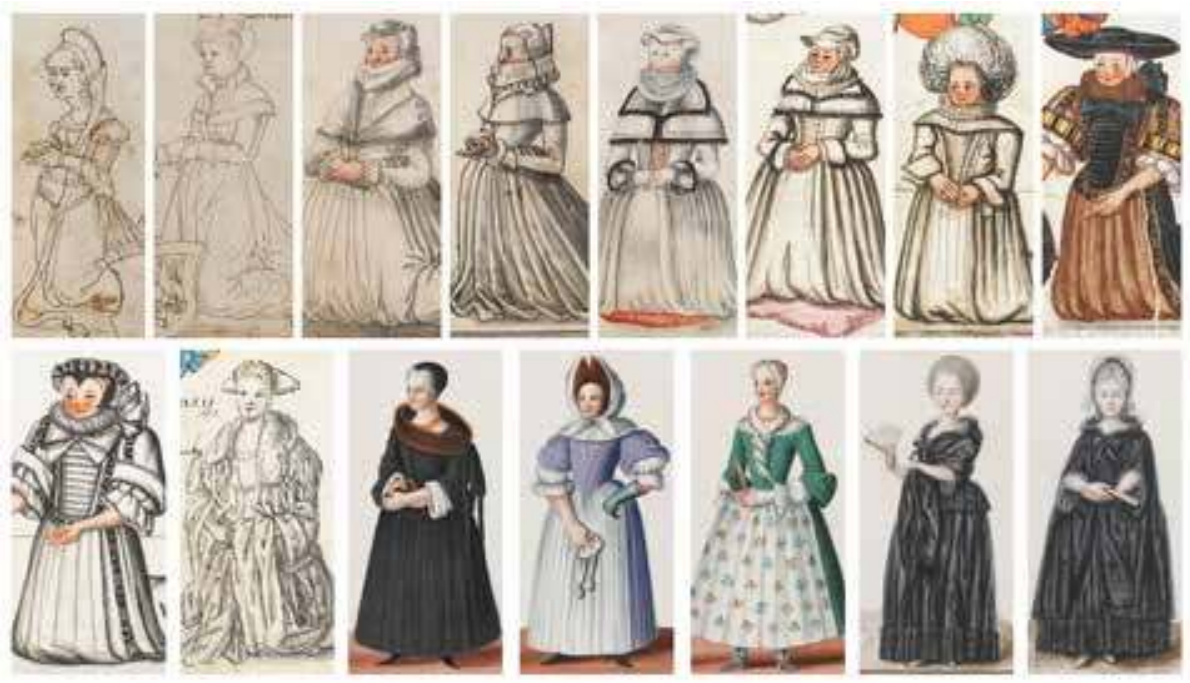

Figure 8.5: Falkner Stammbücher (hereafter FS) I-IV, details: (from left, row one): 1. wife of Heinrich Falckner (fifteenth century), FS I, fol. 8r, added 1574 (attributed to Hans Hug Kluber); 2. Ursula Falcknerin (d. 1552), FS I, fol. 16r, added 1574 (attributed to Hans Hug Kluber); 3. Justina Mieg (m. 1575), FS II, fol. 18r, added 1598; 4. Susanna Brauin (m. 1601), FS II, fol. 27r, added ca. 1601; 5. Dorothea Ryff (m. 1635), FS II, fol. 35r, added ca. 1635; 6. Dorothea Ryff (m. 1635), FS III, p. 61, added ca. 1690; 7. Barbara Spätlin (m. 1635), FS III, p. 69, added ca. 1690; 8. Anna Catharina Königin (m. 1671, d. 1721), Falkner Stammbuch III, p. 87, added ca. 1690; (from left, row two): 9. Rachel Johann Anderösein (husband Hans Heinrich Falkner 1644-1709), FS III, p. 89, added ca. 1690; 10. Catharina Birrin (1680-1763), FS III, p. 99, added around 1696 (text) and around 1763 (picture); 11. Catharina Birrin (1680-1763), FS IV, p. 31, added 1741; 12. Anna Catharina Greissin (husband Hans Ulrich Falkner*1649), FS IV, p. 30, added 1741; 13. Anna Thierry (1713-1779), FS IV, p. 34, added 1741; 14. Sybilla Stöklin (m. 1782), FS IV, p. 38, added ca. 1782; 15. Catarina Stöklin (m. 1778, d. 1778), FS IV, p. 39, added around 1780. Image @ Falkner Stammbuch I: Basel, Historisches Museum Basel, inv. no. 1887.159; Falkner Stammbuch II: Basel, Historisches Museum Basel, inv. no. 1984.279; Falkner Stammbuch III: Basel, Staatsarchiv Basel, PA 445a 2; Falkner Stammbuch IV: Basel, Historisches Museum Basel, inv. no. 1916.94.

The third Falkner album, compiled a century later, depicted the wives of the previous album virtually wholesale, only unveiling the face of the professor's daughter Dorothea Ryff, the last to have an illustrated entry in the second album. ${ }^{39}$ A marked change in fashion then emerged a few entries later when, beginning with Barbara Spätlin, nine wives from the Falkner family who were married between 1635 and 1658 appear unveiled wearing the fashionable Brawenkappe (fur cap) and ruff (Krös). Brawenkappen, regulated along with other garments in Basel's extensive 1637 Reformation ordinance, had been newly depicted in Hans Heinrich Glaser's costume book of 1634 and were thus documented contemporaneously in the album. By 1671 , the advent of the fashionable broad-brimmed black hat, worn

39 Der Falckner zu Basel Stammbuch. Stammbuch der Familie Falkner. Angelegt von Daniel Falkner, Basel 169o, StaBS PA 445a 2, 61. 
over a white coif, is manifested in the entry pertaining to the bookseller's daughter Anna Catharina König. From this point on, accelerated changes in Basel fashion during the final third of the seventeenth century are marked with the beaded coiffe $a b e c$, an elite headdress modelled by Rachel Johan Anderösein of Strasbourg on the very next page, ${ }^{40}$ followed shortly thereafter by the simple headscarf of Ursula Britlen, which foreshadowed future forms of headwear like the dormeuse cap. Novel pointed hoods are the latest trend seen in the 1696 entry for Catharina Birrin, while the fourth Falkner album documented emerging eighteenth-century modes such as powdered hair in 1778 and the lace mob cap. Veils and wimples were definitely confined to the past.

The four Falkner family albums by no means offer individualized images of how various family members dressed; they rather document prevalent and popular costume, accounting for shifts in fashion over an extended period. The illustrations after 1587 , for example, mark the revival of facial veiling outside of church-wear - a shift that coincided with the realignment of the church in Basel and its increasingly orthodox confessionalization politics. It also ran parallel to the growing social closure of the upper class, which in Basel led to oligarchical family rule. The albums suggest that this social segregation also manifested itself in the caste-conscious wearing of the Sturz and the (chin-covering) veil, which, from the early seventeenth century, could also be combined with fur-trimmed collars and sleeves. Accordingly, the return of the chin-cloth should not be read simply as a sign of a new, anti-fashion modesty; on the contrary, this form of veiling upheld the family's distinction.

\section{Local Costume Books: Social Orientation and Tradition Building}

Towards the end of the sixteenth century, interest in the social orienting function of dress was increasingly evident in the illustrations of manuscripts like the Falkner albums, in the costume figures of the libri amicorum, popular among (southern) German students, and above all in the local costume books that emerged from the late sixteenth century onward, notably in southern Germany, Alsace, and Switzerland. ${ }^{41}$ These costume books provided synopses of the socially differentiated clothing repertoire of a certain local society and swiftly became veritable archives of local and regional tradition building through dress. Costume images and costume books circulated extensively in Europe, offering opportunities for comparison

40 Falknerstammbuch 169o, 89. Léone Prigent, "La perception de coiffes à becs au XVIIIe siècle," in Quelques paillettes, un peu de soie. Coiffes d'Alsace du VXIIIe et du debut du XIXe siècle, ed. Anne Wolff et al. (Colmar: Musée d'Unterlinden, 2009), 20-32, 28.

41 Cf. Augsburg, Nuremberg, Strasbourg, Basel, Zurich, St Gallen. 


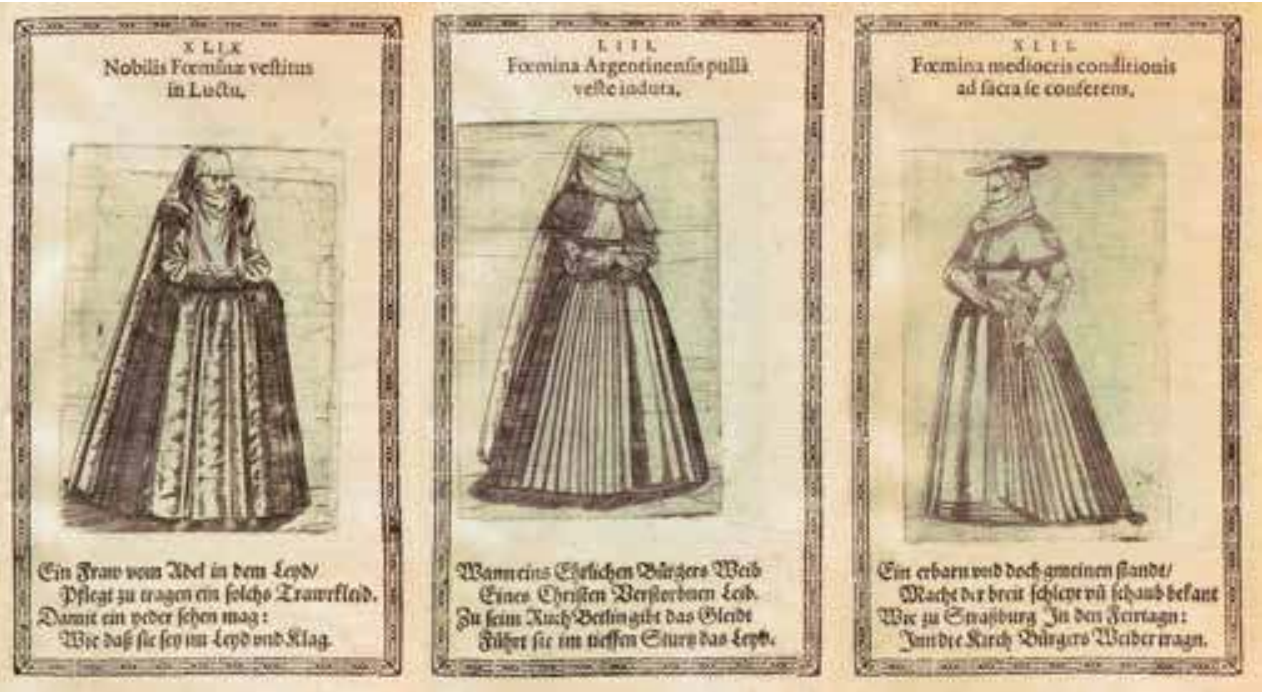

Figure 8.6: Noble and burgher women wearing veils and chin-cloths, in Johan Carolus, Evidens Designatio, Strasbourg 1606, from left: plate 49: Nobilis Foemina vestitu in Luctu; plate 53: Foemina Argentinensis pulla veste induta; plate 42: Foemina mediocris conditionis ad sacra se conferens. Image @ Universitäts- und Landesbibliothek Sachsen-Anhalt, Halle, Saale, urn:nbn:de:gbv:3:3-7713.

that facilitated the emergence of a topography of regional differences. The general interest in local clothing styles corresponded to identity discourses that emphasized regional and social distinctions alike. Thus, the proto-ethnographic costume books could also imbue local dress with emotional resonance. Strasbourg, whose highly elaborated policing of sumptuary regulations introduced a strong degree of social differentiation quite early on, played an influential role in the Upper Rhine region.

The earliest surviving Strasbourg costume book, from 16o6, shows heavily veiled women from the nobility, patriciate, and burgher class still wearing the Sturz as a sign of mourning (Fig. 8.6). ${ }^{42}$ In his preface, the author Johan Carolus explained among other things that it was important for caste differences in Strasbourg - where people were divided into six classes - to be readily visible through women's clothing in particular. Hans Heinrich Glaser produced the first costume book for Basel in 1624. It differentiates only between common and genteel women, generally depicts single women with a pointed felt hat (the Basel hat), shows Basel's married women attending church with veiled faces, and portrays a widow wearing the traditional Tüchli and long bands of fabric as a sign of mourning (Fig. 8.7). Ten years later, Glaser published a greatly expanded series of costumes. Amidst the Thirty Years' War, it documented the emergence of a new fashion, the Brawenkappen, which eleven years later Wenceslaus Hollar already

42 Johan Carolus, Evidens Designatio Receptissimarum Consuetudinum ornamenta quaedam \& insignia continens Magistratui \& Academiae Argentienensi à maioribus relicta (Strasbourg, 1606), preface. 

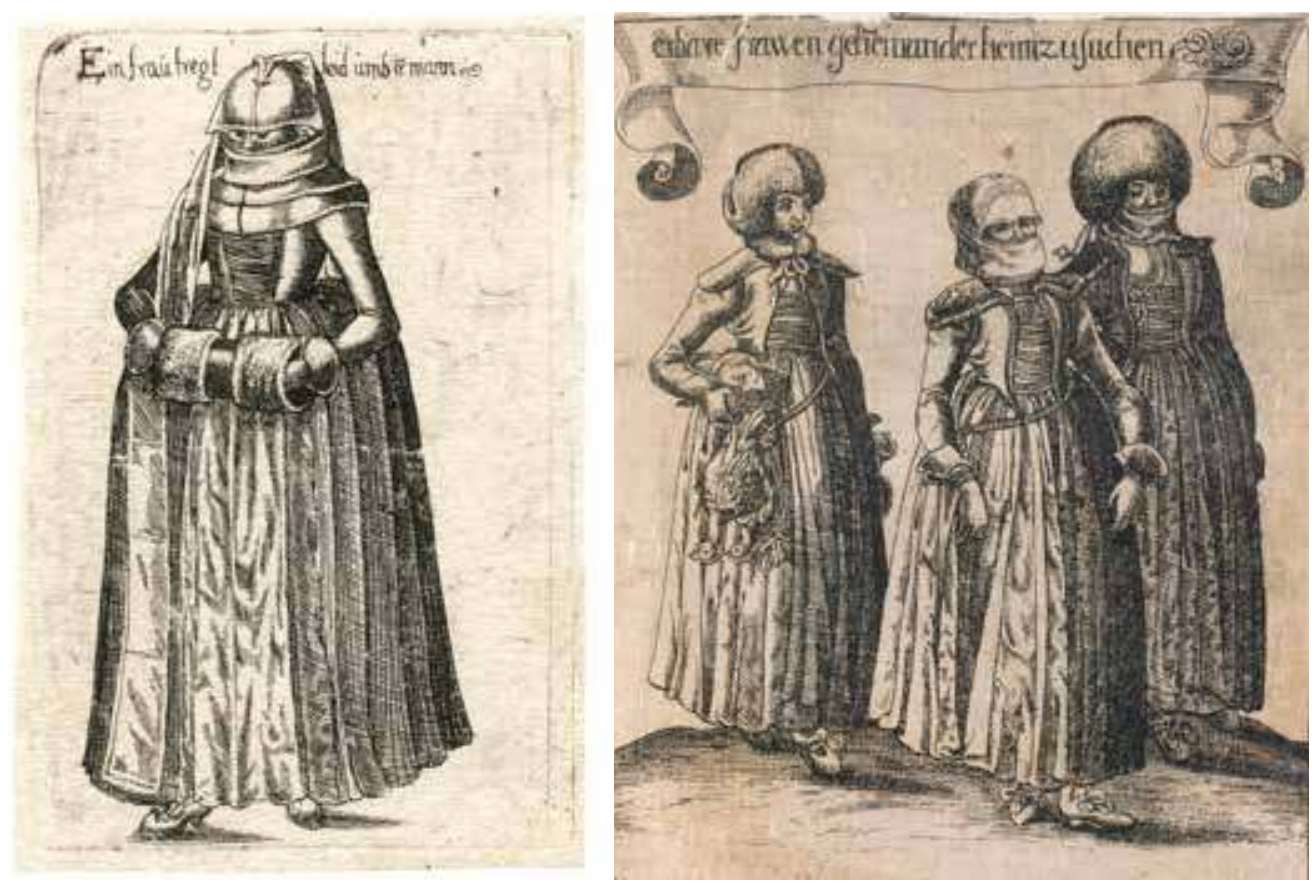

Figure 8.7, left: Hans Heinrich Glaser, A Woman Wearing Mourning Dress for her Husband. Etching. In Hans Heinrich Glaser, 'Habitus solennes hodie Basiliensibus ...', $10.4 \times 6.1 \mathrm{~cm}$, Basel, 1624. Historisches Museum Basel, inv. no. 1983.641.31. Image ๑ Historisches Museum Basel; Figure 8.7, right: Hans Heinrich Glaser, Honourable Women Going Home Together. Etching. In Hans Heinrich Glaser, Basler Kleidung aller hoh- und nidriger Standts-Personen, Basel: Hans Heinrich Glaser, 1634, plate 40. Basel, Universitätsbibliothek Basel, Falk 1464. Image @ Universitätsbibliothek Basel.

included as typical of Basel in his European costume series. These heavy, fur-trimmed caps soon became popular among Basel's women and, as Glaser shows, were combined on the street and in church with the traditional Tüchli as a face veil. Once again, fashion consciousness and traditional items of clothing were not mutually exclusive.

In 1637, just three years after Glaser published his second costume book directed at the authorities, the Basel council enacted a new, highly detailed Reformation ordinance including nearly twenty pages of printed sumptuary regulations. They were intended to combat abuses, sins, vices, and frivolities of all kinds, which had allegedly become habitual. The authorities paid particular attention to the fight against luxury and pride, and the poverty and desire they believed resulted from them. Accordingly, they sharply condemned the influence of foreign fashions; old and young men must neither wear "long alla modo trousers" nor long hair or wigs. ${ }^{43}$ In general, they were to adhere to the old Swiss, patriotic, and "German" manner of dress. Basel closely

43 Emidio Campi and Philipp Wälchli, eds., Basler Kirchenordnungen 1528-1675 (Zurich: TVZ, 2012), $353-354$. 
Table 8.1: Probate inventory for Salome Gottfried-Hacker, 1670

\begin{tabular}{ll}
\hline Item & Total value \\
\hline 30 stürtz à 12sh 6 d & $18 \mathrm{Pfd} .15 \mathrm{sh}$. \\
5 Schwenckel & $10 \mathrm{Pfd}$. \\
4 handsome Umbschlägle & $6 \mathrm{Pfd}$. \\
12 thin umbschlägle & $3 \mathrm{Pfd}$. \\
12 thick Umbschlägle & $3 \mathrm{Pfd}$ \\
30 Haubtstükle & $3 \mathrm{Pfd}$. \\
5 Kappentüchle & $6 \mathrm{Pfd}$. \\
12 pure tüchlehauben & $15 \mathrm{Pfd} .10 \mathrm{sh}$. \\
12 less valuable [tüchlehauben] &
\end{tabular}

followed the corresponding stipulations enacted by the Strasbourg council in $1628 .{ }^{44}$ In Basel, too, men and women alike had to observe the detailed, socially differentiated prescriptions for various types of material as well as adornments and appliqués. Informal dress was permitted neither on the street nor in church. Wives had to appear at Sunday and Tuesday sermons in the traditional "tüchli and schaube" with covered heads and long (open) coats, and after taking Communion they had to wear their veils until evening. ${ }^{45}$ Thus the authorities linked the marking of personal propriety and piousness with the staging of socially desirable orthodoxy in the church space and on Basel's streets. Miniaturist Johann Sixt Ringle's 1650 interior of the Basel Minster reveals the enforcement of compulsory veiling for women in church. ${ }^{46}$ All married women covered their faces with traditional wimples, even while wearing fashionable Brawenkappen, which in 1637 were still explicitly condemned as "monstrous and abominable." Half a generation later, these caps had apparently already established themselves as a widespread, acceptable form of headwear for church too. ${ }^{47}$

Unlike in Nuremberg, ${ }^{48}$ Sturz and Tüchli were still part of Basel female attire even into the 1660 s, as estate inventories of the time show. According to an inventory

44 Der Statt Straßburg Policeij Ordnung (Strasbourg: Johann Carolo, 1628), 42-43.

45 Basler Kirchenordnungen, 357; Susanna Burghartz, "Die 'durchgehende' Reformation - Basler Mandate von 1529 bis 1780," Basler Zeitschrift für Geschichte und Altertumskunde 116 (2016): 89-111.

46 Johann Sixt Ringle, "Innenansicht des Basler Münsters mit Blick gegen den Chor," Basel 1650, HMB Inv. 1906.3238. Reproduced in Susanna Burghartz, "Covered Women? Veiling in Early Modern Europe," History Workshop Journal 8o, no. 1 (2015): 1-32.

47 Emanuel Grossmann, "Die Entwicklung der Basler Tracht im 17. Jahrhundert," Schweizerisches Archiv für Volkskunde 38 (1940): 1-66, 33; Julie Heierli, "Basler Trachten um die Mitte des XVII. Jahrhunderts," Schweizerisches Archiv für Volkskunde 14 (1910): 108-117.

48 Zander-Seidel rarely found Stürze listed in sixteenth-century upper-class inventories, and by the seventeenth century they are absent altogether. Jutta Zander-Seidel, Textiler Hausrat. Kleider und Haustextilien in Nürnberg von 1500-1650 (Munich: Deutscher Kunstverlag, 1990), 116. 
of 15 October 166o, Judith Bruckherin, for instance, left " 3 sturz, 2 umbschleglin, 1 maullümplin [mouth handkerchief] [...] an old laidtbinde [mourning band] [...], a tüchlin hauben [veil-hood] [...], two kappenhauben [cap-like hoods]."49 And at her death in 1670 , Salome Gottfried-Hacker, daughter and wife of apothecaries, left an extensive collection of head-coverings with their values listed (Table 8.1). ${ }^{50}$ Here we see that the fabrics used for the Sturz were not especially valuable and that the value of the so-called Schwenkel, the long linen strip whose chief significance was a sign of mourning, cost twice as much as the Sturz..$^{1}$ The inventory also reveals that the closet of an apothecary's wife contained various qualities of wimples (Umbschlägle) with widely differing prices.

\section{The Crisis of the Church Veil and Women's Growing Resistance: 1665-1709}

At the beginning of the eighteenth century, the traditional Sturz went unchallenged as a church veil for upper-class women. The contemporaries Barbara Wentz-Meyer and Anna Magdalena de Beyer published a costume series showing a woman in such a church veil from the front and back, for example. And in 1707, the society painter and mayor's son Johann Rudolf Huber, who enjoyed great success in Basel and Bern, depicted several women in the Sturz, to whom the fluttering Schwenkel lent a lively appearance (Fig. 8.8)..$^{2}$ In light of additional sources, however, these images in fact seem to be signs of crisis or nostalgic swan songs, since the decades between 1660 and 1720 witnessed an intense struggle over the church veil in Basel, which probably ended with the disappearance of the Sturz (and helps us understand the previously-cited ironic denigration in Spreng's dictionary).

The first cracks in this established tradition became evident in a 1665 "Reformation Reminder." For the first time, an age limit was established for wearing the Sturz and an explicit distinction was drawn between Sturtz, Tüchlin, and Umbschläglin. Women under forty who were not personally in mourning should wear the socially clearly connoted Sturz for funerals only, and the Tüchli and Umbschlägli for all

49 StaBS Gerichtsarchiv K 19, Schultheissengericht der mehrern Stadt, Beschreibbüchlein 166o May 18 to 1666 May $15,15.10 .1660$, fol. 11v, 12 r.

50 StaBS Privatarchive 255, Inventory and division of the estate of Johann Gottfried (1621-1675) and of Salome Gottfried Hacker (1633-1670), 1676 + 1670, Inventory of 12 September 1670, fol. 193r.

$5^{1}$ This was likely because the Schwenkel required substantial volumes of fabric, maintaining a long drape and generous width that was typically folded in on itself several times.

$5^{2}$ On Huber, see Manuel Kehrli, "sein Geist ist zu allem fähig.” Der Maler, Sammler und Kunstkenner Johann RudolfHuber 1668-1748 (Basel: Schwabe Verlag, 2010). 

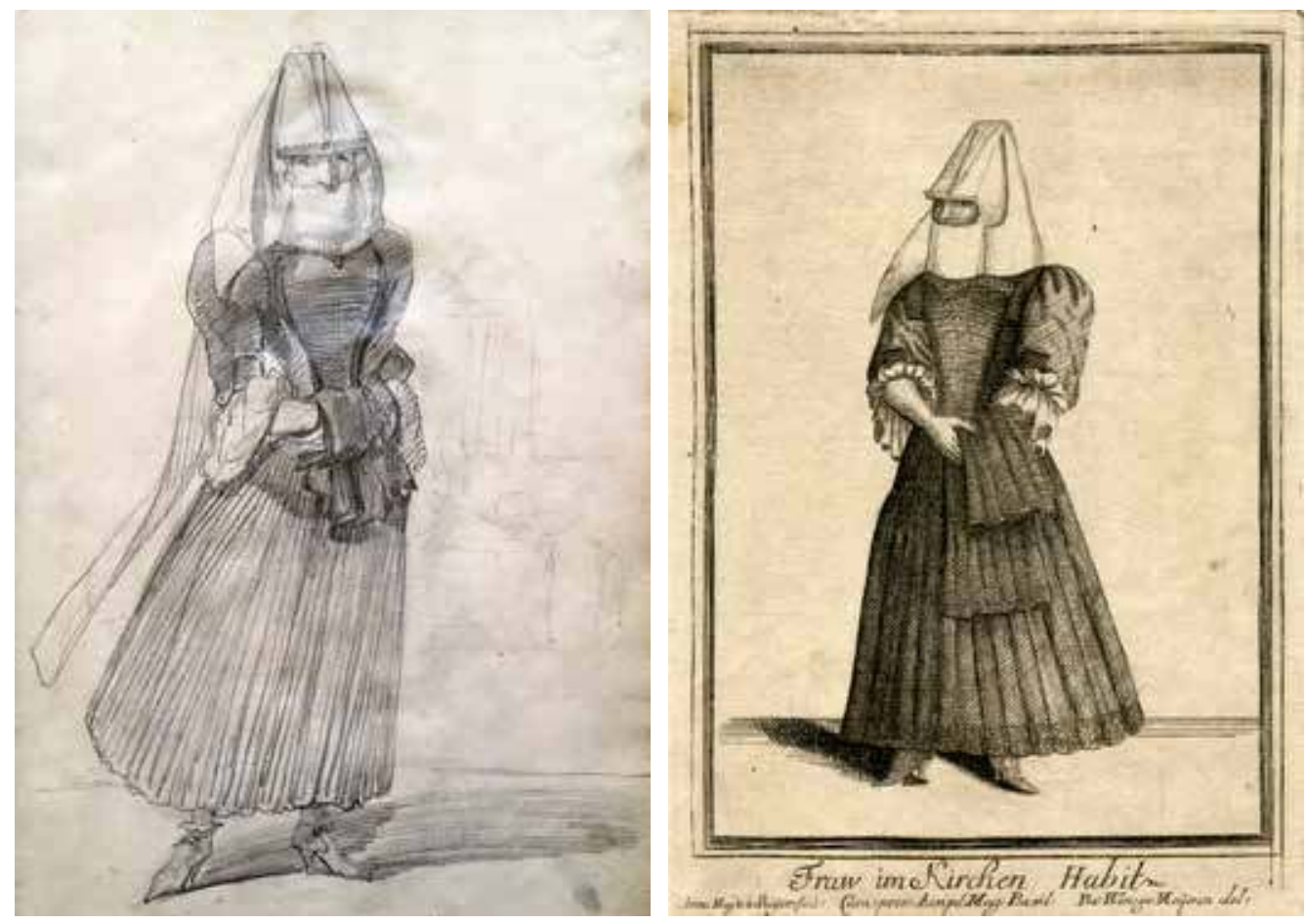

Figure 8.8, left: Johann Rudolf Huber, Basler Trachten von Anno 1700, Nr. 13: Woman Wearing the Sturz, ca. 1700. Pencil and crayon on paper, $31.9 \times 21.2 \mathrm{~cm}$. Kunst Museum Winterthur, Graphische Sammlung, Geschenk von Johann Rudolf Schellenberg d.J., 1849; Photo: Susanna Burghartz; Figure 8.8, right: Anna Magdalena de Beyer after Barbara Wentz-Meyer, Woman Dressed for Church Wearing Sturz and Tüchli. Etching, $19.2 \times 14.9 \mathrm{~cm}$. In Eigentliche Vorstellung Der Kleider Tracht Lob, Basel: Anna Magdalena de Beyer, ca. 1700. Basel, Historisches Museum Basel, inv. no. 1987.701. Image ๑ Historisches Museum Basel.

other services (including christenings and weddings). ${ }^{33}$ For the first time, wearing the church veil was determined by age rather than status differences. The fact that younger women were admonished at the same time to "avoid all innovations altogether" suggests that these women's growing interest in fashion, as also reflected in the Falkner's third album of 1690, may have awakened the authorities' sense of a need for new regulations. At the same time, the new regulation also tallied with the growing clerical critique of luxury, since the Sturz was both impractical and elaborate. For example, under the heading Sturzmähl (Sturz starch), Spreng's dictionary refers to Kraft-oder Steifmähl. ${ }^{4} \mathrm{He}$ told his readers that the church veil

54 Johann Jacob Spreng, Allgemeines Deutsches Glossarium, vol. X.14. (note) 1-485 Squies-syxh, Universitätsbibliothek Basel, mscr. Sign NL 71.X (Zettel), transcribed by Heinrich Löffler. I thank Heinrich Löffler for bringing this to my attention: "Sturzmähl, Kraft. oder Steifmähl. (Laur. Fr.) Hat den Namen von den 
was shaped using special starch flour. It is from Krünitz' Oekonomische Encyclopädie that we learn that such starch flour was made from Ammelmehl. 55 Requiring a several-day production process, this wheat or spelt flour was used to stiffen laundry and fine linens and was apparently effective enough to create the board-like effect Spreng mentions. ${ }^{6}$ Nevertheless, the new age-specific stipulations on the wearing of the Sturz do not seem to have been successful; at any rate, they were no longer mentioned in 1674.57

That this conflict was also about critiques of elaborate, upper-class dress is evident at the beginning of the greatest political unrest in ancien régime Basel. ${ }^{8} \mathrm{In}$ November 169o, bereaved women were forbidden to wear the relatively costly and "perniciously profligate" Schwenkel; only the turned down veil (nidergelitze Sturtz) was permitted. ${ }^{59}$ As the uprising continued, the clergy submitted a memorandum of central concerns. At first, they criticized the common practice of gift-giving and corruption, immediately following with, in the second item, the issue of the Sturz as obligatory church dress for married women of quality. ${ }^{60}$ At first glance, it may seem surprising that it was mentioned in the same breath as grave accusations of corruption, the sale of offices, and electoral fraud - the central issues behind the unrest. Interestingly enough, just a few weeks after the upheaval was put down, the importance of dress to the clergy became clear. In late 1691 they complained about their meagre salaries, which did not allow them to dress properly. In a lengthy supplication citing the difficult times and the need to reform the administration of secularized church properties, the pastors insisted that their salaries be increased not least so they could dress appropriately. Only then, they continued, would it be possible not to be judged as misfits by others. ${ }^{61}$ Clearly, sumptuary regulations, including questions of church dress, were of serious importance for the clergy. Their struggle against luxury was implicitly designed to help themselves and their wives to dress properly according to the class they belonged to - the burghers - even in times of growing wealth and rising consumption among the better-off. The very

ehmaligen Stürzen oder steifen Schleÿern und Hüllen der Weiber, welche man insonderheit darmit zu stärken pflegte."

55 “Ammelmehl," in J. G. Krünitz, ed., Oekonomische Encyklopädie, vol. 87 (Berlin, 1802), 424.

56 Despite assertions in the literature, there is no indication that a wire frame was used to give the Sturz its form. For Nuremberg, cf. Zander-Seidel, Textiler Hausrat, 116, which rejects this assumption.

57 StaBS Bf 1 A 6-23, Mandate of 4 November 1674.

$5^{8}$ For a brief overview of the events and the significance of the 1691 unrest for gender history, see Susanna Burghartz, "Frauen - Politik - Weiberregiment. Schlagworte zur Bewältigung der politischen Krise von 1691 in Basel," in Head-König and Tanner, Frauen in der Stadt, 113-134.

59 StaBS Bf 1 A 6-56, Mandate of 19 November 1690.

60 StaBS Politisches W 2.2., Bedencken der Herren Geistlichen.

61 StaBS Kirchen F3, "Geistlichkeit. Besoldung, Pensionierung, Gnadenzeit. 1530-1574-1806," read on 11.11 .1691 . 
next year, in 1692, the production of new Schauben (traditional coats for church) was prohibited. Now, "female persons should gradually abandon them as a useless and very costly costume." At the same time, however, Basel's women were again admonished to appear at early weekday sermons and evening prayers in decorous dress, wearing a Sturz or Tüchli. ${ }^{62}$ There was no more mention of banning the Sturz. This by no means ended the conflict, though, and the struggle between traditionalists, opponents of luxury, and followers of fashion continued.

We know from Bern that resistance to the traditional church veil arose there in the 1670 s and 1680s. In December 1678, the Bern Reformationskammer "noted that women mostly wore caps in church rather than tüchli, and therefore instructed those in charge of fire safety to visit every house and ensure mothers and daughters who were to go to church on Sundays or Christmas and take Communion should not wear caps but the customary "veil." ${ }^{63}$ And in 1688 , people complained that the pastor of Reichenbach was demanding that old women come to his sermons wearing the Tüchli and had to keep it on for the whole day, which was deemed unbearable. ${ }^{64}$ This was the first mention of the great discomfort of wearing veils all day.

In Basel, too, in the first half of the eighteenth century, wealthy women no longer accepted without complaint what Spreng called the "stiff stuff." While from 1704 they could loosen their veils as they wished in order to receive Communion more easily, ${ }^{65}$ this concession did not prevent the numerous violations of compulsory veiling in church in subsequent years. In October 1705, the tribunal of Reformationsherren heard the cases of seven women from Kleinbasel who had dared to attend church unveiled ${ }^{66}$ Walter Merian's wife argued that her health prevented her from wearing a veil; "they could do whatever they wanted to her, but she simply could not wear the sturz." Others claimed ignorance of the regulation or cited economic reasons, declaring themselves too poor to produce a Sturz. Wholly in keeping with previous policy, the Basel guardians of morals differentiated their verdicts according to social criteria. They were lenient towards poor women who violated compulsory

62 StaBS Bf 1 A 6-61, Mandate of 29 March 1692, repeated on 3 April 1695 and 13 February 1697.

63 André Holenstein, "Regulating Sumptuousness: Changing Configurations of Morals, Politics and Economies in Swiss Cities in the Seventeenth and Eighteenth Centuries," in The Right to Dress: Sumptuary Laws in a Global Perspective, c. 1200-180o, ed. Giorgio Riello and Ulinka Rublack (Cambridge: Cambridge University Press, 2019), 129.

64 Adolf Fluri, "Kleidermandate und Trachtenbilder in gegenseitiger Beleuchtung," Blätter für Bernische Geschichte und Altertumskunde 23 (1927): 278.

65 Quoted in Grossmann, "Entwicklung," 19-20.

66 This body of overseers of morals consisted of the Oberstzunftmeister and three representatives of the Little and four of the Great Council. For more detail, see Sonia Calvi, "Zur inspection und handhabung der angestellten reformation': Die Basler Reformationsherren im 17. und 18. Jahrhundert," Basler Zeitschrift für Geschichte und Altertumskunde 118 (2018): 249-279. 
veiling and did not insist that they wear the Sturz. The socially better positioned Merian, however, was punished for her loose talk. ${ }^{67}$

Four years later, resistance erupted anew. In September 1709, fifteen wives had to explain themselves for not wearing the Sturz. Acting as spokeswoman for the malcontents in court, Ulrich Passavant's wife stated that she could not wear the Sturz, "an expensive and very uncomfortable outfit," adding critically, that it promoted neither "the honour of God nor the public." She preferred to avoid church rather than wear it. ${ }^{68}$ While this represents a fundamental opposition to wearing the traditional church veil, two of the husbands present in court promised to ensure that their wives fulfilled their duty in future. The Reformationsherren admonished all participants to obey the mandate or submit a petition if they "could not wear the Sturz." ${ }^{\prime 69}$ Just a month later, the authorities enacted a new Reformation mandate against all abominations, excessive splendour, and fashionable foolishness and again explicitly prescribed the Sturz for the wives of "men of rank." ${ }^{\circ}$ But this did not break the women's resistance. On 27 November 1709, the Reformationsherren were compelled to hear the cases of twenty-eight women who had violated compulsory veiling. Notary Hofmann, who represented his wife in court, cited medical reasons and the judgement of doctors, who had stated that his wife could not wear the Sturz because of a chest condition. If she wore it, she could disturb her neighbours in church by coughing and might contract additional ailments. The Reformationsherren did not accept Hofmann's request for a dispensation for health reasons and instead fined him 12 Batzen. They also refused to accept ignorance as an excuse. The excuse that the miller Oswald Ritter offered for his wife shows how highly charged the conflict had become: she had always worn the Sturz until recently, when she believed it had fallen out of fashion. Resistance was already widespread, and many women seem to have shared the hope of ridding themselves of the burdensome obligation to wear the outmoded, uncomfortable Sturz. Thus, the wife of council member Stehelin had her maid state in court that she would only wear the Sturz if others did as well. The Reformationsherren continued to cling doggedly to tradition. Accordingly, even Jacob Mechel's heavily pregnant wife was fined 6 Batzen. Other wives of town councillors and master artisans cited the "well-known affect" - breathing troubles or indisposition - as an argument in court, thus referring to physical ailments they attributed to the church veil's restrictive form and rigidity. Both clearly elicited reluctance and complaints in Basel as they had in Bern from the late seventeenth century. Presumably, the form and quality of

67 All quotations from StaBS, Protokolle E 13,1, Reformation 18 November 1674 to 17 January 1714, entry of 7.10.1705.

68 Quoted in Grossmann, "Entwicklung," 24.

69 StaBS, Protokolle E 13,1, entry of 13 September 1709; see also Grossmann, "Entwicklung," 24.

70 StaBS Bf 1 A 7-19, Reformationsmandat 12. Oktober 1709, A3. 
the starched material had scarcely changed since the fifteenth century. What had changed were women's feelings and body awareness. Thus, the heavy traditional coats and stiff veils for church were increasingly considered old-fashioned and uncomfortable. While poorer women managed to lower the fines by stating that they were "common folk" who could not afford the costly Sturz, ${ }^{71}$ the desire of Basel's better-off women to dress more comfortably and fashionably for church were treated with increasing severity by Basel's guardians of morals.

The efforts of the clerics and Reformationsherren to maintain the traditional church veil coincided with the socio-political unrest of the years around 1691, when the clergy was engaged in a protracted power struggle for influence over Basel politics and an intense campaign against the sale of office, electoral fraud, and corruption. These years also saw the beginning of the great protoindustrial transformation that led to heightened social conflict, the gradual emergence of new, luxury-oriented consumption, and not least to constitutional changes with lasting effects on the patronage system and the professional bureaucracy. At the end of this period of transformation, according to foreign travellers, Basel's women still dressed "uniformly and according to a long-outmoded design." ${ }^{72}$ If we are to believe the assessment of the Enlightenment philosopher and garden theorist Christian Cay Lorenz Hirschfeld, who in 1776 described the costume of Basel's women as "hideous," the authorities' persistent struggle against foreign fashion and the "mania for innovation" actually enjoyed some success. In 1780, the town council nevertheless still felt compelled to enact a new Reformation ordinance harshly criticizing foreign dress and the introduction of new costumes as "one of the greatest evils." And with regard to church veils, circumstances in Basel had apparently changed fundamentally. There had been no more convictions for failing to wear a veil for some time, and the relevant mandates no longer mention the Sturz. Instead, veils had clearly become fashion items, alongside plumes for hats and hoop petticoats - an item the authorities forbade women to wear to church on pain of a 20-pound fine. ${ }^{73}$

StaBS, Protokolle E 13,1, entries for 27 November 1709. Christian Cay Lorenz Hirschfeld, Briefe die Schweiz betreffend (Leipzig, 1776), 244. StaBS Bf 1 A 14-35, Reformationsordnung of 24.7.1780, 13 . 


\section{Zurich's Discursive Matériel Battles and the Regulation of Church Dress}

Like Basel, Zurich underwent an intense period of transformation in the textile sector around $1700 .{ }^{74}$ During these years, the struggle over new consumption habits and clothing practices in the city was, with the aid of dress and luxury regulations, a veritable matériel battle. Numerous mandates exhaustively addressed and regulated the fabrics, form/cut, appliqués, and situations of use of textiles and articles of clothing. This very detailed discourse on dress, luxury, fashion, and morals peaked between 1690 and 1730. When the Huguenot Anne-Marguerite de Petit (married du Noyer), passed through Zurich in 1686 after the lifting of the Edict of Nantes, she was appalled by what local burgher women wore to church:

But the attire of the ladies of Zurich is terrible: It consists of a large, loose, pleated black covering, like the robes of Benedictine monks, with long sleeves hanging down the sides: they cross their arms inside their great sleeves. On their heads they wear a cloth that falls to their eyes and a large heavy linen above, and on their chins they wear another pleated cloth like a hand towel, which covers them to the upper lip, such that one sees only the tips of their noses. They go to church and return in groups, two-by-two, their eyes lowered; if when one sees them walking thus one might think they were a procession of black monks; and afterwards they lock themselves in at home. ${ }^{75}$

In Zurich, the attempt to uphold old-fashioned morals against fashionable innovations had become almost counterproductive, for in the Huguenot's account, the procession of black-cloaked ladies was unfortunately reminiscent of processions of Catholic monks. The Frenchwoman's ironically critical observations came at a time when well-funded Huguenots with European trade networks were entering textile production in Zurich. They participated in the silk industry and the production of woollen and silk stockings and, much to the dismay of the city's merchants, purchased cottons from rural producers for export. This seems to have offered so much potential for conflict that Zurich expelled the Huguenots in 1699. And in Zurich, too, a remarkable tension arose between constancy and change, repetition and innovation, dense regulation and moral frugality. Driven by moral traditionalism, worries about exploding materiality plagued the clergy and with them the secular authorities (Graph 8.2). 


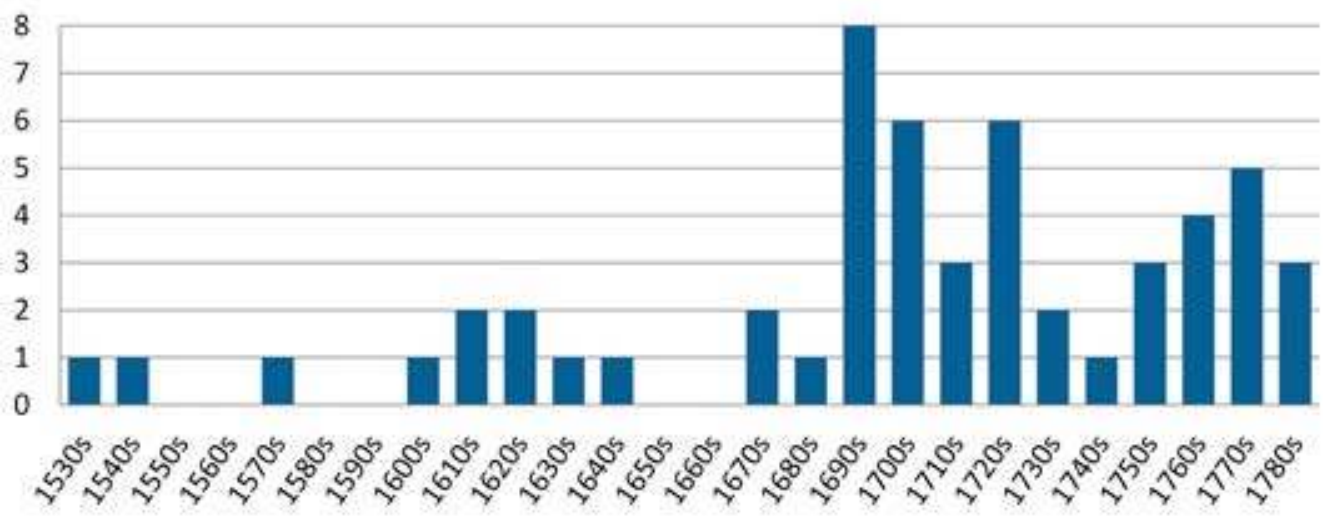

Graph 8.2: Number of mandates with clothing regulations for the city and canton of Zurich per decade, sixteenth to eighteenth centuries.

Note: Data on which the graph is based come from a database of all surviving sixteenth- to eighteenthcentury mandates in Zurich, which Sandra Reisinger from the Staatsarchiv Zurich was kind enough to provide for me.

At the beginning of the seventeenth century, the mandates were already complaining that overweening pride was taking over and had reached women's fashion. In particular, the mandates continued, this "suspicious" consumption was evident in clothing and home furnishings. ${ }^{76} \mathrm{~A} 1628$ ordinance expressed for the first time particular requirements for a godly way of life among pastors' wives and children and explicitly demanded that their clothing avoid anything that might "cause a nuisance." This particularly applied to large, pleated collars, the fashionable Hinderfür 77 - a voluminous, bulging cap for women featuring two closely connected rows of fringed woollen bands - and anything else that might be considered prideful and which could disrupt their husband's or father's teaching. ${ }^{78}$ The material differentiation of clothing regulations reached an initial high point in the Great Mandate of 1636 . This law arose during the Thirty Years' War in the context of an advanced, superregional discourse on the Reformation and sin, marked by orthodox intensification and exaggeration. ${ }^{79}$ Undesirable fashions and luxurious practices in matters of dress

76 StaZH B III 171 fol. 225 (Mandate 16o9).

77 Jenny Schneider, "Hut ab vor soviel Kopfbedeckungen!: 20o Jahre Frauenhüte und -hauben in der Schweiz," Zeitschrift für schweizerische Archäologie und Kunstgeschichte 38, no. 4 (1981): 305-312, esp. 307-308. In n. 3, Schneider gives the weight of various fur caps in the Swiss National Museum's collection as $33^{2-345} \mathrm{~g}$, and for Hinderfürs as $660-965 \mathrm{~g}$.

78 Emidio Campi and Philipp Wälchli, eds., Zürcher Kirchenordnungen 1520-1675, vol. 1 (Zurich: TVZ, 2011), Nr. 238 (3.5.1628), 680-681.

79 Burghartz, “'durchgehende' Reformation," 94-101; see also Andrea Iseli, "Krisenbewältigung im 17. Jahrhundert. Die Rolle der guten Policey," in Die Krise in der Frühen Neuzeit, ed. Rudolf Schlögl et al. Historische Semantik 26 (Göttingen: Vandenhoeck \& Ruprecht, 2016), 147-167. 
were listed separately for men and women. The law forbade, for example, long, tight, "foreign" breeches that tied under the knee, overly large and pleated ruffs known as Kröße, gold and silver embroideries on men's gloves, and Hinderfürs for women embroidered with gold and silver or otherwise richly trimmed and adorned with ribbons. ${ }^{80}$ This discursive matériel battle peaked in the $1690 \mathrm{~s}$, when the Zurich council published a new mandate nearly every year.

By 1680 , passages from the printed elucidation of the Great Mandate of 1636 had turned into an anti-fashion mandate, attacking "pride in dress" as a "despicable pawn of sin" and the "pride of wretched Satan," which would ruin the citizenry and the entire country. ${ }^{81}$ Fashionable clothing details were now exhaustively criticized. For the first time, the text spoke of "large, indecorous tächlenen" (literally, little roofs), a peculiarity of the Zurich church hood. Daughters and wives were admonished to avoid

[...] any wearing of multiple collars in the churches/ around their necks with bands behind and in front/ the vexatious large corners on their tüchli/ with large indecorous tächlenen on them/ all wearing of ribbons on their heads in the city/ as well as long ribbons around their necks/ the new manner of black velvet [eye] brows in the churches $[. .$.$] on pain of a 5$-pound fine. ${ }^{82}$

As if this were not enough, they also imposed fines for fur trim on caps, velvet shoes in church, or (prayer) books with costly silver and gold fastenings. Additional detailed prohibitions applied to students, candidates for ecclesiastical office, and other clerics and their wives and daughters. ${ }^{83}$ As stated in the mandates themselves, the various prescriptions and prohibitions aimed to "curtail superfluity and splendour" and above all to ensure that the people of Zurich "enter the Lord's house in respectable clothing." ${ }^{4}$ The vehemently worded general critique of fashion is interesting here, but so are the prohibitions on neckerchiefs of ribbons and silk directed especially at housemaids, since these textiles were not imported but belonged to the range of products that had recently begun to be manufactured in Zurich. ${ }^{85}$

The traditionalists' struggle intensified over the next fifty years, leading to new, obsessively detailed mandates. Traditionally oriented church dress still had a part to play here. The extremely extensive sumptuary law of 1691 contains lengthy

8 o StaZH III AAb 1.3, Mandate $1636, \mathrm{~F}_{3}$.

81 StaZH III AAb 1.5, Mandate 1680, 10.

82 Ibid., 12.

83 Ibid., 13-14.

84 Ibid.

85 Pfister, Fabriques, 63-65. 

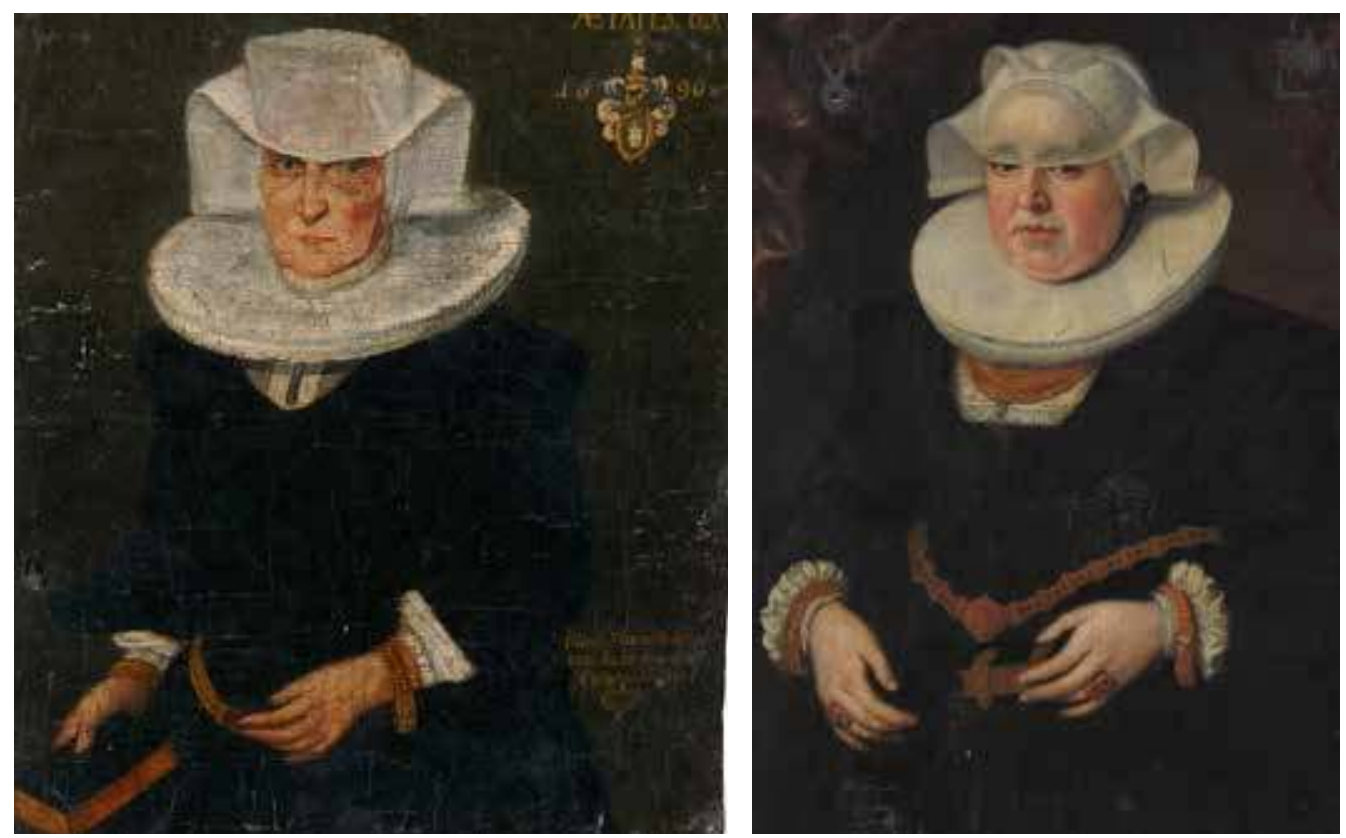

Figure 8.9, left: Anna Waser, Portrait of Regula Escher-Werdmüller, Wife of Mayor Heinrich Escher, 1690. Oil on canvas, $25.7 \times 22 \mathrm{~cm}$. Zurich, Zentralbibliothek Zurich, inv. no. 378. Image @ Zentralbibliothek Zürich, Graphische Sammlung und Fotoarchiv; Figure 8.9, right: Anonymous, Portrait of Catharina Hirzel-Orelli, about 1660-1670. Oil on canvas, $91.5 \times 75.5 \mathrm{~cm}$. Schweizerisches Nationalmuseum, IN-7170. Image $\odot$ Schweizerisches Nationalmuseum.

stipulations about women's veils. "The large, vexatious corners on the tüchli / and the large, indecorous tächlein on top" were forbidden. The Tüchli-Auffsetzeren, women who were responsible for the special handling of church veils, were to be admonished to modesty, and the proper wearing of Tüchli and Tächli should be dictated to them with the aid of a pattern if necessary (Fig. 8.9). ${ }^{86}$

Again, traditionally firmly established material discourses were elaborated and expanded with new intensity. For the first time, exceptions were permitted for health reasons. Henceforth, the presiding judge of the Reformationsherren could release "young and old women and matrons" from the obligation to attend church in a Huseggen (coat) if they could not wear the heavy, body-concealing coats because of weakness or other serious causes. ${ }^{87}$ The same mandate strictly forbade the adornment of these church coats with braided cords or roses and flowers. ${ }^{88} \mathrm{In}$

86 StaZH III AAb 1.5, Mandate 1691, 17-18.

87 Ibid., 10. From 1697 the "councillors of the Reformation" were collectively authorized to do so, StaZH III AAb 1.6, Mandate of 1697, 11.

88 StaZH III AAb 1.5, Mandate of 1691, 12. 
1699 the passage on the large "indecorous tächlein" was expanded with the remark that the length of the veils should be limited to between one cubit $(59.3 \mathrm{~cm})$ and a maximum of five Vierling $(74 \mathrm{~cm}) .{ }^{89}$ The renewed increase in detail is also evident in other stipulations such as that concerning hoods, which now explicitly could only be adorned at the back with a simple black bow. Wearing the heavy church coat was declared compulsory for the last time in 1701, with coloured clothing forbidden under the Huseggen. ${ }^{90}$ When the ordinance was reprinted the next year there was a clear change: Zurich's women could now elect not to wear the Huseggen but were still obliged to wear the Tüchli. Also banned were the "coloured hood roses, including the black ones attached to iron wires and higher than three inches" as well as "embroidered chin-bands." ${ }^{11}$ All of these regulations were attached to 10-pound fines, while wives and daughters who took Communion in town or the country wearing coloured sleeves faced a 100-pound fine..$^{2}$ Elsewhere, too, the prescriptions and prohibitions became more elaborate. The authorities carefully noted all attempts at innovation, development, and variation and sought to stop them in their tracks. Clergy and laity were consequently admonished to report violations of any kind to the Reformation court. As much as the mandates sought to banish fashion and uphold tradition, all of these prescriptions also indicate the Zurich population's interest in a growing diversity of dress styles and trends. The continuous stream of constantly expanded and adapted sumptuary regulations reveals very clearly that the authorities of the textile export city of Zurich failed in the medium term to prevent innovations in fashion. ${ }^{93}$ At the same time, the sumptuary laws published around 1700 reveal that for traditionalists, what women wore to church represented the ultimate pièce de résistance.

\section{Clothing in Court: The Zurich Reformationskammer in the Eighteenth Century}

The transcripts of Zurich's Reformation court, which from 1627 was responsible for sanctioning infringements of the sumptuary laws, alongside brawls and violations

89 StaZH III AAb 1.6, Mandate of 23.11.1699, 12.

90 StaZH III AAb 1.7, Mandate of 1701, 10-11.

91 Ibid., Mandate of 24.11.1702, 12-13.

92 Ibid., 13-15.

93 To what extent the authorities of the textile centre of Zurich actually wanted this remains an open question. A comparison with Basel in any case suggests that the authorities were not a completely coherent actor, and that conflicts of interest between various groups (e.g. textile merchants, manufacturers, artisans, and clerics) certainly may have played a role. 
of Sunday observance, survive for the period from November $1709 \cdot{ }^{94}$ Infringements of the sumptuary laws play a significant role in the early volumes, in particular (Graph 8.3).

The authorities conducted a veritable battle against fashionable conduct before the Reformation court and did not hesitate to penalize local notables, officials, and their wives and daughters. ${ }^{95}$ Around 1700 they were particularly anxious to combat the growing influence of French fashion, as the lament of 12 August 1710 - "French - everywhere" - made especially clear. ${ }^{96}$ On 6 November of the same year, ten daughters and wives were fined for wearing a Schöpli or bodice. Women in particular, but occasionally men as well, were regularly convicted of violating numerous sumptuary laws. Women were punished with particular frequency for wearing cuffs or sleeves in church, excessively large bunches of ribbons on so-called Bodenkappen, gold chains, and the abovementioned bodices. In contrast, the Reformation court rarely treated the "vexatious large corners" atop their Tüchli or the excessively large Tächli on their hoods repeatedly cited in the mandates. This did not stop the pastor of the Zurich orphanage, Johann Jacob Ulrich, from lambasting the vices of lust, pride, and profligacy in his forty-four-page penitential sermon of 1720, in which Tüchli received especial complaint. He criticized rich and poor alike, since he foresaw an imminent danger that senseless ambitions and status consumption would ultimately be the ruin of all. The daughters of tanners, weavers, cobblers, and tailors, Ulrich noted, were as splendidly dressed as those of the most distinguished gentlemen: "You cannot tell the people apart anymore." His comparison between the inhabitants of Zurich and those of Sodom and Gomorrah was accordingly drastic: the latter could never compete with Zurich splendour. He believed this was especially evident in the church veils:

Had the elegant wives of Sodom/ worn tächlein-tüchlein/ to distinguish themselves from others/ I greatly doubt/ that they would have been as common in their city as they are in ours. After all, this costume so common among us is no sign of our humility/ but rather of a stinking, foolish pride. ${ }^{97}$

He firmly rejected the objection that outward appearances were not worth the bother. It was only in the 1740 os that "church habit" increasingly became an issue before the Reformation court. There were open refusals, but also petitions asking not to have to wear the uncomfortable church costume for health reasons, backed

94 There are records for only two months of 1709; therefore, the figures are not comparable with those of other years and are not included in the graph.

95 Cf. similar observations for Bern in Holenstein, "Regulating Sumptuousness," 126-127.

96 StaZH BIII 173, 50. See also Schneider, "Hut ab," 309.

97 Johann Jacob Ulrich, Auserlesene Predigten, ed. Hans Conrad Wirz, Part 1 (Zurich, 1733), 73-116, 103. 


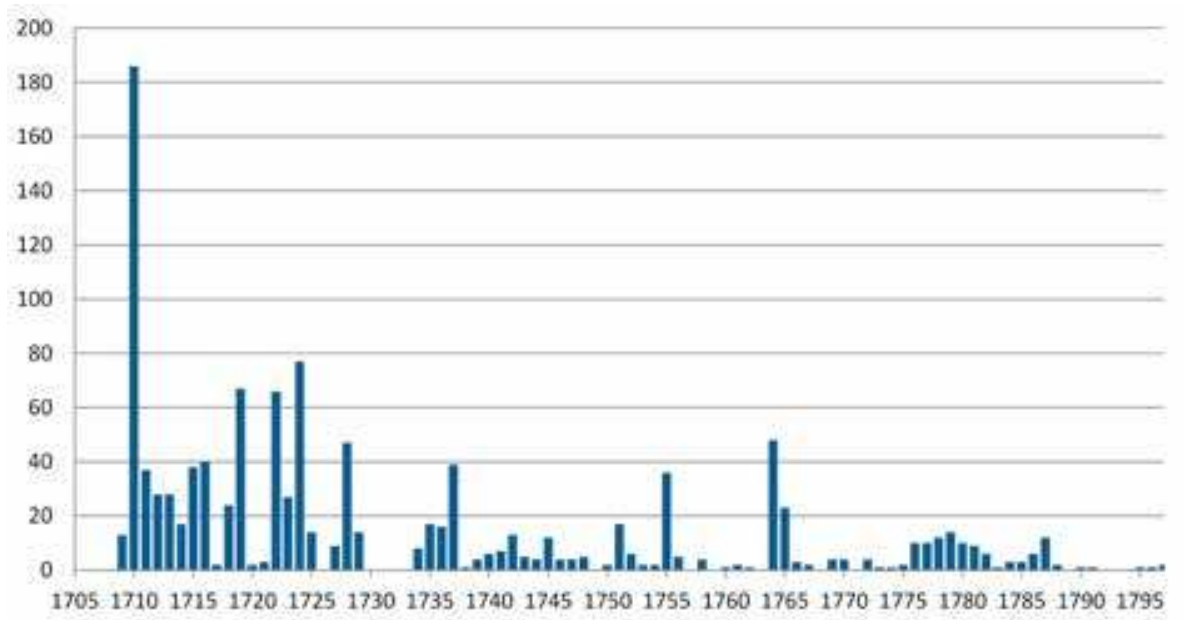

Graph 8.3: Offences of clothing and pride before the Zurich Reformation Chamber, 1709-1797 Note: While no transcripts survive for the years 1730-1733, in 1749, 1757, 1759, 1768, 1771, 1789 and 1792-1794 no cases involving haughtiness or violations of the sumptuary laws came before the Zurich Reformationsherren.

up by doctors' letters. In June 1744 the wife of guild master Waser, having "humbly presented her bodily frailty," received permission, for the first time, to attend weekly sermons without the Tüchli, although the merciful judges would have preferred her to appear in the veil prescribed for female citizens..$^{98}$ Finally, in September $175^{0}$, at the request of the "honourable stillstand" (oversight committee) of the congregation of the Great Minster, the morals court was to continue to keenly monitor the "retention of the tächli." 99

Quantitative analysis of the Reformation court transcripts plainly shows that despite the detailed clothing regulations in the mandates, Zurich, too, did not experience a steady stream of convictions for violations of sumptuary laws. Instead we repeatedly encounter campaigns by the Reformationsherren targeting particular clothing items, practices, and fashions, such as the large piles of ribbons on hoods, men's walking sticks, or the wearing of coloured ribbons at weddings. Violations of the clothing mandates were also pursued by the responsible body with widely varying intensity. Weeks, months, or even years in which the court scarcely heard one case were repeatedly followed by sessions in which the authorities responded with explicit morality campaigns against new fashion trends and specific clothing practices and accessories. Overall, however, instances dropped sharply from the late 1730 s.

98 StaZH B III 181, 5 for 4.6.1744 (the pagination in this volume is repeated every year, see also the following note).

99 Ibid., 4 for 8.9.1750. 


\section{New Transparency? Enlightenment Thinkers Oppose the Veil}

From the 1720s, women's headwear and veils became topics of discussion beyond the mandates as well. As we have seen, the Zurich pastor Johann Jacob Ulrich harshly condemned the vices he associated with prideful dress in a 1720 penitential sermon comparing Zurich's citizens with those of Sodom and Gomorrah. The very next year, in 1721, Zurich's best-known Enlightenment thinker, Johann Jakob Bodmer, presented a morally ironizing image of a Zurich citizen in wig and ruff together with two townswomen, one wearing a Tächli-Tüchli, the other a high beribboned hood or fontange, on the frontispiece to his weekly Discourse der Mahler. ${ }^{100}$

Twenty-five years later, in the forty-fifth issue of his magazine Der Mahler der Sitten, Bodmer again turned to questions of pride and appropriate dress for women. This time, in 1746, he offered observations on taste, dress, and "the undertakings of the female sex," criticized the overly elaborate headdresses of Zurich's women, and distanced himself, ironically, from these enormous constructions. Following a satirical analysis of the "rough costume of beards," ${ }^{, 01}$ men's high wigs, and the gigantic fontanges worn by women, the Mahler der Sitten (Painter of Manners) tackled the "excessively large wrapping of the head" more generally, ${ }^{102}$ a practice which he hoped to render unpopular among womenfolk. Falling back on arguments used since antiquity, he asked them to consider "that the natural beauties of the head are obscured thereby." Under the motto In facie legitur homo (one can read a man's character from his face), he explained that the visage was a bright mirror "which uncovers the state and positions of the heart," thereby showing "all the inward movements of the spirit, joy, sadness, love, shame, anger, jealousy." All this, he believed was "squandered and destroyed by the contraptions, which lend the head a different and alien shape and symmetry. ${ }^{{ }^{103}}$ Bodmer took up an argument here that has been marshalled repeatedly in the history of veiling: True virtue has nothing to hide; its purity is evident in a face openly displayed. Similar arguments had already been used by humanists like Juan Luís Vives in sixteenth-century Spain. ${ }^{104}$

How relevant the church veil remained at this time is evident from the detailed description of Zurich church customs by the Zurich publisher and engraver David Herrliberger, which he published in $175^{\circ}$ as an appendix to his German edition of Picart's Cérémonies religieuses (Fig. 8.10).

100 Die Discourse der Mahlern, Erster Theil (Zürich, 1721).

101 Johann Jakob Bodmer, Der Mahler der Sitten (Zurich, 1746), chap. 45, 518.

102 For this and the following quotations, see ibid., 529-530.

103 Ibid., 530.

104 See Bass and Wunder, "The Veiled Ladies" for Spain. 


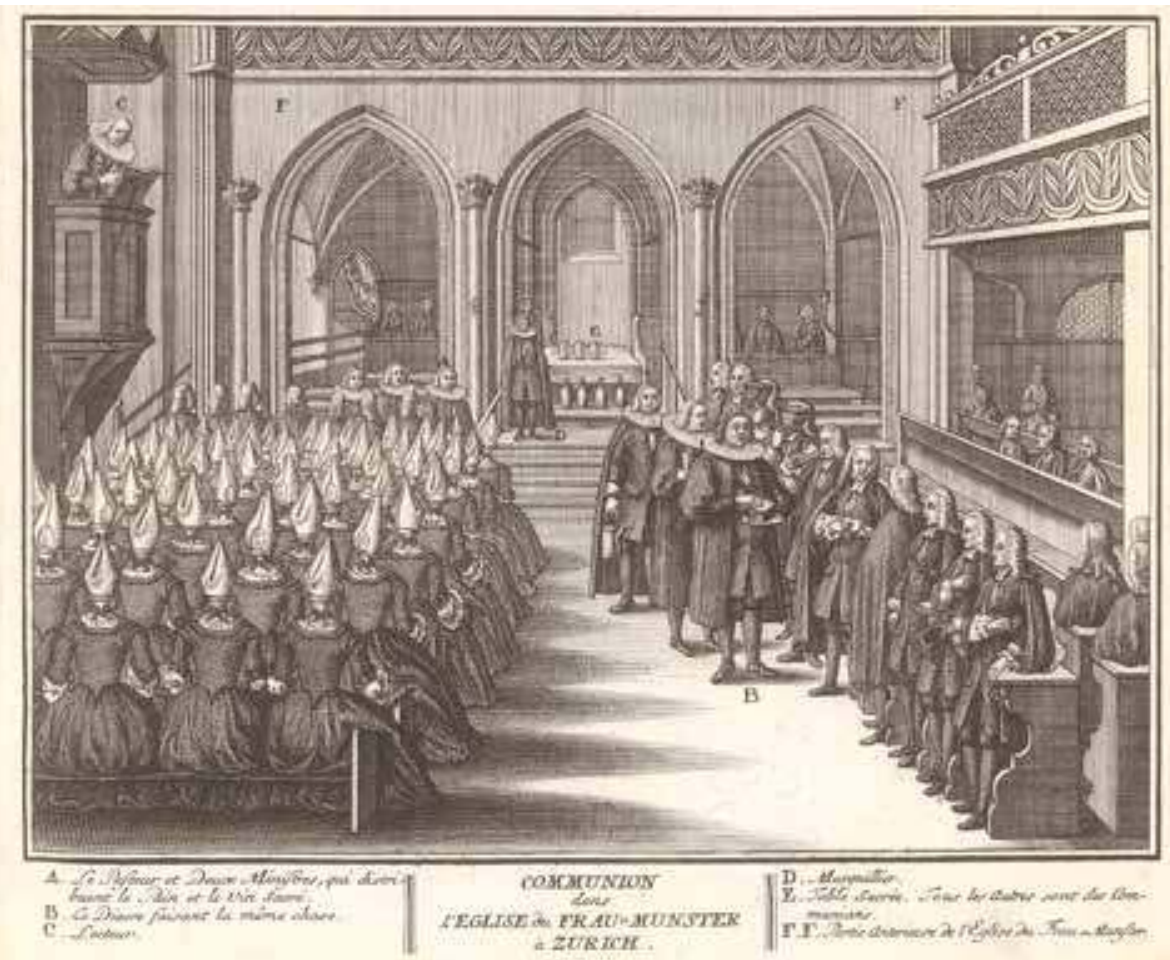

Figure 8.10: David Herrliberger, Communion in the Zurich Fraumünster. Engraving. In David Herrliberger, Kurze Beschreibung der Gottesdienstlichen Gebräuche, Wie solche in der Reformirten Kirchen der Stadt und Landschaft Zürich begangen werden, Zurich: Daniel Eckenstein, 1751, plate VII/2. Zurich, Zentralbibliothek Zurich, shelf no. Res 11, 10.3931/e-rara-18198. Image @ Zentralbibliothek Zurich.

The church costume of noble or other gentlewomen consists of a tall, conical fine white headdress known as a tächli-tüchlein: At funerals, however, the noblewomen can be distinguished from the others by a so-called schwängel or long strip of the same cloth.

Herrliberger accordingly depicted various occasions during which the genteel ladies of Zurich wore the Tächli-Tüchli described here: christenings, sympathy visits, funeral processions, and funeral services, but also at Communion.

With their striking, uniform shape and stiff but sheer material, which followed wearer's movements, the head veils turned women into a uniform body that could nonetheless still be differentiated according to rank. Herrliberger continued his description of the church veil by pointing to other versions that tended to be more cumbersome, specifically mentioning the Tüchlein worn by burgher women, which did not come to a point but were broader on top. When judging this church costume, which he deemed old-fashioned, he refers to the Mahler der Sitten. 
Both costumes are worn only to church nowadays. They are old-fashioned and verdicts about them can be read with pleasure in the Zurich Sitten-Mahlern. Yet they have assumed a far more attractive form and look at least as good as the headscarves and dress worn in Protestant ceremonies by certain Lutheran women in Germany; notably since the excessively low and shapelessly wide tüchlein formerly worn in Zurich have disappeared, along with the monstrous overcoats (hüsacken) pleated like pulpit gowns with long sleeves reaching to the ground.

According to Herrliberger, the Zurich church costume had thus become more modern and moderate in recent years. The "head-contraption" worn by Zurich women continued to differ from church veils in other towns, although no longer need fear comparison with them; it was far less extravagant than previously, "when lofty piles of ribbons etc. were worn." ${ }^{105}$

\section{The Tächli-Tüchli: An Embodied Object of Research}

The materiality and affective properties of such church veils were fortunately made accessible for embodied research thanks to the preservation in Zurich's Swiss National Museum of a church costume with a Tächli-Tüchli dating to the first half of the eighteenth century. The outfit, referred to as a Gottenkleid (godmother's gown), consists of a richly pleated skirt of wool crepe, a thick black woollen bodice with fishbone stays, separate sleeves and detachable hip cushions, pleated linen cuffs, a fine linen shoulder cloth, a white cotton hood, and a semi-transparent cotton veil with a long strap used as a Tächli-Tüchli for church, and a pair of black velvet buckle shoes. As a complete ensemble, it offers a rare insight into the materiality of burgher women's church costumes in an eighteenth-century Reformed Swiss city (Fig. 8.11). ${ }^{106}$

The hood and veil are made from fine woven materials and, in their unstarched state, are semi-transparent, light, and flexible. The veil is a delicate, cotton mousseline fabric with a thread-count of $30 \times 30 \mathrm{z}$-twist threads per centimetre. ${ }^{107}$ The weaving of fine mousseline from wet spun Löthligarn was introduced in Zurich around 1700, producing fine, semi-transparent cotton cloth. Various portraits of the period show that at the end of the seventeenth century, Zurich's women embraced semi-sheer fabrics for various fashionable head-coverings. The Tächli-Tüchli from the Swiss

105 David Herrliberger, Heilige Ceremonien, Gottesdienstliche Kirchen=Uebungen und Gewohnheiten der heutigen Reformirten Kirchen der Stadt und Landschaft Zürich (Zurich, 1750/51), 41-42.

106 Unfortunately, we know little thus far about these items' provenance.

107 Many thanks to Ms Elke Mürau, head of conservation at the Swiss National Museum in Zurich, for this information and her kind support in studying the object. I would also like to thank the curator of textiles, Ms Andrea Franzen, who also greatly assisted the investigation on site. 

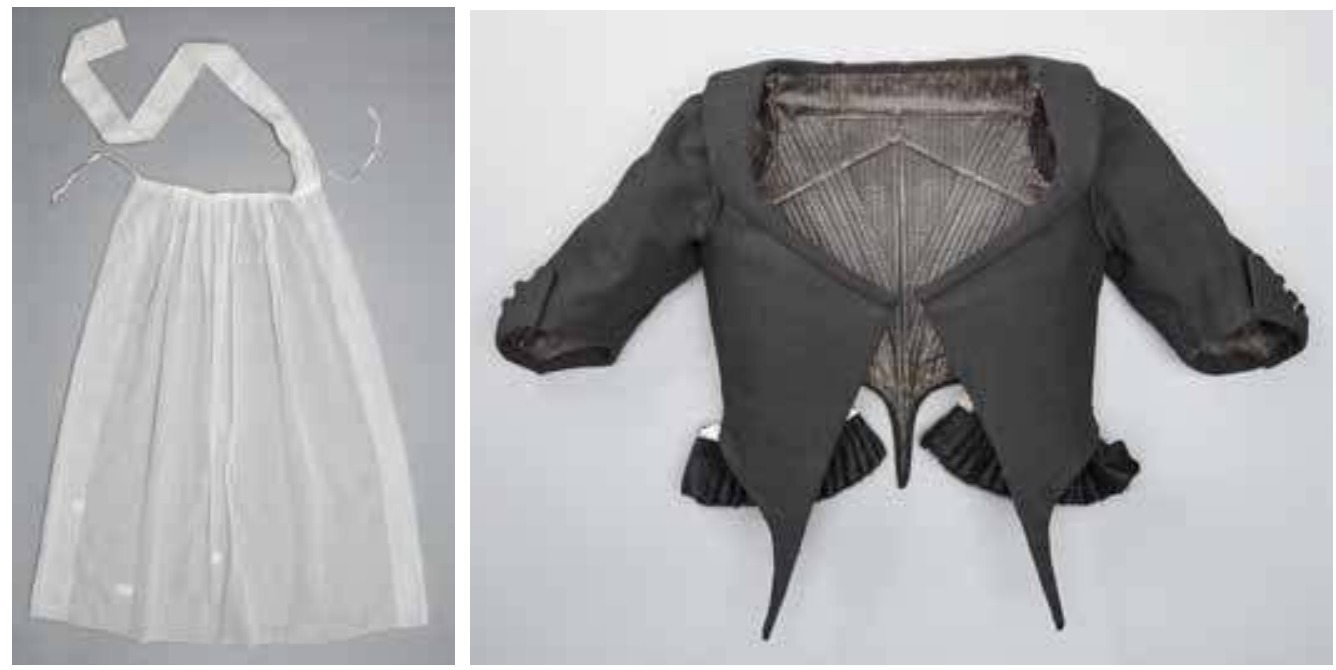

Figure 8.11: Veil and bodice from the Gottenkleid of the Edlibach Family, 1600-1700. Zurich, Schweizerisches Nationalmuseum, inv. no. DEP-1008.7 + DEP-1008.1. Image @ Schweizerisches Nationalmuseum.

National Museum confirms that this was also the case for church veils. With a drape of $76 \mathrm{~cm}$, the veil corresponds almost exactly to the maximum length of fünfVierling $(74 \mathrm{~cm})$ that the Great Mandate of 1699 set for the Tächli. ${ }^{108}$ Gathered into rough pleats at one end, with a 6-cm-wide and 82-cm-long, folded chin-band attached, the veil could achieve a rounded, conical shape and structure reminiscent of contemporary depictions of the Tächli-Tüchli by Andreas Pfeffel from around 1750 (Fig. 8.12).

After close material analysis, and with the technical expertise of dress and textile specialist Hilary Davidson, a contemporary reinterpretation of the Tächli-Tüchli was composed using the finest cotton textile presently available to replicate the veil's weight, density, and plasticity. The reconstruction exercise sought a greater understanding of the sheer and lightweight veil's seemingly antithetical crisp, precise lines and stiff composition as Tächli-Tüchli were recorded to have maintained. The soft fabric's malleability needed to be counteracted and fixed with starch. Sealing the gaps in a textile's weave, starching affects transparency. Starches often produced a cloudy or milky mixture, more suitable for linen shirts for instance; however, it was possible for contemporaries to accomplish greater translucency using ingredients like gum arabic and isinglass (a transparent, gelatinous substance taken from certain fish). ${ }^{109}$ We used a modern spray starch that correspondingly

108 See n. 98 .

109 As is documented in English household recipe books such as Hannah Wooley's The Compleat ServantMaid [...] (London: T. Passinger, 1677), 65-66; and Anne Barker, The Complete Servant Maid: or, Young Woman's Best Companion [...] (London: J. Cooke, 1770), 23-24. 

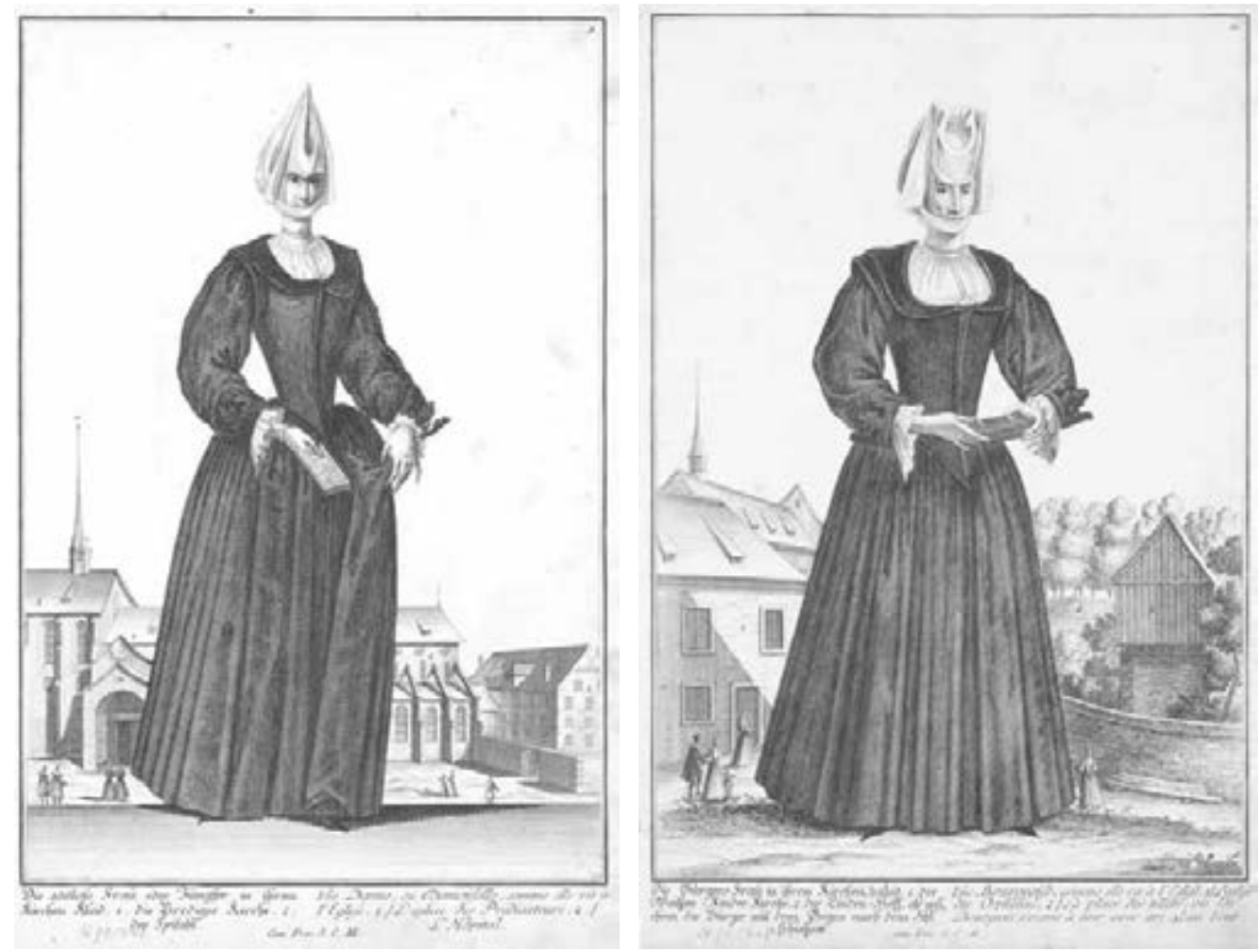

Figure 8.12: Johann Andreas Pfeffel, Noblewoman in her church-wear (left), and Burgher woman in her church-wear (right). Engraving. In Johann Andreas Pfeffel, Schweizerisches Trachten-Cabinet, Augsburg, ca. 1750, plates 8 and 10. Schweizerische Nationalbibliothek Bern. Image $\odot$ https://www.e-helvetica.nb.admin. $\mathrm{ch} /$ search?urn=nbdig-26228.

permitted translucency, but which is weaker in its stabilizing power than period starches. Heat-set with an iron, the cotton textile was transformed into a crisp, papery material that could be moulded, folded, and pinned into an upright shape.

The period's unusually favourable sources supported the embodied methodology undertaken through this exercise. ${ }^{110}$ The requirement for specialist TüchliAuffsetzeren, for instance, women recorded to have passed between houses on Sunday mornings to prepare ladies' church veils before service, ${ }^{111}$ was further highlighted in that a deft hand was needed to manipulate the pliable textile into its composition without creasing or unstiffening its fragile condition.

110 Hilary Davidson, "The Embodied Turn: Making and Remaking Dress as an Academic Practice," Fashion Theory 23 , no. 3 (2019): 329-362.

111 Julie Heierli, “Das 'Tächli-Tüchli', die Kirchenhaube der Zürcherinnen im 17. und 18. Jahrhundert,” Anzeiger für schweizerische Altertumskunde NF 13 (1911): 190-197, here 192. 
The reconstruction exercise also emphasized how important the choice of this particular fabric was for the veil's look. While the height of the Tächli and the tightly tied chin-band doubly restricted the wearer's freedom of movement, the extremely fine and light appearance of the semi-transparent fabric, even when starched, united an attractive and sumptuous luminosity with the material's capacity to respond to wearers' movements - a unique, dual effect that was made clear through the reconstruction effort. Unseen in the contemporary copperplate engravings, the play of opacity and transparency achieved by the interplay between form and fabric emerged as a striking feature. This effect is more apparent in contemporary oil paintings. Moreover, the effects of this specific form of veiling on the wearer's bodily and especially head posture was palpable, with the model reporting sensing the need for gentle, redacted, and controlled movement. We should not underestimate the effect of the uniform veiling of Zurich gentlewomen assembled as a congregation within the church space. The veils presumably achieved a specific and encompassing group effect upheld by the simultaneity of movement, and rigid but luminous form, splendidly suited to creating distinction through exclusivity. The experiment also highlighted how elaborate the styling of Tächli-Tüchli must have been, going some way to explain the occupation of the dedicated Tüchli-setters who helped other women prepare for church. If Zurich church veiling had merely been about covering women's heads for modesty's sake, therefore, then other, more solid textiles and practical forms of veiling would have been far more convenient.

\section{Conclusion}

The conscious choice to use mousseline fabric for church veils in eighteenth-century Zurich ultimately once again brings into play the material's specific semi-transparent character. In his lexicon article on the Sturz, the theologian Spreng, cited at the beginning of this chapter, observed the apparent contradiction of its shield-like stiffness. And in another entry on the veil (Schleier) he also notes: "Schleÿer, a type of \{woollen\} textile much produced in France and Switzerland. Also known in French as voile because of its thinness."112 According to him, "veil" was a term that referred at once to an article of clothing used to cover the head and face, and to an especially thin fabric. In his entry Spreng associated this quality above all with the function of this fabric; indeed, countless images show quite clearly how, by the Renaissance, the combination of different opaque and transparent fabrics with their varying appearances were used and prized for covering the head and face. That this

112 Johann Jacob Spreng, Allgemeines Deutsches Glossarium, Band X.11. (Zettel) 1-425 s-schlÿg, Universitätsbibliothek Basel, mscr. Sign NL 71.X (Zettel), transcribed by Heinrich Löffler. 
continued to be the case after the demise of the Sturz and Tächli-Tüchli is clear not only from the Basel regulation of 1780 , which explicitly prohibited the wearing of fashionable veils in church. The sustained appreciation of veils and veiling fabrics is also evident in the extensive entry under the headword Schleier in volume 145 of Krünitz's 1827 Oekonomische Encyclopädie. The entry states, among other things, "it now belongs once again to the headdress of the other sex. In the middle and even at the end of the past century it was worn only in deepest mourning in black." Silesia, Bohemia, Saxony, Swabia, Westphalia, and Switzerland are mentioned as important regions of production. Special mention is given to Putz- und Schleierflor (crepe trappings and veils), and a gauze veil made of silk or silk mixed with cotton or nettle yarn produced in Bologna and Zurich as "black mourning crepe and white voile (crespo nero, velo bianco). ${ }^{{ }^{\prime 13}}$ But even in Krünitz, in the age of early industrialization, the veil had not lost its capacity to evoke affects. Thus the lexicon explains under the headword Schleier, (Frauenzimmer) (Veil (women's)):

The veil, if pinned up and folded well, and if the other clothing worn with it is tasteful and carefully chosen, lends the woman much grace, especially if she has a fresh, blooming complexion that shines through the sheer fabric. The various manners of wearing a veil, for example hanging down the back, from the side etc., heighten the elegance of the entire ensemble. ${ }^{114}$

Looking at the early modern practices between 1450 and 1800 , it becomes clear that throughout the whole period veils were present as semi-transparent textiles and as more or less opaque headwear. Their ambiguous ability to simultaneously cover and make visible made veils attractive, widely used, and, at certain times, highly controversial, both as garments and as fabrics. Moreover, veils were among the most traditional garments for women, nevertheless offering considerable opportunities for change and fashion through little details. They thus made a specific contribution to social positioning and the formation of women's individual identities. In addition, the production and sale of veils outside guild structures opened up a specific economic space for women in the Protestant cities of Basel and Zurich, which lasted well into the seventeenth century. Around 1700 then, the church veil became the battleground of the clergy and its moral politics in the luxury debates of an emerging consumer society. And finally, by the eighteenth century, Enlightenment thinkers declared the face veil to be a decidedly outdated, traditional form that only served to conceal the face - a clearly legible expression of natural purity.

113 J. G. Krünitz, ed., Oekonomische Encyklopädie, vol. 145 (Berlin, 1827), 386.

114 Ibid., 387. 
As specifically female headwear, the various forms of veils worn during this period had affective, physical effects on their wearers, for example through their weight, their (starched) stiffness, their ability to mark or impede movement, or their different degrees of translucency. In the first decades of the eighteenth century, women's perception and bodily experience of the material qualities of traditional (church) veils changed markedly. Accordingly, the history of these veils clearly shows the level to which their material aspects affected women's emotional and sensory worlds, their economic spheres of action, and their social positioning. And it reveals at the same time the extent to which the perception and experience of materials and materiality can be historically and culturally coded. It is not surprising, therefore, that in the long run the fierce struggle over the (church) veil meant that women compelled to conceal were led to reveal.

\section{Bibliography}

\section{Unpublished Primary Sources}

Historisches Museum Basel

Inv. 1887.159: Der Falckner Stammbaum. Stammbuch der Familie Falkner. Angelegt von Niclaus Falkner [Basel, 1574]

Inv. 1984.279: Der Falckner zu Basel Stammbuch. Stammbuch der Familie Falckner. Angelegt von Daniel und Hans Heinrich Falkner [Basel, 1598]

Staatsarchiv Basel-Stadt (StaBS)

Bf 1 A 6-23, 6-56, 6-61, 7-19, 14-35

Finanz X 4.1

Gerichtsarchiv K 19: Schultheissengericht der mehrern Stadt, Beschreibbüchlein Kirchen F3: "Geistlichkeit. Besoldung, Pensionierung, Gnadenzeit. 1530-1574-1806"

PA 445a 2: Der Falckner zu Basel Stammbuch. Stammbuch der Familie Falkner. Angelegt von Daniel Falkner [Basel, 169o]

Politisches W 2.2: Bedencken der Herren Geistlichen

Privatarchive 255: Inventory and division of the estate of Johann Gottfried (1621-1675) and of Salome Gottfried Hacker (1633-1670)

Protokolle E 13,1

Staatsarchiv Zürich (StaZH)

III AAb 1.3, 1.5, 1.6, 1.7

A 26.4

A 74.1 7_1620, 8_1620, 14 
B III 171, 173, 181

B V 43

B VI 322, 2666

Universitätsbibliothek Basel

mscr. Sign NL 71.X: Johann Jacob Spreng. Allgemeines Deutsches Glossarium. Vol. X.14

\section{Published Primary Sources}

Barker, Anne. The Complete Servant Maid: or, Young Woman's Best Companion [...]. London: J. Cooke, 1770.

Bodmer, Johann Jakob. Der Mahler der Sitten. Zurich, 1746.

Campi, Emidio, and Philipp Wälchli, eds. Zürcher Kirchenordnungen 1520-1675, vol. 1. Zurich: TVZ, 2011.

Campi, Emidio, and Philipp Wälchli, eds. Basler Kirchenordnungen 1528-1675. Zurich: TVZ, 2012.

Carolus, Johan. Evidens Designatio Receptissimarum Consuetudinum ornamenta quaedam \& insignia continens Magistratui \& Academiae Argentienensi à maioribus relicta. Strasbourg, 1606.

Der Statt Straßburg Policeij Ordnung. Strasbourg: Johann Carolo, 1628.

Die Discourse der Mahlern, Erster Theil. Zürich, 1721.

Du Noyer, Madame. Memoires de Madame du $N^{* *}$, écrits par elle-même, vol. 1. Cologne, 1710.

Herrliberger, David. Heilige Ceremonien, Gottesdienstliche Kirchen=Uebungen und Gewohnheiten der heutigen Reformirten Kirchen der Stadt und Landschaft Zürich. Zurich, 1750/51.

Hirschfeld, Christian Cay Lorenz. Briefe die Schweiz betreffend. Leipzig, 1776.

Idioticon Rauracum oder Baseldeutsches Wörterbuch von 1768. Johann Jakob Spreng. Edited by Heinrich Löffler. Edition of manuscript AA I 3 , Universitätsbibliothek Basel. Basel: Schwabe Verlag, 2014.

Krünitz, J. G., ed. Oekonomische Encyklopädie, vol. 87. Berlin, 1802.

Krünitz, J. G., ed. Oekonomische Encyklopädie, vol. 145. Berlin, 1827.

Ulrich, Johann Jacob. Auserlesene Predigten, edited by Hans Conrad Wirz, Part 1. Zurich, 1733.

Wooley, Hannah. The Compleat Servant-Maid [...]. London: T. Passinger, 1677.

\section{Secondary Literature}

Bass, Laura R., and Amanda Wunder. "The Veiled Ladies of the Early Modern Spanish World: Seduction and Scandal in Seville, Madrid, and Lima." Hispanic Review 77, no. 1 (Winter 2009): 97-144.

Benkert, Davina. "Messbücher und Messrechnungen. Zur Geschichte der Basler Messen bis 1647.” In Wiegen, Zählen, Registrieren. Handelsgeschichtliche Massenquellen und die 
Erforschung mitteleuropäischer Märkte (13.-18. Jahrhundert), edited by Peter Rauscher and Andrea Serles, 69-9o. Innsbruck: Studien Verlag, 2015.

Bodmer, Walter. Die Entwicklung der schweizerischen Textilwirtschaft im Rahmen der übrigen Industrien und Wirtschaftszweige. Zürich: Verlag Berichthaus, 1960.

Burghartz, Susanna. "Frauen - Politik - Weiberregiment. Schlagworte zur Bewältigung der politischen Krise von 1691 in Basel." In Frauen in der Stadt, edited by Anne-Lise Head-König and Albert Tanner, 113-134. Zurich: Chronos, 1993.

Burghartz, Susanna. “Covered Women? Veiling in Early Modern Europe." History Workshop Journal 80, no. 1 (2015): 1-32.

Burghartz, Susanna. "Die 'durchgehende' Reformation - Basler Mandate von 1529 bis 1780. ." Basler Zeitschrift für Geschichte und Altertumskunde 116 (2016): 89-111.

Bürkli-Meyer, Alfred. Zürcherische Fabrikgesetzgebung vom Beginn des 14. Jahrhunderts an bis zur schweizerischen Staatsumwälzung von 1798. Zurich: Ulrich \& Co., 1884.

Calvi, Sonia. “'Zur inspection und handhabung der angestellten reformation': Die Basler Reformationsherren im 17. und 18. Jahrhundert." Basler Zeitschrift für Geschichte und Altertumskunde 118 (2018): 249-279.

Davidson, Hilary. "The Embodied Turn: Making and Remaking Dress as an Academic Practice." Fashion Theory 23, no. 3 (2019): 329-362.

Fluri, Adolf. "Kleidermandate und Trachtenbilder in gegenseitiger Beleuchtung." Blätter für Bernische Geschichte und Altertumskunde 23 (1927): 259-284.

Geering, Traugott. Handel und Industrie der Stadt Basel. Zunftwesen und Wirtschaftsgeschichte bis zum Ende des XVII.Jahrhunderts, aus den Archiven dargestellt. Basel: Felix Schneider, 1886.

Grossmann, Emanuel. “Die Entwicklung der Basler Tracht im 17. Jahrhundert.” Schweizerisches Archiv für Volkskunde 38 (1940): 1-66.

Haegi, Oscar. “Die Entwicklung der zürcher-oberländischen Baumwollindustrie.” PhD diss., Weinfelden, 1925.

Head-König, Anne-Lise, and Albert Tanner, eds. Frauen in der Stadt. Zurich: Chronos, 1993. Heierli, Julie. "Basler Trachten um die Mitte des XVII. Jahrhunderts." Schweizerisches Archiv für Volkskunde 14 (1910): 108-117.

Heierli, Julie. "Das 'Tächli-Tüchli', die Kirchenhaube der Zürcherinnen im 17. und 18. Jahrhundert." Anzeiger für schweizerische Altertumskunde NF 13 (1911): 190-197.

Hills, Paul. Veiled Presence: Body and Drapery from Giotto to Titian. New Haven, CT: Yale University Press, 2018.

Holenstein, André. "Regulating Sumptuousness: Changing Configurations of Morals, Politics and Economies in Swiss Cities in the Seventeenth and Eighteenth Centuries." In The Right to Dress: Sumptuary Laws in a Global Perspective, c. 1200-1800, edited by Giorgio Riello and Ulinka Rublack, 121-142. Cambridge: Cambridge University Press, 2019. Iseli, Andrea. "Krisenbewältigung im 17. Jahrhundert. Die Rolle der guten Policey." In Die Krise in der Frühen Neuzeit, edited by Rudolf Schlögl et al., 147-167. Historische Semantik 26. Göttingen: Vandenhoeck \& Ruprecht, 2016. 
Kehrli, Manuel. "sein Geist ist zu allem fähig.” Der Maler, Sammler und Kunstkenner Johann RudolfHuber 1668-1748. Basel: Schwabe Verlag, 2010.

Künzle, Emil. Die zürcherische Baumwollindustrie von ihren Anfängen bis zur Einführung des Fabrikbetriebes. Zurich: F. Rosenberger, 1906.

Löffler, Heinrich. “JJ. Sprengs Allgemeines deutsches Glossarium'. Das Original, seine Geschichte und seine Edition." Sprachspiegel 74, no. 3 (2018): 66-73.

Molà, Luca. "I tessuti dimenticati: Consumo e produzione dei veli a Venezia nel Rinascimento." In Il velo in area mediterranea fra storia e simbolo, edited by Maria Giuseppina Muzzarelli, Maria Grazia Nico Ottaviano, and Gabriella Zarri, 155-171. Bologna: il Mulino, 2014.

Muzzarelli, Maria Guiseppina. A capo coperto. Storie di donne e diveli. Bologna: il Mulino, 2016.

Muzzarelli, Maria Giuseppina, Maria Grazia Nico Ottaviano, and Gabriella Zarri, eds. Il velo in area mediterranea fra storia e simbolo. Bologna: il Mulino, 2014.

Orlandi, Angela. "Impalpabili e trasparenti: I veli Bolognesi nella documentazione Datiniana." In Ilvelo in area mediterranea fra storia e simbolo, edited by Maria Giuseppina Muzzarelli, Maria Grazia Nico Ottaviano, and Gabriella Zarri, 307-324. Bologna: il Mulino, 2014.

Paulicelli, Eugenia. "From the Sacred to the Secular: The Gendered Geography of Veils in Italian Cinquecento Fashion." In Ornamentalism: The Art of Renaissance Accessories, edited by Bella Mirabella, 40-58. Ann Arbor, MI: University of Michigan Press, 2011.

Pfister, Ulrich. Die Zürcher Fabriques. Protoindustrielles Wachstum vom 16. zum 18. Jahrhundert. Zurich: Chronos, 1992.

Pfister, Ulrich. "Städtisches Textilgewerbe. Protoindustrialisierung und Frauenarbeit in der frühneuzeitlichen Schweiz." In Frauen in der Stadt, edited by Anne-Lise Head-König and Albert Tanner, 35-6o. Zurich: Chronos, 1993.

Prigent, Léone. "La perception de coiffes à becs au XVIIIe siècle." In Quelques paillettes, un peu de soie. Coiffes d'Alsace du XVIIIe et du debut du XIXe siècle, edited by Anne Wolff et al., 20-32. Colmar: Musée d'Unterlinden, 2009.

Reimann, Anna. "Die Falkner gestalten. Vier Basler Familienbücher als dynamische Wissensspeicher in Bildern." Unpublished. MA thesis, University of Basel, 2018.

Sander, Jochen. "Die ‘Darmstädter Madonna'. Entstehungsgeschichte von Holbeins Madonnenbild für Jakob Meyer zum Hasen.” In Hans Holbeins Madonna im Städel, edited by Bodo Brinkmann, 33-44. Exh. cat. Petersberg: M. Imhof, 2004.

Schneider, Jenny. "Hut ab vor soviel Kopfbedeckungen!: 20o Jahre Frauenhüte und -hauben in der Schweiz." Zeitschrift für schweizerische Archäologie und Kunstgeschichte 38, no. 4 (1981): 305-312.

Schnyder, Werner. Quellen zur Zürcher Wirtschaftsgeschichte, vol. 2, no. 1526. Zürich: Rascher, 1937 .

Wallach Scott, Joan. The Politics of the Veil. Princeton, NJ: Princeton University Press, 2007. Zander-Seidel, Jutta. "Das erbar gepent. Zur ständischen Kleidung in Nürnberg im 15. und 16. Jahrhundert.” Waffen- und Kostümkunde 27 (1985): 119-140. 
Zander-Seidel, Jutta. "Ständische Kleidung in der mittelalterlichen und frühneuzeitlichen Stadt." In Terminologie und Typologie mittelalterlicher Sachgüter:Das Beispiel Kleidung. International round table, Krems an der Donau, 6 October 1986, 59-75. Vienna: Verlag der Österreichischen Akademie der Wissenschaften, 1988.

Zander-Seidel, Jutta. Textiler Hausrat. Kleider und Haustextilien in Nürnberg von 1500-1650. Munich: Deutscher Kunstverlag, 1990.

Zander-Seidel, Jutta. “Des Bürgermeisters neue Kleider.” In Hans Holbeins Madonna im Städel, edited by Bodo Brinkmann, 55-61. Exh. cat. Petersberg: M. Imhof, 2004.

Zander-Seidel, Jutta. "'Haubendämmerung'. Frauenkopfbedeckungen zwischen Spätmittelalter und früher Neuzeit." In Fashion and Clothing in Late Medieval Europe - Mode und Kleidung im Europa des späten Mittelalters, edited by Regula Schorta and Rainer Christoph Schwinges, 37-43. Basel: Schwabe Verlag, 2010.

Zanoboni, Maria Paola. “'Pro trafegando in exercitio seu arte veletarum': Tipologia e produzione dei veli nella Milano del secondo Quattrocento." In Il velo in area mediterranea fra storia e simbolo, edited by Maria Giuseppina Muzzarelli, Maria Grazia Nico Ottaviano, and Gabriella Zarri, 123-138. Bologna: il Mulino, 2014.

\section{About the Author}

Susanna Burghartz is Professor of Renaissance and Early Modern History at the University of Basel. She has published on the Reformation, confessionalization and gender history, as well as early European globalization and material culture. Her current research investigates advertising journals as the new marketplaces for the emerging consumer society of the eighteenth century and includes a micro-global history of the Leisler family and Basel's silk ribbon industry. 


\section{Index}

actor-network theory $\quad 28$

affect $\quad 24-28,36-40,42,44,45,46,47,48,171$

Albert V, Duke of Bavaria 288, 289-300

Albert VII, Archduke 25

Alberti, Leon Battista $\quad 242,248,261$

alchemy $202,208,233,235,244,257,260,261$, 263-264, 268, 269, 271, 272, 313

Alexander the Great 199, 253

America(s) (see also New World) 208 staging of, by the Württemberg court (1599) 188, 189-199, 193, 197-199, 199-201, $214,216,217,217,223,224$

Amsterdam 164, 234, 235, 236, 243, 261

Andreae, Johann Valentin 213

Anna of Austria 293

Anne of Austria 148, 293

Antoniano, Silvio $\quad 351$

Antonio of Alvise 114

Antwerp 37, 39, 40, 43, 47, 138, 143, 144, 235, 243, 261, 282, 283, 288, 297

Aretino, Pietro $80-86,87-88,93$

Aristotle 252

Astorga 356,357

Asturias 356,360

Attalus III of Pergamon 257

Augsburg 23, 155, 164, 216, 288, 299, 342, 373

Augsburg Imperial Diet (1530) 153

Augsburger Kunstbüchlin 285, 306, 308-310, 309, 310

August II 157

Aureli, Giovanni Calegari $\quad 128$

Avogrado family 126

Bär, Magdalena $\quad 373,375$

Barbara Sophia of Brandenburg $\quad 218$

Barbari, Jacopo de 105

Barovier family 106,107

Barovier, Angelo 71

Barovier, Giovanni $\quad 115$

Barovier, Marcantonio 128

Barovier, Marco $\quad 113,115$

Barovier, Taddeo $\quad 106,107$

Basel 37, 47

veils and veiling in $\quad 369-370,373,374,374$, $376-380,379,380-382,381,383-386,384$, $386-391,387,405$

Basque region $330,342,354-363,364$

Baxandall, Michael $32,42,70$

Beatis, Antonio de $35^{2}$

Bembo, Bonifacio $\quad 376$

Bembo, Pietro 339,346

Benzoni, Girolamo $\quad 238,253$

Bern 389, 390

Besold, Cristoph $\quad 213$
Beurs, Willem 259

Beyer, Anna Magdalena de $\quad 386,387$

Biringuccio, Vanuccio $\quad 73-74$

Bizarus, Petrus 302

blinckentheyt $236,240,241,243,245$

Bodmer, Johann Jakob 399

Boissard, Jean Jacques $31,328,339,340,343,352,353$

Bologna 340, 341, 344, 376, 405

Boorde, Andrew 360

Bornitz, Jakob 212-213

Bortolussi family $102,114,121-130,123$

Bortolussi, Andrea 126,127

Bortolussi, Andriana 124,128

Bortolussi, Bortolo 122,123

Bortolussi, Domenico 122

Bortolussi, Gian Pietro 126,127

Bortolussi, Giovanni $\quad$ 114, 124-125, 126, 127-128, 129

Bortolussi, Iacopo 122

Bortolussi, Piero 124

Bortolussi, Vicenzo 122-123

Botero, Giovanni 201

Botticelli, Sandro $\quad 287,376$

Bourbon, François de 148

Brabant $35^{2}$

Bruegel, Pieter the Elder $\quad 249,250$

Brueghel, Jan the Elder $\quad 25,40$

Bruges 234, 241, $35^{2}$

Brugge, Geerard ter 303

Brunoro, Cristina 113

Brussels 138, 144

Bry, Theodor de 189, 190, 192, 194, 196, 208, 216, 223

Buonarroti, Michelangelo. See Michelangelo

Calw 203, 205

Caner, Leonardo 114

Carati, Piero 129

Carolus, John 383,383

Castiglione, Baldassare $\quad 86,339,346$

Castille 342

Catholicism 202, 218, 295, 327, 392

Cellini, Benvenuto $\quad 325-326$

Cellius Erhart 202, 203, 204, 206-207, 212, 224

Cennini, Cennino $\quad 257,260,261,285,286,306$

Cervoni, Isabella 338

chambers of rhetoric $\quad 43,240$

Charles V, Emperor $\quad 153,295,356$

Christianity $77-85$

Christina of Lorraine $\quad 187$

Clovio, Giulio $\quad 283,287,303$

colour 46, 118, 169, 173, 190, 194, 221, 244

and affect $70,233,237,242,244,263,311$

allure (beauty) of $46,48,250,253,255,271,272$

animative force of $42,237,249$ 
colour palette $76,243,257,268$,

deceptiveness of $74,249,255,271$

effects of $34,37,45,203-206,219,241,242,245$, $247,249,250,251,253,263,269,272,298$

found in nature

birds/feathers $138,150,15^{2}, 162-163,164$, 208, 249

flowers 249

rainbows 243,258

shells 249

the sun $242,248,256$

heraldic colours $236,248,252,256,262$

imitative power of $24,46,190,233,248$, $25^{1-252,256,256,258,260,269, ~} 286$

knowledge of $235,236,244,248,262,271,272$

meanings of $76,219,255,262$

New World colour $164,205,253$

performing 203-206

in recipes $76,305^{-306,308}$

sense for $44,45,73,244$

in sumptuary legislation $\quad 396,398$

sympathy and antipathy between colours 248

vocabularies of $76,247-255$

Columbus, Christopher 196

commodity $23,85,87,210$

feathers and featherwork as $39,140,143,148$, $164,170,177$

glass as $59,60,67,69,73,92,101,112,115$

constcamer, collection $\quad 24,25,36,43$

and feathers $138,139,163^{-164}, 170,178,208-214$, $218,220,223$

and glass $\quad 68,89$

and paintings $43,288,291,298,311$

and shells 301

and veils 386

Contarini, Gasparo 85

Corneliszoon, Cornelis 238

Coryat, Thomas $58,342-343,346$

costs (see also value) $\quad 42,70$

feathers and featherwork $156,157,168,169,170$, $172,189,190,201,215,219,221$

glass $114,118,121$

shell gold 303

veils $379,386,388,389,391$

costume books $327-328,335-363,364,381$, $382-386$

Counter-Reformation $\quad 34,295,361$

Cranach, Lucas, the Elder 152,155

dal Gallo, Angelo 117

Dall'Aquila family 113

Dalmatia 102

Dannenritter, Hans $\quad 215,216-217$

Darduin family $122-123$

Daubenhauer, Salomon 215

dildoes $88-93,90,91$

Dolce, Lodovico $\quad 25^{1-252}$

Donà, Ermolao $\quad 124,128$

Drake, Francis 174
Dresden 138, 143, 192

Dürer, Albrecht $\quad 36-37,250,370,374,376$

Saint Jerome in His Study (1514) 116

Woman of Nuremberg Dressed for Church (1500) 371

Women of Nuremberg and Venice (ca. 1495) 372

Egen, Carl 194, 202, 208, 209, 216, 217

Elizabeth I, Queen of England $\quad 172-174,173,202$

emotion $26,28,29,36,37,38-39,40,43,48,87$

colours and 242

costume books and 383

feathers and $46,138,149,159,163,171,177,178$, $188,191,208$

glass and $85,88-89$

gold and 46

veils and $47,327,349,370,406$

Enghein, Duke of 148

Enkhuizen 209, 210, 212

epistemology $152,237,272$

Este, Isabelle d', 68-69, 353

Fabri, Felix $\quad 5^{8}$

Falkner family $\quad 380-382,381,387$

feathers and featherwork $35,39,43,45^{-46}$,

$138-178,187-224,211,212,213$

and affect $137,138,140,149,171,172,177-178$, 219,224

and air 170, 206-208

dyeing $15^{0,153,160,165^{-170}, 172,188}$

fans $172-177$

and identity 138,140

Latin American 188

panaches $171-177$

production and manufacturing processes 138 , 139-140, 149-171, 153, 161, 177-178, 194

properties and qualities $138,139,149,150,158$, $160,171,176-178,188,208$

in Protestant Union festivals 219, 222, 224

remaking $160-171,162,163$

spending on, by Württemberg court $\quad$ 214-218

in staging of America by Württemberg court (1599) 189-199, 193, 197-199, 199-201, 205, $214,216,217,217,223,224$

trade $140-149,141,142,162,164,177-178,188$

Ferdinand I, Emperor 293

Florence 188, 190

veil-making industry, production, and

trade $330-332,334,336,340-342,354,363$

Francken, Hieronymous II 25

Frankfurt 145, 164, 201, 204, 208, 216, 300, 377

Frederick I, Duke of Württemberg $\quad 188,189-191$,

201-203, 205-206, 218, 223

collections of curiosities $\quad 208-214,218,223$

environmental policies 206-208

Frederick III, Duke of Schleswig-Holstein $\quad 218$

Frederick V of the Palatinate 218, 221

fresco painting $87,238,250,286$

friendship $39,47,287,300-304$ 
Frischlin, Jakob $\quad 189,190,191,192,193,196,199-201$, $205,208,223,224$

Fugger, Hans 23, 35

Fugger, Johann Jakob $\quad 31$

Fugger, Marx 288

Garibay, Esteban de 342

Garzoni, Tommaso $\quad 336-337,339$

Geizkofler, Ferdinand $\quad 218$

Gheyn, Jacques de 241

Giberti, Gian Matteo 85

Glaser, Hans Heinrich $\quad 381,383-384,384$

glass and glassmaking $27,39,40,43,45,57-60$ and affect $\quad 59,67,93$

branding 69-70,109-121

calcedonio (chalcedony) 71, 72, 74, 117

cristallo (crystal) $58,59,69,71,74,75,76,77$, $106,111,113,117,118$

filigrana (filigree) $75,76,114,117,118,119$

engraving $76,114,117,118$

and identity 101,121-130

lattimo (milk glass) $\quad 73,73,74,75,117,118$

production and processes $\quad 65-66,67-77,93$, 110-121, 111

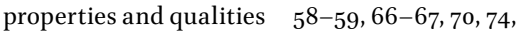
92-94, 109, 117-118

religious association $\quad 77-86,93$

reticello $75,76,117,120$

retortoli $75,76,119$

secrecy $\quad 99-100,101,102-109$

value $59,62,66-67,109$

vetro ghiaccio (ice glass) 76, 118, 121

gloeyentheyt 245

glow (see also gloeyentheyt) 28, 44

painting and $46,233,234,241,242,243$, $244-245,247,248,249,251,256,260,261,263$ 268,271

Gnalič shipwreck $\quad 63-65,63,64,65$

Goeree, Willem 260

gold 41, 239, 267, 281, 299

as decoration in feather-work $148,153,156,171$, 173, 201

as decoration in veils and fabrics $332,334,336$, 346,394

gold colour (see also pigments: orpiment, realgar) $24,46,48,236,255^{-256,260-261}$

and identity $47,264-265,313$

liquid gold (see also shell gold) 46, 281-282, $284,305,311,312$

properties, qualities, and appearances (see also blinckentheyt, shine, sparkle, vibrancy) 24 , $46,48,236,255^{-25} 6,257,306$

golden age 236,262

golden year, gulden jaer $\quad 239-240$

Goltzius, Hendrick 236, 237, 238, 243, 244, 245, 251, 261, 262, 263-271, 272

conversion to colour $244-245$

fashioning and self-fashioning as alchemist and natural philosopher $\quad 243,265$ friendship with Karel van Mander $\quad 238$

DRAWINGS

"Eer boven Gold" (1600) 265

PAINTINGS

Allegory of the Arts (1611) 269-270, 269, 270

Danaë(1603) 268

Mercury (1611) 267,268-269, 268

"PEN WORK"

Without Ceres and Bacchus, Venus Would Freeze

(1599-1602) 263, 264

Gonzaga, Francesco II 87

Gonzago, Guglielmo 69

Gower, George

Queen Elizabeth I (ca. 1588) 173

Graf, Urs 159

Gregory XIII, Pope $\quad 238$

guilds 118,129

feather-workers $143^{-144,148,15^{0}, 15^{1}}$

glassmakers $71,75,103,110-111,115,121,125,127$

glass-resellers 115

painters $\quad 283$

silk $\quad 340-342$

veil-makers $330,331,333$

weavers 377

Guth von Sulz-Durchausen, Johann Jakob 208

Haarlem 39, 234, 235, 236, 237, 239, 240, 243, 271 as new "birthplace" of painting $234,238,243$

new centre of painting $\quad 239,271$

rhetoricians in 240

site of the new Helicon 240

Habsburgs 189, 202, 218, 293, 295, 328

Hainhofer, Philip 160, 208, 219, 220

Harrewijn, Jacobus 266

Harriot, Thomas 189

Hartlib, Samuel 213

Haydocke, Richard $\quad 258$

Heere, Lucas de $\quad$ 237, 241, 243

Henri IV, King of France 143,338

Henry VIII, King of England 144,149

Herrliberger, David 399-401, 400

Hilliard, Nicholas $\quad 287,308$

Hippocrates $\quad 256$

Hirschfeld, Christian Cay Lorenz 391

Hoefnagel, Joris $\quad 47,282-284,310,311-313$

Allegory for Abraham Ortelius (1593) 287, 299, 300-304, 302-303, 311, 312

Allegory of the Rule of Duke Albert Vof Bavaria (1579) 287-300, 290, 291-292, 294, 296, 311, 312

Guide for Constructing the Ligature ffi (1591-1596) 312, 312

Holbein, Hans, the Younger $\quad 287,373,374,376$

Madonna des Bürgermeisters Jakob Meyer zum Hasen (1525/26 and 1528) 375

A Woman of Basel Turned to the Right (ca. 1523) 374

Homer 256

Horenbout, Lucas $\quad 287$ 
Huber, Johann Rudolf $\quad 386,387$

Huguenots 201, 378, 392

Hulsius, Levinus 216

Huyghens, Christian 297

identity $26-30,45,47,59,86,240,313$ and secretiveness $\quad 102-109$

ingenium 37

interobjectivity 28

Isabella Clara Eugenia, Archduchess $\quad 25$

Isidore of Seville 256

Italian art $235,237,238,250,25^{1}$

jewels $173,177,201,222,243,245,282,334,338$

jewellery $25,61,62,171,173,175,200,215^{-216}, 219$, 221, 247

Kannengießer, Dorothea $\quad 373,375$

Karg, Hans 192

Kassel 223

Ketel, Cornelis $\quad$ 239, 244, 248, 255

knowledge transfer featherworking $\quad 145$ glassmaking 102-109

Kress zu Kressenstein, Christoph $\quad$ 153, 156

John Frederick, Duke of Württemberg $\quad 188,218$, 219, 224

John Frederick I, Elector of Saxony $\quad$ 153, 155

John George I, Elector of Saxony 143

Julius Caesar 199

Lailang, Antoine $\quad 356$

Lampsonius, Dominicus 241

Lancre, Pierre de $361,362,364$

Landshut 290, 291

Latour, Bruno $\quad 28,37$

Le blason des couleurs en armes, livrees et devises 252, 262

Leipzig $138,143,144,150,164$

Lessius, Leonardus 42

Lewis-Frederic, Prince of Württemberg 220

Leyden papyrus $\quad 285$

Liber illuministarum 286, 305, 306-308, 307, 310

liefhebber 25, 43, 235, 239, 240, 291

Linschoten, Jan Huygen ２09-211, 212

Livy 253

Lomazzo, Giovan Paolo $\quad 235,241,248,258,260$

Lombardy $346,348,353$

London $138,144,157$

Louis XIII, King of France 148

Louis XIV, King of France 149

lust, desire $\quad 85,86,205,213,339$ produced by artefacts and objects $\quad 25,29,39$, 42,48

and feathers $140,143,147,150,177$ and glass $\quad 59,70,74,87,88-89,108,110,117$ and painting 244,251 and veils $\quad 47,343,361,384,397$ lustre (see also blinckentheyt) 32, 45

of glass 74

of gold 24, 233, 260

and painting $24,32,233,241,245,260$

and veils and veil fabrics $329,334,335,336$, $339,340-342$

Lutheranism 189, 201-203, 223, 401

Lyon 144, 145

Madrid $138,144,148,149,160,163,170,172$

Maelsen, François 211

Magdalena of Saxony 334

malleability

of glass $27,45,59,73,76,89,93$

of gold 265

of veils and veil fabrics $36,47,327,328$, $346-354,358,402$

Mantua $74,87,348,353$

Manuel, Niklaus $\quad 157,158$

Marcolini, Francesco 86

marvellous $71,74,93,253,354$

mass production $61,63,65,67,101,109,175$

materials $24-30$

processing $28,29,32,34,42,45,46$

properties and qualities $30-36,37,44,45,46$, 47,48

Maximilian, Emperor 373

Medici, Catherine de', 148

Medici, Maria de', 338

Medici, Maria Maddalena de', 334, 338

Medici, Piero di Cosimo de', 286

Melchor de Jovellanos, Gaspar 342

Mercury (Roman god) 247, 250, 265, 266, 267, 268-269, 268, 271

mercury (metal) 285, 286

Merian, Walter $37,389,390$

Messel fan $174-175,174,176$

Meyer zum Hasen, Jakob $\quad 373,375$

Michelangelo $33,34,241,25^{\circ}$

Milan 138, 175, 344, 353

miniature painting $\quad 283,287-304,308,310,311$, 312,313

miracle $77,78,80,81,83,243$

Mitelli, Giuseppe Maria 111

mobility $29,45,71,101,102,103,104,144-146$

Montaigne, Michel de 361

Montbelliard 201, 209, 212

Morgues, Jacques le Moyne de 194

Munich 288, 291, 295, 298, 311

Murano $39,45,57,58,65,66,67,68,69,87,101$, 102-109, 105, 109-121

Moritz of Hesse $\quad 209$

Navagero, Andrea 363

Netherlandish art $\quad 41,46-47,234,235,236-237$ 241-246, 248, 250, 251, 252, 261, 262, 271-272

Neumair, Johann Wilhelm 40

Nevers, Duke of 148

New World (see also America(s)) 137, 144, 190, 205, 253 
Norgate, Edward 303,308

Nuremberg $23,37,138,140,141,143,144,145,146$, $147,151,157,164,170,171,216,35^{-}-35^{2}, 370-373$, $371,372,374$

Occo, Adolf, III $\quad 288$

oil painting 33,404

affects $234,237,242,243,248$

alchemy of $233,235,244,257,260,261$, $263-264,268,269,271,272$

centres of (see also Amsterdam, Antwerp,

Haarlem) 46, 234, 235, 236, 243

on copper $41,245^{-247}, 246,253^{-255}$

costs and values of $40,42,43,70$

as effeminate art $235,241,250$

as epistemic practice 237

and (Netherlandish) identity 241

"invention", "birth," and "rebirth" of 47, 234, $237,240,241,242,244,245,271$

and life-likeness $\quad 233,234,241,25^{2}$

manners of

impasto 259

neat manner of painting $\quad 250-251$

rough manner of painting $25^{\circ}$

with feet and fingers 244,255

properties, qualities, appearances $24,32,33,41$, $43,233-234,236,237,241,242,243,245,246$, $251-252,263,269,271,272$

theory of 234,237

vocabulary of $46,237,272$

Ortelius, Abraham 288-289, 301-302, 311

Ochssenbach, Niclas 208

Ovid 235

Padua 103, 339, 340

painting (see also fresco painting, miniature painting, oil painting) $\quad 24,40,42,46,77$ centres of $46,234,235,238,239,240,243,271$ materiality of $24,32,47,244$

value $43,46,236$

versus drawing $\quad 249-25^{\circ}$

painting tools 298,312

brushes $239,244,263,267,268,268,269,295$, 301, 302, 302, 303, 303, 304, 306, 308, 312, 313

maulsticks $\quad 239,266,268,269$

palettes $239,243,267,268,268,269,270,271$, 297

shells 284, 297, 298, 299, 299, 301, 302, 306, 307, $308,309,312,312$

Palazzo del Té (Mantua) $\quad 87$

Palladio, Andrea 77

Paludanus, Bernhardus $\quad$ 209-213, 210, 218

Pandora $\quad 249-250,263,271$

Paris $138,140,143,144,146,147,148,150,157,160$, $163,169,172,339$

Parma $346,347,348$

Passe, Crispijn de 260

Passion of Christ 82

passions 23, 224, 248, 339
Pasti, Matteo d', 286

Paul IV, Pope 83

Pausias 248

performance $36,46,158,160,224,328$

Pfeffel, Andreas 402, 403

Philip II, King of Spain 149

phoenix 262, 263

pigments (see also vermilion, shell gold) 26,28 ,

203, 269, 271, 284, 297, 298, 299, 301, 302

giallorino/giallolino $\quad 257-258$

lamp black 251

manufacturing of $\quad 68,261$

massicot/masticot $\quad 243,251,257-258,259-260$

minium (meny) $\quad 71,258$

ochre $234,251,257,260,271$

orpiment $257,259,260-261$

properties and qualities $46,233^{-234}, 243,248$, $251,257-261,312$

realgar 257,260

recipes and reconstruction exercises $\quad 304-310$ schiet-gheel 257,260

trade in 261

uses, applications, and effects $46,77,169$, $233^{-234}, 241,243,248,251,257-261,262$

Pisseleu d'Heilly, Anne de $325-326$

Pliny 248, 262

Po valley 102

porcelain $43,73,75$

Prague $43,138,144,148,163,213$

Prometheus 249-250, 263, 271

Pronner, Wolfgang 299

Protestant Union 46, 188, 218, 224

Protestantism (see also Reformation) 37, 47, 19o, 202, 205, 209, 211, 219, 223

and veiling (see also veils: church) 373, 401, 405

Querini family 124

Quiccheberg, Samuel 298

Rademacher, Johannes $\quad 283,302$

Raimondi, Marcantonio 87,89

Woman with a Dildo (ca. 1525) 91

Rathgeb, Jacob 209, 211, 212, 224

red

feathers $148,153,164,166,169,171,172,174,192$ $194,195,196,198,203,204,205,220,221$

glass 62,76

and painting $234,242,243,247,249,251,252$, $255,256,256,260,261,262,263,271,298,301$

reflexy-const (art of painting reflections) 41, 242, 271

Reformation $\quad 295,373,381,384,386,389,390,391$, $393,396,397,398,398$

Regensburg Imperial Diet (1594) 149, 215

Reims 144

Rembrandt

Belshazzar's Feast (ca. 1636-38) 258, 259, 259

Ringle, Johann Sixt $\quad 385$

Roberts, Lewes 23 
Romano, Giulio 87

Rome $33,238,349,35^{\circ}$

Rosso, Marco 115

Rothschild Bowl 73,75

Rubens, Peter Paul 40, 261, 266, 268

Rudolf II, Emperor $\quad 163,170,189,213,263,300,312$

Ryff, Walther Hermann $\quad 242,248,261$

Saint-Jean-Pied-de-Port $\quad 358,359$

Salome 338

San Giorgio Maggiore $\quad 77,80,83$

San Sebastiàn 355

Sant'Andrea 62

Santa Maria delle Grazie $\quad 60-61,60,61$

Santiago de Compostela $\quad 35^{8}$

Savonarola 349

Schickhardt, Heinrich 202

Scipio Africanus, Publius Cornelius $\quad$ 253, 255

Serena brothers 117

Seville 144,163

veil-making industry, production, and trade $330-331,333-334,363$

Sforza, Bona 353

shell gold $39,47,282,283,284,298-299,301,302$, 302-304, 311-313, 312

applications $\quad 286-287$

recipes $36,284-286,304-310,307,309,310,313$

reconstruction $\quad 304-310,307,309,310,313$

shells (see also shell gold) $\quad 284,297,299,301,302$

shine $28,32,243,245,248,257,333,339,342$

Sibylla of Anhalt, Duchess of Württemberg 199, 200, 203, 205, 223

Sistine chapel 33

softness $24,45,170,175,177,265,271,333$

Solimei, Castellano di 342

Solomon's Temple 257

space $28,29,38$

Spanish empire $\quad 25$

sparkle (see also blinckentheyt) $85,243,245,255$

Spranger, Bartholomeus 238

Spreng, Johann Jacob $369,386,387-388,404$

Strasbourg 204, 369, 383,385

Stuart, Elizabeth, Electress of the Palatinate $\quad 218$

Stuttgart $138,148,156,164,170,188,189,190,191,192$, 211, 212, 219, 223, 224

sumptuary legislation $30,79,86,376,383,384$, $386-391,392-398,402,405$

Theophilus, Presbyter $\quad 285$

Thirty Years' War 46, 220, 224, 383, 393

Tintoretto 237

Titian 250, 271 Pietro Aretino (ca. 1537) 83,84

Toledo 344

Tornabuoni, Lucrezia 338

trade secrets $\quad 99-100,101,102-109$

translucency $28,43,219,221$ of feathers $46,138,189$ of glass $27,76,93,118$

and painting 233

of veils and veil fabrics $24,31,36,39,328$, $335^{-}-346,363,373,402,403,406$

transparency $44,45,207,25^{2}$

of glass $24,27,48,59,71,74,75,76,77,81,82,83$, $84,85,93,117,118$

and painting 260

of veils and veil fabrics $326,327,329,335,336$, $339,344,349,363,370-376,399-401,402$, 404, 405

Treaty of Prague 190

Treviso 103

Tübingen 201, 209

Turin 138

Turquet de Mayerne, Theodore $\quad$ 259, 261

Tuscany 102

Ulrich, Johann Jacob $\quad 397,399$

Unangst, Jacob $156,215,221$

value $29,30,40-44,46,47,48$

Van Cleve, Joos 376

Van Croes, Jacques 266

Van Eyck, Hubert 243

Van Eyck, Jan $\quad 234,241-242,243,244,250,263,271$, 272

Van Heemskerck, Maarten $\quad 251$

Van Leyden, Lucas $25^{0}$

Van Mander, Karel $\quad 37,41,234,237-240,244$

245-247, 267, 271-272, 287, 288, 297

"Academie" of Cornelis Corneliszoon, Hendrick Goltzius, and Karel van Mander 238

PAINTINGS

The Continence of Scipio (1600) 253-255, 254

Allegory of Nature (1600, verso of The Continence of Scipio) 254,256

Before the Flood (1600) 41

Emblematic Depiction (1600, verso of Before the Flood)) 246

Landscape with the Dance around the Golden Calf (1602) 245

WRITINGS

Schilder-Boeck 43, 46, 233, 234-235, 237, 239, 240, 243, 247, 248, 253, 255, 271, 282

Den Grondt der Edel Vry Schilderconst 235 $236,238,242,247-262$

Lives of Egyptian, Greek, and Roman painters 235

Lives of Italian painters 235

Lives of Netherlandish and German painters 236

Wtlegghing Op den Metamorphosis 235

Wtbeeldinghe der Figueren 235, 247, 262

De KerckderDeught $\quad 239,265$

Den Nederduytschen Helicon 240

T'Stadt Haerlems Beeldt 243

Van Ouwater, Albert 240 
Vasari, Giorgio $\quad 235,238,241,250,271$

Vecellio, Cesare $\quad 328,330,335-338,337,340,341$, $342,344,345,346-351,347,350,362$

veils $31,36,47,337,340,341,343,345,347,350,353$, $355,357,359-360,372,374,383,402$

and affect $330,338,346,351,364,401,405,406$

Bündlein 373

church $37,39,340,341,361,369-376,371,384$, $385,386-391,387,392-398,395,399-404,403$, 404-406

and identity $326,327,328,329,335,354,363$, $364,383,405$

production, processes, and trade $329-335$, $341-342,344,351-35^{2}, 363,376-380,379$

properties, qualities, and forms 327,329 , $335-363,364,370-376,380-382,381,382-386$, 401-406

reconstruction exercise 401-404

Schwenkel $373,386,388,400$

Sturz $35^{2}, 369,370,371-372,373,380,382,383$, $385,386,387,387,388,389,390,391,404,405$

tocados $354-363,355,357,359,360$

uses and applications $\quad 325-326$

value 328

women's resistance to $389-391,397-398,406$

Venice $27,37,77,78,81,83-85,86,93-94,105,261$, 272, 286

citizenship $123,125^{-127}$

featherworking industry, production, and trade $138,144,160-162,163,164,165-168$, $169,170,171,175$

glass industry, production, and trade 43,45 , $57-77,83,84,93,101,102-121$

pigments, uses and trade $\quad 251,261,272$

veil production and styles $335,337,342,343$, $343,344,345,346,349,351,363,370,371,372$

Verdun 352,353

vermilion $\quad 233,234,248,251,261,268$

Verona 349

Veronese, Paolo 93

Wedding Feast at Cana (1563) $\quad 77-85,78,82$

Vespucci, Amerigo 196, 202, 208

Viatis, Bartholomäus $\quad 145^{-146,151,164}$

vibrancy $24,34,37,48$

of feathers $24,139,150,176,177,194,205$

of gold $46,284,286,309$

and painting $\quad 247,249,255,284,286,309$

Vicenza 103

Vienna 144

Virgil 293

Visentin family 107

Visentin, Bartolomeo 106
Vital, Laurent $\quad 328,356,360,361,362$

Vives, Juan Luís 399

Vivianus, Johannes 283

Vlerick, Pieter 237

Von Lamersheym, Junker Philip 194

Waghenaer, Lucas Jansz 211

Warburg, Aby $\quad 187-188,348$

Waser, Anna 395

Weckherlin, Rudolf $\quad$ 221-222

Weiditz, Cristoph $\quad 358,360$

Wentz-Meyer, Barbara $\quad 386,387$

White, John $\quad 189$

Wijntgis, Melchior $\quad 248,251$

Wilhelm V, Duke of Bavaria 289, 299

Wittelsbach $\quad 289,291,293,295$

Wollandt, Hans $\quad 145,147$

workshops $39,43,48$

feather $140,144,146-148,160-171$

glass $39,45,57,59,64,68,69,71,104,105,106$, $110,112,115$

painting 286,298

veil and fabrics $329,330,332,334$

Wurmbein, Johann 140,141

Württemberg $46,139,148,155,164,213$

and colour $\quad 203-206$

and the element of air $\quad 206-208$

Lutheranism in 201-203

and Protestant Union festivals 218-222

spending on feathers and featherwork $214-218$

staging America by the court (1599) 188,

189-199, 193, 197-199, 199-201, 204, 214, 216, $217,217,223,224$

Wyts, Lambert 356

yellow (see also pigments: giallorino/giallolino, massicot/masticot, schiet-gheel, ochre, orpiment realgar) 48

feathers $149,163,169,170,171,172,194,195,196$, $203,204,221$

glass 76

as colour of gold $\quad 46,236,248,255^{-262}, 263$

paint $46,233,234,236,247,248,251,255^{-262}$, $263,271,295$

veils 334

Zanchi, Gian Antonio 114

Ziliol, Giulio 126

Zurich $39,47,393,398$

veils and veiling in $\quad 376-380,392-396,395$, 396-398, 399-401, 404, 405 

This collection embraces the increasing interest in the material world of the Renaissance and the early modern period, which has both fascinated contemporaries and initiated in recent years a distinguished historiography. The scholarship within is distinctive for engaging with the agentive qualities of matter, showing how affective dimensions in history connect with material history, and exploring the religious and cultural identity dimensions of the use of materials and artefacts. It thus aims to refocus our understanding of the meaning of the material world in this period by centring on the vibrancy of matter itself.

To achieve this goal, the authors approach "the material" through four themes - glass, feathers, gold paints, and veils - in relation to specific individuals, material milieus, and interpretative communities. In examining these four types of materialities and object groups, which were attached to different sensory regimes and valorizations, this book charts how each underwent significant changes during this period.

Susanna Burghartz is Professor of Renaissance and Early Modern History at the University of Basel.

Lucas Burkart is Professor of Medieval and Renaissance History at the University of Basel.

Christine Göttler is Professor emerita of Art History at the University of Bern and specializes in the art of early modern Europe.

Ulinka Rublack is Professor of Early Modern History at Cambridge University and Fellow of St John's College. 